\title{
Liability for Asbestos-Related Injuries
}

Citation for published version (APA):

Sobczak, F. (2013). Liability for Asbestos-Related Injuries. [Doctoral Thesis, Maastricht University]. Datawyse / Universitaire Pers Maastricht. https://doi.org/10.26481/dis.20130117fs

Document status and date:

Published: 01/01/2013

DOI:

$10.26481 /$ dis.20130117fs

Document Version:

Publisher's PDF, also known as Version of record

\section{Please check the document version of this publication:}

- A submitted manuscript is the version of the article upon submission and before peer-review. There can be important differences between the submitted version and the official published version of record.

People interested in the research are advised to contact the author for the final version of the publication, or visit the DOI to the publisher's website.

- The final author version and the galley proof are versions of the publication after peer review.

- The final published version features the final layout of the paper including the volume, issue and page numbers.

Link to publication

\footnotetext{
General rights rights.

- You may freely distribute the URL identifying the publication in the public portal. please follow below link for the End User Agreement:

www.umlib.nl/taverne-license

Take down policy

If you believe that this document breaches copyright please contact us at:

repository@maastrichtuniversity.nl

providing details and we will investigate your claim.
}

Copyright and moral rights for the publications made accessible in the public portal are retained by the authors and/or other copyright owners and it is a condition of accessing publications that users recognise and abide by the legal requirements associated with these

- Users may download and print one copy of any publication from the public portal for the purpose of private study or research.

- You may not further distribute the material or use it for any profit-making activity or commercial gain

If the publication is distributed under the terms of Article $25 \mathrm{fa}$ of the Dutch Copyright Act, indicated by the "Taverne" license above, 
Liability for Asbestos-Related Injuries

Faro Sobczak 
ISBN: 9789461591937

Universitaire Pers Maastricht

(C) F. Sobczak, Maastricht 2013

Lay-out: Faro Sobczak

Cover design: Richard Stark

No part of this book may be reproduced, stored in a retrieval system, or transmitted, in any form or by any means without written permission from the author, unless otherwise allowed by Law.

The research presented in this thesis was conducted at the School for Public Health and Primary Care: CAPHRI, Department of Health, Ethics, and Society, of Maastricht University. CAPHRI participates in the Netherlands School of Primary Care Research CaRe. Caphri was classified as 'excellent' by the external evaluation committee of leading international experts that reviewed CAPHRI in December 2010. 


\section{Liability for Asbestos-Related Injuries}

\section{PROEFSCHRIFT}

ter verkrijging van de graad van doctor aan de Universiteit Maastricht, op gezag van de Rector Magnificus,

Prof. dr. L.L.G. Soete,

volgens het besluit van het College van Decanen,

in het openbaar te verdedigen

op donderdag 17 januari 2013 om 14.00 uur

door

Faro Sobczak

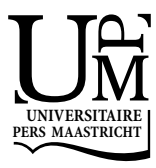


Promotor

Prof. mr. G.E. van Maanen

Co-promotor

Dr. D.M.R Townend

Beoordelingscommissie

Prof. mr. T. Hartlief (chair)

Prof. mr. A.J. Akkermans (Vrije Universiteit Amsterdam)

Prof. dr. M.P.A Zeegers 


\section{Contents}

\section{Chapter 1: Introduction}

1.1 Introduction

1.1.1 The rising number of asbestos victims and claims for asbestos-related diseases 17

1.1.2 Causal uncertainty in asbestos-related cases ............................ 19

1.1.3 Judges and epidemiological experts: lost in translation?................... 20

1.2 The chemical nature of asbestos fibres and sources of exposure 21

1.2.1 The chemical nature of asbestos fibres.................................. 21

1.2.2 Sources of exposure to asbestos ..................................... 24

1.2.2.1 Occupational exposure to asbestos .............................. 24

1.2.2.2 Household, para-occupational or environmental exposure to asbestos ... 25

1.2 .3 Conclusion ........................................................ 26

1.3 Asbestos-related injuries and its medical and legal complexity 26

1.3.1 Asbestosis (divisible disease) ...................................... 27

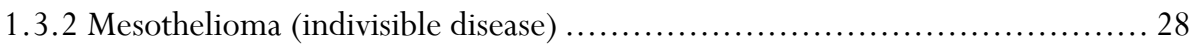

1.3.2.1 Medical information about mesothelioma in a legal perspective ......... 30

1.3.2.2 Uncertainty about the specific tortfeasor ............................ 31

1.3.3 Lung cancer which could have been asbestos-related $\ldots \ldots \ldots \ldots \ldots \ldots \ldots \ldots . \ldots \ldots 2$

1.3.3.1 Medical information about lung cancer in a legal perspective ............ 33

1.3.3.2 Uncertainty about the cause of the damage: multiple causation ......... 34

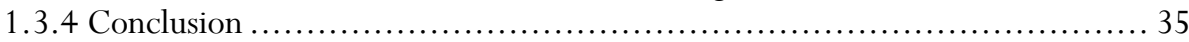

1.4 Claims for asbestos-related injuries and its long-tail risks for insurers 35

1.4.1 Coverage under an 'act committed' insurance policy ..................... 37

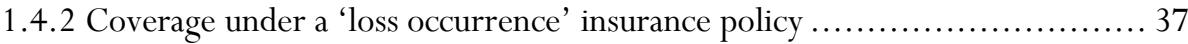

1.4.3 Coverage under a 'claims made' insurance policy ............................ 39

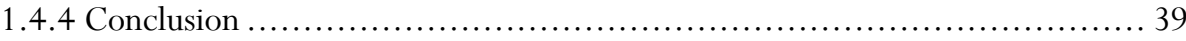

1.5 Examples and research objectives $\quad 40$

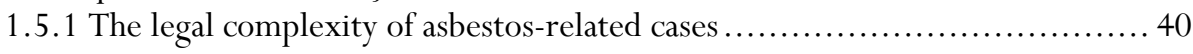

1.5.2 Research objectives .................................................. 42 


\section{Chapter 2: Causal Uncertainty in Asbestos- Related Cases: A Comparative Overview of Dutch and English Laws}

\section{PART ONE: INTRODUCTION TO DUTCH AND ENGLISH LAW ON LIABILITY}

2.2 Introduction to Dutch law 46

2.2.1 Grounds for liability in asbestos-related cases .......................... 48

2.2.1.1 Applying Article 7:658 BW after occupational exposure to asbestos .... 48

2.2.1.1.1 Requirements and rules of evidence.......................... 49

* Exposure to asbestos in the course of the employment ................... 50

* Damage for legal purposes? ........................................ 51

* A connection between the exposure to asbestos and the damage ............ 52

* A duty of care owed by the employer to the employee(s) ................. 53

2.2.1.1.2 Disputing causation ....................................... 57

2.2.1.1.3 Conclusion................................................. 58

2.2.1.2 Applying Article 6:162 BW after household, para-occupational or environmental exposure to asbestos ..................................... 59

2.2.1.2.1 Liability for products containing asbestos ...................... 60

2.2.1.2.2 Liability for para-occupational exposure to asbestos................6 62

2.2.1.2.3 Liability for environmental exposure to asbestos ................ 64

2.2.1.2.4 Conclusion................................................ 65

$\begin{array}{ll}2.3 \text { Introduction to English law } & 67\end{array}$

2.3.1 The Tort of negligence: a remedy for asbestos victims? .................. 70

2.3.1.1 Requirements to establish liability under the Tort of negligence ......... 70

2.3.1.1.1 The duty of care in asbestos-related cases ....................... 71

* A duty of care owed by the employer to the employee(s) ................ 72

* Non-employers' liability cases........................................ 73

* A duty of care owed by the employer to third parties .................... 75

2.3.1.1.2 The breach of the duty of care................................ 76

2.3.1.1.3 Damage .................................................. 76

2.3.1.1.4 Causation ........................................................ 77

2.3.2 Overall conclusion ................................................. 78 


\section{PART TWO: CAUSATION: A COMPARATIVE OVERVIEW OF DUTCH AND ENGLISH LAWS}

2.4 Causation 79

2.4.1 A conventional two-step approach to causation.......................... 80

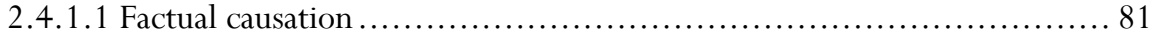

2.4.1.2 Legal causation ............................................... 83

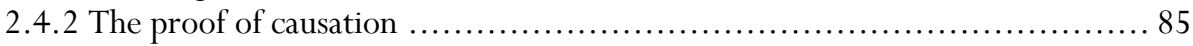

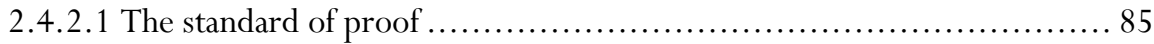

2.4.2.2 The burden of proof ......................................... 86

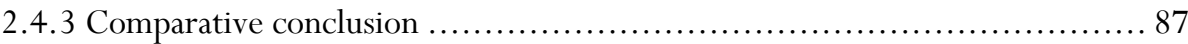

2.5 Critique on the condicio sine qua non (but-for) test and its all-or-nothing result $\quad 88$

2.5.1 The traditional principle of all-or-nothing compensation $\ldots \ldots \ldots \ldots \ldots \ldots \ldots . \ldots 8$

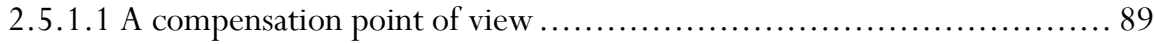

2.5.1.2 A prevention point of view ..................................... 89

2.5.1.3 Conclusion ................................................... 90

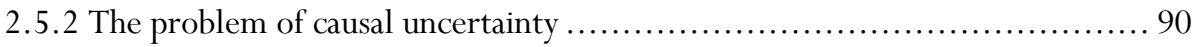

2.5.2.1 Uncertainty about the cause of the damage: multiple causation ......... 91

2.5.2.2 Uncertainty about the specific tortfeasor ......................... 92

2.5.2.3 Multiple causation and uncertainty about the tortfeasor ................ 93

2.5.2.4 Conclusion .................................................... 93

\section{PART THREE: CAUSATION PROBLEMS IN ASBESTOS-RELATED CASES}

2.6 Causal uncertainty in asbestos-related cases 93

2.6.1 The proof of causation and its consequences ........................... 95

2.6.2 Claims for mesothelioma ............................................... 96

2.6.2.1 Uncertainty about the specific tortfeasor ......................... 97

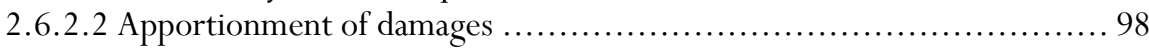

2.6.2.2.1 Dutch law: joint and several liability ......................... 99

2.6.2.2.2 English law: proportional liability or joint and several liability? ....100

* Fairchild v Glenhaven Funeral Services Ltd: joint and/or several liability? .. 100

* Barker v Corus: proportional liability in claims for indivisible mesothel-

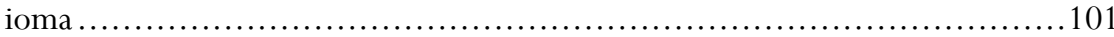

- Proportional liability in claims for divisible asbestosis..................... 104

* The Compensation Act 2006 ....................................... 105

* Sienciewicz v Greif (UK) Limited: joint and several liability ................106

2.6.2.3 Overall conclusion: claims for mesothelioma in Dutch and English laws107

2.6.3 Claims for lung cancer which could have been asbestos-related..............109

2.6.3.1 Uncertainty about the cause of the damage: multiple causation .........110

2.6.3.2 Dutch law: proportional liability ...............................111

2.6.3.2.1 Schaier/De Schelde: the first application of proportional liability ..111

2.6.3.2.2 Nefalit/Karamus: a smoking claimant .......................112

* The holding of the Dutch Supreme Court .............................114 
2.6.3.2.3 Hollink/Eternit: a non-smoking claimant ......................115

2.6.3.2.4 The Supreme Administrative Court ............................. 115

2.6.3.2.5 Attribution of factors ...................................... 116

2.6.3.2.6 Restrictions................................................... 116

2.6.3.2.7 Justification in legislation? ................................... 117

2.6.3.2.8 Some first conclusions on Dutch law ............................ 118

2.6.3.3 English law: partial liability ................................... 120

2.6.3.3.1 Badger v Ministry of Defence: lung cancer and asbestosis ..........120

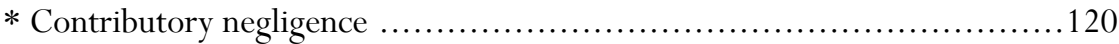

2.6.3.3.2 Shortell v Bical Construction Ltd: lung cancer in the absence of asbestosis ......................................................... 121

* The proof of causation ........................................... 122

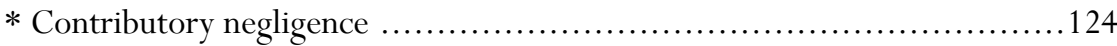

2.6.3.3.3 Some first conclusions on English law .........................124

2.6.3.4 Australian law: the far-reaching consequences connected to the English approach........................................................ 125

2.6.4 Multiple causation and uncertainty about the tortfeasor.................... 126

2.6.5 Claims for pleural plaques ......................................... 127

2.6.5.1 Pleural plaques without psychiatric illness or anxiety ................128

2.6.5.2 Pleural plaques with the risk of future illness or anxiety ...............129

2.6.5.3 Pleural plaques with clinical depression............................131

2.6.6 Overall conclusion................................................... 132

\section{Chapter 3: Solutions to the Problem of Uncertain Causation in Asbestos-Related Cases}

\section{PART ONE: PROPORTIONAL APPROACHES IN TORT LAW}

3.2 Damages in proportion to the probability of causation: proportional liability 137

3.2.1 Legal grounds for adopting proportional liability in Dutch law ...............138

3.2.2 Arguments in favour of proportional liability ..........................139

3.2.3 Critique and discussion............................................. 141

3.2.3.1 Possibility versus probability ..................................... 143

3.2.3.2 A problem of terminology: partial liability or proportional liability? ....144

3.2.3.3 The contribution of smoking ................................... 146

3.2.3.4 The problem of argumentation .................................. 146

3.2.3.5 The fear for far-reaching consequences ............................ 147

3.2.3.6 The claimant's predispostion .................................. 147 
3.2.3.7 Undermining traditional principles .................................149

3.2.4 Weighing the pros and cons ........................................ 149

3.2.5 Future developments and the effects of Nefalit/Karamus on other claims ....150

3.2.5.1 Multiple and single legal causal uncertainty ........................152

3.2.5.2 Applying proportional liability in specific non-asbestos-related

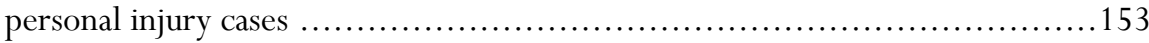

3.2.5.2.1 Claims for burn-outs and RSI............................... 154

3.2.5.2.2 Claims for lung injuries which could have been caused by exposure to tobacco smoke ................................................. 155

3.2.5.2.3 Claims for ionizing radiation exposure........................ 157

3.2.5.3 Conclusion .................................................... 160

3.3 Contributory negligence as a tool to reduce the total amount of damages 161

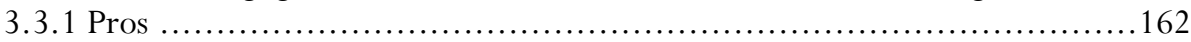

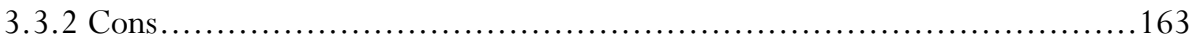

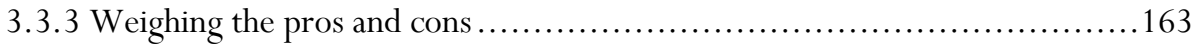

$\begin{array}{ll}3.4 \text { The loss of a chance theory } & 164\end{array}$

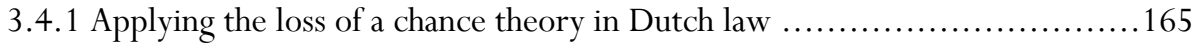

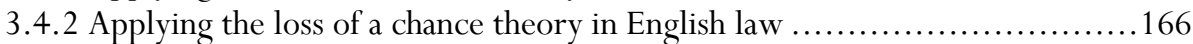

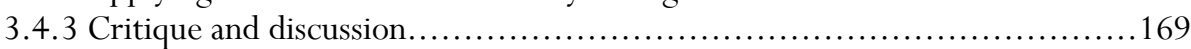

3.4.4 Conclusion .................................................... 170

$\begin{array}{ll}3.5 \text { Market-share liability } & 171\end{array}$

3.6 Overall conclusion 173

\section{PART TWO: ALTERNATIVE SOLUTIONS IN TORT LAW}

3.7 Setting aside the requirement of causation $\quad 175$

3.8 Expanding the notion of causation 176

3.8.1 Claims for mesothelioma .......................................... 177

3.8.1.1 The limits of the Fairchild-principle ............................. 180

3.9 The duty to provide an extra motivated pleading $\quad 182$

3.10 Adaptation of the traditional requirements 183

3.11 Reversal of the burden of proof 184

3.11.1 Dutch law ...................................................... 184

3.11.2 English law ..................................................... 185

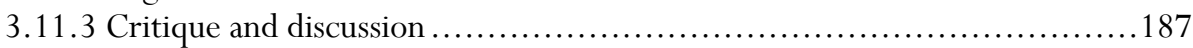

3.12 Conclusion 188

\section{PART THREE: ALTERNATIVES TO TORT LIABILITY}

3.13 Alternative schemes to compensate asbestos victims: a comparative overview $\quad 190$ 3.14 Mesothelioma 191

3.14.1 The Belgium jurisdiction: an Asbestos Fund ............................ 191

3.14.2 The Dutch jurisdiction: an Institute for Asbestos Victims ................... 194

3.14.2.1 TAS-scheme.............................................. 195 


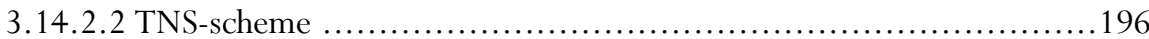

3.14.3 The English jurisdiction: two government schemes ........................ 197

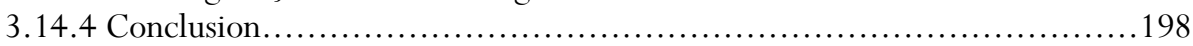

3.15 Lung cancer that could have been asbestos-related 200

3.15.1 A compensation scheme for lung cancer?...........................201

$\begin{array}{ll}3.16 \text { Overall conclusion } & 203\end{array}$

\section{Chapter 4: The Assessment of the Probability of Causation and the Role of Experts in Asbestos- Related Cases}

4.1 Chapter introduction 205

4.2 The appointment of experts in Dutch and English laws 206

4.2.1 The appointment of experts in asbestos-related cases....................209

4.3 The assessment of the probability of causation in claims for lung cancer that could have been asbestos-related $\quad 210$

4.3.1 An assessment of the claimant's cumulative exposure to asbestos ............211

4.3.2 The relative risk and risk coefficient ...................................214

4.3.2.1 The interaction between smoking and exposure to asbestos............216

4.3.2.2 The impact of different fibre types in the development of lung cancer ..219

4.3.2.3 Genetic predisposition ......................................220

4.3.3 A formula to determine the Probability of Causation ......................221

4.3.4 The assessment of the probability of causation in case law ...................222

4.3.4.1 A smoking employee: Nefalit/Karamus ..........................222

4.3.4.2 A non-smoking employee: Hollink/Eternit.........................224

4.3.4.3 Conclusion .................................................... 225

4.4 Transferring epidemiological findings to legal judgments in individual cases 226

4.4.1 The 'fairness-correction' as a tool to include normative elements............228

4.5 Proportional liability and the findings of experts: solutions to miscommunication 230

4.5.1 The formulation of questions for the expert............................. 232

4.5.2 Methods to determine the reliability of expert evidence ....................234

4.5.2.1 A checklist to determine the reliability of expert evidence .............234

4.5.2.2 Disclosure of information on the expert's expertise ...................235

4.6 Overall conclusion 239 


\section{Chapter 5: Conclusions}

Bibliography

Cases

Samenvatting

Summary

Curriculum Vitae

293

List of Publications 



\section{Acknowledgements}

Dit proefschrift is het resultaat van een vijf jaar durende aanstelling bij de Universiteit Maastricht. Terugkijkend op deze periode realiseer ik mij dat ik veel heb geleerd van het geven van onderwijs, een unieke kans heb gekregen om samen te mogen werken met de crème de la crème van de academische wereld, een mooi netwerk heb kunnen opbouwen, mijn creatieve geest heb mogen ontplooien en mij - ook op persoonlijk vlak verder heb kunnen ontwikkelen. Ik wil van deze gelegenheid gebruik maken om een aantal mensen te bedanken, die mij in deze periode hebben bijgestaan en mede verantwoordelijk zijn voor het tot stand komen van dit proefschrift. Na een korte brainstormsessie ben ik echter al snel tot de conclusie gekomen dat het onmogelijk is om iedereen in dit voorwoord een speciale vermelding te geven. Desalniettemin ben ik aan hen die een wezenlijke bijdrage hebben geleverd aan dit proefschrift een woord van dank verschuldigd.

Cliché, doch op zijn plaats, bedank ik allereerst mijn beide promotoren: Gerrit van Maanen en David Townend. Gerrit, ik wil je bedanken voor je inzet gedurende het gehele traject en het vertrouwen dat je mij bij elke bespreking hebt gegeven. Jouw deur stond altijd voor mij open en je snelle kritische reflecties op mijn werk zijn van aanzienlijke waarde geweest. Van jouw to the point benadering met veel oog voor de praktijk kunnen andere academici nog veel leren. Ook delen wij de passie voor paarden, honden, landgoederen en 'hooien': bouwstenen voor een zeer plezierige samenwerking!

David, moving from Sheffield to Maastricht with your family is a big step in life, but I am very grateful that you did it. I want to thank you for your typical English politeness and our interesting discussions on several legal and non-legal topics. You made me realize that philosophy is - indeed - part of law. It has been a pleasure to work with you and hopefully you will sing a song for me someday!

Nathan and Sarah Cooper, I want to thank for making me part of your life in Sheffield and for the delicious meals. You made me feel at home and our discussions about 'SouthAfrica', 'what to cook on Boxing Day', and 'the Amazon' will always be remembered. I wish the 'family Cooper' all the best.

David Cass and Adrian Budgen, I want to make use of this opportunity to thank you for our fruitful cooperation at Irwin Mitchell in Sheffield. You showed me the practical sight of my work and I now realize that solicitors can make the difference in claims for asbestos-related diseases. 
Ik wil alle collega's van het Department of Health, Ethics and Society (HES) enorm bedanken. Jullie verschillende achtergronden hebben tot interessante discussies geleid en hebben mij laten inzien dat juridische vraagstukken ook vanuit andere perspectieven moeten worden bezien. Een speciale vermelding ben ik verschuldigd aan mijn kamergenoten Lisette Bongers en Laurens Landeweerd. Lisette, je bent drie jaar lang mijn kamergenote geweest en ik had me geen fijnere kamergenote kunnen wensen! Ik wens je veel succes met het afronden van je eigen proefschrift, hoop dat je de planten op de vensterbank voldoende water blijft geven, en ga onze leuke gesprekken zeker missen. Laurens, jij drinkt de koffie het liefst zo sterk mogelijk. Ik wil je bedanken voor je 'raar maar waar' of 'waar maar raar' verhalen en onze gedeelde passie voor het kopen van een vervallen boerderijtje in Frankrijk.

Rankie ten Hoopen, van jou heb ik in de afgelopen vijf jaar ontzettend veel geleerd. Ik kijk terug op een zeer plezierige samenwerking en heb veel bewondering voor je niet te evenaren parate kennis en werkmentaliteit. Mede door jou deel ik nu de passie voor het gezondheidsrecht.

Ik wil mijn medische medepromovendi bedanken voor de gezellige lunches, shakes, leuke borrels en goede gesprekken. Samefko Ludidi, Daniel Keszthelyi, Guy Vijgen en Mark van Avesaat, het is mij toch gelukt om eerder klaar te zijn dan jullie. Maar treur niet, ik zal jullie mentaal blijven bijstaan bij het bereiken van deze mijlpaal. Laten we snel weer een drankje doen in de stad! Ik wil Sander Schoonbrood bedanken voor het organiseren van leuke feesten, waar iedereen elkaar weer kan treffen.

Mr. Luc Deschodt, Mr. Ronny Sassen en Mr. Frank Tilmans. Wij hebben samen gestudeerd en zoeken elkaar nog geregeld op. Ik waardeer jullie betrokkenheid bij mijn proefschrift en kijk uit naar leuke avonturen in Amsterdam, Roermond en Maastricht.

Michelle Wegter, studente aan de vertaalacademie te Maastricht. Ik wil je bedanken voor je waardevolle suggesties ten aanzien van het Engelse taalgebruik in dit proefschrift. Een cocktail heb je echter nog te goed. Laten we bij dezen afspreken dat ik niet alleen jou, maar ook je vriend Bas Kardaun zal trakteren op een cocktail.

Joeri Sobczak, Melanie Wolffs en Bas Pi van de Venne. Jullie laten zien dat het schrijven van een proefschrift niet ten koste hoeft te gaan van een goede familieband. Het voelt goed dat ik weet dat jullie altijd voor mij klaar zullen staan.

Robert Janssen en Sjacko Sobczak. Robert, zonder al die stimulerende gesprekken bij Hein en Marlies zou ik geen rechten zijn gaan studeren en zou dit proefschrift niet hebben bestaan. Jouw enthousiasme voor het recht en de advocatuur werkt aanstekelijk. Sjacko, jij bent zelf gepromoveerd en hebt mij voor de eerste keer meegenomen naar de Universiteit. Jij bent mijn rolmodel en ik kan me geen fijnere persoon wensen om levensvragen mee te bespreken. 
Uiteraard krijgen mijn paranimfen Cas Sobczak en Samefko Ludidi een speciale vermelding in dit voorwoord. Cas, mijn lieve tweelingbroertje, in de praktijk ben jij de dokter, maar jij hebt de waardigheid van 'doctor' (nog?) niet verworven. Het ligt voor de hand dat je mij nu altijd gelijk gaat geven in onze urendurende discussies over onderwerpen die voor ons van grote waarde zijn! Samefko, bedankt voor je creatieve cover ideeën. Ik ken jou al vanaf de brugklas en vanaf dat moment hebben onze paden zich steeds gekruist: we hebben beiden in Maastricht gestudeerd en hebben beiden besloten om onze verdere academische vorming voort te zetten in Maastricht. Waar anderen zich kunnen irriteren aan jouw altijd gedetailleerde besprekingen van dingen die jij hebt meegemaakt, geniet ik enorm. Ik kan mij geen betere paranimf wensen!

Mam, jij bent mijn bron van inspiratie en ik bewonder jouw doorzettingsvermogen. Jij stimuleert alles dat ik doe en bent de drijvende kracht achter dit proefschrift. Ik ben trots op mijzelf met het behalen van dit resultaat, maar ik weet dat jij en pap nog trotser zijn. Pap, ik vind het heel erg jammer dat jij dit niet mee hebt mogen maken!

Last but not least, een speciaal woord van dank aan mijn vriendin Nina Kardaun. Nina, wij zijn al meer dan zeven jaar samen en delen dezelfde passies. Alles is met jou bespreekbaar en je staat achter elke beslissing die ik neem. Ik ben jaloers op je grote relativeringsvermogen en hoop dat ik nog veel mag schrijven met jou aan mijn zijde! Ik wil ook je ouders, George en Patricia Kardaun bedanken voor hun openhartigheid, positiviteit en lekkere maaltijden. 



\section{Chapter 1}

\section{Introduction}

\subsection{Introduction}

Mr Karamus was wrongfully exposed to asbestos in the course of his employment from 1964 till 1979. In 1997, Mr Karamus developed lung cancer and he died from the consequences of that disease in 2000. The lung cancer was a potential consequence of exposure to asbestos. However, it was also possible that the lung cancer was caused by his 28 years of heavy smoking, his genetic predisposition, external causes, and/or simply by ageing. The case of Mr Karamus' lung cancer posed a very difficult question for Dutch Tort law ${ }^{1}$ which will resonate in other jurisdictions: is it fair to deny all compensation or to award full compensation (through an all-or-nothing scheme) when the actual cause of lung cancer cannot be specifically determined?

A comparable question can be raised in other asbestos-related cases, such as the English case of Mr Fairchild who died from the consequences of mesothelioma in 1996 after he had been exposed to asbestos in several different employments. In cases of mesothelioma causal uncertainty could arise as to the identity of the specific tortfeasor who has caused the mesothelioma to begin forming. Asbestos is the only known cause to contract this disease, which means that no uncertainty arises as to the cause of the damage. ${ }^{2}$ In these particular cases the claimant is, however, unable to identify which particular tortfeasor, in a group of possible tortfeasors, has caused his damage. The case of $\mathrm{Mr}$ Fairchild posed a very difficult question for English Tort law ${ }^{3}$, and this is also a problem for other jurisdictions: is it fair to deny all compensation or to award full compensation in cases where the claimant is unable to prove whether employer ' $A$ ' or employer ' $B$ ' has caused the mesothelioma to begin forming?

\subsubsection{The rising number of asbestos victims and claims for asbestos-related diseases}

Scientists who specialise in epidemiological research on asbestos-related injuries in the Netherlands have estimated the number of asbestos victims for the period 1996-2030. The shocking research results were published in 1997 and revealed that, in the Netherlands alone, almost 40,000 persons will develop an asbestos-related injury during this

\footnotetext{
${ }^{1}$ Hoge Raad 31 maart 2006, NJ 2011, 250 (Nefalit/Karamus).

${ }^{2}$ Lemen et al. 1980 , p. 8: None of the epidemiological studies have shown an increase of mesothelioma among smokers as compared to non-smokers.

${ }^{3}$ Fairchild v Glenhaven Funeral Services Ltd, [2002] UKHL 22.
} 


\section{Chapter 1}

particular period. ${ }^{4}$ Taking into account the long latency period, between the exposure to asbestos and the development of the injury, and the seriousness of asbestos-related diseases, it is most likely that another 20,000 Dutch citizens will die in the coming 35 years as a consequence of negligent exposure to asbestos in the past. ${ }^{5}$ According to other prominent research, some 19,000 Dutch men will die from the consequences of asbestos-related lung cancer during the period 1996-2035. ${ }^{6}$

The asbestos problem could thus be seen as a 'long-tail' risk and, because of the serious consequences, the rising number of asbestos victims is an extremely disturbing development within our society. ${ }^{7}$ In order to better understand the intensity and consequences of this problem, I will discuss more alarming data. At this moment, more than 600 Dutch citizens are diagnosed with a fatal case of mesothelioma. ${ }^{8}$ Although the storage and processing of asbestos has been banned in the Netherlands since 1993 and has been banned in Europe since $2005^{9}$, because of its long incubation period, the number of victims diagnosed with asbestos-related injuries will increase drastically in the coming 15 years and is predicted to reach a peak of approximately 700 mesothelioma sufferers per year in about 2018. ${ }^{10}$ These figures put the Netherlands in the third place in Europe when it comes to cases of mesothelioma per inhabitant. ${ }^{11}$

The situation in the United Kingdom $\left(\mathrm{UK}^{12}\right)$ is worse, even though blue and brown asbestos has been banned since 1985: the number of deceased mesothelioma victims will reach a peak of 2,540 deaths per year in 2015 approximately. ${ }^{13}$ It is predicted that in total almost 90,000 people will die in the UK from the consequences of mesothelioma. ${ }^{14}$ The rising number of asbestos victims is extremely disturbing for English society, especially when we take into consideration that the abovementioned data on mesothelioma does not include persons who suffer from other asbestos-related diseases, such a lung cancer which could have been asbestos-related and asbestosis. Research shows that in the UK approximately 3,500 persons die from the consequences of asbestos exposure per year. ${ }^{15}$ Although nowadays the use, production, and shipment of asbestos is forbidden in all European countries, some Third World countries still use and produce asbestos-

\footnotetext{
${ }^{4}$ Burdorf et al. 1997a, p. 1-77.

${ }^{5}$ See for example: Rechtbank Haarlem 1 april 2009, LJN: BI1010; Rechtbank Almelo 4 juni 2008, LJN: BD3218; Rechtbank Almelo 2 oktober 2007, LJN: BB4632; Gerechtshof Arnhem 5 juni 2007, LJN: BA3664; Baas et al. 2005, p. 759-763.

${ }^{6}$ De Ruiter 1997, p. 63. This research is known as the: 'De Ruiter Report'. See also: Burdorf et al. 2003, p. 485: 'In the Netherlands, a country with one of the highest incidences of mesothelioma, the most plausible scenario predicts an increase in pleural mesothelioma mortality among men from nearly 300 cases in 2000 to 490 cases in 2017 and a total death toll close to 12400 cases during 2000-2018.'

${ }^{7}$ The highest number of Dutch citizens suffering from an asbestos-related injury can be expected between 2015-2022.

${ }^{8}$ www.asbestslachtoffers.nl [Last visited 31 August, 2012].

${ }^{9}$ Directive 1997/77/EG.

${ }^{10}$ Burdorf et al. 1997b, p. 1093-1098.

${ }^{11}$ Montanaro et al. 2003, p. 191-803.

${ }^{12}$ United Kingdom: England, Scotland, Wales and Northern Ireland.

${ }^{13}$ Control of Asbestos Regulations 2006. White asbestos was banned in 1999.

${ }^{14} \mathrm{http}$ :/ / www.irwinmitchell.com/search/pages/newsviewer.aspx?f=item145.aspx [Last visited 31 August, 2012].

${ }^{15}$ http: / / www.allaboutasbestos.co.uk/dutyofcare.html [Last visited 31 August, 2012].
} 
containing materials. ${ }^{16}$ In such countries the negative consequences that asbestos has on the health of their citizens will last for a very long time.

Anger is often the first reaction after someone has been diagnosed with an asbestosrelated injury. ${ }^{17}$ Depending on the source of the exposure, asbestos victims - who have become cancer patients - blame their employer(s), asbestos factories ${ }^{18}$, and the government for not taking sufficient precautionary measures to prevent them from suffering health damage. ${ }^{19}$ Besides their physical distress, these victims also have to handle complex medical and financial issues while asbestos victims and their relatives are already stressed out and in pain. Nowadays, many lawsuits are filed against the companies who are responsible for the wrongful exposure to asbestos and even more claims are about to come. Because these claims are managed, in many jurisdictions, through the tort system, they can become costly disputes in terms of money, time, and emotion. The starting point for this research is, in part, a need to respond to problematic issues within tort regimes: the increase in the number of claims, and the technical legal difficulties posed by the medical nature of asbestos-related diseases, particularly their causes.

\subsubsection{Causal uncertainty in asbestos-related cases}

Generally, the Netherlands and England both require the claimant to prove a causal link between the defendant's intervention and the claimant's damage, in order to establish the liability of the defendant. In most claims in Tort, the assessment of causation results in a simple yes or no answer. In asbestos-related cases in which the claimant contracted lung cancer as a potential consequence of asbestos exposure the assessment of causation can, however, only be based on a probabilistic basis. In such cases causation is expressed in terms of 'probabilities' and 'percentages'. Epidemiological findings are used in individual cases to determine the probability that asbestos caused the claimant's lung cancer. Proving the causal link between the exposure to asbestos and the development of lung cancer, is a significant hurdle to take for the claimant. Identifying whether the asbestosrelated injury is caused by the exposure to asbestos in the course of the employment or by interference from external causes is an unanswerable question by definition. Medical science is unable to determine the cause of the injury in cases where the exposure to asbestos could have caused the claimant's lung cancer, and cannot identify the specific tortfeasor who has caused the injury in cases where two or more employers have exposed the claimant to asbestos in several different employments. ${ }^{20}$ Moreover, causal uncertainty could also arise in claims for mesothelioma in which one employer has nonwrongfully (for example: during 1940-1958) and wrongfully (for example: during 1960-

\footnotetext{
${ }^{16}$ For example in countries such as: India, parts of Africa, and parts of South-America. The situation in Canada, although this is not a Third World country, concerns me as well because the asbestos industry still produces chrysotile.

${ }^{17}$ Hughes \& Arber 2008, p. 66-71.

${ }^{18}$ See for example: Hoge Raad 25 november 2005, LJN: AT8782 (Nieborg-Horsting/Eternit); Rechtbank Rotterdam 24 april 2009, LJN: BI8604.

${ }^{19}$ Governmental liability for asbestos-related diseases has been extensively discussed in Ruers 2012 and will not be subject to discussion in this thesis research.

${ }^{20}$ Keep in mind that these questions of causation are central to the fair attribution of responsibility and liability.
} 


\section{Chapter 1}

1970) exposed his employee to asbestos in the course of the employement. The latter problem of uncertain causation will, however, not be further examined in this thesis research because case law is very clear on this point. ${ }^{21}$ Asbestos-related cases have, due to its complexity, proved to be an incentive in the development of Tort law and as a case study to detect and extent the possibilities for compensation in situations where the claimant is unable to prove the requirement of causation. ${ }^{22}$

The Netherlands is, however, not the only country that has to deal with this expanding social and legal problem. As stated above, research shows that England also experiences a growing number of asbestos victims and it has been acknowledged that judges encounter similar problems when deciding asbestos-related cases. Furthermore, causal uncertainty as such, is a problem lawyers and judges encounter worldwide. In addition, it is important to note that the problem of uncertain causality not only arises in cases concerning the liability for asbestos-related injuries but is present in all areas of Tort law, for example in medical malpractice cases and cases concerning the liability for other occupational diseases. ${ }^{23} \mathrm{~A}$ just, clear, and correct way of handling the problem of causal uncertainty is of the utmost importance in order to reach the most reasonable outcome for both the claimant and the defendant. Do the two jurisdictions considered here apply different rules of evidence to establish causation in asbestos-related cases and what could law offer to asbestos victims in order to improve their legal position? Is it in these particular cases desirable to award compensation in proportion to the probability of causation or should we rather stick to the traditional principle of all-or-nothing compensation?

\subsubsection{Judges and epidemiological experts: lost in translation?}

The establishment of causation in asbestos-related cases involves a multidisciplinary interaction between judges and experts. In these particular cases judges are faced with legal questions which cannot be resolved without the help of experts. Judges do not have the relevant experience or qualification to assess the probability that asbestos exposure has caused the claimant's damage. In asbestos-related cases, the judge calls on expert opinion to assess the likelihood that a given activity (exposure to asbestos) causes a known damage (lung cancer). It is very clear that judges and experts do not speak the same 'language' and, as a consequence, this cross-disciplinary discussion can lead to miscommunication. In most asbestos-related cases it seems as if judges do not know or do not understand the basic assumption of the research done by the expert (witness) because most, if

\footnotetext{
${ }^{21}$ Hoge Raad 25 juni 1993, NJ 1993, 686, paragraph 3.8.4 (Cijsouw/De Schelde 1). See also: Waterman 2009, p. 340. The Supreme Court established the liability of De Schelde and ruled that employers could be held liable for unknown risks in cases where they have breached their duty of care to prevent employees from contracting known risks (asbestosis) connected to asbestos exposure.

${ }^{22}$ Lindenbergh 2005, p. 39.

${ }^{23}$ Here, one could also think of the uncertainties surrounding climate change liability. See: Haritz 2010. See for medical malpractice cases: Rechtbank Utrecht 8 december 2010, LJN: BO6888; Rechtbank Amsterdam 14 juli 2010, LJN: BO3288; Gerechtshof Amsterdam 4 januari 1996, NJ 1997, 213 (Baby Ruth); Gerechtshof Arnhem 24 juni 1997 en 14 december 1999, NJ 2000, 742; Gerechtshof 's-Gravenhage 10 oktober 2002, NJ 2003, 99; Gerechtshof Arnhem 17 januari 2006, JA 2006, 37. See for more information on causal uncertainty in medical informed consent cases: Hendrix \& Akkermans 2007, p. 498-515; Informed consent cases always give rise to causal uncertainty. See for an overview of informed consent cases in a comparative perspective: Akkermans 2007, p. 433-442; Paz Garcia Rubio 2004, p. 443-449; Hyslop 2008, p. 629-644.
} 
not all judges are not schooled in analyzing epidemiological and statistical data. ${ }^{24}$ This is an alarming development since the recently applied proportional liability theory depends almost completely on the findings of the appointed experts. Work is needed to ensure that the judiciary and lawyers are familiar with which conclusions can and cannot be drawn from the expert evidence, and that evidence must be presented in simple, clear ways to avoid confusion. Therefore, the role of experts and the use of epidemiological data to assess the probability of causation in claims for lung cancer that could have been asbestos-related will be extensively examined in Chapter 4 .

\subsection{The chemical nature of asbestos fibres and sources of exposure}

Taking into consideration the subject of this research one should, from my point of view, first examine asbestos in all its aspects before one is capable to write a comparative dissertation on: 'Liability for Asbestos-Related Injuries'. Today most people know that asbestos exposure is dangerous and can lead to negative health effects. However, if you subsequently ask them to distinguish the negative health effects between different asbestos-related diseases, or between different kinds of asbestos and sources of exposure, most people remain rather quiet as they do not have a detailed knowledge of the area. Most lay people only know that being exposed to asbestos can lead to lung damage. They are correct because it is widely accepted knowledge that exposure to asbestos can cause different types of lung cancer, but the issue is much more complex. The following sections of this thesis, therefore, addresses the nature of asbestos and the medical issues in asbestos exposure, albeit from my perspective as a lawyer who has sought to educate himself in this area. ${ }^{25}$ In order to explore and clarify the causal link between exposure and the asbestos-related injury, I will first consider factors which also (should) influence the liability of the defendant, such as: the chemical nature of asbestos fibres, the source of the exposure to asbestos, and the asbestos-related injury itself.

\subsubsection{The chemical nature of asbestos fibres}

'Asbestos' is Greek for unquenchable ${ }^{26}$ and is: 'a generic term for several different mineral silicates, usually from open mines. It is classified into two groups: 1 . the serpentines,

\footnotetext{
${ }^{24}$ This could lead, and has already led, to (mis)communication problems and, more disturbing, to incorrect judgments. See for an example outside the area of asbestos claims: Rechtbank Maastricht 13 juli 2005, JA 2006, 44: In this case a man was bitten in his hand by a dog. Instead of cleaning the wound and leave it open, the physician glued and closed the wound. Subsequently, the patient developed dystrophy. In court, the specialist stated that normally (following the correct procedure) the chance on dystrophy is $1-2 \%$. Because of the physician following the wrong procedure, the chance on dystrophy had risen to $2-4 \%$. In view of the judge, this means that - at worst - the malpractice caused a 3\% (4 minus 1) higher risk on dystrophy. This percentage is too little to assume sufficient causation. However, they should have judged that there is a $50 \%$ chance (attributable risk) on a causal relation between the medical malpractice and the dystrophy. Had they applied the instrument of proportional liability, the judge should have awarded $50 \%$ of the damages. This is a perfect example of miscommunication between judges and experts and judges not knowing how to use epidemiological and statistical evidence. See for more examples in case law: Rechtbank Amsterdam 14 juli 2010, JA 2011, 4; Gerechtshof 's-Gravenhage 28 april 2009, LJN: BI4768. See also: Van \& Wijne 2012, p. 16-24; Van Velthoven 2011, p. 29, 36; Van Dijk 2010, p. 106, 107; Lindenbergh 2006, p. 741.

${ }^{25}$ See for a medical acceptance: Beers et al. 2003, p. 297. See for a legal acceptance: Hoge Raad $31 \mathrm{maart}$ 2006, NJ 2011, 250 (Nefalit/Karamus); Fairchild v Glenhaven Funeral Services Ltd, [2002] UKHL 22.

${ }^{26}$ Dutch translation: 'Onuitblusbaar'.
} 
which include chrysotile (white asbestos); and 2. amphiboles, which include crocidolite (blue asbestos), amosite (brown asbestos), tremolite, anthophyllite, and several other minerals not used for commercial purposes. Asbestos is composed of fibres of varying sizes- many of which are very small, depending on the type of asbestos and how it has been processed.' Planteydt also states that: 'the remarkable properties of asbestos (i.e., that it is fire proof, insulates and has an enormous tensile strength) has led to its use in more than 3.000 products. ${ }^{27}$

This description of asbestos remains, for legal experts, difficult to understand since most, if not all legal experts ${ }^{28}$, are not schooled in analyzing issues concerning mineral silicates. From a legal perspective it is, however, important to note that mineral silicates can be classified into two groups and that white asbestos belongs to another group than blue and brown asbestos. Why is it important to distinguish different types of asbestos? The answer is relatively simple: not all asbestos fibres have the same impact in causing harm to the lungs of the exposed person. Whether or not a person exposed to asbestos will contract an asbestos-related injury could depend on the specific fibres inhaled by the person concerned. The chemical nature of the inhaled asbestos fibres is an important medical and legal factor: white asbestos seems to be less dangerous than blue or brown asbestos. Blue asbestos is a thicker, relatively straight fibre that is extremely stable in the lungs. These fibres are long and needle-like, which makes it hard for the body to expel the fibres from the lungs of the exposed person. Blue asbestos is, due to its shape, highly associated with mesothelioma, which is a fatal type of lung cancer. ${ }^{29}$ Mesothelioma will be explained more extensively in section 1.3.2.

Very few cases of mesothelioma caused by pure chrysotile have been described in medical literature. A possible explanation is that white asbestos does not have the same chemical nature and shape. ${ }^{30}$ Unlike blue and brown asbestos belonging to the amphiboles, which fibres are long and needle-like, white asbestos belongs to the serpentines, which fibres are curly and pliable. ${ }^{31}$ The curly shape of white asbestos fibres makes it easier for the body to expel the fibres from the lungs of the exposed person. An overview of the abovementioned terms relating to asbestos can be found on the following page to clarify the differences:

\footnotetext{
${ }^{27}$ Planteydt 1991, p. 56-59.

${ }^{28}$ I have no intention to treat all legal experts alike.

${ }^{29}$ Hart \& Aberle 1996, p. 92.

${ }^{30}$ Planteydt 1991, p. 56-59.

${ }^{31}$ Light \& Gary Lee 2003, p. 436.
} 


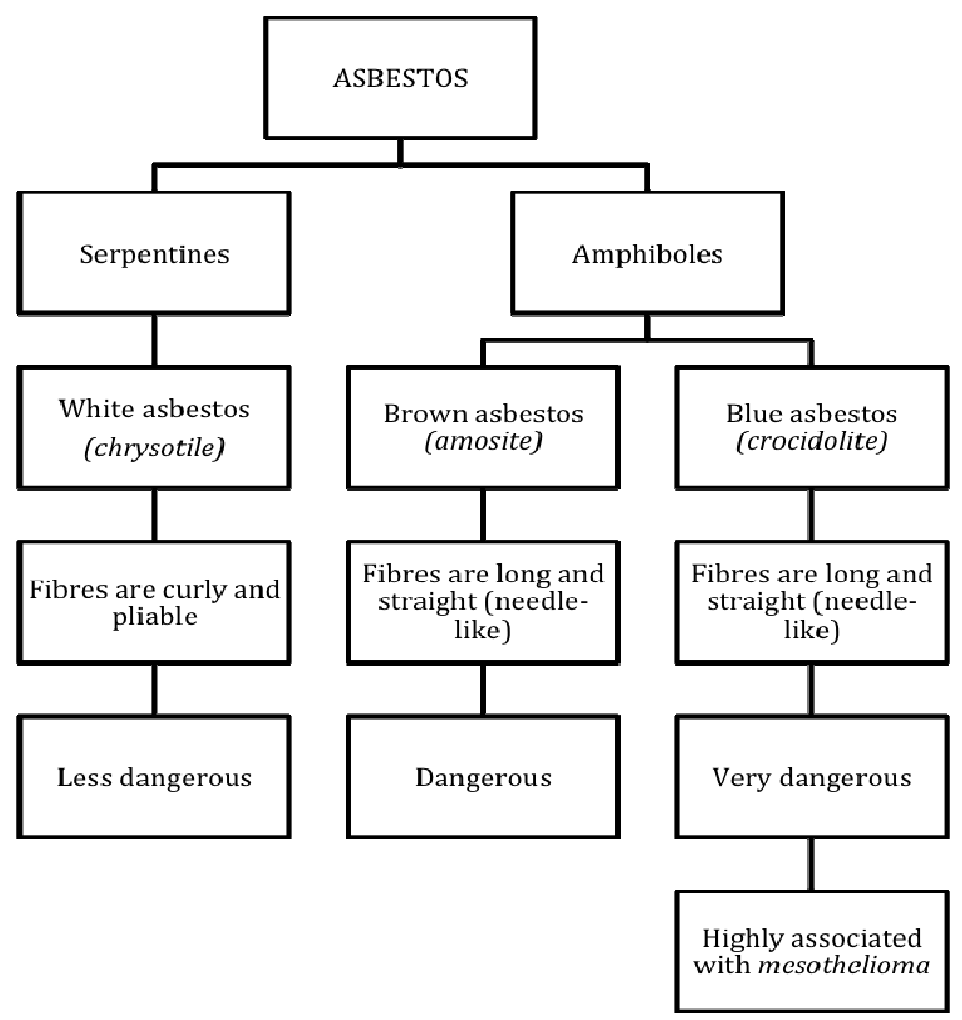

Another important fact in Planteydt's description of asbestos is that, between 1900 and the mid-1980s, asbestos was used in over 3,000 products, which suggests that many products still exist that contain asbestos fibres. ${ }^{32}$ An alarming development is that asbestos is often associated with a problem that had disappeared since asbestos was banned completely in the Netherlands (1993) and in England (1985: blue and brown asbestos). ${ }^{33}$ The consequence is that asbestos is often regarded as a real risk for a previous generation. The younger generation starting to work in the construction industry could think this risk does not apply to them, but it does. If they work on buildings built before 1985 (in England) or 1993 (in the Netherlands) it could still contain asbestos fibres. ${ }^{34}$ This risk to be exposed to asbestos fibres also counts for individuals who renovate their own properties. Many properties still contain asbestos materials. Younger generations must be made aware of potential dangerous buildings and products that contain asbestos in order to prevent health damage in the future. Therefore, providing adequate information on asbestos is still of the utmost importance in order to reduce the number of asbestos victims

\footnotetext{
32 See for a not exhaustive list of products which contain asbestos: http://www.mesotheliomacenter.org/about/asbestos-products.php [Last visited 31 August, 2012].

${ }^{33}$ Besluit Wijziging Asbestbesluit, Staatsblad 19-02-1993, p. 135; Control of Asbestos Regulations 2006: white asbestos was banned in 1999 .

${ }^{34}$ In England, the buildings built before 1999 could still contain white asbestos because white asbestos was banned in 1999 .
} 


\section{Chapter 1}

in the future. Moreover, the lack of information indicates that the liability issues surrounding asbestos will continue for the foreseeable future.

\subsubsection{Sources of exposure to asbestos}

Almost all European citizens have been exposed to asbestos during their lifetime. The exposure could, however, have taken place in various ways. From a medical and legal point of view it is important to note that exposure to asbestos does not automatically lead to an asbestos-related injury. Fortunately, most people who come into contact with asbestos do not get ill as a result or, to put it differently, do not develop an asbestosrelated injury at all. Some groups, however, have an increased chance to develop an asbestos-related injury, such as employees who have been exposed to asbestos in the course of their employment(s). ${ }^{35}$ However, not only occupationally exposed persons have an increased chance. In the last decades, case law shows an important structural development in claims for asbestos-related diseases. At first, only employees who had been exposed to asbestos in the course of the employment filed a lawsuit against their (former) employers. In the mid-1990s, however, a new category of asbestos victims found their way to court. Here, one might think of persons who have used asbestos materials to consolidate their farmyard or private roads or persons who have been exposed to asbestos by interference from external causes, such as domestic and environmental causes. ${ }^{36}$ Successful lawsuits have been filed against asbestos producing factories that sold or gave away materials which contained asbestos. ${ }^{37}$ Family members of asbestos workers have a higher risk of developing an asbestos-related injury as well. Courts in several countries have linked the development of mesothelioma under family members of occupationally exposed persons, with the asbestos-containing work clothes that the exposed employee took home after work. ${ }^{38}$ The latter situation will be subject to discussion in section 2.2.1.2.2.

\subsubsection{Occupational exposure to asbestos}

When picturing someone who suffers from an asbestos-related injury most people immediately think of an employee who has worked with asbestos in the course of his employment. $^{39}$ This assumption is correct: asbestos-related injuries are almost exclusively traceable to occupational exposure. ${ }^{40}$ Many employees in Europe have been occupationally exposed to asbestos during the period 1945-1985. If an employee has been exposed to asbestos in the course of his employment, a contractual relationship between employee and employer exists of existed. If the claimant has been occupationally exposed to

\footnotetext{
${ }^{35}$ Betlem \& Klinge- Van Rooij 1996, p. 166-167.

${ }^{36}$ Van der Laan 2005, p. 2422-2425; Sinninghe Damsté et al. 2007, p. 2453-2459.

37 Hoge Raad 25 november 2005, LJN: AT8782 (Nieborg-Horsting/Eternit); Gerechtshof Arnhem 27 februari 2007, LJN: AZ9763.

${ }^{38}$ Burdorf et al. 1997b, p. 29; Burdorf et al. 2003, p. 487; Rechtbank Almelo 27 januari 1999, VR 2000, 24; Rechtbank Amsterdam 24 maart 1999, VR 2000, 25.

${ }^{39}$ www.ilo.org [Last visited 31 August, 2012]: The International Labour Organization (ILO) has recognized asbestos-related lung cancer as an occupational disease.

${ }^{40}$ Gezondheidsraad 1999, p. 10.
} 
asbestos, the conditions to impose liability on the defendant are less demanding, which means that the claim for damages is more likely to succeed. ${ }^{41}$

Most legal systems require employers to protect the health and safety of their employees. If an employee has developed an asbestos-related injury, it is most likely that one or more rules to prevent the employee from encountering health damage have been ignored by the employer. ${ }^{42}$ Depending on the knowledge of the company about (the dangers of using) asbestos at the time of exposure, the employer had or had not exposed his employee wrongfully to asbestos in the course of the employment. ${ }^{43}$ The employer acted negligently when he knew or ought to have known that the exposure to asbestos was dangerous. In such a situation, the employer can be held liable for the claimant's damage unless the claimant fails to prove the other requirements to establish the liability of his employer. The applicable rules of evidence in such cases are examined in section 2.2.1.1.

\subsubsection{Household, para-occupational or environmental exposure to asbes- tos}

The fact that the exposure to asbestos in the course of the employment could have caused the claimant's asbestos-related injury does not imply that occupational exposure to asbestos is the only possible cause to develop such an injury. Exposure to asbestos is also possible outside the course of the employment. Here, one might think of persons who were exposed while washing the asbestos-containing work clothes that the asbestos worker took home after work, or persons who worked with products that contained asbestos fibres at home ${ }^{44}$, or even people who were exposed to asbestos in their living environment. ${ }^{45}$

The risk to contract asbestosis, mesothelioma, lung cancer, or another asbestosrelated injury is, for these so called 'para-occupationally', 'household', or 'environmentally' exposed groups, much lower when compared to occupationally exposed persons. ${ }^{46}$ However, there is an exception to every rule. Several studies conclude that environmental exposure to asbestos fibres in the area around Goor ${ }^{47}$ has been established as the cause of mesothelioma in women. ${ }^{48}$ In this area the incidence of mesothelioma in women is five

\footnotetext{
${ }^{41}$ When compared to a claim for non-occupational exposure to asbestos.

${ }^{42}$ Cancian- van Ballegooijen 2004, p. 8.

${ }^{43}$ See for a good explanation of the 'knowledge' factor: Rechtbank Almelo 13 oktober 2009, LJN: BK0098. In this case the employer (small company) could not be held liable because he should not ought to have known that exposure to white asbestos was dangerous at the time of the exposure (1966-1968).

${ }^{44}$ See for more information: Burdorf et al. 2003, p. 487. See for a good example of someone who developed mesothelioma after he worked with products which contained asbestos materials at home: Rechtbank Maastricht 16 april 2007, LJN: BA3241. See also Hoge Raad 25 november 2005, LJN: AT8782 in which the Dutch Supreme Court held the asbestos factory (producer) liable for the claimant's mesothelioma.

${ }^{45}$ Gerechtshof Arnhem 27 februari 2007, LJN: AZ9763 is the first successful claim in which the claimant established the liability of the defendant after he had been environmentally exposed to asbestos. See for a more extensive description on the liabilty for non- occupational asbestos exposure: Vloemans 2008, p. 3547; Meijer \& Lindenbergh 2008, p. 436-443; De Lang 2007, p. 57-62.

${ }^{46}$ Planteydt 1991, p. 56-59; Lemen et al. 1980, p. 7.

${ }^{47}$ The place where the Eternit factory was based.

${ }^{48}$ Sinninghe Damsté et al. 2007, p. 2453-2459.
} 
times higher than elsewhere in the Netherlands due to environmental exposure to asbestos. In men it is twice as high. ${ }^{49}$ This emphasizes the problem even more: asbestosrelated injuries are not only work-related.

\subsubsection{Conclusion}

Almost all European citizens have been exposed to asbestos during their lifetime. The chemical nature of the inhaled asbestos fibres and the source of the exposure to asbestos influences the likelihood that the asbestos-related injury was caused by the exposure to asbestos in the past. Not all asbestos fibres have the same impact in causing harm to the lungs of the exposed person. The shape of the asbestos fibres is an extremely relevant factor as well. Long, straight fibres seem to be more dangerous than short curled fibres. Therefore, white asbestos (chrysotile) is less dangerous than blue (crocidolite) or brown (amosite) asbestos. The source of the exposure to asbestos is also an important factor to the outcome of a civil liability claim: asbestos victims who have been exposed to asbestos in the course of their employment(s) have the opportunity of successfully establishing liability on the part of their employer(s) who owes them a duty of care. Although most asbestos-related injuries are exclusively traceable to occupational exposure to asbestos, there is a slight possibility that persons who have experienced a household, paraoccupational, or environmental exposure to asbestos will develop an asbestos-related injury. In the latter situation, the conditions to impose extra-contractual liability are more demanding because these victims do not have (an) obvious individual(s) who owes them a duty of care in relation to the exposure.

\subsection{Asbestos-related injuries and its medical and legal complexity}

Whether or not an asbestos-related injury is eligible for compensation also depends on the type of injury which the potential ${ }^{50}$ asbestos victim contracted. Victims suffering from an asbestos-related injury may experience symptoms ranging from minor irritations to very serious problems. Three distinct diseases are linked to asbestos exposure: asbestosis, mesothelioma, and lung cancer which may be asbestos-related. Lung cancer can take on various types of forms. Presently, medical science is able to isolate and name one particular form, Mesothelioma, but other forms are - except for a distinction in four histological types - not (yet) distinguished at this time. ${ }^{51}$

In addition to, and sometimes in combination with, these three well known diseases, exposure to asbestos can lead to the development of pleural plaques on the visceral pleura and sometimes the parietal pleura, that is, localised areas of pleural thickening with well demarcated edges. ${ }^{52}$ The Pleura are the covering of the lungs and inside of the chest walls. Pleural plaques often contain calcium, which makes them easy to see on chest X-

\footnotetext{
${ }^{49}$ Dogger 2006, p. 38.

${ }^{50}$ Here, I have used the word 'potential' because it is not always clear whether or not asbestos has caused the claimant's injury.

${ }^{51}$ Tossavainen 1997, p. 313: 'squamous, adeno-, large-cell and small-cell carcinoma.' See for more information: http://www.longkanker.info [Last visited 31 August, 2012]. See also Hoogsteden 1997, p. 58: Asbestos exposure can cause all forms of lung cancer.

${ }^{52}$ See for example: Gerechtshof 's-Hertogenbosch 6 mei 2008, LJN: BD5666; Rechtbank Middelburg 30 mei 2001, JAR 2001/232; Rechtbank Zwolle-Lelystad 30 mei 2007, zaaknr. 249185.
} 
rays. ${ }^{53}$ Clinical experience shows that, when pleural plaques are radiological detectable, there is nearly always a history of significant occupational exposure to asbestos. ${ }^{54}$ There is no consensus, however, whether finding pleural plaques indicates a minimum level of exposure. Furthermore, and perhaps most importantly for Tort law, current medical consensus seems to show that the presence of pleural plaques gives no indication of whether the individual will or will not develop lung cancer because of the exposure that they have had to asbestos. The general view is that the presence of pleural plaques does not indicate an increased risk of developing asbestos-related lung cancer, but it only confirms an exposure to asbestos. These pleural plaques do not become cancerous. ${ }^{55}$ According to the dominant view, pleural plaques do not cause any external symptoms, they only mark the presence in the lungs and pleura of asbestos fibres, which may independently cause life-threatening or fatal diseases, such as asbestosis, mesothelioma, or lung cancer. The liability for pleural plaques in Dutch and English laws will be examined in section 2.6.5.

My thesis research mainly focuses on the liability for mesothelioma or lung cancer which could have been asbestos-related. Asbestosis will be discussed in general, but particular emphasis goes to cases in which the claimant developed lung cancer which could have been, and in some cases could only be, asbestos-related. In order to assess the liability for asbestos-related injuries in the best possible way, a clear view in regard to the major asbestos-related diseases is required. Therefore, in the next section I start with examining and describing the abovementioned injuries. It is essential to understand (at least) some parts of the medical issues involved in the cases, from a legal point of view as well. The following subsections do not only provide medical information on the asbestos-related disease itself but also point out legal issues in general, such as the problem of causal uncertainty with regard to the cause and development of the specific injury. Keep in mind that knowledge on asbestos-related diseases is also based on statistical analysis and epidemiology. The literature cited in the footnotes provides further medical details.

\subsubsection{Asbestosis (divisible disease)}

Asbestosis is a chronic disease caused by the inhalation of high quantities of asbestos dust or fibres, and causes excess fibrous tissue to develop in the lungs of the exposed person. This scars the lungs and results in a severe loss of elasticity. Finally, the lung loses its ability to take up oxygen. This can cause abnormal chest sounds. The lung scarring eventually results in serious breathing problems, disability and death. Symptoms as breathlessness associated with a dry cough and a decreased ability to exercise are recognizable after 10-15 years after the exposure to asbestos and the symptoms appear gradually only when large areas of the lung have become scarred. In a person who has a history of exposure to asbestos, a doctor can diagnose asbestosis with a chest X-ray or a CT-scan that shows these characteristic changes.

Asbestos exposure is regarded as the only cause of asbestosis, which means that there is no connection between the inhalation of tobacco smoke and (the development of)

\footnotetext{
${ }^{53}$ Beers et al. 2003, p. 298.

${ }^{54}$ Hoogsteden 1997, p. 51-52.

${ }^{55}$ Beers et al. 2003, p. 296.
} 


\section{Chapter 1}

asbestosis. Most cases of asbestosis occur after exposure to high dust concentrations over many years. A certain 'dose' or level of exposure is required for the development of asbestosis. This means that a dose-response relationship is present in the development of asbestosis. ${ }^{56}$ Therefore, asbestosis is regarded as a cumulative (divisible) condition because a cumulative causal effect is present in such cases. The intensity and duration of the exposure seem to be of great importance: the greater and/or longer the victim has been exposed to asbestos, the greater the likelihood that the victim will develop asbestosis in the future. The severity of the disease is thus related to the quantity of asbestos that is ingested. ${ }^{57}$ There is also a strong association between asbestosis and lung cancer, and this is exaggerated in cigarette smokers. ${ }^{58}$ Approximately half of the patients with asbestosis die from a form of lung cancer. ${ }^{59}$ Most treatments for asbestosis only ease symptoms. Occasionally, lung transplantation has proven to be successful in treating asbestosis. ${ }^{60}$

\subsubsection{Mesothelioma (indivisible disease)}

Mesothelioma is a primary tumour of the mesothelium, which covers the serosal cavities of the pleura (covering the lungs and inside of the chest walls), the pericardium (covering the heart) and the peritoneum (covering the abdomen). The connection between asbestos exposure and mesothelioma has been described in medical literature since $1960 .{ }^{61}$ Other forms of mesothelioma, both benign and malignant, are rare and have no correlation to asbestos exposure. These other forms are not included in my thesis research because a causal link between the exposure to asbestos and the development of this specific disease, is missing completely. Mesothelioma is almost always caused by crocidolite ${ }^{62}$ or amosite $^{63}$. Very few cases of mesothelioma caused by pure chrysotile ${ }^{64}$ have been described in medical literature. However, chrysotile is often contaminated with tremolite and crocidolite, which can cause mesothelioma to begin forming. ${ }^{65}$ The type of fibre which is inhaled by the exposed person is thus regarded as a factor that influences the incidence of mesothelioma. Persistent chest pain, shortness of breath, and weight loss are the most common symptoms associated with mesothelioma. ${ }^{66}$ The majority of mesothelioma sufferers have evidence of pleural plaques which, as discussed in section 1.3, only confirms an exposure to asbestos in the past. ${ }^{67}$ Approximately twenty percent of the patients suffering from mesothelioma will have radiographic signs of asbestosis.

Medical science is able to prove that mesothelioma could start with the inhalation of one asbestos fibre, a few asbestos fibres, or many asbestos fibres. Mesothelioma is re-

\footnotetext{
${ }^{56}$ Hart \& Aberle 1996, p. 92; Burdorf \& Swuste 1999, p. 58.

${ }^{57}$ Sienciewicz v Greif (UK) Limited, [2011] UKSC 10, paragraph 14.

${ }^{58}$ Axford \& O' Callaghan 2004, p. 379.

${ }^{59}$ Gezondheidsraad 1999, p. 10, 11.

${ }^{60}$ Beers et al. 2003, p. 296-299.

${ }^{61}$ Wagner et al. 1960 , p. 260-271.

${ }^{62}$ Blue asbestos.

${ }^{63}$ Brown asbestos.

${ }^{64}$ White asbestos.

${ }^{65}$ Planteydt 1991, p. 56-59.

${ }^{66}$ Axford \& O' Callaghan 2004, p. 379.

${ }^{67}$ Sobczak et al. 2009, p. 207-217; Light \& Gary Lee 2003, p. 437.
} 
garded as a non-cumulative condition and is referred to as an indivisible disease. ${ }^{68}$ Unlike asbestosis, in which a dose-response relationship is present, mesothelioma has been reported with relatively trivial exposures, including environmental and household exposures. ${ }^{69}$ To put it differently: in cases of mesothelioma there is no safe exposure threshold. However, it has been established that the more asbestos fibres that are inhaled, the greater the risk of contracting mesothelioma. ${ }^{70}$ The period between the development of the first malignant cell and the point at which mesothelioma can be diagnosed is now thought to be at least 5 years. It is important to note that - during this period - further exposure to asbestos fibres will have no causative effect. ${ }^{71}$ The latency period, from the first exposure to asbestos until the manifestation of mesothelioma ${ }^{72}$, varies from 20 to 50 years. It has been established that the latency period is at least 10 years and at last 60 years. In a very few cases a latency period of less then 10 years has been reported in the literature. ${ }^{73}$ The long latency period also explains why patients suffering from mesothelioma come forward at an average age of $60 .^{74}$

Only in a small number of cases it has proven to be difficult to establish beyond doubt that the person concerned is indeed suffering from mesothelioma. ${ }^{75}$ Therefore, the Health Council of the Netherlands, which is the official body to advise the government on health issues, felt it necessary to emphasize the importance of a forum of experts in cases where, based on the information available, no consensus could be reached on the diagnosis. ${ }^{76}$ In around eighty percent of the cases, the diagnosis of malignant mesothelioma can be reached on the basis of a clinical-pathological examination of fluid extracted from the pleural cavity, or a biopsy of the pathological pleural tissue, which would be required if a radiographic examination of the lungs revealed abnormalities. ${ }^{77}$ In addition, the existence of mesothelioma can be established post mortem.

Unfortunately, mesotheliomas are generally very resistant to any form of therapy or treatment and are invariably fatal. Mesothelioma is a very serious disease: approximately eighty percent of the patients diagnosed with mesothelioma die within twelve months and only very few of them survive the second year. ${ }^{78}$ At this moment, no therapy has been demonstrated to prolong life or has been proven to be effective for the treatment of

\footnotetext{
${ }^{68}$ Sienciewicz v Greif (UK) Limited, [2011] UKSC 10, paragraph 19.

${ }^{69}$ Hart \& Aberle 1996, p. 99; Burdorf \& Swuste 1999, p. 58; Burdorf et al. 2003, p. 487.

${ }^{70}$ Sienciewicz v Greif (UK) Limited, [2011] UKSC 10, paragraph 19.

${ }^{71}$ Sienciewicz v Greif (UK) Limited, [2011] UKSC 10, paragraph 19.

${ }^{72}$ Mesothelioma that could be clinical diagnosed.

${ }^{73}$ Mossman \& Gee 1989, p. 1721-1730; Muscat \& Wynder 1991, p. 2263-2267.

${ }^{74}$ Souhami \& Moxham 2002, p. 717.

${ }^{75}$ Gezondheidsraad 1998, p. 16: 'The diagnosis of malignant mesothelioma can be reached in around eighty percent of cases on the basis of a clinical-pathological examination of fluid extracted from the pleural cavity, or a biopsy of the pathological pleural tissue, which would be required if a radiographic examination of the lungs revealed abnormalities.'

${ }^{76}$ Gezondheidsraad 1998, p. 17: This forum of experts should consist of experts specialized in lung diseases, industrial medicine, clinical pathology and occupational hygiene, possibly supplemented with experts in any other fields that may be necessary. In the Netherlands, a Dutch Mesothelioma Panel has been introduced consisting of pathologists with specific expertise on mesothelioma.

${ }^{77}$ Gezondheidsraad 1998, p. 16.

${ }^{78}$ Bol 2002, p. 498.
} 
mesothelioma. ${ }^{79}$ Chemotherapy and radiation therapy does not work well; surgical removal of the tumour does not cure the cancer. ${ }^{80}$ However, new research seems to indicate that gene therapy might offer a successful cure to mesothelioma. ${ }^{81}$

\subsubsection{Medical information about mesothelioma in a legal perspective}

In order to better understand the legal problems involved in mesothelioma cases it is essential to examine the abovementioned medical information from a legal perspective. It goes without saying that the long latency period (20-50 years) complicates the proof of the exposure to asbestos. Persons who suffer from mesothelioma, therefore, encounter difficulties in proving that they have been exposed to asbestos in the course of their employment(s). Furthermore, mesothelioma sufferers encounter difficulties in proving the wrongful intervention of the employer at the time of the exposure as the wrongfulness of the defendant's intervention depends on whether or not the defendant knew or ought to have known that asbestos exposure could harm the claimant's health. In addition, the question of whether or not the claimant's claim has become time-barred remains - due to the long latency period - difficult to answer in the majority of the cases. These legal problems, except for the limitation of actions, will be generally discussed in Chapter 2 .

My thesis research, however, focuses on an extremely problematic requirement to establish the liability of the defendant: the proof of causation. Therefore, causation is subject to an in-depth discussion. Asbestos is the only known cause of mesothelioma, which explains why no specific problems of proof of the causal relationship between an established exposure to asbestos and the mesothelioma are raised in claims for mesothelioma. ${ }^{82}$ In these particular cases, no uncertainty arises as to the cause of the damage: the inhalation of tobacco smoke cannot cause and/or exaggerate the development of mesothelioma: none of the empidemiological studies have shown an increase of mesothelioma among smokers as compared to non-smokers. ${ }^{83}$ Research shows that in 80 to 87 percent of mesothelioma cases a connection can be established between mesothelioma and exposure to asbestos in the past. ${ }^{84}$ In cases where the mesothelioma sufferer has no record of occupational exposure to asbestos, the disease most likely results from the inhalation of asbestos fibres in the environment. ${ }^{85}$ If a doctor, however, diagnoses mesothelioma in his patient's lungs, and if the person concerned has only been exposed to asbestos in the course of one of his employments, then a legal causal link between the exposure to asbestos and the disease may be assumed to exist. Any search for an alternative cause of mesothelioma in a person occupationally exposed to asbestos is unnecessary. ${ }^{86}$ In such a situation it is almost completely certain that this particular exposure to asbestos led to the forming of mesothelioma.

\footnotetext{
${ }^{79}$ Light \& Gary Lee 2003, p. 435.

${ }^{80}$ Beers et al. 2003, p. 298.

${ }^{81}$ For more information see: Light \& Gary Lee 2003, p. 440.

${ }^{82}$ Sinninghe Damsté et al. 2007, p. 2453.

${ }^{83}$ Lemen et al. 1980 , p. 8.

${ }^{84}$ Hillerdal \& Henderson 1997, p. 93-103.

${ }^{85}$ Sienciewicz v Greif (UK) Limited, [2011] UKSC 10, paragraph 19.

${ }^{86}$ Miller 2002, p. 119-139.
} 
As said before, medical science is able to prove that mesothelioma could start with the inhalation of one asbestos fibre, a few asbestos fibres, or many asbestos fibres. ${ }^{87} \mathrm{~A}$ minimal exposure to asbestos can be sufficient to contract mesothelioma. In fact, no exposure threshold is indicated here. ${ }^{88}$ In theory, mesothelioma can be caused by the inhalation of one asbestos fibre. However, medical science is unable to determine the exact moment of the exposed person inhaling the fatal asbestos fibre. A clear consensus remains: increased exposure to asbestos increases the risk of contracting mesothelioma, but in the event of a sequence of separate periods of exposure, current science cannot identify the one in which the condition was initiated, which means that it is impossible to prove which employer has caused the employee's mesothelioma. ${ }^{89}$ Causal uncertainty could thus arise with regard to which specific tortfeasor caused the claimant's mesothelioma to begin forming. Moreover, causal uncertainty could also arise in claims for mesothelioma in which one employer has non-wrongfully (for example: during 1940-1958) and wrongfully (for example: during 1960-1970) exposed his employee to asbestos in the course of the employement. The latter problem of uncertain causation will, however, not be further examined in this thesis research because case law is very clear on this point. $^{90}$

\subsubsection{Uncertainty about the specific tortfeasor}

When someone suffers from mesothelioma after having been occupationally exposed to asbestos in the past, uncertainty could arise as to the specific tortfeasor. In cases where the employee has worked for several employers all exposing him to asbestos it remains uncertain which particular tortfeasor is responsible for and 'has caused' the claimant's damage. In cases of mesothelioma, the defendant's breach of duty (wrongfully exposing the employee to asbestos in the course of the employment) may have acted as a 'trigger' for the claimant's condition, but there could only be one trigger. As said before, medical science is unable to tell us the exact moment the person concerned inhaled the 'fatal asbestos fibre' which led to the development of mesothelioma, and therefore a mesothelioma victim who has been exposed to asbestos by a number of different employers cannot prove which employer caused his illness: 'technically it is impossible to establish where and when the patient inhaled the fatal asbestos fibre. ${ }^{91}$

Applying traditional causation principles, the result would be that not one of the employers could be held liable since it is impossible to identify which employer has caused the damage to the employee. In such cases the claimant is, under Dutch law, unable to prove causation to 'a reasonable degree of certainty' ${ }^{\text {'2 }}$. Nor can he, under

\footnotetext{
${ }^{87}$ According to Wiegersma the 'fatal asbestos fibre' does not exist: Wiegersma 1998, p. 1354.

${ }^{88}$ Gezondheidsraad 1998, p. 16.

${ }^{89}$ Miller 2002, p. 119-139.

${ }^{90}$ Hoge Raad 25 juni 1993, NJ 1993, 686, paragraph 3.8.4 (Cijsouw/De Schelde 1). See also: Waterman 2009, p. 340. The Supreme Court established the liability of De Schelde and ruled that employers could be held liable for unknown risks in cases where they have breached their duty of care to prevent employees from contracting known risks (asbestosis) connected to asbestos exposure.

${ }^{91}$ Van Dam 2006, p. 146.

${ }^{92}$ Threshold to establish causation in Dutch law.
} 
English law, prove that it is 'on the balance of probabilities more likely than not ${ }^{, 93}$ that employer 'A' or 'B' has caused the mesothelioma. Applying traditional causation principles, the claimant thus leaves empty-handed in cases where the claimant suffers from mesothelioma after he has been wrongfully exposed to asbestos in several different employments.

\subsubsection{Lung cancer which could have been asbestos-related}

Lung cancer is, when compared to other asbestos-related diseases such as mesothelioma and asbestosis, a totally different story. The Health Council of the Netherlands published an advisory report on lung cancer in 2005. Previously, the Health Council published an advisory report on asbestosis ${ }^{94}$ (1999) and mesothelioma ${ }^{95}$ (1998). Lung cancer as a potential consequence of asbestos exposure is a difficult legal and medical issue. As of 1955, research showed that the inhalation of asbestos fibres increases the chance of developing lung cancer. ${ }^{96}$ At this moment, medical science has still not been able to determine whether lung cancer which someone contracted after having been exposed to asbestos had been caused by the exposure to asbestos or by other factors, such as smoking, genetic predisposition, external causes, or ageing. ${ }^{97}$ It can be concluded with scientific certainty that exposure to asbestos increases the risk of developing lung cancer. However, histopathology cannot determine the cause of this specific injury. Slot phrased the complexity very clearly: 'asbestos is by no means the only causative agent of lung tumours.' 98

The development of lung cancer differs from the development of asbestosis. Lung cancer is regarded as an all-or-nothing disease. The severity of the disease, once it has started to develop, is not related to the degree of exposure to asbestos fibres. ${ }^{99}$ To put it differently: once the risk has been increased, the development of the condition itself is not dose-related. Furthermore, in claims for asbestosis the exposure must exceed a certain threshold before the exposure causes the onset of the disease while a safe threshold does not exist in lung cancer cases. Lung cancer has a latency period ranging from 10 to 30 years. ${ }^{100}$ Compared to mesothelioma, the life expectancy of sufferers is slightly better but is still very alarming. Approximately 60 percent of the patients diagnosed with lung cancer will die within the first year, 80 percent die within the first two years, and 90 percent of the patients will die within four years. ${ }^{101}$ Extensive epidemiological research has been done on the relationship between asbestosis and lung cancer, but it still remains controversial whether or not lung cancer can be attributed to asbestos exposure in the absence of asbestosis. ${ }^{102}$

\footnotetext{
${ }^{93}$ Threshold to establish causation in English law.

${ }^{94}$ Gezondheidsraad 1999, Protocollen asbestziekten: asbestose.

${ }^{95}$ Gezondheidsraad 1998, Protocollen asbestziekten: maligne mesothelioom.

${ }^{96}$ Doll 1955, p. 81-86.

${ }^{97}$ See for a good example: Hoge Raad 31 maart 2006, NJ 2011, 250 (Nefalit/Karamus).

${ }^{98}$ Slot 2005, p. 39.

${ }^{99}$ Sienciewicz v Greif (UK) Limited, [2011] UKSC 10, paragraph 13.

${ }^{100}$ For more information I refer to section 4.3, which discusses the assessment of the probability of causation in case of lung cancer which could have been caused by exposure to asbestos.

${ }^{101}$ Burdorf et al. 1997a, p. 32.

${ }^{102}$ Hessel et al. 2005, p. 433-436: The scientific question of whether or not lung cancer arises only in de presence of asbestosis may be unanswerable epidemiologically. See also: Gibbs et al. 2007, p. 181.
} 
In 1968, prominent epidemiologists established that smoking and exposure to asbestos could reinforce the development of lung cancer since exceedingly high lung cancer rates had been reported in such cases. ${ }^{103}$ This extremely complex effect is also known as the '(sub)multiplicative effect' of smoking and asbestos exposure, which means that the effect of two or more causes together is greater than the sum of the individual effects. To put it differently: the risk of lung cancer in people who both smoke and have been exposed to asbestos is much higher than would be indicated by a simple addition of the risks from smoking and exposure to asbestos. ${ }^{104}$

\subsubsection{Medical information about lung cancer in a legal perspective}

Although the latency period in case of lung cancer (10 to 30 years) is shorter when compared to the latency period in case of mesothelioma (20 to 50 years), the legal problems which have been discussed in section 1.3.2.1 also apply to non-mesothelioma lung cancer sufferers who have been exposed to asbestos in the past. This means that lung cancer sufferers could also encounter difficulties in proving that they have been exposed to asbestos in the past and that the exposure to asbestos was wrongful. In addition, the fear that the claim for damages has become time-barred is - due to the long latency period also present in claims for lung cancer which could have been asbestos-related.

However, when it comes to causation, mesothelioma cases differ strongly from cases in which an employee contracted one of the other non-mesothelioma forms of lung cancer, where asbestos exposure is only one of a number of possible causes of the damage. In these particular non-mesothelioma cases, two or more causes are present where at least one of them can be imputed to the claimant. ${ }^{105}$ To give an example: the employee may have worked for only one employer and has been exposed to asbestos in the course of this employment but the lung cancer that he or she contracted could also have been caused by smoking tobacco, genetic predisposition, external causes, or ageing. Histopathology cannot determine the cause of this disease. Many factors, which might have played a causal role in the development of lung cancer, complicate the issue of establishing liability and assigning compensation.

The question of whether or not a lung tumour is attributable to exposure to asbestos is far more difficult to answer when it is compared to the corresponding question in cases where victims suffer from asbestosis or mesothelioma. In cases in which someone has been exposed to asbestos and has developed lung cancer, the question of whether or not asbestos exposure caused lung cancer can never be answered with a simple yes or no. An important factor for Tort law is that the development of lung cancer is related to the level of exposure to asbestos fibres. This implies that a dose-response relationship is present in such cases. Therefore, most non-occupationally ${ }^{106}$ exposed persons are at extremely low risk of developing non-mesothelioma lung cancer. ${ }^{107}$

\footnotetext{
${ }^{103}$ Selikoff et al. 1968, p. 106-112.

${ }^{104}$ Health Council of the Netherlands: Asbestos diseases: lung cancer, p. 17.

${ }^{105}$ See for example the case: Hoge Raad 31 maart 2006, NJ 2011, 250 (Nefalit/Karamus).

${ }^{106}$ One could also speak of: 'para-occupationally' or 'environmentally' exposed persons.

${ }^{107}$ Beers et al. 2003, p. 297.
} 
The situation is even more complex in cases where the lung cancer sufferer has not only been exposed to asbestos but was also a tobacco smoker. Both factors together could reinforce the development of lung cancer. In addition, it is questionable whether or not the claimant's smoking history should be attributed to the claimant and whether or not the probability that lung cancer is caused by the claimant's smoking history can be assessed by experts, knowing that medical science is unable to determine which factor caused lung cancer in the specific claimant's case.

In order to assess the 'increased risk of developing lung cancer', extensive epidemiological and toxicological research is required, but is not always available in the specific claimant's case. In civil liability claims under the current law, judges have to determine the probability that the lung tumour resulted from the negligent occupational exposure to asbestos. In assessing the 'probability of causation', a certain model has been advised by the Health Council of the Netherlands in 2005. This important model, to determine the probability of causation in case of lung cancer which could have been asbestos-related, will be examined in section 4.3. In such cases it is, from a legal point of view, important to note that causal uncertainty could both arise as to the cause of the damage as well as to the specific tortfeasor who, in a group of possible tortfeasors, could have caused the claimant's lung cancer. As the uncertainty about the specific tortfeasor has already been discussed in section 1.3.2.2, I will only discuss the uncertainty of the cause of damage in the next section.

\subsubsection{Uncertainty about the cause of the damage: multiple causation}

It has proven to be extremely difficult to establish causation in a situation where two or more causes are present which all could have caused the damage separately, and where at least one of them can be imputed to the claimant. In these particular cases there are multiple factors that all could have caused the damage to the claimant. How should legal systems deal with complex issues like these? Should the legal system apply the traditional principle of all-or-nothing compensation and decline damages since there is simply too much doubt about the causal link between the negligent exposure to asbestos and the claimant's lung cancer, or should the legal system deviate from traditional rules in order to improve the problematic legal position of persons who suffer from lung cancer?

In multiple causation cases, the claimant faces great difficulties: the Dutch claimant will almost certainly be unable to prove causation to 'a reasonable degree of certainty', nor can the English claimant prove that it is 'on the balance of probabilities more likely than not' that asbestos exposure has caused his damage. Article 3:103 (1) PETL gives a clear 'proportional' solution for cases concerned with the problem of alternative causality:

'In a case of multiple activities, where each of them alone would have been sufficient to cause the damage, but it remains uncertain which one in fact caused it, each activity is regarded as a cause to the extend corresponding to the likelihood that it may have caused the victim's damage.'

The instrument of proportional liability will be extensively examined in Chapter 3 in which solutions to the problem of uncertain causation will be presented. 


\subsubsection{Conclusion}

The more and longer a person has been exposed to asbestos fibres, the greater the risk of developing an asbestos-related disease in the future. The extent and duration of the exposure are considered to be extremely relevant factors in causing harm to the exposed person. Although medical science is able to establish a causal link between the exposure to asbestos and the development of asbestosis and mesothelioma, this certainly does not imply that, from a legal point of view, both diseases should be treated equally.

Asbestosis is a cumulative (divisible) condition, which means that the intensity and duration of the exposure are of great importance in the development of the disease. In cases of mesothelioma, the inhalation of only one asbestos fibre could be sufficient to trigger the development of mesothelioma and, once caused, the condition itself is not aggravated by further exposure. The risk that mesothelioma will occur increases when the inhaled dose of asbestos fibres increases. However, the severity of the condition and the resulting disability do not, as opposed to asbestosis, vary with the dose. In cases of asbestosis or mesothelioma no uncertainty arises as to the cause of the damage because asbestos is the only known cause to get both diseases. Uncertainty could, depending on the facts of the case, arise as to the specific tortfeasor who, in a group of possible tortfeasors, could have caused the claimant to suffer from asbestosis or mesothelioma.

The development of lung cancer which could have been asbestos-related is even more complex. Although the development of this general type of lung cancer is dose-related, it differs from the development of asbestosis. Lung cancer is regarded as an all-or-nothing disease: once the risk has been increased, the development of the condition itself is not dose-related. Uncertainty arises as to the cause of the damage because the lung cancer which the claimant contracted could have been caused by multiple factors. Histopathology cannot determine the cause of this specific injury. This complicates the issue of establishing liability and assigning compensation.

Another extremely relevant factor for Tort law is that not all asbestos fibres have the same impact in causing harm to the lungs of the exposed person. The shape of the asbestos fibres is an important factor as well. Long, straight fibres seem to be more dangerous than short curled fibres. White asbestos (chrysotile) is less dangerous than blue (crocidolite) or brown (amosite) asbestos. Experts should take all factors (the source of the exposure, the chemical nature of the asbestos fibres, the extent and duration of the exposure, and the asbestos-related injury itself) into account in order to adequately determine the likelihood that asbestos exposure has caused the claimant's injury. If experts and judges do not take all factors into account decisions may easily become arbitrary. This would not be a good development in the pursuit of legal security, which is one of the fundamental values of law. ${ }^{108}$

\subsection{Claims for asbestos-related injuries and its long-tail risks for insurers}

To get a better view on the gravity of the asbestos problem, it is worth mentioning that Liability Insurances for Companies have faced an incredible amount of claims for wrongful exposure to asbestos in the past, and they still are up to this today. Asbestos is not only regarded as a long-tail risk for persons who have been exposed to it, but can also be

${ }^{108}$ Garcia Maynez 1949, p. 496. 
regarded as a long-tail risk for insurance companies who could, like many others, not foresee its consequences. The majority of asbestos victims who have been exposed to asbestos in the course of their employments and subsequently have contracted an asbestos-related injury, file a lawsuit against their former employers who were responsible for the negligent exposure to asbestos in the past. During the time of exposure, most companies in the Netherlands were, by taking out a Liability Insurance for Companies ${ }^{109}$, insured for occupational diseases, such as asbestos-related personal injury claims caused by occupational exposure to asbestos. At the end of the nineteen-eighties and in the beginning of the nineteen-nineties, insurance companies were confronted with an increasing number of claims for asbestos-related diseases, and they faced two major problems.

The first problem is mainly practical. As explained in the previous sections, asbestosrelated injuries have a latency period that varies from 20 to 50 years. This could make the question as to which insurance company or group of insurance companies should take those claims into account, and under which policy conditions they were obliged to do this, difficult to answer. ${ }^{110}$ In several cases it has proved to be impossible to sort out which particular insurance policy was used at the time of the exposure; in some cases it even seemed impossible to sort out which insurance company gave out the insurance policy in question.

The second problem concerns the price of the insurance policy at the time of the exposure. The insurance premiums were far too low when compared to the high amount and increasing number of claims brought up by asbestos victims or their relatives. This means that the received insurance premiums were simply not comparable to the high amounts claimed by the policy holders. This, however, is not surprising. Insurance companies did not expect, when underwriting an insurance policy during the period 19451970, such a floodgate of high valued claims in the future. For insurance companies, and for many others, asbestos seemed to be a good product without negative consequences. However, due to developments in medical and epidemiological science over the years, the existence of a causal link between the exposure to asbestos and the development of an asbestos-related injury was established. Such a causal connection was, at the time of signing the insurance contract, unknown for most insurers. Considering what we know today, we can conclude without a doubt that insurance companies based their insurance premiums on the wrong assumptions.

Moreover, one could also highlight the position of other insurers who face higher costs as a consequence of asbestos exposure in the past. It is common knowledge that lung cancer patients need intensive and expensive medical treatment, which is, except for the policy excess, covered by the victim's private medical insurance. The number of asbestos victims increases every year and, as predicted, will continue increasing until 2022. Consequently, private medical insurers could feel the need to increase their premiums to cover the policy holder's health damage, or they might even consider suing the responsible employers or the government to compensate those additional and unexpected costs in the future. Private health insurers will - if allowed - also be happy to perform a risk assessment, which could lead to no longer accepting a person who has

\footnotetext{
${ }^{109}$ In Dutch: AVB-verzekering: Aansprakelijkheidsverzekering Bedrijven.

${ }^{110}$ Fransen van de Putte 2005, p. 67.
} 
been exposed to asbestos in the past, and thus has an increased chance to develop an asbestos-related injury, under the basic insurance policy.

\subsubsection{Coverage under an 'act committed' insurance policy}

Why do recent claims for asbestos-related injuries, caused by occupational exposure to asbestos in the past, cause so much stress for insurers? The stress relates to the kind of coverage the Liability Insurance for Companies offered in their insurance policies. ${ }^{111}$ From 1945 to 1970 , almost all liability insurances for companies in the Netherlands were based on a so called 'act committed' policy. Damages for occupational diseases are covered by the insurer if the damage was caused 'during the duration of the insurance'. In claims for asbestos-related diseases, the exposure to asbestos should thus have been taken place during the duration of the insurance contract. This policy, to cover the policy holder's damage, has far-reaching consequences. Nowadays, insurance companies are confronted with claims under a policy which originated a long time ago, and are obliged to cover damages resulting from asbestos exposure even when the particular insurance contract was terminated a long time ago. This - again - explains why asbestos is not only regarded as a long-tail risk for persons who have been exposed to it, but can also be regarded as a long-tail risk for insurance companies who were unable to foresee its consequences. $^{112}$

Spier argues that the long-tail risk connected to asbestos exposure was already known in the 1970s. ${ }^{113}$ However, it took a while before insurance companies decided to change their insurance policies. Insurance companies have learned their (financial) lesson and never want to be confronted again with such a high amount and increasing number of claims which they could not foresee. Therefore, insurance companies have completely removed the 'act committed' policy from their insurance policies for companies and developed new techniques to improve their financial and legal position with regard to claims for (new) occupational diseases. Two examples are found in policies such as the 'loss occurrence' policy and the 'claims made' policy. Both policies, to cover the policy holder's damage, will be discussed in the next sections. The discussion is, however, not extensive as an in-depth discussion would exceed the scope of this research. The literature cited in the footnotes provides further details.

\subsubsection{Coverage under a 'loss occurrence' insurance policy}

In the 1970s, insurance companies decided to no longer apply the 'act committed' policy to cover damages for occupational diseases and changed to a so called 'loss occurrence' policy. ${ }^{114}$ Most Liability Insurances for Companies were based on a 'loss occurrence' policy from the 1970s until the mid-1990s. Applying this policy, the insurance company is no longer obliged to cover the policy holder's damage after the insurance contract has been terminated. When compared to an 'act committed' policy, insurance companies assumed that this policy would have two major advantages for their general liabilities.

\footnotetext{
${ }^{111}$ Fransen van de Putte 2005, p. 68; Waterman 2009, p. 339; Lindenbergh 2000, p. 108-110.

${ }^{112}$ Van Dijk \& MacLean 2002, p. 37; Fransen van de Putte 2005, p. 69.

${ }^{113}$ Spier 1990, p. 32.

${ }^{114}$ Van Dijk \& MacLean 2002, p. 37; Spier 1990, p. 33.
} 


\section{Chapter 1}

First of all, the insurer assumed that he would lose the long-tail risk connected to occupational diseases almost completely. Second of all, the insurer is entitled to terminate the insurance contract if the amount of claims give a reason to do so. This means that, once the insurer has terminated the insurance policy in time, new claims for damages are no longer covered by the insurance company. ${ }^{115}$ One could wonder, however, if this limited system to cover the policy holder's damage leads to desirable results in claims for asbestos-related injuries caused by occupational exposure to asbestos?

It probably would not. Insurance companies assumed that, by changing to a different policy, they would not be obliged to cover damages resulting from long-tail risks connected to occupational diseases. However, the coverage description in the insurance policy turned out to be far from clear with regard to the long-tail risks connected to asbestos-related injuries. ${ }^{116}$ According to the coverage description, the injury should have: 'occurred within the duration of the contract period' in order for the damage to be covered. ${ }^{117}$ It is arguable that the asbestos-related injury occurred at the moment the employee inhaled asbestos fibres in the course of the employment. If this assumption is correct, the insurance company will, if the employer was insured during this particular period, be obliged to cover the damages which resulted from the exposure to asbestos in the course of the employment. When explaining the word 'occurred' in the abovementioned way, this explanation definitely contradicts the expectations of insurance companies as the word 'occurred' is explained in favour of the policy holder. Following this explanation, one can conclude that the (exact) moment the employee inhaled asbestos fibres in the course of the employment is decisive for the coverage. ${ }^{118}$ This way, insurance companies are - (once) again - obliged to cover unexpected claims for asbestosrelated injuries. The word 'occurred' could, however, also be explained in favour of the insurer. It is arguable that the moment when the first symptoms of the specific asbestosrelated injury come to light should be decisive for the coverage. If this assumption is correct, insurance companies are not obliged to cover the policy holder's damage when the insurance contract was already terminated when the first symptoms of the asbestosrelated injury came to light. This would mean that employers who have not gone out of business will, despite having paid insurance premiums every year, find themselves uninsured. The (former) employer has to pay compensation to victims directly, which could cause insolvency.

Whether or not insurance companies would have to cover damages resulting from occupational exposure to asbestos under policies based on a 'loss occurrence' system was eventually up to the judge to decide. ${ }^{119}$ Applying a 'loss occurrence' policy, the insurance company has to compensate damage which occurred during the duration of the insurance contract. The moment of submitting the claim is not decisive for the coverage. This

\footnotetext{
${ }^{115}$ Fransen van de Putte 2005, p. 69.

${ }^{116}$ For more information on the coverage description I refer to: Tolman 2008, p. 64-72.

${ }^{117}$ In Dutch: 'Dat het letstel, de aantasting van de gezondheid of de zaakbeschadiging binnen de duur van de contractstermijn is ontstaan.' This has also been subject to discussion in English case law. See: Bolton Metropolitan Borough Council v Commercial Uniun and Municipal Mutual Insurance, [2006] EWCH Civ 50.

${ }^{118}$ Van Dijk \& MacLean 2002, p. 37.

${ }^{119}$ Hoge Raad 25 juni 1993, NJ 1993, 686 (Cijsouw/De Schelde 1). See also: Waterman 2009, p. 340.
} 
means that claims are covered irrespectively of whether the claim is submitted after the insurance contract has been terminated or not. ${ }^{120}$

\subsubsection{Coverage under a 'claims made' insurance policy}

Up until 1996, the Liability Insurance for Companies was based on a 'loss occurrence' policy. In 1996, Dutch Liability Insurers introduced a new insurance policy for the Liability Insurance for Companies. ${ }^{121}$ As of that moment, most insurance companies changed their system to a so called 'claims made' policy in order to escape any obligation to cover damages resulting from long-tail risks connected to occupational diseases. Nowadays, most Liability Insurances for Companies are based on a 'claims made' policy. ${ }^{122}$

Characteristic for a 'claims made' policy is that the obligation to cover the policy holder's damage ends at the moment the insurance contract has been terminated by one of the parties. ${ }^{123}$ In fact, the insurance company will only cover the policy holder's (employer's) damage if the claim of the third person (employee) is submitted by the policy holder during the duration of the insurance contract. The moment when the policy holder informes the insurance company about the claim for damages is decisive for the coverage. In case the policy holder informs the insurance company after the insurance contract has been terminated, no damages are covered. ${ }^{124}$

Changing to a 'claims made' policy made sure that insurance companies would - in the future - no longer be surprised by claims under policies that were terminated a long time ago. The 'claims made' policy thus provides more certainty for the insurer in future cases. ${ }^{125}$ To sum up: using a 'claims made' policy, the insurer cannot be obliged to cover the policy holder's damages resulting from the long-tail risks connected to occupational diseases, after the insurance contract was terminated by one of the parties. ${ }^{126}$ This new policy does, however, not solve the problems of insurers in claims for asbestosrelated cases as most, if not all claims are covered under either the 'act committed' policy or 'loss occurrence' policy.

\subsubsection{Conclusion}

Due to developments in medical and epidemiological science over the years, the existence of a causal link between the exposure to asbestos and (the development of) lung cancer has been established. Such a causal connection was, at the time of closing an insurance contract under the Liability Insurance for Companies, unknown. Insurance companies have faced and are still facing an incredible number of claims for asbestos-related injuries caused by occupational exposure to asbestos. From 1945 to 1970, most Liability Insurances for Companies used an 'act committed' policy to cover the policy holder's damage. Using an 'act committed' policy, damages resulting from occupational diseases

\footnotetext{
${ }^{120}$ Wansink 1987, p. 104.

${ }^{121}$ For more information I refer to a Dutch Journal which has discussed this issue in a special issue: Polismodel AVB 1996, A \& V 1996, nr. 6.

${ }^{122}$ Waterman 2009, p. 339, 340; Spier 1990, p. 33.

${ }^{123}$ Van der Meer 2007, p. 63.

${ }^{124}$ Fransen van de Putte 2005, p. 69; Waterman 2009, p. 342: apart from exceptions.

${ }^{125}$ Waterman 2009, p. 342.

${ }^{126}$ Fransen van de Putte 2005, p. 71.
} 


\section{Chapter 1}

are covered if the damage was caused during the duration of the insurance. The consequence of using such a policy is that insurance companies are now faced with a high number of high valued claims which they could not foresee.

Insurance companies, however, learned their financial lesson and changed their insurance policies into a 'loss occurrence' model in the 1970s. Using this policy, the obligation to cover the policy holder's damage is only present when 'the injury occurred within the duration of the insurance'. The coverage description has proven to be problematic in asbestos-related-related cases due to the long latency period. The explanation given to the word 'occurred' determines whether or not the insurer is still or no longer obliged to compensate the policy holder's damage.

For both the policy holder and the asbestos victim, friendly coverage policies belong to the past when it comes to future claims for occupational diseases. In the mid-1990s, insurance companies changed their system to cover the policy holder's damage into a so called 'claims made' policy in order to escape any obligation to cover damages resulting from the long-tail risks connected to occupational diseases. Applying this policy, insurance companies are not obliged to cover the policy holder's damage after the insurance contract has been terminated by one of the parties. This new policy does, however, not solve the problems of insurers in claims for asbestos-related cases as most, if not all claims are covered under either the 'act committed' policy or 'loss occurrence' policy.

Although this system is in line with the expectation of insurance companies, and provides certainty for these companies in future cases, it is an alarming development. In the near future, claims for new occupational diseases will no longer be covered after the insurance contract has been terminated by the employer or the insurer. The legal position of victims who develop an occupational disease in the future is uncertain because there could be a possibility that the victim's damage is no longer covered by the Liability Insurance for Companies. In such a hypothetical situation, these victims can only receive compensation if the employer has been traced successfully and has the capacity to compensate the claimant's damage. In the worst case scenario, if the employer is untraceable or has gone out of business, the claimant leaves empty-handed unless the Liability Insurance for Companies has not yet been terminated by either the former employer (policy holder) or the insurance company.

\subsection{Examples and research objectives \\ 1.5.1 The legal complexity of asbestos-related cases}

The two examples given below illustrate the scientific complexity connected to asbestosrelated cases, and this medical uncertainty forms the heart of the legal uncertainty. Although these examples are not based on historical facts, they do describe almost all problems that arise in asbestos-related cases, which will be explored in this comparative research. In both examples, it is established that the exposure to asbestos was wrongful. Whether or not the tortfeasor acted negligently, in terms of 'wrongfulness', will not be discussed in detail because this would exceed the scope of this research. As said previously, the focus is on the causation requirement, because this essential condition to establish the liability of the defendant is extremely difficult to prove in claims for asbestos-related diseases. In the two examples, both claimants want to file a lawsuit against their former 
employer(s) in order to receive compensation for the health damage which they have encountered. The question for each legal system in the comparison is the same: can they successfully claim compensation from their former employer(s)?

\section{Example 1:}

'Mr ' $\mathrm{X}$ ' was born in Amsterdam (The Netherlands) in 1945 and is regarded as a heavy smoker since 1960. Mr ' $\mathrm{X}$ ' worked for company 'A' during the period 19701980. It is established that $\mathrm{Mr}$ ' $\mathrm{X}$ ' has been wrongfully exposed to asbestos in the course of the employment. In 1995, Mr ' $\mathrm{X}$ ' developed lung cancer as a potential consequence of asbestos exposure in the past. ${ }^{127}$

\section{A few explanatory remarks on example 1:}

In this situation $\mathrm{Mr}$ ' $\mathrm{X}$ ' developed a form of lung cancer which could be asbestos-related. In these particular cases multiple factors are present - any one of which could have caused the specific disease (lung cancer) - but it is impossible to tell which one has actually caused the cancer in the specific claimant's case. The lung cancer could have been caused by the exposure to asbestos in the course of the employment. It is, however, also possible that the claimant's lung cancer was caused by smoking tobacco, genetic predisposition, external causes, eating habits, and/or simply ageing. Histopathology cannot determine the cause of the claimant's injury. In both Dutch and English law, the element of causation is a fundamental requirement to establish the liability of the tortfeasor, which makes causation an extremely important element in establishing liability.

In both jurisdictions taken into consideration in this thesis (The Netherlands and England), $\mathrm{Mr}$ ' $\mathrm{X}$ ' must prove a causal link between the negligent exposure to asbestos in the course of the employment and the damage which he incurred. This is almost an impossible hurdle to take since $\mathrm{Mr}$ ' $\mathrm{X}$ ' is most likely unable to prove causation between the exposure and the damage to 'a reasonable degree of certainty' ${ }^{\text {'28 }}$. Neither can he prove 'on the balance of probabilities' that it is 'more likely than not ${ }^{129}$ that employer 'A' has caused the lung cancer. In this complex situation, uncertainty exists as to the cause of the damage because it is impossible to determine the cause of the damage in the specific claimant's case. Applying traditional principles, it is most likely that the claim for compensation will be dismissed, which results in the fact that the claimant leaves emptyhanded. One could wonder, however, whether this outcome is fair now that it has been determined that employer 'A' negligently exposed Mr ' $\mathrm{X}$ ' to asbestos?

\section{Example 2:}

'Mr ' $\mathrm{Y}$ ' was born in The Hague (The Netherlands) in 1938 and never smoked tobacco in his life. Mr 'Y' worked for company 'A' during the period 1965-1967, for company 'B' during the period 1968-1970, and for company ' $\mathrm{C}$ ' during the period 1971-1973. It is established that $\mathrm{Mr}$ ' $\mathrm{Y}$ ' has been wrongfully exposed to asbestos in

\footnotetext{
${ }^{127}$ Although the facts in example 1 could have actually happened, the example is not based on historical facts.

${ }^{128}$ Threshold to establish causation in Dutch law.

129 Threshold to establish causation in English law.
} 


\section{Chapter 1}

three different employments. In 2000, $\mathrm{Mr}$ ' $\mathrm{Y}$ ' developed mesothelioma as a consequence of asbestos exposure in the past. ${ }^{, 130}$

\section{A few explanatory remarks on example 2:}

In this situation Mr ' $\mathrm{Y}$ ' developed mesothelioma after he has been exposed to asbestos in three different employments. Medical science is able to prove that mesothelioma could start with the inhalation of one asbestos fibre, a few asbestos fibres, or many asbestos fibres. This implies that only a minimal exposure to asbestos is required. There remains a clear consensus, however, that increased exposure to asbestos increases the risk of contracting mesothelioma but, in the event of a sequence of separate periods of exposure, current medical science is unable to identify the one in which the condition was initiated. ${ }^{131}$

$\mathrm{Mr}$ ' $\mathrm{Y}$ ' is, as opposed to the situation in example 1, able to prove the cause of his damage because asbestos is the only known cause to contract mesothelioma. $\mathrm{Mr}$ ' $\mathrm{Y}$ ' is, however, unable to identify which particular tortfeasor, in a group of possible tortfeasors, has caused his damage. Mr ' $\mathrm{Y}$ ' is unable to prove to 'a reasonable degree of certainty $^{\prime 132}$ which employer has caused the mesothelioma to begin forming. Neither can he prove that it is 'on the balance of probabilities more likely than not ${ }^{\text {'133 }}$ that the intervention of employer 'A', 'B', or 'C' has led to the forming of the mesothelioma. Applying traditional principles, it is most likely that the claim for compensation will be dismissed which results in the fact that $\mathrm{Mr}$ ' $\mathrm{Y}$ ' leaves empty-handed.

As is seen in both examples, asbestos-related cases are extremely difficult to 'solve'. There are, of course, a number of variations that could also be explored. For example, in the first case, $\mathrm{Mr}$ ' $\mathrm{X}$ ' might not have been a smoker or could have worked for a number of different employers all exposing him to asbestos. However, the two cases are specifically chosen as they contain the central difficulties and, to a certain extent, once those fundamental principles are resolved, the variant cases are solved by the logical application of the solutions and do not require new thinking. However, the case remains that due to the lack of medical science many legal questions remain unanswered and many problematic medical and legal issues are still unsolved. As a result the key principles are not obvious to find.

\subsubsection{Research objectives}

This research project is set in a comparative perspective and addresses the problematic legal position of asbestos victims who - in general - have to bear the negative consequences of the medical and legal causal uncertainty in asbestos-related cases. The Dutch legal system is not the only legal system which has been explored with regard to this specific subject. English law is also taken into consideration to extensively study the liability for asbestos-related injuries. Examining Dutch and English law is not a random choice. It is interesting to compare the English 'on the balance of probabilities more

\footnotetext{
${ }^{130}$ Although the facts in example 2 could have actually happened, the example is not based on historical facts.

${ }^{131}$ Miller 2002, p. 119-139.

132 Threshold to establish causation in Dutch law.

133 Threshold to establish causation in English law.
} 
likely than not' threshold with the Dutch 'reasonable degree of certainty' threshold to establish causation. The consequences of the variety in approaching the concept of causation will be explored in this research. My thesis research thus compares a civil law legal system (The Netherlands) with a common law legal system (England). The focus is on employers' liability in asbestos-related cases because most lawsuits are filed against employers who have wrongfully exposed their employees to asbestos in the course of their employments.

The relatively new instrument of proportional liability was applied for the first time by the Dutch Supreme Court in March 2006. ${ }^{134}$ Applying this instrument, the judge did not simply award or reject the total amount of damages. He did not make a traditional decision by determining whether or not there was sufficient proof of causation, keeping in mind causal uncertainty. Instead, he awarded damages in proportion to the probability of causality. The Supreme Court chose to deviate from the traditional principle of all-ornothing compensation in order to strengthen the position of asbestos victims who generally bear the consequences of the causal uncertainty in such cases. Whereas Nefalit ${ }^{135}$ establishes the instrument of proportional liability, the Dutch Supreme Court has not explained the legal instrument of proportional liability in detail yet. The Supreme Court has used the term 'in general' three times in its decision in order to have more space to adjust his former decision if necessary. Although the Supreme Court extended the applicability of the Nefalit-principle on 24 December 2010 in Fortis/Bourgonje ${ }^{136}$, the precise consequences of Nefalit are still not completely clear. It goes without saying that 'cautiousness' has a negative effect on the goal to achieve legal security, in particular because proportional liability is regarded as an emotionally loaded theme in the Dutch legal system but also across the borders. One of the key objectives of this research is to explore how Dutch and English laws approach the problem of uncertain causation in asbestosrelated cases. The legal instrument of proportional liability will be compared to alternative solutions for uncertain causation within and outside Tort law, which have or have not yet been applied (together) by the jurisdictions taken under consideration here to strengthen the claimant's position in an environment of causal uncertainty. In addition, the consequences and range of applications of the proportional liability theory, as applied in Nefalit/Karamus, will be explored. The question of whether or not the proportional liability theory is also applicable and desirable in specific claims for other personal injuries will be addressed.

We have to recognize and realize that there is no perfect solution available in asbestos-related cases since the problem of uncertain causation is intractable due to the lack of medical science. However, it is still of the utmost importance to explore whether or not the instrument of proportional liability is a reasonable and fair solution to settle specific asbestos-related cases and to assign compensation. Therefore, this research explores the practical as well as theoretical problems that judges (will) encounter in applying proportional liability in asbestos-related cases. The differences and similarities in approach of each legal system with regard to this topic will be discussed, because legal rules that have

\footnotetext{
${ }^{134}$ Hoge Raad 31 maart 2006, NJ 2011, 250 (Nefalit/Karamus).

${ }^{135}$ Hoge Raad 31 maart 2006, NJ 2011, 250 (Nefalit/Karamus).

${ }^{136}$ Hoge Raad 24 december 2010, NJ 2011, 251, paragraph 3.8 (Fortis/Bourgonje).
} 


\section{Chapter 1}

been used in one jurisdiction may serve as a source of inspiration to improve the existing rules in other legal systems. Another problematic aspect in asbestos-related cases is the multidisciplinary interaction between judges and experts. In practice, courts call on expert opinion as to the likelihood that a given activity caused a known damage, expressed as a 'probability of causation'. The proportional liability theory depends almost completely on the findings of the appointed expert(s). This emphasizes the problem even more. It is clear, and well established in literature ${ }^{137}$, that judges and experts have different scientific backgrounds and, therefore, do not speak the same 'language'. This could eventually lead and has already led to incorrect judgments. ${ }^{138}$ Exploring the role of experts and the different ways in which judges and experts approach the problem of causal uncertainty in asbestos-related cases is of the utmost importance. The aim is to introduce solutions to these problems because communication problems between judges and experts can have enormous negative consequences for both the claimant and the defendant.

The researcher does not have the ambition to provide a complete overview on employers' liability in the Netherlands and England and focuses, except for a discussion on alternative schemes to compensate asbestos victims, on Tort law solely. The emphasis is on the situation in the Netherlands and England as it is today. Historical developments on employers' liability are only pointed out to sketch the broader picture. This also counts for a discussion on social security and private insurances in Chapter 3 (Part Three) as an elaborate discussion on other possibilities to compensate the employee would exceed the scope of this research. Although still a topical subject, the same goes for a discussion on the limitation of actions with regard to claims for asbestos-related diseases.

This thesis research addresses the following three main questions:

- How can legal causation be defined in claims for asbestos-related diseases and what legal consequences are connected to the classification of different types of causal uncertainty?

- What is the most desirable solution to the legal problem of causal uncertainty in claims for asbestos-related diseases?

- How should judges deal with (epidemiological) expert evidence in claims for asbestos-related diseases and what techniques can be proposed to improve the legal decision in such cases?

\footnotetext{
${ }^{137}$ For more information, I refer to two special editions of Dutch Journals in which this was discussed: Schadevaststelling en de rol van de deskundige, NTBR 2007/10, p. 427-509; Bewijs, Ars Aequi juli/augustus 2010, p. 449-452.

${ }^{138}$ See for example: Rechtbank Amsterdam 4 juli 2010, JA 2011, 4; Gerechtshof 's-Gravenhage 28 april 2009, LJN: BI4768; Rechtbank Maastricht 13 juli 2005, JA 2006, 44.
} 


\section{Causal Uncertainty in Asbestos-Related Cases: A Comparative Overview of Dutch and English} Laws

\subsection{Chapter introduction}

This chapter presents a comparative analysis between the Dutch and English law relating to the problem of uncertain causation in asbestos-related cases. For the sake of clarity, this chapter is divided into three parts, starting with an 'Introduction to Dutch and English law on liability' (Part One), 'Causation: A comparative overview of Dutch and English laws' (Part Two), and 'Causation problems in asbestos-related cases' (Part Three).

Part One provides a general overview of different grounds to apply for compensation in asbestos-related cases and generally explores whether asbestos-related diseases are considered as 'damage' which is eligible for compensation in Dutch and English laws. In addition, this Part is aimed to provide the reader with background information on the jurisdictions. In Dutch law, the source of the experienced exposure to asbestos is relevant to the outcome of the civil action. Persons who suffer from an asbestos-related disease after they have been occupationally exposed to asbestos can file a lawsuit against their (former) employer(s) on the basis of Article 7:658 $\mathrm{BW}^{139}$. Persons who have not been exposed to asbestos in the course of their employment can apply for compensation on the basis of Article 6:162 $\mathrm{BW}^{140}$. However, the applicable rules of evidence show that the conditions to impose liability on the defendant are more demanding if the claimant's claim is based on Article 6:162 BW. Under English law, most claims for asbestos-related diseases are, irrespective of whether or not the claimant has been occupationally exposed to asbestos, based on the Tort of negligence, which requires the fulfilling of four conditions in order to establish the liability of the defendant. The Tort of negligence is entirely the creation of judges and is: 'one of the most dynamic and rapidly changing areas of liability in modern common law. ${ }^{141}$ An overview of the different grounds to apply for compensation in asbestos-related cases and a discussion on the requirements and the applicable rules of evidence to establish the liability of the defendant gives the reader more information on how to solve asbestos-related cases under Dutch and English laws.

\footnotetext{
${ }^{139}$ Employers' liability.

${ }^{140}$ Extra-contractual liability.

${ }^{141}$ Deakin et al. 2003, p. 73.
} 
Most jurisdictions, including the two jurisdictions considered here, generally require the claimant to prove causation between the defendant's intervention and the damage which the claimant incurred, in order to establish the liability of the defendant. The requirement of causation forms the heart of this research because the proof of this requirement is extremely difficult in most claims for asbestos-related diseases. The general rule is that the claimant must establish condicio sine qua non (but-for), which means that the claimant must prove to 'a reasonable degree of certainty ${ }^{\text {'142 }}$ or 'on the balance of probabilities ${ }^{143}$ that the damage would not have occurred without the intervention of the defendant. The concept of causation is examined in Part Two, which distinguishes different 'stages' of causation, explores the applicable rules of evidence, and the consequences of the traditional principle of all-or-nothing compensation in cases characterized by the problem of uncertain causation. Note that Part Two provides general information on causation, which is not only confined to claims for asbestos-related diseases but can be used in all areas of Tort law.

The problematic issue of uncertain causation in asbestos-related cases will be examined in Part Three. This part explores specific problems which arise in asbestos-related cases. The emphasis is put on the problem of uncertain causation with regard to the specific tortfeasor, the cause of the damage, or both. Overall, Part Three builds on Part Two and gives an overview of specific problems in claims for mesothelioma, lung cancer which could have been asbestos-related, and pleural plaques. Among other issues, the concept of 'damage' will also be subject to discussion in section 2.6.5 as it has proved to be difficult to show that a person who contracted pleural plaques has suffered 'damage' which is eligible for compensation.

\section{PART ONE: INTRODUCTION TO DUTCH AND ENGLISH LAW ON LIABILITY}

\subsection{Introduction to Dutch law}

In the Netherlands the production and use of asbestos started a long time ago. In the 1960s, 70s, and 80s the Netherlands imported asbestos on a large scale and new asbestos producing factories were founded, such as the Eternit factory in Goor. ${ }^{144}$ As a consequence, many employees have been exposed to asbestos from 1945 to 1990. Scientific research has established that, from 1996 to 2030, almost 40,000 persons will develop an asbestos-related injury in the Netherlands. ${ }^{145}$ Taking into account the long latency period, between the exposure to asbestos and the development of the injury, and the seriousness of asbestos-related diseases, it is most likely that another 20,000 Dutch citizens will die in the coming 35 years as a consequence of negligent exposure to asbestos in the past. ${ }^{146}$ The asbestos problem could thus be seen as a long-tail risk and, because of the

\footnotetext{
${ }^{142}$ Threshold to establish causation in Dutch law.

${ }^{143}$ Threshold to establish causation in English law.

${ }^{144}$ Waterman 2009, p. 316; See also: Burdorf et al. 1997, p. 15-26.

${ }^{145}$ Burdorf et al. 1997a, p. 1-77.

${ }^{146}$ See for example: Rechtbank Haarlem 1 april 2009, LJN: BI1010; Rechtbank Almelo 4 juni 2008, LJN: BD3218; Rechtbank Almelo 2 oktober 2007, LJN: BB4632; Gerechtshof Arnhem 5 juni 2007, LJN:
} 
serious consequences, the rising number of asbestos victims is an extremely disturbing development within our society. ${ }^{147}$

From 1950 to 1973 , the import of asbestos in the Netherlands amounted to approximately 20,000 tons per year and reached a peak of approximately 50,000 tons per year in 1975. Luckily, the import of asbestos decreased rapidly in the years to follow as more information on health-related issues became available. The decrease of import can also be attributed to the development of healthier alternatives for asbestos and safety regulations on the use of asbestos issued by the government. ${ }^{148}$ At this moment, more than 600 Dutch citizens are diagnosed with a fatal case of mesothelioma per year. ${ }^{149}$ However, although asbestos has been banned in the Netherlands since 1993 and has been banned in Europe since 2005, the number of victims diagnosed with asbestos-related injuries will increase drastically in the coming 15 years and is predicted to reach a peak of approximately 700 mesothelioma sufferers per year in about $2018 .^{150}$

The Dutch legal system is, like many European - continental - legal systems, organized as a civil law jurisdiction operating through the Dutch Civil Code (BW). ${ }^{151}$ Some parts of this Civil Code have recently been renewed. ${ }^{152}$ Depending on the situation, a victim who suffers from an asbestos-related disease will base his civil action on either Article $6: 162 \mathrm{BW}^{153}$ or Article 7:658 $\mathrm{BW}^{154}$. The source of the exposure to asbestos influences the applicability of Article 7:658 BW: only persons who have been occupationally exposed to asbestos can file a lawsuit against their employer on the basis of Article 7:658 BW. Persons who suffer from an asbestos-related disease after they have used products containing asbestos at home (household exposure) or have been paraoccupationally or environmentally exposed to asbestos have successfully claimed damages from the responsible person(s) on the basis of Article 6:162 BW.

The requirements to establish the liability of the defendant are, in common with the applicable rules of evidence, influenced by the liability ground. Many diverging views exist on the role these requirements play in the process of determining whether a Tort has been committed. ${ }^{155}$ Generally, both grounds require the claimant to prove causation between, on the one hand, the wrongful conduct of the defendant, and on the other hand, the damage to the victim. ${ }^{156}$ The other requirements to establish the liability of the

BA3664; Baas et al. 2005, p. 759-763; De Ruiter 1997, p. 63. This research is known as the: 'De Ruiter Report'; See also: Burdorf et al. 2003, p. 485: 'In the Netherlands, a country with one of the highest incidences of mesothelioma, the most plausible scenario predicts an increase in pleural mesothelioma mortality among men from nearly 300 cases in 2000 to 490 cases in 2017 and a total death toll close to 12400 cases during 2000-2018.'

147 The highest number of Dutch citizens suffering from an asbestos-related injury can be expected between 2015-2022.

${ }^{148}$ The publication of the first Asbestos Decree followed in 1978; De Ruiter 1997, p. 71.

${ }^{149}$ www.asbestslachtoffers.nl [Last visited 31 August, 2012].

${ }^{150}$ Burdorf et al. 1997b, p. 1093-1098.

${ }^{151}$ For a general introduction to Dutch law in the English language see: Chorus et al. 2006; in Dutch see: Verheugt 2009.

${ }^{152}$ In 1992 book 3, 5, 6 and the first part of book 7 of the Dutch Civil Code came into operation.

${ }^{153}$ Extra-contractual liability.

${ }^{154}$ Employers' liability.

${ }^{155}$ Brans 2001, p. 243.

${ }^{156}$ Hartkamp 2006, p. 146. 
defendant in claims for asbestos-related diseases will also pass the review but are not subject to in-depth discussion. The literature cited in the footnotes provides further details as a full description would exceed the scope of this research.

Section 2.2.1 discusses different liability grounds that can be applied to establish the liability of the defendant in asbestos-related cases. The requirements to establish the liability of the defendant and the applicable rules of evidence are also examined in this section to illustrate the complexity connected to asbestos-related cases and to provide the readers who operate in a different legal system with more information on Dutch Tort law. Finally, in section 2.2.2 a conclusion is presented that emphasizes the importance of the source of the exposure to asbestos to the outcome of the claimant's civil action.

\subsubsection{Grounds for liability in asbestos-related cases}

As established in section 1.2.2, exposure to asbestos could have taken place in various ways. Most persons who suffer from an asbestos-related disease have been exposed to asbestos in the course of their employment(s). In the past, that is, before the 1990s, claims for asbestos-related diseases were only brought up by employees who had been occupationally exposed to asbestos. Such claims were solely based on Article 7A:1638x Old Dutch Civil Code (BW), which has been replaced by Article 7:658 BW in 1997. However, persons who have used products which contained asbestos at home or have experienced a para-occupational or environmental exposure to asbestos, and contracted an asbestos-related disease as a potential consequence of the exposure, cannot claim damages on the basis of Article 7:658 BW.

In the last decades, case law showed an important structural development in claims for asbestos-related diseases. At first, only employees who had been exposed to asbestos in the course of their employment filed a lawsuit against their employer. They grounded their claims on Article 7:658 BW as the conditions to impose liability are more demanding under the extra-contractual regime of Article 6:162 BW. ${ }^{157}$ In the mid-1990s, however, a new category of asbestos victims found their way to court using Article 6:162 BW as the basis for their claims. Here, one could think of persons who have used asbestos materials to consolidate their farmyard or private roads or persons who have been exposed to asbestos by interference from external causes, such as domestic and environmental causes, which will be examined in section 2.2.1.2. ${ }^{158}$

\subsubsection{Applying Article 7:658 BW after occupational exposure to asbestos}

Employees have multiple options to claim damages for work-related accidents and diseases: social security, private insurance, and Tort law. ${ }^{159}$ Tort law can be applied to receive additional compensation which is not covered under the social security benefits or private insurance. Although this section examines claims for asbestos-related diseases, it also has proved to be necessary to consider case law on other (non-asbestos-related)

\footnotetext{
${ }^{157}$ Hartlief et al. 2009, p. 37.

${ }^{158}$ See also: Van der Laan 2005, p. 2422-2425; Sinninghe Damsté et al. 2007, p. 2453-2459.

159 Philipsen 2007, p. 161; he refers to this as 'different compensation layers'. For more information on social security and private insurance I refer to Waterman 2009; Engelhard 2007b; Hoop 2007; Philipsen 2007.
} 
occupational accidents and diseases in order to explain the legal position of employees in asbestos-related cases. However, non-asbestos-related cases will only be discussed when they are needed to examine and clarify the applicable rules of evidence in claims for asbestos-related injuries.

It is important to note that case law has established that the new ${ }^{160}$ Article 7:658 BW is also applicable in cases where the damage occurred a long time ago. ${ }^{161}$ Dutch employers' liability law is still based on fault but case law shows that employers' liability is changing into a rather strict ground for compensation. ${ }^{162}$ In addition, it is important to note that Dutch employers' liability is based on the principle of restitutio in integrum: the employer is liable and obliged to compensate the claimant in full or is not liable and does not have to compensate the claimant at all. Over the years, Article 7:658 BW has been severely discussed and criticised in literature and ideas have been opted to replace this relatively 'strict' system, to establish the liability of the employer, into a system of compulsory direct insurance by the employer to the benefit of their employees. ${ }^{163}$ However, such ideas have not been elaborated further which means that Article 7:658 BW still applies in employers' liability cases.

The following subsections examine employers' liability for asbestos-related injuries in the Netherlands as it is today, which means that historical developments on employers' liability are not taken into consideration. ${ }^{164}$ An estimated number of claims for occupational accidents and diseases on the basis of Article 7:658 BW is, however, difficult to find. Philipsen used annual statistical reports of the Netherlands Association of Insurers to obtain more information on the number of claims in the Netherlands but the general data could - unfortunately - not be filtered into data that specifically deals with asbestosrelated diseases. ${ }^{165}$ The following subsections not only discuss the requirements to establish the liability of the employer on the basis of Article 7:658 BW but also examine the applicable rules of evidence in asbestos-related cases.

\subsection{Requirements and rules of evidence}

The ratio behind Article 7:658 BW is to protect employees in relation to their employers. In cases where the claimant developed an asbestos-related injury after he has been exposed to asbestos in the course of the employment his claim is - most likely - based on Article 7:658 BW. ${ }^{166}$ The requirements to establish the liability of the employer are when compared to a claim which is based on Article 6:162 BW - less demanding, which

\footnotetext{
${ }^{160}$ Article 7A:1638x Old Dutch Civil Code was replaced by Article 7:658 BW, which has become operative in 1997.

${ }^{161}$ Hoge Raad 17 november 2000, NJ 2001, 596 (Unilever/Dikmans).

${ }^{162}$ It is not a strict liability because Dutch law does not require employers to take their duty of care to absolute extremes. See for example: Hoge Raad 27 april 2007, NJ 2008, 462 (Kalai/Petit); Hoge Raad 12 december 2008, NJ 2009, 332 (Maatzorg/Van der Graaf).

${ }^{163}$ For more information see: Van Dunné 1994, p. 19; Lindenbergh 2000, p. 110-113; Faure et al. 2006, p. 1; Engelhard 2007b; Waterman 2009.

${ }^{164}$ For historical developments on employers' liability in the Netherlands see: Waterman 2009; Engelhard $2007 b$; Hoop 2007.

${ }^{165}$ Philipsen 2007, p. 161.

${ }^{166}$ For more information on the applicability of Article 7:658 BW in asbestos-related cases see: Hartlief 2005, p. 41-48.
} 
means that the claimant's claim is more likely to succeed. Rules of evidence are more favourable to employees. Under the regime of Article 7:658 BW, the claimant does not have to prove the wrongfulness of the defendant's intervention but it will be up to the employer to state and (if the claimant sufficiently contested the employer's statement) prove that he had not breached his duty of care towards his employee in order to escape liability. ${ }^{167}$ If the employer is unable to do so he can try to dispute the causal link in order to escape (full) liability. In this plea, the defendant tries to demonstrate that the employee's damage would also have existed if he did not breach his duty of care. If the employer is unable to dispute the causal link he can also escape liability by proving that the employee's damage was caused by the employee's 'own intent or deliberate recklessness ${ }^{\text {'168 }}$. However, case law shows that the latter clause to escape liability has not played a decisive role in asbestos-related cases and will, therefore, not be examined more closely in the following part(s) of this research.

Although Article 150 Dutch Code of Civil Procedure (Rv) gives some guidance with regard to the burden of proof in civil litigation, case law made it clear that rules of evidence have changed over the years to strengthen the claimants' legal position in employers' liability cases. ${ }^{169}$ In addition, it is important to note that the applicable rules of evidence in claims for occupational diseases differ from the applicable rules of evidence in claims for occupational accidents because the causal link between the employer's breach of duty and the damage suffered by the employee, is less clear in claims for occupational diseases. In civil litigation, the rules of evidence have not been crystallized, which makes it difficult to discuss general rules on the burden of proof in cases where the employee suffers from an asbestos-related injury after he has been occupationally exposed to asbestos. However, some general rules can be found in case law on this specific topic.

An employee who suffers from an asbestos-related disease after he has been occupationally exposed to asbestos must, in order to establish the liability of the employer under the regime of Article 7:658 BW, state and (if the employer sufficiently contested the claimant's statement) prove that (1) he was employed by the defendant and exposed to asbestos in the course of that employment; and (2) that he suffers from a disease (damage) which could be a consequence of asbestos exposure. ${ }^{170}$

\section{* Exposure to asbestos in the course of the employment}

The proof of the exposure to asbestos while working for the defendant can be rather problematic due to the long latency period between the exposure and the manifestation of the injury. ${ }^{171}$ Former colleagues, who can confirm that the claimant had been occupationally exposed to asbestos, might be untraceable or have deceased. In addition, measurement data on the level of exposure is not always available in the specific claimant's

\footnotetext{
${ }^{167}$ Hartlief et al. 2009, p. 42; Hoge Raad 17 november 2000, NJ 2001, 596 (Unilever/Dikmans).

${ }^{168}$ Article 7:658 s. 2 BW: 'opzet of bewuste roekeloosheid'.

${ }^{169}$ Hoge Raad 11 maart 2005, NJ 2010, 309 (ABN AMRO/Nieuwenhuys).

${ }^{170}$ I refer to Yvonne Waterman's Ph.D-dissertation for a more in-depth discussion on rules of evidence in employers' liability cases: Waterman 2009, p. 1-510. Keep in mind that 'in the course of the employment' should be interpreted with a broad view.

${ }^{171}$ I refer to section 1.3 for more information on the latency period in asbestos-related cases.
} 
case. It thus should be noted that there is a lack of evidence in the majority of the cases. $^{172}$

Case law shows that the employee must prove that he has been exposed to asbestos in the course of the employment in cases where the employer has sufficiently ${ }^{173}$ contested the exposure. ${ }^{174}$ In Weststrate/De Schelde ${ }^{175}$ (2001), the Dutch Supreme Court ruled that it is not sufficient to prove a possible exposure to asbestos in the course of the employment to establish the liability of the defendant. The Supreme Court thus decided not to extend the liability of the employer in cases where the claimant is unable to prove that he had been exposed to asbestos in the course of the employment but could only prove a possible exposure to asbestos while working for the defendant. ${ }^{176}$ This rule of law has been confirmed in a recent case in 2009 in which the claimant developed mesothelioma. In this case the Court of Appeal also dismissed the claimant's claim for compensation because the claimant was - after the defendant has sufficiently contested the exposure to asbestos in the course of the employment - unable to prove that he had been exposed to asbestos while working for the defendant. ${ }^{177}$ The inability to prove the occupational exposure to asbestos has far-reaching consequences for the claimant: he leaves emptyhanded.

\section{* Damage for legal purposes?}

Irrespective of whether the claimant's claim is based on Article 7:658 BW or Article 6:162 BW, Dutch law requires the claimant to show that he has suffered 'damage' which is eligible for compensation in order to establish the liability of the defendant. ${ }^{178}$ It is now widely accepted that exposure to asbestos can lead to lung cancer and there is no question of whether lung cancer contracted unequivocally by another's negligence causes damage for legal purposes. ${ }^{179}$ Lung cancer is actual 'damage' under Dutch law and the most common asbestos-related injuries, such as mesothelioma, lung cancer and asbestosis, are considered as damage which is eligible for compensation. ${ }^{180}$

However, in specific cases in which the claimant only contracted pleural plaques it can be questioned whether or not the claimant has suffered damage which is eligible for compensation. According to the dominant view, pleural plaques do not cause any external symptoms, they only mark the presence in the lungs and pleura of asbestos fibres which may independently cause life-threatening diseases such as asbestosis, mesothelio-

\footnotetext{
${ }^{172}$ I refer to the sections 1.3.2 and 1.3.3 for more information on the latency period.

${ }^{173}$ Clearly motivated.

${ }^{174}$ See: Hoge Raad 26 januari 2001, NJ 2001, 597 (Weststrate/De Schelde).

${ }^{175}$ Hoge Raad 26 januari 2001, NJ 2001, 597 (Weststrate/De Schelde).

176 This has been confirmed by the Court of Appeal in another but similar case: Gerechtshof Amsterdam (nevenzittingsplaats Arnhem) 26 augustus 2008, nr. 104.003.877 (unpublished).

${ }^{177}$ Gerechtshof 's-Gravenhage 18 augustus 2009, LJN: BJ5651. See also: Rechtbank 's-Gravenhage 4 april 2012, LJN: BW1118 in which the claimant also failed to prove that he had been exposed to asbestos in the course of the employment.

${ }^{178}$ Both Articles 7:658 BW (contractual) and 6:162 BW (extra-contractual) require the claimant to prove that he has suffered 'damage' in order to establish the liability of the defendant.

${ }^{179}$ See for a medical acceptance: Beers et al. 2003, p. 297. See for a legal acceptance: Hoge Raad 31 maart 2006, NJ 2011, 250 (Nefalit/Karamus) or Fairchild v Glenhaven Funeral Services Ltd, [2002] UKHL 22.

${ }^{180}$ I refer to Chapter 1 for medical information on the asbestos-related diseases itself.
} 
ma, or lung cancer. Furthermore, and perhaps most importantly for Tort law, current medical consensus seems to show that the presence of pleural plaques gives no indication of whether the individual will or will not develop lung cancer because of the exposure which they have had to asbestos: the general view is that the presence of pleural plaques is not an indication of an increased risk of developing an asbestos-related lung cancer, but it 'only' confirms an exposure to asbestos. As will be explained more extensively in section 2.6.5, Dutch claimants who have contracted pleural plaques have to establish that they have suffered 'actual' damage and can be compensated for the additional costs of regular monitoring their medical condition (material damage). In such cases, the Court of Appeal and Courts of First Instance have established that serious anxiety alone can also give rise to a claim for pain and suffering (non-pecuniary damage) which would be within the ambit of Article 6:106 lid 1 sub b BW. ${ }^{181}$ This means that serious anxiety as a result of the contraction of pleural plaques does not necessarily have to lead to a psychiatric illness in order to be eligible for compensation. ${ }^{182}$

In the majority of asbestos-related cases, the proof of the damage requirement is relatively straightforward. Because the proof of damage is not a real burden in the majority of the cases ${ }^{183}$, the concept of 'damage' is not subject to in-depth discussion in this thesis. However, it is important to keep in mind that the word 'damage' refers to the claimant's injury and that 'damages' refers to the amount of compensation. Apart from the distinction that is made in Article 6:95 BW between patrimonial damage and nonpecuniary damage, the term 'damage' is not further defined by law. Damage is most commonly described as diminution ${ }^{184}$ or detriment ${ }^{185}$ of/to an object. The Dutch legislator thus has restricted the recovery of damage to two main types of damage: pecuniary losses and non-pecuniary losses. ${ }^{186}$ Articles 6:95 BW and 6:96 BW describe the forms of damage that are eligible for compensation. Non-pecuniary damage, like pain and suffering, can be compensated according to the rules set out in Article 6:106 BW. For the proof of damage it is, however, not necessary to provide for an exact amount. It is sufficient to demonstrate that the existence of the damage is plausible. ${ }^{187}$

\section{* A connection between the exposure to asbestos and the damage}

In cases where it has been established that the employee had been exposed to asbestos in the course of the employment, the claimant subsequently must state and (if the defendant sufficiently contested the claimant's statement) prove that there is a connection ${ }^{188}$

\footnotetext{
${ }^{181}$ Gerechtshof 's-Hertogenbosch 6 mei 2008, LJN: BD5666; Rechtbank Middelburg 30 mei 2001, JAR 2001, 232; Rechtbank Zwolle-Lelystad 30 mei 2007, zaaknr. 249185.

${ }^{182}$ Sobczak et al. 2009, p. 207-217: In case the victim only contracted pleural plaques the 'damage question' is far more difficult to answer. See for example: Johnston v NEI International Combustion Limited, [2007] UKHL 39.

${ }^{183}$ The most common asbestos-related injuries are: asbestosis, mesothelioma, and lung cancer.

${ }^{184}$ Dutch translation: 'vermindering'.

${ }^{185}$ Dutch translation: 'nadeel'.

${ }^{186}$ Hartlief 2003a, nr. 199, 200.

${ }^{187}$ Hoge Raad 13 juni 1980, NJ 1980, 185.

${ }^{188}$ The requirement of causation is captured in Article 7:658 (1) BW: '...in the course of his employment'.
} 
between the exposure to asbestos and the damage (disease) which the claimant encountered.

There is important case law on the proof of a connection between the exposure to asbestos in the course of the employment and the claimant's damage, in claims for mesothelioma. Havermans/Luyckx (2006) shows that the claimant must state and (if the defendant sufficiently contested the claimant's statement) prove that he suffers from a condition which could be a consequence of the exposure in the course of the employment. ${ }^{189}$ Proving that the employee's damage could have been caused by the exposure to asbestos in the course of the employment is not complicated in asbestos-related cases in which the claimant suffers from mesothelioma. ${ }^{190}$ In such cases, scientific evidence has established that a safe level of exposure to asbestos does not exist. ${ }^{191}$ This means that, irrespective of the level of exposure, the exposure to asbestos in the course of the employment can lead to the development of mesothelioma. However, in claims for asbestosis the proof of a sufficient connection is more complicated because a certain 'dose' or level of exposure is required for the development of the disease. ${ }^{192}$ In such cases, scientific evidence has established that there is a safe level of exposure, which means that it is up to the claimant to show that the exposure in the course of the employment has exceeded a certain 'level' of exposure (threshold) in order to establish the liability of the employer. ${ }^{193}$

\section{* A duty of care owed by the employer to the employee(s)}

This subcategory examines the employer's duty of care towards his employee in cases where the employee suffers from an asbestos-related injury after he had been occupationally exposed to asbestos. Article 7:658 BW lays down employers' responsibility for the working environment of their employees. This means that Dutch employers have a duty of care to:

'organize the workplace, the equipment and tools in which or with which he has labor performed, takes safety measures and gives instructions and supervision regarding the same, in such a way as may reasonable be expected of him in order to prevent the employee from coming to harm while in and during the course of his employment.' ${ }^{194}$

In the Netherlands, employers are obliged to strive for an optimum level of protection but Dutch law does not require employers to take their duty of care to absolute extremes, which - strictly speaking - implies that employers' liability is still based on

\footnotetext{
${ }^{189}$ Hoge Raad 23 juni 2006, NJ 2006, 354 (Havermans/Luyckx). See also: Hoge Raad 17 november 2000, NJ 2001, 596 (Unilever/Dikmans).

${ }^{190}$ In cases in which it is not clear whether or not one could speak of an occupational accident or an occupational disease, proving that the damage could have been employment-related can, however, be a difficult hurdle to take for the claimant. See for example: Hoge Raad 9 januari 2009, JA 2009/58, LJN: BF8875 (Landskroon/BAM) in which the employee could not prove that his pain in the back could have been employment-related.

${ }^{191}$ Gezondheidsraad 1999, p. 10-11.

${ }^{192}$ Hart \& Aberle 1996, p. 92; Burdorf \& Swuste 1999, p. 58.

${ }^{193}$ See also: Hoge Raad 16 mei 2008, LJN: BC7683.

${ }^{194}$ Article 7:658 (1) BW. Translation: Waterman 2009, p. 443.
} 
fault and cannot be considered as a strict liability. ${ }^{195}$ In addition, it is important to note that the employer's duty of care does not only count for known risks but also for risks which the employer ought to have known. ${ }^{196}$ Case law on asbestos-related injuries even shows that employers can also be held responsible for risks which they not even ought to have known. ${ }^{197}$

In principle, the employer can be held liable in asbestos-related cases in which the claimant has proved that he has been exposed to asbestos in the course of the employment and that he suffers from a disease which could be a consequence of the exposure to asbestos. However, the employer can escape liability if he is able to state and (if the claimant sufficiently contested the employer's statement) prove that he did not breach his duty of care in the specific claimant's case. ${ }^{198}$ In order to establish whether or not the employer has breached his duty of care one has to take into consideration the moment (time period) in which the exposure to asbestos occurred. In civil litigation, the Court decides whether or not the employer has breached his duty of care on the basis of what employers knew or ought to have known about the risks connected to asbestos exposure at the moment of the exposure to asbestos. In Janssen/Nefabas ${ }^{199}$ (1990), Mr Janssen has been employed by Nefabas from 1945 to 1972. During this period, he had been exposed to asbestos in the course of the employment and he developed asbestosis as a consequence of the exposure. The Supreme Court ruled that there was a duty resting upon the employer to provide for a safe working environment and thus to investigate the risks connected to asbestos exposure in order to take sufficient precautionary measures to prevent injury. ${ }^{200}$ The Supreme Court further ruled that the employer had breached his duty of care as he ought to have known the risks connected to asbestos exposure.

In the subsequence case of Cijsouw /De Schelde $1^{201}$ (1993), Mr Cijsouw was employed by De Schelde from 1949 to 1967 and was exposed to asbestos in the course of that employment. In Cijsouw 1, the Supreme Court had to decide on which moment the employer had to take precautionary measures to prevent the employee from contracting mesothelioma. The employer denied liability arguing that - before 1960 - it had not yet been established that asbestos exposure could lead to the development mesothelioma. De Schelde thus argued that - prior to 1960 - he was not familiar with the causal link between asbestos exposure and mesothelioma. In his view, this implied that he was not obliged to take precautionary measures and thus did not breach his duty of care towards Mr Cijsouw. The Supreme Court, however, established the liability of De Schelde and ruled that employers could be held liable for unknown risks in cases where they have breached their duty of care to prevent employees from contracting known risks (asbesto-

\footnotetext{
195 SER 2005, Advisory Report: Evaluation of the Working Conditions Act 1998, p. 47; Lindenbergh 2000, p. 28; Waterman 2009, p. 443.

${ }^{196}$ Hoge Raad 6 april 1990, NJ 1990, 573 (Janssen/Nefabas).

${ }^{197}$ Hoge Raad 25 juni 1993, NJ 1993, 686 (Cijsouw/De Schelde 1).

${ }^{198}$ See: Hoge Raad 17 februari 2006, NJ 2007, 285 (Van Buuren/Heesbeen).

${ }^{199}$ Hoge Raad 6 april 1990, NJ 1990, 573 (Janssen/Nefabas).

${ }^{200}$ Hoge Raad 6 april 1990, NJ 1990, 573, paragraph 3.4 (Janssen/Nefabas).

${ }^{201}$ Hoge Raad 25 juni 1993, NJ 1993, 686 (Cijsouw/De Schelde 1).
} 
sis) connected to asbestos exposure. ${ }^{202}$ In Cijsouw/De Schelde $2^{203}(1998)$, the employer tried to escape liability arguing that other employers also did not take precautionary measures to prevent their employees from contracting mesothelioma and that the government did not take any action against the exposure to asbestos in the course of the employment. The Supreme Court, however, quashed this plea as - according to the Supreme Court - both arguments did not free De Schelde from his duty to take precautionary measures in order to prevent their employees from risks which he knew or ought to have known (asbestosis). ${ }^{204}$

The cases Janssen/Nefabas, Cijsouw /De Schelde 1, and Cijsouw/De Schelde 2 show that it is extremely difficult for employers to prove that they have not breached their duty of care towards their employees. However, other case law shows that it is not impossible to escape liability on the basis of such a plea. In Van Buuren/Heesbeen ${ }^{205}$ (2006), Mr Heesbeen was employed by Van Buuren from 1965 to 1967 and developed mesothelioma after he was exposed to asbestos in the course of this employment. In appeal, the Court of First Instance ${ }^{206}$ quashed the decision of the cantonal judge and followed the decision in Cijsouw/De Schelde 1. The Court of First Instance established the liability of the employer because Van Buuren knew or ought to have known about the risks of asbestosis; he neglected his duty to take precautionary measures to prevent employees from contracting asbestosis. Subsequently, Van Buuren took this case to the Supreme Court arguing that liability should be denied as the level of exposure to asbestos in the course of the employment was limited ${ }^{207}$ and could thus not have caused asbestosis because the exposure did not exceed a certain threshold (level of exposure). The Supreme Court deviated from the decision of the lower court and denied the liability of the employer stating that the intensity and duration of the exposure should be taken into account to decide whether or not the employer has breached his duty of care towards his employee. ${ }^{208}$

After Van Buuren/Heesbeen, claims for mesothelioma were less likely to succeed in cases where the employee had only been exposed for a short period to low concentrations of asbestos fibres in a time period in which the risks of mesothelioma were unknown. ${ }^{209}$ In these particular cases, the claimant had to show that the intensity and duration of the exposure exceeded a certain threshold (level of exposure) which reasonably lead to the consequence that a breach of the employer's duty of care can be established. ${ }^{210}$

\footnotetext{
${ }^{202}$ Hoge Raad 25 juni 1993, NJ 1993, 686, paragraph 3.8.4 (Cijsouw/De Schelde 1). This rule of law has been confirmed in Hoge Raad 31 maart 2006, NJ 2011, 250 (Nefalit/Karamus).

${ }^{203}$ Hoge Raad 2 oktober 1998, NJ 1999, 683 (Cijsouw/De Schelde 2).

${ }^{204}$ Hoge Raad 2 oktober 1998, NJ 1999, 683, paragraph 3.3.2 (Cijsouw/De Schelde 2).

${ }^{205}$ Hoge Raad 17 februari 2006, NJ 2007, 285 (Van Buuren/Heesbeen).

${ }^{206}$ Rechtbank 's-Gravenhage 24 maart 2004 (not published).

${ }^{207}$ In terms of exposure level.

${ }^{208}$ Hoge Raad 17 februari 2006, NJ 2007, 285, paragraph 4.7 (Van Buuren/Heesbeen).

209 This has been confirmed in: Gerechtshof 's-Hertogenbosch 22 maart 2011, LJN: BP8866. See also: Sobczak 2011, p. 34.

${ }^{210}$ Meijer \& Lindenbergh 2008, p. 436-443.
} 
In Broug/Gemex ${ }^{211}$ (2004), Gemex also successfully escaped liability arguing that he did not breach his duty of care as he was not familiar with the risk of mesothelioma. In Broug, the employee worked for Gemex from 1965 to 1979. The employee had been exposed to white asbestos (chrysotile) in the course of that employment, which could have led to the development of mesothelioma in 1998. The Court of First Instance deviated from the decision in Cijsouw/De Schelde 1 and denied the liability of the employer stating that - during the time of exposure - the employer was not familiar with the risks connected to white asbestos. The Supreme Court confirmed the decision of the Court of First Instance without further discussing the distinction between different types of asbestos fibres.

In subsequent case law, more employers tried to escape liability arguing that they have only exposed their employees to white asbestos (chrysotile) and thus did not breach their duty of care towards their employees as they were not familiar with the risks connected to white asbestos. ${ }^{212}$ However, in other cases the courts have quashed this plea, established a breach of the employer's duty of care, and held the employers liable for the claimant's damage. ${ }^{213}$ A reasonable explanation for the fact that the employer's duty of care was not breached in Broug, but had been breached in the two subsequent cases ${ }^{214}$ taken under consideration here, is that Gemex (the employer in Broug) was only a garage and not an asbestos producing company as in the other two cases (Hertel and Nefalit). It seems that asbestos producing companies, such as Hertel and Nefalit, ought to have known the risks of exposure to white asbestos. A recent decision of the Court of Appeal in February 2011 seems to confirm this conclusion. ${ }^{215}$

Another, rather practical, problem which relates to the latter plea (the defendant was not familiar with the risks connected to white asbestos) is that it is almost impossible to prove that the employee has only been exposed to white asbestos in the course of the employment. As explained in section 1.3.2, white asbestos is often contaminated with tremolite and crocidolite. This makes it is rather exceptional that an employee has only been exposed to white asbestos. ${ }^{216}$ Laboratory research is necessary to determine the chemical nature of the asbestos fibres because one is unable to determine the chemical nature of asbestos fibres with the naked eye. After a few decades, which is the consequence of such a long latency period, laboratory research cannot be performed anymore unless the employee or former colleagues have kept some asbestos materials. ${ }^{217}$ This also confirms the conclusion which I draw at the end of section 2.2.1.1.1: there is a lack of evidence in the majority of asbestos-related cases.

\footnotetext{
${ }^{211}$ Hoge Raad 4 juni 2004, JAR 2004, 287 (Broug/Gemex).

${ }^{212}$ For example: Gerechtshof Amsterdam 22 maart 2011, LJN: BP8854. See also: Sobczak 2011, p. 34.

${ }^{213}$ Hoge Raad 17 december 2004, NJ 2006, 147, paragraph 3.9 (Hertel/Van der Lugt); Rechtbank Almelo 9 juli 2008, LJN: BF1904, paragraph 18. A similar explanation can be found in: Rechtbank Rotterdam 1 augustus 2006, LJN: AY5429 (Okker/Eternit), and - although the claim is based on Article 6:162 BW -: Hoge Raad 25 november 2005, LJN: AT8782 (Nieborg-Horsting/Eternit).

${ }^{214}$ Hoge Raad 17 december 2004, NJ 2006, 147, paragraph 3.9 (Hertel/Van der Lugt); Rechtbank Almelo 9 juli 2008, LJN: BF1904, paragraph 18.

${ }^{215}$ Gerechtshof Leeuwarden 8 februari 2011, LJN: BQ0520. See also: De Lang \& Van 2008, p. 52.

${ }^{216}$ Planteydt 1991, p. 56-59.

${ }^{217}$ De Lang \& Van 2008, p. 53.
} 


\subsection{Disputing causation}

Once - after passing all the difficulties mentioned above - it has been established that the employer has breached his duty of care, the employer can still escape liability if he is able to prove that the claimant's damage would also have occurred if he had not breached his duty of care. ${ }^{218}$ In this plea, the employer disputes the causal link between his intervention (breach of duty: exposure to asbestos) and the claimant's damage. The mesothelioma case Cijsouw/De Schelde $1^{219}$ shows, however, that it is impossible for the employer to prove that his employee had not inhaled the fatal asbestos fibre while working for De Schelde. Proving that the damage would also have occurred without the employer's breach of duty is, due to the complexity, an impossible hurdle to take in claims for mesothelioma in which the employee had only been exposed to asbestos in the course of one employment. In Cijsouw 1, the Dutch Supreme Court further ruled that it was not the purpose of the rule - protecting employees against employment risks - to lay the burden of proof, that the employee inhaled the fatal asbestos fibre while being employed by De Schelde, on the claimant. ${ }^{220}$

As discussed in section 1.3.2.2, in claims for mesothelioma causal uncertainty could arise as to the specific tortfeasor in cases where the employee has worked for two or more employers all exposing the employee to asbestos in several different employments. In these particular cases, it is impossible to tell which employer, in a group of possible tortfeasors (employers), has caused the claimant's damage. ${ }^{221}$ The employer will be unable to dispute causation between the breach of his duty of care and the claimant's mesothelioma because he cannot prove that the employee would not have contracted mesothelioma if he had not breached his duty of care, i.e., the employer cannot prove that the employee did not inhale the fatal asbestos fibre in the course of that employment.

In claims for lung cancer, employers have also tried to escape (full) liability. In Nefalit/Karamus ${ }^{222}$ and Hollink/Eternit ${ }^{223}$ the employers tried to dispute causation arguing that the claimants could also have developed lung cancer if the employers did not breach their duty of care. To put it differently: the employers tried to prove that the lung cancer was caused by (an) external factor(s) that did not even touch the sphere of employment. In such cases, it remains unclear whether or not the damage (lung cancer) is the consequence of a breach of the employer's duty of care because medical science is unable to determine the precise cause of lung cancer. The Dutch Supreme Court quashed the employers' plea to escape full liability and decided to award damages in proportion to the probability of causation because it would be unfair to devolve the causal uncertainty to

\footnotetext{
${ }^{218}$ Article 7:658 (2) BW.

${ }^{219}$ Hoge Raad 25 juni 1993, NJ 1993, 686 (Cijsouw/De Schelde 1).

${ }^{220}$ Hoge Raad 25 juni 1993, NJ 1993, 686 (Cijsouw/De Schelde 1); Lindenbergh 2000, p. 96.

${ }^{221}$ In mesothelioma cases where two or more employers have exposed the employee to asbestos in the course of the separate employments the claimant cannot prove which employer has caused the mesothelioma to begin forming because medical science cannot determine when the employee inhaled the fatal asbestos fibre. In such cases the employers are held jointly liable on the basis of Article 6:99 BW and Article 6:166 BW. See also: Hoge Raad 9 oktober 1992, NJ 1994, 535 (DES-dochters) in which the Dutch Supreme Court denied market-share liability.

${ }^{222}$ Hoge Raad 31 maart 2006, NJ 2011, 250 (Nefalit/Karamus).

${ }^{223}$ Hoge Raad 31 maart 2006, LJN: AU6093 (Hollink/Eternit).
} 
either the claimant or the defendant. ${ }^{224}$ The concept of causation will be extensively discussed in section 2.4 and solutions to the problem of uncertain causation in asbestosrelated cases will be presented in Chapter 3.

\subsection{Conclusion}

In order to establish the liability of the employer, the claimant must - under the regime of Article 7:658 BW - state and (if the employer sufficiently contested the claimant's statement) prove that he had been exposed to asbestos in the course of the employment and that he contracted a disease (damage) which could have been a consequence of the exposure to asbestos. The proof of a possible exposure to asbestos is not sufficient to establish the liability of the employer. In cases in which the employee suffers from mesothelioma after he had been occupationally exposed to asbestos, the claimant will not encounter difficulties in proving that the disease could have been caused by the occupational exposure because a safe level of asbestos exposure does not exist. Employees will encounter more difficulties to prove a sufficient connection in claims for asbestosis: the claimant must state and (if the employer sufficiently contested the claimant's statement) prove that the exposure to asbestos in the course of the employment exceeded a certain threshold (level of exposure) in order to claim compensation successfully.

The employer can be held liable for the claimant's damage if the claimant is able to prove the abovementioned conditions unless the defendant can prove that he did not breach his duty of care in the claimant's case. ${ }^{225}$ Case law shows, however, that it is very difficult for employers to state and (if the claimant sufficiently contested the employers' statement) prove that they have not breached their duty of care in cases where they have exposed their employees to asbestos in the course of the employments. Such a plea only proved to be successful in very specific cases in which the employee had been exposed only for a short period of time to low concentrations of asbestos fibres in a time period in which the risks of mesothelioma were unknown (before 1960s) or had only been exposed to white asbestos by a non-asbestos-producing company (garage) in a time period in which the employer not ought to have been familiar with the risks connected to white asbestos.

In cases where it has been established that the employer has breached his duty of care the employer can still escape liability if he is able to prove that the claimant's damage would also have occurred if he did not breach his duty of care. ${ }^{226}$ In this plea, the employer disputes causation between his intervention (breach of duty: exposure to asbestos) and the claimant's damage. Case law on mesothelioma shows that it is almost impossible for the employer to prove that his employee had not inhaled the fatal asbestos fibre in the course of that employment. Proving that the damage would also have occurred without the employer's breach of duty is, due to the complexity, an impossible hurdle to take in claims for mesothelioma. In claims for lung cancer, employers have also tried to dispute causation arguing that the employee's lung cancer had not been caused by the exposure

\footnotetext{
${ }^{224}$ Hoge Raad 31 maart 2006, NJ 2011, 250, paragraph 3.13 (Nefalit/Karamus).

${ }^{225}$ Swagemakers \& Taminau 2007, p. 7, 8; Hartlief et al. 2009, p. 47; Hoge Raad 17 februari 2006, NJ 2007, 285 (Van Buuren/Heesbeen).

${ }^{226}$ Article 7:658 (2) BW.
} 
to asbestos in the course of that employment but by (an)other factor(s) for which the employer cannot be held responsible. In these particular cases, the Supreme Court decided to award damages in proportion to the probability that asbestos exposure has caused the claimant's lung cancer because it would be unfair to devolve the causal uncertainty to either the claimant or the defendant. Furthermore, if the employer is unable to dispute the causal link he could only escape liability if he is able to prove that the employee's damage was caused by the employee's 'own intent or deliberate recklessness ${ }^{227}$. This latter clause to escape liability has, however, not played a decisive role in claims for asbestos-related diseases.

\subsubsection{Applying Article 6:162 BW after household, para-occupational or environmental exposure to asbestos}

Although most victims who suffer from an asbestos-related disease have been occupationally exposed to asbestos, more and more victims who have not been exposed to asbestos in the course of their employment(s) find their way to court. As discussed in section 1.2.2.2, persons who have used asbestos-containing materials at home or have experienced a para-occupational or environmental exposure to asbestos, and contracted an asbestos-related injury as a potential consequence of the exposure, cannot claim damages from their employer on the basis of Article 7:658 BW. Such victims, or their relatives, will try to sue the responsible asbestos factory who brought asbestos fibres into the environment or sold/gave away the remaining parts of asbestos-containing materials (waste) to locals without warning them enough about the risks and without providing them sufficient information on using methods. ${ }^{228}$ In addition, one could refer to real life cases in which asbestos workers took their filthy (i.e., asbestos-containing) work clothes home, which could have caused mesothelioma to the asbestos worker's $\operatorname{child}^{229}$ and wife $^{230}$. In all abovementioned cases, it is rather unlikely that the claimant could claim damages from the responsible company on the basis of Article 6:175 BW (liability for dangerous substances) or Article 6:185 BW (product liability) because in most situations both Articles came into operation after the victim had been exposed to asbestos and after the asbestos-containing product had been manufactured and was put onto the market. ${ }^{231}$

The claimant can base his extra-contractual liability claim on Article 6:162 $\mathrm{BW}^{232}$. However, if a claim is based on Article 6:162 BW it is - when compared to Article 7:658

\footnotetext{
${ }^{227}$ Article 7:658 (2) BW: 'opzet of bewuste roekeloosheid'.

${ }^{228}$ See for example: Gerechtshof 's-Gravenhage 3 april 2012, LJN: BW0093; Gerechtshof Arnhem 20 december 2011, JA 2012, 100; Rechtbank Almelo 9 juli 2008, LJN: BF1904; Rechtbank Almelo 4 juni 2008, LJN: BD3218; Rechtbank Almelo 2 oktober 2007, LJN: BB4632; Gerechtshof Arnhem 5 juni 2007, LJN: BA6364; See for an English case on environmental exposure: Margereson \& Hancock v J.W. Roberts Ltd, [1996] PIQR 154; June Hancock was the first mesothelioma sufferer in the UK who received compensation for neighbourhood exposure to asbestos because she lived in close proximity to an asbestos factory.

${ }^{229}$ Rechtbank Almelo 27 januari 1999, VR 2000, 24.

${ }^{230}$ Rechtbank Amsterdam 24 maart 1999, VR 2000, 25.

${ }^{231}$ De Lang \& Van 2008, p. 61-62.

${ }^{232}$ Article 6:162 (1) BW: 'A person who commits an unlawful act toward another which can be imputed to him, must repair the damage which the other person suffers as a consequence thereof.'
} 
BW - more difficult to establish the liability of the defendant since the conditions to impose liability are more demanding. ${ }^{233}$ As this research mainly focuses on employers' liability, I will only provide general information on claims brought up by persons who have used products containing asbestos at home and persons who have been paraoccupationally or environmentally exposed to asbestos. As opposed to Article 7:658 BW, Article 6:162 BW requires the claimant to prove the wrongfulness of the defendant's intervention. As discussed in section 2.2.1.1.1, under the regime of Article 7:658 BW the claimant is not obliged to prove the wrongfulness of the defendant's intervention, but it is up to the employer to state and (if the claimant sufficiently contested the defendant's statement) prove that he had not breached his duty of care towards his employee in order to escape liability. ${ }^{234}$ Applying Article 6:162 BW, the rules of evidence are less victim friendly: in order to establish the wrongful conduct of the defendant the claimant must show that the defendant knew or ought to have known the risks connected to asbestos exposure at the moment of the exposure.

Applying Article 6:162 BW, it is - in general and in line with Article $150 \mathrm{Rv}$ - up to the claimant to state and (if the defendant sufficiently contested the claimant's statement) prove that there is: (1) a wrongful conduct which is (2) attributable to the defendant, (3) damage, and last but not least (4) a causal link between the wrongful conduct of the defendant and the damage which the claimant has encountered. ${ }^{235}$ In addition, the claimant must prove that the violated norm intended to protect the injured person against the victim's damage. ${ }^{236}$ In the following subsections the liability for products containing asbestos, the liability for para-occupational exposure to asbestos, and the liability for environmental exposure to asbestos pass the review.

\subsection{Liability for products containing asbestos}

This section examines the liability for products containing asbestos, i.e., the liability of the manufacturer of products containing asbestos who has sold or gave away such products to persons who have developed an asbestos-related injury as a potential consequence of the product. In 2005, the Supreme Court had to decide whether a manufacturer of products containing asbestos can be held liable for a woman's mesothelioma. ${ }^{237}$ In this case, the claimant's only established exposure to asbestos had taken place in 1971 when her brothers built a shed next to the claimant's house. Products containing asbestos were used to construct the shed and the claimant argued that she shook out the asbestos dust from her brothers' work clothes. ${ }^{238}$ It had been established that the Eternit factory in

\footnotetext{
Article 6:162 (2) BW: 'Except where there is a ground for justification, the following acts are deemed to be unlawful: the violation of a right, an act or omission violating a statutory duty or a rule of unwritten law pertaining to proper social conduct.'

Article 6:162 (3) BW: 'An unlawful act can be imputed to it's author if it results from his fault or from a cause for which he is answerable according to law or common opinion.'

${ }^{233}$ Van Boom 2005b, p. 139.

${ }^{234}$ Hartlief et al. 2009, p. 42; Hoge Raad 17 november 2000, NJ 2001, 596 (Unilever/Dikmans).

${ }^{235}$ Meijer \& Lindenbergh 2008, p. 438.

${ }^{236}$ Article 6:163 BW. In Dutch law, this Article is known as the 'scope of the rule' provision.

${ }^{237}$ Hoge Raad 25 november 2005, LJN: AT8782 (Nieborg-Horsting/Eternit).

${ }^{238}$ De Lang 2007, p. 59.
} 
Goor sold the products containing asbestos to build the shed. The claimant tried to establish the defendant's wrongful conduct arguing that the risks connected to asbestos had been known before Eternit put the products containing asbestos onto the market.

Both the Court of First Instance ${ }^{239}$ and the Court of Appeal ${ }^{240}$ allowed the claim attaching great value to the fact that the defendant had put the product containing asbestos onto the market without any warning sign while the defendant knew or ought to have known about the risks connected to asbestos exposure. ${ }^{241}$ Subsequently, the defendant questioned causation to escape liability arguing that the claimant failed to prove that the defendant put the products containing asbestos, which were used to build the shed, onto the market. Furthermore, the defendant argued that the claimant could not prove that the defendant's products had caused the claimant's mesothelioma. The claimant, however, argued that causation could be established on the basis of Article 6:99 BW ${ }^{242}$ (alternative causality). Both courts ruled that Article 6:99 BW can be applied in this case. Applying Article 6:99 BW, it was up to the defendant to prove that the claimant's mesothelioma was not a consequence of the intervention for which the defendant is liable. This means that the defendant must prove that the materials containing asbestos, which were used to build the shed, were not put onto the market by the defendant. In order to escape liability, the defendant thus must prove that the claimant's mesothelioma was not caused by the defendant's products but was a consequence of another experienced exposure to asbestos for which the defendant cannot be held responsible. ${ }^{243}$

In 2004, the Supreme Court, referring to Hertel/Van der Lugt ${ }^{244}$, upheld the decision of the Court of Appeal on the issue of the defendant's wrongful conduct which means that the defendant has acted wrongfully towards the claimant. However, the Supreme Court has referred the case back to the Court of Appeal as the Court of Appeal did not clearly motivate whether or not the claimant's action was brought to court in time. As a consequence, the Supreme Court also did not decide on the important requirement of causation. In 2008, the Court of Appeal did not discuss the issue of causation in its decision but solely dealt with the question of whether or not the claimant's civil action has become time-barred. ${ }^{245}$

However, in 2008 the Court of First Instance Almelo ${ }^{246}$ did discuss the requirement of causation in an almost similar case. ${ }^{247}$ In this case a person (Mr Wolting) contracted

\footnotetext{
${ }^{239}$ Rechtbank Almelo 22 mei 2003, LJN: AF 9060.

${ }^{240}$ Gerechtshof Arnhem 13 april 2004, LJN: AO8064.

${ }^{241}$ See also: Gerechtshof 's-Gravenhage 3 april 2012, LJN: BW0093 and Gerechtshof Arnhem 20 december 2011, JA 2012, 100 in which this rule of law was confirmed. However, the Rechtbank Almelo 27 april 2011, LJN: BQ4019 decided on 27 April 2011 that a company who sold asbestos-containing product between 1982-1984 did not have to warn the buyer about the risks connected to asbestos exposure.

${ }^{242}$ Article 6:99 BW: 'Where the damage has resulted from two or more events for each of which a different person is liable, and where it has been determined that the damage has arisen from at least one of these events, the obligation to repair the damage rest upon each of these persons, unless he proves that the damage is not the result of the event for which he himself is liable.'

${ }^{243}$ Gerechtshof Arnhem 13 april 2004, LJN: AO8064, paragraph 4.9.

${ }^{244}$ Hoge Raad 17 december 2004, NJ 2006, 147 (Hertel/Van der Lugt).

${ }^{245}$ Gerechtshof 's-Hertogenbosch 25 maart 2008, JA 2008, 96.

${ }^{246}$ Rechtbank Almelo 9 juli 2008, LJN: BF1904.
} 
mesothelioma after he experienced only one established exposure to asbestos when he used asbestos as roofing material to build a shed in 1979. The roofing material came from the defendant (Nefalit). The defendant denied liability and questioned causation arguing that the claimant failed to prove that the roofing material came from the defendant. In addition, the defendant argued that the claimant could not prove that the exposure to asbestos has led to the development of mesothelioma. The Court of First Instance, however, quashed this plea to dispute the causal link and ruled that the defendant failed to show that the roofing material did not come from the defendant and that the claimant's mesothelioma had another cause other than the exposure to asbestos in $1979 .{ }^{248}$

Looking at the abovementioned case law, it seems that it is rather difficult to dispute the causal link in such cases, especially when we take into consideration the fact that Article 6:99 BW can be applied in cases where the mesothelioma sufferer has experienced multiple exposures to asbestos for which two or more persons can be held liable. ${ }^{249}$ This means that, in order to escape liability, it is up to the defendants to prove that they did not cause the claimant's mesothelioma, which is an impossible hurdle to take in claims for mesothelioma.

However, in a more recent decision of the Court of Appeal Leeuwarden in 2009 the defendant successfully disputed causation and managed to escape liability. In this case the court also had to decide whether a mesothelioma sufferer can establish the liability of a manufacturer from who he bought materials containing asbestos. The mesothelioma sufferer had been exposed to asbestos from 1967 to 1973 while working for his father's company. The claim was, however, unsuccessful because the claimant failed to prove that the mesothelioma was caused by the products which the defendant had put onto the market. ${ }^{250}$ The additional plea to apply Article 6:99 BW also failed because the claimant could not point out another person who could be held liable for the development of mesothelioma. ${ }^{251}$

\subsection{Liability for para-occupational exposure to asbestos}

Few people have contracted an asbestos-related injury as a consequence of paraoccupational exposure to asbestos. Here, one could refer to real life cases in which an asbestos worker took his work clothes that contained asbestos home, which could have caused mesothelioma to his child ${ }^{252}$ and wife ${ }^{253}$. Such victims have filed successful lawsuits against the employer of the asbestos worker on the basis of Article 6:162 BW.

In 1999, the Court of First Instance Almelo had to decide whether or not the son (Mr Grootenhuis junior) of an asbestos worker, who contracted mesothelioma and died from the consequences of that disease in 1997 at the age of 32, could establish the liabil-

\footnotetext{
${ }^{247}$ See also Rechtbank Maastricht 16 april 2007, LJN: BA3241 in which the claimant established the liability of the defendant (Nefalit) from who he bought asbestos-containing materials to construct a floor without being warned about the risks connected to asbestos.

${ }^{248}$ Rechtbank Almelo 9 juli 2008, LJN: BF1904, paragraph 25.

${ }^{249}$ De Lang \& Van 2008, p. 82.

${ }^{250}$ Gerechtshof Leeuwarden 13 januari 2009, LJN: BH2762, paragraph 19.

${ }^{251}$ Gerechtshof Leeuwarden 13 januari 2009, LJN: BH2762, paragraph 20.

${ }^{252}$ Rechtbank Almelo 27 januari 1999, VR 2000, 24.

${ }^{253}$ Rechtbank Amsterdam 24 maart 1999, VR 2000, 25.
} 
ity of the employer (defendant) who exposed his father to asbestos in the course of the employment. Mr Grootenhuis senior had been exposed to asbestos in the course of his employment from April 1969 to September 1970 and from August 1976 to May 1977 while working for the defendant. The court established that Mr Grootenhuis junior experienced a para-occupational exposure to asbestos as he had been exposed to his father's work clothes that contained asbestos. The defendant failed to prove the existence of (an)other factor(s) which could have caused Mr Grootenhuis junior's mesothelioma. ${ }^{254}$ The court also established that the defendant has wrongfully exposed Mr Grootenhuis junior to asbestos arguing that by the end of 1960s the defendant ought to have known the risks connected to para-occupational exposure to asbestos. The defendant's plea that the government neglected its duty to issue safety regulations on asbestos exposure in time and that the defendant acted in line with other employers failed. ${ }^{255}$

In 1999, the Court of First Instance Amsterdam also had to decide whether or not the wife (Mrs Vat-Wetman) of an asbestos worker, who contracted mesothelioma and died from the consequences of that disease in 1995 at the age of 74, can establish the liability of the employer (defendant: Ajax) who exposed her husband (Mr Vat) to asbestos in the course of the employment. In this case, the court decided that the defendant had breached a safety regulation which implies that also damage outside the normal scope (household exposure to asbestos) can be attributed to the defendant. ${ }^{256}$

From 27 January 1999 onwards, employers can be held liable for para-occupational exposure to asbestos, i.e., the risk that the asbestos-containing work clothes of the occupationally exposed employee have caused the family members'/roommates' mesothelioma. Case law shows that courts apply a victim-friendly regime with regard to the applicable rules of evidence to establish the liability of the defendant in such cases. ${ }^{257}$ Causation can easily be established if the defendant fails to prove that the claimant (victim of household exposure to asbestos) had not experienced another exposure to asbestos other than the para-occupational exposure. The fact that the defendant breached a safety regulation also implies that damage outside the normal scope can be attributed to the defendant, which is in line with existing case law on this issue. ${ }^{258}$ It also proved not to be difficult to establish that the defendant had wrongfully exposed the employee's family member/roommate to asbestos because employers ought to have known about the risks connected to para-occupational exposure to asbestos by the end of the 1960s. Furthermore, the plea that the government neglected its duty to issue safety regulations on asbestos exposure in time and that the defendant acted in line with other employers has proved to be unsuccessful to dispute the wrongfulness of the defendant's intervention. ${ }^{259}$

\footnotetext{
${ }^{254}$ Rechtbank Almelo 27 januari 1999, VR 2000, 24, paragraph 4.1.

${ }^{255}$ Rechtbank Almelo 27 januari 1999, VR 2000, 24, paragraph 4.4, 4.6.

${ }^{256}$ Rechtbank Amsterdam 24 maart 1999, VR 2000, 25, paragraph 11.2, 12.

${ }^{257}$ De Lang 2007, p. 58.

${ }^{258}$ See for example: Hoge Raad 13 januari 1995, NJ 1997, 175 (De Heel/Korver).

259 This decision is in line with Hoge Raad 2 oktober 1998, NJ 1999, 683, paragraph 3.3.2 (Cijsouw/De Schelde 2).
} 


\subsection{Liability for environmental exposure to asbestos}

As discussed in section 1.2.2.2, exposure to asbestos is also possible outside the course of the employment. Here, one could also think of people who were exposed to asbestos in their living environment. ${ }^{260}$ Several studies conclude that environmental exposure to asbestos fibres in the area around Goor ${ }^{261}$ has been established as the cause of mesothelioma in women. ${ }^{262}$ In this area the incidence of mesothelioma in women is five times higher than elsewhere in the Netherlands due to environmental exposure to asbestos. In men it is twice as high. ${ }^{263}$ This even more emphasizes the problem: asbestos-related injuries are not only work-related.

The decision of the Court of First Instance Almelo ${ }^{264}$ in 2003 is - to my knowledge the first reported case in which the claimant argues that his asbestos-related disease (mesothelioma) was a consequence of environmental exposure to asbestos in the past. In his childhood, the claimant, who developed mesothelioma and died from the consequences of that disease at the age of 45 , played on public roads which contained asbestos because the district had used asbestos waste to consolidate some public roads. It had been established that, from 1945 to 1972, the defendant (Eternit) sold and/or gave away the remaining parts of asbestos-containing material to locals and districts to consolidate private and public roads. The claimant argues that the defendant knew or ought to have known the risks connected to asbestos exposure and thus acted wrongfully by polluting the environment. However, the Court of First Instance dismissed this plea and ruled that the defendant did not know and also ought not to have known the risks connected to the use of remaining parts of asbestos materials to consolidate roads. The defendant could thus not be held liable as he did not commit a wrongful act, which is one of the requirements to establish the liability of the defendant under the extra-contractual regime of Article 6:162 BW.

In two subsequence almost similar cases, the Court of First Instance Almelo also denied the claimants' claim. ${ }^{265}$ However, in the latter decision the Court of Appeal quashed the decision of the Court of First Instance, established liability, and awarded damages to the claimant. ${ }^{266}$ In Jansman/Eternit ${ }^{267}$, the Court of Appeal ruled that - as of the year 1967 - the defendant (Eternit) ought to have known about the risks connected to the use of the remaining parts of asbestos materials to consolidate roads. By doing so, the

\footnotetext{
${ }^{260}$ Gerechtshof Arnhem 27 februari 2007, LJN: AZ9763 is the first successful claim in which the claimant established the liability of the defendant after he had been environmentally exposed to asbestos. See for a more extensive description on the liabilty for non-occupational asbestos exposure: Vloemans 2008, p. 35 47; Meijer \& Lindenbergh 2008, p. 436-443; De Lang 2007, p. 57-62. See for an English case on environmental exposure: Margereson \& Hancock v J.W. Roberts Ltd, [1996] PIQR 154: June Hancock was the first mesothelioma sufferer in the UK who received compensation for neighbourhood exposure to asbestos because she lived in close proximity to an asbestos factory.

${ }^{261}$ The place where the Eternit factory was based.

${ }^{262}$ Sinninghe Damsté et al. 2007, p. 2453-2459.

${ }^{263}$ Dogger 2006, p. 38.

${ }^{264}$ Rechtbank Almelo 29 oktober 2003, NJ 2004, 32.

${ }^{265}$ Rechtbank Almelo 19 april 2006, JA 2006, 91; Rechtbank Almelo 28 april 2006, nr. $77519 /$ KG ZA 06 -

76 (unpublished).

${ }^{266}$ Gerechtshof Arnhem 27 februari 2007, LJN: AZ9763 (Jansman/Eternit).

${ }^{267}$ Gerechtshof Arnhem 27 februari 2007, LJN: AZ9763 (Jansman/Eternit).
} 
defendant acted wrongfully, especially because the defendant did not warn them enough about the risks and also failed to provide sufficient information on using methods. ${ }^{268}$ When it comes to causation, the Court of Appeal took a claimant-friendly approach and established causation on the basis of the figure of factual presumption. ${ }^{269}$ Subsequently, the defendant failed to prove that the claimant also experienced other exposures to asbestos during his life and could thus not establish another cause of the claimant's mesothelioma other than the environmental exposure to asbestos for which he can be held responsible. ${ }^{270}$ In similar subsequence cases, the Court of Appeal Arnhem ${ }^{271}$ and the Court of First Instance Almelo ${ }^{272}$ followed the decision in Jansman and also awarded damages to claimants who had been wrongfully environmentally exposed to asbestos in the past.

\subsection{Conclusion}

Persons who have used asbestos-containing materials at home or have experienced a para-occupational or environmental exposure to asbestos, and developed mesothelioma as a potential consequence of the exposure, may seek compensation. Such victims can file a lawsuit against the responsible producer, the employer of the family member who took his work clothes that contained asbestos home, or the company who is responsible for exposure to asbestos in their living environment on the basis of Article 6:162 BW. ${ }^{273}$

In cases in which a person suffers from mesothelioma after he has bought asbestoscontaining products, he can file a lawsuit against the manufacturer from who he has bought the products. The claim is most likely to succeed if the claimant can show that the products containing asbestos, which could have caused the illness, came from the defendant and that the claimant did not experience another exposure to asbestos other than the exposure to the defendant's products. In cases where the claimant suffers from mesothelioma after he had only experienced a para-occupational exposure to asbestos, i.e., cases in which the claimant has been exposed to asbestos as a consequence of exposure to the asbestos worker's clothes, he can file a lawsuit against the employer who has exposed the asbestos worker to asbestos in the course of his employment. Such cases are most likely to succeed if the claimant (family member) can show that the asbestos worker had been exposed to asbestos in the course of his employment and that the mesothelioma sufferer did not experience another exposure to asbestos other than the para-occupational exposure to asbestos. Persons who suffer from mesothelioma after they have been environmentally exposed to asbestos can file a lawsuit against the company who was responsible for the environmental pollution. Such claims are most likely to succeed if the claimant is able to show that the asbestos waste to consolidate roads came from the defendant and that the mesothelioma sufferer did not experience another exposure to asbestos other than the environmental one.

\footnotetext{
${ }^{268}$ Gerechtshof Arnhem 27 februari 2007, LJN: AZ9763, paragraph 4.9 (Jansman/Eternit).

${ }^{269}$ See for a more extensive description of this case: De Lang 2007, p. 57-62.

${ }^{270}$ Gerechtshof Arnhem 27 februari 2007, LJN: AZ9763, paragraph 4.13 (Jansman/Eternit).

${ }^{271}$ Gerechtshof Arnhem 5 juni 2007, LJN: BA6364.

${ }^{272}$ Rechtbank Almelo 2 oktober 2007, LJN: BB4632 (Freriksen-Klokman/Eternit).

${ }^{273}$ Persons who suffer from an asbestos-related disease but have not been exposed to asbestos in the course of an employment cannot file a successful lawsuit against their employer on the basis of Article 7:658 BW.
} 
To sum up: in all abovementioned claims for mesothelioma the claimant can establish the liability of the defendant on the basis of Article 6:162 BW if he is able to show that the exposure to asbestos is wrongful and that this exposure could have caused his damage. Such a claim is most likely to succeed if the defendant is unable to dispute causation and cannot disprove the wrongfulness of his intervention, i.e., present evidence which establishes that the defendant did not know and also ought not to have known the risks connected to asbestos exposure at the time of the exposure.

\subsubsection{Overall conclusion}

In the Netherlands, the number of asbestos victims is rising and will reach a peak of approximately 700 mesothelioma sufferers per year in about 2018. It is predicted that 19,000 Dutch men will die from the consequences of asbestos-related lung cancers in the period 1996-2035. In the years to come, it is most likely that the number of claims brought up by asbestos victims will also increase. Such claims for asbestos-related diseases can either be based on Article 7:658 BW or Article 6:162 BW. The source of the exposure to asbestos influences the applicability of Article 7:658 BW. Only persons who suffer from an asbestos-related disease after they have been occupationally exposed to asbestos can ground their civil action on Article 7:658 BW. Both grounds to establish the liability of the defendant require the claimant to demonstrate that he has suffered damage. In asbestos-related cases the question of whether or not asbestos victims have suffered any 'damage' is not problematic because the most common asbestos-related injuries are regarded as actual damage, which is eligible for compensation under Dutch law. ${ }^{274}$ The proof of the damage requirement is, therefore, relatively straightforward in the majority of the cases.

Employers' liability is - strictly speaking - still based on fault but is changing into a rather strict ground for compensation because the claimant does not have to prove that the defendant has breached his duty of care, i.e., present evidence that the employer has wrongfully exposed his employee to asbestos in the course of the employment, in order to establish the liability of the employer. However, Dutch law does not require employers to take their duty of care to absolute extremes. For a successful civil action, the claimant must state and (if the employer sufficiently contested the claimant's statement) prove that he was employed by the defendant and exposed to asbestos in the course of that employment. Case law shows that the claimant leaves empty-handed if he is only able to prove a possible exposure to asbestos while working for the defendant. Once the claimant has proved that he had been occupationally exposed to asbestos it is sufficient to show that the employee's injury (damage) could have been caused by the exposure. If the employee has established that he has been occupationally exposed to asbestos and that the exposure could have caused his damage, the defendant can escape liability if he is able to demonstrate that he did not breach his duty of care or successfully disputes the causal link between the exposure and the claimant's damage. Finally, if both defences fail the defendant can try to convince the judge that the employee's damage was caused by his 'own intent or deliberate recklessness', although this has not played a decisive role in asbestos litigation.

\footnotetext{
${ }^{274}$ For example: mesothelioma, asbestosis, and lung cancer which could have been asbestos-related.
} 
Not all persons who suffer from an asbestos-related disease have been occupationally exposed to asbestos. An increasing number of claims are recognized in persons who have used products containing asbestos at home or have been para-occupationally or environmentally exposed to asbestos. Mesothelioma sufferers have filed successful lawsuits against producers of products containing asbestos, the asbestos worker's employer who has (secondary) exposed the asbestos worker's children and wife to asbestos, and companies who can be held responsible for environmental pollution. Such liability claims fall under the regime of Article 6:162 BW.

The conditions to impose liability on the defendant are less demanding in cases where the claimant can base his claim on Article 7:658 BW. Under the regime of Article 6:162 BW, the claimant must, among other requirements and as opposed to Article 7:658 BW, also prove the wrongfulness of the defendant's intervention. The claimant can establish the liability of the defendant if he can show that he has been wrongfully exposed to asbestos and that this exposure could have caused his damage. Such a claim is most likely to succeed if the defendant is unable to dispute causation and cannot disprove the wrongfulness of his intervention, i.e., present evidence which establishes that the defendant did not know and also ought not to have known the risks connected to asbestos exposure at the time of the exposure.

\subsection{Introduction to English law}

In England, the number of claims brought by persons who suffer from an asbestos-related injury is increasing rapidly. The asbestos problem in the United Kingdom $\left(\mathrm{UK}^{275}\right)$ is, when compared to the situation in the Netherlands, worse. Scientific research has established that the number of deceased mesothelioma victims will reach a peak of 2,540 deaths per year in 2015 approximately. It is predicted that in total almost 90,000 people will die in the UK from the consequences of mesothelioma. ${ }^{276}$ The asbestos problem could thus be seen as a long-tail risk and, because of the serious consequences, the rising number of asbestos victims is an extremely disturbing development for the English society, especially when we take into consideration that the abovementioned data do not include persons who suffer from other asbestos-related diseases, such as lung cancer which could have been asbestos-related and asbestosis. Research shows that approximately 3,500 persons die from the consequences of asbestos exposure per year. ${ }^{277}$

The English government has taken precautionary measures, in the form of Regulations, to decline the number of persons who suffer from health damage as a consequence of asbestos exposure. The Control of Asbestos Regulations 2006 came into force on 13 November 2006, which has brought together the three previous sets of Regulations covering the prohibition of asbestos, the control of asbestos at work and asbestos licensing in England. ${ }^{278}$ The Regulations prohibit the importation, supply and use of all forms of

\footnotetext{
${ }^{275}$ England, Scotland, Wales and Northern Ireland.

276 http://www.irwinmitchell.com/search/pages/newsviewer.aspx?f=item145.aspx [Last visited $31 \mathrm{Au}-$ gust, 2012].

${ }^{277}$ http: / / www.allaboutasbestos.co.uk/dutyofcare.html [Last visited 31 August, 2012].

278 The Control of Asbestos at Work Regulations 2002:

http://www.legislation.gov.uk/uksi/2002/2675/contents/made; The Asbestos (Prohibitions) (Amendment) (No. 2) Regulations 1999: http://www.legislation.gov.uk/uksi/1999/2977/contents/made; The
} 
asbestos and continue the ban introduced for blue and brown asbestos in 1985 and for white asbestos in 1999. In addition, they also continue to ban the second-hand use of products containing asbestos. ${ }^{279}$

England is a common law country which does not, like the continental legal systems, operate through a Civil Code. The structure of this legal system thus differs from civil law jurisdictions, such as the Netherlands. Common law has been mainly developed by courts in case law. Traditionally, judges are central figures in developing the substance of the law, using principles and precedents (previously decided cases which are comparable to the case at hand) to develop legal solutions to previously undecided problems. Centuries of case law may still be relevant in deciding important questions of law in cases today. That said, today's common law is tempered by two developments: first, from the 1870 s and the fusion of the common law and equitable jurisdictions, the stark, rule-based justice of courts hearing tort cases have been modified in procedure and available remedies by equitable principles and mechanisms; and in more recent years, the judge-based rule-making has been tempered by an increasing tendency for Parliament both to legislate to respond to newly identified social problems, and to codify (with accompanying revision) areas of judge-made law into statutes. However, where there is no statute, the courts themselves have the power through precedent to develop laws that then bind individuals. ${ }^{280}$

Van Dam phrased the distinction between a common law and civil law system as: 'the common law system is not run by rules but by cases and precedents. ${ }^{281}$ This way, cases rather than rules provide the guidelines for a decision. If a particular question of law, X, is settled in case A, then this decision should be applied in all cases concerned with the same question of law. ${ }^{282}$ However, the abovementioned example seems to indicate that it is generally accepted that only common law should be taken into consideration when deciding new cases. Although this consideration might seem correct at first glance, we must keep in mind that, in addition to the key role of independent judges in developing common law, statutes have always played a role in correcting, adapting, and supplementing common law. ${ }^{283}$

Judicial decisions can, however, also be reversed by Parliament. This way, statutory law takes priority over precedents in the case of conflict. For instance, within the scope of this research, take the example of the Compensation Act $2006^{284}$, which was enacted in response to the House of Lords' decision in Barker ${ }_{v}$ Corus $^{285}$. In Barker, the House of

asbestos (Licensing) (Amendment) Regulations 1998: http://www.legislation.gov.uk/uksi/1998/3233/ contents/made [Last visited 31 August, 2012].

${ }^{279}$ The Control of Asbestos Regulations 2006.

See: http:/ /www.legislation.gov.uk/uksi/2006/2739/contents/made [Last visited 31 August, 2012].

280 Townend 2006, p. 181, 182.

${ }^{281}$ Van Dam 2006, p. 80.

${ }^{282}$ See for more information on the doctrine of precedent: Adams \& Brownsword 1999, 112-120.

${ }^{283}$ Van Dam 2006, p. 81: One might think of the Occupier's Liability Act 1957 and the Occupier's Liability Act 1984, the Highway Act 1980, the Consumer Protection Act 1987, the Animals Act 1971, the Human Rights Act 1998, and the Torts Act 1977.

${ }^{284}$ Compensation Act 2006 (s.3): Employers could be held jointly liable in case of mesothelioma. See: http: / / www.legislation.gov.uk/ukpga/2006/29/contents [Last visited 31 August, 2012].

${ }^{285}$ Barker v Corus, [2006] UKHL 20. 
Lords held the defendants severally liable for the claimant's damage (mesothelioma), which means that each defendant can only be held liable for a proportion of the claimant's mesothelioma. This leads to the consequence that a mesothelioma victim has to sue (and find) every responsible tortfeasor in order to obtain compensation for the entire loss (100\%). The Compensation Act 2006, however, reverses the effect of this decision, and now, applying the Compensation Act 2006, employers can be held jointly and severally liable in cases where asbestos victims suffer from mesothelioma after they had been wrongfully exposed to asbestos. ${ }^{286}$ The Compensation Act 2006 illustrates that the judiciary's capacity to develop common law is limited by the Parliament's ability to pass statutes. ${ }^{287}$ The applicability of the Compensation Act 2006 and the important House of Lords' decisions in Barker and Sienciewicz $v$ Greif (UK) Limited $^{288}$ will be extensively discussed in section 2.6.2. However, one must keep in mind that English Tort law has an extremely long history in judge-made Common Law, and the major principles are well established in key cases and developed into a detailed set of rules in further case law. Statutory provisions, such as the Compensation Act 2006, are often very specific and hardly ever contain general principles for Tort law. ${ }^{289}$

The following sections mainly focus on employers' liability because most lawsuits are filed against employers who have wrongfully exposed their employees to asbestos in the course of their employments. Although there is or has been an employment contract between the employer and his employee, most claims are based on extra-contractual Tort law which traditionally sits in the Common Law courts, and is found in both judgemade law and statute. ${ }^{290}$ Therefore, my thesis research solely examines the Tort of negligence as a ground to establish the liability of the defendant in claims for asbestos-related diseases. I start to examine the Tort of negligence as a potential remedy for asbestos victims in section 2.3.1. Among other issues, the subsequence section 2.3.1.1 examines the requirements to establish the liability of the defendant under the regime of the Tort of negligence in order to show what persons who suffer from an asbestos-related injury must demonstrate in order to claim damages successfully. Keep in mind that, although the requirement of causation is only subject to a general discussion here, causation is subject to an extensive study in the following parts of this thesis. Finally, in section 2.3.2 a conclusion is presented in which some general observations are made on the liability for asbestos-related diseases under English law.

\footnotetext{
${ }^{286}$ See for example: Sienciewicz v Greif (UK) Limited, [2011] UKSC 10.

${ }^{287}$ Van Dam 2006, p. 85.

288 Sienciewicz v Greif (UK) Limited, [2011] UKSC 10.

289 The Compensation Act 2006 only counts for mesothelioma victims and could not be applied in any other type of occupational disease (asbestosis, lung cancer). For more information on the interpretation of statutes see: Adams \& Brownsword 1999, p. 77- 102.

${ }^{290}$ The most important statutory duties are: Employer's Liability (Defective Equipment) Act 1969, The Factories Act 1961, and Health and Safety at Work 1974 (HSWA). The statutory duties can be studied to examine whether or not the employer has breached his duty of care. See also: Waterman 2009, p. 231, 232, 233.
} 


\subsubsection{The Tort of negligence: a remedy for asbestos victims?}

Over the $20^{\text {th }}$ century English courts have developed the Tort of negligence into a general rule to establish the liability of the defendant. ${ }^{291}$ The Tort of negligence is entirely the creation of the judges and is regarded as: 'one of the most dynamic and rapidly changing areas of liability in the modern common law. ${ }^{292}$ This section examines whether or not the Tort of negligence could serve as a remedy for persons who suffer from an asbestos-related disease. It should be noted that most, if not all claims for asbestosrelated injuries are based on the Tort of negligence and/or breach of statutory duty. Most persons who have been occupationally exposed to asbestos, and have developed an asbestos-related disease as a potential consequence of the exposure to asbestos, ground their claims on the Tort of negligence. The same is true for persons who have been exposed to products containing asbestos or have been para-occupationally or environmentally exposed to asbestos in the past.

The following subsections will make it clear that imposing liability for damage caused by only 'pure' intentional or negligent conduct is not accepted under English law. This means that merely acting negligently or intentionally alone is not sufficient to establish the liability of the defendant under the Tort of negligence. Van Dam clearly argues that the Tort of negligence: 'imposes liability on someone who has not acted carefully but only if this person owed the other person a duty of care. ${ }^{, 293}$

\subsubsection{Requirements to establish liability under the Tort of negligence}

The Tort of negligence requires the fulfilling of four conditions in order to recover damages. First, it is essential that the defendant owed the victim a duty of care; secondly, the defendant must have breached that duty of care; thirdly, the claimant must have suffered damage which is eligible for compensation, and fourthly, the damage must have been caused by the defendant's breach of duty. The latter implies that a causal connection between the breach of the duty of care and the damage suffered, must exist. To sum up: duty, breach, damage, and causation are the required elements which together make up a successful claim in negligence. However, the fluidity and equivocation of the abovementioned basic concepts of negligence make it hard to find the 'correct' technical form to phrase an issue. ${ }^{294} \mathrm{~A}$ judge can decide to deny a claim in negligence on the ground that the requirement of a 'duty of care ${ }^{295}$ could not be established, or on the ground that the claimant's damage was 'too remote' ${ }^{296}$.

Legal scholars, such as Markesinis and Deakin, therefore wonder whether the existing conceptual structure of the Tort of negligence is serving a useful purpose as the conceptual basis for a ruling (for example: the lack of a duty) can often be exchanged for

\footnotetext{
${ }^{291}$ Van Dam 2006, p. 91.

${ }^{292}$ Deakin et al. 2003, p. 74.

${ }^{293}$ Van Dam 2006, p. 103 (emphasis added).

${ }^{294}$ Deakin et al. 2003, p. 74, 83.

295 The question of whether or not the claimant suffered damage and whether or not there is causation is no longer relevant because the existence of a duty of care is a necessary factor to establish liability on the basis of the Tort of negligence.

${ }^{296}$ The judge established that there is a duty of care resting upon the defendant but the defendant cannot be held liable because the damage which the claimant suffered is too remote.
} 
another (for example: the remoteness of damage) without making any difference to the outcome of the case. ${ }^{297}$ I agree that exchanging the conceptual basis for a ruling in similar cases can have a negative effect on legal predictability, which is one of the fundamental values of law. ${ }^{298}$ However, I wonder whether or not the conceptual structure of the Tort of negligence should be changed for the very reason that the conceptual basis for a ruling can be exchanged for another while the outcome remains the same. From my point of view, it is not necessary to change the conceptual structure of the Tort of negligence. As said previously, in general all requirements (duty/breach/damage/causation) need to be demonstrated in order to hold the defendant liable in negligence. If the claimant is unable to prove one of the requirements, irrespective of which requirement cannot be proved, the defendant can - in general - not be held liable in negligence. However, as this is more a matter of interpreting the words of the law in order to place the matter in a specific area, which also plays a role in civil law jurisdictions, I choose not to further analyze this criticism. In the following sections the four requirements to establish the liability of the defendant pass the review.

\subsection{The duty of care in asbestos-related cases}

Showing that the defendant owed the claimant a duty of care is the first step in order to establish the liability of the defendant under the Tort of negligence. Keep in mind that 'the question of whether a duty of care exists in a given situation is a question of law upon which the appellate courts are the final arbiter. ${ }^{, 99}$ Whether or not a duty of care is accepted thus depends on the interpretation of the facts in the specific claimant's case. Van Dam phrased the importance of the existence of a duty of care very clearly: 'in the framework of the tort of negligence, the emphasis is on the question of whether the defendant owed the victim a duty of care. ${ }^{300}$ It is common ground that the defendant cannot be held responsible for every careless act. Therefore, the existence of a duty of care is not accepted in every situation. Whilst, it is necessary to show the extent of the duty of care, it is not regarded as a problematic factor in the majority of asbestos-related cases. In cases in which the claimant has been exposed to asbestos in the course of his employment, it is - nowadays - common ground that employers owe their employees a duty of care to take reasonable care of the health, safety and welfare of their employees in all circumstances. This also means that employers owe their employees a duty of care to protect them from the risks connected to asbestos exposure in the course of the employment. However, in the past it has not always been evident that employers owe their employees a duty of care. The establishment of a duty of care in employers' liability cases has been subject to a long history in case law. ${ }^{301}$ The same goes for the establishment of a duty of care in non-employers' liability cases. ${ }^{302}$

\footnotetext{
${ }^{297}$ Deakin et al. 2003, p. 84.

${ }^{298}$ Garcia Maynez 1949, p. 496.

${ }^{299}$ Deakin et al. 2003, p. 85.

${ }^{300}$ Van Dam 2006, p. 142.

${ }^{301}$ Priestley v Fowler [1837] 3 Mees \& Wels 1 launched the common employment doctrine and is the first reported case in which an employee, who suffered from work-related injuries, filed a lawsuit against his employer. The court acknowledged that the employer was 'bound to provide for the safety of his servant in the course of the employment' and thus, although in vague terms, established that the employer owed his
} 
The following subsections, however, solely examine specific asbestos-related cases in which English courts have acknowledged that a duty of care is owed by the defendant to the claimant. The claims for asbestos-related diseases are divided into three categories because not all victims of asbestos-related diseases have been occupationally exposed to asbestos. The first category examines whether employers owe a duty of care to their employees, the subsequence category explores whether defendants could also owe a duty of care to claimants in non-employers' liability cases, and the third category examines whether employers owe a duty of care to the employee's wife and children (third parties) not to subject them to secondary exposure to asbestos dust.

\section{* A duty of care owed by the employer to the employee(s)}

Employers must, as far as reasonable practicable, act as reasonable employers, which means that they have to take sufficient precautions to remove the risks to the health of their employees in their working environment. Although employers are obliged to strive for an optimum level of protection, English law does not require employers to take their duty of care to absolute extremes. The extend of the employer's duty of care is limited by the requirement of 'reasonable care', which implies that an employer can only be placed under a duty to take steps that a reasonable employer would have taken in the circumstances of the case. As established in Chapter 1, asbestos-related injuries are characterized by a long latency period. In most, if not all claims for asbestos-related diseases the occupational exposure to asbestos occurred a long time ago. In such cases a duty of

employee a duty of care to provide for a safe working environment. Some thirteen years later such a duty of care resting upon an employer towards his employees was upheld in Hutchinson v York, Newcastle and Berwick Railway Company [1850] 5 Exch. 343 in which the claimant's action was brought up under the Fatal Accident Act 1846 by the widow of the servant who died when he collided with another defendant's carriage in the course of his employment. Subsequently, in Brydon v Stewart [1855] 2 Macq 30 in which a mine worker died in an open lift carrying him out of a shaft, the House of Lords clearly established that employers owe their employees a duty of care and thus clearly acknowledged a responsibility to provide for a safe workplace. From that moment on, more successful lawsuits have been filed against employers who owed their employees a duty of care to protect them against dangerous situations at work. See for more information: Waterman 2009, p. 222-224, Hoop 2007, p. 113.

302 The most famous generalization of the duty of care requirement was made by Lord Atkin in the Scottish case Donoghue v Stevenson [1932] AC 562, which principle is known as: 'the neighbour principle'. Lord Atkin held in his speech, expressing the majority view (three to two), that: 'You must take reasonable care to avoid acts or omissions which you can reasonable foresee would be likely to injure your neighbour. Who, then, in law is my neighbour? The answer seems to be persons who are so closely and directly affected by my act that I ought reasonably to have them in contemplation as being so affected when I am directing my mind to the acts or omissions which are called in question.' Some 46 years after the landmark decision in Donoghue, the House of Lords felt it right to extend the scope of the duty of care in Anns $v$ Merton London Borough Council [1978] AC 728. This approach to establish the existence of a duty of care is known as the 'Anns-test' or the 'two stage test'. The establishment of a duty of care requires a sufficient relationship of proximity based upon foreseeability and, secondly, there must be any considerations or reasons that there should not be a duty of care. Finally, in specific cases in which the claimant has only suffered pure economic loss or mental harm the Caparo test is applied in order to establish whether the defendant owed the claimant a duty of care. In Caparo Industries plc v Dickman (1990), which concerned compensation for pure economic loss, the House of Lords created three conditions which had to be demonstrated before a duty of care could be established. Firstly, the claimant's damage has to be reasonable foreseeable. Secondly, there has to be proximity between the claimant and the defendant, and thirdly, imposing a duty of care on one party for the benefit of the other has to be fair, just and reasonable. This approach is known as the 'three stage test'. 
care can only be established if the employer knew or ought to have known that the occupational exposure to asbestos could affect the health of his employee. It goes without saying that 50 years ago an employer would have had less information on the health effects connected to asbestos exposure than 20 years ago. Obviously, the latter is under a duty to take more precautions than the former. Generally, one can say that the employer owes his employee a duty of care if the employee's damage is reasonable foreseeable.

\section{* Non-employers' liability cases}

Nowadays, it is an established fact that asbestos factories have polluted the environment which could have caused mesothelioma to people who have lived in close proximity to factories in which asbestos was extensively used. In Margereson and Hancock v J.W. Roberts $\operatorname{Ltd}^{303}$ (1996), the Court of Appeal had - for the first time - to decide whether or not a manufacturing company can be held liable for environmental cancers caused by emissions from their plant. ${ }^{304}$ Both claimants had lived in close proximity to the asbestos factory and have contracted mesothelioma as a potential consequence of environmental exposure to asbestos. ${ }^{305}$ In this case asbestos dust escaped from within the factory itself and deposited in vast amounts beyond the factory perimeter. The emission of dust was increased by employees leaving the factory. The defendants tried to escape liability arguing that, although they owe their employees a duty of care, they could not be held to owe a duty to other local people. However, both the Court of First Instance and the Court of Appeal applied Donoghue v Stevenson ${ }^{306}$ and quashed this plea. ${ }^{307}$ The most crucial issue which had to be resolved was the foreseeability of the claimants' damage. The claimants' argued that the same failure in safety standards (the defendant did not meet the ordinary standards of safety and did no comply with the Asbestos Regulations 1931) for the defendants' employees caused the claimants to suffer from mesothelioma.

The Court of Appeal clarified two important conditions to establish the defendants' liability. First, the court addressed the test of foreseeability in establishing a duty of care and, secondly, it established the relevant date of knowledge for the operation of that test. ${ }^{308}$ On the issue of the foreseeablity of the damage, the court applied Lord Loyd's test in Page v Smith ${ }^{309}$ : 'The test in every case ought to be whether the defendant can reasonably foresee that his conduct will expose the plaintiff to the risk of personal injury. If so, he comes under a duty of care to that plaintiff.' However, the Court of Appeal added that the defendants should reasonably have foreseen a risk of some pulmonary injury, not necessarily mesothelioma. ${ }^{310}$ This means that harm, rather than a particular disease, was all that mattered to determine the foreseeability of the claimants' damage.

\footnotetext{
${ }^{303}$ Margereson and Hancock v J.W. Roberts Ltd, [1996] PIQR 154.

${ }^{304}$ Steele \& Wikeley 1997, p. 265.

${ }^{305}$ See also: Betlem \& Klinge- van Rooij 1996, p. 166.

${ }^{306}$ Donoghue v Stevenson, [1932] AC 562.

${ }^{307}$ Steele \& Wikeley 1997, p. 274.

${ }^{308}$ Steele \& Wikeley 1997, p. 272.

${ }^{309}$ Page v Smith, [1996] 1 AC 155.

${ }^{310}$ In Margereson and Hancock v J.W. Roberts Ltd, [1996] PIQR 154: the Court of Appeal added: 'liability only attaches to these Defendants if the evidence demonstrated that they should reasonably have foreseen a risk of some pulmonary injury, not necessarily mesothelioma.' (emphasis added).
} 
Having set out the requirement of foreseeability of the claimants' damage, the court continued to discuss the relevant date of knowledge and held that: 'the date of knowledge in issue was the date at which information was available to establish that exposure to asbestos dust was likely to be harmful to the lungs - and this dangerousness could be understood more broadly than the knowledge of a risk of asbestosis.' The claimants failed to show culpability on the part of the defendants by virtue of their knowledge of the risk prior to $1933 .^{311}$ The date of knowledge was established at 1933 which was chosen because of the influential Merewether price Report of 1930, and the promulgation of the Asbestos Industry Regulations 1931. This means that the defendants 'were given a degree of leeway - two years - before being taken to possess the relevant knowledge underlying the Regulations. ${ }^{, 312}$

In Margereson, the Court of Appeal established that the defendants owed the claimants a duty of care and further ruled that: 'There is nothing in the law that circumscribes the duty of care by reference to the factory wall.... If the evidence shows with respect to a person outside the factory that he or she was exposed to the knowledge of the defendants, actual or constructive, to conditions in terms of dust emissions not materially different to those giving rise within the factory to a duty of care, then I can see no reason not to extend to that extra-mural neighbour a comparable duty of care.'

The question of whether a duty of care is owed by the defendant to the claimant is thus not confined to cases in which employers owe their employees a duty of care to protect them from injuries. Margereson shows that it is possible to extend the employer's duty of care to locals who have lived in close proximity to factories in which asbestos was extensively used. In these particular cases a duty of care can be established if the claimant's damage was reasonable foreseeable, i.e., the defendant should have reasonable foreseen a risk of some pulmonary injury, not necessarily mesothelioma. The Court of Appeal took 1933 as the applicable date of knowledge to determine whether or not the defendants could have reasonably foreseen the claimants' damage.

Furthermore, case law shows that the existence of a duty of care is not solely confined to employers and asbestos producing companies but even local authorities can owe pupils of a local authority school a duty of care. Here, one can refer to a successful claims against a local authority brought up by pupils of a local authority school. In Willmore $v$ Knowsley $M B C^{313}$ (2009), Dianne Willsmore died from the consequences of mesothelioma at the age of 49 after she was exposed to asbestos when she was a pupil at Bowring Comprehensive School from 1972 to 1979. In 2007, she was diagnosed as having mesothelioma. ${ }^{314}$ The Court of Appeal decided - for the first time - that a local authority can be held liable for exposing a former pupil to asbestos dust from damaged ceiling tiles. The Court of Appeal ruled that the local authority owed the claimant a duty of care as the defendant knew or ought to have known that, from 1972 to 1979, exposure to asbestos

\footnotetext{
${ }^{311}$ Margereson and Hancock v J.W. Roberts Ltd, [1996] PIQR 154, paragraph 9.

${ }^{312}$ Steele \& Wikeley 1997, p. 270.

${ }^{313}$ Willmore v Knowsley MBC, [2009] EWCA Civ. 1211.

${ }^{314}$ See: Health and Safety newsletter April 2011: www.weightmans.com [Last visited 31 August, 2012].
} 
was a foreseeable health hazard. This decision was recently upheld by the Supreme Court in $2011 .^{315}$

\section{* A duty of care owed by the employer to third parties}

In very specific situations employers find themselves owing a duty of care to protect third parties, the so called 'secondary victims', to whom the development of an asbestosrelated injury would have been reasonable foreseeable. Although most persons who suffer from an asbestos-related disease have been exposed to asbestos in the course of their employment(s), this does not mean that all asbestos-related diseases are exclusively traceable to occupational exposure to asbestos. Here, one could also think of persons who have developed an asbestos-related disease after they had been para-occupationally exposed to asbestos. In such cases the wife or children of asbestos workers have been exposed to asbestos by the asbestos worker's work clothes that the asbestos worker took home after work. Such para-occupational asbestos victims have been exposed to asbestos fibres trapped in the asbestos workers' clothes. One could wonder, however, whether the employer of the asbestos worker also owed a duty of care to the asbestos worker's wife or children not to subject them to secondary exposure to asbestos. It can be generally said that the liability of the asbestos worker's employer(s) depends on the extent of asbestos awareness at the moment the exposure occurred. Case law shows that such claims can be successful if the exposure occurred after $1965 .{ }^{316}$

In Maquire $v$ Harland \& Woolf ${ }^{17}$, Mrs Maquire died from the consequences of mesothelioma in May 2004 after she had been para-occupationally exposed to asbestos, that is, exposure to asbestos dust brought to their home at the end of each working day by her husband. Mrs Maguire was not employed by the defendants, which means that the defendants owed her none of the specific duties which are owed by an employer to an employee. The question to be answered was of whether or not the risk of serious injury to Mrs Maquire's health was, and should have been by the defendants, reasonable foreseeable in the period 1961 to 1965 (the time period in which her husband had been occupationally exposed to asbestos). ${ }^{318}$ The Court of Appeal established that, in or before 1965, the Chief Inspector of Factories, or more generally, British scientists or experts on industrial health, could not have reasonable foreseen that there was a serious risk of asbestosrelated disease occurring to those who have lived with asbestos workers. The Court of Appeal ruled, with a two to one majority, that: 'it was not reasonable foreseeable between 1960-1965 that a wife washing the clothes of a husband who was himself exposed to asbestos to a negligent degree would herself be likely to suffer risk of personal injury. ${ }^{319}$

However, it seems that - if the exposure to asbestos occurred after 1965 - the asbestos worker's employer might find himself owing a duty of care to the asbestos worker's wife and child(ren). Furthermore, it should be noted that the principle approved in

\footnotetext{
${ }^{315}$ Knowsley Metropolitan Borough Council v Willmore, [2011] UKSC 10.

${ }^{316}$ Maquire v Harland \& Woolf, [2005] EWCA Civ 1.

${ }^{317}$ Maquire v Harland \& Woolf, [2005] EWCA Civ 1.

${ }^{318}$ Maquire $v$ Harland \& Woolf, [2005] EWCA Civ 1, paragraph 5.

${ }^{319}$ Maquire v Harland \& Woolf, [2005] EWCA Civ 1, paragraph 97.
} 
Margereson $^{320}$, that is, the case on environmental exposure to asbestos which has previously been discussed, has potential application to cases of para-occupationally exposed victims of asbestos-related diseases. However, in Maquire ${ }^{321}$, it was not established that the dust to which Mrs Maquire was exposed effectively replicated her husband's level of exposure, nor indeed that her level of exposure, if repeated in factory conditions, would have constituted a breach of duty to the employer's employee.

\subsection{The breach of the duty of care}

The requirement of negligence is embodied in the breach of the duty of care: if the defendant has breached his duty of care he acted negligently towards the claimant. Under English law, it is assumed that a person has breached his duty of care when he fails to act as a reasonable person (bones pater familias) would have acted, or to put it differently: the defendant breached his duty of care if he did not take the steps that a reasonable person would have taken to fulfill that duty. ${ }^{322}$ Markesinis and Deakin clearly explain that: 'the issue of breach of duty is concerned with whether the defendant was careless, in the sense of failing to conform to the standard of care applicable to him. The level at which the standard is set is a question of law. ${ }^{323}$ The question whether reasonable care has been taken in the specific claimant's case is a question of fact for the court to decide, paid regard to all circumstances to the case. It goes without saying that in cases where a high standard of care is applied a breach of the defendant's duty of care is easier to establish. Case law shows that the burden to prove the defendant's breach of duty can, by applying the principle of res ipsa loquitur, be shifted in specific circumstances. ${ }^{324}$

The defendant could, however, only have breached his duty of care once it has been established that the defendant owed the claimant a duty of care. In asbestos-related cases the defendant, who has exposed the claimant to asbestos, has breached his duty of care in cases where a 'reasonable man' knew or ought to have known that the exposure to asbestos could affect the claimant's health.

\subsection{Damage}

Irrespective of whether or not the claimant, who suffers from an asbestos-related injury, has been occupationally exposed to asbestos or has experienced a para-occupational or environmental exposure to asbestos, he must have suffered 'damage' which is eligible for compensation in order to establish the liability of the defendant. A claim in tort based on negligence is incomplete without proof of damage. Damage in this sense is an abstract concept of being worse off, physically or economically, so that compensation is an appropriate remedy. ${ }^{325}$ Although a clear concept of damage has not been formulated in English law, it is now widely accepted that exposure to asbestos can lead to lung can-

\footnotetext{
${ }^{320}$ Margereson and Hancock v J.W. Roberts Ltd, [1996] PIQR 154.

${ }^{321}$ Maquire v Harland \& Woolf, [2005] EWCA Civ 1, paragraph 48.

${ }^{322}$ Van Dam 2006, p. 95.

${ }^{323}$ Deakin et al. 2003, p. 167.

${ }^{324}$ Scott v London and St Katherine's Docks Co, [1865] 3 H\&C 596.

${ }^{325}$ Rothwell $v$ Chemical \& Insulating Co Ltd, [2006] EWCA Civ 27, 4 ALL ER 1161.
} 
cer. ${ }^{326}$ There is now no question of whether lung cancer contracted unequivocally by another's negligence causes damage for legal purposes. Lung cancer is regarded as actionable damage under English law and the most common asbestos-related injuries, such as mesothelioma, lung cancer, and asbestosis are considered as damage which is eligible for compensation. ${ }^{327}$ In the majority of asbestos-related cases, the proof of the damage requirement is relatively straightforward. Therefore, the concept of damage is not subject to in-depth discussion here and will only be discussed in general.

However, it should be noted that in specific asbestos-related cases, i.e., cases in which the claimant only contracted pleural plaques, it can be questioned whether or not the claimant has suffered damage which is eligible for compensation. ${ }^{328}$ According to the dominant view pleural plaques do not cause any external symptoms, they only mark the presence in the lungs and pleura of asbestos fibres which may independently cause lifethreatening diseases such as asbestosis, mesothelioma, or lung cancer. Furthermore, and perhaps most importantly for Tort law, current medical consensus seems to show that the presence of pleural plaques gives no indication of whether the individual will or will not develop lung cancer because of the exposure which they have had to asbestos: the general view is that the presence of pleural plaques is not an indication of an increased risk of developing an asbestos-related lung cancer, but it only confirms an exposure to asbestos.

As will be explained more extensively in section 2.6.5, case law has established that the presence of pleural plaques, whether or not combined with a serious risk of developing an asbestos-related disease and anxiety about that risk, does not constitute actionable or compensatable damage and, therefore, cannot form the basis of a claim in negligence under English law. ${ }^{329}$ However, persons who suffer from an actionable asbestos-related injury such as mesothelioma, lung cancer, and asbestosis can successfully claim damages in negligence, unless they are unable to prove the other conditions to establish the liability of the defendant(s).

\subsection{Causation}

The fourth, and for victims of asbestos-related injuries an extremely problematic requirement to prove is: consequential damage. In order to hold the defendant liable in negligence the claimant must prove a causal link between the defendant's breach of the duty of care and the damage which the claimant encountered ${ }^{330}$, or to put it differently: 'the defendant's carelessness must be shown to have caused the loss or damage in ques-

\footnotetext{
${ }^{326}$ See for a medical acceptance: Beers et al. 2003, p. 297. See for a legal acceptance: Hoge Raad 31 maart 2006, NJ 2011, 250 (Nefalit/Karamus) or Fairchild v Glenhaven Funeral Services Ltd, [2002] UKHL 22.

${ }^{327}$ I refer to Chapter 1 for extensive medical information on the most common asbestos-related diseases. See for a mesothelioma case: Fairchild $v$ Glenhaven Funeral Services Ltd, [2002] UKHL 22; See for a lung cancer case: Shortell v Bical Construction Ltd., [2008] QBD Liverpool (16-05-2008); See for an asbestosis case: Holtby v Brigham \& Cowan (Hull) Ltd, [2000] 3 ALL ER 421.

${ }^{328}$ Sobczak et al. 2009, p. 207-217: In case the victim only contracted pleural plaques the 'damage question' is far more difficult to answer. See for example the case of Mr Johnston: Johnston v NEI International Combustion Limited, [2007] UKHL 39.

${ }^{329}$ Johnston v NEI International Combustion Limited, [2007] UKHL 39.

${ }^{330}$ See for an in-depth discussion on causation and remoteness of damage: Hepple et al. 2000, p. 345-422.
} 
tion. ${ }^{331}$ In asbestos-related cases, the claimant must demonstrate that the defendant's breach of duty has caused or materially increased the risk of injury from which the claimant suffers. In such cases the defendant will, however, try to dispute causation showing that the claimant's illness could also have been caused by something other than asbestos (i.e., causal uncertainty about the cause of the claimant's damage), or that another person could also have caused the claimant's injury (i.e., causal uncertainty about the specific tortfeasor who has caused the claimant's damage), or that the negligent exposure did not exceed a certain threshold and could thus not have caused the claimant's injury at all (for example in claims for asbestosis). The requirement of causation forms the heart of this research and will be extensively discussed in the following parts.

\subsubsection{Overall conclusion}

In England, the number of claims brought up by asbestos victims increases rapidly and it is predicted that in total almost 90,000 people will die in the $\mathrm{UK}^{332}$ from the consequences of mesothelioma. England is a common law country which does not, like the continental legal systems, operate through a Civil Code. Independent judges play a key role in developing common law but statutes have always played a role in correcting, adapting and supplementing common law. ${ }^{333}$ Judicial decisions can, however, also be reversed by Parliament. In claims for mesothelioma the Compensation Act 2006, which reverses the negative effects of Barker ${ }_{v}$ Corus $^{334}$, illustrates that the judiciary's capacity to develop common law is limited by the Parliament's ability to pass statutes.

Most, if not all claims for asbestos-related diseases are based on the Tort of negligence irrespective of whether the claimant has been occupationally, para-occupationally, or environmentally exposed to asbestos. Applying the Tort of negligence, four conditions need to be demonstrated in order to hold the defendant liable in negligence. Firstly, it is of the utmost importance that the defendant owed the claimant a duty of care. If the claimant is unable to show that the defendant owed the claimant a duty of care, then no liability in negligence can be established. The question of whether or not a duty of care is owed by the defendant to the claimant is subject to a long history in case law. From the $19^{\text {th }}$ century onwards, case law made it clear that employers can owe their employees a duty of care to provide for a safe working environment. In the $20^{\text {th }}$ century, three landmark decisions have clarified the concept of a duty of care in cases where the defendant was not the claimant's employer. In claims for asbestos-related diseases, a duty of care has been established in cases where employers have exposed their employees to asbestos in the course of the employments. Employers also owe a duty of care to the employee's wife or children (third parties) not to subject them to secondary exposure to asbestos dust. Furthermore, case law shows that a duty of care can also be established in non-employers' liability cases in which the claimant has been environmentally exposed to asbestos.

\footnotetext{
${ }^{331}$ Deakin et al. 2003, p. 185.

${ }^{332}$ United Kingdom: England, Scotland, Wales and Northern Ireland.

${ }^{333}$ Van Dam 2006, p. 81.

${ }^{334}$ Barker v Corus, [2006] UKHL 20.
} 
Once it has been established that the defendant owed the claimant a duty of care, it is necessary to demonstrate that the defendant has also breached that duty, i.e., that the defendant failed to act as a reasonable person (bonus pater familias) would have acted, in the specific claimant's case. In cases in which a high standard of care is applied a breach of the defendant's duty of care is easier to establish. Thirdly, the claimant must have suffered damage which is eligible for compensation. Showing that the claimant has suffered damage is not problematic in the majority of asbestos-related cases as the most common asbestos-related diseases, such as mesothelioma, lung cancer, and asbestosis are considered as damage which is eligible for compensation. However, in cases where the claimant has only contracted pleural plaques the damage is not actionable, which means that the claimant cannot hold the defendant liable for the damage which he has suffered. Last but not least, the claimant must demonstrate that the damage which he has suffered is causally connected with the defendant's breach of duty. In claims for asbestos-related diseases, the requirement of causation is rather problematic to prove because such claims are characterized by the problem of uncertain causation: uncertainty about the cause of the damage and/or uncertainty about the specific tortfeasor who has caused the claimant's damage. To sum up: duty, breach, damage, and causation are the required elements which together make up a successful claim in negligence.

PART TWO: CAUSATION: A COMPARATIVE OVERVIEW OF DUTCH AND ENGLISH LAWS

\subsection{Causation}

One of the requirements to establish the liability of the defendant is the proof of a causal link between, on the one hand, the wrongful conduct of the defendant, and on the other hand, the damage to the victim. This clearly implies the importance of a causal link: causation is a fundamental requirement to establish the liability of the defendant. In Dutch law, the requirement of causation is captured in the formulation of Article 6:74 $\mathrm{BW}^{335}$ : 'therefrom', Article 6:162 $\mathrm{BW}^{336}$ : 'as a consequence thereof', and Article $7: 658$ (1) $\mathrm{BW}^{337}$ : 'in the course of his employment'. Under English law, the Tort of negligence requires the proof of consequential damage, which means that the damage suffered by the claimant must be causally connected with the defendant's breach of duty. In both Dutch and English laws, rules on causation have been developed by courts and the courts approaches to causation are driven by policy considerations. ${ }^{338}$ Rules on the second stage of causation, the 'extent' phase, have also been codified in the Dutch Civil Code, which makes Dutch law one of the few jurisdictions who hold a specific statutory provision on this subject.

\footnotetext{
${ }^{335}$ Article 6:74 BW (contractual liability): 'Every failure in the performance of an obligation obliges the debtor to repair the damage which the creditor suffers therefrom, unless the failure cannot be imputed to the debtor.'

${ }^{336}$ Extra-contractual liability.

${ }^{337}$ Employers' liability. Article 7:658 (1) BW: ‘. . . in de uitoefening van zijn werkzaamheden’.

${ }^{338}$ Deakin et al. 2003, p. 81.
} 
It is common knowledge that causation is one of the most complex issues within Tort law. Prosser describes causation as: 'a tangle and a jungle, a palace of mirrors and a maze. ${ }^{339}$ Van Dam refers to causation as being an 'elusive phenomenon' which can be stretched and shrunk according to the magnitude of the other requirements to establish the liability of the defendant. ${ }^{340}$ The upcoming sections generally examine the applicable rules on (the proof of) causation in Dutch and English laws and explore the shortcomings of the condicio sine qua non (the but-for) test in order to define the concept of causation in Tort law.

\subsubsection{A conventional two-step approach to causation}

Most jurisdictions, including Dutch and English laws, use a conventional two-step test to establish causation. The first step, usually referred to as 'factual causation', establishes causation and the second step, usually referred to as 'legal causation', limits the consequences for which the tortfeasor must answer. ${ }^{341}$ This distinction in 'stages' has also been emphasized in Dutch case law. ${ }^{342}$ In the wrongful life case Baby Kelly ${ }^{343}$ (2005), the Dutch Supreme Court ruled that the condicio sine qua non test is an essential element to establish factual causation. Furthermore, decisions on the reversal rule, that is, the procedural rule that reverses the burden of proving causation ${ }^{344}$, have made it very clear that the reversal rule reverses the burden of proof with regard to the proof of factual causation, which means that the burden of proof with regard to the proof of legal causation is not automatically reversed too. ${ }^{345}$

This two-step approach has also been subject to criticism. Often it has proved to be unclear whether the point of law is about factual causation or about legal causation as the point of law is not always formulated explicit enough. ${ }^{346}$ Some English and Dutch legal scholars are also not completely satisfied with this distinction and argue that one unfortunate consequence is: 'the misleading impression that the first stage of inquiry is, by and large, a simply technical or evidentiary one, from which policy factors are absent, in contrast to an apparently evaluative and normative second stage when policy comes to the fore. ${ }^{347}$ In the next sections both stages of causation will be examined in order to

\footnotetext{
${ }^{339}$ Prosser 1950, p. 369.

${ }^{340}$ Van Dam 2006, p. 266-268. In order to establish negligence, the question to be addressed relates to the likelihood of the damage being caused by the negligent conduct (foreseeability). In order to establish causation, the question to be addressed is how likely it is that the damage was caused by the defendant's negligent conduct. Furthermore, the concept of contributory negligence, which is applicable in both jurisdictions under consideration here, is also closely connected to causation as the reduction in damages as a consequence of the claimant's contributory negligence is related to the claimant's causal contribution to the damage. See for Dutch law: Article 6:101 BW. See for English law: The Law Reform (Contributory Negligence) Act 1954.

${ }^{341}$ The first stage of causation is usually referred to as: 'factual causation', 'condicio sine qua non', 'but-for' or 'cause in fact'.

${ }^{342}$ Hoge Raad 24 december 2010, NJ 2011, 251, paragraph 3.8 (Fortis/Bourgonje).

${ }^{343}$ Hoge Raad 18 maart 2005, NJ 2006, 606 (Baby Kelly).

${ }^{344}$ See section 3.11 for more information on the reversal of the burden of proof.

345 Hoge Raad 29 november 2002, NJ 2004, 304/305; Hoge Raad 18 april 2003, RvdW 2003, 81(Verzekeraars/Fino). See also: Akkermans 2003, p. 94.

${ }^{346}$ Engelhard 2007, p. 20; Hartlief 2000.

${ }^{347}$ Deakin et al. 2003, p. 186; Akkermans 1997, p. 458.
} 
provide legal scholars operating in a different legal system with more information on the important requirement of causation in Dutch and English laws.

\subsubsection{Factual causation}

The principle of condicio sine qua non, the 'but-for' test in Anglo-American jurisdictions, is applied in both Dutch and English laws to establish factual causation: a condition without which the damage would not have occurred. Article 3:101 Principles of European Tort Law (PETL) gives the following clear definition:

'An activity or conduct is a cause of the victim's damage if, in the absence of the activity, the damage would not have occurred.'

To determine whether the requirements of the condicio sine qua non test are satisfied the relevant question to answer is: would the damage also have occurred if the tortfeasor had not acted in the way he did? If the damage would also have occurred without the intervention of the tortfeasor, then the causal link is not established, which means that - in general - no liability can arise. ${ }^{348}$ This way, damages are due to the victim but only if the harm was due to the tortfeasor. ${ }^{349}$ The condicio sine qua non (but-for) test is a workable approach to establish causation in most situations but always calls for an answer to a hypothetical situation, which means that the outcome of this test inserts a certain element of speculation. ${ }^{350}$

A classic and very clear illustration of the application of this first 'stage' of causation can be found in English case law. In Barnett ${ }_{v}$ Chelsea and Kensington Hospital Management Committee $^{351}$ (1968), Mr Barnett, complaining of abdominal pain, was sent home from a hospital and was told to contact his general practitioner the next morning. Mr Barnett, however, died a few hours after being turned away from the hospital. It was established that he died from arsenic poisoning and that the hospital negligently turned Mr Barnett away. Is the hospital liable for this negligent act? Scientific evidence established that it would not have been possible to diagnose and treat the poisoning in time, which meant that Mr Barnett's life could not be saved. There was no chance that the antidote could have been administered before Mr Barnett's death and experts concluded that nothing could have been done to save Mr Barnett's life. ${ }^{352}$ Liability could not be established because the claimant could not prove causation between the breach of duty (sending $\mathrm{Mr}$ Barnett home) and Mr Barnett's death (damage). Although it had been established that the hospital acted wrongfully, the claimant's claim failed because causation is a fundamental condition for liability to arise.

Proving causation is, in most claims in Tort law, relatively straightforward and does not give rise to insurmountable problems. Generally, the condicio sine qua non test is seen as the only objective appropriate test to establish factual causation. Like most commenta-

\footnotetext{
${ }^{348}$ I choose the term 'in general' because the liability of the defendant can, in special circumstances, also be established in cases where condicio sine qua non has not been demonstrated by the claimant.

${ }^{349}$ Weir 2002, p. 67.

${ }^{350}$ Fleming 1985, p. 107; Roijackers 2009, p. 7.

${ }^{351}$ Barnett $v$ Chelsea and Kensington Hospital Management Committee, [1968] 1 ALL ER 1068.

${ }^{352}$ Oliphant 2008, p. 1062.
} 
tors, I agree that the condicio sine qua non test is a workable approach to establish causation in most situations. To give an example: in a case where A, whether intentionally or accidentally, smacks B in his face and B suffers injury (scar on his face) as a result of this smack, it is rather obvious that if A did not smack B in his face, B would not have suffered the scar on his face. ${ }^{353}$ In this situation, factual causation can easily be established because the claimant can prove condicio sine qua non between the defendant's intervention and the scar on his face. The application of this test is also desirable in cases where the scientific evidence is reasonable clear-cut, which implies that the causal link is almost completely certain in such cases.

However, proof of causation can be rather difficult in cases in which the scientific evidence is far from clear-cut, where multiple causes of the damage are present and no certainty exist on the situation that would have existed without the defendant's intervention. Difficulties about causation mainly arise in cases concerning occupational diseases or medical negligence. ${ }^{354}$ As will be discussed throughout this research, if the claimant's claim is characterized by scientific uncertainty a problematic debate on the requirement of causation will follow. ${ }^{355}$ Claims for asbestos-related diseases are also an area in Tort law in which the abovementioned discussed problems occur frequently because the precise process of the diseases is unknown in the specific claimant's case. In claims for lung cancer which could have been caused by asbestos exposure causation is regarded as an extremely controversial issue in bringing a successful claim. The same is true for claims for mesothelioma in cases where the employee has been exposed to asbestos in several different employments. A strict application of the condicio sine qua non test will lead to undesirable results in situations where the causal link is uncertain: the claimant will almost certainly be unable to prove factual causation and this - generally - leads to the consequence that victims remain empty-handed while there is still a considerable chance that the wrongful intervention of the defendant did cause the claimant's damage. This way, the claimant thus bears the consequences of the causal uncertainty.

One of the drawbacks of the condicio sine qua non test is that it considers all necessary conditions as equal regardless whether they are likely or unlikely, foreseeable or unforeseeable, direct or remote: without each of them the effect would not have been brought about. ${ }^{356}$ A problematic aspect is that conditions that are not necessarily relevant to the law can still be qualified as condicio sine qua non for the claimant's damage. The legal system thus has to limit the consequences for which the tortfeasor must answer because the tortfeasor cannot be held liable for all the damage that possibly results from his action. The scope of reparation can be limited in the second causation step, the 'extent' phase.

\footnotetext{
${ }^{353}$ Van Gerven et al. 2000, p. 427/1.

${ }^{354}$ Cascão 2005, p. 45: It is extremely difficult to establish the link of causation between medical treatment and the injury sustained by the patient. The precise process of injuries or diseases as well as the precise consequences of medical techniques is often unknown. For that reason it proved to be extremely difficult to establish whether the doctors fault has caused the damage and to which extent.

${ }^{355}$ Haritz 2010, p. 202.

${ }^{356}$ Van Dam 2006, p. 269; Witjens 2011, p. 245.
} 


\subsubsection{Legal causation}

Traditionally, the second stage of causation comes into play after the required condicio sine qua non (but-for) test has been satisfied. ${ }^{357}$ If the claimant is able to prove factual causation, the defendant may still escape liability when he is able to prove the absence of what is called a 'legal cause'. ${ }^{358}$ Rules on legal causation vary from jurisdiction to jurisdiction. From 1970 onwards, the Dutch Supreme Court chose to abandon the Theory of Adequacy $^{359}$ and introduced the 'attribution according to reasonableness theory', which had gained popularity in legal writings during the previous years as a more reasonable standard to determine the scope of the defendant's liability. ${ }^{360}$ Rules on 'reasonable attribution' can be found in Article 6:98 BW:

'Reparation can only be claimed for damage which is related to the event giving rise to the liability of the debtor in such a fashion that the damage, also taking into account its nature and that of the liability, can be imputed to the debtor as a result of this event.' 361

This 'extent' phase is concerned with the problem of remoteness of damages and the question of whether or not the tortfeasor is actually obliged to pay for all the damages suffered by the claimant. Article 6:98 BW aims to distinguish the damage for which the defendant can and cannot be held liable. However, it does not contain the word 'reasonable' and also fails to explain why attribution is reasonable. ${ }^{362}$ The Dutch legislator did not want the judge to dispose of a discretionary power when deciding whether attribution would be reasonable or not. Furthermore, it was not the purpose of the rule that 'reasonableness' would be seen as the only criterion to determine the scope of the damage. ${ }^{363}$ Nevertheless, Article 6:98 BW is still referred to as 'attribution according to

\footnotetext{
${ }^{357}$ Hoge Raad 9 april 2004, NJ 2004, 308 (D./Achmea); Hoge Raad 24 december 2010, NJ 2011, 251, paragraph 3.8 (Fortis/Bourgonje).

${ }_{358}$ Deakin et al. 2003, p. 185.

359 The Theory of Adequacy, also known as the 'theory of adequate cause', was originally developed in German law, where two layers of causation can be distinguished. Firstly, the haftungsbegründe Kausalität which determines the founding of liability and secondly, the haftungsausfüllende Kausalität which determines the specific liability. Applying the Theory of Adequacy, the defendant only has to compensate the claimant's damages which were foreseeable for an objective and skilled observer. This way, the theory limits the consequences for which the tortfeasor must answer. Dissatisfaction with the theory grew over the years. The critique was the outcome is easy to manipulate: the foreseeablity increases if the consequence is more and more generalized. Getting hurt as a result of a fight is, for example, more foreseeable than the occurrence of a very specific injury as a result of a fight, like missing three teeths. Therefore, opponents conclude that the theory offers a false sense of certainty. See: Witjens 2011, p. 247; Haritz 2010, p. 207; Van Dam 2006, p. 270 .

${ }^{360}$ Hoge Raad 20 maart 1970, NJ 1970, 251 (Waterwingebied-arrest).

${ }^{361}$ Article 6:98 BW: 'Voor vergoeding komt slechts in aanmerking schade die in zodanig verband staat met de gebeurtenis waarop de aansprakelijkheid van de schuldenaar berust, dat zij hem, mede gezien de aard van de aansprakelijkheid en de schade, als een gevolg van deze gebeurtenis kan worden toegerekend.' See also: Van Dam 2006, p. 266.

${ }^{362}$ Witjens 2011, p. 247.

${ }^{363}$ MvA2, Parl. Gesch. 6, p. 445.
} 
reasonableness', which is a positive development in the pursuit of legal security because the judge is obliged to motivate his decision clearly. ${ }^{364}$

Brunner has inferred some additional rules of causation from case law. ${ }^{365}$ These rules of thumb, which are generally accepted, are in accordance with Article 3:201 PETL ${ }^{366}$ and give some guidance when deciding whether or not an effect is reasonable attributable to the defendant:

- Attribution of liability is justified sooner, where the consequence, according to rules of experience, is more likely (foreseeability);

- Attribution of liability is justified sooner, where the consequence is less far removed from the wrongful conduct;

- A generous attribution of damages caused by death or physical injury is justified, where safety or traffic norms, constructed with the purpose to prevent accidents, are violated;

- A more generous attribution is justified, where the measure of reproach to the damaging event is greater;

- Damage caused by death or injury is attributed sooner than damage to an object, damage to an object sooner than damage consisting of extra costs and expenses and damage by loss of wealth sooner than loss of profit;

- Attribution may be justified sooner, where the liable person is conducting a business, than where he is a private person or practicing a profession. ${ }^{367}$

Although some of the abovementioned aspects are listed in Article 6:98 BW ${ }^{368}$, the Article is not exhaustive. The Dutch legislator chose for a 'multi-factor' approach. The degree of fault and the degree of foreseeability are also relevant factors to determine whether the damage could be attributed to the defendant or not. ${ }^{369}$ It is important to note that Dutch law offers a wide scope of reparation in personal injury claims, which seems to be in accordance with Article 2:102 PETL. ${ }^{370}$ Firstly, this has to do with the

\footnotetext{
364 The judge must motivate why attribution is reasonable in a specific case. See also: Asser/Hartkamp 2004, nr. 432.

${ }^{365}$ Brunner 1981, p. 210-216, 233-236.

${ }^{366}$ Article 3:201 PETL: 'Where an activity is a cause within the meaning of Section 1 of this Chapter, whether and to what extent damage may be attributed to a person depends on factors such as:

a) the foreseeability of the damage to a reasonable person at the time of the activity, taking into account in particular the closeness in time or space between the damaging activity and its consequence, or the magnitude of the damage in relation to the normal consequences of such an activity;

b) the nature and the value of the protected interest (Article 2:102);

c) the basis of liability (Article 1:101);

d) the extent of the ordinary risks of life; and

e) the protective purpose of the rule that has been violated.'

${ }^{367}$ Hartlief 2003a, nr. 218.

368 The nature of the liability and the nature of the damage.

${ }^{369}$ Hartlief 2003a, nr. 218.

370 Article 2:102 (1) PETL: The scope of protection of an interest depends on its nature; the higher its value, the precision of its definition and its obviousness, the more extensive is its protection.'

(2): 'Life, bodily or mental integrity, human dignity and liberty enjoy the most extensive protection.'

(3): 'Extensive protection is granted to property rights, including those in intangible property.'
} 
nature of the damage: personal injury. Secondly, the damage is often caused by an infringement of a standard which has its roots in the prevention of such an injury. Moreover, it should - in the light of this research - be noted that the range of recoverable damages is also more extensive in cases in which the defendant has breached a safety standard, that is, a standard that is aimed to prevent injuries. ${ }^{371}$

Similar to the Dutch jurisdiction, the English legal system also limits the consequences of the but-for test. A but-for cause which does not pass the stage of legal causation is a factor to which the law attaches no causal responsibility in terms of liability in damages. ${ }^{372}$ For liability to arise some consequences are just too far removed from the defendant's intervention, which means that the claimant's damage is too unusual. Several instruments have been applied to limit the scope of the defendant's liability. Here, one could think of the reasonable foreseeability of the damage, the probability that the damage would occur, and the directness of the consequential damage. The rules concerning the remoteness of damage requires the claimant to prove that the damage was reasonably foreseeable, which plays an extremely important role in English causation law. ${ }^{373}$ English law is formally committed to the rule that negligent parties can only be held liable for the foreseeable consequences of their negligence. ${ }^{374}$ Only the kind of damage that is foreseeable is eligible for compensation. The requirement of foreseeability only covers the type of the damage, which means that causation can be established even if the scope of the damage was larger than could have been foreseen, as long as it was not too remote to be foreseen at all. ${ }^{375}$ To put it differently: if the kind of harm is foreseeable, then the extent of the damage is not limited. ${ }^{376}$

\subsubsection{The proof of causation}

\subsubsection{The standard of proof}

In personal injury claims causation seems to be the area of Tort law where rules concerning the burden of proving a causal link can have the greatest impact on the outcome of the case. ${ }^{377}$ In the majority of the cases, it is not possible to prove with absolute certainty

(4): 'Protection of pure economic interests or contractual relationships may be more limited in scope. In such cases, due regard must be had especially to the proximity between the actor and the endangered person, or to the fact that the actor is aware of the fact that he will cause damage even though his interests are necessarily valued lower than those of the victim.'

(5): 'The scope of protection may also be affected by the nature of liability, so that an interest may receive more extensive protection against intentional harm than in other cases.'

(6): 'In determining the scope of protection, the interests of the actor, especially in liberty of action and in exercising his rights, as well as public interests also have to be taken in consideration.'

${ }^{371}$ See for example: Hoge Raad 9 juni 1972, NJ 1972, 360; Hoge Raad 2 november 1979, NJ 1980, 77; Hoge Raad 8 februari 1985, NJ 1986, 136; Hoge Raad 8 februari 1985, NJ 1986, 137; Hoge Raad 4 november 1988, NJ 1989, 751.

${ }^{372}$ Deakin et al. 2003, p. 185.

373 Harpwood 2000, p. 149; Van Dam 2006, p. 275-277: This does, however, not mean that the foreseeablity test has a monopoly. The scope of the rule theory and other techniques have also been applied to limit the scope of the defendant's liability.

${ }^{374}$ Weir 2002, p. 77, 78.

${ }^{375}$ Haritz 2010, p. 206.

${ }^{376}$ See for example: Overseas tankship Ltd v Morts and Doch Engineering Co Ltd, [1961] 1 ALL ER 404.

${ }^{377}$ Van Gerven et al. 2000, p. 428/13. 
that certain facts did or did not happen. Both Dutch and English laws, as in most other legal systems, do not demand absolute (100\%) certainty between the defendant's wrongful conduct and the claimant's damage. ${ }^{378}$ Dutch law requires a 'reasonable degree of certainty' to assume a causal link. When this criterion is satisfied, however, remains unclear since there is no percentage threshold given by the Dutch legislator or Supreme Court to indicate 'reasonableness'. ${ }^{379}$ Dutch judges have a discretionary power to answer the question of whether or not a 'reasonable degree of certainty' could be established or not in the specific claimant's case. This means that judgments may easily become arbitrary.

In English law, the balance of probabilities approach is applied to prove causation. ${ }^{380}$ Under this approach, an English claimant must adduce evidence that it is, on the balance of probabilities, more likely than not that the wrongful conduct of the defendant has caused the claimant's damage. ${ }^{381}$ English law uses a percentage threshold to determine whether or not causation can be established. Applying the balance of probabilities standard, the claimant must prove that there is, metaphorically, a chance of greater than 50 percent that the accident happened because of the breach of duty in order to establish factual causation. ${ }^{382}$ However, keep in mind that in most cases in Tort law, judges do not use mathematical calculations to determine whether the threshold to establish causation is met. It is about saying that, on balance, one side is more believable than the other. Chances greater than 50 percent are taken as a certainty of 100 percent: it is assumed that the accident would not have happened without the breach of the defendant's duty of care.

\subsubsection{The burden of proof}

In Dutch law, procedural rules are found in The Code of Civil Procedure (Rv) ${ }^{383}$ and rules on the burden of proof are placed in Article $150 \mathrm{Rv} .{ }^{384}$ As in most legal systems, it is up to the claimant to prove all the elements of the liability claim, unless a special rule exist or the principles of reasonableness and fairness demand another division of the burden of proof. This means that the requirement of causation must be demonstrated by the claimant. The general rule is that the claimant must prove to a reasonable degree of certainty that the intervention of the defendant has caused the damage which the claimant incurred. However, exceptions have been made by the Dutch legislator and Supreme Court: procedural rules may change in favour of the claimant when fairness demands

\footnotetext{
${ }^{378}$ Klaassen \& Kortmann 2012, p. 6.

${ }^{379}$ Giesen 2001, p. 59-60.

${ }^{380}$ This should be compared with the burden of proof in English criminal law; 'beyond reasonable doubt'. In the civil standard of proof, the balance of probabilities seeks to resolve a problem between the two parties, seeks to find the more believable story (hence the metaphor of the $51 \%+$ believability of the one story against the other). In criminal law, the issue is not to find the winner between the competing parties, but to measure the conduct of the defendant against the acceptable standards of behaviour in the particular jurisdiction.

${ }^{381}$ Clerk \& Lindsell 2006, p. 47.

${ }^{382}$ Tan 2007a, p. 933-940; Van Dam 2006, p. 275.

${ }^{383}$ Wetboek van Burgerlijke Rechtsvordering (Rv).

${ }^{384}$ Article 150 of the Code of Civil Procedure (Rv). The claimant has to prove all the elements of the claim.
} 
another arrangement of the burden of proof. ${ }^{385}$ This means that fairness could, in specific circumstances, require an exception to the normal burden of proof rule. Besides the option to reverse the burden of proof, several other procedural instruments can be applied to strengthen the claimant's legal position, such as the defendant's duty to provide an extra motivated pleading and the option to lessen the burden of proof, which will be subject to discussion in Chapter 3.

In English law, it is a firm principle of case law that the claimant must prove that the defendant owed him a duty of care, which implies the existence of a relationship between the claimant and the defendant previous to the infliction of harm. But is it also up to the claimant to prove the other requirements to establish the liability of the defendant? Yes, similar to Dutch law, the English claimant has to prove all the elements of the liability claim. This means that the asserting party who bases his claim on the Tort of negligence will have to prove that the defendant has not handled conform the appropriate standard of care and, therefore, breached his duty of care. Subsequently, the claimant must prove a causal link between the defendant's breach of the duty of care and the damage which the claimant incurred. The claimant thus has to demonstrate that it is, on the balance of probabilities, more likely than not that he would not have suffered damage without the wrongful intervention of the defendant.

\subsubsection{Comparative conclusion}

In both Dutch and English laws, the existence of a causal link between the defendant's intervention and the claimant's damage, is a fundamental requirement to establish the liability of the defendant. Both jurisdictions distinguish two aspects of causation, i.e., factual causation and legal causation. The general rule is that factual causation must be established first before going on to determine the scope of the damage. This distinction is, however, not clear cut and is heavily debated in literature. The condicio sine qua non (but-for) test is applied to establish factual causation and is seen as a workable approach in most situations. The second stage of causation, the 'extent' phase, gives the legal system the opportunity to limit the consequences for which the defendant has to answer as some consequences are just too far removed from the defendant's intervention for liability to arise. In Dutch law, Article 6:98 BW limits the scope of the reparation holding that the attribution of damage must be reasonable. English law, on the other hand, does not hold a specific statutory provision on this subject but uses several instruments, such as the reasonable foreseeability of the damage, the probability that the damage would occur, and the directness of the consequential damage to limit the scope of the defendant's liability.

The general rule in both jurisdictions is that the asserting party has to prove all the elements of the liability claim. While English law does not hold a specific statutory provision on the burden of proof in civil litigation this rule is, in Dutch law, codified in Article $150 \mathrm{Rv}$. Under English law, the rule that the asserting party has to prove all the elements of the claim is a firm principle of case law. Both jurisdictions do not demand absolute $(100 \%)$ certainty to demonstrate causation between the defendant's intervention and the claimant's damage. The Dutch standard of proof, however, differs from the English

\footnotetext{
${ }^{385}$ See: Article 150 of the Code of Civil Procedure (Rv).
} 
standard. The Dutch claimant must prove causation to a 'reasonable degree of certainty' while English law requires the claimant to prove causation 'on the balance of probabilities'. Applying the balance of probabilities approach, the English claimant, who is able to prove that there is a chance of less than 50 percent for the accident to happen without the breach of duty, proved the causal link between conduct and damage. It is about saying that, on balance, one side is more believable than the other. To that extent there is a similarity in 'reasonableness'. It is arguable, however, that Dutch law requires a higher threshold to establish factual causation. Under English law, a 51 percent probability is sufficient while this threshold might not be enough to pass the Dutch 'reasonable degree of certainty' threshold to prove causation. ${ }^{386}$

\subsection{Critique on the condicio sine qua non (but-for) test and its all-or-nothing result}

This section examines the drawbacks connected to the application of the condicio sine qua non (but-for) test in Tort law. This test, and especially the all-or-nothing result that it produces, has been subject of criticism. In section 2.5.1, the traditional principle of allor-nothing compensation will be explained. The subsequent subsections not only examine the desirability of the all-or-nothing approach from a perspective of compensation in section 2.5.1.1, but also from a perspective of prevention in section 2.5.1.2 because prevention of damage is an objective of liability which has become more and more accepted in European Private law. Subsequently, section 2.5.2 examines the drawbacks connected to the condicio sine qua non test in cases that are characterized by the problem of uncertain causation.

\subsubsection{The traditional principle of all-or-nothing compensation}

In order to establish factual causation one has to make a hypothetical reconstruction of the situation that would have been present had the tortfeasor not acted in the way he did. The application of the condicio sine qua non test leads to a traditional all-or-nothing recovery. ${ }^{387}$ When causation is accepted by the court, it will grant full damages. When causation is not proved the claimant leaves empty-handed. Both Dutch and English laws apply the so called 'threshold liability rule' to award compensation in most situations. This means that full compensation is awarded only when the probability, that the harm was caused by the defendant's intervention, passes a certain threshold. Whether damages will be awarded in full or totally be rejected thus depends on the assessed probability of causation. In the majority of the cases, awarding all-or-nothing on the basis of the threshold liability approach is seen as a just and justifiable approach to settle the case.

However, the Dutch standard of proof is not expressed in a percentage since no percentage threshold is given by the Dutch legislator or Supreme Court to indicate 'reasonableness'. Depending on the facts of the case the threshold to award all-or-nothing

\footnotetext{
${ }^{386}$ Giesen 2001, p. 59-60; Van Dam 2006, p. 275.

${ }^{387}$ In Dutch law, employers' liability is based on the principle of 'restitutio in integrum': the employer is either liable and obliged to compensate the claimant in full or is not liable and does not have to compensate the claimant at all.
} 
could be 50, 60 or even 70 percent, which makes all-or-nothing recovery arbitrary. ${ }^{388}$ English law, on the other hand, requires the claimant to prove that it is on the balance of probabilities more likely than not that that defendant's intervention has caused the claimant's damage. If the English claimant is able to prove that there is a metaphorical probability of 51 percent or more, causation is established and the claimant will receive full compensation. In cases where experts have only established a metaphorical 49 percent chance, it is most likely that the claimant's action will fail even if there is an admission of carelessness. ${ }^{389}$ A strict application of the English standard of proof leads to the result that one percent can make the difference between being fully compensated or leaving empty-handed. Moreover, the closer the estimated percentage comes to the turning point, the more the outcome of the all-or-nothing approach will be felt as undesirable. ${ }^{390}$ The percentages are, however, metaphorical in that it is an indication that one side's presentation of the claim is more believable than the other's presentation.

\subsubsection{A compensation point of view}

When the all-or-nothing approach is examined with respect to compensation, which is arguably the most important goal of Tort law ${ }^{391}$, this traditional approach leads to undesirable results in cases in which the requirement of causation is uncertain. If it has been established that the defendant has acted negligently and there is a considerable chance that this negligence (for example: exposure to asbestos) has caused damage (for example: lung cancer) to the claimant, it would be undesirable for the victim to leave emptyhanded because he is unable to prove condicio sine qua non to the required 'reasonable degree of certainty' or 'on the balance of probabilities'. Conversely, it would also be undesirable for the defendant to pay full damages if there is only a 51 percent chance ${ }^{392}$ that his wrongful intervention has caused the claimant's damage. The defendant would then be responsible in full even when there is a considerable chance that his negligence did not cause the claimant's damage. In such situations, the principle of all-or nothing recovery leads to over- or under-compensation. ${ }^{393}$

\subsubsection{A prevention point of view}

Prevention of damage is an objective of liability which has become more and more accepted in European Private law. Nowadays, the prevention function is adopted as one of the guiding principles of liability in the Principles of European Tort Law. ${ }^{394}$ In order to examine the prevention function of the traditional principle of all-or-nothing compensa-

\footnotetext{
${ }^{388}$ Giesen 2001, p. 59-60.

${ }^{389}$ Deakin et al. 2003, p. 189.

${ }^{390}$ Akkermans 1997, p. 92.

391 Akkermans 1997, p. 213; Clerk \& Lindsell 2006, p. 7.

${ }^{392}$ Assuming that the turning point lies at 49/51 percent. This threshold to establish causation is applied in English law. In England causation has to be proved on the balance of probabilities. This means that the claimant has to prove that there was a chance of less than fifty percent (on the balance of probabilities more likely than not) for the accident to happen without the defendant's breach of duty.

${ }^{393}$ Kortmann 2006, p. 1405.

${ }^{394}$ Article 10:101 PETL: 'Damages also serve the aim of preventing harm'.
} 
tion, it is essential to address the question of whether or not 'all-or-nothing' is an incentive for careful behaviour? ${ }^{395}$

It probably would not. Defendants will not get the right incentives to correct their wrongful behaviour when they manage to escape liability despite the fact that they have acted negligently and there is a considerable chance that this negligence has caused the claimant's damage. In such a situation acting negligently remains without consequences while it may have caused enormous damage to the claimant. In cases concerning employers' liability, not being obliged to compensate the employee's damage will definitely not motivate employers to take good or better care, which could result in the fact that precautionary measures to prevent employees from encountering health damage will not be taken sufficiently. It is, however, also undesirable to hold employers liable in full when there is a considerable chance that the employer did not cause the damage to the claimant. If an employer is held liable for more damage than he possibly could have caused desirable activities for society may possibly not be performed (anymore) by the employer. ${ }^{396}$ The principle of all-or-nothing compensation is not a desirable instrument to prevent claimants from encountering health damage because defendants do not (always) get the right incentives to correct their wrongful behaviour.

\subsubsection{Conclusion}

Applying the condicio sine qua non (but-for) test leads to a traditional all-or-nothing recovery. When the all-or-nothing solution to award or reject compensation is examined from compensation and prevention perspectives one can conclude that the application of this traditional scheme to compensate the claimant's damage is unsatisfactory. Claimants will, in cases where causation could just or just not be proved to a 'reasonable degree of certainty' or 'on the balance of probabilities', either be fully compensated or leave empty-handed. Seen from a compensation point of view, it is unfair to oblige the defendant to pay for all the damage when there is a considerable chance that his negligent intervention did not cause the claimant's damage. Conversely, it is unfair towards the claimant to leave empty-handed when there is a considerable chance that the defendant had caused his damage. Furthermore, if - in cases concerning employers' liability - the negligent employer is able to escape liability while he could have caused the employee's damage he will not receive the right incentive to correct his wrongful behaviour. Wrongful behaviour should, from a perspective of prevention, never remain without consequences. However, these consequences should not lead to the fact that desirable activities for society will not be performed (anymore) by the defendant(s).

\subsubsection{The problem of causal uncertainty}

Before examining the issue of 'causal uncertainty' as a drawback connected to the application of the condicio sine qua non test, it is important to note that causal uncertainty is not only a problem in Dutch and English laws. The problem of uncertain causation is taxing most, if not all jurisdictions. Many examples exist in Tort law of situations where there is uncertainty concerning the causal relationship between the tortuous act and the dam-

\footnotetext{
${ }^{395}$ Faure \& Hartlief 1996, p. 38.

${ }^{396}$ Hartlief 2000, p. 13; Visscher 2007, p. 102; Van Velthoven \& Van Wijck 2008, p. 130-140.
} 
age. ${ }^{397}$ Furthermore, uncertainty as such, is not uncommon in law and is a common feature in many cases in Tort law. Uncertainty could, as examined in this research, arise with regard to the element of causation. However, uncertainty could also arise with regard to other elements of the liability claim. Here, one might think of the uncertainty about the wrongful conduct of the tortfeasor, and the uncertainty about the amount of damages which the claimant has suffered. ${ }^{398}$ This research, however, solely focuses on causal uncertainty between the defendant's intervention and the claimant's damage.

In section 2.4.1.1, I have concluded that the condicio sine qua non test is a workable approach to establish causation in most situations. However, a strict application of this test leads to undesirable results in cases where the assessment of causation cannot result in a simple yes or no answer. In the next sections, different types of causal uncertainty pass the review in order to show that a strict application of the condicio sine qua non test, and the all-or-nothing result that this test produces, does not lead to desirable results.

\subsubsection{Uncertainty about the cause of the damage: multiple causation}

Causal uncertainty that arises with regard to the cause of the damage is often referred to as 'multiple causation'. Good examples of this problem can be found in claims for occupational diseases and medical negligence. ${ }^{399}$ In situations where multiple possible causes of the damage are present and uncertainty exists on the situation that would have existed without the tortuous event (a hypothetical situation), the condicio sine qua non test fails. This can be illustrated with a simple example:

Mr 'X' developed musculoskeletal disorder (RSI) after he worked as an office worker for an employer who took no precautionary measures to prevent RSI. Mr ' $\mathrm{X}$ ' wanted to hold his employer liable for his damage (RSI). It was established that the employer breached his duty of care to ensure a safe working environment. The employer acted negligently because he did not take any precautionary measures to prevent his employee from contracting RSI. Subsequently, the claimant has to prove causation in order to establish the liability of the employer. This implies that he has to prove to a 'reasonable degree of certainty ${ }^{400}$ or 'on the balance of probabilities' ${ }^{401}$ that, had the employer not breached his duty of care, he would not have contracted RSI. The appointed expert concluded that Mr 'X's illness could have been caused by the employer's negligence. However, the illness could also have been caused by the claimant's hobby (playing computer games) or by the claimant's genetic predisposition. Science could not determine whether the job, the hobby, or the genetic predisposition, caused the illness. Expert evidence could thus not determine the cause of the disease, because multiple causes could bring about the effect. The consequence was that $\mathrm{Mr}$ ' $\mathrm{X}$ ' could not prove factual causation on

\footnotetext{
${ }^{397}$ Faure 1993b, p. 79.

${ }^{398}$ Bosch Kemper 1998, p. 165.

${ }^{399}$ In medical negligence cases it is rather difficult to prove that the defendant's negligence has caused the claimant's damage because the claimant already suffers from a medical condition. Claims for occupational diseases can also cause problems. Here, one could for example think of claims for musculoskeletal disorder (RSI), claims for burn-out, and claims for asbestos-related injuries.

${ }^{400}$ Dutch threshold to establish causation.

${ }^{401}$ English threshold to establish causation.
} 
the basis of the condicio sine qua non test. Applying traditional principles, the claim for compensation would probably be dismissed: $\mathrm{Mr}$ ' $\mathrm{X}$ ' remains empty-handed while there is a considerable chance that the negligence of his employer has caused his damage.

The essential problem of multiple causation is the fact that it is impossible to prove which factor has caused the claimant's damage: multiple factors are present any one of which could have caused the damage separately. ${ }^{402}$ This poses a significant hurdle for the claimant as it is - in general - the claimant who bears the consequences of the uncertainty in such cases. The application of the condicio sine qua non test will produce injustice in cases where multiple factors are present that all could have caused the claimant's damage, particularly when it has been proved that the defendant had been at fault and that there is a real probability that this fault has caused the damage to the claimant. In such situations a strict application of the condicio sine qua non test is contrary to common sense: 'Tort law is and should be about compensating those who are wrongfully injured.' 403

\subsubsection{Uncertainty about the specific tortfeasor}

Besides the uncertainty with regard to the cause of the damage, causal uncertainty could also arise with regard to which specific tortfeasor caused the claimant's damage. This situation can be illustrated with a classical example in which three defendants are out hunting and all fire shots. One bullet, which was fired by one of three defendants, hit the claimant in his left arm, which led to the consequence that the capacity of the left arm was reduced by 60 percent. However, there was no means of telling from whose gun the shot was fired. The claimant is unable to prove to the required 'reasonable degree of certainty ${ }^{\text {'404 }}$ or 'on the balance of probabilities' ${ }^{405}$ that defendant 'A' has caused his damage, nor can he prove that defendant ' $\mathrm{B}$ ' or ' $\mathrm{C}$ ' has caused his damage. A strict application of the condicio sine qua non test would lead to the result that the claimant remains empty-handed as he is unable to prove causation between the intervention of one specific tortfeasors (hunters) and the damage which he incurred.

This specific type of causal uncertainty also did arise in the well known Dutch DESdaughters case ${ }^{406}$. English legal scholars could be familiar with the facts because this case has also been discussed by the House of Lords in Fairchild $v$ Glenhaven Funeral Services $L t d^{407}$. DES is a defective drug which was put onto the market by a large number of manufacturers to prevent miscarriage. Daughters of DES-using mothers suffer from cancer and fertility problems caused by the drug. The drug caused damage to a large number of claimants. However, although the claimants in DES could prove the cause of the damage they were unable to prove which manufacturer had produced the drug which their mothers had taken. The approach set out by the Dutch Supreme Court to bypass the condicio

\footnotetext{
${ }^{402}$ Tan 2007a, p. 935.

${ }^{403}$ Fairchild $v$ Glenhaven Funeral Services Ltd, [2002] UKHL 22, paragraph 11 (Lord Bingham). See also: AsserHartkamp 4-1, p. 351-356.

${ }^{404}$ Threshold to establish causation in Dutch law.

405 Threshold to establish causation in English law.

${ }^{406}$ Hoge Raad 9 oktober 1992, NJ 1994, 535.

${ }^{407}$ Fairchild v Glenhaven Funeral Services Ltd, [2002] UKHL 22. In this case the claimant could not prove which employer had caused the mesothelioma (damage) to begin forming.
} 
sine qua non requirement in order to reach a desirable outcome will be extensively discussed in section 3.5.

\subsubsection{Multiple causation and uncertainty about the tortfeasor}

The most difficult situation arises in claims in which causal uncertainty is present as to both the specific tortfeasor and the cause of the damage. Here, I can return to the example in section 2.5.2.1 in which an employee suffers from musculoskeletal disorder (RSI). If we now assume that the employee has worked for two employers who both have neglected their duty to take precautionary measures to prevent RSI, the case becomes even more complicated. We know that the claimant's RSI could have been caused by multiple factors because there are two or more causes present where at least one of them can be attributed to the claimant (playing computer games). As discussed, the claimant is unable to prove which factor has caused his illness. In addition, the claimant is also unable to prove to 'a reasonable degree of certainty' or 'on the balance of probabilities' that employer 'A' has caused his damage, nor can he prove that employer 'B' has caused his damage (RSI). Applying traditional rules on causation, the claimant's claim fails as he is unable to prove which tortfeasor, if any, did cause his damage.

\subsubsection{Conclusion}

The former sections have generally discussed the issue of uncertain causation in Dutch and English Tort law. Uncertainty as such, is a common feature in Tort law as it can arise with regard to all the elements of the liability claim. Causal uncertainty is a problematic issue in all jurisdictions and can arise in numerous situations: with regard to the cause of the damage, the specific tortfeasor, or both. Generally, it is the claimant who bears the consequences in cases where the causal link between the defendant's intervention and the claimant's damage, is uncertain. If the claimant is unable to prove causation to the required 'reasonable degree of certainty' or 'on the balance of probabilities', it is most likely that the claimant leaves empty-handed while there is still a chance that (one of) the tortfeasor(s) has caused the damage which the claimant incurred. The condicio sine qua non (but-for) test has proven to be inadequate to establish factual causation in cases where multiple factors are present that all could have caused the claimant's damage separately. The same is true for cases in which uncertainty arises with regard to which specific tortfeasor caused the claimant's damage. A strict application of the condicio sine qua non (butfor) test, and in particular the all-or-nothing result that this test produces, leads to injustice in cases that are characterized by the problem of uncertain causation.

\section{PART THREE: CAUSATION PROBLEMS IN ASBESTOS-RELATED CASES}

\subsection{Causal uncertainty in asbestos-related cases}

The fact that asbestos-related cases are characterized by the problem of uncertain causation can have enormous and undesirable consequences for victims who suffer from asbestos-related injuries. It is now widely accepted that exposure to asbestos can lead to lung 
cancer and there is now no question of whether or not lung cancer contracted unequivocally by another's negligence causes damages for legal purposes: lung cancer is actual 'damage' under Dutch law and is seen as actionable 'damage' under English law. ${ }^{408}$ It is the causal link between the tortious act and the damage which remains a problematic legal and scientific issue in asbestos-related cases. It should also be acknowledged that the problem of uncertain causation in asbestos-related cases is not only recognized in the two jurisdictions taken under consideration here: courts all over the world encounter similar problems when deciding asbestos-related cases.

In asbestos-related cases the difficulty with regard to the requirement of causation stems from scientific uncertainty. Medical science cannot provide absolute certainties in cases of mesothelioma or lung cancer which could have been caused by exposure to asbestos. In these particular cases it has proven to be extremely difficult to establish causation to the required 'reasonable degree of certainty' or 'on the balance of probabilities'. In asbestos-related cases in which an employee contracted mesothelioma after having been exposed to asbestos in several different employments, medical science cannot determine the exact moment the employee inhaled the fatal asbestos fibre which led to the forming of mesothelioma. Subsequently, the claimant is unable to prove to a 'reasonable degree of certainty' or 'on the balance of probabilities' that employer 'A' or 'B' (or 'C', or 'D') has caused the mesothelioma. Moreover, causal uncertainty could also arise in claims for mesothelioma in which one employer has non-wrongfully (for example: during 19401958) and wrongfully (for example: during 1960-1970) exposed his employee to asbestos in the course of the employement. The latter problem of uncertain causation will, however, not be further examined in this thesis because case law is very clear on this point. $^{409}$

The employee could, however, also contract lung cancer which could have been caused by exposure to asbestos. In cases of lung cancer, as opposed to mesothelioma cases, medical science is unable to determine the cause of the injury which means that the claimant is unable to prove whether or not asbestos exposure caused his damage. Even if the employee has only been exposed to asbestos in the course of one employment, it remains problematic to prove that asbestos exposure caused the lung cancer in the specific claimant's case. The most complex situation arises in cases where an employee contracted lung cancer as a potential consequence of asbestos exposure after he has been exposed to asbestos in several different employments. In these particular cases, uncertainty arises as to both the cause of the damage and the specific tortfeasor who has caused the claimant's damage.

\footnotetext{
${ }^{408}$ See for a medical acceptance: Beers et al. 2003, p. 297. See for a legal acceptance: Hoge Raad 31 maart 2006, NJ 2011, 250 (Nefalit/Karamus); Fairchild v Glenhaven Funeral Services Ltd, [2002] UKHL 22; Sobczak et al. 2009, p. 207-217. In case the victim only contracted pleural plaques the 'damage question' is far more difficult to answer. See for a good example in English law: Johnston $v$ NEI International Combustion Limited, [2007] UKHL 39.

${ }^{409}$ Hoge Raad 25 juni 1993, NJ 1993, 686, paragraph 3.8.4 (Cijsouw/De Schelde 1). See also: Waterman 2009 , p. 340. The Supreme Court established the liability of De Schelde and ruled that employers could be held liable for unknown risks in cases where they have breached their duty of care to prevent employees from contracting known risks (asbestosis) connected to asbestos exposure.
} 
A legal and medical distinction can be made between, on the one hand, situations in which uncertainty exists about the specific tortfeasor (i.e., because there are multiple possible tortfeasors for the single, undisputed cause of lung cancer) and, on the other hand, situations where uncertainty exist as to the (medical) cause of the illness and subsequential damage. Employees who have been exposed to asbestos in the course of the employment could thus contract lung cancer which could have been, and in some cases (i.e., mesothelioma) could only be, asbestos-related. In addition, creating a situation in which the specific tortfeasor and the cause of the damage is uncertain is not unimaginable. I refer to section 1.3 for more extensive medical and legal details with regard to the specific asbestos-related injuries in question.

The following sections examine how Dutch and English laws have approached the problem of causal uncertainty that arises in asbestos-related cases. Section 2.6.1 examines the burden of proof in asbestos-related cases and illustrates that the application of the traditional all-or-nothing solution leads to undesirable results in cases that are characterized by the problem of uncertain causation. The subsequent sections focus on specific causation problems in claims for asbestos-related diseases. The inability to establish causation in mesothelioma cases will be explored in section 2.6.2, the uncertainty about the cause of the damage in cases where lung cancer is a potential consequence of asbestos exposure will be examined in section 2.6.3. Section 2.6.4 explores asbestos-related cases in which uncertainty arises as to both the cause of the damage and the specific tortfeasor who has caused the damage. Furthermore, the liability for pleural plaques in Dutch and English laws will be examined in section 2.6.5 to sketch the broader picture.

\subsubsection{The proof of causation and its consequences}

In claims for asbestos-related diseases, the claimant must - in general - prove the causal link between the defendant's intervention and the damage which he incurred. ${ }^{410}$ The proof of causation is problematic in asbestos-related cases because such cases are characterized by the fact that uncertainty could arise in numerous ways: uncertainty about the cause of the damage, uncertainty about the specific tortfeasor, or both. It goes without saying that the inability to prove causation will be very frustrating for the claimant since he is - in general - the one who bears the consequences of the uncertainty in such cases, which eventually may lead to an unsuccessful liability claim. This means that asbestos victims are, with regard to the burden of proof, put in an unfavourable position as opposed to the defendants who have wrongfully exposed them to asbestos. ${ }^{411}$ The claimant not only suffers from the asbestos-related injury itself but also suffers from the inability of scientific research to identify the specific tortfeasor who, in a group of possible tortfeasors, has caused the claimant's damage or to determine the cause of the damage in cases where multiple factors are present any one of which could have caused the claimant's damage separately.

In asbestos-related cases it is impossible to prove with absolute certainty (100\%) that specific facts did or did not happen. If the causal link is uncertain, the victim will most

\footnotetext{
${ }^{410}$ I refer to section 2.4.2 for more information on the burden (and standard) of proof.

${ }^{411}$ In the majority of asbestos-related cases asbestos victims have been exposed to asbestos in the course of their employment(s).
} 
likely fail to prove causation ${ }^{412}$ to the required 'reasonable degree of certainty' or 'on the balance of probabilities', unless he will get the opportunity to benefit from special rules concerning the burden of proof, which possibly could lead to a reversal of the burden of proof with regard to the requirement of causation. The application of the reversal rule, which means that a causal connection between the act and the effect is assumed and the defendant bears the burden of disproving causation, is presented as a solution for causal uncertainty in section 3.11.

A strict application of the condicio sine qua non test leads to all-or-nothing recovery. In cases where the claimant is unable to prove to a 'reasonable degree of certainty' or 'on the balance of probabilities' that his damage would not have occurred without the intervention of the tortfeasor he generally remains empty-handed. Application of this traditional rule to compensate the claimant is problematic in asbestos-related cases because the causal link is uncertain by definition. In the majority of the asbestos-related cases, the claimant is unable to pass the required threshold to establish causation. In both jurisdictions considered in this thesis, the applied threshold to establish causation is considered as an impossible burden for the claimant. Applying traditional principles, the result is that law declines all compensation in cases where the claimant is unable to prove causation but can prove that he has been wrongfully exposed to asbestos in the course of the employment(s). This means that the claimant, who is not to blame, should bear the whole loss rather than the defendant, who, at least to some degree, can be blamed for his wrongful conduct. This leaves the question of whether or not the strict rules on (the proof) of causation should be modified in order to address the gaps in scientific knowledge regarding the causal link between asbestos exposure and lung cancer. ${ }^{413}$

\subsubsection{Claims for mesothelioma}

Persons who have been exposed to asbestos have an increased chance to develop mesothelioma. As discussed above, mesothelioma is a primary tumour of the mesothelium, which covers the serosal cavities of the pleura (covering the lungs and inside of the chest walls), the pericardium (covering the heart) and the peritoneum (covering the abdomen). ${ }^{414}$ The latency period, from the first exposure to asbestos until the manifestation of mesothelioma, varies from 20 to 50 years which complicates the establishment of liability. In the English case Fairchild v Glenhaven Funeral Services Ltd ${ }^{415}$ (2002), Lord Bingham ${ }^{416}$ identi-

\footnotetext{
${ }^{412}$ The claimant is unable to prove condicio sine qua non (but-for).

${ }^{413}$ Giliker \& Beckwith 2000, p. 153.

${ }^{414}$ I refer to section 1.3.2 for more medical information on mesothelioma.

${ }^{415}$ Fairchild v Glenhaven Funeral Services Ltd, [2002] UKHL 22.

${ }^{416}$ Fairchild v Glenhaven Funeral Services Ltd, [2002] UKHL 22, paragraph 7; Lord Bingham: 'So if C is employed successively by $\mathrm{A}$ and $\mathrm{B}$ and is exposed to asbestos dust and fibres during each employment and develops a mesothelioma, the very strong probability is that this will have been caused by inhalation of asbestos dust containing fibers. But $\mathrm{C}$ could have inhaled a single fiber giving rise to his condition during employment by A, in which case his exposure by B will have had no effect on his condition; or he could have inhaled a single fiber giving rise to his condition during his employment by $\mathrm{B}$, in which case his exposure by A will have had no effect on his condition; or he could have inhaled fibers during his employment by A and B which together gave rise to his condition; but medial science cannot support the suggestion that any of these possibilities is to be regarded as more probable than any other. There is no way of identifying, even on a
} 
fied the present state of the art about the causal relation between exposure to asbestos and the onset of mesothelioma. He correctly argued that: the more dust that was inhaled, the more likely it was that mesothelioma would develop. The risk that mesothelioma will occur increases when the inhaled dose of asbestos fibres increases. However, the severity of the condition and the resulting disability do, as examined in section 1.3.2, not vary with the dose. ${ }^{417}$ It has been established that the condition can be caused by the inhalation of a single asbestos fibre, a few fibres, or many fibres. Furthermore, it is important to note that the condition, once caused, is not aggravated by further exposure. In practice this implies that, in cases where an employee had been exposed to asbestos by two employers in succession, the mesothelioma could have been caused by the inhalation of a single fibre during the first or the second employment. However, the condition could also have been caused by the inhalation of many fibres during both employments. In claims for mesothelioma not one of these possibilities is any more probable than the other. ${ }^{418}$

The following subsections examine causation problems which arise in mesothelioma cases. Claims for mesothelioma are characterized by the fact that uncertainty can arise about the specific tortfeasor who has caused the mesothelioma in the specific claimant's case. Case law and legislation will be discussed to show how Dutch and English laws have approached this problem in claims for mesothelioma. Keep in mind that the requirement of causation hardly ever causes problems in cases where the claimant suffers from mesothelioma after he has only been exposed to asbestos in the course of one employment. In such cases it is less complicated to establish the liability of the employer who has wrongfully exposed his employee to asbestos because asbestos is considered as the only cause to contract mesothelioma, and no uncertainty can arise as to the specific tortfeasor because only one tortfeasor can be pointed out. ${ }^{419}$ Therefore, the subsequence subsections focus on claims for mesothelioma in which two or more defendants have wrongfully exposed the claimant to asbestos.

\subsubsection{Uncertainty about the specific tortfeasor}

Mesothelioma is regarded as a non-cumulative condition: the inhalation of only one asbestos fibre can lead to the development of mesothelioma. As discussed in section 1.3.2, medical science is unable to tell us the exact moment the person concerned inhaled the 'fatal asbestos fibre' which led to the development of mesothelioma, and therefore a mesothelioma victim who has been exposed to asbestos by a number of different defendants cannot prove which defendant has caused his illness: 'technically it is impossible to establish where and when the patient inhaled the fatal asbestos fibre. ${ }^{420}$ When someone suffers from mesothelioma after having been occupationally exposed to asbestos in the past, uncertainty could thus arise with regard to which specific tortfeasor caused the claimant's mesothelioma to develop. In cases where the employee has worked for several

balance of probabilities, the source of the fiber or fibers which initiated the genetic process which culminated in the malignant tumour.'

${ }^{417}$ Jones 2006, p. 251-269.

${ }^{418}$ Fairchild v Glenhaven Funeral Services Ltd, [2002] UKHL 22, paragraph 7 (Lord Bingham).

${ }^{419}$ However, proof of the other requirements to establish the liability of the defendant can still be difficult.

${ }^{420}$ Van Dam 2006, p. 146. 
employers all exposing him to asbestos in the course of the separate employments, it remains uncertain which particular employer is responsible for and 'has caused' the claimant's damage.

Applying traditional principles to establish causation, it has proved to be difficult to establish the liability of the defendant in cases where it is uncertain which tortfeasor, in a group of possible tortfeasors, has caused the damage to the claimant. In cases of mesothelioma this problem arises frequently. The mesothelioma sufferer could have been exposed to asbestos while working for two or more employers all exposing him to asbestos in the course of the separate employments. In these particular cases it is impossible to prove causation because the claimant is unable to prove during which employment he has inhaled the 'fatal asbestos fibre' which led to the forming of mesothelioma. Applying traditional principles, the result would be that the claimant leaves empty-handed because the claimant is unable to prove to a 'reasonable degree of certainty' or 'on the balance of probabilities' that employer 'A', or 'B' (or 'C' or 'D') has caused his damage.

The problem of compensating victims who suffer from mesothelioma after they have been wrongfully exposed to asbestos by two or more defendants has also been subject to discussion in Dutch and English case law. ${ }^{421}$ The most important rules following from the case law will be discussed in the next subsections. A more extensive discussion on specific solutions to the problem of causal uncertainty will follow in Chapter 3.

\subsubsection{Apportionment of damages}

This section addresses the apportionment of damages in claims for mesothelioma in which the claimant has been wrongfully exposed to asbestos by two or more defendants. The apportionment of damages can be problematic when two or more defendants could have caused the claimant's damage separately. In such cases one could wonder whether the defendants should be held jointly and/or severally liable for the claimant's damage. Both solutions have pros and cons depending on the perspective from which the solution is approached. If the defendant is held jointly and severally liable he has to compensate the claimant in full but he can have a right of recourse against the other responsible defendant(s). In this situation the liable defendant thus bears the risk that one of the other defendants is untraceable or has gone out of business. Applying the several liability solution, the defendants can only be held liable for their proportionate share. This, however, implies that the claimant has to sue all defendants in order to receive full compensation. In such a situation the claimant thus bears the risk that one of the defendants is untraceable or has gone out of business.

\footnotetext{
${ }^{421}$ See for Dutch case law: Centrale Raad van Beroep 21 juni 2007, LJN: BA8436. The Supreme Administrative Court $(\mathrm{CRvB})$ had to decide whether one of the employers could be held liable for the claimant's damage. During the first period of employment the employee worked for DSM, and during the second period of employment (from 1965 till 1989) he worked for the District Oss. The employee contracted mesothelioma and died from the consequences of mesothelioma in 1994. See for more mesothelioma cases; Rechtbank Haarlem 1 april 2009, LJN: BI1010, Rechtbank Almelo 4 juni 2008, LJN: BD3218; Rechtbank Almelo 2 oktober 2007, LJN: BB4632; Gerechtshof Arnhem 5 juni 2007, LJN BA6364. See for English case law on this issue: Fairchild v Glenhaven Funeral Services Ltd, [2002] UKHL 22; Barker v Corus, [2006] UKHL 20.
} 


\subsection{Dutch law: joint and several liability}

Dutch mesothelioma victims who have been wrongfully exposed to asbestos by two or more defendants do not have to trace all possible defendants in order to receive full compensation. Each defendant, in a group of possible tortfeasors, is jointly and severally liable on the basis of Article 6:99 BW unless the defendant is able to prove that he did not cause the claimant's damage. ${ }^{422}$ Article 6:99 BW, also referred to as 'alternative causality', reads:

'Where the damage has resulted from two or more events for each of which a different person is liable, and where it has been determined that the damage has arisen from at least one of these events, the obligation to repair the damage rest upon each of these persons, unless he proves that the damage is not the result of the event for which he himself is liable.'

This Article is in line with Article 9:101 lid 2 PETL $^{423}$ and Article 3:103 PETL. ${ }^{424}$ In mesothelioma cases it is almost impossible for defendants who have exposed the claimant to asbestos to prove that they have not caused the claimant's damage as they are unable to prove that the claimant did not inhale the 'fatal asbestos fibre' during the exposure for which the defendant is responsible. ${ }^{425}$ This implies that the in Article 6:99 BW adopted clause to escape liability is a death sentence in mesothelioma cases where two or more defendants have exposed the claimant to asbestos.

The application of Article 6:99 BW has positive consequences for the claimant. A Dutch claimant does not have to fear for insolvency of one of the tortfeasors and the burden of proof (disproving causation) lies firmly with the tortfeasor rather than the victim. Joint and several liability appears when the claimant's injury could only have been caused by the fault of one out of several possible tortfeasors, in circumstances where the person who has actually committed the unlawful act cannot be pointed out. This means that the mesothelioma victim does not have to sue every employer who has exposed him to asbestos in several different employments, because it is sufficient to sue one responsible employer. This employer can be held liable in full, and could have a right of recourse against the other responsible employer(s). This does, however, not create the right incentives for employers. If an employer is held liable for more damage than he possibly could have caused this could, as discussed in section 2.5.1.2, eventually lead to the consequence that desirable activities for society may not be performed anymore by the employer. ${ }^{426}$

\footnotetext{
${ }^{422}$ See for the application of Article 6:99 BW in a mesothelioma case: Gerechtshof Arnhem 13 april 2004, LJN: AO8064.

${ }^{423}$ Article 9:101 (2) PETL: 'Where persons are subject to solidary liability, the victim may claim full compensation from any one or more of them, provided that the victim may not recover more than the full amount of the damage suffered by him.'

${ }^{424}$ Article 3:103 (1) PETL: 'In case of multiple activities, where each of them alone would have been sufficient to cause the damage, but it remains uncertain which one in fact caused it, each activity is regarded as a cause to the extent corresponding to the likelihood that it may have caused the victim's damage.'

${ }^{425}$ Hoge Raad 25 juni 1993, NJ 1993, 686 (Cijsouw/De Schelde 1).

${ }^{426}$ Hartlief 2000, p. 13; Visscher 2007, p. 102; Van Velthoven \& Van Wijck 2008, p. 130-140.
} 


\subsection{English law: proportional liability or joint and several liability?}

In cases where the acts or omissions of more than one person make a causal contribution to the same indivisible damage, each defendant is - in general - liable to the claimant in full, but each defendant may, under the Civil Liability (Contribution) Act 1978, claim contribution against the other responsible defendant(s) ${ }^{427}$ The way in which mesothelioma victims, who have experienced two or more exposures to asbestos, should be compensated has been subject to discussion in both case law and Parliament. Three cases seem the most important and are, therefore, subject to a more extensive discussion. In the 'multiple exposure ${ }^{428}$ cases Fairchild v Glenhaven Funeral Services Ltd ${ }^{429}(2002)$ and Barker v Corus $^{430}$ (2006), the claimants contracted mesothelioma after they had been wrongfully exposed to asbestos in several different employments. In the 'single exposure ${ }^{\text {,431 }}$ case Sienciewicz v Greif (UK) Limited ${ }^{432}$ (2011), the claimant suffered from mesothelioma after she had been occupationally and environmentally exposed to asbestos. All three cases will be discussed in order to show that the Law Lords have changed their mind with regard to the way in which damages should be apportioned in mesothelioma cases. In addition, the Compensation Act 2006 will be examined in order to show how Parliament has - on the basis of policy considerations - overruled the decision in Barker on the issue of apportionment of damages.

\section{* Fairchild v Glenhaven Funeral Services Ltd: joint and/or several liability?}

In Fairchild $v$ Glenhaven Funeral Services Ltd, Mr Fairchild died as a result of the inhalation of asbestos fibres which led to development of mesothelioma. ${ }^{433}$ In the years prior to the disease, Mr Fairchild worked for different employers who were, all admitted, in breach of duty. Two employers have negligently exposed Mr Fairchild to asbestos in the course of the separate employments. It was admitted that on each of these jobs Mr Fairchild was exposed to substantial quantities of asbestos-containing debris and dust. Any cause of contracting mesothelioma other than the inhalation of asbestos dust at work can be effectively discounted. ${ }^{434}$ This means that any search for an alternative cause of mesothelioma in a person occupationally exposed to asbestos is unnecessary. The principal issue at stake was whether or not an employee could recover damages where he was able to prove negligence but, having worked for more than one employer, was unable to prove the identity of the person who has caused the injury which he sustained. Fairchild, and other mesothelioma cases, was about the claimant's need to identify, among a number of defendants, the one whose negligence led to the claimant's damage. ${ }^{435}$

\footnotetext{
${ }^{427}$ Rogers 2000, p. 197, 198.

${ }^{428}$ Different defendants are responsible for the claimant's exposure to asbestos.

${ }^{429}$ Fairchild v Glenhaven Funeral Services Ltd, [2002] UKHL 22.

${ }^{430}$ Barker v Corus, [2006] UKHL 20.

${ }^{431}$ A single defendant is responsible for the claimant's exposure to asbestos.

432 Sienciewicz v Greif (UK) Limited, [2011] UKSC 10.

${ }^{433}$ Arthur Fairchild was born in 1935. In 1995 he began to exhibit signs of mesothelioma. The onset of symptoms was first noted in about May 1995. When he knew he was dying, he gave up his work in 1996. Arthur Fairchild died in September 1996.

${ }^{434}$ Fairchild v Glenhaven Funeral Services Ltd, [2002] UKHL 22, paragraph 2 (Lord Bingham).

${ }^{435}$ Miller 2002, p. 119-139.
} 
The claimant was not able to prove causation between one of the occupational exposures to asbestos and the mesothelioma, on the 'balance of probabilities'. Therefore, the House of Lords expanded the notion of causation and accepted liability on the ground that the breach of duty had made a material contribution to the risk of mesothelioma. ${ }^{436}$ In Fairchild, it was sufficient to show that the defendant's breach of duty had materially increased the risk of mesothelioma. An exception to the traditional test to establish causation should be recognized in cases where the application of the but-for test would produce a result at odds with the underlying rationale of the liability in question. This solution, i.e., expanding the notion of causation to strengthen the claimant's legal position in cases where the causal link is uncertain, will be discussed more extensively in section 3.8 .

Although the issue of apportionment of damages was not raised by the parties in Fairchild and has not been discussed by the Law Lords, lower courts have applied the principle of joint and several liability in subsequent claims for mesothelioma in which two or more defendants could have caused the claimant's damage. ${ }^{437}$ The defendants (employers) were, however, not satisfied with the decision in Fairchild. Defendants and their insurers argued that joint and several liability is a fair solution to compensate the claimant's damage as long as all the possible defendants are solvent or insured. In such cases the defendant can seek contribution from the other solvent defendants and their insurers under the Civil Liability (Contribution) Act 1978. ${ }^{438}$ However, the application of joint and several liability could have major negative consequences in cases where one or more defendants are untraceable or have gone out of business. The defendant who is individually liable to compensate the claimant in full thus bears the risk that other responsible tortfeasors cannot pay their share.

\section{* Barker v Corus: proportional liability in claims for indivisible mesotheli- oma}

Four years after the important decision in Fairchild, the House of Lords was - again faced with another complex asbestos-related case. In Barker v Corus ${ }^{439}$, Mr Barker had been negligently exposed to asbestos while working for two employers both exposing him to asbestos in the course of the separate employments. Mr Barker contracted mesothelioma and died from the consequences of that disease in 1996. The facts, however, differed from the facts in Fairchild since Mr Barker has also exposed himself to asbestos while working as a self-employed plasterer. Unlike the facts in Fairchild, not all exposures which could have caused Mr Barker's mesothelioma involved a breach of the defendants' duty of care or were within the control of the defendants. ${ }^{440}$ In fact, the exposure to asbestos during his work as a self-employed plasterer was a failure made by $\mathrm{Mr}$ Barker to take reasonable care for its own safety. It goes without saying that Mr Barker

\footnotetext{
${ }^{436}$ This solution was applied in non-mesothelioma cases for the first time: Bonnington Castings Ltd v Wardlaw, [1956] AC 613 and McGhee v National Coal Board, [1973] 1 WLR 1.

${ }^{437}$ Mullis \& Nolan 2007, p. 457; McBride \& Bagshaw 2008, p. 554.

${ }^{438}$ See for an electronic link: http://www.legislation.gov.uk/ukpga/1978/47/crossheading/supplemental [Last visited 31 August, 2012].

${ }^{439}$ Barker v Corus, [2006] UKHL 20.

${ }^{440}$ Barker v Corus, [2006] UKHL 20, paragraph 3.
} 
himself was culpable during that particular period. In Barker, the House of Lords was asked to consider and explain the scope of the Fairchild-principle and to decide on the apportionment of damages in cases where two or more defendants could have caused the claimant's damage. ${ }^{441}$ The Fairchild-principle has been stretched in Barker as this exception is now also applicable in cases where the claimant experienced both wrongful and non-wrongful exposures to asbestos. The exact limits of the Fairchild-principle, i.e., expanding the notion of causation in cases where causation is uncertain, will be extensively explored in section 3.8 and is not subject to further discussion here.

I continue to discuss the Law Lords' decision on the apportionment of damages. In Barker, the Law Lords had to decide whether or not to apply (1) proportional liability, i.e., each defendant is only entitled to an apportionment of his liability to reflect the extent of the overall exposure attributable to his breach of duty, or (2) joint and several liability, i.e., the defendants are each individually liable to compensate the claimant in full. In claims for mesothelioma the issue of apportionment is extremely complex because mesothelioma is an indivisible injury. ${ }^{442}$ As said previously, there remains a clear consensus that increased exposure to asbestos increases the risk of contracting mesothelioma but, in the event of a sequence of separate periods of exposure, current science is unable to identify the one in which the condition was initiated. ${ }^{443}$ This implies that the defendants in cases such as Fairchild and Barker appear to be concurrent joint tortfeasors.

The traditional principle of joint and several liability could give problems in mesothelioma cases and other cases in which concurrent joint tortfeasors are present. Problems will arise in cases where, in a group of possible tortfeasors, not all tortfeasors appear to be solvent. Although this defendant might only be responsible for a small proportion of the claimant's overall exposure to asbestos he has to compensate the claimant's damage in full. In such cases the defendant can have a right of recourse against the other responsible tortfeasors. However, if the other responsible tortfeasors have gone out of business they cannot pay their share, which means that the solvent defendant might have to compensate more than he possibly could have caused. ${ }^{444}$

Will Barker deviate from the traditional principle of joint and several liability in order to take away the injustice? Should each tortfeasor, in a group of possible tortfeasors, be held severally liable, according to the share of risk created by their breach of duty, so that solvent tortfeasors do not have to pay for the insolvent ones? Yes, the majority of their Lordships were of the opinion that a fair balance should be created between both the interests of the defendants and the interests of the claimants. In order to reach this 'fair' solution the House of Lords held the defendants severally liable for the claimant's damage (mesothelioma). The Law Lords ruled that each of the defendants should only be held liable to compensate the claimant for a proportion of the mesothelioma. ${ }^{45}$

The House of Lords thus choose for a proportional liability approach and decided that each employer is liable 'by reference to the share of risk attributable to the breaches

\footnotetext{
${ }^{441}$ Kramer 2006, p. 547-553.

${ }^{442}$ See for more information: Sobczak 2011, p. 32-41.

${ }^{443}$ Miller 2002, p. 119-139.

${ }^{444}$ On the basis of population level figures.

${ }^{445}$ McBride \& Bagshaw 2008, p. 554.
} 
of duty by the defendants. ${ }^{446}$ This means that each negligent employer could be held responsible for its relative contribution to the risk of the employee contracting mesothelioma. Each negligent employer would have to pay his own share of compensation. Lord Hoffmann clearly held that: 'It may be that the most practical method of apportionment will be according to the time of exposure for which each defendant is responsible, but allowance may have to be made for the intensity of exposure and the type of asbestos. ${ }^{447}$ This way, the extent of the liability of a defendant must commensurate with the degree of risk for which the defendant was responsible. This implies that solvent tortfeasors do not anymore have to pay for the risks created by the insolvent ones. However, and rather disappointingly, the House of Lords did not decide how the relative proportions of liability should be determined, and left this difficult task to lower courts and insurers to decide. $^{448}$

Few legal scholars favoured the decision in Barker arguing that not being able to obtain compensation for the entire loss is not a result of the apportionment rule itself but is a result of tortfeasors becoming insolvent. If medical science is able to trace the mesothelioma to a particular fibre and a particular exposure, then their would be no apportionment at all. In fact, claimants would receive no compensation at all in cases where the particular exposure, which led to the forming of mesothelioma, was caused by an insolvent tortfeasor or by the claimant himself. ${ }^{49}$ It goes without saying that employers definitely will welcome this decision because it will give them some comfort about the level of payments they can expect to be required to make.

It deserves special mention that Lord Rodger of Earlsferry was the only Law Lord who did not agree with the application of this proportional liability approach, which made employers severally liable for the claimant's damage. In his dissenting opinion, he stated that: 'Now the House is deciding that, in this particular enclave of the law, the risk of the insolvency of a wrongdoer or his insurer is to bypass the other wrongdoers and their insurers and to be shouldered entirely by the innocent claimant. As a result, claimants will often end up with only a small proportion of the damages which would normally be payable for their loss. The desirability of the courts, rather than Parliament, throwing this lifeline to wrongdoers and their insurers at the expense of claimants is not obvious to me. ${ }^{450}$ Lord Rodger thus did not agree with the fact that asbestos victims should pay for their own damages in cases where one or more possible tortfeasors are insolvent or untraceable. ${ }^{451}$ He agreed that the application of joint and several liability is hard on defendants in cases where one defendant is held liable for 100 percent of the claimant's damages while he, in fact, only made a 5 percent contribution to the damage. However, in his opinion joint and several liability should be preferred as a matter of policy. ${ }^{452}$ Lord Rodger is clearly a speaker in favour of asbestos victims who suffer from mesothelioma. However, not being able to receive full compensation is not the only drawback caused by

\footnotetext{
${ }^{446}$ Barker v Corus, [2006] UKHL 20, paragraph 49.

${ }^{447}$ Barker v Corus, [2006] UKHL 20, paragraph 48.

${ }^{448}$ See for more information: Sobczak 2011, p. 32-41.

${ }^{449}$ Kramer 2006, p. 547-553.

${ }^{450}$ Barker v Corus, [2006] UKHL 20, paragraph 90.

${ }^{451}$ Kortmann 2006, p. 1411.

${ }^{452}$ Barker v Corus, [2006] UKHL 20, paragraph 90.
} 
this decision. Applying several liability, claims could take much longer to be concluded. It will take a lot of time before asbestos victims have traced and sued all the possible tortfeasors, while these victims and their relatives are already under considerable pain and stress. Prolonging the time of the civil liability procedure is an extremely negative development in claims for mesothelioma.

\section{- Proportional liability in claims for divisible asbestosis}

The proportional liability approach set out in Barker to apportion the claimant's damages had previously been applied in claims for asbestosis, which is, unlike mesothelioma, a divisible (cumulative) condition: the greater and/or longer the victim had been exposed to asbestos the greater the likelihood that the victim will develop asbestosis. ${ }^{453}$ In Holtby $v$ Brigham \& Cowan (Hull) $L t d^{454}$ (2000), the claimant developed asbestosis after he worked for 24 years as a marine fitter. For twelve of those years he worked for the defendants. None of his employers, including the defendants, took any precautions to protect him against asbestos fibres. ${ }^{45}$

Prior to Holtby, each employer was regarded jointly and severally liable for the full loss if two or more defendants were found to have materially contributed to the damage which the claimant sustained. The defendant has a right of contribution against the other defendants in respect of the same damage under the Civil Liability (Contribution) Act 1978. ${ }^{456}$ However, in Holtby the judge deviated from this traditional approach and held that the defendants were only liable for their proportionate contribution. ${ }^{457}$ Evidence shows that if the claimant had only been exposed to asbestos whilst working for the defendants his condition would probably have been less severe. Therefore, damages were reduced by 25 percent, a reduction upheld by the Court of Appeal. This means that if the defendants had not acted wrongfully, the claimant would still have suffered a quarter of the asbestosis that he was currently suffering from. ${ }^{458}$ The defendants were held liable for 75 percent percent of the claimant's asbestosis.

The tenor of Holtby is that defendants are only found liable for their proportionate contribution. This implies that defendant ' $\mathrm{A}$ ' is not liable for the same damage as defendant 'B' or ' $C$ '. Defendant 'A' has no right of recourse, and thus no claim for contribution against other defendants who have also exposed the claimant wrongfully to asbestos. Holtby acknowledged an attribution of responsibility amongst multiple defendants in relation to a divisible condition (asbestosis). In claims for asbestosis the extent of the defendant's material contribution to the damage is measurable on the basis of populationlevel figures and the defendant will only be liable to the extent of his contribution on a population level. Applying several liability in claims for asbestosis, it is most likely that the extent of the liability of a defendant will commensurate with the defendant's responsibility on a macro level.

\footnotetext{
${ }^{453}$ I refer to section 1.3.1 for more medical information on the disease itself.

${ }^{454}$ Holtby v Brigham \& Cowan (Hull) Ltd, [2000] 3 ALL ER 421.

${ }^{455}$ McBride \& Bagshaw 2008, p. 538.

${ }^{456}$ Jones 2006, p. 251-269.

${ }^{457}$ Kramer 2006, p. 547-553.

${ }^{458}$ McBride \& Bagshaw 2008, p. 538.
} 


\section{* The Compensation Act 2006}

Parliament, however, totally disagreed with the Law Lords' decision in Barker and thus to the application of only a several liability rule to apportion damages in claims for mesothelioma. Parliament had to re-establish the principle that defendants are jointly and severally liable for the claimant's damage in cases of mesothelioma. In order to achieve reasonableness the English government (Labour) has introduced new legislation to overrule the House of Lords decision in Barker. ${ }^{459}$

The Compensation Act 2006 (Section 3: Mesothelioma) provides that where a person ('the responsible person') has negligently or in breach of statutory duty caused or permitted another person ('the victim') to be exposed to asbestos, and the victim has contracted mesothelioma as a result of the exposure to asbestos, and it is not possible to determine with certainty whether it was that exposure or another exposure which caused the victim to contract mesothelioma, and the responsible person is liable in tort, by virtue of the exposure, in connection with damage caused to the victim by the disease (whether by reason of having materially increased a risk or for any other reason), the 'responsible person' is liable in respect of the whole damage caused to the victim by the disease. However, it should be noted that the damages payable may be reduced by any contributory negligence on the claimant's part.

Applying the Compensation Act 2006, the defendant (responsible person) is liable for whole of the damage, and if anyone else was responsible, they are liable jointly and severally. ${ }^{460}$ In claims for mesothelioma in which the claimant was careless in exposing himself to asbestos, the defendant is liable in full but the damages payable to the claimant by the defendant will be reduced to take into account the claimant's contributory negligence. ${ }^{461}$ In conclusion one could say that the Compensation Act 2006 reverses the negative side-effects of Barker in claims for mesothelioma. This Act enables mesothelioma victims to recover full compensation from any liable person. The defendant is liable in respect of the whole damage caused to the claimant. ${ }^{462}$ However, it will be open to the person who has paid the compensation to seek a contribution from the other negligent tortfeasors. ${ }^{463}$ The consequence is that mesothelioma sufferers do not have to pay for their own damages anymore in cases where one or more tortfeasors are untraceable or have gone out of business. The claimant thus does not anymore have to trace and sue all the possible tortfeasors in order to obtain compensation for the entire loss.

It goes without saying that the Compensation Act 2006 has a positive effect on the duration of trial procedures in claims for mesothelioma. However, although the decision in Barker on the apportionment issue has been reversed by Parliament, the relevant provision still applies to claims for other personal injuries. This means that Barker's several

\footnotetext{
${ }^{459}$ Brazier \& Cave 2007, p. 177.

${ }^{460}$ Compensation Act 2006, Section 3 (2A and B). The wording 'or (ii) by the defendant in circumstances in which he has no liability in tort' indicates that the defendant can also be liable for whole of the damage (minus the claimant's contributory negligence) in circumstances where part of the victim's total exposure to asbestos is attributable to non-negligent conduct by the defendant.

${ }^{461}$ McBride \& Bagshaw 2008, p. 555.

${ }^{462}$ See for more information: Sobczak 2011, p. 32-41.

${ }^{463}$ Contribution from another responsible person has been explicitly arranged in the Compensation Act 2006, Section (3).
} 
liability approach can still be applied in other personal injury cases in which the exact same problem arises. Applying Barker in cases where more than one tortfeasor could have caused the claimant's damage, the claimant still has to sue all the responsible tortfeasors in order to receive full compensation: each tortfeasor is only liable for its relative contribution to the risk of the claimant contracting the injury. ${ }^{464}$

\section{* Sienciewicz v Greif (UK) Limited: joint and several liability}

Sienciewicz ${ }_{V}$ Greif (UK) Limited ${ }^{465}$ (2011) is the first case in which the Supreme Court had to decide on both the limits of the Fairchild-exception and the applicability of the Compensation Act 2006. In Sienciewicz, an employee (Mrs Costello) died from the consequences of mesothelioma in 2006 at the age of 74. From 1966 to 1984, Mrs Costello worked as an office worker at the defendant's factory premises. Sienciewicz is referred to as a 'single exposure' case which means that a single defendant is responsible for Mrs Costello's exposure to asbestos. It has been established that she experienced two sources of asbestos exposure in her life. Firstly, although Mrs Costello did not work on the factory floor, she inhaled asbestos fibres which had been released into the factory atmosphere. Secondly, she lived in close proximity to the factory premises and, in common with other inhabitants in the local area, also experienced a general environmental exposure to asbestos as a low level of asbestos fibres has been established in the general atmosphere. The occupational exposure, although the extent of the exposure was very small, was regarded as a negligent cause of Mrs Costello's mesothelioma while the general environmental exposure to asbestos was regarded as a non-negligent cause. Experts concluded that the occupational exposure to asbestos only increased the total amount of exposure, which Mrs Costello would have experienced as a result of environmental exposure by 18 percent. ${ }^{466}$ The defendant thus increased the risk of developing mesothelioma by 18 percent.

The employer denied liability arguing that the claimant failed to prove on the balance of probabilities that the defendant had caused Mrs Costello's mesothelioma. The defendant argued that the claimant could not prove that the occupational exposure to asbestos had not more than doubled the environmental exposure to asbestos, or to put in differently: the claimant could not prove that the occupational exposure to asbestos at least doubled the risk of contracting mesothelioma. The Supreme Court (previously the House of Lords) quashed this plea and made it clear that the Fairchild-principle should be applied to establish causation in such cases. ${ }^{467}$ However, does an 18 percent increase in risk constitute a 'material contribution to the risk of injury' ${ }^{468}$ All seven Law Lords decided in favour of the claimant holding that the claimant successfully established causation by proving that the occupational exposure to asbestos materially increased the risk of mesothelioma. After Barker, the Fairchild-principle has - again - been stretched in Sienciewicz: from now on the notion of causation can also be expanded in 'single exposure' cases, and it has been established that an 18 percent increase in risk is sufficient to

\footnotetext{
${ }^{464}$ Jones 2006, p. 251-269.

${ }^{465}$ Sienciewicz v Greif (UK) Limited, [2011] UKSC 10.

${ }^{466}$ Sienciewicz v Greif (UK) Limited, [2011] UKSC 10, paragraph 4 (Lord Phillips).

${ }^{467}$ See section 3.8.1.1 for more information on the limits of the Fairchild-principle.

${ }^{468}$ See for more information: Sobczak 2011, p. 32-41.
} 
establish causation in claims for mesothelioma. The Fairchild-principle will be discussed more extensively in section 3.8 in which this exception to the traditional standard to prove causation is presented as a solution for causal uncertainty.

After having made an important decision on the limits of the Fairchild-principle, the Supreme Court had to decide on the apportionment of damages. The Supreme Court applied the Compensation Act 2006 and made it clear that the responsible person is liable for whole of the claimant's damage, irrespective of whether the claimant has been wrongfully and non-wrongfully exposed to asbestos. However, it should be noted that, in cases where the claimant himself is responsible for a part of the total exposure to asbestos, the claimant's contributory negligence must be deducted from the total amount of compensation. ${ }^{469}$

\subsubsection{Overall conclusion: claims for mesothelioma in Dutch and English laws}

In claims for mesothelioma where two or more defendants have exposed the claimant to asbestos, causal uncertainty arises with regard to which specific tortfeasor did cause the claimant's mesothelioma to develop. Applying traditional principles to establish causation, i.e., the condicio sine qua non (but-for) test and the all-or-nothing result that this test produces, the claimant leaves empty-handed because the claimant is unable to prove to a 'reasonable degree of certainty' or 'on the balance of probabilities' that defendant 'A' or 'B' (or 'C' or 'D') has caused his damage.

In Dutch law, the claimant does not have to trace all defendants in order to receive full compensation. Each defendant, in a group of possible tortfeasors, is jointly and severally liable on the basis of Article 6:99 BW unless the defendant is able to prove that he did not cause the claimant's damage. The in Article 6:99 BW adopted clause which defendants can use to escape liability is a death sentence in claims for mesothelioma: a defendant who has exposed the claimant to asbestos is unable to prove that the claimant did not inhale the 'fatal asbestos fibre' during the exposure for which the defendant is responsible.

Joint and several liability can produce injustice in cases where concurrent joint tortfeasors are present. If, in a group of possible tortfeasors, not all tortfeasors appear to be solvent, the solvent tortfeasor(s) cannot seek contribution from the insolvent ones. The solvent defendant thus bears the risk of insolvency of other responsible tortfeasors. Defendants (employers and their insurers) are not satisfied with the application of joint and several liability. In their view joint and several liability is only a fair solution to compensate the claimant's damage in cases where all the possible defendants are solvent or insured. Under English law, the defendant can seek contribution from the other defendants and their insurers under the Civil Liability (Contribution) Act 1978. However, the application of joint and several liability could have major negative consequences in cases where one or more possible tortfeasors are untraceable or have gone out of business.

In Barker v Corus (2006), the House of Lords tried to take away the potential unfairness with regard to some solvent companies and tried to redress any imbalance caused by the Fairchild decision. Did Barker take away this unfairness? Probably not. Barker tried to

${ }^{469}$ Compensation Act 2006, Section 3 (2A) in conjunction with (3B). 


\section{Chapter 2}

reach a conclusion that is 'fair' to both the claimant and the defendants by holding the defendants severally liable for the claimant's damage. This means that the defendant is only liable to the extent that his breach of duty increased the risk that the claimant would develop mesothelioma. ${ }^{470}$ This proportional liability approach to apportion the claimant's damages had previously been applied in claims asbestosis, which is, unlike mesothelioma, a divisible condition. ${ }^{471}$ Barker thus created an exception to the rule of joint and several liability in claims for mesothelioma aiming to reduce the future costs of companies who have exposed their employees to asbestos in the past. The House of Lords held that it was not fair that an employee could claim all the damages from one employer in cases where several tortfeasors may have been involved. The decision in Barker clearly is in favour of employers who have negligently exposed their employees to asbestos in the course of their employment(s). Employers will welcome this decision because it will give them some comfort about the level of payments they can expect to be required to make. Claimants were, however, confronted with the burden of identifying each (individual) tortfeasor in order to receive full compensation. ${ }^{472}$ In practice, an asbestos victim would have to sue and trace all the possible tortfeasors in order to obtain compensation for the entire loss. In cases where one or more tortfeasors are uninsured or have gone out of business, the claimant will not be able to receive 100 percent compensation. Given the time it takes for the mesothelioma to manifest itself (long latency period), it is most likely that the majority of claimants will only receive partial compensation.

Although it must be said that the problem of multiple tortfeasors of which one or more tortfeasor(s) appear(s) to be insolvent does not arise in the majority of claims for mesothelioma, it does pose serious problems in few cases. However, a Dutch claimant does, unlike the English asbestos victim prior to the enactment of the Compensation Act 2006, not have to fear for insolvency of one of the tortfeasors and the burden of proof (disproving causation) lies firmly with the tortfeasor rather than the victim. In addition, when applying a severally liability rule claims could take much longer to be concluded. It goes without saying that it will take a lot of time before asbestos victims have traced and sued all the possible tortfeasors. Keep in mind that asbestos victims and their relatives are already stressed out and in pain. Therefore, prolonging the time of the civil liability procedure is regarded as an extremely negative development.

Although the majority of their Lordships in Barker were of the opinion that the Barker-principle (several liability) created a fair balance between both the interests of the defendants and the interests of the claimant, Parliament did not agree. In order to achieve reasonableness the English government has introduced new legislation to overrule the House of Lords decision in Barker v Corus. The Compensation Act 2006 (Section 3: Mesothelioma) re-established the principle of joint and several liability in claims for mesothelioma. Applying the Compensation Act 2006, defendants are held jointly and severally liable for the claimant's damage (mesothelioma). The Compensation Act 2006 thus reverses the negative side-effects of the Barker decision. The consequence is that mesothelioma

\footnotetext{
${ }^{470}$ See for a comparative case note on German law: Kruse \& Geiger 2008, p. 339-351.

${ }^{471}$ Holtby v Brigham \& Cowan (Hull) Ltd, [2000] 3 ALL ER 421. I refer to section 1.3.1 for more medical information.

${ }^{472}$ Jones 2006, p. 251-269.
} 
sufferers do not have to pay for their own damages anymore in cases where one or more possible tortfeasors are untraceable or have gone out of business. However, statutory provisions, such as the Compensation Act 2006, are often very specific and hardly ever contain general principles for Tort law. ${ }^{473}$ The Barker-principle cannot anymore be applied in cases of mesothelioma but is still applicable in claims for other personal injuries in which the exact same problems could arise. Applying Barker, each tortfeasor is only liable for its relative contribution to the risk of the claimant contracting the injury which means that the claimant has to sue all responsible tortfeasors to receive full compensation and thus also bears the risk of insolvency of one of the responsible tortfeasors.

Is the Fairchild-principle and the Compensation Act 2006 also applicable in 'single exposure' cases? Yes, Sienciewicz (2011) shows that causation can be established even though the claimant could not prove that the wrongful occupational exposure had more than doubled the non-wrongful environmental exposure to asbestos. The Supreme Court made it clear that the claimant must prove that the wrongful occupational exposure to asbestos materially increased the risk of mesothelioma in order to establish causation: an 18 percent increase in risk was sufficient. Furthermore, Sienciewicz shows that the Compensation Act 2006 is applicable irrespective of whether the claimant has been wrongfully and non-wrongfully exposed to asbestos. After all, (the dissenting) Lord Rodger of Earlsferry was right in Barker: in claims for mesothelioma joint and several liability should be preferred as a matter of policy.

\subsubsection{Claims for lung cancer which could have been asbestos-related}

In both the Netherlands and England far fewer claims have, when compared to the number of claims for mesothelioma, been brought up by potential asbestos victims who suffer from lung cancer which could have been asbestos-related. An explanation can be found in the fact that it has proved to be difficult to connect the diagnosis of lung cancer to previous asbestos exposure, over other causes which also could have caused the claimant's damage. In the past, such claims were not brought to court because lawyers assumed that the claimant could not prove causation to the required 'reasonable degree of certainty' or 'on the balance of probabilities', especially in cases in which the lung cancer sufferer was also a tobacco smoker, which is seen as the main factor to contract lung cancer at population level. ${ }^{474}$

Persons who have been exposed to asbestos have an increased chance to develop lung cancer. However, lung cancer as a potential consequence of asbestos exposure is, when compared to mesothelioma, a totally different story. In claims for lung cancer asbestos is not seen as the only cause to contract the disease and it has been established that the latency period, between the exposure to asbestos and the development of the disease, is shorter. ${ }^{475}$ The life expectancy of sufferers is slightly better but is still very alarming: research shows that approximately 60 percent of the patients diagnosed with lung cancer

\footnotetext{
${ }^{473}$ The Compensation Act 2006 only counts for mesothelioma victims and could not be applied in any other type of occupational disease (asbestosis, lung cancer). For more information on the interpretation of statutes see: Adams \& Brownsword 1999, p. 77- 102.

${ }^{474}$ Gezondheidsraad 1999, p. 16.

${ }^{475}$ I refer to section 1.3.3 for more information on the disease itself.
} 
will die within the first year, 80 percent die within the first two years, and 90 percent of the patients will die within four years. ${ }^{476}$

The following subsections examine causation problems which arise in lung cancer cases. Claims for lung cancer are characterized by the fact that uncertainty arises as to the cause of the claimant's damage. Case law and legislation will be discussed to show how Dutch and English laws have approached this problem of multiple causation in claims for lung cancer. Keep in mind that causal uncertainty could also arise with regard to the tortfeasor in specific claims for lung cancer, i.e., claims in which the claimant has worked for a number of different employers all exposing him to asbestos in the course of the separate employments. The latter - most complex - situation, in which uncertainty arises as to both the cause of the damage and the specific tortfeasor who has caused the damage, is subject to discussion in section 2.6.4.

\subsubsection{Uncertainty about the cause of the damage: multiple causation}

In cases where employees have contracted lung cancer as a potential consequence of asbestos exposure uncertainty arises as to the cause of the damage. Unlike mesothelioma, the lung cancer that he or she contracted could also have been caused by other factors, such as smoking tobacco, genetic predisposition, external causes, or ageing. In claims for lung cancer asbestos is by no means the only causative agent of lung cancer. Histopathology cannot determine the cause of this disease. Many factors, which might have played a causal role in the development of lung cancer, complicate the issue of establishing liability and assigning compensation. It should be noted that the effects of smoking tobacco in combination with being exposed to asbestos fibres could reinforce each other in the development of lung cancer. ${ }^{477}$ This means that the total risk of both smoking and exposure to asbestos is greater than adding up the individual effects, which is known as the '(sub)multiplicative effect of smoking'. ${ }^{478}$

It has proved to be extremely difficult to establish causation in a situation where two or more causes are present which could have caused the damage separately, and where at least one of them can be imputed to the claimant. In these particular cases it is most likely that the claimant is also unable to prove to the required 'reasonable degree of certainty' or 'on the balance of probabilities' that asbestos exposure caused his damage. Applying traditional principles, the result would be that the claimant leaves emptyhanded while there is a considerable chance that the defendant's wrongful intervention has caused the claimant's damage. The problem of compensating victims who suffer from lung cancer after they have been wrongfully exposed to asbestos has also been subject to discussion in Dutch and English case law. The most important rules following from the case law will be discussed in the next subsections. An extensive discussion on specific solutions to the problem of causal uncertainty will follow in Chapter 3.

\footnotetext{
${ }^{476}$ Burdorf et al. 1997a, p. 32.

477 Gezondheidsraad 2005, p. 17.

${ }^{478}$ This will be extensively discussed in Chapter 4. See also: Waterman 2006, p. 13.
} 


\subsubsection{Dutch law: proportional liability}

In cases in which the claimant suffers from lung cancer as a potential consequence of occupational asbestos exposure the claimant will encounter difficulties in establishing the liability of the employer, even if it has been established that the employer wrongfully exposed his employee to asbestos in the course of the employment. The following subsections examine the application of the proportional liability theory in claims for lung cancer that could possibly remove the drawbacks connected to the condicio sine qua non test which results in all-or-nothing compensation. Applying proportional liability, a judge does not simply award or reject the total amount of damages, but he or she awards damages in proportion to the probability of causality. This means that the claimant, who suffers from lung cancer which is potentially asbestos-related, will be compensated in line with the percentage representing the chance by which the cancer was caused by the wrongful exposure to asbestos. This revolutionary approach results in a claim only being partially awarded. ${ }^{479}$ Applying this principle, damages can be awarded in cases of relative low exposure to asbestos while - when applying traditional principles - the claimant would otherwise be left empty-handed. In the following subsections the instrument of proportional liability is not examined in detail, which means that the pros and cons of this theory will not be discussed here. Proportional liability will be presented as a solution to the problem of uncertain causation in section 3.2. The consequences that the application of the proportional liability theory has on other (non-asbestos-related) claims will be examined in section 3.2.5. The assessment of the probability of causation, which is of central importance to the outcome of the case, will be subject to discussion in section 4.3.

\subsection{Schaier/De Schelde: the first application of proportional liability}

The case Schaier/De Schelde $e^{480}(1999)$ is, in claims for asbestos-related diseases, seen as the starting point for awarding compensation in line with the probability of causation. I will sketch the facts and the outcome of this case very short. From 1955 to $1988, \mathrm{Mr}$ Schaier worked for shipyard De Schelde and was exposed to asbestos in the course of this employment. In 1991, medical doctors diagnosed Mr Schaier with lung cancer which could have been caused by the wrongful exposure to asbestos but could also have been caused by other factors, such as smoking. Mr Schaier smoked tobacco for 40 years and expert evidence defined that he had smoked 20 cigarettes a day over the last 10 years. $\mathrm{Mr}$ Schaier died from the consequences of lung cancer in 1994.

On 1 February 1999, the trial judge in Middelburg ruled that an employer can be held liable in proportion to the probability of causation for lung cancer which could have been caused by the wrongful occupational exposure to asbestos. However, it has proved to be extremely difficult to establish a causal link between the wrongful exposure to asbestos and Mr Schaier's lung cancer. As stated previously, lung cancer could have been caused by a number of factors: exposure to asbestos, smoking tobacco, by smoking and exposure, genetic predisposition, ageing, and external causes. In Schaier, the judge called

\footnotetext{
${ }^{479}$ Van Maanen \& Valk 2008, p. 316.

${ }^{480}$ Kantongerecht Middelburg 1 februari 1999, TMA 1996/6 (Schaier/De Schelde).
} 
for, and eventually relied on, experts' opinion. The appointed experts ${ }^{481}$ had to determine the causal link between exposure to asbestos and lung cancer. Three experts unanimously concluded that it was impossible to determine the cause of lung cancer in the specific claimant's case: lung cancer which could have been caused by exposure to asbestos cannot be distinguished from lung cancer which is caused by smoking tobacco.

All experts agreed that the lung cancer was most plausibly caused by a combination of both smoking and asbestos exposure. They assessed the chance that the lung cancer was caused by the wrongful exposure to asbestos, at 26 percent, with a minimum of 13 percent and a maximum of 36 percent. The assessment of causation was based on a detailed reconstruction of Mr Schaier's employment history and general data on the degree of asbestos exposure in the shipyard industry. ${ }^{482}$ The degree to which the smoking history contributed to the development of Mr Schaier's lung cancer was, however, not expressed in a percentage. The trial judge ruled in favour of the employee and deviated from the traditional principle of all-or-nothing compensation. The judge followed the expert evidence and held De Schelde liable for this 26 percent. ${ }^{483}$ This way, Mr Schaier's claim was awarded on the extent to which the lung cancer can be attributed to exposure to asbestos. I refer to Chapter 4 for detailed information on the assessment of the probability of causation in claims for lung cancer as a potential consequence of asbestos exposure.

\subsection{Nefalit/Karamus: a smoking claimant}

The Dutch landmark case Nefalit/Karamus ${ }^{484}$ (2006) also concerns the liability for lung cancer which could have been asbestos-related. The facts in Nefalit are similar to the facts in Schaier/De Schelde ${ }^{485}$. Both cases differ from the ones where employees have contracted mesothelioma. From 1964 to 1979, Mr Karamus was wrongfully exposed to asbestos in the course of his employment. Mr Karamus developed lung cancer in 1997 and he died from the consequences of that disease in 2000. Mr Karamus smoked for 28 years, and smoking tobacco could have been seen as the main cause in contracting lung cancer at population level. ${ }^{486}$

It has been established that Nefalit (employer) neglected his duty of care as defined by Article 7:658 BW and that Mr Karamus' lung cancer could have been caused by the exposure to asbestos in the course of the employment. However, does this knowledge lead to the conclusion that Mr Karamus' lung cancer was caused by the admitted exposure to asbestos and that the employer thus should be held liable to fully compensate the claimant's damage? The answer is negative. The exposure to asbestos does not take away the possibility that the lung cancer was caused by Mr Karamus' smoking history, genetic predisposition, age, or external causes. Mr Karamus could not prove, to surpass the

\footnotetext{
${ }^{481}$ A lung specialist, an epidemiological expert, and an industrial hygienist.

${ }^{482}$ See for general data on the level of exposure: http: / / www.asbestkaart.nl [Last visited 31 August, 2012].

${ }^{483}$ See for more information and one of the few critical reviews: Van Maanen 2000, p. 43. See for positive reviews on the proportional approach in Schaier/De Schelde: Akkermans et al. 2000, p. 115, Van 2000, p. 143.

${ }^{484}$ Hoge Raad 31 maart 2006, NJ 2011, 250 (Nefalit/Karamus).

${ }^{485}$ Kantongerecht Middelburg 1 februari 1999, TMA 1996/6 (Schaier/De Schelde).

${ }^{486}$ Gezondheidsraad 2005, p. 16.
} 
required threshold of a 'reasonable degree of certainty', that the lung cancer was caused by the wrongful occupational exposure to asbestos. Applying the condicio sine qua non test and the traditional all-or-nothing result that this test produces, it is most likely that the Supreme Court would have dismissed this claim since the claimant was unable to prove factual causation which is an essential requirement to establish the liability of the defendant. ${ }^{487}$ Would this outcome have been fair?

To answer this question it should be noted that - in this specific situation - it is possible to express the degree of probability, that the exposure to asbestos caused Mr Karamus' lung cancer, in a percentage. Great weight is therefore placed upon expert(s) opinion estimating the chance, and extent to which, the lung cancer was caused by the exposure to asbestos dust in relation to a number of possible causes. In special circumstances the inability of the claimant to prove condicio sine qua non does not exclude the tortfeasor from liability. In order to hold the employer liable for the injury which the employee sustained, the employee must try to establish that the wrongful occupational exposure to asbestos could have caused the lung cancer. To put it differently: there has to be a certain probability that the occupational exposure to asbestos has caused the claimant's lung cancer. ${ }^{488}$ Applying the traditional principle of all-or-nothing compensation, the employee would receive full compensation if the claimant is able to prove that there is a high ${ }^{489}$ chance that the exposure to asbestos dust caused the lung cancer. However, the claimant leaves empty-handed if experts determine that there is only a low ${ }^{490}$ chance that the claimant's lung cancer was caused by the occupational exposure to asbestos dust. ${ }^{491}$

Nefalit unsuccessfully denied liability on the ground that there was a considerable chance that the lung cancer was not caused by the admitted exposure to asbestos but by the employee's 28 years of heavy smoking. Nefalit argued that Mr Karamus' smoking history had to be considered as a factor which only concerned Mr Karamus' private life and did not even touch the sphere of employment. Medical science had at that time, and indeed still today, not been able to determine whether lung cancer was caused by exposure to asbestos or by other factors which could be attributed to the employee. Furthermore, Nefalit unsuccessfully tried to escape liability by arguing that he did not know of the multiplicative relation between smoking and exposure to asbestos at the time of the exposure and that he thus had not breached his duty of care. Following Cijsouw/De Schelde 1 and Cijsouw/De Schelde 2, the judge correctly held that if an employer failed to take sufficient precautionary measures to prevent a known disease (such as mesothelioma or asbestosis), he is also liable for an, at that time, unknown disease (lung cancer without asbestosis) which could have been prevented by the same precautionary measures. ${ }^{492}$

The Court of Appeal, confirming the judgment of the Court of First Instance, deviated from the traditional principle of all-or-nothing compensation and decided to award

\footnotetext{
${ }^{487}$ Van Kampen \& Maclean do not agree arguing that a 55 percent chance would have been sufficient to prove factual causation. Van Kampen \& Maclean 2006, p. 1-5.

${ }^{488}$ Swagemakers \&Taminau 2007, p. 9.

489 The probability is high enough to pass the 'reasonable degree of certainty' threshold.

${ }^{490}$ The probability is too low to pass the 'reasonable degree of certainty' threshold.

${ }^{491}$ In cases in which the assessed probability of causation is, for example, less than 50 percent.

${ }^{492}$ Hoge Raad 25 juni 1993, NJ 1993, 686 (Cijsouw/De Schelde 1); Hoge Raad 2 oktober 1998, NJ 1999, 683 (Cijsouw/De Schelde 2).
} 
damages in proportion to the probability of causation. The key evidence on causation was given by an epidemiologist, who referred to asbestos exposure as adding to the risk of lung cancer. The epidemiologist assessed the chance that the lung cancer was caused by the exposure to asbestos dust at 55 percent, which will be extensively examined in section 4.3.4.1. ${ }^{493}$ On that basis, the Court of Appeal awarded 55 percent of the damages claimed. Subsequently, Nefalit took the case to the Supreme Court hoping to escape liability entirely. ${ }^{494}$ The question remains: is the Dutch Supreme Court also willing to deviate from the traditional principle of all-or-nothing compensation in specific asbestosrelated cases in order to compensate potential victims of wrongful occupational exposure to asbestos?

\section{* The holding of the Dutch Supreme Court}

The Supreme Court followed a line of cases from lower courts ${ }^{495}$ and other legal opinion favouring proportional liability and affirmed the judgment of the Court of Appeal. In such cases great weight is placed upon expert(s) opinion estimating the chance, and extent to which, the lung cancer was caused by the exposure to asbestos dust in relation to a number of possible causes. It should be noted that the Supreme Court did not use the term 'proportional liability' in his decision. ${ }^{496}$ It is clear that the Supreme Court has grounded the claim on the thought behind the Articles 6:99 BW and 6:101 BW. ${ }^{497}$ However, the exact formulation of proportional liability remained unclear, could be explained in multiple ways, and has been subject to much discussion and criticism in legal writings, which will be examined in section 3.2.3. The Supreme Court, confirming the two earlier verdicts of the Court of First Instance and the Court of Appeal, decided that the percentage representing the chance by which the cancer was caused by the exposure to asbestos had to be paid out (55\%). I refer to section 4.3.4.1 for detailed information on the assessment of the probability of causation in Nefalit, but I can say that the claim is

\footnotetext{
${ }^{493}$ I refer to Chapter 4 for detailed information on the assessment of the probability of causation in claims for lung cancer as a potential consequence of asbestos exposure.

${ }^{494}$ Fluit 2006, p. 178; Roijackers 2009, p. 6.

${ }^{495}$ Kantongerecht Middelburg 1 februari 1999, TMA 1999/6 (Schaier/De Schelde); Gerechtshof Amsterdam 18 maart 2004, JAR 2004/96 (Winkelaar/Hertel); Kantongerecht Amsterdam 20 juni 2002, JAR 2004/18 (Ten Pierik/Hertel); Gerechtshof 's-Gravenhage 1 oktober 2004, VR 2005, 109 (Rietveld/Wilton Fijenoord).

496 The Supreme Court did also not use the term 'proportional liability' in the subsequence case: Hoge Raad 24 december 2010, NJ 2011, 251 (Fortis/Bourgonje).

${ }^{497}$ Hoge Raad 31 maart 2006, NJ 2011, 250, paragraph 3.13 (Nefalit/Karamus): '.....Mede gelet op de aan de artikelen 6:99 en 6:101 BW ten grondslag liggende uitgangspunten moet daarom worden aangenomen dat, indien een werknemer schade heeft geleden die, gelet op de hiervoor bedoelde kanspercentages, zowel kan zijn veroorzaakt door een toerekenbare tekortkoming van zijn werkgever in de nakoming van zijn verplichting de werknemer in de uitoefening van diens werkzaamheden voldoende te beschermen tegen een voor de gezondheid gevaarlijke stof, als door een aan de werknemer zelf toe te rekenen omstandigheid als hiervoor bedoeld, als door een combinatie daarvan, zonder dat met voldoende zekerheid is vast te stellen in welke mate de schade van de werknemer door deze omstandigheden of één daarvan is ontstaan, de rechter de werkgever tot vergoeding van de gehele schade van de werknemer mag veroordelen, met vermindering van de vergoedingsplicht van de werkgever in evenredigheid met de, op een gemotiveerde schatting berustende, mate waarin de aan de werknemer toe te rekenen omstandigheden tot diens schade hebben bijgedragen.'
} 
awarded for the extent to which the lung cancer can be attributed to exposure to asbestos. Experts established a probability of 55 percent that asbestos exposure caused the lung cancer. However, we cannot conclude that there is a probability of 45 percent that Mr Karamus' lung cancer was caused by smoking tobacco because the remaining 45 percent does not only represent Mr Karamus' smoking history but also all other factors which could have caused Mr Karamus' lung cancer. ${ }^{498}$ But what would be the outcome of this case if Mr Karamus did not smoke tobacco?

\subsection{Hollink/Eternit: a non-smoking claimant}

In Hollink/Eternit ${ }^{499}$ (2006), a non-smoking claimant contracted lung cancer after he had been occupationally exposed to asbestos. The Supreme Court decided to apply proportional liability and awarded 63.5 percent of the damages claimed, which will be extensively examined in section 4.3.4.2. The established 63.5 percent represented the probability that asbestos exposure had caused the claimant's lung cancer. The employer was held liable for his theoretical share (63.5\%). The employee's share can be assessed at $(100 \%-63.5 \%=) 36.5$ percent. This 36.5 percent does, however, not represent the probability that the employee's smoking history has caused the lung cancer because the employee did not smoke tobacco. The remaining 36.5 percent represent all other factors who come for account and risk of the employee and for which the employer cannot be held responsible. The attribution of factors will be generally discussed in section 2.6.3.2.5.

Hollink shows that the application of proportional liability is not only confined to cases in which the claimant has been exposed to asbestos and smoked tobacco. De Lang and Van, however, argue that it - in this case - would have been more reasonable not to deviate from the traditional principle of all-or-nothing compensation. Applying traditional principles, it is most likely that the claimant would have been fully compensated. A possible explanation can be found in the fact that the conclusions of the Dutch Health Council $^{500}$, especially on the risk-coefficient ${ }^{501}$ for non-smokers, could not be taken into consideration now the expert report had been presented in the procedure before the report of the Dutch Health Council had been published. ${ }^{502}$ The assessment of the probability of causation in claims for lung cancer will be subject to extensive discussion in Chapter 4.

\subsection{The Supreme Administrative Court}

In 2009, the Supreme Administrative Court (CRvB) had to decide whether or not a 12 percent probability is sufficient to award damages in line with the probability of causa-

\footnotetext{
${ }^{498}$ Kortmann does agree: Kortmann 2006, p. 1405.

${ }^{499}$ Hoge Raad 31 maart 2006, LJN: AU6093 (Hollink/Eternit): In this case the claimant worked for Eternit and has been exposed to asbestos in the course of his employment (1961-1975). However, the claimant had no smoking history. The Supreme Court awarded 63.5 percent of the total damages.

${ }^{500}$ Gezondheidsraad 1999.

${ }^{501}$ The increased risk of developing lung cancer. I refer to section 4.3.2 for more information.

${ }^{502}$ De Lang \& Van 2008, p. 61. They referred to Gerechtshof 's-Gravenhage 7 september 2007, LJN: BB5063 in which the employer was held liable in full because he did not state that there was an indication on the part of the employee that the diagnosis (RSI) might not have been correct.
} 
tion. ${ }^{503}$ In this case a public servant had been wrongfully exposed to asbestos in the course of his employment from 1971 to 1979. In 2000, he was diagnosed with lung cancer as a potential consequence of asbestos exposure and died from the consequences of that disease in 2002. Similar to Schaier/De Schelde, Nefalit/Karamus and Hollink/Eternit, the lung cancer could have had multiple causes which resulted in the fact that the causal link between exposure to asbestos and lung cancer was uncertain. The party-appointed expert, Professor Smid, who also assessed the probability of causation in Schaier, Nefalit, and Hollink has assessed the chance that the lung cancer was caused by the exposure to asbestos in the course of the employment at 12 percent.

Following the expert evidence and deviating from the traditional principle of all-ornothing compensation, the CRvB held the Ministry of Defense (employer) liable for 12 percent and awarded 12 percent of the total damages claimed. This case shows that a 12 percent probability is not too low to apply proportional liability. In view of the CRvB, the option to award damages in proportion to the probability of causation is still applicable in cases where the claimant has only been exposed to asbestos for a short period of time and has been exposed to relative low dust concentrations. ${ }^{504}$

\subsection{Attribution of factors}

In Nefalit, the Supreme Court ruled that the employer is responsible for the exposure to asbestos in the course of the employment. However, Mr Karamus' smoking history, genetic predisposition, age, and external causes are imputed to Mr Karamus. Mr Karamus' predisposition thus comes for account and risk of the employee (himself). ${ }^{505}$ The Supreme Court ruled that those factors should, in relation to the employer, be considered as a private risk of the employee, especially where smoking was concerned.

\subsection{Restrictions}

One could wonder whether the traditional principle of all-or-nothing compensation belongs to the past now the Supreme Court has applied the instrument of proportional liability in cases where causation is uncertain. In addition, it can be questioned whether the applicability of proportional liability leads to a floodgate of claims now compensation can be awarded in cases where the claimant is unable to prove causation to a 'reasonable degree of certainty'. The answer to both questions is probably negative as the Supreme Court has restricted the applicability of proportional liability as follows: compensation should be denied if the probability that the exposure to asbestos has caused the lung cancer is very small. Contrary, full compensation should be awarded if this probability is very large. ${ }^{506}$ To put it differently: if it is apparent that the tortfeasor had caused the claimant's damage (the chance is very large), than full compensation should be awarded. Contrary, if it is apparent that the tortfeasor did not cause the claimant's damage (the chance is very small), than no liability can be established and the claimant leaves emptyhanded. It would be unacceptable to deny or accept full liability for situations in between

\footnotetext{
${ }^{503}$ Centrale Raad van Beroep 9 april 2009, LJN: BI2805.

${ }^{504}$ Sobczak 2010a, p. 407-412.

${ }^{505}$ Alt 2008, p. 18.

${ }^{506}$ Hoge Raad 31 maart 2006, NJ 2011, 250, paragraph 3.13 (Nefalit/Karamus).
} 
these extremes. ${ }^{507}$ No percentage threshold was, however, given to this notion by the Dutch Supreme Court which is not a good development in the pursuit of legal security. Up until now, it still remains uncertain whether, for example, a probability of 11 percent is sufficient to award compensation in proportion to the probability of causation or whether the principle of all-or-nothing compensation prevails in such a situation?

Furthermore, for proportional liability to be applied, the claimant must have been exposed to 'a substance which is dangerous for your health'. This leaves the question of whether or not proportional liability can also be applied in other (non-asbestos-related) cases in which the problem of multiple causal uncertainty also arises. The decision in Nefalit relates to a 'potential' asbestos victim but, taking into consideration the way in which the application of proportional liability is restricted, this decision is not exclusively geared for victims of asbestos-related diseases. Nefalit could thus also affect victims of other occupational diseases because asbestos is not the only substance which is dangerous for your health. A recent decision of the Supreme Court (2010) shows that proportional liability can also be applied in the general law of obligations. ${ }^{508}$ In addition, it should be noted that the Supreme Court has used the term 'in general' three times in Nefalit in order to have more space to adjust his former decision (if necessary). Therefore, the precise consequences of Nefalit, and the effects on other claims, are unclear and must be clarified by the Supreme Court in a future decision. The consequences connected to the application of proportional liability and the range of Nefalit will be extensively examined in section 3.2 in which proportional liability is presented as a general solution for causal uncertainty.

\subsection{Justification in legislation?}

In Nefalit, the Supreme Court ruled that, although the exact formulation remains unclear, the underlying principle of the Articles 6:99 BW and 6:101 BW supports the application of proportional liability. ${ }^{509}$ Article 6:99 BW deals with alternative causality and reads:

'Where the damage has resulted from two or more events for each of which a different person is liable, and where it has been determined that the damage has arisen from at least one of these events, the obligation to repair the damage rest upon each of these persons, unless he proves that the damage is not the result of the event for which he himself is liable.'

The Dutch legislator has regulated contributory negligence on the part of the claimant in Article 6:101 BW:

'Where the circumstances which can be imputed to the victim have contributed to the damage, the obligation to repair is diminished by apportioning the damage between victim and the person who has the obligation to repair, in proportion to the

\footnotetext{
${ }^{507}$ Hoge Raad 31 maart 2006, NJ 2011, 250, paragraph 3.13 (Nefalit/Karamus).

${ }^{508}$ Hoge Raad 24 december 2010, NJ 2011, 251 (Fortis/Bourgonje). See also: Giesen 2011, p. 149-150.

${ }^{509}$ Hoge Raad 31 maart 2006, NJ 2011, 250, paragraph 3.13 (Nefalit/Karamus); Kortmann does agree: Kortmann 2006, p. 1408.
} 
degree in which the circumstance can be imputed to each of them, have contributed to the damage. The apportionment may vary or the obligation to repair can either be completely extinguished or not apportioned at all, if equity so requires due to the different degree of gravity of the faults committed or any other circumstance in the case.'

In 1997, Akkermans argued that the combination of the Articles 6:99 and 6:101 BW would form a solid basis to apply proportional liability in cases where the causal link is uncertain. ${ }^{510}$ However, one of the main arguments to deny proportional liability in asbestos-related cases, in which the claimant contracted lung cancer as a potential consequence of asbestos exposure, is that the Articles 6:99 and 6:101 BW are not applicable in such cases. Article 6:99 BW deals with alternative causality and is difficult to apply in cases where a combination of two or more factors, i.e., smoking tobacco and exposure to asbestos, could have caused the damage. This Article requires that at least one cause has been established, which is not the case in multiple causation cases. ${ }^{511}$ Article 6:101 BW, on the other hand, is applicable in cases where multiple causes have been established but does not depart from a situation where causation is uncertain. This makes Article 6:101 BW difficult to apply in asbestos-related cases because no factor could, due to the lack of medical science, be pointed out as 'the' factor which has caused the claimant's damage. $^{512}$

This legal ground to apply proportional liability has been subject to much criticism. Both Kortmann and Lindenbergh argue that Dutch law has still not adopted the legal instrument of 'proportional liability' as a legal device, which implies that all Articles in the Dutch Civil Code do not serve as a sufficient basis to regulate proportional liability as such. ${ }^{513}$ In Nefalit, both Articles 6:99 BW and 6:101 BW have been stretched in order to achieve a fair result, to strengthen the claimant's legal position, and to award damages in proportion to the probability of causation in cases where the claimant would otherwise remained empty-handed. Kortmann noticed the drawbacks but made it clear that it does not matter which Article in the Dutch Civil Code is stretched to award damages in proportion to the probability of causation because the legal instrument of proportional liability serves a higher purpose, that is, public interest. ${ }^{514}$ On similar grounds, Giesen also argued that it is not the legal basis but the desirability of the result that is of central importance. ${ }^{515}$ This means that adopting a new Article in the Dutch Civil Code which solely deals with proportional liability is not of central importance because the same results can be achieved without the codification of such an instrument.

\subsection{Some first conclusions on Dutch law}

In asbestos-related cases in which the claimant has been exposed to asbestos in the course of the employment and suffers from lung cancer as a potential consequence of the expo-

\footnotetext{
${ }^{510}$ Akkermans 1997, p. 105.

${ }^{511}$ Akkermans 1997, p. 97.

${ }^{512}$ Waterman 2009, p. 144.

${ }^{513}$ Kortmann 2006, p. 1408; Lindenbergh 2006, p. 738.

${ }^{514}$ Kortmann 2006, p. 1408.

${ }^{515}$ Giesen \& Tjong Tjin Tai 2008, p. 64.
} 
sure to asbestos uncertainty arises as to the cause of the damage. In these particular cases epidemiological experts are appointed to assess the probability that the claimant's lung cancer was caused by the exposure to asbestos. In Nefalit/Karamus (2006), the Supreme Court followed a line of cases from lower courts and other legal opinion favouring proportional liability and ruled that, although the exact formulation remains unclear, the underlying principle of the Articles 6:99 and 6:101 BW supports the application of proportional liability. Legal scholars have questioned this ground to apply proportional liability as none of the Articles in the Dutch Civil Code serves as a sufficient basis to regulate proportional liability as such. This does, however, not take away the fact that the majority favours proportional liability arguing that it is not the legal basis but the desirability of the result that is of central importance. The instrument of proportional liability serves a higher purpose, that is, public interest.

Applying proportional liability, a judge does not simply award or reject the total amount of damages, but he or she awards damages in proportion to the probability of causality. The decisions in Schaier/De Schelde, Hollink/Eternit, and Nefalit/Karamus thus deviate from the general principles of Dutch Tort law. The principle that the claimant's damage should be fully compensated will not be satisfied because the claimants in the cases taken under consideration here have only received compensation in line with the probability of causation $(26 \%, 63.5 \%$, and $55 \%$ of the total damages claimed). This argument can, however, be quashed because it is arguable the damage which was caused by the employer's intervention has been fully compensated. This way, one can also argue that the principle that the claimant's damage should be fully compensated still stands strong in cases where the instrument of proportional liability is applied to determine the outcome of the case.

Nefalit/Karamus and Hollink/Eternit show that proportional liability can be applied irrespective of whether the claimant did or did not smoke tobacco. However, the applicability of proportional liability has been restricted by the Supreme Court. In Nefalit, the Supreme Court ruled that compensation should be denied if the probability that the exposure to asbestos has caused the lung cancer is 'very small'. Contrary, full compensation should be awarded if this probability is 'very large'. ${ }^{516}$ The proportional liability theory applies in all situations in between these extremes. In 2009, the Supreme Administrative Court $(\mathrm{CRvB})$ ruled that a 12 percent probability is sufficient to apply proportional liability and to award compensation in line with the probability of causation in a case in which the claimant contracted lung cancer after he had been occupationally exposed to asbestos. ${ }^{517}$ Up until now, the exact threshold to apply proportional liability is still unsure because the Supreme Court and the Supreme Administrative Court have not bound a percentage to the notion 'very small' or 'very large'. Furthermore, for proportional liability to be applied, the claimant must have been exposed to 'a substance which is dangerous for your health'. However, a recent decision of the Supreme Court shows that the application of proportional liability is not exclusively geared for victims of asbes-

\footnotetext{
${ }^{516}$ Hoge Raad 31 maart 2006, NJ 2011, 250, paragraph 3.13 (Nefalit/Karamus).

${ }^{517}$ Centrale Raad van Beroep 9 april 2009, LJN: BI2805.
} 
tos-related diseases and might, as will be discussed in section 3.2.5, influence the outcome of other claims in which the problem of uncertain causation also arises. ${ }^{518}$

\subsubsection{English law: partial liability}

This section examines the liability for lung cancer that could have been caused by the exposure to asbestos under English law. Similar to Dutch law, claimants encounter difficulties in proving causation as multiple factors are present which all could have caused the claimant's damage separately. In the past, such claims were not brought to court as lawyers assumed that the claimant could not prove causation on the 'balance of probabilities', especially in cases in which the lung cancer sufferer was also a tobacco smoker, which could be seen as the main factor to contract lung cancer at population level. ${ }^{519}$ There are two important cases in which English courts have awarded damages for lung cancer after the claimant has been wrongfully exposed to asbestos in the course of his employment. Both cases will be examined in the following subsections in order to show how English law approaches the problem of multiple causation in specific asbestosrelated cases.

\subsection{Badger $\mathrm{v}$ Ministry of Defence: lung cancer and asbestosis}

Badger v Ministry of Defence ${ }^{520}$ (2005) is the first reported asbestos-related case in which a court was asked to consider whether or not the claimant's smoking history could influence the liability of the defendant. The claimant's husband (Mr Badger) had been exposed to asbestos while working for the defendant (Ministry of Defence) as a boiler maker from 1954 to 1987. Mr Badger developed asbestosis before he was diagnosed with lung cancer. Mr Badger died from the consequences of lung cancer in May 2002 at the age of 63. Mr Badger's lung cancer could have been caused by multiple factors, and evidence showed that Mr Badger was a heavy smoker. ${ }^{521}$ In Badger, both appointed experts attributed Mr Badger's lung cancer and hence premature death to both tobacco and asbestos. $^{522}$ Should Mr Badger be fully compensated?

\section{* Contributory negligence}

The defendant admitted primary liability for the claimant's claim. Causation between the wrongful exposure to asbestos and Mr Badger's lung cancer was not contested now the claimant developed asbestosis before he was diagnosed with lung cancer. As discussed in section 1.3.1, a certain 'dose' or level of asbestos exposure is required for the development of asbestosis. The defendant, however, argued that the claimant's damages had to be reduced by 25 percent on account of Mr Badger's contributory negligence. ${ }^{523}$ The

\footnotetext{
${ }^{518}$ Hoge Raad 24 december 2010, NJ 2011, 251 (Fortis/Bourgonje). See also: Giesen 2011, p. 149-150.

${ }^{519}$ Gezondheidsraad 1999, p. 16.

${ }^{520}$ Badger v Ministry of Defence, [2005] EWHC 2941 (QB), [2006] 3 ALL ER 173.

${ }^{521}$ Evidence established that Mr Badger smoked 20 cigarettes a day throughout his adult life.

${ }^{522}$ Badger v Ministry of Defence, [2005] EWHC 2941 (QB), [2006] 3 ALL ER 173, paragraph 17.

${ }^{523}$ Badger v Ministry of Defence, [2005] EWHC 2941 (QB), [2006] 3 ALL ER 173, paragraph 2: The claimant argues that Mr Badger's smoking did not amount to contributory negligence, and if it did so, no reduction should be made to the claim. If a reduction is made, it should be at a minimal level, as low as one percent, and certainly less than 25 percent.
} 
concept of contributory negligence has been created to acknowledge properly that a person has a certain responsibility for his own actions. Section 1 (1) of the Law Reform (Contributory Negligence) Act 1954 reads:

'Where any person suffers damage as a result partly of his own fault and partly of the fault of any other person or persons....the damages recoverable in respect thereof shall be reduced to such extent as the court thinks just and equitable having regard to the claimant's share in the responsibility for the damage.'

That Mr Badger's smoking was a substantial cause of his death was not in dispute. ${ }^{524}$ Evidence established that the English government issued the first health warnings about smoking in the 1970s, and that Mr Badger had received numerous warnings about the damage that his continued smoking was causing to his health. From November 1968 onwards, medical doctors strongly advised Mr Badger to stop smoking cigarettes. However, despite the warnings that he had received, he continued smoking. The court ruled that Mr Badger continued smoking when he knew or ought to have known that this could harm his health and could lead to the development of lung cancer.

The defendant accepted that it was guilty of breaches of statutory duty at a time when the dangers of asbestos were known. Therefore, Mr Badger's contributory negligence was less than 50 percent. The court ruled that Mr Badger must have known that there is a causal link between smoking cigarettes and the development of lung cancer, and decided that a reasonable prudent person in his position and with his knowledge would have stopped smoking by the mid-1970s which should have reduced the risk of contracting lung cancer. However, when Mr Badger began smoking the causal link between smoking and health damage, was not widely accepted yet. This means that $\mathrm{Mr}$ Badger cannot be criticised for starting to smoke in 1955. Mr Badger's fault was in failing to give up smoking. The court held Mr Badger responsible for a fault that was partly responsible for his own death. In view of the High Court, the appropriate deduction for Mr Badger's contributory negligence was 20 percent. The recoverable damages were reduced by that amount which resulted in the fact that the court awarded 80 percent of the total damages claimed.

\subsection{Shortell $v$ Bical Construction Ltd: lung cancer in the absence of asbestosis}

After Badger v Ministry of Defence it remained unclear what the position of lung cancer sufferers would be in the absence of asbestosis. In Shortell $v$ Bical Construction Ltd ${ }^{525}$ (2008), John Joseph Shortell died from lung cancer on July 2006 at the age of 74 after he had been exposed to asbestos in the course of his employment. The employee did not develop asbestosis before he was diagnosed with lung cancer. ${ }^{526}$ Lung cancer could have been caused by multiple factors. Evidence established that Mr Shortell had been a heavy

\footnotetext{
${ }^{524}$ Badger v Ministry of Defence, [2005] EWHC 2941 (QB), [2006] 3 ALL ER 173, paragraph 17.

${ }^{525}$ Shortell v Bical Construction Ltd., [2008] QBD Liverpool (16-05-2008).

${ }^{526}$ Hessel et al. 2005, p. 433-436: The scientific question of whether or not lung cancer arises only in the presence of asbestosis may be unanswerable epidemiologically. See also: Gibbs et al. 2007, p. 181.
} 
smoker for most of his life but he had given up smoking more than 20 years before he died. The question posed in this case was whether or not causation between the wrongful exposure to asbestos and Mr Shortell's lung cancer can be established, and whether $\mathrm{Mr}$ Shortell's smoking history constituted contributory negligence in a way that the total damages should be reduced by the amount to which smoking could have caused $\mathrm{Mr}$ Shortell's lung cancer, which is in line with the claimant's share in the responsibility for the damage.

\section{* The proof of causation}

On the problematic issue of causation the court relied on expert evidence on the level of exposure provided by engineers, medical evidence brought up by medical experts, and epidemiological evidence brought up by two prominent epidemiologists. Both parties have appointed their own experts ${ }^{527}$ to determine the level of exposure in the course of the employment. Mr Deary, appointed by the claimant, calculated Mr Shortell's total asbestos dose while in the employ of the defendant and concluded that this would have been 99 fibre years. ${ }^{528}$ The court found that the claimant has proved the level of exposure (99 fibre years) on the balance of probabilities and proceeded on the basis that this level can be considered as an established fact. ${ }^{529}$ However, what that lifetime burden comprised, in terms of fibre types, had to be established on the basis of the epidemiological expert evidence.

The medical expert, Dr Rudd, appointed by the claimant, applied the Helsinki Criteria $^{530}$ and concluded that the relative risk ${ }^{531}$ is doubled at the figure of 25 fibre years. Dr Rudd argued that Mr Shortell's asbestos burden in itself, so without taking into account Mr Shortell's smoking history, would have satisfied the but-for test to establish causation. ${ }^{532}$ However, the Helsinki Criteria, who are used to determine whether or not it can be reasonably concluded that the lung cancer had been caused by exposure to asbestos, were based on exposure to blue and brown asbestos while Mr Shortell has also been exposed to white asbestos. The epidemiological experts argued that the Helsinki Criteria failed to take sufficient account of the differences between different types of asbestos fibres. ${ }^{533}$ In addition, it should be noted that the Helsinki Criteria have emphasized the

\footnotetext{
${ }^{527}$ Both parties have appointed a consultant engineer: the claimant appointed Mr Deary and the defendant appointed Mr Walker to submit evidence on the level of exposure in the course of the employment.

${ }^{528}$ One fibre year is the exposure to air during one year which contains one asbestos fibre per cubic centimeter. See: Shortell v Bical Construction Ltd., [2008] QBD Liverpool (16-05-2008), paragraph 21.

${ }^{529}$ Shortell v Bical Construction Ltd., [2008] QBD Liverpool (16-05-2008), paragraph 31.

530 The International Expert Meeting on Asbestos, Asbestosis, and Cancer was organized in Helsinki on 2022 January 1997. Collectively, the nineteen worldwide specialists have published over 1000 articles on the risks connected to asbestos exposure and decided to name their findings: The Helsinki Criteria. The Helsinki Criteria were put forward as state of the art criteria to determine the relationship between asbestos exposure and lung cancer. The Helsinki Criteria have been further updated in 2004: Henderson et al. 2004, p. 517 550 .

${ }^{531}$ Relative measure of risk estimating the magnitude of association between an exposure and disease (or other outcome) indicating the likelihood of developing the disease in those exposed relative to those unexposed. See section 4.3.2 for more information.

532 Shortell v Bical Construction Ltd., [2008] QBD Liverpool (16-05-2008), paragraph 31.

${ }^{533}$ Shortell v Bical Construction Ltd., [2008] QBD Liverpool (16-05-2008), paragraph 40.
} 
presence of asbestosis as an (non-exclusive) indication that the lung cancer can be attributed to asbestos exposure. Applying the Helsinki Criteria, the absence of asbestosis could lead to an unsuccessful claim in Tort law ${ }^{534}$, especially knowing that recent attacks on the creditability of the Helsinki Criteria have been unsuccessful. ${ }^{535}$

As discussed in section 1.2.1, the type of the inhaled asbestos fibres is an important factor for the development of asbestos-related diseases. Blue and brown asbestos fibres are considered to be more dangerous than white asbestos fibres. In Shortell, the epidemiological expert concluded that the employee had been exposed to both blue/brown ( $50 \%$ amphiboles) and white asbestos (50\% chrysotile) in the course of the employment. As stated above, Mr Deary assessed the level of exposure to asbestos while working for the defendant at 99 fibre years. Dr Rudd concluded that, where the exposure was 50 percent white asbestos and 50 percent blue/brown asbestos, it would need 40 fibre years to double the risk. ${ }^{536}$ On that basis Dr Rudd concluded that asbestos exposure has accounted for 80 percent of the total risk of contracting the lung cancer. ${ }^{537}$ Subsequently, the epidemiological experts attempted to isolate the contributions of asbestos exposure and smoking. Dr Leigh used the 'Chase model' to isolate the contribution of smoking alone, and reached a figure of 21 percent for smoking alone, which became 28 percent if the figures of Professor Berry ${ }^{538}$ were applied.

The court seized the opportunity to discuss the concept of causation and found that: 'The traditional test for the proof of causation is that the claimant must show on the balance of probability that the defendant's breach of duty made a material contribution to the occurrence of the event in question or, put another way, that but for the defendants breach of duty it would not have occurred. ${ }^{, 539} \mathrm{Mr}$ Feeny, the defendants' representative, rightly conceded that 'if the claimant proves on a balance of probabilities that the risk factor created by his client's breach of duty more than doubled the deceased's relative risk of contracting lung cancer then the claimant's case is proved, and the only remaining issue is contributory negligence.' In Shortell, the court was satisfied on the balance of probabilities that the tortfeasor's breach of duty has on any view more than doubled $\mathrm{Mr}$ Shortell's relative risk of contracting lung cancer. ${ }^{540}$ Subsequently, the court ruled that once the requirement of causation between exposure to asbestos and Mr Shortell's lung

\footnotetext{
${ }^{534}$ Gibbs et al. 2007, p. 182: The Helsinki Criteria state that the risk of developing lung cancer is materially increased (by a factor of 2), even without asbestosis, under the following conditions: 1. One year of heavy exposure (eg, manufacturing of asbestos products, asbestos spraying, insulation work with asbestos materials, demolition of old buildings ) or 5 or 10 years of moderate exposure (eg, construction, shipbuilding); 2. Estimated cumulative exposure to mixed (amphibole plus chrysotile) asbestos fibers of 25 fiber years; 3 . A lung fiber burden within the range recorded for asbestosis in the same laboratory; 4. Retained fibre levels of 2 million amphibole fibers per gram of dry lung tissue, as determined by electron microscopic analysis; 5 . Asbestos body concentrations determined by light microscopic analysis greater than 10000 per gram of dry lung tissue.

${ }^{535}$ See the unreported case: Treble v Rio Tinto and Imperial Chemical Industries, [2008] Bristol Country Court.

${ }^{536}$ Shortell v Bical Construction Ltd., [2008] QBD Liverpool (16-05-2008), paragraph 35.

${ }^{537}$ Shortell v Bical Construction Ltd., [2008] QBD Liverpool (16-05-2008), paragraph 37.

${ }^{538}$ Pofessor Berry is the other appointed epidemiological expert. See for more information about this expert: Shortell v Bical Construction Ltd., [2008] QBD Liverpool (16-05-2008), paragraph 39.

${ }^{539}$ Shortell v Bical Construction Ltd., [2008] QBD Liverpool (16-05-2008), paragraph 47.

${ }^{540}$ Shortell v Bical Construction Ltd., [2008] QBD Liverpool (16-05-2008), paragraph 49.
} 
cancer was proved, it is not relevant to argue that another agent (tortious or otherwise) may also have contributed to the occurrence of the disease. ${ }^{541}$

\section{* Contributory negligence}

Mr Shortell's contributory negligence had to be assessed to decide whether or not there should follow a reduction in damages to reflect the extend to which smoking contributed to the damage. The court applied the rules set out in Badger v Ministry of Defence to determine Mr Shortell's degree of contributory negligence. Evidence established that Mr Shortell had given up smoking more 20 years before he died. However, he smoked 1520 cigarettes per day from age 18 to $53 .^{542}$ The court had to decide whether or not $\mathrm{Mr}$ Shortell was at fault in order to hold Mr Shortell partly responsible for his own damage. In order to establish fault the lack of care that he took for his own health must fall below the standard to be expected of a person in his position at that time. ${ }^{543}$

Following the decision in Badger, the court decided that Mr Shortell should have known from the risks from smoking from 1971 onwards and that he was at fault in smoking after the mid-1970s (approximately 14 years). ${ }^{544}$ However, the court emphasized that Mr Shortell's smoking history cannot be compared to that of Mr Badger in Badger. Mr Badger had a much more extensive smoking history which he maintained until his death. Furthermore, Mr Badger received several warnings from medical doctors to give up smoking because of his health problems. ${ }^{545}$ Therefore, Mr Shortell's share in the responsibility of the damage was assessed at 15 percent. In view of the court, this reduction in damages was just and equitable.

\subsection{Some first conclusions on English law}

The decision in Badger $v$ Ministry of Defence ${ }^{546}$ made it clear that an employer, who has wrongfully exposed his employee to asbestos in the course of the employment, can be held liable for the employee's lung cancer despite the fact that the lung cancer may not have been caused by the intervention of the employer. Mr Badger, a heavy smoker who also suffered from asbestosis, died of lung cancer which could have been caused by multiple factors, of which cigarette smoking is the main factor at population level. ${ }^{547}$ Causation was not contested now it had been established that Mr Badger developed asbestosis before he was diagnosed with lung cancer. However, the claimant did not receive full compensation. Badger established that the employee's smoking history constituted contributory negligence: the total damage must be reduced to such extent as the court thinks just and equitable having regard to the claimant's share in the responsibility for the damage. Mr Badger's fault was in failing to give up smoking after he had been specifically advised not to smoke and ignored the health warnings issued by the English government. This way, the claimant had a certain responsibility for his own actions (smoking). Subse-

\footnotetext{
${ }^{541}$ Shortell v Bical Construction Ltd., [2008] QBD Liverpool (16-05-2008), paragraph 51.

${ }^{542}$ The court has established the year 1985 as the time when Mr Shortell gave up smoking.

${ }^{543}$ Shortell v Bical Construction Ltd., [2008] QBD Liverpool (16-05-2008), paragraph 55.

${ }^{544}$ Shortell v Bical Construction Ltd., [2008] QBD Liverpool (16-05-2008), paragraph 56, 58.

545 Shortell v Bical Construction Ltd., [2008] QBD Liverpool (16-05-2008), paragraph 62.

${ }^{546}$ Badger v Ministry of Defence, [2005] EWHC 2941 (QB), [2006] 3 ALL ER 173.

${ }^{547}$ Gezondheidsraad 1999, p. 16.
} 
quently, the court decided that 20 percent was an appropriate reduction in damages. Prior to Badger, no reported case in which the question of whether or not the claimant's smoking history constitutes contributory negligence, has been considered. This implies that this decision is likely to affect decisions in other cases in which smoking is also a factor which could have caused or contributed to the claimant's damage. ${ }^{548}$

After Badger, it was still unclear what the position of such lung cancer sufferers would be in the absence of asbestosis. Shortell v Bical Construction $L t d^{549}$ is the first successful claim for lung cancer on behalf of a smoker (in this case an ex-smoker) in the absence of asbestosis, and thus shows that such potential asbestos victims can also successfully claim compensation when they have been wrongfully exposed to asbestos in the course of the employment. Mr Shortell died of lung cancer after occupational exposure to asbestos but did not develop asbestosis before he was diagnosed with lung cancer. When it comes to causation, the claimant had to prove that the level of asbestos exposure has exceeded the Helsinki threshold (25 fibre years) in order to demonstrate that the wrongful exposure to asbestos 'doubled the risk' of lung cancer. The traditional but-for test was applied to establish causation. The claimant could prove causation now expert evidence established that the wrongful exposure to asbestos doubled the risk of lung cancer. However, similar to Badger, the claimant did not receive full compensation. Evidence established that Mr Shortell smoked cigarettes for most of his life and that he gave up smoking 20 years before he died. The court decided, in line with the decision in Badger, that $\mathrm{Mr}$ Shortell's smoking history constituted contributory negligence. Taking into consideration the fact that he stopped smoking 20 years before he died and that he had not been specifically warned by medical doctors to give up smoking, a reduction in damages of 15 percent was just and equitable.

\subsubsection{Australian law: the far-reaching consequences connected to the Eng- lish approach}

In Amaca Pty Ltd v Ellis ${ }^{50}$, the High Court of Australia (HCA) faced a difficult case on the issue of causation. I choose to discuss this case to illustrate the commonwealth problem of multiple causation in asbestos-related cases. ${ }^{551}$ Furthermore, and more importantly, this case shows the far-reaching consequences connected to the English approach to causation in cases where the claimant contracted lung cancer that could have been asbestosrelated. The facts: Paul Cotton died from the consequences of lung cancer in 2002 after he had been wrongfully exposed to asbestos in the course of his employment. Evidence established that Mr Cotton smoked around fifteen to twenty cigarettes per day for over 26 years. The vital question to be addressed by the High Court was whether or not the claimant had established that it was more probable than not that the exposure to asbestos during the employment had caused Mr Cotton's lung cancer.

\footnotetext{
${ }^{548}$ Badger v Ministry of Defence, [2005] EWHC 2941 (QB), [2006] 3 ALL ER 173, paragraph 3.

${ }^{549}$ Shortell v Bical Construction Ltd., [2008] QBD Liverpool (16-05-2008).

${ }^{550}$ Amaca Pty v Ellis, [2010] HCA 5 (3 March 2010).

${ }^{551}$ Commonwealth countries, where Britain formerly governed and established the basis of the legal systems, are developing original approaches to common problems. This way, they are useful points of discussion for the development of English law.
} 
Epidemiological evidence showed that there was a 23 percent chance that asbestos exposure had caused the lung cancer, while the probability of smoking causing the lung cancer was assessed at 67 percent. The appointed experts agreed that smoking was more probable a cause of lung cancer than exposure to asbestos. Therefore, the experts concluded that the risk from smoking was greater than the risk from asbestos. Following the epidemiological expert evidence, the High Court ruled that the claimant had not proved causation between the wrongful exposure to asbestos and Mr Cotton's lung cancer and dismissed the claim in negligence. Proving that asbestos may have caused Mr Cotton's lung cancer was not sufficient. On the issue of causation, the High Court's decision was very clear. In view of the High Court, the issue of whether or not asbestos contributed materially to the risk (material contribution) of lung cancer does not have to be examined because causation between the wrongful exposure to asbestos and the lung cancer was not established as it, on a balance of probability, remained unclear whether one cause (asbestos) that can cause injury did cause injury.

The High Court of Australia has, as opposed to similar cases in Dutch law ${ }^{552}$, set the evidentiary barrier extremely high by requiring the claimant to prove that it is on the balance of probabilities more likely than not that asbestos has caused the lung cancer. It is not sufficient to prove that the wrongful exposure to asbestos in the course of the employment materially increased the risk of lung cancer. Australian claimants cannot, as opposed to Dutch claimants, bridge evidentiary gaps with epidemiological data in order to establish causation, unless those figures establish that asbestos exposure more than doubled the risk of lung cancer. This decision has far-reaching consequences for lung cancer sufferers who did smoke and had been exposed to asbestos in the course of their employment(s): a significant decline in the number of claims can be expected in Australia.

\subsubsection{Multiple causation and uncertainty about the tortfeasor}

The most complex situation arises in asbestos-related cases in which causal uncertainty is present with regard to both the identity of the specific tortfeasor and the specific cause of the illness and subsequent damage. Applying traditional principles in these particular cases, the claimant's claim is unsuccessful because he is unable to prove causation to 'a reasonable degree of certainty' or 'on the balance of probabilities'. Let us take a variation of the example presented in Chapter 1:

'Mr 'X' was born in Amsterdam (The Netherlands) in 1945 and is regarded as a heavy smoker since 1960. Mr ' $\mathrm{X}$ ' worked for employer 'A' during the period 19651967, for employer 'B' during the period 1968-1970, and for employer 'C' during the period 1971-1973.'

In this example, it can be assumed that all employers have wrongfully exposed $\mathrm{Mr}$ ' $\mathrm{X}$ ' to asbestos in the course of the separate employments. In 1995, Mr ' $\mathrm{X}$ ' developed a type of lung cancer which could have been caused by asbestos exposure. In this situation multiple factors are present any one of which could have caused the specific disease, but it is im-

\footnotetext{
${ }^{552}$ Hoge Raad 31 maart 2006, NJ 2011, 250 (Nefalit/Karamus).
} 
possible to tell which one has actually caused the cancer in the specific claimant's case. In this situation, $\mathrm{Mr}$ ' $\mathrm{X}$ ' is unable to prove causation between the exposure and the damage, to the required reasonable degree of certainty ${ }^{553}$; neither can he prove that it is on the balance of probabilities more likely than not that employer 'A', 'B' or 'C' has caused his damage. ${ }^{554}$ In the abovementioned example causal uncertainty arises with regard to the cause of the damage and causal uncertainty arises as to the identity of specific tortfeasor who has 'potentially ${ }^{555}$ caused the claimant's lung cancer because it is impossible to determine which employer, if any of the employers, has caused $\mathrm{Mr}$ ' $\mathrm{X}$ 's lung cancer.

I have not found specific case law on this issue in England or the Netherlands. The most logical view is to assume that the approaches which have been discussed in the former sections can also be applied in these highly complex claims for lung cancer. For the English jurisdiction, the concept of contributory negligence can be applied to reduce the amount of compensation and the principle of joint and several liability is applicable to apportion the claimant's damage. For the Dutch jurisdiction, proportional liability can be applied to establish the defendant's liability in proportion to the probability of causation, and the principle of joint and several liability is applicable to apportion the claimant's damage on the basis of Article 6:99 BW.

\subsubsection{Claims for pleural plaques}

In the most common types of asbestos cases, employees have been exposed to asbestos through the employers' negligence and they have, consequently, contracted lung cancer which could have been, and in some cases could only be, asbestos-related. The question of whether or not these asbestos victims suffered any damages is not problematic because lung cancer is actual 'damage' under Dutch law and is seen as actionable 'damage' under English law.

However, exposure to asbestos can also lead to the development of pleural plaques. Research shows that pleural plaques are the most common clinical manifestation following exposure to asbestos with approximately 16.000 new cases per year in the United Kingdom (UK) alone. ${ }^{556}$ According to the dominant view, pleural plaques do not cause any external symptoms, they only mark the presence in the lungs and pleura of asbestos fibres which may independently cause life-threatening diseases, such as asbestosis, mesothelioma, or lung cancer. In the majority of the cases, the evidence of exposure to asbestos comes from x-ray examination of the lungs. The visceral pleura and sometimes the parietal pleura show pleural plaques, that is, localised areas of pleural thickening with well demarcated edges. Clinical experience shows that, when pleural plaques are radiological detectable, there is nearly always a history of significant occupational exposure to

\footnotetext{
${ }^{553}$ Dutch law requires the claimant to prove causation to a 'reasonable degree of certainty'. I refer to section 2.4.2.1 for more information.

${ }^{554}$ English law requires the claimant to prove causation 'on the balance of probabilities'. I refer to section 2.4.2.1 for more information.

${ }^{555}$ I use the word 'potentially' as it is impossible to tell whether or not asbestos exposure has caused the claimant's disease.

${ }^{556}$ Martin-Casals 2009, p. 178.
} 
asbestos. ${ }^{557}$ There is no consensus, however, whether finding pleural plaques indicates a minimum level of exposure.

Furthermore, and perhaps most importantly for Tort law, current medical consensus seems to show that the presence of pleural plaques gives no indication of whether the individual will or will not develop lung cancer because of the exposure that they have had to asbestos: the general view is that the presence of pleural plaques is not an indication of an increased risk of developing an asbestos-related lung cancer, but it 'only' confirms an exposure to asbestos. The diagnosis of pleural plaques may, however, cause the patient to contemplate his future with anxiety or even cause a recognized psychiatric illness, for example, clinical depression. ${ }^{558}$ It goes without saying that if the point is reached that an employee contracts an asbestos-related disease, such as asbestosis, mesothelioma, or lung cancer - and thus the risk under which he his was living actually materializes - his employer will be liable to him in damages. ${ }^{559}$ However, one could wonder whether a claimant who has been negligently exposed to asbestos dust and subsequently developed pleural plaques - but not lung cancer - should be compensated or not? ${ }^{560}$

The first question to be answered is whether pleural plaques on their own will give rise to compensatable damage. The second question is whether the development of pleural plaques and the additional association with the risk of future illness or anxiety about the possibility of that risk materializing, will amount to compensatable damage. The third question is whether a recognized psychiatric illness, such as a clinical depression, as a consequence of pleural plaques, will amount to compensatable damage. These three questions are, therefore, isolated from the question of the compensation where the presence of pleural plaques is found with a full blown lung disease with or without further questions of anxiety-related complications.

\subsubsection{Pleural plaques without psychiatric illness or anxiety}

Do pleural plaques by themselves constitute compensatable damage under Dutch and English laws? The problem for Tort law is that, according to the current prevailing medical opinion, pleural plaques themselves do not give rise to actual damage. Beyond the thickening of the visceral pleura and sometimes the parietal pleura, the plaques themselves do not cause any external symptoms and by themselves do not increase the susceptibility of the claimants to other diseases or shorten their expectation of life. They do not, in general, have any effect on the victim's health at all. ${ }^{561}$

So what would the position of an individual presenting with only pleural plaques be in Dutch Tort law? In Dutch law, and unlike the English Tort of negligence, 'damage' is not a necessary element in the formal sense for extra-contractual liability under Article 6:162 BW. In cases where victims suffer from pleural plaques there is some kind of bodily injury (lesion to the body). Unlike the visible scar in the face, the scars on the pleural membrane, which surrounds the lungs, are not visible for other people. The question for

\footnotetext{
${ }^{557}$ Hoogsteden 1997, p. 51-52.

${ }^{558}$ Johnston v NEI International Combustion Limited, [2007] UKHL 39, paragraph 1 (Lord Hoffmann).

${ }^{559}$ For example: Hoge Raad 31 maart 2006, NJ 2011, 250 (Nefalit/Karamus); Centrale Raad van Beroep 21 juni 2007, LJN: BA8436.

${ }^{560}$ For Dutch law, this question has been addressed in: Sobczak et al. 2009, p. 207-217.

${ }^{561}$ Johnston v NEI International Combustion Limited, [2007] UKHL 39, paragraph 11 (Lord Hoffmann).
} 
Dutch law is whether the plaques are, or are not, 'harmless' injuries. And it is not simply a question for Dutch law of whether the person having been told of the presence of pleural plaques and, therefore, a confirmation that he had an exposure to asbestos, could well want to have regular check-ups in order to monitor his condition. This can result in actual (material) costs. Would this move the injury from the category of harmless to harmful? Indeed, why is such a person not entitled to compensation? Dutch scholars, such as Spier, argue that there should be no hesitation to allow compensation for damages in the case of necessary substance-related monitoring. ${ }^{562}$ However, if there is no psychiatric illness or anxiety and if we accept as a starting point that pleural plaques themselves do not increase the chance of getting lung cancer or any other illness, then we must conclude that there is no other claim for damages than the one relating to the costs of monitoring the claimant's condition. Although the pleural plaques indicate an exposure to asbestos, which could have resulted from the negligence of an employer, such an individual must wait and see if the exposure causes serious illness.

Under English law, the case of Johnston v NEI International Combustion Limited ${ }^{563}$ differs from other asbestos cases in that, whilst the four claimants showed clear evidence of exposure to asbestos, they had not developed lung cancer yet. Johnston shows that the fact that pleural plaques by themselves do not increase the susceptibility of the claimants to other diseases or shorten their expectation of life was decisive for the House of Lords, who uphold the previous decision of the Court of Appeal ${ }^{564}$, to dismiss the claim. ${ }^{565}$ English law is very clear on this point: the presence of pleural plaques does not constitute actionable damage and thus cannot form a basis for a claim in negligence, irrespective of whether or not this condition is combined with a risk of developing an asbestos-related injury in the future and feelings of anxiety about that risk. ${ }^{566}$ In Johnston, all Law Lords unanimously concluded that pleural plaques themselves were not actionable damage. When there is no actual damage at all there is nothing to claim. ${ }^{567}$ And crucially, damages are given for injuries that cause harm, not for injuries that are harmless. ${ }^{568}$ It should, however, be noted that the claimants relied solely on a claim in negligence (Tort of negligence) which means that the Law Lords could not examine the possible outcome of this claim under the contract of employment. ${ }^{569}$

\subsubsection{Pleural plaques with the risk of future illness or anxiety}

Do pleural plaques give rise to compensatable damages if these plaques are taken in association with the risk of future illness or anxiety about the possibility of that risk materializing?

\footnotetext{
${ }^{562}$ Spier 1998 b, p. 12.

${ }^{563}$ Johnston v NEI International Combustion Limited, [2007] UKHL 39.

${ }^{564}$ Rothwell $v$ Chemical \& Insulating Co Ltd, EWCA Civ 27, [2006] 4 ALL ER 1161.

${ }^{565}$ Johnston v NEI International Combustion Limited, [2007] UKHL 39, paragraph 11 (Lord Hoffmann).

${ }^{566}$ Martin-Casals 2009, p. 177.

${ }^{567}$ De minimis non curat lex: there is no cause of action if the damage suffered was negligible.

${ }^{568}$ Johnston v NEI International Combustion Limited, [2007] UKHL, paragraph 47 (Lord Hope of Craighead).

${ }^{569}$ Here, one could for example think of a 'breached contract' by the employer. Lord Scott referred to this possibility very briefly: Johnston v NEI International Combustion Limited, [2007] UKHL, paragraph 74 (Lord Scott).
} 
In Dutch law, serious anxiety could give rise to a claim for non-pecuniary damages, which would be within the scope of Article 6:106 s. 1 sub b BW ${ }^{570}$. I have found three Dutch decisions: one decision of the Court of Appeal and two decisions of two separate Courts of First Instance ${ }^{571}$ (Trial Court), which dealt with the same situation as Johnston. Only one of the cases will be discussed here. In Rechtbank Zwolle-Lelystad (2007), the employee was exposed to asbestos dust for thirty-seven years which led to pleural plaques. ${ }^{572}$ The claimant argued that the existence of pleural plaques led to anxiety. The court considered that an expert opinion was needed to establish whether the complaints of anxiety were to be seen as serious and real. The general opinion in Dutch Law is that anxiety claims - as such - are admissible and will give rise to compensation. ${ }^{573}$ Serious anxiety, as a result of the contraction of pleural plaques, thus does not have to lead to a recognized psychiatric illness in order to be compensated. Equally, whether or not the risk of future illness can be compensated completely depends on the findings of experts. If experts are able to establish that there is a minimal but serious risk of future illness, there could also be a claim in law based on the calculation of the chance for getting the asbestos-related disease. The mere fact of the risk of future illness can be seen as actual damage. However, this risk must then be substantial. A risk of just 2 or 3 percent will not be enough to be seen as actual damage, which is eligible for compensation under Dutch law. The risk of future illness could also be seen as uncertain future damages, which can be regarded as 'threatening irrevocable" ${ }^{574}$ damage. Both approaches put the 'damage concept' in another perspective: 'future damage' is the irrevocable damage and 'actual damage' is the damage relating to the chance for getting the asbestos-related disease. $^{575}$

Under English law, the case of Johnston v NEI International Combustion Limited ${ }^{576}$ made clear that one has to distinguish two situations: in the first situation, the victims claimed non-pecuniary damages for the risk of future illness and anxiety about the possibility of that risk materializing. In the second situation, one victim (Mr Grieves) claimed damages because knowing the risk of future illness in his case has led to a recognized psychiatric illness. However, the House of Lords is still not willing to compensate victims who suffer from pleural plaques. Lord Mance clearly confirmed the unanimous conclusion that: 'pleural plaques by themselves do not constitute or involve injury and damage sufficient to enable an action to lie in tort and that such injury and damage cannot in law be found by 'aggregating' the pleural plaques, the risk of future asbestos-related disease and/or

\footnotetext{
${ }^{570}$ Article 6:106 s. 1 sub b BW: Non-pecuniary damages can be awarded in situations of libel or slander, or in situations where the victim suffered some other type of personal injury. This does, however, not include the grief one suffers because a relative is injured or killed.

571 Gerechtshof 's-Hertogenbosch 6 mei 2008, LJN: BD5666; Rechtbank Middelburg 30 mei 2001, JAR 2001, 232; Rechtbank Zwolle-Lelystad 30 mei 2007, zaaknr. 249185.

${ }^{572}$ Rechtbank Zwolle-Lelystad 30 mei 2007, zaaknr. 249185.

${ }^{573}$ Vegter 2005, p. 400-401; Stolker \& Levine 1999, p.1-19.

${ }^{574}$ In Dutch: 'dreigende definitieve (schade)'.

${ }^{575}$ Spier 1998b; Akkermans 1997, p. 220.

${ }^{576}$ Johnston v NEI International Combustion Limited, [2007] UKHL 39.
} 
the anxiety experienced in relation to such risk in circumstances where none of those factors alone will suffice. ${ }^{577}$

\subsubsection{Pleural plaques with clinical depression}

$\underline{\text { In Dutch law }}$, clinical depression is seen as a recognized psychiatric illness and, therefore, this could also be seen as an 'injury to his person' in the sense of Article 6:106 s. $1 \mathrm{sub} \mathrm{b}$ $\mathrm{BW}^{578}$. However, a second requirement, which needs to be satisfied in order to hold the employer liable, is that there has to be a causal connection between the wrongful conduct of the employer and the damage which the victim encountered (i.e., between the exposure to asbestos and the clinical depression). Proving the wrongful conduct of the employer will not be problematic in cases where the employer acknowledged that he negligently exposed his employee to inhale asbestos dust in the course of the employment. Also, proving the causal connection between the wrongful conduct of the employer and the contracting of pleural plaques will, in general, not be problematic. However, the question remains whether there is a causal connection between the wrongful conduct of the employer and the clinical depression. To answer this question, according to Dutch law, we must first establish whether there is factual causation. The question to be asked is whether the clinical depression (damage) would also have occurred if the employer had not acted in the way he did? The answer to this question is relatively simple: if the employer 'A' did not expose employee ' $\mathrm{X}$ ' to inhale asbestos dust, employee ' $\mathrm{X}$ ' would probably not have developed clinical depression. This means that the first stage of causation - the stage of condicio sine qua non - will be satisfied in the situation where the claimant only worked for one employer who exposed him to inhale asbestos dust in the course of the employment. But if, in fact, the employee worked for two or even more employers and all of them exposed him to asbestos in course of the separate employments, then the question whether there is factual causation will be more problematic to answer. The Dutch legislator solves the problem of 'alternative causality' by Article 6:99 $\mathrm{BW}^{579}$. Dutch asbestos victims will not have to sue all employers. All employers, who have wrongfully exposed employee ' $\mathrm{X}$ ' to asbestos, are jointly and severally liable. ${ }^{580}$ Claims for pleural plaques might be successful in Dutch law in cases where the claimant suffered damage in the form of a clinical depression which could be seen as compensatable (actual) damage according to Article 6:106 s. $1 \mathrm{sub} \mathrm{b} \mathrm{BW}$. The fact that the experts might conclude that pleural plaques would only in very exceptional cases lead to a clinical depression does not exclude the liability of the employers. The mere fact that this damage is not a 'normal' reaction will be a risk for the tortfeasor to bear: he has to take his victim

\footnotetext{
577 Johnston v NEI International Combustion Limited, [2007] UKHL 39, paragraph 103 (Lord Mance).

${ }^{578}$ Article 6:106 s. 1 sub b BW: Non-pecuniary damages can be awarded in situations of libel or slander, or in situations where the victim suffered some other type of personal injury. This does, however, not include the grief one suffers because a relative is injured or killed.

${ }^{579}$ Article 6:99 BW: 'Where the damage has resulted from two or more events for each of which a different person is liable, and where it has been determined that the damage has arisen from at least one of these events, the obligation to repair the damage rest upon each of these persons, unless he proves that the damage is not the result of the event for which he himself is liable.'

${ }^{580}$ I refer to section 2.6.2.2 for more information on the apportionment of damages in claims for mesothelioma.
} 
as he finds him. ${ }^{581}$ A plea that the employee's damage (clinical depression) was not foreseeable thus does not exclude the employers from liability.

Under English law, the case of Johnston v NEI International Combustion Limited ${ }^{582}$ provides a clear answer to the question of whether pleural plaques with clinical depression are eligible for compensation. Mr Grieves, once learning of the risk of future illness, developed a recognized psychiatric illness. He underwent an X-ray examination in 2000 and, after being told that his pleural plaques indicated a significant exposure to asbestos and a risk of future disease, he developed clinical depression. Under English law, clinical depression is a recognized psychiatric illness which is actionable damage as such. However, in Mr Grieves case the clinical depression was not reasonably foreseeable which led to the result that his employer did not owe him a duty of care to prevent Mr Grieves suffering from a clinical depression. ${ }^{583}$ In Lord Hoffmann's view: '......the development of pleural plaques, whether or not associated with the risk of future disease and anxiety about the future, is not actionable injury. The same is true even if the anxiety causes a recognized psychiatric illness such as clinical depression. The right to protection against psychiatric illness is limited and does not extend to an illness which would be suffered only by an unusually vulnerable person because of apprehension that he may suffer a tortuous injury. ${ }^{584}$

\subsubsection{Overall conclusion}

Proving the causal link between the tortfeasor's intervention and the claimant's damage, is extremely problematic in the majority of asbestos-related cases. In such cases causal uncertainty could arise with regard to the cause of the damage, the identity of the specific tortfeasor who has caused the damage, or both. In cases where the asbestos victim suffers from mesothelioma causal uncertainty could only arise with regard to the identity of the specific tortfeasor because asbestos is the only known cause to contract mesothelioma. In Dutch law, Article 6:99 BW can be applied to establish the liability of the defendants in cases where the mesothelioma sufferer has been exposed to asbestos in several different employments. Dutch mesothelioma victims do not have to trace and sue all possible defendants in order to receive full compensation. Applying Article 6:99 BW, the sued employer can be held liable in full, but could also have a right of recourse against the other responsible defendant(s). Under English law, the principle of joint and several liability has not always been applicable in claims for mesothelioma. In 2006, the House of Lords decided to apply an employer-friendly approach to apportion the claimant's damage in such cases. Each defendant, in a group of possible tortfeasors, is only entitled to an apportionment of his liability to reflect the extent of the overall exposure attributable to his breach of duty. Mesothelioma victims had to sue and find all responsible tortfeasors in order to receive full compensation. However, Parliament intervened and has introduced new legislation to overrule the House of Lords' decision in Barker.

\footnotetext{
581 The employer also has to answer for the consequences of the claimant's vulnerabilities and predispositions.

${ }^{582}$ Johnston v NEI International Combustion Limited, [2007] UKHL 39.

${ }^{583}$ Martin-Casals 2009, p. 180.

${ }^{584}$ Johnston v NEI International Combustion Limited, [2007] UKHL 39, paragraph 2 (Lord Hoffmann).
} 
Applying the Compensation Act 2006, the sued defendant is jointly and severally liable in claims for mesothelioma. Nowadays, it is not the claimant but the defendant who bears the risk that one or more defendant(s) are untraceable or have gone out of business.

Mesothelioma is, however, not the only asbestos-related disease. Persons who have been exposed to asbestos have also a higher risk to develop a general type of lung cancer. The situation in such cases is more complex: the lung cancer that the claimant contracted could have been caused by multiple factors. In these particular cases asbestos is not anymore the only known cause to contract the disease and smoking is regarded as the main cause to contract lung cancer at population level. In Dutch law, the Supreme Court ruled that, although the exact formulation remains unclear, the thought behind the Articles 6:99 BW and 6:101 BW supported the application of proportional liability, i.e., the possibility to award damages in proportion to the probability of causation. In such cases experts are appointed to asses the probability that the claimant's lung cancer was caused by the negligent exposure to asbestos in the course of the employment and to express this probability into a percentage. Subsequently, the court evaluates the expert evidence and awards damages for the extent to which the lung cancer can be attributed to asbestos exposure. Under English law, the wrongful exposure to asbestos must have doubled the risk of lung cancer in order to establish sufficient causation. Causation can be assumed in cases in which the claimant developed asbestosis before he was diagnosed with lung cancer. However, causation remains difficult to establish in cases in which the claimant suffers from lung cancer in the absence of asbestosis. Does the English claimant receive full compensation after he is able to prove causation on the balance of probabilities? Not, it has been established that smoking tobacco constitutes contributory negligence from approximately 1971 onwards: the total damages must be reduced to such extent as the court thinks just and equitable having regard to the claimant's share in the responsibility for the damage.

The situation is even more complex when the claimant, who developed a form of lung cancer which could have been caused by multiple factors, has been exposed to asbestos while working for several employers all exposing him to asbestos in the course of the separate employments. In these particular cases uncertainty arises with regard to the identity of the specific tortfeasor and the cause of the damage. Although I have not found specific case law on this issue in the jurisdictions taken under consideration here, the most logical view is to assume that the abovementioned approaches can also be applied in such cases. For the English jurisdiction, the concept of contributory negligence can be applied to reduce the amount of compensation and the principle of joint and several liability is applicable to apportion the claimant's damage. For the Dutch jurisdiction, proportional liability can be applied to establish the defendant's liability in proportion to the probability of causation, and the principle of joint and several liability is applicable to apportion the claimant's damage on the basis of Article 6:99 BW.

In claims for pleural plaques, another problem arises. The question of whether or not the claimant, who developed pleural plaques after he had been exposed to asbestos, has suffered damage is difficult to answer. Employees who have developed pleural plaques are, irrespective of whether the claimant associated these pleural plaques with the risk of future illness, anxiety, or clinical depression, better off in the Netherlands than in Eng- 
land. Under English law, a claim in tort based on negligence is incomplete without proof of damage. Awarding damages for pleural plaques is out of the question, because there is just no actionable damage to claim. In Dutch law, damages for pleural plaques can be awarded because the proof of damage is not a necessary element in the formal sense to establish the liability of the defendant. Damage does not have to be actionable, but the claimant must have suffered 'actual' damage in order to receive compensation. Under Dutch law, the actual (material) costs of monitoring the condition of the pleural plaques sufferer and the costs for mental suffering (non-pecuniary damage) are eligible for compensation. 


\section{Solutions to the Problem of Uncertain Causation in Asbestos-Related Cases}

\subsection{Chapter introduction}

Proof of causation is extremely important because causation is a fundamental requirement to establish liability in Dutch and English laws. As discussed in Chapter 2, the traditional condicio sine qua non (but-for) test has proven to be inadequate to establish causation in cases concerned with the problem of multiple causation. In the majority of asbestosrelated cases, employers have wrongfully exposed their employees to asbestos in the course of their employments, but they escape liability when traditional principles apply. In claims for lung cancer that could have been asbestos-related, the Dutch claimant is - in the majority of the cases - unable to prove causation to 'a reasonable degree of certainty' and the English claimant is unable to prove causation 'on the balance of probabilities'. One could wonder, however, whether it is fair that the claimant, who is not to blame, should bear the whole loss rather than the defendant, who, at least to some degree, can be blamed for his wrongful conduct. ${ }^{585}$ Such an outcome is questionable: particularly when it has been proved that the defendant had been at fault and that there is a real probability that this fault has caused personal injury to the claimant. In such situations the normal outcome of the condicio sine qua non (but-for) test is contrary to common sense. To quote Lord Bingham in Fairchild: 'Tort law is and should be about compensating those who are wrongfully injured. ${ }^{586}$

Chapter 3 builds on Chapter 2 and examines several solutions to the problem of uncertain causation in asbestos-related cases in order to seek a fair balance between the interests of the claimant and the interests of the defendant in case of causal uncertainty. For the sake of clarity, this chapter is divided into three parts, starting with 'Proportional approaches in Tort law' (Part One), 'Alternative solutions in Tort law' (Part Two) and 'Alternatives to Tort liability' (Part Three). Part One examines several approaches that lead to a proportional outcome, such as: the option to award damages in proportion to the probability of causation (proportional liability), contributory negligence as a tool to reduce the total amount of damages, the application of the loss of a chance theory, and the option to establish the liability of the defendant in line with his market share. Among

\footnotetext{
${ }^{585}$ Giliker \& Beckwith 2000, p. 153.

${ }^{586}$ Fairchild v Glenhaven Funeral Services Ltd, [2002] UKHL 22, paragraph 11(Lord Bingham).
} 
other issues, this Part explores the pros and cons connected to the application of a proportional liability approach in cases where the causal link is uncertain. It examines whether or not the instrument of proportional liability is, when compared to the traditional principle of all-or-nothing compensation, a more reasonable approach to compensate the claimant in asbestos-related cases and other specific personal injury cases in which the problem of multiple causation also arises. Furthermore, it addresses the question of whether or not the option to award damages in line with the probability of causation is restricted to claims for lung cancer which could have been asbestos-related and whether it is advisable to extend the range of applications of the proportional liability theory to other specific non-asbestos-related claims. Should the applicability of the proportional liability theory be influenced by the type of causal uncertainty? It is, however, important to note that not all proposed proportional approaches are applied in both jurisdictions taken under consideration here. Therefore, the upcoming discussion on the different proportional solutions mainly focuses on the jurisdiction in which the solution has actually been applied.

Next to the proposed proportional approaches in Tort law, it may be worth searching for alternative solutions within Tort law, which can be used alongside or instead of proportional liability, in order to strengthen the claimant's legal position in asbestosrelated cases and other cases in which the exact same problem of uncertain causation also arises. Part Two builds on Part One and examines alternative solutions to the problem of uncertain causation in asbestos-related cases which have and have not yet been applied (together) in Dutch and English laws. This Part focuses on other solutions in substantive and/or procedural law, such as: the option to set aside the requirement of causation, the solution to expand the notion of causation (as applied in English law), the defendant's duty to provide an extra motivated pleading, the option to lessen the traditional standard to prove causation, and the option to reverse the burden of proof with regard to the requirement of causation.

It can, however, be questioned whether or not the solutions in Tort law lead to satisfactory outcomes in complex claims for asbestos-related diseases. Part Three examines alternatives to Tort liability in order to explore whether instruments outside the area of Tort law are more sufficient to deal with claims for mesothelioma and lung cancer that could have been asbestos-related.

It is important to note that this chapter particularly focuses on the option to award damages in proportion to the probability of causation because this relatively new solution to the problem of uncertain causation has, in 2006, for the first time been applied by the Dutch Supreme Court in a claim for lung cancer that could have been caused by occupational exposure to asbestos. Alternative solutions to the problem of uncertain causation are examined for the sake of completeness, which implies that these solutions are not subject to in-depth discussion in this thesis. The literature cited in the footnotes provides further details. 


\subsection{Damages in proportion to the probability of causation: proportional liability}

Taking into consideration the main goals of Tort law, such as compensation and prevention, the traditional principle of all-or-nothing compensation will lead to undesirable consequences in situations where the causal link is uncertain. As discussed in section 2.5.1, all-or-nothing recovery has its drawbacks. Therefore, it is not surprising that courts and legal scholars have tried to introduce constructions which may remove these drawbacks. Do these drawbacks, however, require or justify a new approach? Legal scholars, such as Spier ${ }^{587}$, Faure ${ }^{588}$, Frenk ${ }^{589}$, and Akkermans ${ }^{590}$ think they do and proposed to reduce the negative side-effects connected to the traditional principle of all-ornothing compensation. Their solution is what has become known as the 'proportional liability theory'. Applying this theory, the judge does not simply award or reject the total amount of damages, rather he or she awards damages in proportion to the probability of causation: 'Liability in proportion to the probability of the cause." 591 According to Akkermans, proportional liability is a Salomon-solution. ${ }^{592}$ Kerkmeester refers to it as judica rusticorum ${ }^{593}$ decisions. ${ }^{594}$

The application of the traditional principle of all-or-nothing compensation leads to undesirable consequences in cases in which the assessed probability of causation lies just above or just below the required threshold to establish causation. ${ }^{595}$ Proportional liability can strengthen the claimant's legal position in cases in which the probability of causation does not exceed the threshold to establish causation. If the probability of causation is assessed as, say, 45 percent, then it is most likely that the claimant will receive 45 percent compensation. ${ }^{596}$ Applying the traditional principle of all-or-nothing compensation, a 45 percent probability is not enough to establish condicio sine qua non (but-for) and, it is most likely that the claim for compensation would have been dismissed. The proportional liability rule thus enables judges to award damages in proportion to the probability of causation in cases where the claimant might not have been compensated under the threshold liability rule.

The following subsections examine the pros and cons connected to the option to award damages in proportion to the probability of causation in cases in which the claimant suffers from lung cancer that could have been asbestos-related in order to establish

\footnotetext{
${ }^{587}$ Spier 1990.

${ }^{588}$ Faure 1993a.

${ }^{589}$ Frenk 1995.

${ }^{590}$ Akkermans 1995; Akkermans 1997.

${ }^{591}$ In Dutch: 'Aansprakelijkheid naar rato van de veroorzakingswaarschijnlijkheid'. See also: Akkermans 1997 , p. 3.

${ }^{592}$ Akkermans 1997, p. 2. Here, I refer to King Salomon from the Bible.

${ }^{593}$ Intermediary (bemiddelende) decisions.

${ }^{594}$ Kerkmeester 1998, p. 435.

${ }^{595}$ In Dutch law, the claimant must prove causation to 'a reasonable degree of certainty'. In English law, the claimant must prove causation 'on the balance of probabilities'.

${ }^{596}$ Young et al. 2004, p. 516, 517.
} 
whether the instrument of proportional liability is, when compared to the traditional principle of all-or-nothing compensation, a more reasonable approach to establish the liability of the defendant. Furthermore, this section examines whether it is possible to apply the instrument of proportional liability in non-asbestos-related personal injury claims and whether this is desirable. Here, the problem of uncertain causation could also arise. Note that the following subsections focus on Dutch law as the application of the Nefalit-principle, i.e., the option to award damages in proportion to the probability of causation, is denied in the English jurisdiction.

\subsubsection{Legal grounds for adopting proportional liability in Dutch law}

Akkermans' Ph.D-dissertation on 'proportional liability' was published in $1997 .{ }^{597}$ Until that moment, the Dutch Supreme Court had not applied the proportional liability theory and it was still not clear whether or not the legal instrument of proportional liability would fit into the Dutch legal system. Akkermans suggested three possible legal grounds to apply proportional liability in Dutch law. The first argument can be found in Article 6:98 BW. This Article is known as 'attribution according to reasonableness' and has been discussed in section 2.4.1.2. Lindenbergh is one of the few scholars who favours this argument to adopt proportional liability because this Article clearly deals with the 'attribution of consequences' to the defendant instead of the division of damages between the claimant and the defendant. He states that, as opposed to Article 6:101 BW, the judge does not, when applying Article 6:98 BW, have to explain which factor(s) can be attributed to the claimant. ${ }^{598}$ This solution has one major drawback: traditionally, Article 6:98 BW only comes into play after the presence of factual causation has been established on the basis of the condicio sine qua non test. ${ }^{599}$ This means that Article 6:98 BW is not meant to establish both factual and legal causation. The second option is to apply the 'loss of a chance theory', which will extensively be discussed in section 3.4. The third option is to combine both Articles 6:99 $\mathrm{BW}^{600}$ (alternative causality) and 6:101 $\mathrm{BW}^{601}$ (contributory negligence). ${ }^{602}$ Applying this solution, it seems that liability can be established on the basis of Article 6:99 BW and the amount of compensation can be diminished on the basis of Article 6:101 BW. ${ }^{603}$

\footnotetext{
${ }^{597}$ Akkermans 1997.

${ }^{598}$ Lindenbergh 2006, p. 739: '... het toerekenen van gevolgen'.

599 Akkermans 1997, p. 441.

${ }^{600}$ Article 6:99 BW: 'Where the damage has resulted from two or more events for each of which a different person is liable, and where it has been determined that the damage has arisen from at least one of these events, the obligation to repair the damage rest upon each of these persons, unless he proves that the damage is not the result of the event for which he himself is liable.'

${ }^{601}$ Article 6:101 BW: 'Where the circumstances which can be imputed to the victim have contributed to the damage, the obligation to repair is diminished by apportioning the damage between victim and the person who has the obligation to repair, in proportion to the degree in which the circumstance can be imputed to each of them, have contributed to the damage. The apportionment may vary or the obligation to repair can either be completely extinguished or not apportioned at all, if equity so requires due to the different degree of gravity of the faults committed or any other circumstance in the case.'

${ }^{602}$ Dommering-van Rongen 1998, p. 19.

${ }^{603}$ Akkermans 1997, p. 80.
} 
In the landmark case Nefalit/Karamus ${ }^{604}$, which concerned the liability for lung cancer that could have been caused by the wrongful exposure to asbestos in the course of the employment, the Supreme Court held that the latter option could be applied to award damages in proportion to the probability of causation. ${ }^{605}$ The Supreme Court ruled that, although the exact meaning of the wordings still remain unclear, the underlying principle of the Articles 6:99 BW and 6:101 BW supports the application of proportional liability. ${ }^{606}$ In claims for lung cancer that could have been asbestos-related, proof of condicio sine qua non is not a fundamental requirement to hold the defendant liable in proportion to the probability of causation. For the assessment of the claimant's damages, the Supreme Court sought alliance with traditional principles and held that the defendant is liable in full minus the claimant's contributory negligence. The applicability of the Articles 6:99 BW and 6:101 BW in claims for lung cancer has, however, been subject to much criticism in legal writings, and I refer to section 2.6.3.2.7 for a more extensive discussion on this issue.

\subsubsection{Arguments in favour of proportional liability}

Most academics, including law and economics scholars, prefer a proportional liability approach instead of an all-or-nothing scheme, which is traditionally based on a threshold of liability, to compensate the claimant in cases where the causal link is uncertain. ${ }^{607}$ It is common ground that the application of the traditional all-or-nothing solution leads to over-compensation if the probability of causation lies above the threshold (the claimant receives full compensation), and leads to under-compensation if the probability of causation does not exceed the threshold (the claimant receives no compensation at all). It is recognized that the proportional liability theory has some advantages over the all-ornothing solution. Applying proportional liability, there is fewer over- and undercompensation, there is less over and under deterrence, and judgments will be less arbitrary. Proportional liability would, seen from a perspective of prevention of damages,

\footnotetext{
${ }^{604}$ Hoge Raad 31 maart 2006, NJ 2011, 250 (Nefalit/Karamus).

${ }^{605}$ This is, however, not the only possible ground to award damages in proportion to the probability of causation.

${ }^{606}$ Hoge Raad 31 maart 2006, NJ 2011, 250, paragraph 3.13: ‘.... Mede gelet op de aan de artikelen 6:99 en 6:101 BW ten grondslag liggende uitgangspunten moet daarom worden aangenomen dat, indien een werknemer schade heeft geleden die, gelet op de hiervoor bedoelde kanspercentages, zowel kan zijn veroorzaakt door een toerekenbare tekortkoming van zijn werkgever in de nakoming van zijn verplichting de werknemer in de uitoefening van diens werkzaamheden voldoende te beschermen tegen een voor de gezondheid gevaarlijke stof, als door een aan de werknemer zelf toe te rekenen omstandigheid als hiervoor bedoeld, als door een combinatie daarvan, zonder dat met voldoende zekerheid is vast te stellen in welke mate de schade van de werknemer door deze omstandigheden of één daarvan is ontstaan, de rechter de werkgever tot vergoeding van de gehele schade van de werknemer mag veroordelen, met vermindering van de vergoedingsplicht van de werkgever in evenredigheid met de, op een gemotiveerde schatting berustende, mate waarin de aan de werknemer toe te rekenen omstandigheden tot diens schade hebben bijgedragen.' Kortmann does agree: Kortmann 2006, p. 1408. The Dutch Supreme Court also applied the proportional liability theory in a similar case. In this case the claimant worked for Eternit and has been exposed to asbestos in the course of his employment (1961-1975). However, the claimant did not smoke tobacco. The Supreme Court awarded 63.5 percent of the total damages claimed. See: Hoge Raad 31 maart 2006, LJN: AU6093 (Hollink/Eternit). ${ }^{607}$ Particularly, in cases in which the causal uncertainty is high: Young et al. 2004, p. 517. See for a very clear economical analysis: Van Velthoven \& Van Wijck 2008, p. 130-140.
} 
also create a better incentive for the parties to behave as required by law. Furthermore, it is more likely that liability and damage payments would correspond to the damage that has, in fact, been negligently caused. ${ }^{608}$ However, prudence is called for. In claims for lung cancer, it is impossible to determine whether asbestos exposure did or did not cause the claimant's lung cancer. The assessment of the probability of causation is based on epidemiological findings. This implies that the assessed probability of causation inserts a certain element of speculation and thus does not exactly reflect reality.

Another argument that favours the application of the proportional liability theory relates to the desired outcome of the case. Applying the traditional principle of all-ornothing compensation in cases of uncertain causation, the outcome of the case is often considered as unreasonable. In such cases it is almost impossible for the claimant to establish causation when traditional principles apply, and the inability to prove causation has enormous negative consequences for the claimant: he leaves empty-handed. Proportional liability, on the other hand, leads to more reasonable results as the compensation corresponds with the probability that the tortfeasor's intervention has caused the claimant's damage. In cases where no compensation is awarded today, the application of the proportional liability theory could enable the claimant to recover a part of the total damages. Furthermore, it should be noted that the idea to award damages in proportion to the probability of causation is in line with Dutch case law and the developments on an European and International level. ${ }^{609}$ Liability for only a certain percentage of the total damage is not an uncommon principle in civil law and common law jurisdictions. Awarding partial compensation has proven to be desirable in cases where the claimant has contributed to his own damage. Proportional liability as such, is therefore not a totally new concept in law. ${ }^{610}$

The application of the proportional liability theory in asbestos-related cases will, even on an individual level, still lead to the most reasonable results in an environment of uncertainty. ${ }^{611}$ It is an uncomfortable compromise that Professor Spier captures well, describing proportional liability as 'the least unreasonable' approach because the proportional liability theory takes all circumstances into account, including those on the side of the tortfeasor. ${ }^{612}$ The over- and under-compensation also applies when using epidemiological evidence. However, some form of proportional compensation, rather than all-ornothing is again arguably the most appropriate compromise, as it confirms fundamental responsibilities of the tortfeasor without assuming a position akin to strict liability for any employers requiring their employees to work with asbestos (or other dangerous situations). Scholars, such as Akkermans underline this, suggesting that not using population-

\footnotetext{
${ }^{608}$ Kadner Graziano 2008, p. 1034.

${ }^{609}$ See for Dutch case law: Hoge Raad 31 maart 2006, NJ 2011, 250 (Nefalit/Karamus); Gerechtshof Arnhem 6 juli 2004, JAR 2004/186; Kantongerecht Middelburg 1 december 1999, VR 1999, 117; Kantongerecht Eindhoven 13 april 2000, JAR 2003/286; Gerechtshof Amsterdam 18 maart 2004, JAR 2004/96, Gerechtshof 's-Gravenhage 1 oktober 2004, JAR 2004/273. See for the developments on an international level: Article 3:103, 3:105, and 3:106 Principles of European Tort Law.

${ }^{610}$ Kadner Graziano 2008, p. 1031.

${ }^{611}$ Akkermans 1997, p. 302, 303.

${ }^{612}$ Spier 1990, p. 9.
} 
level figures in individual cases is even more arbitrary. Some information provides more accuracy than no information at all. ${ }^{613}$

\subsubsection{Critique and discussion}

Not all Dutch legal scholars were satisfied with this relatively new and revolutionary approach to award damages in proportion to the probability of causation. What drawbacks are connected to the application of the proportional liability theory in asbestosrelated cases? An argument to deny the applicability of the proportional liability theory is that the application of proportional liability in cases where the probability of causation is low could easily lead to a floodgate of low valued claims. In such claims it may be wondered whether or not the costs are proportional to the value of the claim. ${ }^{614}$ Furthermore, it should be noted that scientific expert reports are not always univocal and that the proportional liability theory depends, when compared to the all-or-nothing solution, to an even larger extent on the findings of experts. For legal experts, these reports are extremely difficult to read and hard to understand, which could lead to more communication problems. This can have negative consequences for both the claimant and the defendant. ${ }^{615}$

Some academics argue that estimating chances is arbitrary and will lead to less compensation for the claimant and, therefore, consider the proportional liability theory as a non-victim-friendly approach to compensate the claimant's damage. ${ }^{616}$ In addition, English scholars, such as Weir, are unfavourably disposed towards the use of percentages to establish the (proportional) liability of the defendant: 'The idea that recovery should be proportional to the cogency of the proof of causation is utterly unacceptable.' In Weir's view: 'The tendency to state the matter in terms of percentages is to be avoided. 'More likely than not' is a matter of persuasion, not of proof. Statistics are often deployed. There is no reason why they should not be considered, but they cannot be conclusive. ${ }^{617}$ Furthermore, it is arguable that it is unfair to devolve the causal uncertainty partially to the employee in cases where it has been established that the employer has wrongfully exposed his employee to asbestos in the course of his employment, while he knew or ought to have known that this could cause 'damage' to the employee. Keeping this in mind, Waterman argues that: 'Fairness, not mathematics or chance, should always be the guideline of any judgment. ${ }^{618}$ From an ethical point of view, one could therefore wonder whether a fatally ill potential asbestos victim is satisfied with a formula to assess the probability of causation which does not take into consideration the fact that his employer has wrongfully exposed him to asbestos in the course of the employment. Applying pro-

\footnotetext{
${ }^{613}$ Akkermans 1997, p. 190-192.

${ }^{614}$ See for example: Centrale Raad van Beroep 9 april 2009, LJN: BI2805 in which the claimant received 12 percent of Euro 65.433,- = Euro 7850,-. See for more information: Sobczak 2010a, p. 407-412.

${ }^{615}$ I refer to Chapter 4 for more information on the problematic role of experts in asbestos-related cases.

${ }^{616}$ Kerkmeester 1994, p. 45.

${ }^{617}$ Weir 2002, p. 74-75: It seems as if Weir supports the idea that in cases where there is a significant chance that the defendant caused the disease, the defendant should compensate for the full extent of the disease (e.g. $100 \%$ ) because the claimant does not have $75 \%$ of the disease; he has the disease. See also: Nieuwenhuis 2006, p. 177.

${ }^{618}$ Waterman 2006, p. 15.
} 
portional liability, the negligent employer is held liable in proportion to the probability of causation and thus manages to escape full liability for an injury that has 100 percent occurred. $^{619}$

The main criticism is that estimating chances, and assessing the probability of causation in asbestos-related cases, does not correspond with reality. It is impossible to establish accurately (with 100\% certainty) the probability of causation in a specific case due to a lack of data. ${ }^{620}$ The amount of compensation is, even when the proportional liability theory has been applied, often unreasonable: the defendant is still obliged to pay too much compensation or the claimant does not receive enough compensation. Does proportional liability also lead to over-compensation or under-compensation? The answer is yes: on an individual level asbestos victims will always be over- or under-compensated. Asbestos victims will be under-compensated if the wrongful asbestos exposure caused the lung cancer as other possibilities are taken into the equation reducing the overall compensation. Asbestos victims will be over-compensated if the wrongful asbestos exposure did not cause the lung cancer at all. ${ }^{621}$ Some legal scholars have argued that the individual should receive no compensation at all $(0 \%)$ or should obtain compensation for the entire loss $(100 \%)$. In their view, the wrongful exposure to asbestos did or did not cause the claimant's lung cancer: a woman is pregnant or not. ${ }^{622}$ Seen from this perspective, applying the traditional principle of all-or-nothing compensation seems to be more reasonable to award damages.

The proportional liability theory cannot take away the arbitrariness of the decision because a threshold is also used under this 'solution' in order to reach reasonable outcomes and to prevent a floodgate of claims. ${ }^{623}$ Up until now, the exact turning point is unclear as the Dutch Supreme Court only ruled that the traditional principle of all-ornothing compensation applies in cases where the probability of causation is very large or very small. ${ }^{624}$ No percentage threshold was given to this notion. Restricting the applicability of the proportional liability theory by a minimum and maximum probability of causation is not a perfect solution: the use of a 'turning point' creates, although in a more justified way, the same problem as captured within the traditional principle of all-ornothing compensation. When the option to award damages in proportion to the probability of causation is limited to a minimum of, say: 20 percent, similar problems can be expected. If experts are able to determine that there is a 20 percent chance that the negligent conduct caused the claimant's damage, the claimant will receive 20 percent compensation. However, if experts determine that there is only a 19 percent probability, the claimant leaves empty-handed because the all-or-nothing solution applies. In such a situation the under-compensation cannot be justified. This means that, even if the propor-

\footnotetext{
${ }^{619}$ Waterman 2006, p. 13.

${ }^{620}$ Giesen \& Tjong Tjin Tai 2008, p. 64.

${ }^{621}$ Visscher 2007, p. 101, 102.

${ }^{622}$ But, in my view, that is the answer to a very different sort of question - one where the answer is either yes or no. In claims for lung cancer as a potential consequence of asbestos exposure, the question is one where 'maybe' is the only available answer. See also: Van Maanen 2000, p. 43.

${ }^{623}$ In Nefalit, the Supreme Court restricted the applicability of the proportional liability theory by a minimum and a maximum probability of causation. I refer to section 2.6.3.2.6 for more information.

${ }^{624}$ Hoge Raad 31 maart 2006, NJ 2011, 250, paragraph 3.13 (Nefalit/Karamus).
} 
tional liability theory is applied, one percent can still make the difference between being compensated in line with the probability of causation, being fully compensated, or not being compensated at all. Conversely, a similar problem of over-compensation can be expected when the application of the proportional liability theory is limited to a maximum of 80 percent: the claimant is able to obtain compensation for the entire loss $(100 \%)$ when there is only an attributable risk ${ }^{625}$ of 81 percent that the defendant has caused the claimant's damage.

In the following subsections more criticism on the proportional liability theory will be analyzed. In section 3.2.4, the pros and cons are balanced in order to examine whether or not the option to award damages in proportion to the probability of causation is a justified solution to solve the problem of uncertain causation in claims for lung cancer that could have been asbestos-related.

\subsubsection{Possibility versus probability}

Although the majority of Dutch legal scholars favour the opinion that proportional liability is, when compared to the traditional principle of all-or-nothing compensation, a more justified way to approach causal uncertainty and assign compensation in cases that are characterized by the problem of uncertain causation, some scholars think differently. Tan and Nieuwenhuis favour the all-or-nothing solution. ${ }^{626}$ Tan argues that the proportional liability theory makes an insufficient distinction between the possibility that the defendant has caused the damage to the claimant and the probability that the claimant's damage was caused by the defendant's intervention. ${ }^{627}$ He concludes that the principle of all-ornothing compensation is justified if one is able to sufficiently distinguish these concepts (possibility versus probability).

When the threshold, to establish factual causation, lies at 51 percent in a case where experts are able to determine that there is a 49 percent chance that the defendant had caused the damage to the claimant, no liability should be imposed because there is only a possibility that the defendant's act or omission has caused the claimant's damage. In this situation it is, according to Tan, justified that the claimant remains empty-handed. If experts, however, are able to determine that there is a 51 percent chance that the defendant had caused the damage to the claimant, liability should be imposed because the defendant's intervention had probably caused the damage which the claimant encountered. In this situation it is, according to Tan, justified that the claimant will receive compensation for the entire loss. ${ }^{628}$

Distinguishing a defendant's act or omission which probably (51\% or more) or possibly (49\% or less) could have caused the claimant's damage is correct. However, this distinction should not lead to the result that the claimant is either being fully compensated or not compensated at all. If experts are able to determine that there is a 60 percent chance that the defendant's intervention had caused the damage to the claimant one

\footnotetext{
625 'The proportion of the risk of a disease or other outcome in exposed individuals that can be attributed to the exposure.' See: Porta 2008, p. 11.

${ }^{626}$ Tan 2008, p. 23-27; Nieuwenhuis 2006, p. 177-178.

${ }^{627}$ Tan 2008, p. 23-27.

${ }^{628}$ Tan 2008, p. 23-27.
} 
could indeed say that the defendant had probably caused the claimant's damage. However, is it in such a situation justified to oblige the defendant to compensate the claimant in full $(100 \%)$ based on the criterion that his intervention had probably caused the claimant's damage?

Probably not. A proportional liability solution would be more appropriate and reasonable in the abovementioned situation. It can be concluded that the defendant's intervention had probably caused the claimant's damage. This does, however, not exclude the possibility $(40 \%)$ that the defendant did not cause the damage at all. The possibility that the defendant's intervention had not caused the claimant's damage should not come for account and risk of the defendant. Therefore, it would be unfair to oblige the defendant to compensate the claimant in full. Applying the instrument of proportional liability would lead to a more reasonable outcome in this situation. The word 'probably' is, in the above example, based on a 60 percent chance. It is less unreasonable to oblige the defendant to compensate 60 percent of the damages claimed, which is exactly in line with the degree of probability that his act or omission had caused the damage to the claimant. This way, it is more likely that liability and damage payments correspond to the damage that has - in fact - been negligently caused.

\subsubsection{A problem of terminology: partial liability or proportional liability?}

Kortmann made an interesting comment on the Supreme Court's decision in Nefalit, arguing that the Supreme Court did not set limitations to Nefalit's liability as to its theoretical share. ${ }^{629}$ Contrary, the Supreme Court stated that the employer is liable in full but that this obligation to repair was diminished by the degree to which the employee can be held personally responsible for contributing to the damage. ${ }^{630}$ Lindenbergh also acknowledged this problem of terminology but decided that this was not of central importance as it would not have changed the outcome of the case. ${ }^{631}$ However, it is important to note that 'proportional liability' fundamentally differs from 'partial liability'. According to Kortmann, liability in line with the defendant's theoretical share (proportional liability) is not the same as liability in full minus the claimant's theoretical share (the rule applied in Nefalit). Or to put it differently: my piece of cake is not the same as the whole cake minus your piece of cake. ${ }^{632}$ As said previously, the outcome in the Nefalit case would have been the same irrespective of which approach is applied by the Supreme Court because there are - according to Kortmann - only two possible causes which could have caused the claimant's damage. ${ }^{633}$

This means that liability in line with Nefalit's theoretical share (55\%) leads to the same result as full liability minus Mr Karamus' share $(100 \%-45 \%)=55$ percent. I do understand Kortmann's point and agree that a distinction should be made between proportional liability and partial liability, especially in cases where two or more employers have exposed the claimant to asbestos in the course of the separate employments. How-

\footnotetext{
${ }^{629}$ Klaassen \& Kortmann 2012, p. 54; Kortmann 2006, p. 1407.

${ }^{630}$ Hoge Raad 31 maart 2006, NJ 2011, 250 (Nefalit/Karamus).

${ }^{631}$ Lindenbergh 2006, p. 739-741.

${ }^{632}$ Kortmann 2006, p. 1409.

${ }^{633}$ Klaassen \& Kortmann 2012, p. 54; Kortmann 2006, p. 1409.
} 
ever, Kortmann concluded that the outcome in Nefalit remains the same because there are only two possible causes which could have caused the damage. It is not perfectly clear whether he refers to the exposure to asbestos and Mr Karamus' smoking history or whether he refers to causes for which the employer is responsible and causes which can be attributed to the employee. I agree with the latter approach because asbestos-related lung cancer can have multiple causes: exposure to asbestos, smoking, genetic predisposition, ageing, and external causes. Although it has been established that smoking tobacco is the main factor to contract lung cancer at population level, the inhalation of tobacco smoke should not be considered as the only possible other cause to contract lung cancer when assessing the defendant's liability.

Furthermore, one should acknowledge that the exact meaning of the wordings in Nefalit/Karamus is unclear and that the most important rule of law can be explained in multiple ways. ${ }^{634}$ One could, in line with Kortmann and Lindenbergh, argue that, when taking into consideration the guiding principles behind the Articles 6:99 BW and 6:101 BW, the defendant can be held liable in full minus the claimant's contribution to the damage. This would lead to the conclusion that the term 'proportional liability' can also be exchanged for 'partial liability' ${ }^{635}$ However, the change in terminology would not have changed the outcome in Nefalit and will, therefore, not be subject to further discussion in this research. At first sight, it is arguable that this approach is incorrect as it is inconsistent to acknowledge that causation (CSQN), between the exposure to asbestos and the claimant's lung cancer, is uncertain and then decide to hold the defendant liable in full minus the claimant's contribution to the damage. However, it seems that arguments of fairness, and the ratio underlying the Articles 6:99 BW and 6:101 BW, have convinced the Supreme Court to make an exception to the traditional condicio sine qua non requirement in claims for lung cancer that could have been asbestos-related. Proof of condicio sine qua non is - in specific situations - not a fundamental requirement to hold the defendant liable in proportion to the probability of causation. For the assessment of the claimant's damages the Supreme Court sought alliance with traditional principles and held that the defendant is liable in full minus the claimant's contributory negligence.

\footnotetext{
${ }^{634}$ Hoge Raad 31 maart 2006, NJ 2011, 250, paragraph 3.13: ‘.... Mede gelet op de aan de artikelen 6:99 en 6:101 BW ten grondslag liggende uitgangspunten moet daarom worden aangenomen dat, indien een werknemer schade heeft geleden die, gelet op de hiervoor bedoelde kanspercentages, zowel kan zijn veroorzaakt door een toerekenbare tekortkoming van zijn werkgever in de nakoming van zijn verplichting de werknemer in de uitoefening van diens werkzaamheden voldoende te beschermen tegen een voor de gezondheid gevaarlijke stof, als door een aan de werknemer zelf toe te rekenen omstandigheid als hiervoor bedoeld, als door een combinatie daarvan, zonder dat met voldoende zekerheid is vast te stellen in welke mate de schade van de werknemer door deze omstandigheden of één daarvan is ontstaan, de rechter de werkgever tot vergoeding van de gehele schade van de werknemer mag veroordelen, met vermindering van de vergoedingsplicht van de werkgever in evenredigheid met de, op een gemotiveerde schatting berustende, mate waarin de aan de werknemer toe te rekenen omstandigheden tot diens schade hebben bijgedragen.'

${ }^{635}$ Giesen does not agree and argues that the Supreme Court has used the term 'proportional liability' in his annual report 2005-2006. See: Giesen \& Tjong Tjin Tai 2008, p. 53. However, it should be noted that the Supreme Court has not used the term 'proportional liability' in Hoge Raad 24 december 2010, NJ 2011, 251 (Fortis/Bourgonje).
} 


\subsubsection{The contribution of smoking}

Smoking tobacco is a highly relevant factor in the development of lung cancer which is potentially asbestos-related: the risk coefficient ${ }^{636}$ for non-smokers appears to be a factor of 3 times higher, compared to the risk coefficient for regular smokers, in the same level of exposure. ${ }^{67}$ If you do not smoke but have lung cancer, the likelihood of the lung cancer being caused by the asbestos exposure is much higher than in the smoking population, as there is an equally strong chance that the smoking could have caused lung cancer. It is more likely that asbestos caused lung cancer to a non-smoking claimant. Applying proportional liability, the particular impact of smoking needs to be assessed more precisely as its role is clearly important in the development of the disease. Extensive epidemiological research in this field is a prerequisite for obtaining more accurate information about the way in which the habit of smoking affects the likelihood of the development of lung cancer among people who have been exposed to asbestos. ${ }^{638}$ The Dutch Health Council concluded that the effects of smoking tobacco in combination with being exposed to asbestos fibres could reinforce each other in the development of lung cancer. ${ }^{639}$ This means that the total risk of both smoking and exposure to asbestos is greater than adding up the individual effects. ${ }^{640}$ The '(sub)multiplicative relation ${ }^{641}$, between smoking and asbestos exposure has to be shaped out more extensively in order to justify the results that the instrument of proportional liability produces ${ }^{642}$ This important issue is subject to in-depth discussion in Chapter 4 in which the use of epidemiological data and the formula to assess the probability of causation in claims for lung cancer will be examined.

\subsubsection{The problem of argumentation}

In almost all 'proportional' judgments, the judiciary has failed to clearly motivate their decision to award compensation in proportion to the probability of causation in stead of awarding all-or-nothing. In Schaier/De Schelde $e^{643}$, the Court of First Instance did not even discuss the possibility to reduce the amount of compensation on the basis of contributory negligence at all. ${ }^{644}$ It is remarkable that the argumentation to apply the proportional liability theory is ill-founded in Dutch case law as many pros and cons have been discussed in legal writings. ${ }^{645}$ Awarding damages in line with the probability of causation has been avoided for many years. When - out of the blue - the proportional liability theory is applied to solve multiple causation cases, you would at least expect that this 'change of approach' is extensively motivated. Legal scholars, such as Giesen underline this arguing that judges, including Courts of First Instance, have to explain their decision to apply

\footnotetext{
${ }^{636}$ Increased risk of developing lung cancer.

${ }^{637}$ Gezondheidsraad 2005, p. 17, 18.

${ }^{638}$ I refer to Chapter 4 for more information on epidemiological data.

${ }^{639}$ Gezondheidsraad 2005, p. 17.

${ }^{640}$ Waterman 2006, p. 13.

${ }^{641}$ The toxicological effect is known as: 'synergism'.

${ }^{642}$ Waterman 2009, p. 145.

${ }^{643}$ Kantongerecht Middelburg 1 februari 1999, TMA 1996/6 (Schaier/De Schelde).

${ }^{644}$ Giesen \& Tjong Tjin Tai 2008, p. 108-109.

${ }^{645}$ In cases where the Supreme Court has decided to reverse the burden of proof with regard to the requirement of causation, the Supreme Court had to adjust his former decisions several times. This might be the reason why the Supreme Court is extremely cautious with regard to the issue of 'proportional liability'.
} 
proportional liability more adequately, especially when the court's decision deviates from the expert report. ${ }^{646}$ However, not all legal scholars share this opinion. Valk argues that a more adequate and extensive argumentation is not necessary because this is not the task of the judiciary. In Valk's view, this is left for academics. Judges have to base their decision on the facts provided in the case at hand and should not be obliged to motivate their choice for a different proportional approach. ${ }^{647}$ I do not agree with Valk: the judiciary has to supply detailed and cogent grounds for their decisions, in particular in cases where an unorthodox approach is applied to compensate the claimant's damage. Recently, in 2010, the Dutch Supreme Court has also emphasized that judges must extensively motivate their decision to award damages in proportion to the probability of causation because the application of the Nefalit-principle could lead to liability for damage which the defendant did not cause. ${ }^{648}$ In addition, it should be noted that adequate argumentation is generally seen as a good development in the pursuit of legal security.

\subsubsection{The fear for far-reaching consequences}

Comments have also been made on the possible far-reaching consequences for employers' liability. If proportional liability is also applicable in other non-asbestos-related claims for occupational diseases, in which the employee has also been exposed to 'a substance which is dangerous for your health', the effects of this proportional solution can be extensive. ${ }^{649}$ The effects can even be more far-reaching when the instrument of proportional liability becomes applicable in claims for occupational diseases that have not been caused by hazardous substances, such as: musculoskeletal disorder (RSI) and burnouts. Therefore, the range of Nefalit/Karamus ${ }^{650}$, and its effects on other non-asbestosrelated claims will be subject to discussion in section 3.2.5.

\subsubsection{The claimant's predispostion}

In Dutch law, the maxim: 'the tortfeasor has to take his victim as he finds him' applies in most situations. ${ }^{651}$ The general principle is that the defendant has to answer for the consequences of the claimant's vulnerabilities and predispositions ${ }^{652}$, even when the claimant is extremely vulnerable. ${ }^{653}$ Less damage would have been suffered had the injured party been in a normal condition. This predisposition of the injured party can be qualified as additional harm which is - in fact - unrelated to the intervention of the tortfeasor. The tortfeasor's intervention has caused more severe or other damage than the tortfeasor

\footnotetext{
${ }^{646}$ Giesen \& Tjong Tjin Tai 2008, p. 108-109; Hoge Raad 5 december 2003, NJ 2004, 74.

${ }^{647}$ Van Maanen \& Valk 2008, p. 324.

${ }^{648}$ Hoge Raad 24 december 2010, NJ 2011, 251, paragraph 3.8 (Fortis/Bourgonje): ‘.....de rechter die daartoe besluit, in zijn motivering dient te verantwoorden dat de strekking van de geschonden norm en de aard van de normschending - waaronder is begrepen de aard van de door de benadeelde geleden schade deze toepassing in het concrete geval rechtvaardigen.' See also section 3.2.3.4 in which the problem of argumentation has been discussed.

649 ' '...een voor de gezondheid gevaarlijke stof': Hoge Raad 31 maart 2006, NJ 2011, 250, paragraph 3.13 (Nefalit/Karamus).

${ }^{650}$ Hoge Raad 31 maart 2006, NJ 2011, 250 (Nefalit/Karamus).

${ }^{651}$ See for a good example: Hoge Raad 24 januari 1950, NJ 1950, 293.

${ }^{652}$ A physical or psychological susceptibility of a person.

${ }^{653}$ Van Dam 2006, p. 299.
} 


\section{Chapter 3}

could have foreseen in the normal cause of action. Defendants argue that they can only be held liable for the injury which their intervention would normally have caused to an 'objective' claimant and not for the injury which results essentially from factors which are due to the claimant (predispositions). ${ }^{654}$ The question remains: does this maxim also remain strong in asbestos-related cases?

In claims for asbestos-related injuries it may be wondered whether or not physical weakness of the victim must be taken into account as regards to the claim for compensation. In Nefalit, the Dutch Supreme Court ruled that the claimant's smoking history, the claimant's genetic predisposition, the claimant's age, and external factors - as a possible cause of the lung cancer - had to be attributed to the claimant. ${ }^{655}$ However, the Supreme Court made it clear that the latter three factors could not be attributed to the claimant as such, but when taking into consideration the relation employer/employee, those factors should come for account and risk of the employee. ${ }^{656}$ Legal scholars, such as Keirse and Vegter, are more explicit, arguing that a distinction should be made between 'private causes' and 'predispositions'. ${ }^{65}$ They argue that smoking should be treated as a private cause as this can be regarded as someone's own decision. The employee's smoking history, therefore, constitutes contributory negligence. Private causes should fall within the scope of Article 6:101 BW and predispositions should fall outside the scope of Article 6:101 BW, which means that predispositions do not constitute contributory negligence on the part of the claimant. Private causes, on the other hand, do constitute contributory negligence and can lead to a reduction in damages. ${ }^{658}$

The Supreme Court's decision in Nefalit does, however, not imply that the maxim 'the tortfeasor has to take his victim as he finds him' does not remain strong in asbestosrelated cases. Nefalit is about a division of liability as a consequence of uncertain causation with regard to the cause of lung cancer and does not, as in the Renteneurose case ${ }^{659}$, deal with the devision of damage which is caused by the accident. ${ }^{660}$ Therefore, Nefalit is not inconsistant with traditional case law on the claimant's predisposition. ${ }^{661}$

\footnotetext{
${ }^{654}$ Van Gerven et al. 2000, p. 429/1.

${ }^{655}$ Hoge Raad 31 maart 2006, NJ 2011, 250, paragraph 3.13 (Nefalit/Karamus): '....in weerwil van de niet zeer kleine kans dat buiten de uitoefening van de werkzaamheden gelegen omstandigheden die aan de werknemer moeten worden toegerekend (zoals roken, genetische aanleg, veroudering of van buiten komende oorzaken).'

${ }^{656}$ Hoge Raad 31 maart 2006, NJ 2011, 250, paragraph 3.13 (Nefalit/Karamus): ‘...Hierbij verdient opmerking dat die laatste drie omstandigheden de werknemer weliswaar niet kunnen worden verweten, maar in verhouding tot de werkgever voor risico van de werknemer komen.'

${ }^{657}$ See for more information on this distinction: Keirse 2006, p. 66-75; Vegter 2004, p. 73-79.

${ }^{658}$ In claims for RSI, the Court of First Instance Middelburg also ruled that private causes (playing computer games at home) constitute contributory negligence. See: Kantongerecht Middelburg 1 september 2003, NJ 2003, 736 (Thier/Groeneveld).

${ }^{659}$ Hoge Raad 8 februari 1985, NJ 1986, 137 (Renteneurose).

${ }^{660}$ Hoge Raad 31 maart 2006, NJ 2011, 250 (Nefalit/Karamus); noot T.F.E. Tjong Tjin Tai.

${ }^{661}$ Hoge Raad 8 februari 1985, NJ 1986, 136 (Joe/Chicago Bridge); Hoge Raad 8 februari 1985, NJ 1986, 137 (Renteneurose).
} 


\subsubsection{Undermining traditional principles}

At first glance it seems to me that the instrument of proportional liability has changed the perspective by which judges and other legal scholars approach the concept of uncertain causality in asbestos-related cases in which the claimant suffers from lung cancer as a potential consequence of asbestos exposure. The combination of proportionality and liability has finally been accepted by the Supreme Court since Nefalit ${ }^{662}$. Not all legal scholars were enthusiastic about the Supreme Court's verdict with regard to the establishment of liability. Some scholars even criticised the approach taken by the Dutch Supreme Court. Van Kampen and MacLean were of the opinion that using the term 'proportional liability' runs counter to the basic structure of the Dutch Civil Code (BW). They stated that factual causation must be established before going on to determine the scope of the damage (legal causation). They argue that in Nefalit, first factual causation should be established and that an assessment of a 55 percent chance is making the employer 100 percent liable on the basis of Article 7:658 $\mathrm{BW}^{663}$ : and secondly, the estimated percentage (55\%) should be used to determine the amount of damage (Article 6:98 BW). ${ }^{664}$

Other legal scholars underline van Kampen's and MacLean's critique and argue that the legal instrument of proportional liability will undo the basic requirements for liability in a way that condicio sine qua non is not a necessary element for liability anymore. ${ }^{665}$ This criticism is logically, without doubt, correct. However, in multiple causation cases the traditional condicio sine qua non test will bite. In such cases the assessment of causation cannot result in a yes or no answer because the outcome of the condicio sine qua non test is uncertain by definition.

Furthermore, some scholars have argued that the application of the proportional liability theory undermines the traditional principle of all-or-nothing compensation. The all-or-nothing approach is, as discussed in section 2.5.1, based on the idea to award full compensation or reject all compensation. Whether the total amount of damages is awarded or rejected depends on the outcome of the condicio sine qua non test. Proportional liability, on the other hand, is based on the idea of compensating damage in proportion to the probability of causation. Applying proportional liability, the awarded amount of compensation depends on the probability that the tortfeasor's intervention has caused the claimant's damage. However, I do not consider this as a strong argument to deny application of the proportional liability theory because it is arguable that the instrument of proportional liability does not undermine the traditional principle of all-or-nothing compensation: the defendant must still compensate 'all' damage for which he can be held responsible.

\subsubsection{Weighing the pros and cons}

The former sections have addressed the question of whether or not it is desirable to award damages in proportion to the probability of causation in claims for lung cancer

\footnotetext{
${ }^{662}$ Hoge Raad 31 maart 2006, NJ 2011, 250 (Nefalit/Karamus).

${ }^{663}$ Employers' liability.

${ }^{664}$ Van Kampen \& MacLean 2006, p. 1-5.

${ }^{665}$ Zivkovic 2007, p. 38-45.
} 
which could have been asbestos-related. Although it is impossible to accurately (with $100 \%$ certainty) establish the probability of causation in a specific case due to a lack of data, proportional liability is a compromise that is 'the least unreasonable' solution to compensate lung cancer sufferers. Proportional liability is not a perfect solution to solve the problem of causal uncertainty in asbestos-related cases, but it still remains, when compared to the all-or-nothing scheme, the most desirable solution to settle such cases and to assign compensation. Not using epidemiological findings would be more arbitrary. Some information provides more accuracy than no information at all. ${ }^{666}$

At first sight, it is arguable that the Supreme Court's reasoning in Nefalit is incorrect as it is inconsistent to acknowledge that causation (CSQN) between the exposure to asbestos and the claimant's lung cancer, is uncertain and then decide to hold the defendant liable in full minus the claimant's contribution to the damage. However, it seems that arguments of fairness, and the ratio underlying the Articles 6:99 BW and 6:101 BW, have convinced the Supreme Court to make an exception to the traditional condicio sine qua non requirement in specific situations. Proof of condicio sine qua non is - in claims for lung cancer that could have been asbestos-related - not a fundamental requirement to hold the defendant liable in proportion to the probability of causation.

However, the proportional liability theory cannot take away the arbitrariness of the decision because a threshold is also used under this 'solution' in order to reach reasonable outcomes and to prevent a floodgate of claims. ${ }^{667}$ Up until now, the exact turning point is unclear as the Dutch Supreme Court only ruled that the all-or-nothing solution applies in cases where the probability of causation is very large or very small. No percentage threshold was given to this notion. Restricting the applicability of the proportional liability theory by a minimum and maximum probability of causation has drawbacks: the use of a 'turning point' creates, although in a more justified way, the same problem as captured within the traditional principle of all-or-nothing compensation. The over- or under-compensation cannot be justified. This means that, even if the proportional liability theory is applied, one percent can still make the difference between being compensated in line with the probability of causation, being fully compensated, or not being compensated at all.

\subsubsection{Future developments and the effects of Nefalit/Karamus on other claims}

Up until now, whereas Nefalit/Karamus ${ }^{668}$ (2006) establishes the principle of proportional liability, the Supreme Court has not explained the legal instrument of proportional liability in detail. The consequences of Nefalit, and the effects on other personal injury claims, are unclear and must be clarified in future decisions. The principle of all-or-nothing compensation has clearly been breached in claims for lung cancer which could have been asbestos-related. Although Nefalit relates to a potential asbestos victim, this decision is

\footnotetext{
${ }^{666}$ Akkermans 1997, p. 190-192.

${ }^{667}$ In Nefalit, the Supreme Court restricted the applicability of the proportional liability theory by a minimum and a maximum probability of causation.

${ }^{668}$ Hoge Raad 31 maart 2006, NJ 2011, 250 (Nefalit/Karamus).
} 
not exclusively geared for victims of asbestos-related diseases. It goes without saying that Nefalit could rather also affect victims of other (occupational) diseases.

As discussed in section 2.6.3.2.6, Nefalit has restricted the applicability of proportional liability to cases in which the claimant has been exposed to 'a substance which is dangerous for your health. ${ }^{, 69}$ On that basis, it appears - in line with Waterman - that the application of proportional liability is restricted to occupational diseases that have been caused by hazardous materials. This means that the traditional principle of all-or-nothing compensation still applies in claims for occupational accidents. ${ }^{670}$ But does the application of proportional liability stop at lung cancer cases? Probably not. It is arguable that proportional liability can also be applied in claims for non-asbestos-related diseases that are not caused by hazardous materials, but might have been triggered or caused by circumstances in the claimant's private life, such as claims for musculoskeletal disorder (RSI), burn-outs, and other forms of cancer. Furthermore, on 24 December 2010 the Supreme Court has extended the application of the proportional liability theory for the first time and acknowledged that the Nefalit-principle can also be applied in 'the general law of obligations ${ }^{671} \cdot{ }^{672}$ However, the Supreme Court made it very clear that the Nefalitprinciple must be applied with caution because the application of this rule could lead to liability for damage which the defendant did not cause. ${ }^{673}$ Therefore, the Supreme Court emphasized that judges must extensively motivate their decision to award damages in proportion to the probability of causation. ${ }^{674}$

Moreover, it is arguable that full compensation, under an all-or-nothing scheme, not only belongs to the past in cases where multiple factors could have caused the claimant's damage but also in 'monocausal' asbestos-related cases, such as claims for mesothelioma. In such cases the negligent employer will try to prove that the employee had also been exposed to asbestos in his private life. This means that employers, who have wrongfully exposed their employees to asbestos, will try to prove an additional cause for the claimant's asbestos-related injury in order to escape full liability. The negligent employer will gather evidence which shows that he can only be held partial liable for the claimant's damage as circumstances in the claimant's private life, i.e., circumstances for which the employer cannot be held responsible, could also have caused the injury in question. ${ }^{675}$

\footnotetext{
669 '....een voor de gezondheid gevaarlijke stof': Hoge Raad 31 maart 2006, NJ 2011, 250, paragraph 3.13 (Nefalit/Karamus).

${ }^{670}$ Waterman 2009, p. 143.

${ }^{671}$ In Dutch: 'Algemene verbintenissenrecht'.

${ }^{672}$ Hoge Raad 24 december 2010, NJ 2011, 251, paragraph 3.10 (Fortis/Bourgonje). See also: Giesen 2011, p. $149-150$.

${ }^{673}$ Hoge Raad 24 december 2010, NJ 2011, 251, paragraph 3.8 (Fortis/Bourgonje). See also: Roijackers 2011, p. 4; Sobczak 2011, p. 32; Witjens 2011, p. 104; van Tricht 2011, p. 6-9; Giesen 2011, p. 149-150. The Supreme Court did, however, not use the term 'proportional liability'.

${ }^{674}$ Hoge Raad 24 december 2010, NJ 2011, 251, paragraph 3.8 (Fortis/Bourgonje): ‘.....de rechter die daartoe besluit, in zijn motivering dient te verantwoorden dat de strekking van de geschonden norm en de aard van de normschending - waaronder is begrepen de aard van de door de benadeelde geleden schade deze toepassing in het concrete geval rechtvaardigen.' See also section 3.2.3.4 in which the problem of argumentation has been discussed.

${ }^{675}$ Waterman 2006, p. 15.
} 
Furthermore, we must keep in mind that claims for asbestos-related injuries are not the only claims in Tort that are characterized by the problem of causal uncertainty. Causal uncertainty as such, is present in all areas of Tort law. In asbestos-related cases, proportional liability can be applied when it is clear that the defendant has acted wrongfully, but where it is uncertain whether the defendant's intervention has actually caused the claimant's damage because other factors could also have caused the damage which the claimant encountered. After Nefalit, it was still unclear what the court's decision would be in other (non-lung cancer) claims in which the claimant also suffers from a disease which can be attributed to at least two causes, one of which is not work-related. ${ }^{676}$ In the next sections, I will examine whether or not the Nefalit-principle can be extended to claims for musculoskeletal disorder (RSI), burn-outs as an occupational disease, lung injuries which could have been caused by occupational exposure to tobacco smoke, and cancer as a potential consequence of ionizing radiation exposure in the course of the employment.

\subsubsection{Multiple and single legal causal uncertainty}

First of all, it is important to emphasize that - in an environment of causal uncertainty there are always two or more causes that could have caused the claimant's damage. However, from a legal point of view it is essential to make a distinction between, on the one hand, situations where the legal causal uncertainty is caused by the fact that multiple legally relevant factors are present which all could have caused the claimant's damage ('multiple legal causal uncertainty'), and on the other hand, situations where it is uncertain whether the only legally relevant possible cause has actually caused the claimant's damage. I refer to the latter situation as 'single legal causal uncertainty', which does - at first sight - not sound very logical from a non-legal point of view because there are still multiple factors that could have caused the claimant's damage, which implies that the problem of multiple causation does also arise in such cases. The distinction between multiple and single legal causal uncertainty must therefore be regarded as a legal tool to reach desirable outcomes. I have used the term 'single legal causal uncertainty' to refer to situations in which only one of the possible causes of the claimant's damage is legally relevant. ${ }^{677}$ It is, however, not always easy to determine whether one can speak of 'multiple' or 'single' legal causal uncertainty. In order to establish multiple legal causal uncertainty, multiple legally relevant factors that could have caused the claimant's damage must arise. This is, for example, the case in Nefalit/Karamus ${ }^{678}$ in which multiple legally relevant possible causes for the claimant's damage can be pointed out, such as the exposure to asbestos in the course of the employment and the claimant's smoking history.

\footnotetext{
${ }^{676}$ Waterman 2006, p. 9; Lindenbergh 2006, p. 740: for example RSI or burn-outs.

${ }^{677}$ A good example can be found when establishing liability in claims for road accidents. In the majority of the cases, the traffic violation (i.e., the defedant exceeded the speed limit or drove through a red traffic light) is the only legally relevant possible cause that could have caused the claimant's damage. Here, one could speak of 'single' legal causal uncertainty because no other legally relevant possible causes can be pointed out in the majority of the cases. In such cases, the court will decide whether it can be established to a reasonable degree of certainty that the traffic violation did cause the claimant's damage. See also: Giesen \& Tjong Tjin Tai 2008, p. 92.

${ }^{678}$ Hoge Raad 31 maart 2006, NJ 2011, 250 (Nefalit/Karamus).
} 
This means that in Mr Karamus' case multiple legally relevant factors are present any one of which could have caused the damage separately.

In a situation of 'multiple' legal causal uncertainty, the application of the proportional liability theory is desirable because this solutions leads, when compared to the all-ornothing solution, to the most reasonable outcome in cases where it remains uncertain which legally relevant factor did cause the claimant's damage. In cases in which the problem of 'single' legal causal uncertainty arises, only one legally relevant possible cause can be pointed out. In such cases it is not desirable to award damages in proportion to the probability of causation because potential other causes are not legally relevant. It is arguable that the application of the traditional principle of all-or-nothing compensation leads to the most reasonable results in such cases. From a legal point of view, the only legally relevant possible cause for which the defendant is responsible did or did not cause the claimant's damage. ${ }^{679}$

\subsubsection{Applying proportional liability in specific non-asbestos-related per- sonal injury cases}

In an advisory report on proportional liability for the Dutch Association on Civil Law ${ }^{680}$, Giesen argues that, although it is important to explore and understand the decision in Nefalit, it is of the utmost importance to examine what effects this judgment could have for non-asbestos-related personal injury claims that are also characterized by the problem of causal uncertainty. ${ }^{681}$ The 'scope' of the decision in Nefalit is indeed important for Dutch Tort law and will, therefore, be explored in the next sections. In Nefalit, the Supreme Court decided that, for proportional liability to be applied, the employee must have been exposed to 'a substance which is dangerous for your health. ${ }^{, 682}$ Looking at the exact wording of the Supreme Court's decision, I assume that proportional liability can also be applied in non-asbestos-related cases in which the claimant suffers from an occupational disease after he has been exposed to a substance which is dangerous for his health in the course of his employment. One could, however, wonder whether or not proportional liability, as applied in Nefalit, is/could and/or should (be) applied in personal injury claims for musculoskeletal disorder (RSI), burn-outs as an occupational disease, lung injuries which could have been caused by occupational exposure to tobacco smoke, and cancer as a potential consequence of ionizing radiation exposure in the course of the employment. ${ }^{683}$

Whether or not the application of the proportional liability theory is desirable in such cases should depend on the claimant's injury as the type of injury determines whether the case is concerned with the problem of 'multiple' or 'single' legal causal uncertainty. In section 3.2.5.2.4 a diagram of the requirement of causation is presented in which I will argue in what situations the application of the proportional liability theory produces the most desirable outcome.

\footnotetext{
${ }^{679}$ Van Maanen 2000, p. 43.

${ }^{680}$ In Dutch: 'Vereniging voor Burgerlijk Recht'.

${ }^{681}$ Giesen \& Tjong Tjin Tai 2008, p. 54-55. See also: Giesen 2006, p. 646.

682 '....een voor de gezondheid gevaarlijke stof': Hoge Raad 31 maart 2006, NJ 2011, 250, paragraph 3.13 (Nefalit/Karamus).

${ }^{683}$ Giesen \& Tjong Tjin Tai 2008, p. 86.
} 


\subsection{Claims for burn-outs and RSI}

This section examines the liability for burn-outs and the liability for musculoskeletal disorder (RSI). I argue, in line with the common medical opinion that both diseases can be caused by multiple legally relevant factors. In these particular cases two or more legally relevant possible causes are present where (at least) one of them can be attributed to the claimant. This means that one can speak of 'multiple' legal causal uncertainty which, from my point of view, justifies the application of the proportional liability theory in such cases. In order to make my point clear, I will give two examples. In the first example the employee suffers from a burn-out and in the second example the employee suffers from RSI. The burn-out could have been caused by the employer's intervention because he has put the employee under enormous pressure. ${ }^{64}$ The employee's RSI could also have been caused by the employer's intervention because he took no precautionary measures to prevent RSI and thus breached his duty of care to ensure a safe working environment.

To sum up: in both examples the employers could have caused the employees' burnout/RSI. However, the burn-out could also have been caused by domestic problems (divorce) and the RSI could have been caused by the employee's hobby (playing computer games in his private life). ${ }^{685}$ Both claimants, however, argue that the burn-out/RSI is caused by the employer's intervention and claim full compensation. ${ }^{686}$ In both situations the assessment of causation cannot result in a yes or no answer. Medical science is unable to determine whether the claimant's burn-out or RSI was caused by the employer's intervention, by the employee's private life, or by a combination of both factors. Applying traditional principles, it is most likely that both claimants leave empty-handed because they are not able to prove causation to the required 'reasonable degree of certainty'. Proving the causal relationship between the damage and the job is definitely a burden for the claimant, especially in claims where multiple legally relevant factors are present any one of which could have caused the damage separately. In a recent decision in which the claimant suffered from burn-out, the Court of Appeal rendered that the claimant was unable to prove sufficient causation between his damage (burn-out) and his job, which resulted in the fact that the Court of Appeal dismissed the claim. ${ }^{687}$

The application of the proportional liability theory will lead to the most reasonable outcomes in cases that are characterized by the problem of multiple legal causal uncertainty. ${ }^{688}$ If experts are able to assess the probability of causation between the employer's intervention and the employee's damage (burn-out/RSI), the judge can award damages in proportion to the probability of causation by extending the Nefalit-principle to other

\footnotetext{
${ }^{684}$ See for more information: Charlier 2009, p. 3-5.

${ }^{685}$ In claims for RSI, the Dutch Court of First Instance Middelburg also ruled that private causes (playing computer games at home) cannot be attributed to the employer. See: Kantongerecht Middelburg 1 september 2003, NJ 2003, 736 (Thier/Groeneveld).

${ }^{686}$ See for more information on rules of evidence in such cases: Roest 2008; Verheij 2008, p. 160, 161.

${ }^{687}$ Gerechtshof 's-Gravenhage 7 juli 2009, LJN: BJ3803 (X/Da Vinci College). See also: Rechtbank Maastricht 23 augustus 2006, NJ 2007, 225 in which the Court of First Instance decided that the claimant had made a reasonable case that the defendant did breach his duty of care and that it was up to the defendant (employer) to prove that he did not breach his duty of care.

${ }^{688}$ See for more information: Vegter 2004, p. 73-79.
} 
cases dealing with injuries in which factors in the claimant's private life can also have triggered or caused the claimant's injury. If, in the first example, the probability that the claimant's burn-out was caused by the employer's intervention was assessed at, say: 37 percent, than the judge can, assuming that the other requirements for liability have also been established, hold the negligent employer liable for this 37 percent. The claimant who suffers from a burn-out will subsequently receive 37 percent of the damages claimed and has thus been compensated in proportion to the probability of causation. This way, the negligent employer cannot escape (full) liability and, it is more likely that the damage payment corresponds to the damage that has, in fact, been negligently caused. If the probability of causation is assessed adequately the amount of compensation will almost matches reality. However, we have to keep in mind that, similar to asbestos-related cases, it is impossible to be $100 \%$ certain due to the lack of medical science. Proportional liability must be regarded as 'the least unreasonable' approach to compensate the claimant in cases where the problem of multiple legal causal uncertainty arises. ${ }^{689}$

Some Dutch legal scholars, however, do not favour the option to award damages in line with the probability of causation in claims for burn-outs or RSI. In their view, the Nefalit-principle should not be extended to such cases. ${ }^{690}$ However, case law shows that employers can be held partially liable in claims for RSI. In Thier/Groeneveld ${ }^{691}$ (2003), in which the claimant suffered from RSI, the trial judge established causation on the basis of evidence which was brought into the proceeding, but acknowledged that activities in the claimant's private life, which also could have led to the development of RSI, must be deducted from the total amount of compensation on the basis of Article 6:101 BW. ${ }^{692}$ Contributory negligence as a tool to reduce the total amount of compensation and to reach a proportional outcome will be more extensively discussed in section 3.3.

\subsection{Claims for lung injuries which could have been caused by exposure to tobacco smoke}

The Health Council of the Netherlands published a first report on the health dangers of passive smoking in 1990 and, very reluctantly, concluded that passive smoking could possibly lead to an increased risk of developing lung cancer. ${ }^{693}$ In 2003, the Health Council published a second, and more convincing, report on the dangers of passive smoking. ${ }^{694}$ In this report the Council confirmed the existence of a causal link between passive smoking and the development of lung cancer and concluded that, with regard to adults, passive smoking increases the risk of contracting lung cancer with 20 percent. ${ }^{695}$ This means that the total number of victims who contract lung cancer can be reduced by diminishing the passive exposure to tobacco smoke. ${ }^{696}$ As a consequence of this report, the

\footnotetext{
${ }^{689}$ Spier 1990, p. 9.

${ }^{690}$ Schothorst-Gransier 2006, p. 97-98.

${ }^{691}$ Kantongerecht Middelburg 1 september 2003, NJ 2003, 736 (Thier/Groeneveld).

${ }^{692}$ In this case the employer was, however, unable to prove that factors in the employee's private life could also have triggered or caused the disease. See also: Van Dijk 2006, p. 303.

${ }^{693}$ Gezondheidsraad 1990; Waterman 2005, p. 142: the report had little national impact.

${ }^{694}$ Gezondheidsraad 2003.

${ }^{695}$ Gezondheidsraad 2003, p. 22.

${ }^{696}$ Waterman 2005, p. 143.
} 
Tobacco Act 1998 included a new Article which became effective on 1 January $2004{ }^{697}$ Article 11a (1) Tabakswet reads:

'Employers shall make such arrangements that employees will be enabled to perform their work without experiencing any nuisance or discomfort from the [tobacco] smoke of others. ${ }^{, 698}$

This Article not only places a duty of care on the employer to ensure a smoke-free workplace but also gives the employee a right to enforce a smoke-free workplace. Furthermore, the Articles 10, 11 and 11a Tabakswet made it clear that smoking tobacco is prohibited in all workplaces and all public transport in the Netherlands. ${ }^{699}$ As of 1 January 2004, exposure to tobacco smoke at work could lead to employers' liability on the basis of Article 7:658 BW juncto ${ }^{700}$ Article 11a (1) Tabakswet juncto the relevant Articles of the Arbeidsomstandighedenwet (Working Conditions Act). However, Dutch case law shows that, even before 1 January 2004, an employee was able to successfully enforce a smoke-free workplace in a claim which was, and could only be, based on Article 7:658 BW juncto the Working Condition Act. ${ }^{701}$ This means that the enactment of Article 11a (1) Tabakswet has even more strengthened the position of employees in their pursuit of healthier working conditions.

Case law shows that proportional liability can be applied in a situation where a nonsmoking employee suffered from a lung injury (asthma) after she has been exposed to tobacco smoke at work which could have caused or worsened the claimant's condition. ${ }^{702}$ Nowadays, an employee can successfully sue his employer for not taking sufficient safety measures to ensure a safe smoke-free workplace. In such cases, the employer has breached his duty of care to prevent non-smoking employees from encountering health damage. In Riphagen/Isala ${ }^{703}$ (2009), an employee suffered from asthma which could have been caused or worsened by the passive inhalation of tobacco smoke in the course of the employment. Expert evidence showed that a causal connection between the occurrence of the claimant's asthma and the exposure to tobacco smoke at work, was missing because the claimant suffered from asthma from 1988 onwards. The appointed expert assessed the chance that the exposure to tobacco smoke in the course of the employment

\footnotetext{
${ }^{697}$ Zivcovic 2007, p. 41; http://www.nieuwsbank.nl/inp/2004/02/10/F011.htm [Last visited 31 August, 2012].

${ }^{698}$ Keep in mind that this Article does only count for public places.

${ }^{699}$ Staatsblad 2002, 201: Note that an exception to this rule can be made in specific circumstances. See also: Waterman 2005, p. 144. See for more information on this Act (Tabakswet): www.rokenendewet.nl [Last visited 31 August, 2012].

${ }^{700}$ This means: 'together with' or 'in conjunction with'.

${ }^{701}$ Rechtbank Breda, 25 april 2000, KG 2000, 119; Rechtbank Groningen 15 mei 2007, LJN: BA5126. Article 7:658 BW is not an absolute safeguard for work-related risks. See also: Waterman 2005, p. 149, 150,160 .

${ }^{702}$ Hoge Raad 9 januari 2009, LJN: BG4014 (Riphagen/Isala); Gerechtshof Arnhem 26 september 2006, JAR 2006/30.

${ }^{703}$ Hoge Raad 9 januari 2009, LJN: BG4014 (Riphagen/Isala). See also: Gerechtshof Arnhem 26 september 2006, JAR 2006/30, paragraph 2.12. See for more information: Keirse 2010, p. 352-360; Zivkovic 2007, p. 38-45; Waterman 2005, p. 141-168; Verheij 2008, p. 157, 158; Klaassen 2007, p. 1357.
} 
had worsened the claimant's injury at 80 to 100 percent. ${ }^{704}$ However, expert evidence further concluded that there is an 80 to 100 percent chance that the claimant's injury would also have worsened without the exposure to tobacco smoke in the course of the employment. ${ }^{705}$ The Supreme Court, affirming the judgment of the Court of Appeal ${ }^{706}$, ruled - on the basis of Article 7:658 BW - that the employer (Isala) was partial liable for 50 percent of the claimant's damages. In view of the Supreme Court, passive smoking might have affected the claimant's condition to the same extent (50\%) as all other factors taken together. ${ }^{707}$

Experts will have to assess the probability that the exposure to tobacco smoke in the course of the employment has caused or worsened the claimant's injury. The duration and intensity of the exposure should be taken into consideration in order to adequately assess the liability of the employer. However, it is most likely that the claimant has also been exposed to tobacco smoke outside the course of the employment, which does not even touch the sphere of employment. The intensity and duration of this different source of exposure to tobacco smoke should also be taken into consideration because employers cannot be held responsible for such circumstances in the claimant's private life (private causes). Extensive epidemiological research in this field is a prerequisite for obtaining more accurate information about the way in which the passive inhalation of tobacco smoke affects the likelihood of the development of lung injuries among people who do not smoke themselves.

In Riphagen $/$ Isala $^{708}$, the probability that the exposure to tobacco smoke in the course of the employment has caused or worsened the claimant's injury, has been questioned in legal writings. ${ }^{709}$ The main critique is that the assessed probability of causation here is arbitrary due to the lack of extensive epidemiological research in this particular field. ${ }^{710} \mathrm{I}$ agree, but it is important to acknowledge that there is no perfect solution to this problem. It goes without saying that more epidemiological research is required to assess the probability of causation in such cases more precisely. In addition, it is important that courts acknowledge openly that there is a lack of evidence in such cases. Moreover, courts must motivate their decisions to award a part of the claimant's total damages more extensively, which has also been emphasized by the Dutch Supreme Court in Fortis/Bourgonje $e^{711}$.

\subsection{Claims for ionizing radiation exposure}

Employees who have been, and are being, exposed to ionizing radiation in the course of their employment may become ill as a result. A physician (employee) who developed a

\footnotetext{
${ }^{704}$ Gerechtshof Arnhem 26 september 2006, JAR 2006/30, answer to question 13.

${ }^{705}$ Gerechtshof Arnhem 26 september 2006, JAR 2006/30, answer to question 14.

${ }^{706}$ Gerechtshof Arnhem 26 september 2006, JAR 2006/30.

${ }^{707}$ Keirse 2010, p. 357.

${ }^{708}$ Hoge Raad 9 januari 2009, LJN: BG4014 (Riphagen/Isala). See also: Gerechtshof Arnhem 26 september 2006, JAR 2006/30, paragraph 2.12. See for more information: Keirse 2010, p. 352-360; Zivkovic 2007, p. 38-45; Waterman 2005, p. 141-168; Verheij 2008, p. 157, 158; Klaassen 2007, p. 1357.

${ }^{709}$ Zivkovic 2007, p. 40.

${ }^{710}$ Zivkovic 2007, p. 38-45.

${ }^{711}$ Hoge Raad 24 december 2010, NJ 2011, 251 (Fortis/Bourgonje).
} 
cancerous tumour might sue his employer (hospital) because there is a possibility that his damage was caused by the occupational ionizing radiation exposure. ${ }^{712}$ However, similar to claims for lung cancer as a potential consequence of asbestos exposure, the cancerous tumour could also have been caused by other legally relevant factors. In cases of ionizing radiation exposure, medical science is unable to determine the cause of the claimant's cancerous tumour. The problem of multiple legal causal uncertainty does arise in such cases, which could justify the application of the proportional liability theory. Assuming that the ionizing radiation exposure was wrongful, epidemiologists will have to assess the probability that the claimant's cancer was caused by the occupational ionizing radiation exposure in order to establish the liability of the defendant. The duration and intensity of the exposure should be taken into consideration in order to adequately assess the liability of the employer. However, epidemiological studies have established that the probability of causation, or in other words: the probability that the ionizing radiation exposure has caused the claimant's cancer, is very low in cases in which the claimant has been occupationally exposed to ionizing radiation.

As examined in section 2.6.3.2.6, Nefalit $^{713}$ has restricted the application of the proportional liability theory by a minimum and a maximum probability of causation in order to reach reasonable outcomes and to prevent a floodgate of claims. This means that the assessed probability of causation might be too low to award damages in proportion to the probability of causation in claims for ionizing radiation exposure.

\subsection{A diagram of the requirement of causation in Dutch law}

\footnotetext{
${ }^{712}$ Note that the physician can only sue his employer (hospital) on the basis of Article 7:658 BW in case he worked in a so called 'arts-in hospital'. This means that the physician is employed by the hospital.

${ }^{713}$ Hoge Raad 31 maart 2006, NJ 2011, 250 (Nefalit/Karamus).
} 


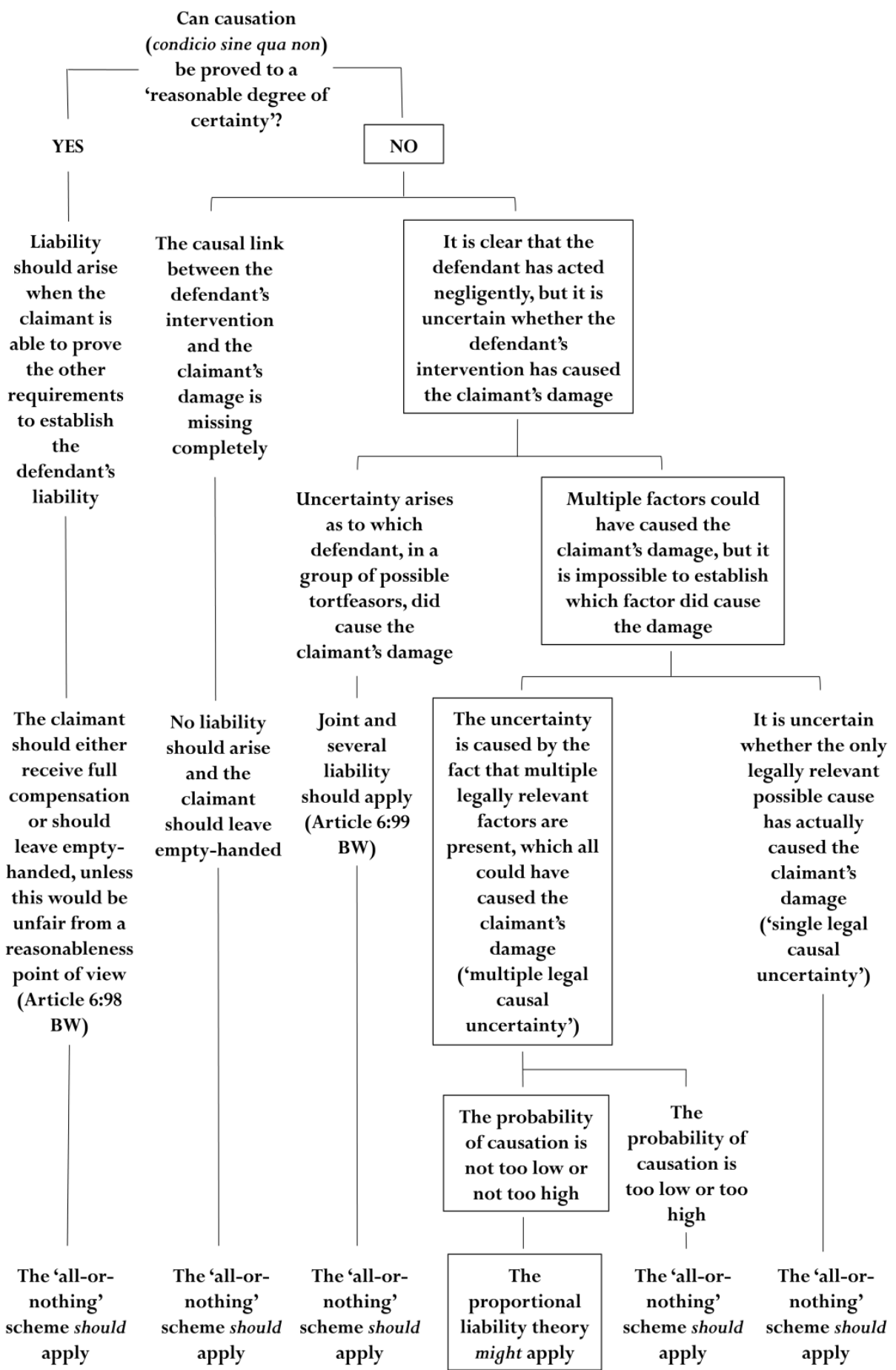




\subsubsection{Conclusion}

In Nefalit/Karamus, the Dutch Supreme Court applied the proportional liability theory for the first time in March 2006 and clearly deviated from the traditional principle of allor-nothing compensation in claims for lung cancer that could have been asbestos-related. Apparently, the Supreme Court was of the opinion that it was not fair to deny all compensation or to award full compensation in cases where the actual cause of the claimant's damage could not be determined. On 24 December 2010, the Supreme Court has - for the first time - extended the application of the proportional liability theory and acknowledged that the Nefalit-principle can also be applied in 'the general law of obligations'. In Fortis/Bourgonje ${ }^{714}$, the Supreme Court made it very clear that the Nefalit-principle must be applied with caution because the application of this rule could lead to liability for damage which the defendant did not cause. ${ }^{715}$ The Supreme Court emphasized that judges must extensively motivate their decision to award damages in proportion to the probability of causation. ${ }^{716}$ What will be the effect of the Nefalit decision on claims for specific other personal injuries?

The answer to this question should depend on the type of injury from which the claimant suffers. First of all, it is important to emphasize that - in an environment of causal uncertainty - there are always two or more causes that could have caused the claimant's damage. However, from a legal point of view it is essential to make a distinction between, on the one hand, situations where the causal uncertainty is caused by the fact that multiple legally relevant factors are present which all could have caused the claimant's damage (multiple legal causal uncertainty), and on the other hand, situations where it is uncertain whether the only legally relevant possible cause has actually caused the claimant's damage (single legal causal uncertainty). In cases concerned with the problem of single legal causal uncertainty, there are still multiple factors that could have caused the claimant's damage but only one possible cause is legally relevant. The distinction between multiple and single legal causal uncertainty must be regarded as a legal tool to reach desirable outcomes. The application of the proportional liability theory is seen as a justified solution to compensate the claimant in cases concerned with the problem of 'multiple' legal causal uncertainty. The option to award damages in proportion to the probability of causation produces the most reasonable results in such cases. Applying proportional liability, it is more likely that liability and damage payments correspond to the damage that has, in fact, been negligently caused. The all-or-nothing solution, on the other hand, produces the most reasonable results in cases concerned with the problem of 'single' legal causal uncertainty. From a legal point of view, the only legally relevant possible cause for which the defendant is responsible did or did not cause the claimant's damage.

\footnotetext{
${ }^{714}$ Hoge Raad 24 december 2010, NJ 2011, 251 (Fortis/Bourgonje).

${ }^{715}$ Hoge Raad 24 december 2010, NJ 2011, 251, paragraph 3.8 (Fortis/Bourgonje). See also: Roijackers 2011, p. 4; Sobczak 2011, p. 32; Witjens 2011, p. 104; van Tricht 2011, p. 6-9; Giesen 2011, p. 149-150.

${ }^{716}$ Hoge Raad 24 december 2010, NJ 2011, 251, paragraph 3.8 (Fortis/Bourgonje): ‘.....de rechter die daartoe besluit, in zijn motivering dient te verantwoorden dat de strekking van de geschonden norm en de aard van de normschending - waaronder is begrepen de aard van de door de benadeelde geleden schade deze toepassing in het concrete geval rechtvaardigen.'
} 
Personal injuries, such as: burn-outs, RSI, lung injuries which could have been caused or worsened by occupational exposure to tobacco smoke, and cancer as a potential consequence of ionizing radiation exposure can be regarded as cases that are characterized by the problem of multiple legal causal uncertainty because multiple legally relevant possible causes do arise in such cases. Proportional liability might be applicable in such cases, which means that the judge can award damages in proportion to the probability of causation. If the probability of causation can be assessed adequately, the application of the proportional liability theory produces a fairer result than had previously been applied. However, the application of proportional liability could lead to incorrect judgments due to the lack of extensive epidemiological research in particular fields. Furthermore, it should be noted that the assessed probability of causation might not exceed the threshold to justify the application of proportional liability. Claims for ionizing radiation exposure might, although the Supreme Court has not expressed the minimum threshold to apply proportional liability in a percentage, not trespass this minimum threshold.

\subsection{Contributory negligence as a tool to reduce the total amount of damages}

In contrast to the Dutch jurisdiction, English courts have not applied the instrument of proportional liability to solve asbestos-related cases in which an employee developed lung cancer as a potential consequence of asbestos exposure. English courts do not directly award damages in proportion to the probability of causation but use the concept of contributory negligence to reduce the total amount of compensation in order to reach a proportional outcome. The facts in Shortell $v$ Bical Construction $\operatorname{Ltd}^{717}$ are almost similar to the facts in the Dutch case Nefalit/Karamus ${ }^{718}$, which makes the cases suitable for comparison: the defendant has wrongfully exposed the employee to asbestos in the course of the employment, the employee contracted lung cancer as a potential consequence of asbestos exposure, the employee did not suffer from asbestosis first, the employee was a heavy smoker, and the causal link between the wrongful exposure to asbestos and the lung cancer was uncertain. However, Dutch and English courts have, irrespective of the similarity, decided to approach the problem of uncertain causation differently. ${ }^{719}$

The Dutch approach, in which the concept of contributory negligence also plays a key role to determine the amount of compensation, has been discussed in the sections 2.6.3.2.2 and 3.2 and will not - again - be subject to discussion here. This section explores how English law uses the concept of contributory negligence to reach a proportional outcome in asbestos-related cases in which a smoking claimant contracted lung cancer that could have been caused by the wrongful occupational exposure to asbestos. In Shortell, the court applied traditional causation principles (but-for test) and decided that the claimant must prove that the wrongful exposure to asbestos has more than doubled the risk of lung cancer in order to establish the liability of the defendant. Following the expert evidence, the court is satisfied on the balance of probabilities that the defendant's

\footnotetext{
${ }^{717}$ Shortell v Bical Construction Ltd., [2008] QBD Liverpool (16-05-2008).

${ }^{718}$ Hoge Raad 31 maart 2006, NJ 2011, 250 (Nefalit/Karamus).

${ }^{719}$ See: Sobczak 2010b, p. 1155-1179.
} 
breach of duty has on any view more than doubled Mr Shortell's relative risk ${ }^{720}$ of contracting lung cancer. ${ }^{721}$ However, applying the decision in Badger v Ministry of Defence ${ }^{722}$, the judge decided, in line with the decision of the Dutch Supreme Court in Nefalit, that Mr Shortell's smoking history constituted contributory negligence and that Mr Shortell himself was responsible for the damage caused by his smoking. The fact that Mr Shortell had not given up smoking constituted contributory negligence because the lack of care that he took for his own health fell below the standard to be expected of a person in his position at that time. ${ }^{723}$ The concept of contributory negligence has been created to acknowledge that a person has a certain responsibility for his own actions. Section 1 (1) of the Law Reform (Contributory Negligence) Act 1954 reads:

'Where any person suffers damage as a result partly of his own fault and partly of the fault of any other person or persons.... the damages recoverable in respect thereof shall be reduced to such extent as the court thinks just and equitable having regard to the claimant's share in the responsibility for the damage.'

Subsequently, the court assessed the likelihood that Mr Shortell's smoking history had caused the lung cancer in order to reduce the total amount of compensation. The High Court ruled that 15 percent was an appropriate reduction in damages and awarded 85 percent of the total damages. English law thus uses the concept of contributory negligence to reduce the total amount of compensation in cases in which a smoking claimant is able to prove sufficient causation between the occupational exposure to asbestos and the claimant's lung cancer.

\subsubsection{Pros}

Under English law, as in Dutch law, the claimant's smoking history is seen as a potential cause of the damage for which the claimant himself is responsible. In such cases the English technique to apply the concept of contributory negligence to reduce the total amount of compensation is, compared to the traditional principle of all-or-nothing compensation, a more reasonable approach to compensate the claimant: it is more likely that liability and damage payments correspond to the damage that has, in fact, been negligently caused. If it has been established that the claimant has contributed to his own damage, it would be unfair to oblige the defendant to compensate the claimant's damage in full. In section 3.2.2, I have argued that the legal instrument to award damages in proportion to the probability of causation reduces the problem of over- and under-compensation, leads to less over- and under-deterrence, and leads to less arbitrary judgments. These arguments in favour of the application of the proportional liability theory also - although in a

\footnotetext{
${ }^{720}$ Relative measure of risk estimating the magnitude of association between an exposure and disease (or other outcome) indicating the likelihood of developing the disease in those exposed relative to those unexposed. See section 4.3.2 for more information.

${ }^{721}$ Shortell v Bical Construction Ltd., [2008] QBD Liverpool (16-05-2008), paragraph 49.

${ }^{722}$ Badger v Ministry of Defence, [2005] EWHC 2941 (QB), [2006] 3 ALL ER 173.

${ }^{723}$ Shortell v Bical Construction Ltd., [2008] QBD Liverpool (16-05-2008), paragraph 37. See for a similar reasoning in the Badger case: Maclntyre 2008, p. 380.
} 
less convincing way - apply to the approach taken by the English courts in the cases Shortell and Badger. ${ }^{724}$

\subsubsection{Cons}

What drawbacks are connected to the English approach? First, it should be noted that the English claimant must, contrary to the Dutch claimant, be able to prove causation on the basis of traditional principles in order to establish the liability of the defendant. This means that the claimant must be able to prove that the occupational exposure to asbestos has more than doubled the claimant's relative risk of contracting lung cancer. In the majority of the cases, a smoking employee who has not been exposed to high dust concentrations will not be able to prove causation on the balance of probabilities. In such a situation, the claimant leaves empty-handed as he is unable to prove a fundamental requirement to establish liability in negligence. This is unfair towards the claimant: epidemiological findings have established that there could still be a considerable chance (0 to $50 \%$ ) that the defendant's intervention has caused his damage.

Secondly, and assuming that the claimant was able to prove causation, awarding partial compensation still leads to over- and under-compensation in such cases. It is impossible to precisely (with 100\% certainty) establish the cause of the claimant's damage. All decisions, including the ones in which the judge decides to award partial compensation, remain more or less arbitrary. Estimating the claimant's contributory negligence inserts a certain element of speculation and thus does not correspond with reality. Therefore, it is of the utmost importance that the probability, that the lung cancer was caused by the claimant's smoking history, is assessed more precisely in future decisions. More epidemiological research is needed to adequately determine the claimant's degree of contributory negligence.

Thirdly, one could wonder what the English court's decision would be if Mr Shortell did not smoke. In such a hypothetical situation, it seems that the claimant would have received full compensation because he did not contribute to his own damage. However, there is, as is shown in Dutch case law ${ }^{725}$, still a chance that the lung cancer was caused by (an)other factor(s) than asbestos exposure, such as: the claimant's genetic predisposition, age, and external factors. This way, the decision to award full compensation in cases in which the claimant did not smoke seems to be unfair towards defendants now that it has been established that there is still a considerable chance that the defendant's intervention did not cause the claimant's damage in such a situation.

\subsubsection{Weighing the pros and cons}

As has been examined in the former sections, the English technique to apply the concept of contributory negligence to reduce the total amount of compensation has its pros and cons. First of all, it is important to acknowledge that it is impossible to precisely (with $100 \%$ certainty) establish the probability that the claimant's lung cancer was caused by the wrongful exposure to asbestos. English courts have, in line with the Dutch Supreme

\footnotetext{
${ }^{724}$ I refer to the sections 2.6.3.3, 3.2.2, and 3.3.2 for more information.

${ }^{725}$ Hoge Raad 31 maart 2006, NJ 2011, 250 (Nefalit/Karamus); Hoge Raad 31 maart 2006, LJN: AU6093 (Hollink/Eternit).
} 


\section{Chapter 3}

Court's decision in Nefalit, decided that the claimant's smoking history constitutes contributory negligence. If the claimant is able to prove that the wrongful exposure to asbestos has more than doubled the risk of contracting lung cancer, the total amount of compensation can be reduced by the amount to which smoking contributed to the damage. This way, the concept of contributory negligence is used as a tool to reach a proportional outcome. This approach is, when compared to the Dutch proportional liability theory, less victim-friendly in most situations: a smoking claimant still leaves empty-handed in the majority of the cases as he is unable to prove a sufficient causal link on the traditional balance of probabilities. Under Dutch law, case law shows that the claimant can - if the assessed probability of causation is not too low - still be compensated in proportion to the probability of causation in cases in which the wrongful occupational exposure to asbestos did not double the risk of lung cancer. ${ }^{726}$ However, the technique applied in English law to reach a proportional outcome is still, when compared to the traditional principle of all-or-nothing compensation, a more reasonable solution to settle such cases. The claimant's degree of contributory negligence should, however, be assessed more precisely as the claimant's smoking history is clearly important in the development of lung cancer.

\subsection{The loss of a chance theory}

Another approach that leads to a proportional outcome is to base the amount of compensation on the claimant's 'lost chance' on a better outcome. The issue of loss of a chance is raised in situations in which the negligence of one person destroys the chance of an outcome favourable to another, but has not been applied in claims for mesothelioma or lung cancer that could have been asbestos-related. ${ }^{727}$ Generally, one can argue that the loss of a chance theory has a broader acceptance when compared to the option to award damages in proportion to the probability of causation (Nefalit-principle). The distinction between the two lies in the fact that - in claims for loss of a chance - the claimant's damage is expressed in chances, while under the Nefalit-principle the probability that the wrongful intervention of the defendant did cause the claimant's damage is expressed in chances. ${ }^{728}$ The loss of a chance theory is commonly known and applied in several jurisdictions, such as: France and Belgium (perte d'une chance). In other continental legal systems, for example in Germany, courts do not award compensation for lost chances. In a common law legal system such as England, compensation for lost chances is awarded in certain categories of cases but is not applicable in others.

Applying traditional principles to establish causal relationships, liability cannot be established in cases where the causal link is too uncertain. In very specific cases it is, however, possible to prove condicio sine qua non between the 'damage' (lost chance) and the wrongful conduct of the tortfeasor. This way, the damage consists of a lost chance to a specific benefit ${ }^{729}$ or a lost chance to avoid a disadvantage ${ }^{730}$. Where causation cannot be

\footnotetext{
${ }^{726}$ Centrale Raad van Beroep 9 april 2009, LJN: BI2805.

${ }^{727}$ Kadner Graziano 2008, p. 1033.

${ }^{728}$ Van \& Wijne 2012, p. 20. See also: Hoge Raad 31 maart 2006, NJ 2011, 250 (Nefalit/Karamus): noot

T.F.E. Tjong Tjin Tai.

${ }^{729}$ For example: to win a price or to win a lawsuit.

${ }^{730}$ For example: a disease.
} 
established with regard to the 'final damage', it can be clearly established with regard to the damage of obtaining a better result (lost chance). ${ }^{731}$ The problem of uncertain causation is thus solved by reformulating the claimant's damage: it is clear that the defendant's intervention has caused the claimant's loss of a chance. Subsequently, the claimant's damage will be compensated in accordance with the assessed lost chance on a better outcome. This way, the lost chance is seen as a separate head of damage which is eligible for compensation. Khoury's definition is most clear: 'If before the defendants fault intervened, a plaintiff possessed a chance to make a gain or to avoid a loss, and the fault destroyed that chance, the plaintiff can obtain compensation for the value of that lost chance instead of claiming for the negative situation in which he has been left. ${ }^{732}$

The basic idea behind the assumptions of a lost chance as a head of damage is that such a chance has a value and that this value can be expressed in money. The question of whether 'chances' can be valued and whether or not this value can be expressed in money has been heavily debated. The general view is that chances do have an economic value. A good example is a lottery ticket. If you have bought a lottery ticket you have a, say: 1:1.000.000 chance, to win Euro 1.000.000,-. The chance to win the Jackpot can be expressed in money. In addition, chances can also influence the value of an object. Here, one could think about a property which is for sale: if there is a chance that a coffee shop $^{733}$ will be build in front of the property the market value of the house is most likely influenced in a negative way. But do medical lost chances also constitute a separate head of damage in the jurisdictions taken under consideration here?

\subsubsection{Applying the loss of a chance theory in Dutch law}

In Dutch law, the loss of a chance theory is notably applied in medical malpractice cases as well as situations in which lawyers allow a term (of appeal) to expire. ${ }^{734}$ In medical malpractice cases the patient or his or her relatives claim to have lost a chance of either being completely healed or that they have lost a chance of being in a better condition, due to the absence of treatment or delay in treatment. In order to determine the lost chance the judge has to make an assessment of the chance on recovery that would have existed had the default not been made. ${ }^{735}$

The loss of a chance theory has, to my knowledge, for the first time been applied by the District Court Utrecht in $1942 .{ }^{736}$ In this case, the claimant's claim was declared

\footnotetext{
731 See for example: Rechtbank Utrecht 8 december 2010, LJN: BO6888; Rechtbank Amsterdam 14 juli 2010, LJN: BO3288; Gerechtshof Amsterdam 4 januari 1996, NJ 1997, 213 (Baby Ruth). See also: MartínCasals 2008, p. 1048.

${ }^{732}$ Khoury 2006, p. 93.

${ }^{733}$ A store or a shop where soft drugs are sold.

${ }^{734}$ The Dutch Supreme Court applied the loss of a chance theory in cases in which solicitors allow a term (of appeal) to expire: Hoge Raad 24 oktober 1997, NJ 1998, 257 (Baijings/mr. H); Hoge Raad 19 januari 2007, NJ 2007, 63 (Kranendonk Holding/A. Advocaten); Hoge Raad 16 februari 2007, RvdW 2007, 203 (Gebroeders Tuin Beheer/mr. X).

${ }^{735}$ I refer to Van \& Wijne 2012, p. 16-24 who have clearly illustrated what failures can be made in assessing the loss of a chance in an individual case. See for an incorrect assessment in case law: Rechtbank Amsterdam 14 juli 2010, JA 2011, 4; Gerechtshof 's-Gravenhage 28 april 2009, LJN: BI4768; Rechtbank Maastricht 13 juli 2005, JA 2006, 44.

${ }^{736}$ Rechtbank Utrecht 28 oktober 1942, NJ 1943, 231.
} 
inadmissible due to a fault of his solicitor since he forgot to attend in court. The District Court Utrecht ruled that the claimant's lost chance had to be compensated. The court estimated the lost chance on a better outcome at 50 percent and held the solicitor liable for this 50 percent without any further motivation. The court did not explain how this percentage (lost chance) was assessed. It goes without saying that this judgment has received a considerable amount of discussion and criticism because the judge did not explain his decision to award compensation. The awarded 50 percent was seen as a random choice. In January 2007, the Dutch Supreme Court has affirmed the applicability of the loss of a chance theory in legal malpractice cases. ${ }^{737}$ In addition, Courts of First Instance have clearly recognized that health chances do constitute a separate head of damage and that the loss of a chance theory is applicable in medical malpractice cases. ${ }^{738}$ However, the applicability of the loss of a chance theory in such cases has not yet been confirmed by the Supreme Court.

\subsubsection{Applying the loss of a chance theory in English law}

Under English law, the claimant's lost chance is treated as actionable damage in specific cases. ${ }^{739}$ A century ago (1911), the Court of Appeal applied the loss of a chance theory for the first time in Chaplin ${ }_{v} H_{i c k s}{ }^{70}$. The facts are described very shortly: the claimant entered into a beauty contest organized by Mr Hicks. The organizer offered engagements as actresses to the twelve contestants selected by the votes of readers of the newspaper. The claimant's picture was selected by the readers of the newspaper. The claimant was one of the 50 contestants who made it to the final. This selection entitled her to an interview for the final selection in which Mr Hicks would chose the twelve winners of a three year theatrical engagement. However, Mr Hicks did not give her adequate notice of the interviews and the twelve winners were chosen in her absence. Subsequently, she was refused an interview. ${ }^{741}$ It was impossible for her to prove that she would have succeeded in the contest. In view of judge Vaughn Williams, the fact that the damage could not be assessed with certainty did not mean that the defendant had no obligation to compensate the claimant's damage. ${ }^{742}$ Therefore, the Court of Appeal awarded $£ 100$ for her lost

\footnotetext{
737 Hoge Raad 19 januari 2007, NJ 2007, 63 (Kranendonk Holding/A. Advocaten). See also: Rechtbank Utrecht 20 februari 2008, JA 2008, 61; Hoge Raad 16 februari 2007, RvdW 2007, 203 (Gebroeders Tuin Beheer/mr. X); Hoge Raad 24 oktober 1997, NJ 1998, 257 (Baijings/mr. H).

${ }^{738}$ Dutch courts, except for the Supreme Court, applied the loss of a chance theory in medical malpractice cases: Gerechtshof Amsterdam 4 januari 1996, NJ 1997, 213 (Baby Ruth); Rechtbank Middelburg 11 maart 1998, NJ 1999, 41; Rechtbank Amsterdam 28 oktober 1998, NJ 1999, 406; Gerechtshof Arnhem 24 juni 1997 en 14 december 1999, NJ 2000, 742; Rechtbank Zwolle 31 mei 2000, NJkort 2000, 89; Gerechtshof 's-Gravenhage 10 oktober 2002, NJ 2003, 99; Rechtbank Amsterdam 28 mei 2003, NJ 2004, 45; Rechtbank Amsterdam 22 december 2004, VR 2005, 104; Rechtbank Maastricht 13 juli 2005, JA 2006, 44; Gerechtshof Arnhem 17 januari 2006, JA 2006, 37; Gerechtshof 's-Gravenhage 28 april 2009, LJN: BI4768; Rechtbank Amsterdam 14 juli 2010, LJN: BO3288. See also: Van \& Wijne 2012, p. 16-24; Van Velthoven 2011, p. 18-37.

739 See for example: Chaplin v Hicks, [1911] 2 KB 786, CA; Kitchen v Royal Air Forces Association, [1958] 1 W.L.R. 377; Spring v Guardian Assurance Plc, [1995] 2 AC; Allied Maples Group Ltd v Simmons and Simmons, [1995] WLR 1602.

${ }^{740}$ Chaplin v Hicks, [1911] 2 KB 786, CA.

${ }^{741}$ McGregor 2008, p. 2-12.

${ }^{742}$ Chaplin v Hicks, [1911] 2 KB 786, CA.
} 
chance to win the competition. The court ruled that the claimant had lost something of value that could be considered as damage. It was held that, for the quantification of the claimant's damage, a precise amount was not necessary. The argument that the assessment of the lost chance is too difficult should never be a reason to deny recovery when someone is legally entitled to it. ${ }^{743}$ Chaplin is seen as the starting point to award damages for a loss of a chance. The evidence of some prospect of success seemed to be sufficient to establish damages for a lost chance, which means that chances can be taken into consideration when assessing the claimant's damage.

After the decision in Chaplin, the idea of awarding damages for a loss of a chance remained quiescent for decades. However, in the 1950 s the idea was pushed forward. ${ }^{744}$ The most common examples are found in cases where a client's claim has become timebarred due to negligent solicitors. In such cases the court will assess damages to the chances that the claim would have otherwise been successful. In Kitchen $v$ Royal Air Forces Association $^{745}$, the claimant's husband had been electrocuted and died while preparing tea in the kitchen of his home. In respect of the wife's possible action against the electricity company under the Fatal Accidents Act 1846, her solicitor let the limitation period run out in the vague hope of obtaining a satisfactory ex gratia $^{746}$ payment. The solicitor thus failed to issue a writ in time. The Court of Appeal held that the claimant was entitled to damages assessed proportionately, according to the chances that she would have had of winning a Fatal Accident Act claim. Taking into consideration the fact that a chance existed that she would have lost the original case, the Court of Appeal upheld an award of $£ 2000$ in damages. ${ }^{747}$ So, if a lawyer negligently fails to bring a claim in time, he can be held responsible for an amount corresponding to the probability of the lost chance. ${ }^{748}$ In English law, many examples exists of cases in which the court awarded damages for loss of a chance in professional negligence actions, primarily against solicitors in litigation ${ }^{749}$, but courts have also awarded damages for loss of a chance actions against accountants. ${ }^{750}$ But do health chances also constitute a separate head of damage which is eligible for compensation, like in the Dutch jurisdiction?

In Hotson v East Berkshire Health Authority ${ }^{751}$, it seemed that the Law Lords were afraid that excepting a loss of a chance as actionable damage would cause the abandoning of the

\footnotetext{
${ }^{743}$ Jansen 1999, p. 271-196.

${ }^{744}$ McGregor 2008, p. 2-12.

${ }^{745}$ Kitchen $v$ Royal Air Forces Association, [1958] 1 W.L.R. 377.

${ }^{746}$ An ex gratia payment is a payment made without the giver recognizing any liability or legal obligation.

${ }^{747}$ Burrows 2008, p. 31-43.

${ }^{748}$ Kadner Graziano 2008, p. 1025.

${ }^{749}$ Sharif $v$ Garrett \& Co, [2001] EWCA Civ 1269.

${ }^{750}$ John D. Wood \& Co Ltd v Knatchbull, [2002] EWHC 2822 QB.

${ }^{751}$ Hotson v East Berkshire Health Authority, [1987] AC 750: The claimant tried to obtain compensation for diminished prospect and formulated his claim as a loss of a chance for avoiding harm. I sketch the facts very shortly: a young boy, aged 13, fell out of a tree and was brought to the hospital for further examination. However, the injury which he sustained (a fracture of the left femoral epiphysis: hip joint) was falsely diagnosed nor treated due to a breach of duty by the attending doctor. Subsequently, Hotson was sent home. After suffering severe pain during 5 days Hotson went back to the hospital. This time the injury was correctly diagnosed and treated: doctors established that the patient suffered from avascular necrosis resulting in a permanent deformity of the hip. Medical science was unable to establish whether the avascular necrosis was caused by the delay in treatment or had been present from the onset of the fall.
} 
all-or-nothing approach in medical malpractice cases. In addition, and closely connected to the first point, the Law Lords were also afraid that the but-for test to establish causation would be set aside. ${ }^{752}$ The House of Lords, however, avoided the question of whether or not a lost chance to avoid harm can be considered as actionable damage. This means that the House of Lords did not - as such - reject the loss of a chance approach in medical malpractice cases in which the causal link is uncertain. After Hotson, it was still unclear whether a loss of a chance to a better outcome in medical malpractice cases can be considered as actionable damage and thus whether such a chance is eligible for compensation. The answer to this question must be clarified in a future decision. Seven years after Hotson, this day finally arrived in the form of Gregg $v S_{c o t t}^{753}$ (2005) in which the House of Lords made it very clear that medical lost chances are not accepted as a separate head of damage under English law. However, the minority, consisting of Lord Nicholls and Lord Hope, favoured application of loss of a chance in medical malpractice cases. Lord Hoffmann and Baroness Hale were opposed, so it was up to Lord Phillips to decide whether a loss of a health chance could be seen as damage in his own right. Lord Phillips, who supported the majority opinion, held that Mr Gregg was unable to prove that he lost a chance of a better medical outcome since he was still alive eight years after his cancer treatment started. Lord Phillips could: 'envisage the application of this approach once the adverse outcome, which the exercise of due care might have averted, has occurred., 754 However, he found it: 'less easy to see the basis on which the claim is established where the adverse outcome is still prospective. ${ }^{, 755}$

Policy arguments, such as the fear of opening the floodgates of litigation in claims against medical practitioners and health services, was the main reason not to award damages for loss of a chance in Gregg and Hotson. Awarding compensation on the basis of loss of a chance would have radical effects: 'almost any claim for loss of an outcome could be reformulated as a claim for loss of a chance of that outcome. ${ }^{756}$ Lord Hoffmann argued, in line with Lord Phillips and Baroness Hale, that, even if such a radical reform would be desirable in cases of medical malpractice, it would be a matter for Parliament and not for courts to decide. ${ }^{757}$ The House of Lords applied traditional principles and ruled that if $\mathrm{Mr}$ Gregg was able to prove - on the balance of probabilities - that the doctor's negligence

\footnotetext{
${ }^{752}$ Hotson v East Berkshire Health Authority, [1987] AC 750.

${ }^{753}$ Gregg v Scott, [2005] UKHL 2: in 1994, Mr Gregg consulted the defendant, Dr Scott (General Practitioner), after he discovered a lump under his arm. Dr Scott diagnosed a benign tumour. However, he breached his duty of care because he did not refer Mr Gregg to a specialist for further diagnosis. In 1995, Mr Gregg decided to contact another doctor who referred him to a tumour specialist for further diagnosis. A biopsy had to be taken in the hospital which revealed that Mr Gregg's tumour was not benign but malignant. The specialist diagnosed him with non-Hodgkin's lymphoma. In the nine months between the first and the second consult the cancer has spread. Medical statistics were used as evidence in court and revealed that the claimant would have had a 42 percent chance of long term survival (10 years) if there had been no negligence in the handling of his case, but at the date of trial, some five years after the first consult, he had only a 25 percent chance of living another five years. Evidence showed that his chance for cure, or survival for more than 10 years, had fallen from 42 percent to 25 percent as a result of the nine months delay in treatment due to Dr Scott's negligence.

${ }^{754}$ Gregg v Scott, [2005] UKHL 2, paragraph 188 (Lord Phillips).

${ }^{755}$ Gregg v Scott, [2005] UKHL 2, paragraph 188 (Lord Phillips).

${ }^{756}$ Gregg v Scott, [2005] UKHL 2, paragraph 190 (Lord Phillips).

${ }^{757}$ Gregg v Scott, [2005] UKHL 2, paragraph 90, 174 (Lord Hoffmann, Lord Phillips).
} 
has caused his damage he would have received full compensation. However, if it is more likely that the doctor's negligence did not cause the damage then the defendant does not have to compensate damage for the 20 percent or 30 percent chance that it did. This way: 'a more likely than not approach to causation suits both sides. ${ }^{, 758}$

Applying loss of a chance, the overall costs of liability would definitely rise. All cases that now succeed would be decided in the same way: if the claimant is able to prove causation 'on the balance of probabilities', the defendant is liable in full. However, the claims that now fail might succeed in part, that is, in proportion to the lost chance on a better outcome. ${ }^{759}$ The English approach not to apply the loss of a chance theory in medical malpractice cases has led to much discussion and criticism in legal writings. Jansen and Edis argue that it does not make sense to protect economic interest better than physical interest. This way, pure economic loss is better protected than life itself. They do not see the rationale of this approach and do not see any reason not to extent the applicability of loss of a chance to medical malpractice cases: it is unacceptable that a loss of a chance to win a beauty contest is recoverable while a physical loss of a chance is not. ${ }^{760}$

\subsubsection{Critique and discussion}

Although Dutch Courts of First Instance and the majority of legal scholars favour the loss of a chance theory, some Dutch legal scholars are not satisfied with the option to award compensation for loss of a chance in medical malpractice cases. Some academics fear that application of the loss of a chance theory in medical negligence cases will have an adverse impact on costs and quality of health care because of the practices of defensive medicine and cost containment, which hospitals will apply to prevent liability. Furthermore, Peeperkorn argues that it is not possible to attach economic value to health chances. A chance is just a chance and nothing else. He agrees that the loss of a chance theory can be applicable when the lost chance is seen as a separate head of damage. However, Peeperkorn argues that the health chance itself is not a separate head of damage which is eligible for compensation. In his view, the health damage itself should not be seen as a loss of a chance, but as a concrete loss or diminishing in labour-capacity. The difference in your wallet that is what counts. In addition, macro economic arguments are used to assign value to health chances while health chances need to be determined on a micro (individual) level. ${ }^{761}$ In Hotson $v$ East Berkshire Health Authority ${ }^{762}$, judge Croom-Johnson has used the same argument to deny application of loss of a chance in medical malpractice cases because it is 'a statistical chance against the whole world and not an individual chance. ${ }^{763}$

Peeperkorn argues that scholars such as Akkermans, treat the lost chance as a 'damage issue' while it should be treated as an 'issue of causation'. Martín-Casals underlined this problem and argued that it is not without risk to accept lost chances as a separate head of damage which is eligible for compensation, otherwise it is very possible that

\footnotetext{
${ }^{758}$ Gregg v Scott, [2005] UKHL 2, paragraph 2, 195, 223 (Lord Nicholls, Lord Phillips, Baroness Hale).

${ }^{759}$ Rogers 2000, p. 200.

${ }^{760}$ Jansen 1999, p. 271-296; Edis 2005.

${ }^{761}$ Peeperkorn 2000, p. 71.

${ }^{762}$ Hotson v East Berkshire Health Authority, [1987] AC 750.

${ }^{763}$ Hotson v East Berkshire Health Authority, [1987] AC 750 (Croom-Johnson).
} 
every case in which the problem of causal uncertainty arises is reclassified as a sort of 'chance' which is lost and, therefore, can be readily compensated. If the element of damage is being manipulated the lost chance is not a question of causation anymore but has become a 'damage issue'. In his view, the loss of a chance should be treated as an issue of uncertain causation. To base his opinion Martín-Casals referred to several Articles adopted in the Principles of European Tort Law for a better understanding. ${ }^{764}$ On similar grounds, Kadner Graziono also argued that the loss of chance should not be regarded as a (new) category of damage but as an issue of alternative causation. ${ }^{765}$ Rules on alternative causation would allow lost chances to be partially compensated and for damages to be apportioned according to the probability of causation. ${ }^{766}$ Article 3:103 Principles of European Tort law provides that:

'in case of multiple activities, where each of them alone would have been sufficient to cause the damage, but it remains uncertain which one in fact caused it, each activity is regarded as a cause to the extent corresponding to the likelihood that it may have caused the victim's damage.'

\subsubsection{Conclusion}

The loss of a chance theory is applied in both Dutch and English laws, but has not been applied to compensate claimants who suffer from mesothelioma or lung cancer that could have been asbestos-related. The disctinction between the Nefalit-principle and the loss of a chance theory lies in the fact that - in claims for loss of a chance - the claimant's damage is expressed in chances, while under the Nefalit-principle the probability that the wrongful intervention of the defendant did cause the claimant's damage is expressed in chances. Applying the loss of a chance theory, the claimant's loss of a chance is considered as damage in his own right. Where causation between the claimant's final damage and the tortfeasor's intervention, cannot be proved to 'a reasonable degree of certainty' or 'on the balance of probabilities', it is possible to establish causation between the loss of a chance (damage) and the tortfeasor's intervention. This way, causation problems are solved by reformulating the damage. In Dutch law, the Supreme Court has confirmed the application of the loss of a chance theory in legal malpractice cases and Courts of First Instance have applied this theory in medical malpractice cases. Under English law, the claimant's lost chance is only regarded as actionable damage in specific cases. Gregg (2005) made it very clear that the application of the loss of a chance theory is denied in medical malpractice cases: medical lost chances are not accepted as a separate head of damage. In the English jurisdiction traditional principles still apply in medical malpractice cases, which means that the claimant must prove causation 'on the balance of probabilities' in order to establish the liability of the defendant. This implies an all-or nothing recovery. The main argument to deny the applicability of the loss of a chance theory in medical malpractice cases is the fear of opening the floodgates of litigation: 'almost any claim for loss of an

\footnotetext{
${ }^{764}$ Martín-Casals 2008, p. 1048-1050. The most important Articles are: 3:103 (alternative causes), 3:104, 3:105 (uncertain partial compensation), 3:106 (uncertain causes within the victim's sphere) PETL.

${ }^{765}$ Kadner Graziano 2008, p. 1009.

${ }^{766}$ Kadner Graziano 2008, p. 1042.
} 
outcome could be reformulated as a claim for loss of a chance of that outcome. ${ }^{, 767}$ In Gregg, the Law Lords concluded that, if such a radical reform would be desirable, it would be a matter for Parliament and not for courts to decide. ${ }^{768}$

It seemed that the Law Lords were afraid that excepting a loss of a chance as actionable damage would cause the abandoning of the all-or-nothing approach in medical malpractice cases. In addition, and closely connected to the first point, the Law Lords were also afraid that the but-for test to establish causation would be set aside. Both objections can be refuted. A closer look reveals that accepting the loss of a chance as actionable damage leaves the but-for test intact. Applying the loss of chance theory, the claimant must still prove causation. Where causation cannot be established with regard to the 'final damage', it can be clearly established with regard to the damage of obtaining a better result (loss of a chance). ${ }^{769}$ Furthermore, it is arguable that the application of the loss of a chance theory does not abandon the traditional principle of all-or-nothing compensation because the defendant must still compensate the full value of the damage, namely the value of the lost chance. This means that the whole lost chance $(100 \%)$ is compensated.

One of the characteristics of English Tort law is the search for limits on liability. Bearing this in mind, it is remarkable that English courts have applied the loss of a chance theory in various cases, such as claims for not winning a beauty contest and professional negligence actions, primarily against solicitors in litigation. However, the application of this theory is, although the recoverability of physical loss of a chance has some advantages over the traditional principle of all-or-nothing compensation as it contributes to the corrective justice and deterrence function of Tort law, not accepted. ${ }^{770}$ This exception is hardly consistent with the precedents established in other fields by English courts. ${ }^{771}$ The fact that the loss of a chance theory is not applicable in medical malpractice cases implies that other interests are better protected than life itself.

\subsection{Market-share liability}

Another example of proportional liability is a company's market share that it enjoyed in the relevant period. Such an approach to establish the liability of the defendants might be applicable in claims for mesothelioma in which two or more employers have exposed the claimant to asbestos in the course of the separate employments. The Dutch Supreme Court, however, decided not to apply this solution in the DES-daughters case ${ }^{772}$. English legal scholars could be familiar with the facts because this case has also been discussed by the House of Lords in Fairchild ${ }^{773}$. DES is a defective drug which was put onto the market

\footnotetext{
${ }^{767}$ Gregg v Scott, [2005] UKHL 2, paragraph 190 (Lord Phillips).

${ }^{768}$ Gregg v Scott, [2005] UKHL 2, paragraph 90, 174 (Lord Hoffmann, Lord Phillips).

${ }^{769}$ See for example: Rechtbank Utrecht 8 december 2010, LJN: BO6888; Rechtbank Amsterdam 14 juli 2010, LJN: BO3288; Gerechtshof Amsterdam 4 januari 1996, NJ 1997, 213 (Baby Ruth). See also: MartínCasals 2008, p. 1048.

${ }^{770}$ Rogers 2000, p. 201.

${ }^{771}$ Chaplin v Hicks, [1911] 2 KB 786, CA; Kitchen $v$ Royal Air Forces Association, [1958] 1 W.L.R. 377; Sharif v Garrett \& Co, [2001] EWCA Civ 1269; John D. Wood \& Co Ltd v Knatchbull, [2002] EWHC 2822 QB.

${ }^{772}$ Hoge Raad 9 oktober 1992, NJ 1994, 535.

${ }^{773}$ Fairchild v Glenhaven Funeral Services Ltd, [2002] UKHL 22.
} 
by a large number of manufacturers to prevent miscarriage. Daughters of DES-using mothers suffer from cancer and fertility problems caused by the drug. The drug caused damage to a large number of claimants.

The claimants could not prove which manufacturer had produced the drug which their mothers had taken. The Supreme Court applied Article 6:99 BW ${ }^{774}$, which forms a good example of how the Dutch legislator has adopted rules on attribution of damages on the basis of presumption of causation. ${ }^{775}$ In order to establish the liability of the defendant it is required that:

'a) the pharmaceutical company in question put DES in circulation during the relevant period and can therefore be found liable because it committed a fault; b) another or several other producers - regardless of whether they are parties to the proceedings or not - also put DES in circulation during the relevant period and can therefore also be found liable because it (they) committed a fault; and c) the claimants suffered injuries that resulted from the use of DES, but that it is no longer possible to determine from which producer the DES originated. ${ }^{, 776}$

The companies who brought DES onto the market could be held jointly and severally liable for the whole damage, unless this was unacceptable from a reasonableness point of view in the given circumstances. ${ }^{777}$ The defendant can escape liability if he is able to prove that the claimant's damage is not the result of the event for which he is liable, which is an impossible evidentiary hurdle to take.

This means that the claimants did not have to sue every company separately. It was sufficient to sue one responsible producer. The sued producer could then be held liable in full, and has a right of recourse against the other responsible producers. This approach to establish liability, and to award compensation, is in accordance with Article 9:102 lid 1 PETL, which deals with the relation between persons subject to solidary liability. ${ }^{778}$ The decision in DES was clearly in favour of the claimants ${ }^{779}$ who, due to the long latency period, found themselves in the impossible position to prove condicio sine qua non between the defendant's wrongful conduct and their damage. The specific tortfeasor (the producer of the drug which their mothers had taken) could not be identified. It goes without saying that most companies who produced DES were not satisfied with the Su-

\footnotetext{
${ }^{774}$ Article 6:99 BW: 'Where the damage has resulted from two or more events for each of which a different person is liable, and where it has been determined that the damage has arisen from at least one of these events, the obligation to repair the damage rest upon each of these persons, unless he proves that the damage is not the result of the event for which he himself is liable.'

775 Akkermans 1997, p. 332; Spier 1998a, p. 193-198; Roijackers 2009, p. 9.

${ }^{776}$ Hoge Raad 9 oktober 1992, NJ 1994, 535, paragraph 3.7.5.

777 Also known as liability in solidum.

${ }^{778}$ Article 9:102 (1) PETL: 'A person subject to solidary liability may recover a contribution from any other person liable to the victim in respect of the same damage. This right is without prejudice to any contract between them determining the allocation of the loss or to any statutory provision or to any right to recover by reason of subrogation [cession legis] or on the basis of unjust enrichment.'

${ }^{779}$ Daughters of DES using mothers.
} 
preme Court's decision. Applying DES, a producer could be held liable for a larger amount of damage than he possibly could have caused (on a macro scale). ${ }^{780}$

The overwhelming criticism on this point was also the reason for the AGHartkamp ${ }^{781}$ to propose a market-share liability solution: an identified producer should only be held liable for the percentage of damage that corresponds with its market share. ${ }^{782}$ In a similar case, the Supreme Court of California denied the applicability of joint and several liability and adopted the 'market-share' approach in Sindell v Abbott Laboratories $^{783}$ in 1980. In Sindell, the claimant was entitled to sue all the manufacturers of DES in the relevant period, and each manufacturer was held liable to compensate the claimant's damage in proportion to the share of the market for DES that it enjoyed at the time the claimant's mother used the drug. ${ }^{784}$ From my point of view, such a proportional liability approach leads to a more justified compensation regime for DES producing companies. However, we have to keep in mind that it still remains unclear whether the damage suffered by the claimant has been actually caused by the sued tortfeasor (producer): causation between the tortfeasor's wrongful intervention and the claimant's damage still remains uncertain. ${ }^{785}$ Is such a market-share liability solution victim friendly in all situations?

It probably would not. Applying market-share liability, the claimant has to sue all possible tortfeasors in order to obtain compensation for the entire loss $(100 \%)$. It is the claimant who bears the consequences in situations where producers have gone out of business or have become untraceable. In such a situation the possibility to receive full compensation is out of the picture. The exact same argument, to deny market-share liability, was given in DES. In view of the Supreme Court, it would be unfair towards the claimants to let them bear the risk that a particular producer is not traceable or has gone out of business. The Supreme Court rejected the proposed market-share liability for reasons of consumer protection and thus deviated from AG-Hartkamp's opinion. Furthermore, DES is illustrative for the way in which courts have balanced the interests of both the claimants and defendants. The case also illustrates how policy choices can be made: it is not impossible to establish liability without fulfilling the required condicio sine qua non test because the producers of the drug can be held jointly and severally liable on the basis of Article 6:99 BW. ${ }^{786}$

\subsection{Overall conclusion}

The former sections have examined four solutions that produce proportionality in Tort law: the option to award damages in proportion to the probability of causation (Nefalitprinciple), the option to use the concept of contributory negligence to reduce the total

\footnotetext{
${ }^{780}$ See for more information section 2.6.2.2.1, which also examines drawbacks connected to the principle of joint and several liability.

${ }^{781}$ The AG (Advocaat-Generaal) advises the Supreme Court.

${ }^{782}$ Van Dam 2006, p. 290.

${ }^{783}$ Sindell v Abbott Laboratories, 607 P 2d 924, 1980 (Supreme Court of California). The facts in this case are comparable to the facts in DES.

${ }^{784}$ McBride \& Bagshaw 2008, p. 556.

${ }^{785}$ Roijackers 2009, p. 9.

${ }^{786}$ Van Dam 2006, p. 289.
} 


\section{Chapter 3}

amount of damages, the application of the loss of a chance theory, and the market-share construction. However, all proposed proportional approaches have drawbacks. The option to award damages in proportion to the probability of causation has, in 2006, been applied in the Dutch jurisdiction to compensate potential asbestos victims who suffer from lung cancer that could have been asbestos-related. Applying the Nefalit-principle, proof of condicio sine qua non is not anymore a fundamental requirement to establish the liability of the defendant. For the assessment of the claimant's damages, the Supreme Court sought alliance with traditional principles and held that the defendant is liable in full minus the claimant's contributory negligence. The applicability of the legal instrument of proportional liability is, however, denied in the English jurisdiction.

In England, traditional principles still apply in claims for lung cancer that could have been asbestos-related, which means that the claimant must prove that the exposure to asbestos has more than doubled the risk of lung cancer. When the claimant is able to prove causation on the balance of probabilities, the concept of contributory negligence is used as a tool to reduce the total amount of damages in such cases. In both jurisdictions, it has been acknowledged that smoking constitutes contributory negligence. Smoking tobacco is thus considered as a factor for which the claimant himself can be held responsible. However, it is important to note that it is impossible to precisely (with $100 \%$ certainty) determine the claimant's degree of contributory negligence, which means that this assessment inserts a certain element of speculation. The English approach is, when compared to the Nefalit-principle, less victim friendly in specific situations: a smoking claimant still leaves empty-handed in the majority of the cases as he is unable to prove that the exposure to asbestos has doubled the risk of lung cancer. In the Dutch jurisdiction, the claimant can - if the assessed probability of causation is not too low - be compensated in proportion to the probability of causation in cases in which the wrongful exposure to asbestos did not double the risk of lung cancer.

The third solution that produces a proportional outcome is the so called 'loss of a chance theory'. This theory has a broader acceptance than the proportional liability theory and can be applied in the Netherlands, England, France, and Belgium. The disctinction between the Nefalit-principle and the loss of a chance theory lies in the fact that - in claims for loss of a chance - the claimant's damage is expressed in chances, while under the Nefalit-principle the probability that the wrongful intervention of the defendant did cause the claimant's damage is expressed in chances. Under the loss of chance theory, causation problems are solved by reformulating the claimant's damage: where causation cannot be established with regard to the 'final damage', it can be clearly established with regard to the damage of obtaining a better result (loss of a chance). This way, the lost chance constitutes a separate head of damage which is eligible for compensation. In the English jurisdiction, the loss of a chance theory has been subject to much criticism and the applicability of this technique has, in contrast to decisions of Courts of First Instance in the Dutch jurisdiction, been denied in medical malpractice cases: health chances are not regarded as actionable damage. In the two jurisdictions taken under consideration here, the loss of a chance theory has not been applied to compensate claimants who suffer from mesothelioma or lung cancer that could have been asbestos-related. 
Finally, the option to directly base the defendant's liability on the company's market share has been examined in section 3.5. This solution has potential application in claims for mesothelioma in which two or more employers could have caused the claimant's damage but it is impossible to tell which employer has actually caused the claimant's damage in an individual case. Applying market-share liability is, however, not a victimfriendly solution in all situations: the claimant has to sue all possible tortfeasors in order to obtain compensation for the entire loss. It is the claimant who bears the consequences in cases where defendants have gone out of business or have become untraceable: the claimant is unable to receive full compensation (100\%) and has to pay for (a part of) his own damage.

\section{PART TWO: ALTERNATIVE SOLUTIONS IN TORT LAW}

Next to the proportional approaches in Tort law, it may be worth searching for alternative solutions in Tort law, which can be used alongside or instead of proportional liability, in order to seek a fair balance between the interests of the claimant and the defendant in case of causal uncertainty. Part 2 of Chapter 3 examines several alternative solutions in substantive and/or procedural law, such as: setting aside the requirement of causation (3.7), expanding the notion of causation (3.8), the defendant's duty to provide an extra motivated pleading (3.9), lessening the traditional standard to prove causation (3.10), and the reversal of the burden of proof with regard to the requirement of causation (3.11). ${ }^{787}$

\subsection{Setting aside the requirement of causation}

The most radical solution to strengthen the claimant's position in asbestos-related cases is to entirely set aside the requirement of causation: causation is then no longer a fundamental requirement to establish the liability of the defendant. ${ }^{788}$ Setting aside a necessary requirement for liability is not uncommon in Dutch law. Strict liabilities, such as liability for animals ${ }^{789}$ and traffic accidents ${ }^{790}$, have set aside the requirement of fault of the defendant or depart from the (rebuttable) presumption of fault. ${ }^{791}$ However, the application of this radical solution in the case of causal uncertainty is hard to imagine, because causation has always been a highly important factor in Dutch and English Tort law. In

\footnotetext{
${ }^{787}$ Note that the abovementioned solutions are examined for the sake of completeness. This means that these solutions are not subject to in-depth discussion because an extensive discussion would exceed the scope of this research. The literature in the footnotes provides further details.

${ }^{788}$ This differs from the - in Dutch law applied - proportionial liability theory. Applying proportional liability, causation is still a necessary element to establish liability: the claimant must still prove a causal link but does not have to prove conditio sine qua non between the defendant's intervention and his damage.

${ }^{789}$ Article 6:179 BW.

${ }^{790}$ Article 185 Wegenverkeerswet. In addition, one could note that in French traffic liability law (The Law Badintair) the requirement of causation has been replaced by 'implication' of the motorized vehicle in the accident. This because 'proof of causation' implies some aspects of fault on the part of the liable person. For that reason the term 'implication' has been introduced.

${ }^{791}$ Giesen \& Tjong Tjin Tai, p. 102-103.
} 
fact, all jurisdictions require a causal connection between conduct and damage to establish the liability of the defendant. It is 'crystal clear' that there must be some relevant (proof of a) connection between a specific event and the damage claim. This means that this radical solution undermines traditional principles of Tort law and is in contradiction with common sense of justice. The option to set aside the requirement of causation would drastically change the liability system of the jurisdictions taken under consideration here. Like the English scholar would say: such a solution opens the floodgates of litigation. A fairer outcome can also be reached when less radical techniques are applied.

\subsection{Expanding the notion of causation}

It is common ground that the claimant will encounter less difficulties in proving causation after the notion of causation has been expanded. This technique is applicable in English law but has not been applied in the Dutch jurisdiction. The notion of causation has been expanded in Bonnington Castings Ltd $v$ Wardlaw $^{792}$ (1956). Here it suffices that the claimant could prove that the defendant's negligence has contributed to the risk of injury. Subsequently, the House of Lords expanded the notion of causation in McGhee $v \mathrm{Na}$ tional Coal Board ${ }^{793}$ (1973) in which the claimant was able to show that the defendant substantially contributed to the harm. ${ }^{794}$ Despite the fact that Mr McGhee could not prove - on the balance of probabilities - a causal link between the negligent omission of his employer (not providing washing facilities) and the dermatitis which he contracted, the House of Lords accepted Mr McGhee's claim and awarded full compensation.

However, in Wilsher $v$ Essex $A H A^{795}$ (1988) the House of Lords felt it right to reaffirm the strict requirements of the but-for test and rejected the 'risk principle' approach set out by Lord Wilberforce in McGhee. The House of Lords held that the claimant must prove, on the balance of probabilities, that the conduct of the alleged tortfeasor was a

\footnotetext{
792 Bonnington Castings Ltd v Wardlaw, [1956] AC 613.

${ }^{793}$ Mc Ghee v National Coal Board, [1973] 1 WLR 1: McGhee was employed to clean out brick kilns and developed dermatitis. The immediate cause of the dermatitis was brick dust with which he came into contact while at work. He sued his employer for negligence. The negligent event was in fact an omission; a failure to ensure that showers were available to wash off dust at the end of the working shift to prevent the out breach of dermatitis. He alleged that he had contracted dermatitis during his work at brick kilns. His employers argued that providing showers would probably not have prevented the illness. The dermatologist called by McGhee could not say that if the appellant had been able to wash off the dust by showers he would not have contracted the disease. However, the dermatologist was prepared to say that the failure to provide showers materially increased the chance, or risk, that dermatitis might set in. The House of Lords had to decide whether the failure to provide for washing facilities had caused the dermatitis. The House of Lords subsequently held that the employer was liable for the damage because of the fact that he - by not providing washing facilities- significantly increased the risk of contracting dermatitis.

${ }^{794}$ Jansen 1999 , p. 275.

${ }^{795}$ Wilsher $v$ Essex AHA, [1986] 3 ALL ER 416: In this case the claimant, who was born three months prematurely, suffered blindness in one eye and near-blindness in the other as a result of a condition known as retrolental fibroplasia. The claimant alleged that this was caused by the carelessness of a hospital doctor who failed to notice that a device for measuring the dosage of oxygen to the blood had been wrongly attached to a vein and not, as it should have been to an artery. The House of Lords held that causation had not been adequately established: 'a failure to take preventive measures against one out of five possible causes is not evidence as to which of those five caused the injury'. So the claimant could not prove - on the balance of probabilities - that the breach of duty of the doctor had caused the blindness. (emphasis added)
} 
cause-in-fact of the injury which the claimant suffered. Medical evidence, however, established five separate potential causes of the claimant's blindness and the claimant was unable to prove the causal link between the fault of the doctor and the blindness from which he was suffering. ${ }^{796}$ Causation had not been adequately established and, therefore, no liability could arise.

Do the facts in McGhee then differ so much from the facts in Wilsher that it justifies another approach to causation? Yes, in view of the House of Lords it did. In Wilsher, at least five possible causes could have caused the specific injury to the claimant, while in $M c$ Ghee there was only one possible cause for the claimant's injury. If multiple factors are present that could have caused the damage, and the defendant's negligence adds a new risk, the claimant cannot rely on the $M c$ Ghee principle (material contribution to the risk). If I understand Wisher correctly I would say that, in situations of multiple risk factors where the defendant's negligence materially increases one of the existing risk factors, the claimant might succeed in his claim provided that he is able to establish that it was that particular risk factor that has caused his damage. However, in practice other risk factors, which have not been created by the defendant's negligence but also could have caused the claimant's damage, make it impossible to prove the causal link. ${ }^{797}$ In such cases liability cannot be established, which means that the claimant leaves empty-handed. However, thirty years after McGhee and fifteen years after Wilsher, the Law Lords decided to overrule Wilsher ${ }^{798}$ and expanded the notion of causation in Fairchild v Glenhaven Funeral Services $\operatorname{Ltd}^{799}$.

\subsubsection{Claims for mesothelioma}

The English case of Fairchild v Glenhaven Funeral Services Ltd ${ }^{800}$ (2002) shows that the notion of causation, specifically regarding the burden of proof, can be expanded in claims for mesothelioma in which two employers have wrongfully exposed their employee to asbestos. Fairchild is seen as a public policy decision which not only overruled Wilsher (1988) but also allowed asbestos claims in situations of alternative causality. Mr Fairchild contracted mesothelioma after he had been exposed to asbestos while working for two different employers. It could not be held that the claimant had proved, on the required balance of probabilities, against the first employer ' $A$ ' that his mesothelioma would probably not have occurred but-for the breach of duty by 'A', nor against the second employer ' $B$ ' that his mesothelioma would probably not have occurred but-for the breach of duty by 'B'. It also could not be held that the claimant had proved against 'A' and 'B' that his mesothelioma would probably not have occurred but-for the breach of duty by both 'A' and 'B'. ${ }^{801}$ The state of scientific knowledge about the mechanism by which asbestos fibres cause mesothelioma did not enable any claimant, who had been exposed to more than one significant source of asbestos, to satisfy this test. ${ }^{802}$ This means

\footnotetext{
${ }^{796}$ Namely: excess oxygen, hypercarbia, intraventricular haemorrhage, apnoea, and patent ductus arteriosus.

${ }^{797}$ Jones 2006, p. 251-269.

${ }^{798}$ Wilsher v Essex AHA, [1986] 3 ALL ER 416.

${ }^{799}$ Fairchild v Glenhaven Funeral Services Ltd, [2002] UKHL 22.

${ }^{800}$ Fairchild v Glenhaven Funeral Services Ltd, [2002] UKHL 22.

${ }^{801}$ Fairchild v Glenhaven Funeral Services Ltd, [2002] UKHL 22, paragraph 2 (Lord Bingham).

${ }^{802}$ Barker v Corus, [2006] UKHL 20, paragraph 1.
} 
that the claimant cannot show which exposure led to the development of the claimant's mesothelioma. Nor is it possible for the claimant to show whether or not the mesothelioma had been caused by a single exposure or by the cumulative effect of exposure over more than one employment. Using policy grounds, Lord Hoffmann argued that the purpose of the requirement of causation was: 'to produce a just result by delimiting the scope of liability in a way which relates to the reason why liability for the conduct in question exists in the first place. ${ }^{803}$

If strict rules on causation are applied in cases such as Fairchild, then it seems that employees who have worked for only one negligent employer would be much better off than employees who have worked for two or more employers all exposing the employee to asbestos in the course of the separate employments. An employee who only worked for one employer is able to establish that it was his employer's negligence that led to the development of the mesothelioma. The cases Shanks v Swan Hunter Group Plc ${ }^{804}$ (2007) and Maggs $v$ Anstey ${ }^{805}$ (2007) show that the claimant did not encounter difficulties to establish the liability of the defendant in cases where only one employer could have caused the claimant's mesothelioma. However, applying traditional principles, an employee who has worked for two or more employers is unable to establish liability. ${ }^{806}$

Therefore, the House of Lords choose to create a narrow, specific exception to the traditional rules on causation ${ }^{807}$, which resulted in the fact that the claimant was able to successfully claim compensation even though he could not prove that but-for his employer's negligence he would not have contracted mesothelioma. The strict application of the but-for test has been modified to avoid a result which under-compensated the claimant who suffered from mesothelioma. A technique to strengthen the claimant's position, and to establish the liability of the defendant, is to treat the defendant's negligence as a material contribution to the risk of injury, even though the injury might well have been caused by the negligence of some other defendant. It is, for the claimant, less difficult to prove causation after the notion of causation has been expanded. The House of Lords ruled that:

\footnotetext{
${ }^{803}$ Fairchild v Glenhaven Funeral Services Ltd, [2002] UKHL 22, paragraph 56 (Lord Hoffmann).

${ }^{804}$ Shanks v Swan Hunter Group Plc, [2007] EWHC 1807 (QB): The claimant had been employed by the defendant in his youth as an electrician for four years. This was his only exposure during his working life. This case differs from mesothelioma cases, such as Fairchild, Barker, Richardson, and Cox. In Shanks, the claimant, still alive, was 59 years old at the date of the trial, and had only been exposed to asbestos by one employer which means that, in this specific case, no uncertainty about the specific tortfeasor arises. Given the fact that asbestos is the only known cause to contract mesothelioma the judge had no difficulties to establish causation between the wrongful exposure to asbestos and the mesothelioma which the claimant contracted.

${ }^{805}$ Maggs v Anstey, [2007] EWHC 515 (QB): The claimant had been employed by the defendant as a lorry driver for over six years, and 27 years later Mr Maggs was diagnosed with mesothelioma. Evidence showed that Mr Maggs had been exposed to asbestos on a single occasion while employed by the defendant. In mesothelioma cases, such as Shanks and Maggs, the claimant had only been exposed to asbestos by one employer, which means that no uncertainty arises about the specific tortfeasor. Therefore, the judge had no difficulties to establish causation between the wrongful exposure to asbestos and the mesothelioma which the claimant contracted.

${ }^{806}$ This is known as: 'the fairness argument'.

${ }^{807}$ Applying traditional rules on causation, English law requires the claimant to prove that it is on the balance of probabilities more likely than not that the defendant has caused the damage to the claimant.
} 
'... it is just and in accordance with common sense to treat the conduct of $\mathrm{A}$ and $\mathrm{B}$ in exposing $\mathrm{C}$ to a risk to which he should not have been exposed as making a material contribution to the contracting by $\mathrm{C}$ of a condition against which it was the duty of $\mathrm{A}$ and B to protect him. ${ }^{, 808}$

The House of Lords thus accepted liability on the ground that the breach of duty had contributed materially to the risk of mesothelioma, while the claimant was unable to prove the causal link between the exposure to asbestos and the development of mesothelioma, on the required balance of probabilities. An exception should be recognized in cases where the application of the but-for test would produce a result at odds with the underlying rationale of the liability in question. ${ }^{809}$

This outcome could be seen as an enormous step in favour of mesothelioma sufferers who are, due to this decision, able to receive full compensation. The reasoning in Fairchild will have a major influence on the law governing factual causation in the future ${ }^{810}$ However, claimants should not get too excited: the Fairchild-principle must not be over-generalized. ${ }^{811}$ The exception is so narrowly formulated that it probably will not significantly change the strict application of the but-for test in the majority of the cases. According to all of their Lordships, prudence is called for when applying this principle. ${ }^{812}$ However, in this specific case the Law Lords came to the conclusion that a strict application of the but-for test would rob the duty to protect employees against mesothelioma and, therefore, ruled that it was sufficient to show a material contribution to the risk of injury. ${ }^{813}$

Furthermore, Fairchild illustrates that the use of comparative law can influence the reasoning and outcome of the case: comparative research has proved to influence the final decision. English case law thus provides a clear example of the use of comparative research. Lord Bingham of Cornhill discussed the Dutch Des-daughters ${ }^{814}$ case and referred to prominent legal scholars in the field of comparative law, such as Von Bar, Markesinis, and Van Gerven. ${ }^{815}$ He held that: ' $\ldots$.. in a shrinking world there must be some virtue in uniformity of outcome whatever the diversity of approach in reaching that outcome. ${ }^{, 816}$ Lord Bingham considered that 'a claimant faced with a similar type of causation problem would be granted a remedy in most other jurisdictions, irrespective of whether the increase in risk is treated as equivalent to a material contribution to the damage, or by placing the burden of proof on the defendant, or by enlarging the ordinary approach to tortfeasors acting in concert, or on more general grounds influenced by policy considerations. ${ }^{817}$ Nowadays, the cases Richardson $v$ Russel ${ }^{818}$ (2008) and Cox v Rolls Royce Industrial

\footnotetext{
${ }^{808}$ Fairchild v Glenhaven Funeral Services Ltd, [2002] UKHL 22, paragraph 34 (Lord Bingham).

${ }^{809}$ See for more information: Sobczak 2011, p. 32-41.

${ }^{810}$ Mullis \& Nolan 2003, p. 383.

${ }^{811}$ Fairchild v Glenhaven Funeral Services Ltd, [2002] UKHL 22, paragraph 43.

${ }^{812}$ Mullis \& Nolan 2003, p. 383.

${ }^{813}$ Fairchild v Glenhaven Funeral Services Ltd, [2002] UKHL 22, paragraph 47.

${ }^{814}$ Hoge Raad 9 oktober 1992, NJ 1994, 535 (DES). This case has been discussed in section 3.5.

${ }^{815}$ Fairchild v Glenhaven Funeral Services Ltd, [2002] UKHL 22, paragraph 27-32 (Lord Bingham). See for a comparative (Danish, German, Greek, and Spanish) case note; Tamasauskas et al. 2004, p. 215-258.

${ }^{816}$ Fairchild v Glenhaven Funeral Services Ltd, [2002] UKHL 22, paragraph 32 (Lord Bingham).

${ }^{817}$ Fairchild v Glenhaven Funeral Services Ltd, [2002] UKHL 22, paragraph 32 (Lord Bingham).
} 
Power (India) $L t d^{819}$ (2007) show that the Fairchild-principle is applied in all claims for mesothelioma in which two or more employers have exposed their employee to asbestos in the course of the separate employments.

\subsubsection{The limits of the Fairchild-principle}

Can the notion of causation only be expanded in cases in which two employers have wrongfully exposed their employee to asbestos, or is it possible to extend the range of applications of the Fairchild-principle to claims for mesothelioma in which the claimant has also exposed himself to asbestos? The case of Barker ${ }_{V}$ Corus ${ }^{820}$ provides a clear answer: Mr Barker developed mesothelioma and died from the consequences of that disease on 14 June 1996. Mr Barker has experienced a number of exposures to asbestos. The first period of exposure occurred in 1958 while working for Graessers Ltd. The second period of exposure occurred while working for Corus Ltd, and the third period of exposure occurred while Mr Barker was self-employed ${ }^{821}$. Mr Barker's estate (claimant) filed a lawsuit against the two employers ${ }^{822}$ who had negligently exposed Mr Barker to asbestos in the course of the separate employments. However, the claimant was unable to prove causation on the traditional balance of probabilities. It could not be held that the claimant had proved against employer 'A' and employer 'B' that his mesothelioma would probably not have occurred but-for the breach of duty by both 'A' and 'B'. The fact that Mr Barker had also been exposed to asbestos while working as a self-employed plasterer during one part of the relevant period made this case extremely complex. ${ }^{823}$ Unlike the facts in Fairchild, not all exposures which could have caused Mr Barker's mesothelioma involved a breach of the defendants duty of care or were within the control of the defendants. ${ }^{824}$ In fact, the exposure to asbestos during his work as a self-employed plasterer is a failure made by Mr Barker to take reasonable care for its own safety. It goes without saying that Mr Barker himself was responsible during this particular period. ${ }^{825}$

\footnotetext{
${ }^{818}$ Richardson $v$ Russel, [2008] EWHC 1708 (QB): The claimant had been exposed to asbestos in the course of three separate employments. The claimant filed a lawsuit against one former employer (defendant). Evidence demonstrated that Mr Richardson's asbestos exposure was sufficient to substantially contribute to his risk of developing mesothelioma. The exposure was not trivial or occasional but had occurred over a number of years. Therfeore, the period of exposure during the employment by the defendant cannot be described as de minimus Subsequently, the judge applied Fairchild and held the defendant liable for the claimant's mesothelioma.

${ }^{819}$ Cox v Rolls Royce Industrial Power (India) Ltd, [2007] EWCA Civ 1198: The claimant had been exposed to asbestos in the course of several different employments. For the claim to succeed the judge needed to be satisfied that the extent and duration of the exposure had constituted a material increase in the risk to $\mathrm{Mr}$ Cox of contracting mesothelioma. The expert evidence established that the exposure by the defendant was not a de minimis case. The type of contract work undoubtedly justified the finding. The Court of Appeal applied the Fairchild-principle, dismissed the appeal, and held the defendant liable for the claimant's damage.

${ }^{820}$ Barker v Corus, [2006] UKHL 20.

${ }^{821}$ Mr Barker worked as a self-employed plasterer.

822 The first exposure to asbestos was for six weeks in 1958, while working for a company called Graessers Ltd. The second exposure to asbestos was between April and October 1962, while working for John Summers Ltd (now Corus Ltd).

${ }^{823}$ At least three short periods between 1968 and 1975.

${ }^{824}$ Barker v Corus, [2006] UKHL 20, paragraph 3.

${ }^{825}$ See also: Sobczak 2011, p. 32-41.
} 
In Barker, the House of Lords had to decide whether the Fairchild-principle could be applied in this specific case and, in case liability could be established, whether or not the defendants are jointly and/or severally liable for the claimant's damage. The second question has previously been addressed in section 2.6.2.2.2 and will not - again - be subject to discussion here. On the first question, about the limits of the Fairchildprinciple, Lord Hoffmann held that: "The purpose of the Fairchild exception is to provide a cause of action against a defendant who has materially increased the risk that the claimant will suffer damage and may have caused that damage, but cannot be proved to have done so because it is impossible to show, on a balance of probability, that some other exposure to the same risk may not have caused it instead. For this purpose, it should be irrelevant whether the other exposure was tortious or non-tortious, by natural causes or human agency or by the claimant himself. ${ }^{, 826}$ The House of Lords thus extended the applicability of the Fairchild-principle to cases such as Barker. ${ }^{827}$

Applying the Fairchild-principle, it has proved not to be necessary to demonstrate that all exposures to asbestos were tortuous. This means that the notion of causation can also be expanded in cases where employer 'A' has negligently exposed the claimant to asbestos and employer ' $\mathrm{B}$ ' has innocently exposed the claimant to asbestos. Furthermore, the House of Lords ruled that the Fairchild-principle was not excluded on the simple fact that one element of the claimant's exposure had been self inflicted. The fact that $\mathrm{Mr}$ Barker exposed himself to asbestos, as a self-employed plasterer, thus did not break the chain of causation. Lord Hoffmann held that the distinction between tortuous and nontortious interventions should not play a role in the establishment of causation, but can be relevant to whether and to whom responsibility can be attributed. ${ }^{828}$

After Barker, the Fairchild-principle has - again - been stretched in Sienciewicz v Greif (UK) Limited $^{829}$ (2011). Nowadays, the technique to expand the notion of causation can also be applied in so called 'single exposure' cases. ${ }^{830}$ In Sienciewicz, the occupational exposure, although the extent of the exposure was very small, was regarded as a negligent cause of Mrs Costello's mesothelioma while the general environmental exposure to asbestos was regarded as a non-negligent cause. ${ }^{831}$ Experts concluded that the occupational exposure to asbestos only increased the total amount of exposure, which Mrs Costello would have experienced as a result of the environmental exposure to asbestos, by 18 percent. ${ }^{832}$ Therefore, the employer denied liability arguing that the claimant failed to prove on the balance of probabilities that the defendant had caused Mrs Costello's mesothelioma. The defendant argued that the claimant could not prove that the occupational exposure to asbestos had more than doubled the environmental exposure to asbestos: he only increased the risk of developing mesothelioma by 18 percent. To put it differently: the claimant could not prove that the occupational exposure to asbestos at least

\footnotetext{
${ }^{826}$ Barker v Corus, [2006] UKHL 20, paragraph 17.

${ }^{827}$ See also Sobczak 2011, p. 32-41.

${ }^{828}$ Barker v Corus, [2006] UKHL 20, paragraph 17.

${ }^{829}$ Sienciewicz v Greif (UK) Limited, [2011] UKSC 10.

${ }^{830}$ A 'single exposure' case means that a single defendant is responsible for the claimant's exposure to asbestos.

${ }^{831}$ See section 2.6.2.2.2 for more information about the facts in Sienciewicz.

${ }^{832}$ Sienciewicz v Greif(UK) Limited, [2011] UKSC 10, paragraph 4 (per Lord Phillips).
} 


\section{Chapter 3}

doubled the risk of contracting mesothelioma. The Supreme Court quashed this plea and made clear that the Fairchild-principle should be applied to establish causation in such cases. However, does an 18 percent increase in risk then constitute a 'material increase in risk' $?^{833}$ Yes, all seven Law Lords decided in favour of the claimant holding that the claimant successfully established that the occupational exposure to asbestos materially increased the risk of mesothelioma. This means that an 18 percent increase in risk is sufficient to establish causation in such claims for mesothelioma.

\subsection{The duty to provide an extra motivated pleading}

The defendant's duty to provide an extra motivated pleading is introduced to help claimants who are unable to gather sufficient information and facts to establish the liability of the defendant. Dutch case law shows that this technique is used to assist the claimant in proving the wrongfulness of the defendant's intervention. In medical malpractice cases this solution has been applied to establish the fault of the defendant. ${ }^{834}$ In such cases the physician is in a better position to provide medical data on the claimant's situation because he has the claimant's medical file at his disposal. ${ }^{835} \mathrm{~A}$ violation of the duty to provide an extra motivated pleading could have negative procedural consequences for the defendant. In Schepers/De Bruijn ${ }^{836}$, the Dutch Supreme Court ruled that the burden to prove the wrongfulness of the defendant's intervention can be reversed to the defendant if the defendant does not fulfill his duty to provide an extra motivated pleading. Furthermore, this technique to strengthen the claimant's position can also be applied with regard to the element of causation. ${ }^{837}$ However, the defendant might not be able to provide the claimant with sufficient information, which means that the duty to provide an extra motivated pleading does not always help the claimant to establish liability.

The duty to provide an extra motivated pleading is, in the majority of the cases, not an effective solution for claimants who suffer from an asbestos-related injury. In asbestos-related cases, the defendant can provide the claimant with information on the level of exposure to asbestos and fibre types, which could help the claimant to prove the wrongful conduct of the defendant at the time of the exposure. This technique could, if the defendant is able to provide sufficient information, strengthen the claimant's legal position with regard to the proof of the wrongful conduct. But does this solution also help the claimant to prove causation? Although information about the level of exposure does not clarify the causal link in cases where the claimant suffers from lung cancer as a potential consequence of asbestos exposure, the claimant can still use this kind of information

\footnotetext{
${ }^{833}$ See for more information: Sobczak 2011, p. 32-41.

${ }^{834}$ See for the application of the defendant's duty to provide an extra motivated pleading in medical negligence cases: Hoge Raad 20 november 1987, NJ 1988, 500 (Timmer/Deutman); Hoge Raad 18 februari 1994, NJ 1994, 368 (Schepers/De Bruijn); Hoge Raad 13 Januari 1995, NJ 1997, 175 (De Heel/Korver). NJ 1997, 175 (De Heel/Korver) in which the Supreme Court applied Article 149 Wetboek van Burgerlijke Rechtsvordering $(\mathrm{Rv})$.

${ }^{837}$ See for example medical 'informed consent' cases, such as: Hoge Raad 23 november 2001, NJ 2002, 386 (Ingenhut/Stichting Gezondheidszorg Oostelijk Zuid- Limburg); Hoge Raad 23 november 2001, NJ 2002, 387 (Niazmandian/Plasmans).
} 
to establish the liability of the defendant. If evidence has established that the claimant has been exposed to high dust concentrations, it is more likely that the exposure to asbestos has caused the claimant's lung cancer. This way, the claimant will encounter fewer difficulties to prove sufficient causation between exposure to asbestos and the development of lung cancer. However, as outlined in section 2.2.1.1.1, the defendant will, due to the long latency period connected to asbestos-related diseases, often be unable to provide an extra motivated pleading in the specific claimant's case. In the majority of the cases, this solution is not effective to strengthen the claimant's legal position in cases where the breach of this rule could not be attributed to the defendant. If the defendant is unable to provide the claimant with sufficient information this cannot have negative (procedural) consequences for the defendant, or to put it differently: in such a situation the application of this rule does not have positive (procedural) consequences for the claimant. ${ }^{838}$

\subsection{Adaptation of the traditional requirements}

Proving causation on the basis of the traditional standard of proof is extremely difficult in asbestos-related cases. In order to establish causation more easily, it might be an option to lessen the standard of proof. ${ }^{839}$ In Dutch law, the term 'certainty' can, for example, be exchanged into 'probability', which means that the standard of proof is set at a 'reasonable degree of probability'. Under this new rule, the standard of proof would be - more or less - comparable to the English balance of probabilities approach: a probability of 50 percent or lower is not sufficient to establish causation. ${ }^{840}$ However, application of this technique will not lead to desirable results in asbestos-related cases because the claimant will also be unable to prove causation to a 'reasonable degree of probability' in the majority of the cases. Lessening the standard of proof in the abovementioned way does not influence the outcome of the case in claims for asbestos-related diseases because most claims will fall just below the 50 percent threshold. This means that the claimant is, although the standard of proof has been lessened, still unable to prove causation on the basis of traditional principles, which has enormous negative consequences: he leaves empty-handed.

The legal outcome of the case is, however, more affected in favour of the claimant when the standard of proof is lessened in a more radical way. More claims for asbestosrelated injuries will succeed if, for example, a probability of 30 percent or more is sufficient to establish causation. Under this approach, the standard of proof has changed from a 'reasonable degree of certainty' or 'on the balance of probabilities' threshold into a 30 percent probability threshold. From my point of view, this radical solution is one bridge too far for Dutch and English Tort law. A required probability of 30 percent or more to establish causation is an arbitrary chosen percentage which is only driven by policy considerations: the idea to compensate as many asbestos victims as possible. This can have negative consequences: if asbestos victims receive full compensation in cases where experts have established a 30 percent probability that the defendant's intervention has

\footnotetext{
${ }^{838}$ Giesen \& Tjong Tjin Tai 2008, p. 104.

${ }^{839}$ In Dutch law, this option to strengthen the claimant's position is applicable in claims against directors (bestuurdersaansprakelijkheid).

${ }^{840}$ Van Dam 2006, p. 275.
} 
caused the claimant's damage, defendants will be obliged to over-compensate asbestos victims. This claimant-friendly liability regime could lead to the consequence that desirable activities for society will not be performed anymore by employers. Such an arbitrary rule will have a negative effect on society and is unfair towards employers who have to compensate the claimant in full, while there is a considerable chance that they did not cause the claimant's damage.

\subsection{Reversal of the burden of proof}

The application of a rule that reverses the burden of proof with regard to the requirement of causation is a commonly known and severely criticised procedural technique to strengthen the claimant's legal position. As examined in section 2.4.2.2, in both jurisdictions taken under consideration here, the burden of proof is on the claimant. Generally, it is up to the claimant to prove all the elements of the liability claim. ${ }^{841}$ Proof of causation can be extremely difficult and is sometimes even impossible in an environment of uncertainty. The inability to prove the causal link will be very frustrating for the claimant because he is the one who generally bears the consequences of the uncertainty, which eventually may lead to an unsuccessful liability claim. The next subsections examine the possibility to reverse the burden of proof with regard to the requirement of causation in Dutch and English laws.

\subsubsection{Dutch law}

In Dutch law, evidential techniques have been designed to reduce the load of the evidentiary burden lying on the claimant. Exceptions to the normal burden of proof rule have been made by the Dutch legislator and Supreme Court: procedural rules may change in favour of the claimant when fairness demands another arrangement of the burden of proof. Procedural rules are found in The Code of Civil Procedure (Rv). The option to reverse the burden of proof with regard to the requirement of causation does, when compared to the previously discussed solutions to set aside the requirement of causation or expand the notion of causation, not undermine the Dutch liability system because the legislator has listed the applicability of this technique as an exception to the principal rule codified in Article $150 \mathrm{Rv}{ }^{842}$ The 'reversal rule ${ }^{843}$ is well-established in literature: Akkermans published a 181 paged book on this subject alone in 2002 and Giesen has, among other issues, analyzed the reversal rule in his Ph.D dissertation in $2001 .^{844}$ This rule is generally seen as a method to make a concession to the victim's precarious position. But what conditions need to be fulfilled in order to actually reverse the burden of proof with regard to the requirement of causation in a specific case?

The option to reverse the burden of proof is seen as a presumption of causation in situations where there is a breach of a norm which is aimed at prevention of a specific risk and if, in general, the breach of this norm increases the risk considerably. In order to

\footnotetext{
${ }^{841}$ Rogers 2000, p. 199.

${ }^{842}$ Wetboek van Burgerlijke Rechtsvordering: Article 150 of the Code of Civil Procedure (Rv): The claimant has to prove all the elements of the claim. Other exceptions, besides the reversal rule, that are listed in Article $150 \mathrm{Rv}$ are: a duty of extra motivation and a factual presumption.

${ }^{843}$ In Dutch: 'de omkeringsregel'.

${ }^{844}$ Akkermans 2002, p. 1-181; Giesen 2001.
} 
actually reverse the burden of proof this specific risk must have been materialized. ${ }^{845}$ After the burden of proof has been reversed it will be up to the defendant to prove that he did not cause the claimant's damage. To put it differently: the causal link between the defendant's intervention and the claimant's damage will be assumed, unless the defendant alleges, and if necessary proves, that the damage would also have occurred without his wrongful intervention. In cases where the standard of proof cannot be met, the placement of the burden of proof can thus decide the outcome of the trial.

The burden of proof with regard to the requirement of causation has also been reversed in asbestos-related cases. Case law shows that Dutch courts not only have decided to reverse the burden of (dis)proving causation towards the defendant in claims for mesothelioma ${ }^{846}$, but have also reversed the burden of proof in claims for lung cancer that could have been caused by occupational exposure to asbestos. ${ }^{847}$ If the reversal rule is applied in claims for mesothelioma, the employer has to prove that the employee did not inhale the 'fatal asbestos fibre' in the course of the employment in order to escape liability. However, in such cases a defendant is, due to the lack in medical science, unable to disprove the causal link between the wrongful exposure and the claimant's mesothelioma. ${ }^{848}$ Medical science simply cannot determine during which period of employment the employee inhaled the fatal asbestos fibre which led to the forming of mesothelioma in cases where two or more employers have exposed the employee to asbestos in the course of the separate employments. Applying the traditional principle of all-or-nothing compensation, it is most likely that the claimant will be fully compensated after the burden of proof has been reversed, while there is still a chance that the defendant did not cause the claimant's damage. Application of the reversal rule will strengthen the claimant's position in asbestos-related cases, but leads to an outcome that is undesirable for defendants. This procedural technique does not solve the problem of uncertain causation as such, but shifts the problem of uncertain causation to the defendant: he bears the consequences of the causal uncertainty.

\subsubsection{English law}

The general rule in English law is that the law does, in contrast to the Dutch jurisdiction, not accept the reversal of the burden of proof as a rule. In Wilsher ${ }_{v}$ Essex $A H A^{849}$, the Law

\footnotetext{
${ }^{845}$ Hoge Raad 7 december 2007, NJ 2007, 644.

${ }^{846}$ See for example: Hoge Raad 17 december 2004, NJ 2006, 147 (Hertel/Van der Lugt).

${ }^{847}$ Centrale Raad van Beroep 12 mei 2005, JB 2005/200, paragraph 4.1, 6.2 (Scheepmaker/Den Helder). See also: Van Maanen 2006, p. 64.

${ }^{848}$ See: Hoge Raad 25 juni 1993, NJ 1993, 686 (Cijsouw/De Schelde 1); Centrale Raad van Beroep 21 juni 2007, LJN: BA8436, paragraph 5.3: the court will take into account the fact that the defendant did not take sufficient precautionary measures to prevent the claimant from encountering health damage, which consequently increases the chance that the claimant could inhale the 'fatal asbestos fibre' in the course of this employment.

${ }^{849}$ Wilsher v Essex AHA, [1986] 3 ALL ER 416: In this case the claimant, who was born three months prematurely, suffered blindness in one eye and near-blindness in the other as a result of a condition known as retrolental fibroplasia. The claimant alleged that this was caused by the carelessness of a hospital doctor who failed to notice that a device for measuring the dosage of oxygen to the blood had been wrongly attached to a vein and not, as it should have been to an artery. The House of Lords held that causation had not been adequately established: 'a failure to take preventive measures against one out of five possible causes is not evi-
} 
Lords applied the law which only Parliament can change and unanimously decided that the reversal rule was no part of English law. However, it is arguable that, although English law is very reluctant to impose a general rule to reverse the burden of proof, a shy acceptance of the reversal rule can be found in McGhee $v$ National Coal Board ${ }^{850}$ and Fairchild v Glenhaven Funeral Services $L t d^{851}{ }^{852}$

In $M c G h e e$, Lord Wilberforce advocated the application of the reversal rule in a multiple causation case. Lord Wilberforce held that:

'...But the question remains whether a pursuer must necessarily fail if, after he has shown a breach of duty, involving an increased risk of disease, he cannot positively prove that this increase of risk caused or materially contributed to the disease while his employers cannot positively prove the contrary. In this intermediate case there is an appearance of logic in the view that the pursuer, on whom the onus lies, should fail - a logic which dictated the judgments below. The question is whether we should be satisfied, in factual situations like the present, with this logical approach. There are further considerations of importance. First, it is a sound principle that where a person has, by a breach of duty of care, created a risk, and injury occurs within the area of that risk, the loss should be borne by him unless he shows that it had some other cause. Secondly, from the evidential point of view, one may ask, why should a man who is able to show that his employer should have taken certain precautions, because without them there is a risk, or an added risk, of injury or disease, and who in fact sustains exactly that injury or disease, have to assume the burden of proving more: namely, that it was the addition to the risk, caused by the breach of duty, which caused or materially contributed to the injury. In many cases, of which the present is typical, this is impossible to prove, just because honest medical opinion cannot segregate the causes of an illness between compound causes. And if one asks which of the parties, the workman or the employers, should suffer from this inherent evidential difficulty, the answer as a matter of policy or justice should be that it is the creator of the risk who ex hypothesi must be taken to have foreseen the possibility of damage, who should bear its consequences. ${ }^{, 853}$

dence as to which of those five caused the injury'. So the claimant could not prove - on the balance of probabilities - that the breach of duty of the doctor had caused the blindness. (emphasis added)

${ }^{850}$ Mc Ghee v National Coal Board, [1973] 1 WLR 1: Mr McGhee was employed to clean out brick kilns and developed dermatitis. The immediate cause of the dermatitis was brick dust with which he came into contact while at work. He sued his employer for negligence. The negligent event was in fact an omission; a failure to ensure that showers were available to wash off dust at the end of the working shift to prevent the out breach of dermatitis. He alleged that he had contracted dermatitis during his work at brick kilns. His employers argued that providing showers would probably not have prevented the illness. The dermatologist called by McGhee could not say that if the appellant had been able to wash off the dust by showers he would not have contracted the disease. However, the dermatologist was prepared to say that the failure to provide showers materially increased the chance, or risk, that dermatitis might set in. The House of Lords had to decide whether the failure to provide for washing facilities had caused the dermatitis. The House of Lords subsequently held that the employer was liable for the damage because of the fact that he - by not providing washing facilities - significantly increased the risk of contracting dermatitis.

${ }^{851}$ Fairchild v Glenhaven Funeral Services Ltd, [2002] UKHL 22.

${ }^{852}$ Van Dam 2006, p. 284; Giesen \& Tjong Tjin Tai 2008, p. 76.

${ }^{853}$ Mc Ghee v National Coal Board, [1973] 1 WLR 1, paragraph 6 (Lord Wilberforce). (emphasis added). 
However, although $M c$ Ghee shows a shy acceptance of the reversal rule, the complete and formal rejection of this rule came with the judgment in Wilsher. ${ }^{854}$ The House of Lords unanimously decided that the reversal of the burden of proof was no part of English law. The claimant alleged that in McGhee the House of Lords accepted the rule that: 'if the defendant materially increased the risk on damage there should follow a reversal of the burden of proof if this damage actually arises.' The House of Lords made it very clear that this was an incorrect interpretation of the decision in $M c G h e e .{ }^{855}$ A shy acceptance of the reversal rule can, however, also be found in claims for mesothelioma. In Fairchild ${ }^{856}$, Lord Nicholls favoured the option to reverse the burden of proof in order to strengthen the claimant's legal position and said that: 'adhering to the traditional approach by laying the burden of proof on the claimant would be deeply offensive to instinctive notions of what justice requires and what fairness demands. ${ }^{857}$ Both Lords Nicholls and Rodger share the opinion that the evidentiary uncertainty in Fairchild should operate to the detriment of the negligent employers who have wrongfully exposed the employee to asbestos rather than that it should operate to the detriment of the blameless employee. ${ }^{858}$ In their view, fairness requires an exception to the normal burden of proof, which reduces the load of the evidentiary burden lying on the claimant.

Furthermore, it should be noted that English courts have developed the principle of res ipsa loquitur, i.e., 'the situation speaks for itself', to improve the claimant's position. ${ }^{859}$ The application of this principle is based on a factual presumption: a judge who encounters problems in the establishment of causation can presume the causal link between the tortious act and the damage. ${ }^{860}$ The causal link is established if the defendant subsequently cannot rebut the presumption of causation. The practical effect is that the claimant does not need to prove precisely what was the relevant act or omission, which set in train the events leading to the accident. ${ }^{861}$ Res ipsa loquitur thus strengthens the claimant's position but has the same drawback as the reversal rule: it does not solve the problem of uncertain causation as such.

\subsubsection{Critique and discussion}

Although it has been acknowledged that the reversal rule can be seen as an incentive for employers to behave as required by law and does not interfere with the condicio sine qua non (but-for) test and the all-or-nothing result that this test produces, there are also drawbacks connected to the application of this procedural technique. The main critique is that the reversal rule, and this critique also goes for the principle of res ipsa loquitur, does not solve the problem of uncertain causation as such. Applying the reversal rule, the problem of (dis)proving causation is shifted to the defendant. At first, it was the claimant

\footnotetext{
${ }^{854}$ Wilsher v Essex AHA, [1986] 3 ALL ER 416.

${ }^{855}$ Rogers 2000, p. 202.

${ }^{856}$ Fairchild v Glenhaven Funeral Services Ltd, [2002] UKHL 22.

${ }^{857}$ Fairchild v Glenhaven Funeral Services Ltd, [2002] UKHL 22, paragraph 36 (Lord Nicholls).

${ }^{858}$ Fairchild v Glenhaven Funeral Services Ltd, [2002] UKHL 22, paragraph 39, 155 (Lord Nicholls, Lord Rodger).

${ }^{859}$ Harpwood 2000, p. 144.

${ }^{860}$ See for more information: Giesen 1997, p. 241-246.

${ }^{861}$ Deakin et al. 2003, p. 182.
} 
who had to bear the consequences of the causal uncertainty, but after the burden of proof has been reversed it is the defendant who is put in an unfavourable position as opposed to the claimant. It goes without saying that asbestos victims favour the application of this rule, but employers who have wrongfully exposed their employees to asbestos in the course of the employment will not be satisfied. Case law on claims for asbestos-related diseases shows that it is almost impossible to disprove causation. Therefore, this rule is undesirable - also seen from a law and economics perspective - because the application of the reversal rule increases the risk that the defendant will be held liable in full, while there is still a chance that the defendant did not cause the claimant's damage at all. ${ }^{862}$ Furthermore, it has been acknowledged that the reversal rule does not solve the arising problems on the amount of damages (all-or-nothing) and thus leads to undesirable results in cases where defendants are unable to disprove causation.

\subsection{Conclusion}

The option to set aside the requirement of causation and the option to expand the notion of causation have in common that the requirement to prove causation on the basis of the traditional condicio sine qua non (but-for) test has been avoided. Applying the first solution, the requirement of causation is banned entirely. Applying the second solution, the requirement of causation does still exist. However, the claimant will, after the notion of causation has been expanded, encounter fewer difficulties to prove causation. In Dutch law, both techniques have not (yet) been applied to solve the problem of uncertain causation. Both techniques have major consequences in favour of claimants who are unable to prove causation on the basis of the traditional condicio sine qua non (but-for) test but also have drawbacks. Both undermine the traditional principles of Tort law by setting aside the requirement of causation or expanding the notion of causation. ${ }^{863}$ Under English law, causation is - as in the Dutch jurisdiction - a necessary factor to establish the liability of the defendant. Setting aside the requirement of causation is neither feasible nor desirable. However, English case law shows that the notion of causation can be expanded in very specific cases. In claims for mesothelioma in which two defendants have wrongfully exposed the claimant to asbestos, the claimant can establish causation if he is able to prove that the defendant's negligence had made a material contribution to the risk of mesothelioma. This means that the strict application of the but-for test has been modified in favour of the claimant. This policy decision is in line with common sense: 'Tort law is and should be about compensating those who are wrongfully injured. ${ }^{864}$ Over the years, the applicability of the Fairchild-principle has been stretched to claims for mesothelioma in which the claimant has also exposed himself to asbestos. In 2011, the Supreme Court even decided to expand the notion of causation in 'single exposure' cases, which means that the Fairchild-principle is also applicable in cases where a single defendant is responsible for the claimant's exposure to asbestos. Nowadays, English courts apply a victimfriendly approach in claims for mesothelioma: an 18 percent increase in risk has proven to be sufficient to establish causation.

\footnotetext{
${ }^{862}$ Giesen \& Tjong Tjin Tai 2008, p. 106.

${ }^{863}$ Giesen \& Tjong Tjin Tai 2008, p. 102-103.

${ }^{864}$ Fairchild v Glenhaven Funeral Services Ltd, [2002] UKHL 22, paragraph 11(Lord Bingham).
} 
The other proposed solutions, such as: the defendant's duty to provide an extra motivated pleading, the option to lessen the requirement of causation, and the option to reverse the burden of proof with regard to the requirement of causation can also strengthen the claimant's position in an environment of uncertainty. However, such techniques have drawbacks in claims for asbestos-related diseases. First, the defendant is, due to the long latency period connected to asbestos-related diseases, not able to provide an extra motivated pleading in the majority of the cases. This leads to the result that the defendant is unable to provide sufficient information, such as: information about the level of exposure to asbestos and fibre types, in a specific claimant's case. The duty to provide an extra motivated pleading does not have positive (procedural) consequences for the claimant in cases where the inability to provide sufficient information cannot be attributed to the defendant. Therefore, it can be concluded that the duty to provide an extra motivated pleading is not an effective solution to strengthen the claimant's position in claims for asbestos-related diseases.

Although it has been acknowledged that the option to lessen the traditional standard to prove causation can strengthen the claimant's position in an environment of uncertainty, the application of this technique easily leads to arbitrary judgments. Changing the traditional Dutch standard to prove causation to a 'reasonable degree of certainty' into a 'reasonable degree of probability' threshold does not lead to desirable outcomes in asbestos-related cases: the claimant will also be unable to prove causation to a 'reasonable degree of probability' in the majority of the cases, which means that he still leaves empty-handed. If the traditional standard to prove causation is lessened more drastically, the claimant will encounter fewer difficulties in proving causation and establishing the liability of the defendant. However, setting the standard of proof at, say: 30 percent, produces unfairness: the defendant can be held liable in full while there is a considerable chance that he did not cause the claimant's damage. Application of such an arbitrary rule is undesirable as it will have a negative effect on society.

The application of a rule that reverses the burden of proof with regard to the requirement of causation is a commonly known and severely criticised procedural technique to strengthen the claimant's position. The reversal rule is applicable in Dutch law but is not accepted as a rule in the English jurisdiction as it would be a matter for Parliament and not for courts to decide. Although this solution leaves the traditional principle of all-or-nothing compensation intact and can be applied alongside the proportional liability theory, it has been acknowledged that the reversal rule does not solve the problem of uncertain causation as such, but shifts the problem of (dis)proving causation to the defendant. Applying the reversal rule in asbestos-related cases, it is the defendant who bears the consequences of the causal uncertainty as he finds himself in a hardly impossible position to disprove causation. Reversing the burden of proof leads to undesirable outcomes in asbestos-related cases as it increases the risk that the defendant will be held liable in full, while there is still a chance that the defendant did not cause the claimant's damage. 


\section{PART THREE: ALTERNATIVES TO TORT LIABILITY}

The conclusions drawn in the previous parts of this chapter show the shortcomings of Tort law in - individual - claims that are characterized by the problem of uncertain causation. It is arguable that Tort law does not always lead to satisfactory outcomes in complex claims for asbestos-related diseases. This Part examines alternatives to Tort liability in order to explore whether instruments outside the area of Tort law are more sufficient to deal with specific claims for mesothelioma (3.14) and lung cancer that could have been asbestos-related (3.15). ${ }^{865}$ An extensive overview would, however, exceed the scope of this research. ${ }^{866}$ Therefore, the emphasis is put on existing alternative schemes for asbestos-related diseases.

\subsection{Alternative schemes to compensate asbestos victims: a comparative overview}

Generally, employees have multiple options to claim damages for asbestos-related diseases: social security, private insurance, and Tort law. ${ }^{867}$ Tort law has been subject to discussion in the previous parts of this chapter and mainly applies to recover further compensation which is not covered under the social security benefits or private insurance. ${ }^{868}$ As seen throughout this research, the problem of uncertain causation is - in a way - insolvable in claims for mesothelioma and lung cancer that could have been caused by exposure to asbestos. All solutions in Tort law on the issue of causal uncertainty aimed to seek a fair balance between the interests of the claimant and the interests of the defendant, but we must acknowledge that all proposed solutions have pros and cons. This also counts for the relatively new instrument of proportional liability which Dutch courts apply to compensate persons who suffer from lung cancer as a potential consequence of wrongful asbestos exposure, especially because the probability of causation must be assessed more accurately in order to better reflect reality. More epidemiological research is needed in this specific field before meaningful conclusions can be drawn on the development of lung cancer in persons who have been exposed to asbestos and did or did not smoke tobacco.

Over the years, several European countries have set up national schemes to compensate persons who suffer from mesothelioma. The aim of such alternative schemes is not only to compensate the mesothelioma sufferer on a less time-consuming and in a less costly way, but also to recognize the impact that asbestos has on society. In the Nether-

\footnotetext{
${ }^{865}$ See for an answer to this question in the Dutch jurisdiction: Hartlief 2003c, p. 151-172.

866 The literature cited in the footnotes provides further details.

${ }^{867}$ Philipsen 2007, p. 161: he refers to this as 'different compensation layers'. For more information on social security and private insurance, I refer to Waterman 2009; Engelhard 2007b; Hoop 2007; Philipsen 2007; Hartlief 1997.

${ }^{868}$ The social security benefits and private insurance cover the medical costs, loss of income, and loss of labour capacity. However, these alternatives do not always cover the claimant's total damage. Further compensation, that is, damage that is not covered under the social insurance system, can be recovered in Tort law. See: Hartlief 1997, p. 29; Faure 2003, p. 72. See for more information on the interaction between Tort law and social insurance: Faure \& Hartlief 2001; Faure \& Hartlief 1998.
} 
lands ${ }^{869}$, England ${ }^{870}$, and Belgium ${ }^{871}$ specific schemes have been set up to compensate victims of specific asbestos-related diseases. ${ }^{872}$ The conditions to apply for a payment under such schemes are less demanding when compared to the requirements to establish the liability of the defendant in Tort law. Part Three is set in a comparative perspective and examines the applicable schemes for asbestos victims in three European countries. The comparison is not only - like in the previous parts of this research - confined to Dutch and English laws but also includes the Belgian jurisdiction as some important developments have recently been made on the issue of compensating mesothelioma (and asbestosis) sufferers. In the three jurisdictions taken under consideration here, the type of causal uncertainty has proven to be of great importance to the question of whether an alternative scheme has been set up that guarantees a payment to the asbestos victim. The asbestos-related injury in question thus determines whether or not persons are eligible to apply for compensation under a specific scheme. Therefore, the upcoming sections will first deal with persons who suffer from mesothelioma (3.14) and, secondly, persons who suffer from lung cancer that could have been asbestos-related (3.15).

\subsection{Mesothelioma}

\subsubsection{The Belgium jurisdiction: an Asbestos Fund}

The complex legal issues connected to claims for mesothelioma, such as the proof of the wrongfulness of the defendant's intervention, the proof of a causal connection between the wrongful occupational exposure to asbestos and the claimant's damage ${ }^{873}$, and the question of whether or not the claimant's civil action has become time-barred have not received many publicity in the Belgian jurisdiction. ${ }^{874}$ Most Belgian mesothelioma sufferers have been exposed to asbestos in the course of their employment(s). This leads to the consequence that those victims apply for compensation under the general scheme for occupational diseases ${ }^{875}$, which is based on social insurance. Generally, persons who have been compensated under the scheme are excluded from filing a civil lawsuit against their (former) employers to recover further compensation. ${ }^{876}$ As of 1 April 2007, a specific no-fault national fund for asbestos-related diseases $\left(\mathrm{AFA}^{877}\right)$, within the general scheme for occupational diseases, came into operation in order to strengthen the position of

\footnotetext{
${ }^{869}$ The Dutch Institute for Asbestos Victims (two schemes for mesothelioma sufferers).

${ }^{870}$ Industrial Injuries Disablement Benefit for pneumoconiosis (including silicosis and asbestosis) byssinosis or an asbestos-related disease. The new Government scheme, which came into operation on 1 October 2008, is set up under The Child Maintenance and other Payments Act 2008 and the Mesothelioma Lump Sum Payment (Conditions and Amounts) Regulations 2008.

${ }^{871}$ Occupational diseases scheme (for mesothelioma and asbestosis sufferers).

${ }^{872}$ The list of countries where government schemes have been set up to compensate asbestos victims is not exhaustive.

${ }^{873}$ In cases in which two or more defendants have exposed the claimant to asbestos.

${ }^{874}$ However, very recently (28 November 2011), the case of Jonckheere/Eternit is regarded as the first successful claim for mesothelioma in which the Court of First Instance Brussels has awarded Euro 250.000,- to the relatives of $\mathrm{Mr}$ Jonckheere, his wife, and two sons who all four died from the consequences of mesothelioma. It goes without saying that this case has received much publicity.

${ }^{875}$ Beroepsziekteregeling.

${ }^{876}$ Article 51 Beroepsziektewet.

${ }^{877}$ Asbestfonds-Fonds d'Amiante.
} 


\section{Chapter 3}

asbestos victims. ${ }^{878}$ This new scheme provides a payment to persons who have developed mesothelioma or asbestosis after they had been occupationally, para-occupationally, or environmentally exposed to asbestos. ${ }^{879}$ Although the source of the exposure to asbestos is no longer an important factor to receive compensation for mesothelioma, it is of the utmost importance that the applicant can prove that he has been exposed to asbestos within the Belgian jurisdiction. The AFA is funded by the government (Euro 10.000 .000 ,- per year), employers' contributions (0.01\% of the employees' wages), contributions of self-employed persons (approximately Euro 750.000,- per year), gifts and legacies, and subrogation.

It is, however, remarkable that the contribution level is equal for all employers, irrespective of whether or not they have increased the risk on the development of asbestos-related injuries. This means that the general contribution of an asbestos producing company is relatively the same as the general contribution to the AFA of a company that produces vegetables. Former asbestos producing companies and their insurers will definitely favour the foundation of the AFA as they are now, as a consequence of their contribution to the AFA, immune for claims of all persons who apply for compensation from the AFA without their general contribution to the funds being higher than equal. The AFA cannot, except for cases in which a deliberate fault has been established, recover damages from the responsible person who contributes to the AFA, which implies that the payment burden stays with the AFA in most circumstances. ${ }^{880}$ It seems that the Belgian jurisdiction thus does not attach great importance to the principle that 'the tortfeasor must - as much as possible - compensate the victim's damage'.

The general occupational diseases scheme and the foundation of the AFA clearly show that the problematic issue of uncertain causation in claims for mesothelioma and asbestosis, which have been subject to extensive discussion in the previous chapters, does not necessarily arise in Belgium. It is important to note that most, if not all mesothelioma sufferers cannot pursue a civil action against the tortfeasor once they have received compensation from the AFA. ${ }^{881}$ This means that additional damages which cannot be recovered from the AFA, such as the costs of medical treatment and funeral expenses, cannot be recovered in a civil action. ${ }^{882}$ As said previously, there is an exception to the rule:

\footnotetext{
${ }^{878}$ See: Programmawet (I) van 27 december 2006, art. 113 tot en met 133 (Belgisch Staatsblad 28/12/06) gewijzigd door de wet van 11/05/07 (Belgisch Staatsblad 26/06/07); and Koninklijk besluit van 11 mei ter uitvoering van hoofdstuk 6, van titel 4, van de Programmawet (I) van 27 december 2006 tot oprichting van een Schadeloosstellingfonds voor asbestslachtoffers (Belgisch Staatsblad 29/05/07).

${ }^{879}$ De Kezel 2008, p. 17, 24, 25, 27: A similar funds for asbestos victims was set up in France (Fonds d'indemnisation des victims de l'amiante 'FIVA') in 2000 after the French Government was found liable for not taking sufficient safety measures in legislation to prevent employees from being exposed to asbestos in the course of their employment(s). However, the way in which the French fund is funded differs from the situation in Belgium (AFA). In France, the asbestos fund is for $1 / 3$ funded by the French government and for $2 / 3$ by employers' contributions. Asbestos producing companies have to pay a higher contribution to the fund. The aim is that the employers who are responsible for the exposure to asbestos compensate the damage which is caused by asbestos exposure by means of subrogation of the fund in the rights of the applicant.

${ }^{880}$ However, keep in mind that the AFA can recover the payment in cases in which there is a liable third person (someone who did not contribute to the AFA). See also: Faure 2003, p. 74.

${ }^{881}$ Article 51 Beroepsziektewet.

${ }^{882}$ Fonds voor Beroepsziekten - Brochure Asbestfonds, p. 18. However, keep in mind that mesothelioma sufferers who have been occupationally exposed to asbestos can recover such damages under the general
} 
additional damages can still be compensated by pursuing a civil action in cases where the tortfeasor deliberately exposed the person concerned to asbestos. However, this exceptional situation will not occur frequently in claims for asbestos-related diseases and must, therefore, be considered as a theoretical possibility with little practical effect. ${ }^{883}$ Very recently, on 28 November 2011, the case of Jonckheere/Eternit is regarded as the first successful claim for mesothelioma in which the Court of First Instance Brussels has awarded Euro 250.000,- to the relatives of Mr Jonckheere, his wife, and two sons who all four died from the consequences of mesothelioma. ${ }^{884}$

It must be emphasized that the Belgian occupational diseases scheme, including the AFA, is not based on liability but on social insurance. The consequence is that the requirements to establish the liability of the defendant which are used under Tort law differ from the requirements to receive compensation under the occupational diseases scheme. If the exposed person is able to demonstrate that he suffers from asbestosis or mesothelioma, and that the exposure took place on Belgian territory, he will 'automatically' receive compensation from the no-fault national fund AFA. ${ }^{885}$ This means that the person concerned does not have to prove a wrongful exposure to asbestos and a causal connection between, on the one hand, the wrongful exposure, and on the other hand, the damage that he has suffered. Moreover, the person concerned also does not have to be afraid that his civil action has become time-barred as a consequence of the long latency period connected mesothelioma.

Subsequently, the applicant will receive a fixed interest of approximately Euro 1600 ,- per month from the day that he has applied for compensation from the AFA. ${ }^{886}$ The amount of compensation is abstract, which means that the concrete circumstances of the victim, such as the victim's age and financial situation, are not taken into consideration to determine the amount of compensation in the individual case. De Kezel and Van Boom have criticised this approach arguing that the concrete circumstances of the claimant must be included in the establishment of the amount of the victim's material and non-pecuniary damages because the damage is higher in cases where the victim suffers from mesothelioma at a relatively young age. ${ }^{887} \mathrm{I}$ can follow this line of reasoning because a younger victim will loose more years of employment and, therefore, suffers more material damages (loss of income). The same can be said about the amount of nonpecuniary damage: a younger person suffers more non-pecuniary damage than an older

\footnotetext{
occupational diseases scheme (beroepsziekteregeling). See also: Hartlief 1997, p. 29 for more information on the function of Tort law and alternative schemes to compensate the claimant's damage.

${ }^{883}$ De Kezel 2008, p. 19.

${ }^{884}$ In this case the claimant pursued a civil claim against his former employer who exposed him to asbestos in the course of his employment.

${ }^{885}$ De Kezel 2008, p. 21.

${ }^{886}$ The amount of compensation is indexed annually. See: Fonds voor Beroepsziekten - Brochure Asbestfonds, p. 19. The mesothelioma sufferer's husband or wife receives a lump sump payment of approximately Euro 32.000,- in cases where the mesothelioma sufferer deceased. The mesothelioma sufferer's children receive approximately Euro 27.000,- each after the mesothelioma sufferer deceased. The amount of compensation is indexed annually. See: Fonds voor Beroepsziekten - Brochure Asbestfonds, p. 21.

${ }^{887}$ De Kezel 2008, p. 26; Van Boom 2005a, p. 64.
} 
person and, therefore, should receive more compensation from the AFA. The latter topic, however, exceeds the scope of this research and will not be discussed further. ${ }^{888}$

\subsubsection{The Dutch jurisdiction: an Institute for Asbestos Victims}

In the Netherlands, former Minister de Ruiter was appointed as head of 'Commission de Ruiter' and asked to advise the government on how to compensate victims of asbestosrelated diseases. ${ }^{889}$ In de Ruiter's view, occupationally exposed victims of asbestosrelated diseases must try to establish the liability of their (former) employer(s) in order to do justice to the principle that 'the tortfeasor has to compensate the victim's damage'. Due to the complexity connected to asbestos-related cases, de Ruiter advised - after having examined multiple options - to set up an Institute that mediates between the asbestos victim and his former employer(s) on the entitlement of damages. This led to the foundation of the Dutch Institute for Asbestos Victims (IAS) in 2000, which was set up by the Asbestos Victims Committee, various employers' and employees' organisations, the Association of Insurance Companies, and the government. ${ }^{890}$ The foundation of the IAS is a sign of social involvement of the government that recognizes the impact which asbestos exposure has on society and leads to a less time-consuming and less costly settlement of claims. ${ }^{891}$ As of the year 2000, mesothelioma victims who have been occupationally exposed to asbestos are eligible to apply for compensation in accordance with the conditions set forth by the IAS. ${ }^{892}$

Since 2003, the occupationally exposed mesothelioma victim will receive an interim payment of Euro $18.626,-{ }^{893}$ if he voluntarily gives assistance to the IAS procedure. The procedure is as follows: the IAS will first instruct the Dutch Mesothelioma Panel to confirm the diagnosis and subsequently advises the Social Insurance Bank (SVB) about the entitlement for compensation in the specific situation. The SVB will base their decision, to award or reject the interim payment, on the information provided by the IAS. In case the SVB decides to award compensation the mesothelioma victim will receive the interim payment within two months. Subsequently, the IAS mediates between employers and employees on the payment of damages in cases where the responsible employer(s) or insurer(s) has been traced successfully. Agreements on the amount of compensation have been made between the Asbestos Victims Committee, employers' and employees' organisations, and the government. The employer is, after he has accepted liability, obliged to pay the standard amount of compensation (Euro 59.536, $-{ }^{894}$ ). The IAS endeavour to complete the entire procedure within six months. The IAS thus tries to recover the dam-

\footnotetext{
${ }^{888}$ See also: Van Boom 2005a, p. 64. Hartlief has, although it does not directly deal with the situation under consideration here, also addressed the question of whether or not a fixed amount of compensation (Euro $10.000,-)$ is desirable to compensate the grief of third parties. See: Hartlief 2003b, p. 82.

${ }^{889}$ De Ruiter 1997.

${ }^{890}$ For a more detailed overview see: Van Boom 2005a, p. 60-67; or: www.asbestslachtoffers.nl [Last visited 31 August, 2012].

${ }^{891}$ De Kezel 2008, p. 22.

${ }^{892}$ Van Dijk \& Osch 2008, p. 378. See also: http://wetten.overheid.nl/BWBR0011113/geldigheidsdatum_19-12-2011/afdrukken+informatie [Last visited 31 August, 2012]

${ }^{893}$ This is the amount applicable for 2012. The amount of compensation is indexed annually.

${ }^{894}$ This is the amount applicable for 2012. The amount of compensation is indexed annually.
} 
ages from the responsible person, which implies that the payment burden does not always stay with the government. In cases in which the former employer has accepted liability after mediation by the IAS, the alternative scheme is self-financing.

The IAS procedure shows that the Dutch jurisdiction has attached much importance to the principle that 'the tortfeasor must - as much as possible - compensate the victim's damage' ${ }^{895}$ The Dutch legislator has, however, not adopted a right of mediation in law, which implies that mediation by the Institute can only be successful if both parties voluntarily give assistance to the procedure. ${ }^{896}$ The mesothelioma victim himself can always decide to file a lawsuit against his (former) employer(s) and thus not to follow the mediation procedure that has been set up by the IAS. ${ }^{897}$ It must, however, be acknowledged that the conditions to establish liability in a civil action are more demanding when compared to the conditions set forth by the IAS. ${ }^{898}$

\subsubsection{TAS-scheme}

But what is the legal position of Dutch mesothelioma sufferers in cases where (former) employers have gone out of business or are untraceable? If the responsible employer and his or her insurer is untraceable or have gone out of business he cannot participate in the mediation procedure set up by the IAS. In such cases it is, however, still possible to apply for compensation under the Asbestos Victims Compensation Scheme (TAS-scheme). The fact that the former employer is not in existence anymore thus does not necessarily lead to the conclusion that the employee will leave empty-handed. The mesothelioma sufferer can still apply for the standard compensation amount of Euro $18.626^{899}$ for nonpecuniary damages, which is guaranteed by the government and awarded by the SVB. The aim of this payment is not to compensate the claimant's damage but to recognize the grief encountered by the asbestos victim or their relatives. A few requirements must be satisfied before compensation can be awarded under the TAS-scheme. The first condition is that the claimant is diagnosed with mesothelioma. Secondly, the claimant must have been exposed to asbestos in the course of the employment. Thirdly, the claimant may not have deceased before 6 June 1997, and fourthly, it must have been established that the employer cannot be held liable anymore. ${ }^{900}$

Up until 2003, only mesothelioma victims who had been exposed to asbestos in the course of their employment(s) were entitled to apply for compensation under the TASscheme. The relatively limited scope of the scheme has changed over the years in favour of mesothelioma sufferers. From 2003 onwards, secondary victims of occupational expo-

\footnotetext{
${ }^{895}$ The same is true for the French jurisdiction in which asbestos producing companies have to pay a higher contribution to the asbestos fund (Fonds d'indemnisation des victims de l'amiante 'FIVA'), which was set up by the French legislator in 2000.

${ }^{896}$ See for more information on the incentives for employees and employers to participate in the mediation procedure: Van Boom 2005a, p. 63, 67.

${ }^{897}$ This could be the case in a situation in which the damage suffered by the mesothelioma victim exceeds the standard amount of compensation that has been established under the IAS-schemes. See also: Van Boom 2005a, p. 62; Van Dijk \& Osch 2008, p. 379.

${ }^{898}$ For more information on the history of compensating asbestos victims I refer to: Peeters 2007; Van Boom 2005a, p. 60-67; Padmos 2000, p. 376-379.

${ }^{899}$ This is the amount applicable for 2012. The amount of compensation is indexed annually.

${ }^{900}$ De Kezel 2008, p. 23.
} 


\section{Chapter 3}

sure to asbestos, i.e., housemates who have contracted mesothelioma due to the fact that the asbestos worker took his work clothes that contained asbestos home, can also apply for the standard payment under the TAS-scheme. However, the non-recoverable payments under the TAS-scheme lead to the undesirable consequence that the payment burden stays with the government, which implies that this specific scheme is not always self-financing: it is not the tortfeasor but the government who compensates the mesothelioma sufferer's damage if the responsible employer (and his insurer) is no longer in existence.

\subsubsection{TNS-scheme}

As of 1 December 2007, the Dutch scheme to compensate mesothelioma victims has - again - been extended in favour of mesothelioma sufferers. Nowadays, Dutch citizens, who have lived in the Netherlands for over 10 years and contracted mesothelioma but have not been exposed to asbestos in the course of their employment(s), can apply for compensation under a new scheme, which is known as: Compensation Scheme for Victims of Non-work-related Mesothelioma (TNS) ${ }^{901}$. The standard amount of compensation for non-pecuniary damages under the TNS-scheme is also guaranteed by the government and awarded by the SVB. ${ }^{902}$ This way, the government shows his social involvement with regard to persons who suffer from mesothelioma.

As said previously, as of 2003 being exposed to asbestos in the course of the employment is no longer an essential requirement in order to receive the standard payment. However, from January 2003 to December 2007, the mesothelioma victim must demonstrate that he has been domestically ${ }^{903}$ exposed to asbestos in order to receive compensation under the TAS-scheme. Due to the enactment of the TNS-scheme, being domestically exposed to asbestos is no longer a necessary requirement to receive compensation in cases where mesothelioma sufferers have not been occupationally exposed to asbestos. Persons who have been environmentally exposed to asbestos or have been exposed to asbestos fibres while working with products which contained asbestos materials at home are entitled to apply for compensation under the TNS-scheme. Nowadays, all mesothelioma sufferers can, irrespective of the source of the exposure to asbestos, receive compensation under one of the alternative schemes set up by the IAS. In 2008, the number of claims for mesothelioma (601) submitted to the IAS was higher than in 2007 (507). This number is significantly higher when compared to 2006 (371). ${ }^{904}$ It goes without saying that the introduction of the TNS-scheme on 1 December 2007 is the main cause of this expansion in the number of claims for mesothelioma. In fact, the introduction of the TNS-scheme has, as opposed to previous years, led to three times as many claims in the month December 2007. ${ }^{905}$

\footnotetext{
${ }^{901}$ Compensation Scheme for Victims of Non- work related Mesothelioma (Regeling tegemoetkoming nietloondienstgerelateerde slachtoffers van mesothelioom).

${ }^{902}$ Euro 18.626,- is the amount applicable for 2012. The amount of compensation is indexed annually.

${ }_{903}$ The applicant must demonstrate that his or her housemate had been occupationally exposed to asbestos in order to be eligible for compensation under the TAS-scheme.

${ }^{904}$ www.asbestslachtoffers.nl [Last visited 31 August, 2012].

${ }^{905}$ For more information on the history of compensating asbestos victims I refer to: Peeters 2007; Van Boom 2005a, p. 60-67; Padmos 2000, p. 376-379.
} 
However, it remains essential that the applicant developed mesothelioma in stead of another injury that is linked to asbestos exposure. Asbestos victims who suffer from asbestosis or lung cancer which could have been asbestos-related, cannot apply for compensation under the TAS-scheme or TNS-scheme. In fact, irrespective of the source and level of the exposure, asbestos victims who do not suffer from mesothelioma cannot apply for any kind of compensation under the schemes set up by the Dutch Institute for Asbestos Victims. Whether or not those non-mesothelioma sufferers will recover compensation thus depends on the outcome of a civil action: Tort law remains their only remedy. ${ }^{906}$

\subsubsection{The English jurisdiction: two government schemes}

In England, a new government scheme came into operation on 1 October $2008 .{ }^{907}$ This scheme aims to provide a lump sum payment to mesothelioma sufferers exposed to asbestos other than in employment within six weeks of making the claim. ${ }^{908}$ This new scheme thus compensates mesothelioma sufferers who have been either environmentally, domestically, or through self-employment exposed to asbestos. Initially, the awards under the new government scheme for mesothelioma used to be lower for nonoccupational exposed persons than for occupationally exposed persons but the level of awards equalized in April 2010 for all mesothelioma victims who have been diagnosed on or after 1 April 2010. Remarkably, the amounts payable under either scheme are dependant upon the age of the sufferer. The younger the age of the sufferer, the higher the lump sum payment ${ }^{909}$, which is shown in the following table:

$\begin{array}{ll}\begin{array}{l}\text { Age of } \\ \text { sufferer }\end{array} & \begin{array}{l}\text { Payment } \\ \text { ployment) } \\ \text { other than }\end{array} \\ 50 & £ 58,059,- \\ 55 & £ 49,632,- \\ 60 & £ 35,372,- \\ 65 & £ 20,729,- \\ 70 & £ 14,634,- \\ 75 & £ 12,478,-\end{array}$

\footnotetext{
906 Dutch courts have awarded damages in claims for asbestosis (Centrale Raad van Beroep 4 november 2004, LJN: AR5654) or lung cancer which could have been asbestos-related (Hoge Raad 31 maart 2006, NJ 2011, 250).

907 The new Government scheme is set up under The Child Maintenance and other Payments Act 2008 and the Mesothelioma Lump Sum Payment (Conditions and Amounts) Regulations 2008.

${ }^{908}$ Irwin Mitchell Asbestos Newsletter Autumn 2008: it is estimated that approximately 600 people per year who do not currently qualify for a payment will now receive one.

${ }^{909}$ The lump sum payment compensates the applicant's material and non-pecuniary damages. This differs from the fixed payments under the Dutch TAS- and TNS-schemes that only compensate the claimant's nonpecuniary damages.
} 


\section{Chapter 3}

Prior to 1 October $2008^{910}$, the English mesothelioma sufferer was, similar to the situation in the Netherlands prior to 1 December $2007^{911}$ and in Belgium prior to 1 April 2007, only eligible to apply for a lump sum payment if he was able to demonstrate that he had been exposed to asbestos in the course of his employment. ${ }^{912}$ Nowadays, all mesothelioma sufferers can - irrespective of the source of exposure to asbestos - receive a fixed amount of compensation. The total damage that the mesothelioma victim has suffered could, however, exceed the - by the age of the mesothelioma sufferer established fixed payment. The victim could decide to pursue a civil action against the responsible person to recover additional damages that are not covered under the government scheme. If the claim is successful, then it will be for the liable person/insurer to repay the government for the early lump sum payment. Strictly speaking, the payments under either scheme are government funded but, if there is a successful civil action, the government recovers the payment made to the claimant from the tortfeasor via the Compensation Recovery Unit. To an extent, the schemes are thus funded by defendants in civil claims as long as the responsible person (or their insurer) is still in existence. The English jurisdiction thus attaches much importance to the principle that 'the tortfeasor must - as much as possible - compensate the victim's damage'. The non-recoverable payments $^{913}$ under either scheme, however, lead the undesirable consequence that the payment burden stays with the government in some situations, which would imply that it is not the tortfeasor but the government who compensates the mesothelioma sufferer. ${ }^{914}$ This way, the English government shows his social involvement.

\subsubsection{Conclusion}

Nowadays, the Belgian ${ }^{915}$, Dutch ${ }^{916}$ and English ${ }^{917}$ jurisdictions do no longer require an occupational exposure to asbestos in order to be eligible to apply for compensation under one of the alternative schemes for asbestos-related diseases. Belgian mesothelioma and asbestosis sufferers could, irrespective of the source of the exposure to asbestos, receive compensation from a specific no-fault national fund (AFA) that has been set up under the - on social insurance based - general occupational diseases scheme in 2007. This differs from the limited scope of the two Dutch alternative schemes where only asbestos victims who suffer from mesothelioma can receive a standard amount of compensation. Another important distinction is that English mesothelioma victims can, irrespective of whether or not the sufferer has been occupationally exposed to asbestos, pursue a civil action to recover additional damages that are not covered in the awards under the specific

\footnotetext{
${ }^{910}$ Industrial Injuries Disablement Benefit for pneumoconiosis (including silicosis and asbestosis) byssinosis or an asbestos-related disease Act 1979, often referred to as Workers Compensation Act 1979.

${ }^{911}$ Except for housemates of the asbestos worker.

${ }^{912}$ Irwin Mitchell: Asbestos Newsletter Autumn 2008.

${ }^{913}$ Not all applicants who have received a payment under either scheme will be able (or in fact wish) to pursue a civil claim.

${ }^{914}$ It is important to note that, prior to 2008, the government had no legislative or regulatory framework at all for recovery of the payments made under the existing 1979 scheme (exposure in employment), which resulted effectively in a windfall for tortfeasors.

${ }^{915}$ From 1 April 2007 onwards.

${ }^{916}$ From 1 December 2007 onwards and for domestically exposed persons from 2003 onwards.

${ }^{917}$ From 1 October 2008 onwards.
} 
schemes. ${ }^{918}$ The Belgian mesothelioma or asbestosis sufferer, on the other hand, cannot pursue a civil action against the tortfeasor once the sufferer has been compensated under the general occupational diseases scheme and/or received compensation from the AFA unless the applicant is able to demonstrate that the tortfeasor has deliberately exposed him to asbestos. The practical effect is that in most, if not all cases in the Belgian jurisdiction, further compensation cannot be recovered in a civil claim. This essentially means that some mesothelioma victims are bound to go under-compensated under such a tortfeasorfriendly system.

The way in which the Belgian AFA is funded differs from the underlying idea to compensate mesothelioma sufferers under the Dutch and English (but also French) schemes. It seems that the Belgian jurisdiction does not attach great importance to the principle that 'the tortfeasor must - as much as possible - compensate the victim's damage'. In Belgium, the contribution level to the AFA is equal for all employers, irrespective of whether or not they have increased the risk on the development of asbestosrelated injuries. Former asbestos producing companies and their insurers will definitely favour the foundation of the AFA as they are now, as a consequence of their general contribution to the AFA, immune for claims of all persons who apply for compensation from the AFA without their general contribution to the funds being higher than equal. It seems as if the Belgian legislator is afraid for an 'American claim culture' in which a high number of claims for asbestos-related diseases led to insolvency of many construction firms. ${ }^{919}$ Although the applicable schemes in the Dutch and English jurisdictions are strictly speaking - government funded, the government tries to recover the payment made to the claimant from the tortfeasor in a civil claim. ${ }^{920}$ To an extent, the alternative schemes in the Netherlands and England are thus funded by defendants in civil claims ${ }^{921}$ as long as the responsible person (or their insurer) is still in existence.

Another important distinction is that the awards under the English government scheme for mesothelioma are, as opposed to the payments under the applicable schemes in the Netherlands and Belgium, dependant upon the age of the sufferer: the younger the age of the sufferer, the higher the lump sum payment under either scheme. In the Netherlands and Belgium, the concrete circumstances of the mesothelioma sufferer are not taken into consideration to determine the amount of compensation, which - essentially implies that all mesothelioma sufferers are put in one box. In Belgium, the mesothelioma sufferer receives, as opposed to the Dutch and English mesothelioma victims, a fixed interest on a monthly basis from the moment that he applied for compensation until his death. This could imply that Dutch and (older) English mesothelioma sufferers are in a better position, especially when we take into consideration the fact that mesothelioma is

\footnotetext{
${ }^{918}$ In the Netherlands, the IAS - and not the mesothelioma sufferer himself - could, once the mesothelioma sufferer decided to participate in the IAS-procedure, decide to file a lawsuit against the responsible tortfeasor by means of subrogation of the IAS in the rights of the applicant.

${ }^{919}$ De Kezel 2008, p. 27.

${ }^{920}$ In the Netherlands, the IAS could, by means of subrogation by the IAS in the rights of the applicant, also recover the payment from the tortfeasor.

${ }^{921}$ Or out of court mediation.
} 
a very serious disease ${ }^{922}$ and the fact that a civil action to recover further compensation is excluded in most situations once the victims has received a fixed payment from the AFA. $^{923}$

\subsection{Lung cancer that could have been asbestos-related}

Contrary to claims for mesothelioma, uncertainty arises as to the cause of the damage in claims for lung cancer that could have been asbestos-related, which implies that such cases are characterized by the problem of multiple causation. Exactly for this reason, most jurisdictions ${ }^{924}$ that have set up specific alternative schemes to award payments to mesothelioma sufferers have not (yet) set up such schemes for victims who suffer from lung cancer that is potentially asbestos-related, which has been subject to much criticism in legal writings. ${ }^{925}$ This section examines whether the foundation of an alternative scheme to compensate lung cancer sufferers would be desirable under certain conditions. As opposed to the previous sections on mesothelioma, the desirability of such a scheme in cases of lung cancer is not examined separately, for each jurisdiction taken under consideration here.

In the Netherlands, persons who suffer from lung cancer which could have been asbestos-related are not entitled to apply for an award under the two schemes set up by the Dutch Institute for Asbestos Victims ${ }^{926}$, and in Belgium such victims cannot apply for compensation from the AFA ${ }^{927}$. Irrespective of the source of the exposure to asbestos, no government scheme has been called into being and no lump sum payments have been made so far. In the Netherlands, mesothelioma sufferers are - seen from a perspective of compensation - in a better position when compared to victims who suffer from another injury that is linked to asbestos exposure. In Belgium, not only mesothelioma sufferers but also persons who have contracted asbestosis are, irrespective of the source of the exposure to asbestos, in a better position to receive a payment that is guaranteed by the government. In England, lung cancer sufferers who have experienced a substantial occupational exposure to asbestos can apply for a state disablement benefit under the Industrial Injuries Disablement Benefit ${ }^{928}$. The disease is described as D8A: primary carcinoma

\footnotetext{
${ }^{922}$ Approximately 80 percent of the patients diagnosed with mesothelioma die within 12 months and only very few of them survive the second year. I refer to Chapter 1 for more medical information.

${ }^{923}$ Very recently (28 November 2011), however, the case of Jonckheere/Eternit is regarded as the first successful claim for mesothelioma in which the Court of First Instance in Brussels awarded Euro 250.000,- to the relatives of $\mathrm{Mr}$ Jonckheere, his wife, and two sons who all four died from the consequences of mesothelioma.

${ }^{924}$ Except for France. In France, the position of lung cancer sufferers is better protected because all victims of asbestos-related diseases can apply for compensation under the Fonds d'indemnisation des victims de l'amiante 'FIVA', which was set up by the French legislator in 2000 after the government was found liable for not taking sufficient safety measures in legislation to prevent employees from being exposed to asbestos in the course of their employment(s).

${ }^{925}$ See for the Dutch jurisdiction: Van Boom 2005a, p. 65-66. See for the Belgian jurisdiction: Fonds voor Beroepsziekten - Brochure Asbestfonds, p. 10.

${ }^{926}$ Lung cancer that could have been asbestos-related does not fall under the scope of the TAS- or TNSscheme.

${ }^{927}$ See: Article 118 (1) (2) Programmawet.

${ }^{928}$ Industrial Injuries Disablement Benefit for pneumoconiosis (including silicosis and asbestosis) byssinosis or an asbestos-related disease Act 1979, often referred to as 'Workers Compensation Act 1979'.
} 
of the lung where exposure to asbestos had occurred in the course of a limited range of occupations and for certain specified minimum periods. ${ }^{929}$ The applied criteria to receive an award are - when compared to the criteria to receive a payment under the applicable schemes for mesothelioma - far more difficult to prove. Moreover, the award for lung cancer sufferers is restricted to persons who have been occupationally exposed to asbestos, which means that persons who have not been exposed to asbestos in the course of their employment(s) cannot apply for a state disablement benefit under the Industrial Injuries Disablement Benefit.

\subsubsection{A compensation scheme for lung cancer?}

The question of whether or not it is desirable to set up a compensation scheme for lung cancer sufferers and what would then be the best way to fund such a scheme is not easy to answer. ${ }^{930}$ Due to many scientific uncertainties with regard to the development of lung cancer among persons who have been exposed to asbestos and did or did not smoke tobacco, the essential conditions that would justify the foundation of a scheme that awards payments to persons who suffer from lung cancer are hard to establish. It is impossible to establish whether or not the lung cancer is caused by the wrongful exposure to asbestos in an individual case. Moreover, it could be criticised that the epidemiological evidence that is used to determine the probability that asbestos has caused the claimant's lung cancer inserts a certain element of speculation in individual cases.

De Kezel and Van Boom argue that it is not impossible to set up a government scheme to compensate lung cancer sufferers. Van Boom suggested that, if we acknowledge that the social involvement of the government with regard to mesothelioma sufferers is a result of the fact that the government is jointly responsible for not taking sufficient safety measures to prevent employees from contracting lung cancer that could only be asbestos-related, the compensation schemes set up by the IAS must also award payments to persons who suffer from lung cancer that is potentially asbestos-related. ${ }^{931}$ Criteria, such as: the intensity of the exposure to asbestos, the duration of the exposure to asbestos, and the claimant's smoking history can be used to determine whether the lung cancer sufferer is eligible to apply for a payment under the lung cancer scheme. Once the total exposure level (fibre years) exceeds a certain threshold, causation between asbestos exposure and lung cancer can be proved. ${ }^{932}$

Subsequently, the most reasonable results can be achieved if the payment under the scheme commensurate with the assessed probability of causation. ${ }^{933}$ However, in practice the same problems which arise in Tort law, such as the proof of sufficient causation between the exposure to asbestos and the development of lung cancer, do also arise under

\footnotetext{
${ }^{929}$ To meet the strict criteria for D8A, exposure to asbestos must have been in the course of: a) The manufacturer of asbestos textiles; or b) Spraying asbestos; or c) Asbestos insulation work; or d) Applying or removing materials containing asbestos in the course of shipbuilding. From 6 April 2006 onwards, evidence of asbestosis is no longer essential but the minimum specified periods of exposure for the abovementioned occupations are either: a) 5 years pre 1975; or b) 10 years post 1995.

${ }^{930}$ See also: Van 1995, p. 276-285.

${ }^{931}$ Van Boom 2005a, p. 66.

${ }^{932}$ De Kezel 2008, p. 25; Van Boom 2005a, p. 66.

${ }^{933}$ Van Boom 2005a, p. 60, 61, 66.
} 


\section{Chapter 3}

such a scheme: it is impossible to determine whether the applicant would also have contracted lung cancer if he had not been (occupationally) exposed to asbestos. ${ }^{934}$ Furthermore, the long latency period connected to lung cancer also complicates the issue. ${ }^{935}$ Under a scheme for lung cancer sufferers, it is expected that the applicant must still be able to show that his occupational exposure exceeded the exposure threshold in order to receive a payment. However, in most cases hardly any measurement data is available which makes the assessment of the applicant's exposure history less reliable. Moreover, a sufficient assessment of the probability of causation is a time-consuming and costly occupation, while alternative compensation schemes normally aim to provide a payment in a less time-consuming and less costly way.

The question of how such a scheme for lung cancer sufferers must be funded is also difficult to answer. If we would attach great importance to the principle that 'the tortfeasor must - as much a possible - compensate the victim's damage', it is the most obvious conclusion to fund the scheme by contributions of employers who have exposed their employees to asbestos and thus increased the risk of developing an asbestos-related injury. However, it goes without saying that such employers will be very reluctant to pay contribution because it is too unsure that they have - by exposing their employee(s) to asbestos - caused lung cancer in an individual case. Furthermore, a scheme that is working efficiently must only award payments to persons who have contracted lung cancer as a consequence of asbestos exposure, which is - contrary to claims for mesothelioma - impossible to prove in individual cases. ${ }^{936}$ If the scheme would be government funded, a precedent could be created for other occupational diseases in which the claimant also suffers from a disease which can be attributed to at least two causes, one of which is work-related. The question is: where do you draw the line?

In 1997, Spier and De Ruiter acknowledged that, if the government would compensate mesothelioma sufferers, the government bears an enormous financial risk, especially because government compensation for mesothelioma sufferers could create a precedent for other occupational diseases. ${ }^{937}$ The government, on the other hand, referred to the problematic nature of mesothelioma as being unique and specific in its kind. The fear of creating a precedent for other occupational diseases was - in view of the government not present due to the cause of the injury, the long latency period, the age of the mesothelioma sufferer, and the seriousness of the illness (mesothelioma). ${ }^{938}$ Van Boom is, however, not convinced of the uniqueness of mesothelioma and argues that, although risk management has become more and more important in the last decades, we perhaps still take too many risks when it comes to other substances which have not been extensively tested yet. ${ }^{939}$

From my point of view, mesothelioma is - and has until now also proven to be - such a unique and specific injury that it is justified to set up a compensation scheme that award fixed payments to mesothelioma sufferers without creating a precedent for other occupa-

\footnotetext{
${ }^{934}$ See also Hartlief and Faure in: Faure 2003, p. 74.

${ }^{935}$ I refer to section 1.3.3 for more medical information.

${ }^{936}$ See also: Faure 2003, p. 74.

${ }^{937}$ De Ruiter 1997, paragraph 4.3; Spier 1997, p. 62.

${ }^{938}$ Kamerstukken II 1996/1997, 25000 XV, nr. 58, p. 5-6.

${ }^{939}$ Van Boom 2005a, p. 65.
} 
tional diseases. However, the foundation of a scheme that award payments to persons who suffer from lung cancer that could have been asbestos-related seems to be one step to far for the jurisdictions taken under consideration here. The latter situation is, when compared to mesothelioma cases, less unique and less specific which means that the fear of creating a precedent for other occupational diseases is more appropriate. ${ }^{940}$ For this moment, and due to the nature of the problem, Tort law remains the only remedy for victims of lung cancer that could be asbestos-related to recover compensation from the tortfeasor in the Netherlands, Belgium, and England.

\subsection{Overall conclusion}

The foundation of alternative schemes to award payments in cases in which no uncertainty arises as to the cause of the damage is desirable in specific claims for asbestos-related diseases. In the Netherlands, Belgium, and England such schemes have been set up to compensate mesothelioma sufferers in a less time-consuming and less costly way. Nowadays, all mesothelioma victims receive, irrespective of the source of the exposure to asbestos, a payment that is guaranteed by the government, which must be seen as a sign of social involvement of the government. Although the awarded fixed amount of compensation does not always cover all damages that the mesothelioma sufferer has encountered, it does recognize the impact that asbestos has on society. In the Netherlands and Belgium, the concrete circumstances of the applicant are not taken into consideration to determine the amount of compensation, which implies that all mesothelioma sufferers are - from a perspective of compensation - put in one box. In England, on the other hand, the amount of compensation under either scheme depends on the age of the applicant: the younger the mesothelioma sufferer, the higher the lump sum payment. It is arguable that the English approach does more justice to the situation.

Strictly speaking, the payments under the schemes for mesothelioma in the jurisdictions taken under consideration here are to a great extent government funded, but if the claimant's civil action is successful, the government recovers the payment made to the claimant from the tortfeasor. In the latter situation, the scheme is working most efficiently as those who have increased the risk to contract mesothelioma compensate those who suffer from mesothelioma. In Belgium, however, civil actions are excluded once the mesothelioma sufferer has received compensation from the AFA unless the claimant can demonstrate that he has been deliberately exposed to asbestos. This leads to the consequence that the possibility to pursue a civil action to recover further compensation from the tortfeasor must be considered as a theoretical one with little practical effect. In the Netherlands and England, more importance is attached to the principle that 'the tortfea-

\footnotetext{
${ }^{940}$ However, it is common knowledge that such lung cancer sufferers make medical costs which is (partly) covered by the victims' private health insurance. Insurance companies might want to claim those (unexpected) costs from the responsible asbestos industry. The foundation of a fund that award payments to the victim's health insurer in order to recover the medical costs might be desirable. If the damage cannot be determined in an individual case but only on a statistical level, Van Maanen proposed to award proportional compensation to health insurers who have made higher costs as a consequence of nuclear accidents. In claims for lung cancer that could be caused by exposure to asbestos, it is arguable that private health insurers must have a right of recourse that is in line with the probability that the lung cancer is caused by the wrongful exposure to asbestos. See: Van Maanen 1993, p. 19-36; Faure 2003, p. 73.
} 
sor must - as much as possible - compensate the victim's damage'. However, in cases in which the awarded payment cannot be recovered from the responsible tortfeasor, it is the government and not the tortfeasor who bears the burden of compensating the mesothelioma sufferer, which means that the applicable schemes are not self-financing in all situations.

The foundation of a scheme that award payments to persons who suffer from lung cancer as a potential consequence of asbestos exposure has proved to be more complex. In these particular cases, uncertainty arises as to the cause of the damage, which implies that other factors could also have caused (or contributed to the development of) lung cancer. Exactly for this reason, the foundation of a compensation scheme is undesirable. Firstly, the same problems that arise in Tort law, such as the proof of sufficient causation between the exposure to asbestos and the development of lung cancer, will also arise under the scheme when establishing the requirements to apply for a payment. An efficiently working scheme must be funded by those who have increased the risk on the development of lung cancer and must only award payments to those who have developed lung cancer as a consequence of asbestos exposure, which is - contrary to claims for mesothelioma - impossible to prove in individual cases. Employers who have exposed their employee(s) to asbestos will be reluctant to pay contribution to the scheme as it is too unsure whether they have caused the applicant's damage. If the amount of compensation under the scheme is based on the assessment of the probability of causation, the procedure will be very costly and time-consuming, which contradicts its purpose. Secondly, the fear that such a scheme would create a precedent for other occupational diseases is more appropriate. Contrary to mesothelioma, lung cancer is less unique and less specific in its kind because many other occupational diseases are also characterized by the problem of multiple causation.

Finally, it is also important to recognize that alternative schemes do - in most situations - not compensate the claimant's damage in full, which means that the applicant will, if this has not been excluded, still have to make an appeal to Tort law to recover further compensation. In a civil claim, persons who suffer from mesothelioma or lung cancer that could have been asbestos-related will always be confronted with the problem of uncertain causation for the simple reason that proof of causation is a fundamental requirement for liability. In conclusion one could say that alternative schemes are solely a solution to recover a part of the claimant's total damage. 


\section{The Assessment of the Probability of Causation and the Role of Experts in Asbestos-Related} Cases

\subsection{Chapter introduction}

Often judges and other legal scholars are faced with legal and scientific questions which cannot be resolved without the help of experts. ${ }^{941}$ In claims for lung cancer that could have been caused by occupational exposure to asbestos, judges do not have the relevant scientific experience or qualification to assess the probability that the claimant's lung cancer was caused by the wrongful exposure to asbestos. The multitude of causal factors and the complex interaction between these factors pose serious problems for those faced with the burden of proving causation between the wrongful exposure to asbestos and the claimant's lung cancer. ${ }^{942}$ In these particular cases the judge calls on expert opinion to assess the likelihood that a given activity (exposure to asbestos) causes a known damage (lung cancer). The establishment of causation in asbestos-related cases thus involves a multidisciplinary interaction between judges and experts. However, it is clear, and well established in literature ${ }^{943}$, that judges and experts do not speak the same 'language', which is often referred to as the 'knowledge-paradox'. This cross-disciplinary discussion can lead to miscommunication and incorrect legal judgments.

In the majority of asbestos-related cases, whether judges understand the basic assumptions of the research done by the expert(s) can be questioned, because most, if not all judges did not have the type of education that would enable them to properly analyze epidemiological and statistical data. ${ }^{944}$ Equally, experts sometimes do not exactly know

\footnotetext{
${ }^{941}$ This problem mainly arises in claims for occupational diseases and medical negligence. See for more information: Verkerk 2010, p. 159; Verkerk 2009, p. 167; De Groot \& Akkermans 2007, p. 501.

${ }^{942}$ Van \& Nijs 1996, p. 48.

${ }^{943}$ For more information, I refer to two special editions of Dutch Journals in which this was discussed: Schadevaststelling en de rol van de deskundige, Nederlands Tijdschrift voor Burgerlijk Recht 2007/10, p. 427509; Bewijs, Ars Aequi juli/augustus 2010, p. 449-452.

${ }^{944}$ This could lead, and has already led, to (mis)communication problems and, more disturbing, to incorrect judgments. See for an example outside the area of asbestos claims: Rechtbank Maastricht 13 juli 2005, JA 2006, 44: In this case a man was bitten in his hand by a dog. Instead of cleaning the wound and leave it open, the physician glued and closed the wound. Subsequently, the patient developed dystrophy. In court, the specialist stated that normally (following the correct procedure) the chance on dystrophy is $1-2 \%$. Because of
} 


\section{Chapter 4}

what questions the judge is seaking to answer. This is an alarming development, especially because the instrument of proportional liability (as recently applied in Dutch law) depends almost completely on the findings of the appointed expert(s). ${ }^{945}$ It is of the utmost importance that the judiciary and lawyers are familiar with which conclusions can and cannot be drawn from the expert evidence, and that evidence is presented in simple, clear ways to avoid confusion. Therefore, the role of experts and the use of epidemiological data to assess the probability that asbestos has caused the claimant's lung cancer will be extensively examined in this multidisciplinary chapter. The aim is to propose solutions to these problems because miscommunication between judges and experts can have enormous negative consequences for both the claimant and the defendant.

In order to better understand the contribution of experts in asbestos-related cases, I first start to generally discuss rules on the appointment of experts in Dutch and English laws. Subsequently, this chapter explains how the probability of causation, i.e., the probability that the exposure to asbestos has caused the claimant's lung cancer, is assessed in claims for lung cancer that could have been asbestos-related. The use of epidemiological data will be examined in order to determine whether or not judges interpret such data in the correct way. If not, judges then decide cases on the basis of wrong assumptions. The question of whether or not the instrument of proportional liability is still the best compromise to establish the liability of the defendant and to assign compensation to the claimant will be addressed. Is it desirable to assess the Probability of Causation (PoC), also known as 'Attributable Risk' ${ }^{946}$, to establish the proportional liability of the defendant? Finally, several solutions are proposed to reduce the number of judgments that are, as a result of miscommunication or incorrect expert reports, based on wrong assumptions.

\subsection{The appointment of experts in Dutch and English laws}

In civil litigation, experts are appointed to involve more expertise in the proceeding in cases where the technical evidence is too complex for the judge to understand. ${ }^{947}$ It must be emphasized, however, that it is not the role of experts to 'decide' the legal outcome of the case and that one scientific truth does not exist due to the subjective nature of

the physician following the wrong procedure, the chance on dystrophy had risen to 2-4\%. In view of the judge, this means that - at worst - the malpractice caused a 3\% (4 minus 1$)$ higher risk on dystrophy. This percentage is too little to assume sufficient causation. However, they should have judged that there is a $50 \%$ chance (attributable risk) on a causal relation between the medical malpractice and the dystrophy. Had they applied the instrument of proportional liability, the judge should have awarded $50 \%$ of the damages. This is a perfect example of miscommunication between judges and experts and judges not knowing how to use epidemiological and statistical evidence. See for more examples in case law: Rechtbank Amsterdam 14 juli 2010, JA 2011, 4; Gerechtshof 's-Gravenhage 28 april 2009, LJN: BI4768. See also: Van \& Wijne 2012, p. 16-24; Van Velthoven 2011, p. 29, 36; Van Dijk 2010, p. 106, 107; Lindenbergh 2006, p. 741.

${ }^{945}$ Centrale Raad van Beroep 9 april 2009, LJN: BI2805; Hoge Raad 31 maart 2006, NJ 2011, 250 (Nefalit/Karamus); Hoge Raad 31 maart 2006, LJN: AU6093 (Hollink/Eternit); Kantongerecht Middelburg 1 februari 1999, TMA 1999/6 (Schaier/De Schelde).

${ }^{946}$ Greenland 1999, p. 1167; Porta 2008, p. 11: 'The proportion of the risk of a disease or other outcome in exposed individuals that can be attributed to the exposure.'

${ }^{947}$ Hartman \& Dekker 2008, p. 91-92; De Groot \& Akkermans 2007, p. 501. 
science. ${ }^{948}$ This section distinguishes the court-appointed expert from the partyappointed expert and generally examines the pros and cons connected to the appointment of such experts in Dutch and English laws. The subsequent section 4.2.1 examines the appointment of experts in asbestos-related cases and addresses the question of whether it is more desirable to appoint court- and/or party-appointed experts in such cases.

In Dutch law, procedural codes have empowered judges to appoint experts to inform the court and not to make the decision on behalf of the court. The court has the power to decide whether or not an expert should be appointed in a specific case. ${ }^{949}$ This means that the court could also decide not to appoint an expert against the wishes of both parties. The court should, before he decides to appoint an expert, first establish whether or not evidence can be gathered more easily and whether or not the costs to appoint an expert is proportional to the value of the claim. It is common knowledge that high valued claims justify higher costs. ${ }^{950}$ Article 198 of the Dutch Code of Civil Procedure (Rv) requires court-appointed experts to be impartial. ${ }^{951}$ In some jurisdictions, such as the Netherlands and Germany, courts keep a list of experts which have been appointed before in similar cases. The keeping of such lists is considered to be 'good practice' because judges can give comments and are able to share their experiences with regard to the time and quality of the delivered expert evidence. Experts who deliver high quality reports will most likely be recommended and appointed in (similar) future cases.

A court-appointed expert system has its merits as it reduces the incentives for experts to be impartial. ${ }^{952}$ However, such a system also has drawbacks. Verkerk argues that it is almost impossible for the parties to convince the judge not to follow the conclusions set up by the court-appointed expert. In addition, there is reason to fear that judges cannot identify mistakes made by the court-appointed expert. ${ }^{953}$ After all, a judge will only appoint an expert when he is not familiar with the technical issues involved in the case. This could illustrate why judges, although case law made it very clear that the judge should check whether or not there is an indication to deviate from the expert report, hardly ever deviate from the conclusions of court-appointed experts. ${ }^{954}$ As a consequence, legal scholars fear that experts decide the (legal) outcome of the case, which is

\footnotetext{
${ }^{948}$ Dekker \& Hartman 2006, p. 6-10. This has been confirmed by the Court of Appeal in 2009: Gerechtshof Amsterdam 24 maart 2009 (rolnr. C07/01414).

${ }^{949}$ See Article 194 Dutch Code of Civil Procedure.

${ }^{950}$ Faure et al. 2006, p. 3, 4: Whether or not expert costs are eligible for compensation depends on the so called 'double reasonableness test': the extent of the costs has to be reasonable and it has to be reasonable to make these costs in the specific claimant's case. In order to determine the 'reasonableness', it is essential to look closer to: the relationship between the amount of the damages and the amount of the costs of expertise, the necessity or superfluousness of the expertise (if the damage was clear and not debated), the willingness of the defendant to compensate the damage and the possibility for the victim to establish the damage in an easier and less costly way.

951 This does, however, not mean that experts are not allowed to have their own expert opinion, which means that science is open to interpretation.

${ }^{952}$ Verkerk 2010, p. 168.

953 This, however, also counts for the party-appointed expert. See for more information: Verkerk 2009, p. 168, 170-173, 178, 180.

${ }^{954}$ Hoge Raad 19 oktober 2007, LJN: BB5172; Van Dijk 2007, p. 435.
} 


\section{Chapter 4}

not a desirable development. Furthermore, De Groot highlights another problematic issue connected to court-appointed experts: the parties involved in the proceeding are afraid to comment on the conclusions set up by court-appointed experts. The consequence is that parties do not correct mistakes in the expert report, which results in the fact that errors remain unknown. ${ }^{955}$ This could lead to the consequence that judges base their legal decisions on incorrect scientific information and thus on contested assumptions.

Dutch law, however, also recognizes the party-appointed expert in stead of, and sometimes alongside, the court-appointed expert. The Dutch Code of Civil Procedure (Rv) allows experts to be appointed by the parties. ${ }^{956}$ A system in which the parties can appoint their own experts has pros and cons. On the one hand, party-appointed experts can be useful to comment on the findings of the court-appointed expert. If both parties agree to appoint one specific expert, the court is willing to attach significant value to the findings of this expert. ${ }^{957}$ However, on the other hand, party-appointed experts can also be used as a so called 'hired gun' by the party who appointed them, which means that the findings and conclusions may not be impartial anymore. It has also been acknowledged that a party-appointed expert system could lead to so called 'junk science' because law does not require the party-appointed expert to have a scientifically based background. ${ }^{958}$ Furthermore, if both parties appoint their own expert, this could result in conflicting expert opinions, which is mostly referred to as the 'battle of experts'. In such a situation it is, for a judge, extremely difficult to choose between two dissenting opinions, especially in cases where the expert evidence is highly technical. ${ }^{959}$ Drawbacks with a more practical nature can also play a role to deny party-appointed experts in civil litigation: if both parties appoint there own expert the time and costs of the procedure will definitely increase. $^{960}$

Under English law, procedural rules are found in the Civil Procedure Rules 1998 (CPR). Similar to Dutch law, English law recognizes the court-appointed expert as well as the party-appointed expert. The pros and cons connected to both systems have previously been discussed and also apply to English law. Due to the drawbacks connected to the party-appointed expert (not always impartial, junk science, conflicting expert opinions, costs, and time), English law has introduced the so called 'single joint expert" ${ }^{\text {'961 }}$ in order to assure more objectivity and to limit the use of experts in civil litigation, which saves money and time. The court has the power to require that evidence is given by one expert only. ${ }^{962}$ In the majority of the cases, the single joint expert is chosen and appointed by both parties involved in the proceedings. However, similar to Dutch law, the court

\footnotetext{
${ }^{955}$ De Groot 2008, p. 444-448.

${ }^{956}$ See for example: Article 200 Dutch Code of Civil Procedure (Rv).

${ }^{957}$ Verkerk 2009, p. 189.

${ }_{958}$ Giard \& Stolker 2003, p. 610-616.

${ }^{959}$ See for an example on how the court must deal with conflicting expert opinions: Hoge Raad 8 juli 2011 , NJ 2011, 311; Hoge Raad 9 december 2011, NJ 2011, 599.

${ }^{960}$ Verkerk 2010, p. 177.

${ }^{961}$ The 'single joint expert' is also known as the 'Part 35 expert'. Part 35 refers to Part 35 of the Civil Procedure Rules 1998. See also: Tzankova 2003, p. 122, 123.

${ }^{962}$ See for more information: Civil Procedure Rules 1998, r. 35.7.
} 
has the power to appoint another expert against the wishes of both parties. The appointment of a single joint expert is, when compared to a situation in which the two parties appoint their own expert, preferred in low valued cases because it reduces the expert costs. However, in high valued and highly technical cases it may be preferred to involve more expertise into the proceeding, which means that a party-appointed expert system can be useful. I argue, in line with Verkerk, that it would, from an evidential point of view, be desirable to allow party-appointed experts alongside, or instead of, courtappointed experts in high valued and highly technical cases. ${ }^{963}$ In such cases, the partyappointed expert is able to comment on the findings of the court-appointed expert, which will help the court to make a well-considered legal decision.

\subsubsection{The appointment of experts in asbestos-related cases}

In claims for lung cancer that could have been caused by the exposure to asbestos in the course of the employment, it is necessary to appoint (an) expert(s) in order to inform the judge about the technical issues involved in the cases. Judges are not schooled to assess the probability that the lung cancer was caused by the occupational exposure to asbestos. Experts have also been appointed in claims for mesothelioma. Although it has been established that asbestos is the only known cause to contract mesothelioma, medical specialists have to confirm that the person concerned is indeed suffering from mesothelioma in order to establish the claimant's damage. Only in a small number of cases it has proved to be difficult to establish beyond doubt that the claimant suffers from mesothelioma. ${ }^{964}$ The Health Council of the Netherlands emphasized the importance of a forum of experts in cases where, based on the available information, no consensus could be reached on the diagnosis. The Health Council concluded that this forum of experts should consist of 'experts specialized in lung diseases, industrial medicine, clinical pathology and occupational hygiene, possibly supplemented with experts in any other fields that may be necessary. ${ }^{, 96}$

In claims for asbestos-related diseases, experts have been appointed for various reasons. In the majority of the cases, experts are appointed to inform the judge about the relationship between the exposure to asbestos and the damage suffered by the claimant. This means that experts are appointed to provide information on the problematic requirement of causation, which will be subject to extensive discussion in the following sections. However, it should be noted that experts have also been appointed to provide information on the claimant's level of asbestos exposure in the course of his employment in order to determine the wrongfulness of the defendant's intervention. Furthermore, in many personal injury cases, experts are appointed to provide information on the (amount of the) claimant's damage(s). ${ }^{966}$

\footnotetext{
${ }^{963}$ Verkerk 2010, p. 181.

${ }^{964}$ Gezondheidsraad 1998, p. 16: 'The diagnosis of malignant mesothelioma can be reached in around eighty percent of cases on the basis of a clinical-pathological examination of fluid extracted from the pleural cavity, or a biopsy of the pathological pleural tissue, which would be required if a radiographic examination of the lungs revealed abnormalities.'

965 Gezondheidsraad 1998, p. 17.

966 See for more information: Lindenbergh 2007, p. 428-434; Giard 2007, p. 442-449; Van Dort 2007, p. 453-456.
} 
It is difficult to decide whether it is more desirable to appoint party- and/or courtappointed experts in claims for asbestos-related diseases. As discussed in the former section, a party-appointed expert system can easily lead to partiality because - it is most likely that - the claimant will only appoint experts who deliver reports which will improve his legal position and the defendant will only appoint experts who deliver reports which favours his position in court. However, it is arguable that, when more expertise is brought into the proceeding, the judge has more information on how to decide the case. The costs to appoint an expert must, however, be proportional to the value of the claim. Depending on the asbestos victim's injury, age, and work history, the claim is classified as a high valued or low valued claim. In low valued claims it might be better to appoint one expert in order to reduce the expert costs. However, although a court-appointed system reduces the incentives for experts to be impartial, it has proved to be almost impossible for the parties to convince the judge not to follow the conclusions set up by the court-appointed expert. In such claims the appointment of a 'single joint expert' seems desirable as it reduces the drawbacks connected to a party-appointed expert system. High valued claims, on the other hand, justify higher costs. In high valued claims for asbestos-related diseases, it seems desirable to allow party-appointed experts alongside, or instead of, court-appointed experts to involve more expertise in the proceeding. If the court decides to appoint an expert and also allows the parties involved in the proceeding to appoint their own expert, the party-appointed expert is then able to comment on the findings of the court-appointed expert, which will help the court to make a wellconsidered legal decision.

\subsection{The assessment of the probability of causation in claims for lung cancer that could have been asbestos-related}

In most claims in Tort, the assessment of causation results in a yes or no answer. However, in specific situations the assessment of causation is a question of probability and percentages. ${ }^{967}$ In practice, courts call on expert opinion to assess the likelihood that a given activity causes a known damage. The likelihood is expressed as a probability and the probability is expressed in a percentage which the court can use to establish the liability of the defendant and to assign compensation to the claimant. ${ }^{968}$ This section examines the assessment of the Probability of Causation (PoC), also known as 'Attributable Risk' ${ }^{969}$, in cases concerning the liability for lung cancer that could have been asbestos-related.

The question of whether or not a lung tumour is attributable to exposure to asbestos is much less easy to answer than the corresponding question in the case of mesothelioma. ${ }^{970}$ In claims for mesothelioma, asbestos is the only known cause to contract the disease. ${ }^{971}$ This means that it is almost completely certain that the exposure to asbestos has led to the development of mesothelioma. Lung cancer is, as explained in section 1.1.3, a

\footnotetext{
${ }^{967}$ Van Gerven et al. 2000, p. 428/2.

${ }^{968}$ Young et al. 2004, p. 517.

${ }^{969}$ Porta 2008, p. 11: 'The proportion of the risk of a disease or other outcome in exposed individuals that can be attributed to the exposure.'

${ }^{970}$ Henderson et al. 2004, p. 517.

${ }^{971}$ Lemen et al. 1980 , p. 8: None of the epidemiological studies have shown an increase of mesothelioma among smokers as compared to non-smokers.
} 
totally different story. Despite an extensive number of publications, the relationship between asbestos exposure and lung cancer is still subject of controversy, even when asbestosis is present. ${ }^{972}$ Slot phrased it very clearly: 'asbestos is by no means the only causative agent of lung tumours. ${ }^{973}$ Establishing the liability of the defendant is, due to the uncertainty about the cause of lung cancer, extremely difficult. In 1999, Burdorf suggested to use a probability model that apportions the relative contribution of asbestos exposure amongst other risk factors. ${ }^{974}$ The Health Council of the Netherlands, who submitted an advisory Report to the State Secretary for Social Affairs and Employment in 2005, also advised to use a specific formula to assess the Probability of Causation (PoC) in such cases. ${ }^{975}$ In order to adequately assess the probability that asbestos exposure caused the lung cancer more information is required on the claimant's exposure history, the chemical nature of the inhaled asbestos fibres, and the (sub)multiplicative relation between smoking and exposure to asbestos. However, such information is not always available in the specific claimant's case, which means that it is inevitable that the outcome of the assessment of causation inserts a certain element of speculation.

\subsubsection{An assessment of the claimant's cumulative exposure to asbestos}

First of all, it is essential to determine whether there is sufficient evidence for occupational exposure to asbestos in the claimant's work history. Therefore, an accurate exposure assessment is of central importance in such claims. Cardier defines exposure as 'a contact of an individual with an agent through any medium or environment.' She further explains that an 'exposure assessment aims to identify whether a person is exposed or not to a particular agent and if the individual is exposed, to develop a ranking of subjects by exposure level. ${ }^{976}$ This means that a life time job history is necessary to make an adequate assessment of the level of asbestos exposure in a specific claimant's case. ${ }^{977}$

The claimant's cumulative exposure to asbestos is generally expressed in 'fibre years', which is seen as an important parameter for asbestos exposure. ${ }^{978}$ One fibre year is the exposure to air during one year which contains one asbestos fibre per cubic centimeter. ${ }^{979}$ A short exposure to high dust concentrations can result in the same cumulative exposure as a long exposure to low dust concentrations: one year of heavy exposure or 5-10 years of moderate exposure may increase the risk to develop lung cancer two-fold or more compared to those who were never exposed to asbestos. ${ }^{980}$ However, as outlined in section 2.2.1.1.1, we must acknowledge that it is, due to the long latency period between the exposure to asbestos and the development of lung cancer, extremely diffi-

\footnotetext{
${ }^{972}$ Henderson et al. 2004, p. 517; Tossavainen 1997, p. 314.

${ }^{973}$ Slot 2005, p. 39.

${ }^{974}$ Burdorf \& Swuste 1999, p. 64.

${ }^{975}$ Gezondheidsraad 2005.

${ }^{976}$ Cordier \& Stewart 2005, p. 438.

${ }^{977}$ Burdorf \& Swuste 1999, p. 57.

978 Tossavainen 1997, p. 311.

${ }^{979}$ Gezondheidsraad 2005, p. 11.

${ }^{980}$ Prediction models can be used to determine in which situation the claimant is more likely to develop lung cancer. See also: Tossavainen 1997, p. 313: 'In some circumstances of extremely high asbestos exposure, a 2 -fold risk of lung cancer can be achieved with exposure of less than 1 year.'
} 


\section{Chapter 4}

cult to precisely assess the cumulative exposure to asbestos in a specific claimant's case. ${ }^{981}$ According to prominent epidemiologists such as Burdorf, the evaluation of the claimant's cumulative exposure to asbestos is best served by an approach that combines qualitative and quantitative estimates of exposure to asbestos: 'a structured assessment of historical occupational exposure to asbestos is based on quantitative exposure data as well as qualitative information on historical developments in the (asbestos) industry. ${ }^{982}$ This means that exposure data is divided into two types of information. On the one hand, direct exposure data of exposure to potential carcinogetic substance, on the other hand, indirect exposure data, such as questionnaire information, diaries, and records of surrogate information. ${ }^{983}$

Generally, direct exposure data is seen as the most accurate type of exposure data due to its objective nature. ${ }^{984}$ However, indirect exposure data, such as those based on questionnaires, are also used to gather (more) information and to facilitate a better exposure classification. ${ }^{985}$ The nature of such data is, however, less objective and the use of such indirect information as evidence in court can be problematic as it may not reflect the claimant's true exposure level, which could lead to incorrect assumptions and legal conclusions. ${ }^{986}$ Especially, when we take into consideration the fact that validation studies have established that jobs in distant past may be difficult to remember. ${ }^{987}$ But direct exposure data may also not represent the claimant's true exposure level because general information is also used to determine the level of exposure in individual cases. Therefore, the accuracy of the claimant's cumulative exposure to asbestos is heavily debated, especially for historical periods before 1970, because quantitative information on working conditions before 1970 is absent in the Netherlands. ${ }^{98}$

In most claims for asbestos-related diseases, hardly any direct exposure data is available due to the long latency period, which means that it is difficult to obtain accurate information on the working processes that were used at the time of the exposure. Experts use general data on the level of exposure in cases where no specific data is available to establish the claimant's cumulative exposure to asbestos. ${ }^{989}$ In the absence of direct exposure data a so called 'job exposure matrix' ${ }^{990}$ is used to collect data on the exposure history in order to assess the individual's cumulative exposure to asbestos. A job exposure matrix contains information on the typical level of exposure to asbestos in particular job titles in particular industries over time. It has been acknowledged that the application of such an expert system will serve to speed up the process of verifying claims for asbestos-related diseases and contribute to a uniform decision-making process in legal proce-

\footnotetext{
981 This is referred to as the long-tail character connected to asbestos-related injuries.

${ }^{982}$ Burdorf \& Swuste 1999, p. 65.

${ }^{983}$ Gibbs et al. 2007, p. 182.

${ }^{984}$ Direct exposure data is measurement data.

985 Tossavainen 1997, p. 311.

${ }^{986}$ Cordier \& Stewart 2005, p. 440-445; Burdorf \& Swuste 1999, p. 62.

${ }^{987}$ Burdorf \& Swuste 1999, p. 57.

${ }^{988}$ Burdorf \& Swuste 1999, p. 62, 64; Henderson et al. 2004, p. 517-550; Tossavainen 1997, p. 311-316.

${ }^{989}$ See for general data on the level of exposure: http: / /www.asbestkaart.nl [Last visited 31 August, 2012].

${ }^{990}$ In Dutch, the 'job exposure matrix' is known as: 'de asbestkaart'.
} 
The Assessment of the Probability of Causation and the Role of Experts in Asbestos-Related Cases dures. ${ }^{991}$ However, application of the Helsinki Criteria ${ }^{992}$ to determine the claimant's cumulative exposure to asbestos can be questioned because prominent epidemiologists argue that Helsinki proponents have not critically reviewed scientific evidence. To give an example, shipbuilding is used in the Helsinki Criteria as an example of moderate exposure to asbestos, which would double the risk of lung cancer after 5 to 10 years compared to those who were never exposed to asbestos. There are, however, many different trades within the shipbuilding industry with different levels of asbestos exposure. Gibbs argues that several cohort studies of the shipbuilding industry have been performed that have demonstrated a risk of lung cancer that is less than two-fold, suggesting that strict application of the job exposure matrix to determine the cumulative exposure to asbestos in individual cases leads to outcomes that may not reflect the claimant's true exposure level. $^{993}$

Information can also be brought up by occupational hygiene experts who can use their expert knowledge and available indirect information ${ }^{994}$ to determine the claimant's cumulative exposure more precisely. ${ }^{995}$ Experts in the fields of occupational epidemiology and occupational hygiene will take into consideration information about the company name, company type, product type, and employment period to conduct an exposure assessment. For a quantification of exposure, a cumulative probability of exposure (CPE) can be calculated, which combines information about the probability of exposure to asbestos and the duration of this exposure. ${ }^{996}$ Subsequently, a minimum and a maximum level of cumulative exposure (fibre years) will be determined. Within this range, the expert points out what - in his opinion - should be taken as the most likely level of cumulative exposure in the specific claimant's case. ${ }^{997}$

As of the 1970s, research shows that more asbestos measurements were performed in the Netherlands, which led to the consequence that more direct data on the level of asbestos exposure became available in certain industries. ${ }^{998}$ However, epidemiologists such as Burdorf, are still not satisfied with the amount of measurement data available in the Netherlands. Burdorf argues that historical information on the level of exposure to

\footnotetext{
${ }^{991}$ Burdorf \& Swuste 1999, p. 57, 65.

992 The International Expert Meeting on Asbestos, Asbestosis, and Cancer was organized in Helsinki on 2022 January 1997. Collectively, the nineteen worldwide specialists have published over 1000 articles on the risks connected to asbestos exposure and decided to name their findings: The Helsinki Criteria. The Helsinki Criteria were put forward as state of the art criteria to determine the relationship between asbestos exposure and lung cancer. The Helsinki Criteria have been further updated in 2004: Henderson et al. 2004, p. 517 550 .

${ }^{993}$ Gibbs et al. 2007, p. 182.

${ }^{994}$ Details about the conditions in which the former employee has worked. Here, one could think of questions to determine the claimant's job history, such as: job title, the name of the company, type of company, time period, and information on the type of products produced at the company. See also: Boers 2005, p. 532.

995 This is also the case for job titles which are not included in the job exposure matrix. Gibbs et al. 2007, p. 182; Burdorf \& Swuste 1999, p. 61.

${ }^{996}$ Boers et al. 2005, p. 532.

997 The nature of the disease causes an enormous evidential difficulty as the data may not have been gathered at the point of contamination (which could have been decades before the case). This, however, is an evidential difficulty and not a difficulty going to the rules to be applied to the evidence.

${ }^{998}$ Burdorf \& Swuste 1999, p. 59.
} 


\section{Chapter 4}

asbestos is lacking because the Dutch Labour Inspectorate, occupational health services, and consultancy agencies have not performed their duties. ${ }^{999}$ Therefore, it is impossible to make an exact reconstruction of the claimant's level of exposure to asbestos, which implies that it is impossible to establish the actual cumulative exposure to asbestos in an individual case. More disturbing is the fact that the lack of sufficient quantitative exposure data and the large uncertainties in interpreting available historical measurements make the estimation of the cumulative exposure to asbestos for an individual worker less reliable, given his specific work situation and job activities. ${ }^{1000}$

\subsubsection{The relative risk and risk coefficient}

In claims for lung cancer that could have been asbestos-related, epidemiology is used to detect the cause of this disease and to assess the probability that asbestos exposure caused the claimant's lung cancer. ${ }^{1001}$ Epidemiological studies cannot only measure the contribution to disease causation of different causal factors on a population level, but also - by catergorizing subcategories of patients and the use of prediction models - on an individual level. ${ }^{1002}$ Generally, the occurrence of lung cancer in a group of people exposed to asbestos is compared to that observed in an unexposed group in order to establish causal relationships between various factors. ${ }^{1003}$ Although epidemiological techniques are appropriate to determine causal relationships between risk factors and health effects, legal schol$\operatorname{ars}^{1004}$ have to keep in mind that population-level studies are not directly applicable in individual cases.

In claims for lung cancer as a potential consequence of asbestos exposure, epidemiology determines the association between a risk factor (exposure to asbestos) and a dis-

\footnotetext{
${ }^{999}$ Burdorf \& Swuste 1999, p. 59.

${ }^{1000}$ Keep in mind that epidemiological experts can still estimate the claimant's cumulative exposure but that the condifence interval will be lower in cases in which important data is lacking. See: Burdorf \& Swuste 1999 , p. 60.

1001 Timmreck 1994, p. 2; 'Some public health professionals view epidemiology as a science. Others view epidemiology as a method rather than a pure science, as it is not a clearly defined field.' Dutch epidemiologists view epidemiology as a science. See: Vandenbroucke \& Hofman 1999, p. 1.

${ }_{1002}$ Bonita et al. 2006, p. 9, 88.

${ }^{1003}$ Rothman et al. 2008, p. 95; Rothman 2002, p. 57, 73; Van 2000, p. 137: There are two main types of epidemiological study: the 'cohort study', which mostly has a prosepective character, and the 'case-control study', which has a retrospective character. In epidemiology, a cohort is defined as: any designated group of individuals who are followed or traced over a period of time. For example, in one cohort a group of individuals is followed that have been exposed to asbestos (exposed cohort) and in another cohort a group of individuals is followed that have not been exposed to asbestos (unexposed cohort). The purpose of following a cohort is to measure the occurrence of one or more specific diseases during the period of follow-up, usually with the aim of comparing the disease rates for two or more cohorts. A case-control study, on the other hand, aims at achieving the same goals as a cohort study but is less costly and takes less time. However, when compared to a cohort study, the outcome is less reliable. In a case-control study one goup (patient group) consists of persons who suffer from a particular disease or have deceased as a consequence of that disease. This group is compared to another goup (control group) consisting of persons with similar relevant characteristics.

${ }^{1004}$ Judges included.
} 
ease (lung cancer). The term relative risk ${ }^{1005}$ is used to measure the strength of association between risk factor and outcome. ${ }^{1006}$ The relative risk can be assessed as followed:

$$
\mathrm{RR}^{1008}=\frac{\mathrm{R} 1^{1007}}{\mathrm{R} 0^{1009}}
$$

A value of 1.0 is obtained if the incidence of lung cancer in the exposed and unexposed groups is identical. A value greater than 1.0 indicates an increased risk among those exposed to the risk factor, and a value less than 1.0 means that the exposure is protective. ${ }^{1010}$ Epidemiologists have established a value of 10 or more in cases in which there is a strong connection between risk factor and outcome. ${ }^{1011}$ A value of 3 is regarded as an indication for a strong connection. A relative risk value of 2 , which determines the connection between the development of breast cancer in daughters whose mothers suffered from breast cancer, indicates a moderate connection. Epidemiologists speak of a weak connection in cases where they have established a relative risk that lies between 1.2 and 1.5. ${ }^{1012}$ Although the value of the relative risk provides information about the strength of association between risk factor and outcome, the nine Bradford Hill-criteria ${ }^{1013}$ can be used to determine whether these statistical associations are also causal associations. ${ }^{1014}$

The Helsinki Criteria ${ }^{1015}$ have established that the risk coefficient, i.e., the increased risk of developing lung cancer, varies from 0.5 percent to 4 percent per fibre year and

${ }^{1005}$ Relative measure of risk estimating the magnitude of association between an exposure and disease (or other outcome) indicating the likelihood of developing the disease in those exposed relative to those unexposed.

${ }^{1006}$ Bailey et al. 2005, p. 3, 34, 35. See also: Porta 2008, p. 213: Relative risk $=$ 'The ratio of the risk of an event among the exposed to the risk among the unexposed.' See also: Akkermans 1995, p. 49; Greenland 1999 , p. 1166.

${ }^{1007}$ Lung cancer incidence in the exposed population.

${ }^{1008}$ Relative Risk.

${ }^{1009}$ Lung cancer incidence in the non-exposed population.

${ }^{1010}$ Van 2000, p. 138, 139.

1011 A relative risk value of 10 or more has been established between smoking and lung cancer.

${ }^{1012}$ Lilienfield \& Stolley 1994, p. 200-201; Van 2000, p. 139-140.

${ }^{1013}$ Hill 1965, p. 295-300: The following nine aspects must be considered to determine whether statistical associations are also causal associations: 1 . Strength of association; 2. Consistency of association; 3. Specifity of association; 4. Temporality; 5. Biologic gradient; 6. Biological plausibility; 7. Coherence; 8. Analogy; 9. Experimental evidence. The temportal relationship of the association (temporality), i.e., in order for an exposure to cause a disease, the exposure must precede the disease, is the strongest criterium to determine a causal relationship. Subsequently, the other criteria can be used to determine the probability of a causal relationship. The final judgment on the existence of a causal association remains, however, rather subjective. ${ }^{1014}$ Merrill 2010, p. 229; Kroes 1993, p. 345-351.

1015 The International Expert Meeting on Asbestos, Asbestosis, and Cancer was organized in Helsinki on 2022 January 1997. Collectively, the nineteen worldwide specialists have published over 1000 articles on the risks connected to asbestos exposure and decided to name their findings: The Helsinki Criteria. The Helsinki Criteria were put forward as state of the art criteria to determine the relationship between asbestos exposure and lung cancer. The Helsinki Criteria have been further updated in 2004: Henderson et al. 2004, p. $517-$ 550 . 


\section{Chapter 4}

advises to use the upper level (4\% per fibre year) of the boundary range to assess the probability that asbestos has caused the lung cancer in the individual case. This would imply that a cumulative exposure of 25 fibre years increases the risk of lung cancer twofold, which would be sufficient to establish causation in the English jurisdiction as it exceeds the 'balance of probabilities' threshold. ${ }^{1016}$ Applying the lowest level of the boundary range $(0.5 \%)$, a cumulative exposure of 200 fibre years is required to increase the risk of lung cancer two-fold. ${ }^{1017}$ Strict application of the Helsinki Criteria to determine the probability that asbestos has caused the claimant's lung cancer has been questioned now the Helsinki Criteria takes no account of the different relative risks by industry and type of fibre exposure. ${ }^{1018}$ Epidemiological studies have established that the claimant's smoking history, the chemical nature of the inhaled asbestos fibres, and the claimant's genetic predisposition influences the increased risk of developing lung cancer (risk coefficient). Therefore, these issues will be subject to discussion in the next subsections.

\subsubsection{The interaction between smoking and exposure to asbestos}

It is now widely established that the main cause of increasing lung cancer death rates is tobacco use. Indeed, smoking represents the strongest identifiable risk factor, and accounts for 90 percent of all lung cancer cases. ${ }^{1019}$ However, other risk factors, such as exposure to asbestos fibres, also contribute to the increased lung cancer burden. The Great Britain Asbestos Survey revealed that asbestos accounted for an estimated 2-3 percent of lung cancer death rates in Britain from 1980 to $2000 .{ }^{1020}$ But how do experts unravel the causative effect of the two? First of all, it must be acknowledged that it is impossible to precisely apportion the relative contributions of asbestos exposure and smoking in an individual case. ${ }^{1021}$ But epidemiology can be used to assess the Attributable Risk ${ }^{1022}$ that the lung cancer was attributable to asbestos exposure. ${ }^{1023}$ However, the fact that workers in the asbestos industry tend to have, when compared to the general population, high smoking rates complicates the assessment of the probability of causation in claims for lung cancer: there is hardly any reliable epidemiological data on the likelihood of the lung cancer being caused by asbestos exposure among persons who did not smoke. ${ }^{1024}$

At the request of the State Secretary for Social Affairs and Employment, the Health Council of the Netherlands ${ }^{1025}$ has also examined the interaction between smoking and exposure to asbestos. The Health Council, who published their research results in 2005, concluded that the risk coefficient ${ }^{1026}$ for non-smokers appears to be a factor of 3 times

\footnotetext{
1016 Tossavainen 1997, p. 314.

${ }^{1017}$ Gibbs et al. 2007, p. 183.

1018 Gibbs et al. 2007, p. 183.

${ }^{1019}$ Frost et al. 2011, p. 1; Boffetta 2005, p. 1412; Henderson et al. 2004, p. 517.

${ }^{1020}$ Darnton 2006, p. 29-38.

1021 Tossavainen 1997, p. 314.

${ }^{1022}$ Porta 2008, p. 11: 'The proportion of the risk of a disease or other outcome in exposed individuals that can be attributed to the exposure.'

${ }^{1023}$ Gezondheidsraad 2005, p. 46.

${ }^{1024}$ Frost et al. 2011, p. 1; Gezondheidsraad 2005, p. 48; Van 2000, p. 144.

${ }^{1025}$ The Dutch Health Council is a government body.

1026 The increased risk of developing lung cancer.
} 
higher, when compared to the increased risk of developing lung cancer for regular smokers, in the same level of exposure. ${ }^{1027}$ If you do not smoke but have lung cancer, the likelihood of the lung cancer being caused by the asbestos exposure is higher than in the smoking population, as there is a much stronger chance that the smoking could have caused lung cancer. This means that it is more likely that asbestos caused the lung cancer to a non-smoking employee.

Epidemiological studies also show that smoking in combination with exposure to asbestos could reinforce each other in the development of lung cancer. ${ }^{1028}$ Persons who both smoke and have been exposed to asbestos have the greatest risk of lung cancer mortality. ${ }^{1029}$ However, the joint relation is not well-defined and has been subject to much debate in an extensive number of studies. ${ }^{1030}$ Most studies have focused on two hypotheses: the combined effect of smoking and asbestos exposure is additive (each factor acts independently) or multiplicative. ${ }^{1031}$ In the multiplicative model, the total risk of both smoking and exposure to asbestos is greater than adding up the individual effects (additive model). ${ }^{1032}$ Wraith clearly states that a multiplicative relation between asbestos exposure and smoking can be established if 'the risk attributed to combined exposure exceeds the risk attributable to each factor alone. ${ }^{1033}$ A multiplicative relation between smoking and asbestos exposure has been established in the majority of the studies and has been accepted by many authorities for about the last 30 years. ${ }^{1034}$ Under the multiplicative hypothesis, the increase in risk of developing lung cancer can be assessed by multiplying the individual relative risks. Applying this model, epidemiological studies show that the use of the same risk coefficient ${ }^{1035}$ for smokers and non-smokers to assess the probability that asbestos has caused the claimant's lung cancer is not in contrast to epidemiological findings: 'the increased risk of developing a malignant lung tumour that can be attributed to asbestos exposure does not depend on the amount that a person has smoked (but, obviously, the risk of developing lung cancer does). ${ }^{1036}$

\footnotetext{
${ }^{1027}$ The Health Council suggested to apply a risk coefficient of $3 \%$ per fibre year to assess the probability of causation in cases where the claimant did not smoke. Gezondheidsraad 2005, p. 17, 18, 58; Berry \& Liddell 2004 , p. 459.

1028 Gezondheidsraad 2005, p. 17.

${ }^{1029}$ Frost et al. 2011, p. 8

${ }^{1030}$ Nelson \& Kelsey 2002, p. 7286: 'Possibly the best mechanistic explanation for the multiplicative effects of asbestos and cigarette smoking involves a model where asbestos fibres serve as a vehicle to deliver concentrated doses of tobacco carcinogens to the nucleus target cell.' See also: Lee 2001, p. 145; Henderson et al. 2004, p. 522: At least four mechanisms have been proposed as potential explanations for the synergy between cigarette smoke and asbestos: 1. tobacco smoke may facilitate penetration of asbestos fibres into bronchial walls; 2. carcinogens in cigarette smoke such as benzo[a]pyrene may be absorbed onto asbestos fibres; 3. tobacco smoke may interfere with the clearance of asbestos from the lungs; 4. free fatty acids in tobacco may translocate iron into cell membranes, with enhancement of cell sensivity to oxidants such as active oxygen species.

${ }^{1031}$ Frost et al. 2011, p. 2.

${ }^{1032}$ Waterman 2006, p. 13; Gezondheidsraad 2005, p. 17; Lee 2001, p. 145.

${ }^{1033}$ Wraith \& Mengersen 2008, p. 171.

${ }^{1034}$ Frost et al. 2011, p. 1-9; Wraith \& Mengersen 2008, p. 171-189; Erren et al. 1999, p. 405-411.

1035 The increased risk of developing lung cancer.

${ }^{1036}$ Gezondheidsraad 2005, p. 17, 41; Henderson et al. 2004, p. 521.
} 
However, some recent epidemiological reviews have suggested that the effect of asbestos exposure and smoking is not additive or multiplicative but 'submultiplicative'. This means that the risk to contract lung cancer is indeed greater than adding up the individual effects (additive model) but the increase in risk of developing lung cancer is, contrary to the multiplicative model, less than multiplying the individual relative risks, which would imply that it is incorrect to use the same risk coefficient ${ }^{1037}$ for smokers and non-smokers to assess the probability that asbestos has caused the claimant's lung cancer. ${ }^{1038}$ For legal, medical, and scientific purposes it is of the utmost importance to better understand the interaction between smoking and asbestos exposure because the (sub)multiplicative relation can influence the liability of the defendant and the attribution of the claimant's damage. In order to better assess the probability of causation, more epidemiological data is required to clarify the interaction between smoking and exposure to asbestos in the development of lung cancer.

Due to its complexity, only a few studies have tried to examine the relation between lung cancer risk and more specific smoking habits (intensity and duration of the asbestos worker's smoking history) and smoking cessation in combination with asbestos exposure. ${ }^{1039}$ It seems important that epidemiologists not only distinguish smokers from nonsmokers but also heavy smokers from moderate smokers in order to determine the probability of causation in a more adequate way. ${ }^{1040}$ Extensive epidemiological research in this field is a prerequisite for obtaining more accurate information about the way in which the habit of smoking affects the likelihood of the development of lung cancer among people who have been exposed to asbestos. A recent (2011) study concludes that the risk of lung cancer mortality increases in situations where asbestos workers have started to smoke at an early age or have smoked many cigarettes for long periods of time. ${ }^{1041}$ Epidemiologists such as Rothman and Lee underline this, but made it very clear that the term 'smoking' is too imprecise to be used as measurement data. One must specify the type of smoke (i.e., cigarette, cigar, and pipe), whether it is filtered or unfiltered, the manner and frequency of inhalation, the onset and duration of smoking, and presumably - passive smoking, in order to achieve more reliable results. ${ }^{1042}$

The Dutch Health Council advises - due to many uncertainties in the epidemiological findings - to assume that there is a multiplicative relation between smoking and exposure to asbestos. This means that, irrespective of the claimant's smoking history, the same risk coefficient can be used for smokers and non-smokers to determine the probability that

\footnotetext{
${ }^{1037}$ Increased risk of developing lung cancer.

${ }^{1038}$ Wraith \& Mengersen 2008, p. 182: ' The overall conclusion is that the relation is more than additive and less than multiplicative, a result consistent with reviews of the literature.'; Gezondheidsraad 2005, p. 40. See also: Liddell 2001, p. 341-356; Liddell \& Armstrong 2002, p. 5-13; Berry \& Liddell 2004, p. 459-462.

${ }^{1039}$ Liddell \& Armstrong 2002, p. 5-13 have examined specific smoking habits in combination with asbestos exposure. De Klerk et al. 1991, p 412-417 and Reid et al. 2006, p. 509-512 have examined the effects of smoking cessation in combination with asbestos exposure.

${ }^{1040}$ The asbestos worker's smoking history is expressed in 'pack-years'. One pack is equivalent to 20 cigarettes. The total smoke exposure (pack-years) is the product of the number of packs smoked per day and smoking duration. See: Frost et al. 2011, p. 3; Berry \& Liddell 2008, p. 459.

${ }^{1041}$ Frost et al. 2011, p. 8.

${ }^{1042}$ Rothman \& Greenland 2005, p. 46-48; Lee 2001, p. 152. See also: Frost et al. 2011, p. 2.
} 
asbestos exposure caused the claimant's lung cancer. ${ }^{1043}$ However, applying the same risk coefficient in cases in which the claimant only smoked occasionally or did not smoke at all - which is correct if a multiplicative relation is assumed to exist - might lead to an underestimation of the probability that the lung cancer was caused by the exposure to asbestos. Research established that the difference in the risk coefficient between smokers and nonsmokers is not more than a factor of 3 times higher for non-smokers when a submultiplicative relation is assumed to exist. ${ }^{1044}$ The Health Council advises to include this knowledge in the assessment of the claimant's damages and also emphasizes the need for more epidemiological research on the interaction between smoking and asbestos exposure. $^{1045}$

\subsubsection{The impact of different fibre types in the development of lung cancer} As outlined in section 1.2.1, 'asbestos is composed of fibres of varying sizes- many of which are very small, depending on the type of asbestos and how it has been processed. ${ }^{1046}$ It is classified into two groups: 1. the serpentines, which include chrysotile (white asbestos); and 2. amphiboles, which include crocidolite (blue asbestos), amosite (brown asbestos), tremolite, anthophyllite, and several other minerals not used for commercial purposes. Whether or not a person exposed to asbestos will contract an asbestos-related injury could depend on the specific fibres inhaled by the person concerned. The chemical nature of the inhaled asbestos fibres is an important medical and legal factor: white asbestos seems to be less dangerous than blue or brown asbestos. Blue asbestos is a thicker, relatively straight fibre that is extremely stable in the lungs. These fibres are long and needle-like, which makes it hard for the body to expel the fibres from the lungs of the exposed person. Unlike blue and brown asbestos belonging to the amphiboles, which fibres are long and needle-like, white asbestos belongs to the serpentines, which fibres are curly and pliable. ${ }^{1047}$ The curly shape of white asbestos fibres makes it easier for the body to expel the fibres from the lungs of the exposed person.

Depending on the way in which asbestos has been used, the risk coefficient ${ }^{1048}$ varies from 0.1 to 5 percent per fibre year. The average risk coefficient lies at 5 percent per fibre year in cases in which the employee had only been exposed to blue and brown asbestos. In cases where the employee had only been exposed to white asbestos, the average risk coefficient lies at 0.5 percent per fibre year. ${ }^{1049}$ The type of asbestos and nature of exposure is thus an important factor to determine the increase in risk of developing lung cancer in persons who have been exposed to asbestos but in most industrial processes different types of asbestos are mixed, which means that pure exposures to a single asbestos type are rare. ${ }^{1050}$ Contrary to the Helsinki Criteria ${ }^{1051}$, the Dutch Health Council con-

\footnotetext{
${ }^{1043}$ Gezondheidsraad 2005, p. 41.

${ }^{1044}$ When compared to the increased risk of developing lung cancer for regular smokers subjected to the same level of exposure. See: Gezondheidsraad 2005, p. 17, 41; Berry \& Liddell 2008, p. 459.

1045 Gezondheidsraad 2005, p. 49.

${ }^{1046}$ Planteydt 1991, p. 56-59.

${ }^{1047}$ Light \& Gary Lee 2003, p. 436.

${ }^{1048}$ Increased risk of developing lung cancer.

${ }^{1049}$ Gezondheidsraad 2005, p. 38.

${ }^{1050}$ Lee 2001, p. 152; Lemen et al. 1980, p. 3.
} 


\section{Chapter 4}

cluded that a risk coefficient of 1 percent per fibre year is, given the lack of precise data on the type of asbestos fibres in the Netherlands, a scientifically accountable starting point to assess the probability that asbestos exposure caused the lung cancer. ${ }^{1052}$ Higher figures are appropriate in case of regular exposure to more hazardous fibre types. ${ }^{1053}$ The Helsinki Criteria, on the other hand, have advised to use the upper level of the boundary range, that is, 4 percent per fibre year. This would imply that the risk to contract lung cancer is doubled in cases where the employee has been exposed to 25 fibre years. ${ }^{1054}$ The Helsinki Criteria have, however, been subject to much criticism because prominent epidemiologists argue that the Helsinki Criteria failed to take sufficient account of the differences between different types of asbestos fibres. ${ }^{1055}$ Therefore, strict application of the Helsinki Criteria might not lead to a correct assessment of the probability of causation.

\subsubsection{Genetic predisposition}

Besides the claimant's exposure history and smoking habit, the claimant's genetic predisposition has also been pointed out as a factor that increases the risks of several types of lung cancer in individuals with a family history of the same or related cancers. ${ }^{1056}$ An extensive study on genetic susceptibility/resistance factors for lung cancer risk as a consequence of smoking, and potentially also asbestos exposure, suggests that: 'genotypic variation may represent an additional confounding factor potentially affecting the strength of association and hence the probability of causal contribution in the individual subject. ${ }^{, 057}$ However, the authors made it very clear that - at present - there is insufficient evidence to draw meaningful conclusions on the influence of resistance/susceptibility factors in the development of lung cancer, which makes this question less significant for the discussion. ${ }^{1058}$ Therfore, I choose not to further address the difficult question of how the claimant's genetic predisposition could influence the development of lung cancer among smokers and non-smokers who have been exposed to asbestos. $^{1059}$

${ }^{1051}$ The International Expert Meeting on Asbestos, Asbestosis, and Cancer was organized in Helsinki on 2022 January 1997. Collectively, the nineteen worldwide specialists have published over 1000 articles on the risks connected to asbestos exposure and decided to name their findings: The Helsinki Criteria. The Helsinki Criteria were put forward as state of the art criteria to determine the relationship between asbestos exposure and lung cancer. The Helsinki Criteria have been further updated in 2004: Henderson et al. 2004, p. 517 550 .

1052 Gezondheidsraad 2005, p. 17.

${ }^{1053}$ Gezondheidsraad 2005, p. 17.

${ }^{1054}$ Tossavainen 1997, p. 311-316; Van der Laan 2004, p. 140. In the past, this approach has been applied by the Dutch Ministry of Defence to compensate asbestos victims ('all or nothing'). In 2010, the CRvB - following the Nefalit decision - applied the instrument of proportional liability to award damages in claims for lung cancer that could have been asbestos-related. For more information see: Sobczak 2010a.

${ }^{1055}$ Shortell v Bical Construction Ltd., [2008] QBD Liverpool (16-05-2008), paragraph 40.

${ }^{1056}$ Boffetta 2005, p. 1429.

${ }^{1057}$ Henderson et al. 2004, p. 517-550.

${ }^{1058}$ Henderson et al. 2004, p. 517.

1059 This does, however, not take away that the claimant's genetic predisposition could be an important factor in the development of lung cancer. 


\subsubsection{A formula to determine the Probability of Causation}

In spite of the difficulty and sometimes even inability to obtain correct data in claims for lung cancer that could have been asbestos-related, the Health Council concluded that the 'Probability of Causation', also known as the 'Attributable Risk' ${ }^{1060}$, to determine the likelihood that the lung cancer was caused by occupational exposure to asbestos, could best be assessed by applying the following formula:

$$
\operatorname{PoC}^{1063}=\frac{E^{1061} \times K^{1062}}{1+E \times K} \times 100
$$

The formula works as follows: employee ' $\mathrm{X}$ ' was exposed to asbestos in the course of his employment and developed lung cancer that could have been caused by the wrongful exposure to asbestos. In these particular cases it is uncertain whether the wrongful exposure caused the lung cancer since it is highly possible that a number of other factors could have caused the lung cancer to employee ' $\mathrm{X}$ ' as well. ${ }^{1064}$ To assess the probability of causation (PoC) between the exposure to asbestos and the contraction of lung cancer, experts are asked to determine the claimant's cumulative exposure (expressed in fibre years). If the appointed experts concluded that the cumulative exposure $(E)$ is thirty-five fibre years and that the risk of developing lung cancer increases with one percent per fibre year $(K=1 \%)$, then the probability of causation (PoC) could be assessed as followed:

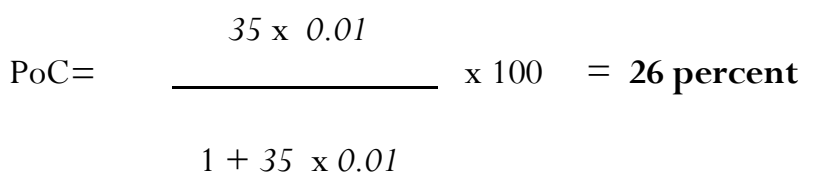

In this example, which is based on the expert evidence in Schaier/De Schelde ${ }^{1065}$, one could conclude that there is an attributable risk ${ }^{1066}$ of $26 \%$ that X's lung cancer is caused by the occupational exposure to asbestos. Applying the instrument of proportional liability, a judge does not simply award or reject the total amount of damages, but awards damages in proportion to the probability of causation. This proportional solution implies that 26 percent of the damages claimed should be awarded as this amount of compensation is exactly in line with the attributable risk that the exposure to asbestos has caused the claimant's lung cancer. Applying traditional principles, the Dutch claimant would leave emp-

\footnotetext{
${ }^{1060}$ Porta 2008, p. 11: 'The proportion of the risk of a disease or other outcome in exposed individuals that can be attributed to the exposure.'

${ }^{1061}$ Fibre years (cumulative exposure).

${ }^{1062}$ Increased risk of lung cancer per fibre year (risk coefficient).

${ }^{1063}$ Probability of Causation. Also referred to as: 'Attributable Risk'.

${ }^{1064}$ Employee ' $\mathrm{X}$ ' was also a tobacco smoker for a long period.

${ }^{1065}$ Kantongerecht Middelburg 1 februari 1999, TMA 1999/6 (Schaier/De Schelde).

${ }^{1066}$ Porta 2008, p. 11: 'The proportion of the risk of a disease or other outcome in exposed individuals that can be attributed to the exposure.'
} 
ty-handed because he is unable to prove causation to a reasonable degree of certainty. Nor is the English claimant in such a case able to prove causation on the balance of probabilities. ${ }^{1067}$

A correct assessment of the claimant's cumulative exposure $(E)$ and the use of a correct risk coefficient ${ }^{1068}(K)$ is of the utmost importance to the outcome of the formula, which is clearly shown in the following graph ${ }^{1069}$ :

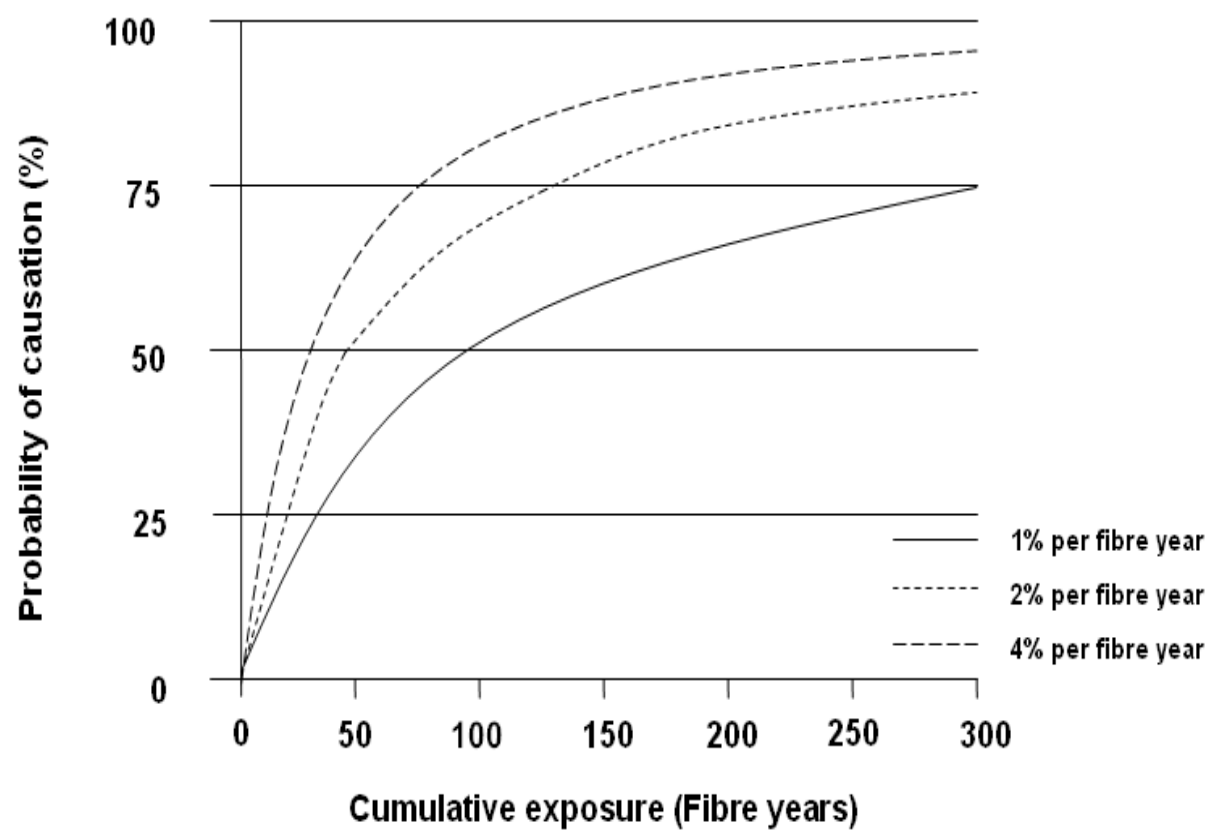

\subsubsection{The assessment of the probability of causation in case law}

\subsubsection{A smoking employee: Nefalit/Karamus}

The appointed expert in Nefalit/Karamus ${ }^{1070}$, Professor Smid, also used a formula to asses the probability that Mr Karamus' lung cancer was caused by the exposure to asbestos in the course of the employment. ${ }^{1071}$ Professor Smid concluded that Mr Karamus' cumulative exposure to asbestos amounted to 125 fibre years $(E=125)$ and that the risk of de-

\footnotetext{
1067 Sobczak 2010b, p. 1171-1172.

${ }^{1068}$ Increased risk of developing lung cancer.

1069 Gezondheidsraad 2005, p. 54.

${ }^{1070}$ Hoge Raad 31 maart 2006, NJ 2011, 250 (Nefalit/Karamus).

${ }^{1071}$ Professor Smid has also been appointed as an expert to assess the probability of causation in the other asbestos-related cases, such as: Kantongerecht Middelburg 1 februari 1999, TMA 1999/6 (Schaier/De Schelde), Hoge Raad 31 maart 2006, LJN: AU6093 (Hollink/Eternit); Centrale Raad van Beroep 9 april 2009, LJN: BI2805.
} 
veloping lung cancer increases with 1 percent per fibre year $(K=1 \%)$. Applying such data in the abovementioned formula leads to the following outcome:

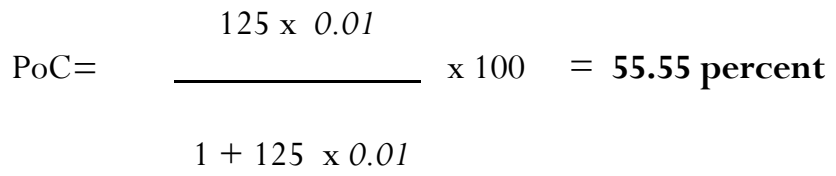

Professor Smid's expert report has been debated in legal writings. Kortmann argues that the expert did take into account Mr Karamus' smoking history to assess the likelihood that the lung cancer was caused by the occupational exposure to asbestos. ${ }^{1072}$ Fluit $^{1073}$, Lindenbergh $^{1074}$, and Waterman ${ }^{1075}$ do not agree and argue that the expert did not take into account Mr Karamus' smoking history. To base his argument, Fluit referred to the answer which Professor Smid gave to question 5 of the expert report, in which he stated that: 'by using this 'calculation model', the chance to contract lung cancer increases with 1 percent per fibre year regardless the smoking history of the employee', which suggests that the claimant's smoking history does not have to be taken into consideration to determine the probability that asbestos has caused the lung cancer. ${ }^{1076}$

It seems that Professor Smid has assumed that, in line with the Health Council's advise, there is a multiplicative relation between smoking and exposure to asbestos. This would imply that the same risk coefficient ${ }^{1077}$ (1\% per fibre year) can be used for smokers and non-smokers to assess the probability that the lung cancer can be attributed to asbestos exposure. ${ }^{1078}$ The Health Council concluded that such a multiplicative model is not in contrast to epidemiological findings. One remark should, however, be made: applying the same risk coefficient in cases in which the claimant only smoked occasionally or did not smoke at all - which is correct if a multiplicative relation is assumed to exist - might lead to an underestimation of the probability that the lung cancer was caused by the exposure to asbestos. However, this is not the case in Mr Karamus' case as Mr Karamus smoked at least 28 years, which means that the probability of causation has been adequately assessed in Nefalit. ${ }^{1079}$ There is an attributable risk ${ }^{1080}$ of 55 percent that occupational asbestos exposure caused Mr Karamus' lung cancer. The impact of smoking has - by using populationlevel figures of smokers - been discounted in the 55 percent. The likelihood of that lung cancer being caused by Mr Karamus' smoking history should not be subtracted from the

\footnotetext{
${ }^{1072}$ Kortmann 2006, p. 1407.

${ }^{1073}$ Fluit 2006, p. 178.

${ }^{1074}$ Lindenbergh 2006, p. 739.

1075 Waterman 2006, p. 13.

${ }^{1076}$ Hoge Raad 31 maart 2006, NJ 2011, 250, paragraph 6.22(c) (Nefalit/Karamus); Van Dijk 2006, p. 305.

${ }^{1077}$ Increase in risk of developing lung cancer.

${ }^{1078}$ Gezondheidsraad 2005, p. 41.

${ }^{1079}$ Assuming that Mr Karamus' cumulative exposure to asbestos (125 fibre years) has also been adequately assessed. See also: Giard 2007, p. 448.

${ }^{1080}$ Porta 2008, p. 11: 'The proportion of the risk of a disease or other outcome in exposed individuals that can be attributed to the exposure.'
} 
assessed 55 percent because the remaining 45 percent represent all other possible causes. $^{1081}$

\subsubsection{A non-smoking employee: Hollink/Eternit}

On 31 March 2006, the Dutch Supreme Court rendered another judgment in a case in which an employee had been occupationally exposed to asbestos and developed lung cancer as a potential consequence of the wrongful exposure to asbestos. Similar to Nefalit, the employee did not suffer from asbestosis before he was diagnosed with lung cancer. However, contrary to Nefalit, the employee in Hollink/Eternit ${ }^{1082}$ did not smoke tobacco. The appointed expert, Professor Smid, concluded that Mr Hollink's cumulative exposure to asbestos amounted to 175 fibre years $(E=175)$ and that, similar to Nefalit, the risk of developing lung cancer increases with 1 percent per fibre year $(K=1 \%)$. Applying such data in the abovementioned formula leads to the following outcome:

$$
\mathrm{PoC}=\frac{175 \times 0.01}{1+175 \times 0.01} \times 100=\mathbf{6 3 . 6 3} \text { percent }
$$

Similar to Nefalit, the Supreme Court applied the instrument of proportional liability and awarded 63.5 percent of the damages claimed, which represented the attributable risk ${ }^{1083}$ that asbestos exposure had caused Mr Hollink's lung cancer. Hollink shows that the instrument of proportional liability is not only confined to cases in which a smoking employee has been occupationally exposed to asbestos. The employer was held liable for his theoretical share (63.5\%). The employee's share can be assessed at $(100 \%-63.5 \%=)$ 36.5 percent. This 36.5 percent does, however, not represent the probability that the employee's smoking history has caused the lung cancer because the employee did not smoke tobacco. The remaining 36.5 percent represents all other factors who come for account and risk of the employee and for which the employer cannot be held responsible. De Lang and Van, however, argue that it would have been more reasonable not to deviate from the traditional principle of all-or-nothing compensation here. Applying traditional principles, it is most likely that the claimant would have been fully compensated. A possible explanation can be found in the fact that the conclusions of the Dutch Health Council $^{1084}$, especially on the increased risk of developing lung cancer for non-smokers, could not be taken into consideration now the expert report had been presented in the procedure before the report of the Dutch Health Council had been published. ${ }^{1085}$

\footnotetext{
${ }^{1081}$ Kortmann does agree: Kortmann 2006, p. 1405.

${ }^{1082}$ Hoge Raad 31 maart 2006, LJN: AU6093 (Hollink/Eternit): In this case the claimant worked for Eternit and has been exposed to asbestos in the course of his employment (1961-1975). However, the claimant did not smoke. The Supreme Court awarded 63.5 percent of the total damages.

${ }^{1083}$ Porta 2008, p. 11: 'The proportion of the risk of a disease or other outcome in exposed individuals that can be attributed to the exposure.'

${ }^{1084}$ Gezondheidsraad 1999.

${ }^{1085}$ De Lang \& Van 2008, p. 61.
} 
As discussed in section 4.3.2.1, applying the same risk coefficient in cases in which the claimant only smoked occasionally or did not smoke at all - which is correct if a multiplicative relation is assumed to exist - could lead to an underestimation of the probability that the lung cancer was caused by the exposure to asbestos. In these particular cases, the establishment of a submultiplicative relation between smoking and asbesostos exposure would lead to more desirable outcomes: epidemiological studies have established that the increased risk of developing lung cancer between smokers and non-smokers is not more than a factor of 3 times higher for non-smokers. ${ }^{1086}$ Applying a risk coefficient of 3 percent per fibre year would drastically have changed the outcome of the assessment of the Probability of Causation in Mr Hollink's case:

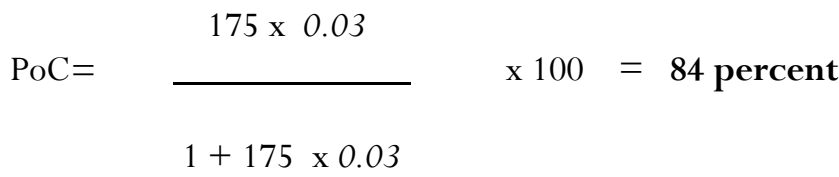

\subsubsection{Conclusion}

In claims for lung cancer that could have been asbestos-related it is impossible to determine the exact probability that asbestos exposure caused the claimant's lung cancer in an individual case. The assessment of the probability of causation thus inserts a certain element of speculation. The appointed expert, Professor Smid, has used the same risk coefficient (1\% per fibre year) to determine the probability of causation in the cases Nefalit and Hollink. Mr Karamus was, however, regarded as a heavy smoker while Mr Hollink did not smoke at all. It seems as if the expert assumed that there is a multiplicative relation between smoking and exposure to asbestos. This means that the same risk coefficient ( $K=1 \%$ per fibre year) can be used for smokers and non-smokers to assess the probability that the lung cancer can be attributed to asbestos exposure. ${ }^{1087}$ However, applying the same risk coefficient in cases in which the claimant only smoked occasionally or did not smoke at all - which is correct if a multiplicative relation is assumed to exist - leads to an underestimation of the probability that the lung cancer was caused by the exposure to asbestos when a submultiplicative relation would be assumed to exist.

Epidemiological studies in which the existence of a submultiplicative relation has been confirmed, have established that the difference in the increased risk of developing lung cancer (risk coefficient) between smokers and non-smokers is not more than a factor of 3 times higher for non-smokers. This knowledge has an enormous impact on the assessment of the probability of causation. Applying a risk coefficient of 3 percent per fibre year in Hollink, the claimant would have received 84 percent of the total damages claimed instead of 63.5 percent. ${ }^{1088}$ It is arguable that the Supreme Court - following the

\footnotetext{
1086 When compared to regular smokers subjected to the same level of exposure. See: Gezondheidsraad 2005, p. 17, 41; Berry \& Liddell 2008, p. 459.

${ }^{1087}$ Gezondheidsraad 2005, p. 17, 41.

${ }^{1088}$ It is, however, questionable whether an 84 percent probability still justifies the application of proportional liability. It is arguable that the probability of causation is too high to deviate from the traditional principle of all-or-nothing compensation. In that case, Mr Hollink would have received full compensation. From
} 


\section{Chapter 4}

expert evidence - has based his decision on wrong assumptions, which suggests that $\mathrm{Mr}$ Hollink has been under-compensated due to the fact that the expert might have used an incorrect risk coefficient to assess the probability that Mr Hollink's lung cancer can be attributed to the wrongful occupational exposure to asbestos. More epidemiological research is required on the interaction between smoking and exposure to asbestos in order to determine the risk coefficient ${ }^{1089}$ more precisely in cases where the exposed lung cancer sufferer did not smoke or only smoked occasionally.

\subsection{Transferring epidemiological findings to legal judgments in individual cases}

The cases Schaier/De Schelde ${ }^{1090}$, Nefalit/Karamus ${ }^{1091}$, Hollink/Eternit ${ }^{1092}$, Shortell v Bical Construction Ltd ${ }^{1093}$, and Badger v Ministry of Defence ${ }^{1094}$ show that Dutch and English courts have directly applied the expert's epidemiological findings in the claimant's civil claim to establish the liability of the defendant. The use of epidemiological findings to determine the probability of causation between the wrongful exposure to asbestos and the claimant's lung cancer in individual cases, has been subject to much discussion and criticism in legal writings. Moreover, there are important distinctions between epidemiological causation and judicial causation. In Tort law, causation deals with a specific level: did the intervention of THE defendant cause THE claimant's damage? This is, however, not the case in epidemiology: the nature of causation is abstract. The question is of whether an act is usually followed by a certain effect? ${ }^{1095}$ The concrete circumstances of the claimant are not always taken into consideration in epidemiological studies. This can result in unreasonable legal judgments in cases where the epidemiological findings are directly applied in the specific claimant's case. ${ }^{1096}$

Akkermans has acknowledged that chances on a population level are not the same as the individual chance that the claimant's lung cancer was caused by asbestos exposure. Nevertheless, population-level figures must be regarded as a useful indication in individual cases: not using these figures is even more arbitrary because some information provides more accuracy than no information at all. ${ }^{1097}$ Akkermans correctly argues that statistical information and epidemiological data is getting more and more individualized. Subcategories of patients within the main group, that have the same relevant characteristics, are more and more categorized and prediction models can be used to assess chances

\footnotetext{
my point of view, the principle of all-or-nothing compensation should not apply in order to do justice to the situation of uncertain causality.

${ }^{1089}$ Increased risk of developing lung cancer.

${ }^{1090}$ Kantongerecht Middelburg 1 februari 1999, TMA 1999/6 (Schaier/De Schelde).

${ }^{1091}$ Hoge Raad 31 maart 2006, NJ 2011, 250 (Nefalit/Karamus).

${ }^{1092}$ Hoge Raad 31 maart 2006, LJN: AU6093 (Hollink/Eternit).

${ }^{1093}$ Shortell v Bical Construction Ltd., [2008] QBD Liverpool (16-05-2008).

${ }^{1094}$ Badger $v$ Ministry of Defence, [2005] EWHC 2941 (QB), [2006] 3 ALL ER 173.

${ }^{1095}$ Witjens 2011, p. 245.

${ }^{1096}$ Van 2000, p. 145, 146: Two good examples can be found in case law: Landrigan v Celotex Corp., 177 N.J. 404, 605 A.2d 1079 (Supreme Court New Jersy, 1992); Rechtbank Amsterdam 9 november 1994, H91.1540. See also: Smulders et al. 2010, p. 3.

${ }^{1097}$ Akkermans 1997, p. 187, 190-192.
} 
in individual cases. This way, the assessment of the attributable risk ${ }^{1098}$ comes closer to the individual probability that the defendant's intervention has caused the claimant's damage. Therefore, the use of statistical information and epidemiological data in court should not be rejected, but the judge should have a discretionary power to interpret the expert report in his own way. The court must consider whether the concrete circumstances of the claimant justify the strict application of epidemiological findings in THE specific (individual) case and should be free to deviate from the expert report stipulated that the decision is motivated clearly. ${ }^{1099}$

Another important distinction between epidemiological causation and judicial causation is that epidemiology merely regards the sum of circumstances that together led to an event as the cause of the event. Judicial causation, on the other hand, determines the individual responsibility of the tortfeasor in question and his or her share in producing the event. ${ }^{1100}$ This way, it is arguable that the scientist is contributing to the explanation of causation while the lawyer is being rather attributive. ${ }^{1101}$ The legal perspective of being held accountable for a wrongful intervention is thus not the same as an epidemiological perspective, which mostly focuses on how effects are caused. ${ }^{102}$ Furthermore, a legal judgment is a normative judgment, which means that - contrary to epidemiological causation - normative elements could influence the court's judgment on judicial causation. It is important to note that natural science and statistics can help the judge to make a normative judgment and not the other way around. ${ }^{103}$ Many examples can be found in case law in which the Supreme Court has, mostly in favour of the claimant, ignored the problems in proving judicial causation between cause and effect on the basis of 'reasonableness and fairness'. ${ }^{1104}$ The assessed probability of causation in the cases Schaier (26\%), Nefalit (55\%), and Hollink (63.5\%) must be seen as a starting point to determine judicial causation. Subsequently, the court's legal interpretation of the epidemiological findings could be influenced by normative elements in the specific claimant's case. ${ }^{1105}$ This so called 'fairness-correction, ${ }^{1106}$ can be used as a tool to include normative elements in the establishment of judicial causation in order to reach outcomes that have balanced out the interests of the claimants and the interests of the defendants fairly, which will be subject to discussion in the next section.

\footnotetext{
1098 'Porta 2008, p. 11: 'The proportion of the risk of a disease or other outcome in exposed individuals that can be attributed to the exposure.'

${ }^{1099}$ Akkermans 1997, p. 192; Van 2000, p. 135-153; Hoge Raad 5 december 2003, NJ 2004, 74.

${ }^{1100}$ Haritz 2010, p. 204; Van 2003, p. 105-110.

1101 The law is called to make a normative rather than purely scientific assessment to establish the liability of the defendant and to award damages to the claimant. See also: Fleming 1985, p. 105; Dekker \& Hartman 2006, p. 8.

${ }^{1102}$ Witjens 2011, p. 246.

${ }^{1103}$ Roijackers 2009, p. 8.

${ }^{1104}$ See for example: Hoge Raad 9 oktober 1999, NJ 1999, 353 (DES); Hoge Raad 25 juni 1993, NJ 1993, 686 (Cijsouw/De Schelde).

${ }^{1105}$ Van 2000, p. 149-150.

${ }^{1106}$ In Dutch: 'billijkheidscorrectie'.
} 


\subsubsection{The 'fairness-correction' as a tool to include normative elements}

Epidemiological data is, as outlined in section 4.3.2, not extensive in asbestos-related cases. Although epidemiological research has established that asbestos exposure could cause lung cancer and that a (sub)multiplicative relation between smoking and exposure to asbestos is present, there is still a long way to go. In claims for lung cancer that could have been asbestos-related, epidemiological studies must be more individualized to do justice to the concrete circumstances of the claimant. ${ }^{1107}$ The cases Nefalit/Karamus ${ }^{108}$ and Hollink/Eternit ${ }^{1109}$ show that the same risk coefficient ( $K=1 \%$ per fibre year) is applied for smokers and non-smokers, which assumption is rather questionable on the basis of recent epidemiological reviews. ${ }^{110}$ Normative elements, such as the fact that the defendant did not take any precautionary measures to ensure a safe working environment for his employees, the fact that the defendant has breached a safety norm, and the fact that the position of employees should be legally protected can be included in the legal interpretation of epidemiological findings. Two possible methods to include normative elements in the establishment of judicial causation can be proposed in claims for lung cancer that could be asbestos-related.

In Schaier, the probability of causation was assessed at 26 percent with a confidence interval $^{111}$ of 13 percent to 36 percent. The court has followed the expert's evidence and applied the middle value of the confidence interval to determine the probability that asbestos has caused Mr Schaier's lung cancer. The confidence interval can, however, also be used as a tool to include normative elements in the court's judgment on judicial causation. Applying a value that lies above the middle value of the confidence interval increases the probability that asbestos has caused lung cancer. The judge could, however, also decide to apply a value that lies below the middle value of the confidence interval, which would result in the fact that the assessed probability of causation decreases. Such a fairness-correction, which is based on reasonableness and fairness, is also used in Dutch criminal law: in cases in which drivers have exceeded a speed limit, the criminal judge applies the lowest value of the assessed confidence interval within the boundary range to determine the driver's fine, which is considered to be a fairness-correction in favour of the driver. ${ }^{1112}$

The court can also use the value of the risk coefficient ${ }^{1113}$ to apply a fairness-correction in the specific claimant's case. In the cases Schaier, Nefalit, and Hollink, the courts have followed the expert's evidence and applied a risk coefficient of one percent per fibre year

\footnotetext{
${ }^{1107}$ Epidemiologists must specify the type of smoke (e.g., cigarette, cigar, and pipe), whether it is filtered or unfiltered, the manner and frequency of inhalation, and the onset and duration of smoking in order to adequately determine the probability that asbestos has caused the lung cancer to a smoking claimant. Furthermore, specified information on the impact of different fibre types is lacking. Epidemiologists must distinguish persons who have been exposed to blue and/or brown and/or white asbestos in order to determine the value of the risk coefficient more adequately.

${ }^{1108}$ Hoge Raad 31 maart 2006, NJ 2011, 250 (Nefalit/Karamus).

${ }^{1109}$ Hoge Raad 31 maart 2006, LJN: AU6093 (Hollink/Eternit).

${ }^{1110}$ See section 4.3.2 for more information.

1111 The range within which the Probability of Causation (PoC) that asbestos has caused the lung cancer is likely to lie. See also: Van Velthoven 2011, p. 31.

${ }^{1112}$ Hoge Raad 17 juni 1997, NJ 1997, 736. See also: Van 2000, p. 150.

${ }^{1113}$ Increased risk of developing lung cancer.
} 
$(K=1 \%)$. If the court would have applied a higher value of the risk coefficient, the probability of causation would increase. The Helsinki Criteria suggest to use a risk coefficient of 4 percent per fibre year $(K=4 \%)$. This would imply that the risk to contract lung cancer is doubled in cases where the claimant has been exposed to 25 fibre years. ${ }^{1114}$ Under English law, such a level of exposure would be sufficient to establish judicial causation on the basis of the traditional balance of probabilities threshold. However, inclusion of normative elements in individual cases does not necessarily lead to an outcome that improves the claimant's position. The court could also decide that it is more reasonable to apply a risk coefficient of 0.5 percent per fibre year $(K=0.5 \%)$. The consequence is that a cumulative exposure of 200 fibre years is required to double the risk of lung cancer, which makes it more difficult for the claimant to establish the liability of the defendant.

I will give an example to show how the fairness-correction works in claims for lung cancer that could have been asbestos-related. In Schaier, the probability of causation was assessed at 26 percent with a confidence interval of 13 percent to 36 percent. The court's legal interpretation of the epidemiological findings can be influenced by normative elements in Mr Schaier's case. Applying the highest number of the confidence interval within the boundary range would lead to the result that the defendant's proportional liability is not 26 percent but 36 percent, which means that Mr Schaier would have received more compensation. This way, the legal interpretation of the epidemiological findings clearly improves the claimant's position. Furthermore, the experts applied a risk coefficient of one percent per fibre year $(K=1 \%)$. If the inclusion of normative elements would have led to the conclusion that epidemiological evidence must be interpreted in favour of the claimant, the court could - in line with the Helsinki Criteria - apply a risk coefficient of 4 percent per fibre year $(K=4 \%)$. The probability that asbestos would have caused $\mathrm{Mr}$ Schaier's lung cancer would then be assessed at 58 percent instead of 26 percent. ${ }^{1115}$

Applying proportional liability in this hypothetical situation, the awarded amount of compensation to Mr Schaier would be more than doubled. Under English law, an applied risk coefficient of 4 percent per fibre year would have had even more far-reaching consequences. Applying traditional principles to establish causation, a 26 percent probability is not sufficient to prove causation on the balance of probabilities, which would have led to the result that the English claimant left empty-handed. However, following the court's decisions in the cases Shortell ${ }^{116}$ and Badger ${ }^{117}$, it is most likely that a 58 percent proba-

\footnotetext{
${ }^{1114}$ Tossavainen 1997, p. 311-316; Van der Laan 2004, p. 140. In the past, this approach has been applied by the Dutch Ministry of Defence to compensate asbestos victims ('all or nothing'). In 2010, the CRvB - following the Nefalit decision - applied the instrument of proportional liability to award damages in claims for lung cancer that could have been asbestos-related. See also: Gibbs et al. 2007, p. 182: The Helsinki Criteria state that the risk of developing lung cancer is materially increased (by a factor of 2), even without asbesto$\underline{\text { sis, }}$ under the following conditions: 1 . One year of heavy exposure (eg, manufacturing of asbestos products, asbestos spraying, insulation work with asbestos materials, demolition of old buildings ) or 5 or 10 years of moderate exposure (eg, construction, shipbuilding); 2. Estimated cumulative exposure to mixed (amphibole plus chrysotile) asbestos fibers of 25 fiber years; 3. A lung fiber burden within the range recorded for asbestosis in the same laboratory; 4. Retained fibre levels of 2 million amphibole fibers per gram of dry lung tissue, as determined by electron microscopic analysis; 5 . Asbestos body concentrations determined by light microscopic analysis greater than 10000 per gram of dry lung tissue.

${ }^{1115}$ Van 2000, p. 150; Tossavainen 1997, p. 311-316.

1116 Shortell v Bical Construction Ltd., [2008] QBD Liverpool (16-05-2008).
} 
bility would have led to full compensation (minus the claimant's contributory negligence, i.e., smoking ${ }^{118}$ ) because the claimant can prove, on the balance of probabilities, that it is more likely than not that asbestos has caused the lung cancer.

\subsection{Proportional liability and the findings of experts: solutions to miscom- munication}

The role of experts is well established in literature ${ }^{1119}$, and judges in asbestos-related cases have acknowledged that they do not have the relevant experience or qualification to make decisions without the help of experts. ${ }^{1120}$ Most, if not all judges did not have the type of education that would enable them to properly evaluate scientific evidence. Judges and experts do not speak the same 'language' and, as a consequence, this crossdisciplinary discussion can lead to miscommunication, particularly with regard to the problematic issue of causation. ${ }^{1121}$ As previously has been discussed, the legal interpretation of epidemiological data is a problematic issue which is taxing many jurisdictions. ${ }^{1122}$ More work is needed to ensure that the judiciary and lawyers are familiar with which conclusions can and cannot be drawn from the expert evidence, and that evidence must be presented in simple, clear ways to avoid confusion.

In cases where the instrument of proportional liability is applied to award damages, the results of the experts are of the utmost importance to the outcome of the case. ${ }^{1123}$ Proportional liability depends, as opposed to the traditional principle of all-or-nothing compensation, to an even larger extent on the expert's findings because damages are directly awarded in accordance with the assessed probability of causation. It seems as if judges tend to use percentages brought up by experts without knowing the basic assumptions of the research done by the experts. It is no surprise: epidemiological data is, for legal experts ${ }^{1124}$, extremely difficult to understand. But what is even more striking is the fact that legal judgments might be based on wrong assumptions. There is reason to fear that judges cannot identify a potential failure in the expert's findings. After all, a judge will only appoint an expert in cases in which he or she is not familiar with the technical issues involved in the case. This could explain why judges hardly ever deviate from the expert report, especially in cases where the court appointed the expert. ${ }^{1125}$

A good example of the court's reluctance to deviate from the expert report can be found when comparing the cases Nefalit/Karamus ${ }^{1126}$ and Hollink/Eternit ${ }^{1127}$. In both cases, the Supreme Court applied the instrument of proportional liability to award damages.

\footnotetext{
${ }^{1117}$ Badger v Ministry of Defence, [2005] EWHC 2941 (QB), [2006] 3 ALL ER 173.

${ }^{1118}$ The claimant's action has to be 'negligent' to reduce the amount of compensation.

${ }^{1119}$ Giard 2007, p. 442-449.

${ }^{1120}$ Hoge Raad 31 maart 2006, LJN: AU6093, paragraph 3.8.2 (Hollink/Eternit).

${ }^{1121}$ This is also known as the 'knowledge-paradox'. See for example: Schuurman 2010, p. 518-521.

${ }^{1122}$ Van der Laan 2004, p. 133-143; Van Maanen 2000, p. 43-57; Van 2000, p. 135-153.

${ }^{1123}$ See the cases: Hoge Raad 31 maart 2006, NJ 2011, 250 (Nefalit/Karamus); Hoge Raad 31 maart 2006, LJN: AU6093 (Hollink/Eternit); Kantongerecht Middelburg 1 februari 1999, TMA $1999 / 6$ (Schaier/De Schelde).

${ }^{1124}$ Judges included.

${ }^{1125}$ Van Dijk 2007, p. 435; Beer \& Dekker 2005, p. 376.

${ }^{1126}$ Hoge Raad 31 maart 2006, NJ 2011, 250 (Nefalit/Karamus).

${ }^{1127}$ Hoge Raad 31 maart 2006, LJN: AU6093 (Hollink/Eternit).
} 
The case of Mr Hollink shows that the application of proportional liability is not only confined to cases in which a smoking employee had been occupationally exposed to asbestos. However, the Supreme Court did not notice a potential failure in the findings of the expert in Mr Hollink's case. As examined in section 4.3.4, if we assume that there is a submultiplicative relation between smoking and exposure to asbestos, the risk coefficient $^{1128}$ must be higher in cases where a non-smoking employee has been exposed to asbestos. ${ }^{1129}$ This means that the likelihood of the lung cancer being caused by exposure to asbestos increases in cases where the claimant did not smoke. However, similar to Nefalit, the expert applied a risk coefficient of one percent per fibre year $(K=1 \%)$ to assess the probability that asbestos has caused the lung cancer in Mr Hollink's case. ${ }^{1130}$ It is arguable that this assessment underestimated the probability that the lung cancer was caused by the wrongful occupational exposure to asbestos.

Does the use of epidemiological data to assess the probability of causation and the potential miscommunication between judges and experts form a valid reason to reject proportional liability in claims for lung cancer that could have been asbestos-related? Probably not. First of all, we have to acknowledge that proportional liability leads to the most desirable outcomes on a population level as the total amount of compensation corresponds to the total damage. Furthermore, we must not forget that epidemiological data is also used as evidence in court under the traditional principle of all-or-nothing compensation. Under this compensation regime, experts are also appointed to inform the judge on the requirement of causation, which means that the court's decision is also based on epidemiological findings. Secondly, it should be noted that incorrect expert reports will have, when compared to proportional liability decisions, more far-reaching consequences for claimants and defendants. This way, proportional liability decisions are more accurate than awarding all or nothing. Thirdly, applying the fairness-correction, normative elements could influence the legal interpretation of the epidemiological findings with regard to the requirement of causation in the specific claimant's case, which leads to an outcome that has balanced out the interests of the claimant and the interests of the defendant fairly. ${ }^{1131}$ One general remark must, however, be made. Irrespective of the applied compensation system, it still remains of the utmost importance that judges and experts communicate more extensively and effectively about the evidence in order to clarify the expert's findings before the judge transfers the epidemiological findings to a legal judgment.

The following subsections propose three solutions that could improve the court's decision in claims for asbestos-related diseases: the formulation of questions for the expert, a checklist to determine the reliability of expert evidence, and a disclosure of information on the expert's expertise. Those solutions could limit the possibility that the

\footnotetext{
${ }^{1128}$ Increased risk of developing lung cancer.

1129 The increased risk of lung cancer (risk coefficient) is not more than a factor of 3 times higher for a nonsmoker when compared to a smoker, subjected to the same level of exposure. See: Gezondheidsraad 2005, p. 17,41 .

${ }^{1130}$ In Nefalit, the expert also applied a risk coefficient (increased risk of developing lung cancer) of one percent per fibre year in case of a heavy smoker.

${ }^{1131}$ Keep in mind that such a 'fairness-correction' can also be applied under the traditional principle of all-ornothing compensation. See section 4.4.1 for more information about the 'fairness-correction'.
} 


\section{Chapter 4}

court's decision is based on wrong assumptions, reduces the number of incorrect expert reports as evidence in court, and diminishes the 'knowledge-paradox' between judges and experts in claims for asbestos-related diseases. ${ }^{1132}$ Other solutions, such as: offering a training for judges on how to interpret scientific evidence and the appointment of specific judges at each Court centre around the country that solely deal with claims for asbestos-related diseases could also contribute to a correct settlement of claims for asbestosrelated diseases but will not be further examined in this research. ${ }^{133}$

\subsubsection{The formulation of questions for the expert}

A legal judgment is an independant normative judgment. ${ }^{1134}$ It must be said that, as has been emphasized at the beginning of this chapter, it is not the role of experts to 'decide' the legal outcome of the case. ${ }^{135}$ Experts should only be appointed to provide for more information in cases where the technical evidence is too complex for the judge to understand. ${ }^{1136}$ It is interesting to explore what questions the experts should be asked to address in claims for lung cancer that could have been asbestos-related. Given the fact that the answer to this question is equal for both jurisdictions taken under consideration here, I choose to answer this question according to Dutch law only. In Dutch law, the judge is free to discuss with the parties what questions are relevant in the specific case and formulates the questions after the parties have been heard. ${ }^{1137}$ This procedure is in line with Article 6 of the European Convention on Human Rights ${ }^{1138}$, which provides a detailed right to a fair trial. ${ }^{1139}$ Subsequently, the judge evaluates the findings of the expert and is free to deviate from the expert report. ${ }^{1140}$ In practice, however, decisions are almost always in line with the findings of the court-appointed experts. This is disturbing, especially when we highlight the fact that judges are unable to point out a potential failure in the expert report in cases where the technical evidence is extremely complex. Furthermore, it is difficult to tell whether the judge has based his decision on correct assumptions in cases where the judge does not exactly know what the expert's findings mean for the specific claimant.

\footnotetext{
${ }^{1132}$ Miscommunication can also arise under the traditional principle of all-or-nothing compensation. Therefore, these solutions also apply to the all-or-nothing approach.

${ }^{1133}$ In England, the Court Practice Direction requires that a specialist judge at each Court centre around the country deals with all mesothelioma claims, which has the desirable effect that many more claims can be settled during the mesothelioma sufferer's lifetime. See also: Irwin Mitchell: Asbestos Newsletter Autumn 2008. In 1997, De Ruiter has also addressed this option in his advise for the Dutch government. See: De Ruiter 1997. See also: Spier 1997, p. 61.

${ }^{1134}$ Roijackers 2009, p. 8; Akkermans et al. 2009, p. 90.

${ }^{1135}$ Dekker \& Hartman 2006, p. 6-10. This has been confirmed by the Court of Appeal in 2009: Gerechtshof Amsterdam 24 maart 2009 (rolnr. C07/01414).

${ }^{1136}$ Hartman \& Dekker 2008, p. 91-92; De Groot \& Akkermans 2007, p. 501.

${ }^{1137}$ Article 194 (2) Dutch Code of Civil Procedure.

${ }^{1138}$ Convention for the Protection of Human Rights and Fundamental Freedoms.

1139 This includes the right to examine witnesses or have them examined. Furthermore, the right to a fair trial implies the right to unbiased and impartial experts. A judge cannot make a decision in cases where the decision is based on information and expert evidence on which one of the parties could not comment. See Articles 19, 194 (2) Dutch Code of Civil Procedure.

${ }^{1140}$ Hoge Raad 5 december 2003, NJ 2004, 74: The decision to deviate from the expert report has to be clearly motivated.
} 
As is seen throughout this chapter, epidemiological causation is not the same as judicial causation. The questions which the appointed expert is asked to address must enable the judge to transfer epidemiological findings into an independent normative legal judgment. We must keep in mind that the way in which the questions are phrased is of central importance to the outcome of the case, although this should not invite the expert to decide the legal outcome of the case. ${ }^{1141}$ Therefore, the use of legal terminology must be avoided as much as possible. ${ }^{1142}$ A correct and clear non-legal formulation can limit the miscommunication between judges and experts. However, it is hardly impossible to formulate questions correctly without extensive communication between the judge and the expert. ${ }^{1143}$ Furthermore, the problem of miscommunication between judges and experts is not only confined to claims for asbestos-related diseases but is part and parcel of the appointment of non-legal experts in civil litigation, which emphasizes the need for a correct formulation of questions even more.

In personal injury claims, the so called Interdisciplinary Study Group Medical Experts (IWMD) ${ }^{1144}$ has, although not yet successfully, tried to develop a specific model on the way in which questions must be phrased with regard to the requirement of causation in order to avoid the undesirable effect that experts decide the legal outcome of the case. ${ }^{1145}$ The Study Group gives preference to a combination of questions with a factual and normative nature. ${ }^{146}$ The questions should invite the expert to explain what circumstances have been an incentive for the expert to draw certain conclusions. This way, legal scholars are able to evaluate whether it is - from a legal point of view - correct to attach much importance to certain arguments. ${ }^{147}$ If not, the judge will draw different legal conclusions attaching great value to other arguments. This enables the judge to clearly motivate why he follows or deviates from the conclusions set up by the appointed expert(s).

The approach suggested by the Interdisciplinary Study Group Medical Experts (IWMD) also seems to be most desirable in claims for lung cancer that could have been asbestos-related: the questions which the expert is asked to address must include both factual and normative elements. If the expert is asked to clearly motivate why he draw certain conclusions in the specific claimant's case, the judge can - from a legal point of view - evaluate whether it is reasonable to attach much importance to such normative arguments. This enables the judge to clearly motivate his decision to follow or deviate from the conclusions set up by the appointed expert(s). In order to avoid that the court's decision is based on wrong assumptions, the way in which the questions are phrased must - more specifically - emphasize the distinction between population-level figures and individual figures because this distinction is important for the legal outcome of the case. The judge should not get the impression that the expert's findings on the assessment of the

\footnotetext{
${ }^{1141}$ Dekker \& Hartman 2006, p. 6-10; Giard \& Stolker 2003, p. 610-616.

${ }^{1142}$ Akkermans et al. 2009, p. 92, 93: this development is also recognizable in case law.

1143 Giard \& Stolker 2003, p. 616.

${ }^{1144}$ In Dutch: 'Interdisciplinaire Werkgroep Medische Deskundigen (IWMD)'.

${ }^{1145}$ Akkermans et al. 2009, p. 89-99; Akkermans \& Van 2002, p. 57-61.

${ }^{1146}$ Hartman and Dekker do not agree and argue that the expert should only be asked to address factual questions. See: Hartman \& Dekker 2007, p. 450, 452.

${ }^{1147}$ Akkermans et al. 2009, p. 99.
} 


\section{Chapter 4}

probability causation in a claim for lung cancer as a potential consequence of asbestos expsoure solely deals with the individual's situation, while - in fact - only populationlevel figures are included in the expert's conclusions. The expert's findings must function as a starting point for the legal judgment, which means that the concrete circumstances of the claimant could be an incentive for the judge to deviate from the expert report.

\subsubsection{Methods to determine the reliability of expert evidence}

Besides the fact that the questions to be addressed by the appointed expert(s) must be phrased in simple, clear ways to avoid confusion in claims for asbestos-related diseases, it is of the utmost importance that judges also examine the reliability of the expert evidence. ${ }^{1148}$ Incorrect expert reports do, irrespective of whether they have been subject to a correct legal evaluation, lead to judgments that are based on wrong assumptions. In the following subsections, two solutions are proposed that can limit the so called 'junk science' in claims for asbestos-related diseases. The first solution to be discussed is the use of a checklist for admitting scientific expert evidence, which has been applied in the American case Daubert $v$ Merrell Dow Pharmaceuticals ${ }^{1149}$ (1993). The second solution that could diminish the use of incorrect expert reports in claims for asbestos-related diseases, and thus also limits the number of judgments that are based on wrong assumptions, is the use of a so called 'disclosure statement' in the expert report.

\subsubsection{A checklist to determine the reliability of expert evidence}

In the American case Daubert $v$ Merrell Dow Pharmaceuticals ${ }^{1150}$ (1993), it was unclear whether or not a specific medicine (Bendectin) could cause birth defects. Daubert is an inspiring decision rendered by the Supreme Court in the United States of America introducing guidelines for admitting scientific expert testimony. ${ }^{1151}$ The aim of the proposed guidelines is to reduce 'junk science' as evidence in court. ${ }^{1152}$ Although the rules on evidence and structure of the American jurisdiction differ from legal systems on the European continent, it is worth to highlight the most important ruling in this case. Daubert set forth a non-exhaustive list of questions (conditions) which trial judges must use to determine whether or not the expert testimony meets the required 'relevancy' ${ }^{1153}$ and 'reliability' ${ }^{1154}$ standard in order to establish its validity. If not, the expert evidence will be excluded.

The so called 'Daubert standard' must be seen as a checklist to examine the quality of expert evidence, which might improve the court's decision in claims for asbestos-related diseases. Daubert made it very clear that every new technique applied by the expert(s) should meet five essential points in order to be admissible at court: the court should first

\footnotetext{
${ }^{1148}$ Faure 2003, p. 50.

1149 Daubert v Merrell Dow Pharmaceuticals, 509, U.S. 579 (1993).

${ }^{1150}$ Daubert v Merrell Dow Pharmaceuticals, 509, U.S. 579 (1993).

${ }^{1151}$ See for more information; Dommering- van Rongen 2000, p. 27-33; Verkerk 2007, p. 491-500; Verkerk 2010, p. 173-177.

${ }^{1152}$ See also: Giard \& Stolker 2003, p. 612; Crombagh 2000, p. 1659-1666.

1153 'Relevant to the task at hand'.

1154 'On a reliable foundation'.
} 
explore whether or not the expert's technique has been tested. Secondly, the court explores whether the applied technique has been subject to peer review and publication. Thirdly, the court examines the potential errors of the applied technique. Fourthly, the court gathers information on the existence of standards for the control of the technique, and fifthly, the court explores whether or not this technique has been generally accepted. This non-exhaustive list of questions intends to help courts to evaluate the reliability of expert evidence. However, applying such a checklist does not always lead to an outcome that improves the claimant's position. If the claimant's expert testimony is excluded he encounters more difficulties in proving the requirements to establish the liability of the defendant. In cases where a defendant has successfully raised a Daubert motion, the claimant's chance to litigate successfully has dwindled. The Daubert standard can be applied in both jurisdictions taken under consideration here. In the Netherlands, the Daubert standard can be applied on the basis of Article 200 Code of Civil Procedure (Rv), which enables the court to hear party-appointed experts. ${ }^{1155}$ Subsequently, the court can use the Daubert list to evaluate the party-appointed expert evidence more critically in order to determine whether such evidence is reliable.

It is, however, questionable whether the use of such a checklist to test the reliability of the expert evidence is desirable in claims for lung cancer that could have been asbestosrelated. In such claims evidence is brought up by epidemiologists who refer to asbestos exposure as adding to the risk of lung cancer. It is common knowledge that epidemiological studies are difficult to read and hard to understand for legal scholars. Application of the Daubert standard makes the judge an amateur scientists who still cannot fulfill his role as gatekeeper of scientific evidence, i.e., assuring that the expert evidence proceeds from scientific knowledge and not junk science. ${ }^{1156}$ Moreover, the judge is - most likely - unable to answer all questions, which implies that he is still unable to adequately determine the reliability of the expert evidence. Therefore, the desirable effect of such a checklist must not be overestimated in claims for asbestos-related diseases.

\section{5.2.2 Disclosure of information on the expert's expertise}

Besides the way in which the questions are phrased, the expertise of the expert is also an important factor for the quality of the expert report. ${ }^{1157}$ Common law requires a disclosure of information on the expertise of the appointed expert (witness). In England, the so called 'Academy of Experts' was founded in 1987 to promote the better use of experts and to ensure that a standard of excellence is maintained and developed. ${ }^{158}$ The Academy of Experts is the premiere profession body for expert witnesses checking the expertise of the expert. ${ }^{1159}$ Good qualified and independent experts in very specific fields can be searched on the website of the Academy of Experts. A body to check and train

\footnotetext{
1155 See for English law: Civil Procedure Rules 1998.

${ }^{1156}$ Gatowski et al. 2001, p. 438.

${ }^{1157}$ Faure 2003, p. 50.

${ }^{1158}$ www.academy-experts.org : 'The Academy is both a professional society and a qualifying body which provides, for the first time, a single source of qualified independent experts experienced in a wide range of professional, commercial and industrial disciplines from around the world.' [Last visited 31 August, 2012]

${ }^{1159}$ See for more information about the Academy of Experts: Tzankova 2003, p. 122-125.
} 


\section{Chapter 4}

reliable experts who deliver good quality expert evidence is, however, missing in the Netherlands.

In the Netherlands, no sound national index that includes information on the qualification of experts is available, which makes it more difficult to find specialized experts who deliver reliable reports in claims for asbestos-related diseases. It is not uncommon that the court appoints an expert to appoint an expert. ${ }^{1160}$ Certain intitiatives have been made to improve expert reports and limit the knowledge-paradox between judges and experts. ${ }^{1161}$ In 2004, a Practice Direction for experts in Dutch civil law cases has been developed by the Council for the Judiciary ${ }^{1162}$, which is meant to provide information relevant to the expert's examination and report. ${ }^{1163}$ In 2005, a general Model expert opinion has been developed by the Council for the Judiciary to standardize the process in order to make the expert opinion more clear. ${ }^{164}$ In May 2009, the Association for Medical Specialistic Reporting (NVMSR) ${ }^{1165}$ has been founded to improve the quality of expert reports. However, the latter Association does not have the same established reputation as the English Academy of Experts. ${ }^{166}$ Therefore, Van Dijk and Smeehuijzen have proposed to disclose information on the expertise of the expert in the expert report in order to establish whether or not an expert has truly sufficient expertise to inform the judge about the technical issues involved in the case. ${ }^{1167}$ A so called 'disclosure statement' could help the court to evaluate expert evidence more critically in claims for asbestos-related diseases. In the English jurisdiction, it is the rule rather than the exception to disclose information on the expertise of the expert in the expert report. ${ }^{168}$ The Practice DirectionExperts and Assessors, which is based on the Civil Procedure Rules, explicitely requires that an expert report must:

'1. give details of the expert's qualifications; 2. give details of any literature or other material which the expert has relied on in making the report; 3. contain a statement

\footnotetext{
${ }^{1160}$ Gerechtshof Amsterdam 19 december 1996, NJ 1997, 490. See also: Akkermans \& Van 2002, p. 59.

${ }^{1161}$ The 'expert-index' does not include information on the qualification of the expert. See: Van Dijk 2007, p. 439; De Groot \& Akkermans 2007, p. 503.

${ }^{1162}$ In Dutch: 'Raad voor de Rechtspraak'.

${ }^{1163}$ In Dutch: 'Leidraad deskundigen in civiele zaken'. See for more information: http://www.rechtspraak.nl/Procedures/Landelijke-regelingen/Sector-civiel-recht/Documents/PracticedirectionforexpertsinDutchcivillawcases.pdf [Last visited 31 August, 2012].

${ }^{1164}$ In Dutch: 'Model deskundigenbericht in civiele zaken'. See for more information: http://www.rechtspraak.nl/Procedures/Landelijke-regelingen/Sector-civiel-

recht/Documents/defengelsevertalingmodeldeskundigenbericht110608.pdf [Last visited 31 August, 2012].

${ }^{1165}$ In Dutch: 'Nederlandse Vereniging voor Medisch Specialistische Rapportage (NVMSR)'. The Association offers education and training for medical specialists who are appointed to draw expert reports in civil procedures. Schuurman (a medical specialist) endorses the development that medical specialists are trained to draw reports. See also the 'Directive Medical Specialistic Reporting' 2008 (Richtlijn Medisch Specialistische Reportage). For more information see: Schuurman 2010, p. 518-521.

${ }^{1166}$ In Europe, certain initiatives have been made in particular scientific fields. The European Network of Forensic Science Institutes has, for example, developed requirements as to the quality of experts. See for more information: www.enfsi.org : 'ENFSI is recognized as a pre-eminent voice in forensic science worldwide by ensuring the quality of development and delivery of forensic science throughout Europe.' [Last visited 31 August, 2012].

${ }^{1167}$ Van Dijk 2007, p. 434-441; Smeehuijzen 2003, p. 126-129.

${ }^{1168}$ Smeehuijzen 2003, p. 126.
} 
setting out the substance of all facts and instructions given to the expert which are material to the opinions expressed in the report or upon which those opinions are based; 4. make clear which of the facts stated in the report are within the expert's own knowledge; 5. say who carried out any examination, measurement, test or experiment which the expert has used for the report, give the qualifications of that person, and say whether or not the test or experiment has been carried out under the expert's supervision; 6 . where there is a range of opinion on the matters dealt with in the report $-\mathrm{a}$. summarise the range of opinion, and b. give reasons for his own opinion.' ${ }^{1169}$

These conditions have been defined more in detail in the Code of Guidance for Experts and those instructing them, which has been developed by the Academy of Experts. The conditions 1 and 6 will be subject to further discussion as they are the most relevant for this research. In the sections 15.5 and 15.6 of the Code of Guidance for Experts and those instructing them, the expert's qualifications are defined as followed:

'(15.5:) The detail of the Expert's qualifications to be given in the report should be commensurate with the nature and complexity of the case. It may be sufficient merely to state the Expert's qualifications in the relevant profession. However, where highly specialized expertise is called for, the Expert should include the detail of the particular training and/or experience that qualifies him to provide that highly specialized evidence; (15.6:) An Expert may wish to state the number of appointments as an Expert witness that he has accepted in respect of such period prior to his appointment as he considers will assist the court, identifying the number of appointments which were for a claimant and which were for a defendant. ${ }^{1170}$

In the sections 15.9 and 15.10 of the Code of Guidance for Experts and those instructing them, condition 6 of the Practice Direction is also defined:

'(15.9:) If the mandatory summary of the range of opinion is based on published sources, the Expert should explain those sources and, where appropriate, should state the qualifications of the originator(s) of the opinions from which he differs, particularly if such opinions represent a well established school of thought; (15.10:) Where there is no available source for the range of opinion, the Expert may need to express an opinion on what he believes to be the range which other experts would arrive at if asked. In those circumstances, the expert should make it clear that the range that he summarises is based on his own judgement and explain the basis of that judgement. ${ }^{1171}$

In the Netherlands, experts are - although Dutch legal scholars have made it very clear that they favour the use of a disclosure statement in personal injury cases - not obliged to disclose information on their expertise in their expert report. ${ }^{172}$ Disclosure of infor-

\footnotetext{
${ }^{1169}$ http: / / www.academy-experts.org [Last visited 31 August, 2012: Search: 'Code of Guidance'].

${ }^{1170}$ http:/ / www.academy-experts.org [Last visited 31 August, 2012: Search: 'Code of Guidance'].

1171 http: / / www.academy-experts.org [Last visited 31 August, 2012: Search: 'Code of Guidance'].

${ }^{1172}$ Van Dijk 2007, p. 434-441; Smeehuijzen 2003, p. 126-129; Tzankova 2003, p. 122-126.
} 


\section{Chapter 4}

mation on the expertise of the expert in claims for asbestos-related diseases could, however, limit the number of judgments that are based on wrong assumptions. It seems desirable to disclose information on the expert's professional qualities and his expertise history $^{1173}$. Information about the expert's (former) employer(s) and the expert's additional job (history), which has not been included in the sections 15.5 and 15.6 of the Code of Guidance for Experts and those instructing them, can be relevant as well and must also be included in the report for a better evaluation of the expert's evidence in claims for asbestos-related diseases. ${ }^{1174}$

Furthermore, information on dissenting scientific opinions can also influence the legal outcome of the case and must be included in a disclosure statement. ${ }^{1175}$ As examined in section 4.3.2.1, in claims for lung cancer that could have been asbestos-related the influence of smoking has been subject to much debate in epidemiological studies. Although most studies have established a multiplicative relation between smoking and exposure to asbestos, some recent reviews draw different conlusions on the interaction between the two. ${ }^{1176}$ In such claims it would be desirable that, in line with the sections 15.9 and 15.10 of the Code of Guidance for Experts and those instructing them, the expert summarizes the range of scientific opinion in his report and that he give reasons for his dissenting own opinion. If the expert's opinion on the interaction between smoking and asbestos exposure differs from the opinion of other prominent epidemiologists, he should inform the judge about the ranges of opinion. This enables the judge to evaluate the expert's findings more critically, which can limit the number of judgments that are based on wrong assumptions. Disclosure of information on the appointed expert and the ranges of scientific opinion could have led to another outcome in Nefalit/Karamus ${ }^{177}$ and Hollink/Eternit ${ }^{1178}$.

Until there is no sound national list of qualified experts in the Netherlands, a disclosure statement must be included in the expert report in claims for asbestos-related diseases, like in the English jurisdiction. ${ }^{1179}$ However, the desirable effect of the inclusion of a disclosure statement in the expert report must, similar to the effect of the use of a checklist, not be overestimated in claims for asbestos-related diseases. The judge remains a legal expert who, although more information on the qualifications of the expert and the ranges of scientific opinion enables him to draw better legal conclusions, cannot perform the research himself and will still encounter difficulties when evaluating the expert's findings.

\footnotetext{
${ }^{1173}$ How often the expert has been appointed by claimants or defendants.

${ }^{1174}$ Smeehuijzen 2003, p. 128.

1175 Akkermans \& Smeehuijzen have proposed specific questions for experts in personal injury cases. See: Akkermans \& Smeehuijzen 2005. See Hoge Raad 8 juli 2011, NJ 2011, 311 and Hoge Raad 9 december 2011, NJ 2011, 599 for an example of how the court must deal with conflicting expert opinions.

${ }^{1176}$ Recent epidemiological studies have established a submultiplicative relation between smoking and exposure to asbestos. See: Berry \& Liddell 2008, p. 459.

${ }^{1177}$ Hoge Raad 31 maart 2006, NJ 2011, 250 (Nefalit/Karamus).

${ }^{1178}$ Hoge Raad 31 maart 2006, LJN: AU6093 (Hollink/Eternit).

${ }^{1179}$ See also: Van Dijk 2007, p. 441.
} 


\subsection{Overall conclusion}

In claims for lung cancer that could have been asbestos-related, the appointment of experts is inevitable because judges do not have the relevant experience or qualification to assess the probability that the lung cancer was caused by the wrongful exposure to asbestos. In order to adequately assess the Probability of Causation (PoC), more information is required on the claimant's exposure history, the chemical nature of the inhaled asbestos fibres, and the (sub)multiplicative relation between smoking and exposure to asbestos. First of all, it is necessary to perform an exposure assessment to determine the claimant's cumulative exposure to asbestos, which is generally expressed in fibre years. It is, due to the long latency period connected to lung cancer, impossible to establish the actual cumulative exposure to asbestos in an individual case, which means that the estimation of the claimant's cumulative exposure to asbestos inserts a certain element of speculation and thus might not correspond to the claimant's true exposure level.

Once the expert has established the claimant's cumulative exposure to asbestos he must determine the increased risk of lung cancer (risk coefficient) in the specific claimant's case. In the Netherlands, case law shows that, irrespective of the claimant's smoking history, a risk coefficient of one percent per fibre year $(K=1 \%)$ is used to assess the probability that asbestos has caused the lung cancer. Courts assume that there is a multiplicative relation between smoking and exposure to asbestos, which implies that the same risk coefficient can used for smokers and non-smokers. Recent epidemiological studies have, however, suggested that the interaction between asbestos exposure and smoking is not additive or multiplicative but submultiplicative. This would imply that a higher risk coefficient must be used in cases where the claimant did not smoke as it is more likely that asbestos has caused lung cancer to a non-smoking claimant. ${ }^{1180}$ In addition, it has also been suggested to use a higher risk coefficient in cases where the claimant has been regularly exposed to more hazardous fibre types, such as blue and brown asbestos. The latter, however, runs up against practical difficulties: in most industrial processes different types of asbestos are mixed, which means that pure exposures to a single asbestos type are rare.

Subsequently, the expert's findings must be transferred to a legal judgment. Legal scholars have to keep in mind that epidemiology is a study of populations, that can - by categorizing subcategories of patients and the use prediction models - also be used to estimate chances on an individual level. The assessment of the probability of causation in individual cases will, however, always insert a certain element of speculation due to a lack of specific data on the concrete circumstances of the claimant. Case law in the Dutch and English jurisdiction shows that courts have directly applied the epidemiological findings to establish the liability of the defendant. ${ }^{1181}$ Judges must be (more) aware of the distinctions between epidemiological causation and judicial causation. The court's legal interpretation of the epidemiological findings can, contrary to epidemiological causation,

\footnotetext{
${ }^{1180}$ The increased risk of lung cancer (risk coefficient) is not more than a factor of 3 times higher for a nonsmoker when compared to a smoker, subjected to the same level of exposure.

${ }^{1181}$ See for the Dutch jurisdiction: Hoge Raad 31 maart 2006, NJ 2011, 250 (Nefalit/Karamus); Hoge Raad 31 maart 2006, LJN: AU6093 (Hollink/Eternit); Kantongerecht Middelburg 1 februari 1999, TMA 1996/6 (Schaier/De Schelde). See for the English jurisdiction: Shortell v Bical Construction Ltd., [2008] QBD Liverpool (16-05-2008); Badger ${ }_{v}$ Ministry of Defence, [2005] EWHC 2941 (QB), [2006] 3 ALL ER 173.
} 


\section{Chapter 4}

be influenced by normative elements. Therefore, the assessed probability of causation must be regarded as a starting point to determine judicial causation. The fairnesscorrection, which is based on reasonableness and fairness, can be used as a tool to include normative elements in specific cases in order to reach outcomes that have balanced out the interests of the claimants and the interests of the defendants fairly.

Two possible methods can be proposed. Firstly, the court can decide to use a value of the confidence interval that lies above or below the middle value. If the inclusion of normative elements in the specific claimant's case gives reason to interpret the epidemiological findings in favour of the claimant, the court can take the highest value of the confidence interval within the boundary range to determine the proportional liability of the defendant. Secondly, the court can also decide to use a value of the risk coefficient that lies above or below the starting point value of one percent per fibre year. If the court decides that normative elements give reason to interpret the epidemiological findings in favour of the claimant, the court can use a higher value of the risk coefficient to establish judicial causation.

When compared to the traditional principle of all-or-nothing compensation, the instrument of proportional liability depends to an even larger extent on the findings of experts. Is this a valid reason to deny the application of proportional liability in claims for lung cancer that could have been asbestos-related? Probably not. Epidemiological evidence is also used under the traditional principle of all-or-nothing compensation and incorrect expert reports or wrong assumptions will have more far-reaching (negative) consequences under this traditional compensation regime. It is necessary that judges and experts acknowledge that epidemiological data is not yet advanced in the field of asbestos-related diseases, which means that epidemiological findings must be applied with caution. Future epidemiological studies must be more individualized to do justice to the concrete circumstances of the claimant.

Furthermore, it must be acknowledged that the way in which the questions to be addressed by the expert are phrased is of central importance to the outcome of the case, although this should not invite the expert to decide the legal outcome of the case. A simple, clear way of phrasing the question avoids miscommunication in claims for asbestosrelated diseases. It seems that a combination of questions with a factual and normative nature can limit the possibility that the court's decision is based on wrong assumptions. If the expert is asked to clearly motivate why he draw certain conclusions in the specific claimant's case, the judge can - from a legal point of view - evaluate whether it is reasonable to attach much importance to such normative arguments. This enables the judge to clearly motivate his legal decision to follow or deviate from the conclusions set up by the appointed expert(s). In addition, the use of a checklist to determine the reliability of expert evidence or a disclosure statement on the expert's expertise could diminish the use of incorrect expert reports in claims for asbestos-related diseases, which thus also limits the number of judgments that are based on wrong assumptions. However, the desirable effect of the inclusion of a disclosure statement must, similar to the effect of the use of checklists, not be overestimated in claims for asbestos-related diseases. The judge remains a legal expert who cannot perform the scientific research himself, which means that he still encounters difficulties when evaluating the expert's findings. Finally, one 
The Assessment of the Probability of Causation and the Role of Experts in Asbestos-Related Cases general remark must be made: a fixed solution for the knowledge-paradox between judges and experts is missing. The most reasonable results in individual claims for asbestos-related diseases can only be achieved if judges and experts communicate more extensively about the expert's findings. 



\section{Chapter 5}

\section{Conclusions}

The problem of compensating a growing number of people who have contracted an asbestos-related injury is taxing many legal systems, all facing the exact same problems. Most asbestos-related injuries are exclusively traceable to occupational exposure to asbestos, but there is a slight possibility that persons who have experienced a household, para-occupational, or environmental exposure to asbestos will also be faced with the long-tail risks connected to asbestos exposure. This emphasizes the problem even more: asbestos-related injuries are not only work-related. Although a variety of problematic legal and scientific issues are captured in claims for asbestos-related diseases, this research mainly focused on an extremely problematic requirement to establish the liability of the defendant: the proof of causation in Dutch and English laws.

Uncertain causality arises frequently in claims for asbestos-related diseases and can be classified in two main types, uncertainty about the tortfeasor (who caused the damage?) and uncertainty as to the cause of the damage (what caused the damage?). In claims for mesothelioma, uncertainty arises as to the specific tortfeasor in cases in which two or more defendants have exposed the claimant to asbestos. Although asbestos is regarded as the only known cause to contract mesothelioma, science is unable to determine during which exposure the claimant has inhaled the fatal asbestos fibre that caused the mesothelioma to develop. In claims for lung cancer that could have been asbestos-related, uncertainty arises as to the cause of the damage: medical science is unable to determine whether lung cancer is caused by (wrongful) exposure to asbestos or by other factors that could cause or contribute to the development of lung cancer, such as smoking, genetic predisposition, ageing, eating habits and so on. Applying traditional principles, the claimant's inability to prove causation leads to a full dismissal of the claim in the majority of the cases, while there could still be a real probability that the defendant's wrongful intervention has caused the claimant's damage. Therefore, strict application of the condicio sine qua non (but-for) test, and the all-or-nothing result that this test produces, leads to undesirable outcomes in cases where the assessment of causation cannot result in a simple yes or no answer.

This research mapped out complex legal and scientific problems that arise in specific claims for asbestos-related diseases and examined a number of internal (within Tort law) and external (outside Tort law) solutions to the problem of uncertain causation. The aim was to find a way to solve the problem of uncertain causation, seeking a fair balance between the interests of the claimant and the interests of the defendant. It can be said 


\section{Chapter 5}

that, in claims for mesothelioma, both jurisdictions apply a claimant-friendly regime to compensate mesothelioma sufferers. Dutch and English mesothelioma sufferers, who have been exposed to asbestos in several different employments, do not encounter major difficulties as a consequence of respectively the creation of Article 6:99 BW and the option to expand the notion of causation.

In the Netherlands, mesothelioma victims do not have to trace all possible defendants to receive full compensation: each defendant, in a group of possible tortfeasors, is jointly and severally liable on the basis of Article 6:99 $\mathrm{BW}^{1182}$. Dutch claimants do not have to fear for insolvency of one of the tortfeasors and the burden of proof (disproving causation) lies firmly with the tortfeasor rather than the victim. In England, the House of Lords decided to expand the notion of causation in 2002, which made the proof of causation less difficult for mesothelioma sufferers. The question of how the damages should be apportioned has, however, been subject to extensive discussion in England. In 2006, the House of Lords applied a defendant-friendly approach to reduce the future costs of companies who have exposed their employees to asbestos in the past, holding each defendant liable by reference to the share of risk attributable to the breaches of duty by the defendants. Applying this rule of law, mesothelioma sufferers have to pay for (a part of) their own damages in cases where one or more possible tortfeasors are untraceable or have gone out of business. This regime has received a considerable amount of criticism, resulting in the enactment of the Compensation Act 2006 that reversed the negative side-effects of the House of Lords' decision in Barker. Due to the Parliament's intervention, English mesothelioma sufferers no longer have to hold each defendant liable by reference to the share of risk attributable to the breaches of duty by the defendants in order to receive full compensation, like Dutch mesothelioma sufferers. After all, (the dissenting) Lord Rodger of Earlsferry was right in Barker: in claims for mesothelioma joint and several liability should be preferred as a matter of policy.

In both the Netherlands and England far fewer claims have, when compared to the number of claims for mesothelioma, been brought up by potential asbestos victims who suffer from lung cancer which could have been asbestos-related. In these particular cases both jurisdictions have their own approach to establish the liability of the defendant. Traditionally, the claimant will, depending on the outcome of the condicio sine qua non (but-for) test, obtain compensation for the entire loss or receive no compensation at all. Over the years, the traditional principle of all-or-nothing recovery has received a considerable amount of criticism in cases that are characterized by the problem of multiple causation. The main critique relates to the fact that the claimant will be either over- or under-compensated, that (just) one percent can make the difference between being fully compensated or not being compensated at all, and that it does not give the right incentive for prevention.

Dutch courts and legal scholars have recognized the drawbacks and have tried to introduce constructions which may remove these drawbacks by adopting the legal instrument of proportional liability: the judge does not simply award or reject the total amount of damages, rather he or she awards damages in proportion to the probability of

\footnotetext{
${ }^{1182}$ Unless the defendant is able to prove that he did not cause the claimant's damage, which - essentially - is a death sentence in claims for mesothelioma.
} 
causation. This Salomon-solution, which was applied for the first time by the Hoge Raad in 2006, deviates from the conventional two-step test to establish causation because condicio sine qua non is not a necessary element for liability anymore. Although heavily debated in legal writings, the underlying principle of the Articles 6:99 and 6:101 BW supports the application of proportional liability.

So far, the discussion on proportional liability has primarily focused on its (missing) legal basis and the unsolvable question of where to set the minimum and maximum threshold to limit the applicability of this instrument, in order to reach reasonable outcomes. This research shows that, due to the nature of this problem, the use of a maximum threshold is unsatisfactory and that practical considerations might make it necessary to use a minimum threshold. If the court accepts as evidence that there is a probability of 90 percent that asbestos has caused the lung cancer, the court must not award full compensation to do justice to the situation of causal uncertainty: it is still possible that the wrongful exposure to asbestos did not cause the claimant's lung cancer as multiple factors could have caused or contributed to the development of lung cancer. Although it is unsatisfactory to use a maximum threshold, arguments with a more practical nature might suggest that it is necessary to limit the applicability of proportional liability with a minimum threshold. The use of a fixed percentage is, although suggested in legal writings, not advisable here. Similar problems can be expected: the problem of over- or under-compensation will, although in a more justified way, arise and one percent can again - make the difference between either being compensated in accordance with the probability of causation or not being compensated at all. Therefore, the question of whether or not proportional liability is justified in a specific claimant's case must be determined on a case by case basis. Here, courts must take into consideration factors such as: the assessed probability of causation, the value of the claimant's claim, and the fear for a floodgate of claims.

Under English law, the instrument of proportional liability is not applied to solve claims for lung cancer, but traditional causation principles still apply to establish the liability of the defendant. Case law made it clear that the claimant must prove causation by showing that the wrongful exposure to asbestos has doubled the risk of lung cancer. Once causation has been established, the concept of contributory negligence is used as a tool to reduce the total amount of compensation by the amount to which smoking contributed to the damage. Not giving up smoking constitutes fault in cases where the lack of care that the claimant took for his own health fell below the standard to be expected of a person in his position at that time.

A comparative analysis of case law in the two jurisdictions taken under consideration here, reveals a shocking difference: one could wonder what the outcome would be in cases where English lung cancer sufferers did not smoke. Under Dutch law, proportional liability is not only confined to smoking claimants, which means that a non-smoking claimant will also be compensated in accordance with the probability that asbestos has caused the lung cancer as other factors are also taken into consideration reducing the overall compensation. Although I have not found (an) English courts verdict(s) in which a non-smoking claimant pursued a civil claim against the person who was responsible for the (wrongful) exposure to asbestos, it seems that the claimant would receive full com- 


\section{Chapter 5}

pensation in cases in which there is still a (real) probability that the lung cancer was caused by (an)other factor(s). The English approach is favourable to the claimant in cases in which a non-smoking lung cancer sufferer is able to prove that the exposure to asbestos has doubled the risk of lung cancer. In these particular cases, it is most likely that English courts will award full compensation while Dutch courts will (only) award damages in line with the assessed probability of causation. The Dutch approach is, however, favourable to the claimant in cases in which a smoking employee could not prove that the exposure to asbestos did double the risk of lung cancer. In the English jurisdiction, the claimant would leave empty-handed while the Dutch claimant would have received an award that corresponds to the probability that asbestos has caused the lung cancer.

In search of the most justified way to deal with the problem of uncertain causation in claims for asbestos-related diseases, this research, apart from the proportional approaches in Tort law, also examined other solutions to the problem of uncertain causation in substantive and procedural law. The results were rather disappointing. Although all proposed alternative solutions in Tort law do improve the problematic position of the claimant, they all result in an all-or-nothing outcome which does not do justice to the complex situation of causal uncertainty. Applying one of these solutions would result in an outcome that does not balance out the interests of the claimant and the interests of the defendant fairly. Subsequently, alternatives to Tort liability have been examined in order to explore whether instruments outside the area of Tort law are more sufficient to deal with specific claims for asbestos-related diseases. In the Netherlands and England, the type of causal uncertainty has proven to be of great importance to the enactment of an alternative scheme. In both jurisdictions, schemes have been set up that, as a sign of social involvement of the government, award fixed payments to mesothelioma sufferers in a less time-consuming and a less costly way, irrespective of the source of the exposure to asbestos. Although the schemes would work most efficiently if those who increase the risk of contracting mesothelioma compensate those who suffer from mesothelioma, they are not self-financing in all situations. In regard to the amount of the payment, it is advisable to - like in the English jurisdiction - take the age of the applicant into consideration to do (more) justice to the concrete circumstances of the mesothelioma sufferer. Another point of critique is that the payment does not always compensate the applicant in full, which means that the applicant must, if a civil action has not been excluded, still make an appeal to Tort law to receive further compensation. The foundation of a scheme that awards payments to persons who suffer from lung cancer as a potential consequence of asbestos exposure is too complex and therefore not advisable. The exact same problems that arise in Tort law will also arise when establishing the conditions to apply for a payment under the scheme, which contradicts its purpose. Moreover, lung cancer is, contrary to mesothelioma, less specific and less unique in its kind which makes the fear of creating a precedent for other occupational diseases more appropriate. For this moment, and due to the nature of the problem, Tort law remains the only remedy for persons who suffer from lung cancer as a potential consequence of wrongful exposure to asbestos.

All proposed internal and external solutions to the problem of uncertain causation have drawbacks. We have to recognize and realize that there is simply no perfect solu- 
tion available in such complex cases. The problem of uncertain causality is invincible in claims for lung cancer because medical science is still unable to determine whether or not the lung cancer was caused by the wrongful exposure to asbestos. Even more striking is the fact that the issue of multiple legal causal uncertainty is not only confined to claims for lung cancer, but also presents itself in other personal injury claims, such as: burnouts, RSI, lung injuries which could have been caused or worsened by occupational exposure to tobacco smoke, and cancer as a potential consequence of ionizing radiation exposure. It is not fair to deny all compensation or to award full compensation in cases where the causal uncertainty is caused by the fact that multiple legally relevant factors are present which all could have caused the claimant's damage (multiple legal causal uncertainty). However, in cases in which it is uncertain whether the only legally relevant possible cause has actually caused the claimant's damage (single legal causal uncertainty), the traditional principle of all-or-nothing compensation still produces the most reasonable results. The range of applications of the instrument of proportional liability must not be extended to such cases because - from a legal point of view - the legally relevant possible cause for which the defendant is responsible did or did not cause the claimant's damage. The distinction between 'single' and 'multiple' legal causal uncertainty might not sound very logical from a non-legal point of view because - in both situations - there are multiple factors that could have caused the damage. Therefore, this distinction must be regarded as a legal tool to reach the most desirable outcome in cases that are characterized by the problem of causal uncertainty.

The appointment of experts in civil litigation and the use of epidemiological data to assess the probability of causation in claims for lung cancer have been subject to much discussion and criticism in legal writings. It can be said that the defendant caused the damage to a certain degree, which subsequently could be expressed in probabilities and percentages. In order to adequately assess the probability that asbestos exposure has caused lung cancer, more information is required on the claimant's exposure history, the chemical nature of the inhaled asbestos fibres, and the (sub)multiplicative relation between smoking and exposure to asbestos. It is, due to the long latency period connected to lung cancer, impossible to establish the actual cumulative exposure to asbestos (fibre years) in an individual case, which means that the estimation of the claimant's cumulative exposure to asbestos inserts a certain element of speculation and thus might not correspond to the claimant's true exposure level.

In accordance with the leading decisions in the two jurisdictions taken under consideration here, I agree that smoking must be regarded as a circumstance that can be attributed to the claimant because smoking can be regarded as a private cause (someone's own decision). There must be a reduction in damages to reflect the extent to which smoking may have contributed to the risk of developing lung cancer. This way, the total damages are reduced in line with the claimant's share in the potential responsibility for the damage. However, a critical note must be made here: the term smoking is too imprecise to be used as measurement data and, in future cases, the specific impact of smoking must be assessed more precisely as its role is clearly important in the development of lung cancer. Epidemiologists must shape out the (sub)multiplicative relation between smoking and asbestos exposure more extensively and should not only distinguish smok- 


\section{Chapter 5}

ers from non-smokers but also heavy smokers from moderate smokers in order to determine the probability of causation properly. Moreover, epidemiologists must also specify the type of smoke, whether it is filtered or unfiltered, the manner and frequency of inhalation, and - presumably - passive smoking. Extensive epidemiological research in this field is required to clarify the interaction between smoking and asbestos exposure in the development of lung cancer.

Prudence is called for when transferring epidemiological findings to legal judgments. Although it must be acknowledged that the assessment of the probability of causation is getting more and more individualized by categorizing subcategories of patients and the use of prediction models, epidemiology cannot precisely (with 100\% certainty) determine the probability that asbestos has caused lung cancer in an individual case. This should, however, not lead to the undesirable consequence that courts will refuse to take epidemiological findings into consideration: not using such findings is even more arbitrary. Courts should, however, be (more) aware of the distinctions between epidemiological causation and judicial causation and must make use of their discretionary power to interpret the expert's findings in their own way. The findings on epidemiological causation must be considered as a starting point to determine judicial causation because the court's legal interpretation of the epidemiological findings can, contrary to epidemiological causation, be influenced by normative elements. The fairness-correction, which can be based on reasonableness and fairness, can be used as a tool to include normative elements in the establishment of judicial causation. Depending on the concrete circumstances in the claimant's case, the court can use a value of the confidence interval that lies above or below the middle value, or a value of the risk coefficient that lies above or below the starting point value of one percent per fibre year to determine the (proportional) liability of the defendant. The inclusion of normative elements in the specific claimant's case can, in order to do justice to the situation, be an incentive to interpret the epidemiological findings in favour of the claimant or in favour of the defendant.

The establishment of causation in claims for lung cancer involves a multidisciplinary interaction between judges and experts and, as a consequence, this cross-disciplinary discussion can lead to miscommunication. The correct interpretation of epidemiological data is a problematic issue, which is considered a worldwide problem. Most, if not all judges did not have the type of education that would enable them to properly evaluate scientific evidence. Incorrect expert reports do, irrespective of whether they have been subject to a correct legal evaluation, lead to judgments that are based on contested assumptions. Although there is reason to fear that judges cannot identify mistakes made by the appointed expert(s), this is not a valid argument to deny the applicability of proportional liability as this is part and parcel of the appointment of experts in civil litigation. Irrespective of the applied compensation regime, it is of the utmost importance that judges and experts communicate more extensively and effectively about the expert's findings. A simple, clear way of phrasing the questions to be addressed by the expert, the use of a checklist to determine the reliability of expert evidence, a disclosure of information on the expert's expertise, a training for judges to improve their skills on how to interpret scientific evidence, and the appointment of specific judges that solely deal with claims for asbestos-related diseases are all proposed ideas that, although they need to be 
further specified, could contribute to a better settlement of claims for asbestos-related diseases and other cases in which similar problems arise. The desirable effects must, however, not be overestimated: the judge remains a legal expert who cannot perform the scientific research himself, which places him in a rather dependant position.

One last concluding remark is worth making here with respect to the scope of the proportional liability theory. Proportional liability seems to produce the most reasonable results in claims for lung cancer that could have been asbestos-related and should be applied in preference to the traditional principle of all-or-nothing compensation. Instead of retaining traditional principles of establishing causal relationships which so often produce unjust outcomes, proportional liability should be accepted as an enrichment to both legal systems and as a sufficiently just resolution until medical science lifts the evidential fog. Proportional liability is not exclusively geared for victims of asbestos-related diseases. The application of this instrument also seems desirable in specific personal injury cases that are also characterized by the problem of multiple legal causal uncertainty, provided that the probability of causation can be assessed accurately and does exceed the minimum threshold that justifies its application. 



\section{Bibliography}

Note: this bibliography lists the short titles with prepositions in alphabetical order. This implies that De Groot is listed under the 'D' and Van Maanen under the 'V'.

\section{Adams \& Brownsword 1999}

J. N. Adams, R. Brownsword, Understanding Law, London: Sweet \& Maxwell, second edition.

\section{Akkermans 1995}

A.J. Akkermans, Statistisch causaliteitsbewijs bij toxische schadeveroorzaking, Het Verzekerings Archief 1995, p. 44-53.

\section{Akkermans 1997}

A.J. Akkermans, Proportionele aansprakelijkheid bij onzeker causaal verband: een rechtsvergelijkend onderzoek naar de wenselijkheid, grondslagen en afgrenzingen van aansprakelijkheid naar rato van veroorzakingswaarschijnlijkheid,

Deventer: W.E.J. Tjeenk Willink, eerste druk.

\section{Akkermans et al. 2000}

A.J. Akkermans, M. Faure, T. Hartlief, Proportionele aansprakelijkheid, Den Haag: Boom Juridische Uitgevers.

\section{Akkermans 2002}

A.J. Akkermans, De 'omkeringsregel' bij het bewijs van causaal verband, Den Haag: Boom Juridische Uitgevers.

\section{Akkermans \& Van 2002}

A.J. Akkermans, A.J. Van, De medische expertise bij personenschade: knelpunten en mogelijke oplossingen, Tijdschrift voor Vergoeding Personenschade, 2002/2, p. 57-61.

\section{Akkermans 2003}

A.J. Akkermans, Causaliteit bij letselschade en medische expertise, Tijdschrift voor Vergoeding Personenschade, 2003/4, p. 93-104.

\section{Akkermans \& Smeehuijzen 2005}

A.J. Akkermans, J.L. Smeehuijzen, Disclosure statement, August 2005, www.rechten.vu.nl/immd $>$ Projecten $>$ Vraagstellingen $>$ Disclosure statement. 
Bibliography

Akkermans 2007

A.J. Akkermans, Informed Consent and the requirement of causation, Chester v. Afshar, 14 October 2004 (Dutch case note), European Review of Private Law, 2007/3, p. 433-442.

\section{Akkermans et al. 2009}

A.J. Akkermans, L.G.J. Hendrix, A.J. Van, De vraagstelling voor expertises in medische aansprakelijkheidszaken, Tijdschrift voor Vergoeding Personenschade, 2009/3, p. 89-99.

\section{Alt 2008}

H.J.W. Alt, Werkgeversaansprakelijkheid ex art. 7:658 BW anno 2007: persoonlijke predispositie, de zorgplicht van de werkgever en de stelplicht van de werknemer, Arbeidsrecht, 2008/12, p. $18-22$.

\section{Asser-Hartkamp 2004}

Asser-Hartkamp 4-1, Verbintenissenrecht, De verbintenis in het algemeen,

Deventer: Kluwer, twaalfde druk.

\section{Axford \& O' Callgahan 2004}

J. S. Axford, C. A.O' Callaghan, Medicine,

Blackwell Publishing, second edition.

\section{Baas et al. 2005}

P. Baas, P. Sleeswijk, W.F.M. Strankinga, E.J. van Hezik, J.A. Burgers, K.Y. Tan, J.H. Schouwink, Asbestslachtoffers: beoordeling door de werkgroep Mesotheliomen van de Nederlandse Vereniging van Artsen voor Longziekten en Tuberculose, Nederlands Tijdschrift voor Geneeskunde, 2005/149, p. 759-763.

\section{Bailey et al. 2005}

L. Bailey, K. Vardulaki, J. Langham, D. Chandramohan, Introduction to Epidemiology, Berkshire: Open University Press.

\section{Beer \& Dekker 2005}

J.M. Beer, B.P. Dekker, Deskundigheid in het medische traject: Een van de vergeten problemen van het schaderegelingsproces, Verkeersrecht, 2005/12, p. 374-376.

\section{Beers et al. 2003}

M.H. Beers, A.J. Fletcher, T.V. Jones, R. Porter, M. Berkwits, J.L. Kaplan, The Merck Manual of Medical Information,

Merck Research Laboratories.

\section{Berry \& Liddell 2004}

G. Berry, F.D.K. Liddell, The Interaction of Asbestos and Smoking in Lung Cancer: A Modiefied Measure of Effect, The Annals of Occupational Hygiene, 2004, Vol. 48/5, p. 459-462. 


\section{Betlem \& Klinge-Van Rooij 1996}

G. Betlem, I. Klinge- Van Rooij, Europees Privaatrecht, Tijdschrift voor Milieuschade en Aansprakelijkheid, 1996/06, p. 166-167.

\section{Boers et al. 2005}

D. Boers, M.P.A. Zeegers, G.M. Swaen, IJ. Kant, P.A. van den Brandt, The influence of occupational exposure to pesticides, polycyclic aromatic hydrocarbons, diesel exhaust, metal dust, metal fumes, and mineral oil on prostate cancer: a prospective cohort study, Occupational and Environmental Medicine, 2005/62, p. 531-537.

\section{Boffetta 2005}

P. Boffetta, Cancer epidemiology, in; W. Ahrens, I. Pigeot, Handbook of Epidemiology. Berlin: Springer.

\section{Bol 2002}

P. Bol, Asbestose en mesothelioom, Nederlands Tijdschrift Tandheelkunde, 2002/109, p. 497-498.

\section{Bonita et al. 2006}

R. Bonita, R. Beaglehole, T. Kjellström, Basic Epidemiology,

World Health Organization.

\section{Bosch Kemper 1998}

H.J.J. de Bosch Kemper, Boekbespreking A.J. Akkermans, Proportionele aansprakelijkheid bij onzeker causaal verband, Verkeersrecht, 1998, p. 165.

\section{Brahn \& Reehuis 2002}

O.K. Brahn, W.H.M. Reehuis, Zwaartepunten van het vermogensrecht,

Deventer: Kluwer, zevende druk.

\section{Brans 2001}

E.H.P. Brans, Liability for damage to public natural resources, Kluwer International Law.

\section{Brazier \& Cave 2007}

M. Brazier, E. Cave, Medicine, Patients and the Law,

Penguin Books, fourth edition.

\section{Brunner 1981}

C.J.H. Brunner, Causaliteit en toerekening van schade (I) and (II),, Verkeersrecht, 1981, p. 201-217, 233-236. 
Bibliography

\section{Burdorf et al. 1997a}

A. Burdorf, J.J. Barendregt, P.H.J.J. Swuste, D.J.J. Heederik, Schatting van asbestgerelateerde ziekten in de periode 1996-2030 door beroepsmatige blootstelling in het verleden, Onderzoek uitgevoerd in opdracht van het Ministerie van Sociale Zaken en Werkgelegenheid, maart 1997.

\section{Burdorf et al. 1997b}

A. Burdorf, J.J. Barendregt, P.H.J.J. Swuste, D.J.J. Heederik, Toenemende incidentie van mesothelioom in de toekomst door beroepsmatige blootstelling aan asbest in het verleden, Nederlands Tijdschrift voor Geneeskunde, 1997/141, p. 1093-1098.

\section{Burdorf \& Swuste 1999}

A. Burdorf, P. Swuste, An Expert System for the Evaluation of Historical Asbestos Expsoure as Diagnostic Criterion in Asbestos-related Diseases, The Annals of Occupational Hygiene, 1999, 43/1, p. 57-66.

\section{Burdorf et al. 2003}

A. Burdorf, M. Dahhan, P.H.J.J. Swuste, Occupational Characteristics of Cases with Asbestosrelated Diseases in The Netherlands, The Annals of Occupational Hygiene, 2003, 47/6, p. 485-493.

\section{Burrows 2008}

A. Burrows, Uncertainty about uncertainty: damages for loss of a chance, Journal of Personal Injury Law, 2008/1, p. 31-43.

\section{Cancian- van Ballegooijen 2004}

N. Cancian- van Ballegooijen, Alles of niets?! Werkgeversaansprakelijkheid en schuldverdeling bij beroepsziekten, Arbeidsrecht, 2004/4, p. 8-14.

\section{Cancian- van Ballegooien 2006}

N. Cancian- van Ballegooien, Juridische knelpunten van de proportionele benadering, Verslag Expertmeeting asbest en longkanker Instituut Asbestslachtoffers, IAS publicatie 2006/2 (juni), p. 20-21.

\section{Cascão 2005}

R.M.P.P. Cascão, Prevention and Compensation of Treatment Injury: A Roadmap for Reform, Boom Juridische Uitgevers.

\section{Charlier 2009}

L. Charlier, De overspannen werknemer objectief bezien, Letsel \& Schade, 2009/3, p. 3-5. 
Chorus et al. 2006

J.M.J. Chorus, P.H.M. Gerver, E.H. Hondius, Introduction to Dutch law, Kluwer Law International, fourth edition.

\section{Clerk \& Lindsell 2006}

Clerk \& Lindsell, Clerk \& Lindsell on torts,

London: Sweet \& Maxwell, nineteenth edition.

\section{Cordier \& Stewart 2005}

S. Cordier, S.A. Stewart, Exposure assessment, in; W. Ahrens, I. Pigeot, Handbook of Epidemiology.

Berlin: Springer.

\section{Crombagh 2000}

H.F.M. Crombagh, Rechters \& deskundigen, Nederlands Juristenblad, 2000/33, p. 16591666.

\section{Darnton et al 2006}

A.J. Darnton, D.M. McElvenny, J.T Hodgson, Estimating the number of asbestos-related lung cancer deaths in Great Brittain from 1980 to 2000, The Annals of Occupational Hygiene, 2006/50, p. 29-38.

\section{Deakin et al. 2003}

S. Deakin, A. Johnston, B. Markesinis, Markesinis and Deakin's tort law, Oxford: Clarendon Press, fifth edition.

\section{De Groot 2008}

G. de Groot, Het deskundigenadvies in de Civiele Procedure,

Deventer: Kluwer.

\section{De Groot \& Akkermans 2007}

G. de Groot, A.J. Akkermans, Schadevaststelling, bewijslastverdeling en deskundigenbericht, Nederlands Tijdschrift voor Burgerlijk Recht, 2007/10, p. 501-509.

\section{De Kezel 2008}

E. de Kezel, Een oplossing voor de asbestproblematiek via schadevergoedingsfondsen? Het nieuw opgerichte Fonds voor Asbestslachtoffers in België, Tijdschrift voor Vergoeding Personenschade, 2008/1, p. 17-28.

\section{De Klerk et al. 1991}

N.H. De Klerk, A.W. Musk, B.K. Armstrong, Smoking, exposure to crocidolite, and the incidence of lung cancer and asbestosis, Britisch Journal of Industrial Medicine, 1991/48, p. 412-417. 


\section{De Lang 2007}

S. de Lang, Aansprakelijkheid voor asbestblootstelling, Tijdschrift voor Vergoeding Personenschade, 2007/2, p. 57-62.

\section{De Lang \& Van 2008}

S. de Lang, A.J. Van, Aansprakelijkheid voor blootstelling aan asbest, in; J. Wildeboer \& S. Binkhorst (Eds.), Handboek Personenschade, hoofdstuk 2075, p. 1-142.

Deventer: Kluwer.

\section{Dekker \& Hartman 2006}

B.P. Dekker, M. Hartman, "Dan gaat de rechter op de stoel van de dokter zitten.” Over de vraagstelling en de rol van de deskundige in medische aansprakelijkheidszaken, Letsel \& Schade, 2006/4, p. 6-10.

\section{De Ruiter 1997}

J. de Ruiter, Asbestslachtoffers. Advies in opdracht van het Ministerie van Sociale Zaken en Werkgelegenheid,

Den Haag.

\section{Dogger 2006}

J.W. Dogger, Health Council wants asbestos standards updated, Network \# 2 (Health and environment), august 2006, volume 21, p. 38.

\section{Doll 1995}

R. Doll, Mortality from lung cancer in asbestos workers, British Journal of Industrial Medicine, $1995 / 12$, p. 81-86.

\section{Dommering- van Rongen 1998}

L. Dommering- van Rongen, Recensies A.J. Akkermans; proportionele aansprakelijkheid bij onzeker causaal verband, Nederlands Tijdschrift voor Burgerlijk Recht, 1998/1, p. 19.

\section{Dommering- van Rongen 2000}

L. Dommering- van Rongen, Wetenschappelijk en technisch bewijs in het aansprakelijkheidsrecht, Aansprakelijkheid \& Verzekering, 2000/2, p. 27-33.

\section{Dute 2003}

J. Dute, Medical Malpractice Liability: No Easy Solutions, European Journal Of Health Law, 2003 (2), p. 85-90.

\section{Edis 2005}

A. Edis, A lost cause: principle in the law of causation in tort: a review of recent developments, 24 February 2005, Atlantic Chambers. 


\section{Engelhard \& Van Maanen 1998}

E.F.D. Engelhard, G.E. Van Maanen, Aansprakelijkheid voor verkeersongevallen: een rechtsvergelijkend perspectief op het Nederlandse verkeersongevallenrecht, Ars Aequi 1998.

\section{Engelhard 2007a}

E.F.D. Engelhard, Kroniek schadevergoedingsrecht, Aansprakelijkheid Verzekering \& Schade, februari 2007, p. 14-23.

\section{Engelhard 2007b}

E.F.D. Engelhard, Shifts of Work-Related Injury Compensation. Background Analysis: The Concurrence of Compensation Schemes, in: S. Klosse, T. Hartlief (eds), Shifts in Compensating Work-Related Injuries and Diseases,

Springer Wien New York.

\section{Erren et al. 1999}

T. Erren, M. Jacobsen, C. Piekarski, Synergy between asbestos and smoking on lung cancer risks, Epidemiology, 1999, 10(4), p. 405-411.

\section{Faure \& Hartlief 1996}

M.G. Faure, T. Hartlief, Een asbestfonds als alternatief voor de aansprakelijkheid van de werkgever?, Nederlands Tijdschrift voor Sociaal Recht, februari 1996, p. 37-43.

\section{Faure 1993a}

M. Faure, (G)een schijn van kans, Oratie UM, Antwerpen, 1993.

\section{Faure 1993b}

M. Faure, Causal Uncertainty, Joint and Several Liability and Insurance, in: H. Koziol/J. Spier (eds.), Tort and Insurance Law, 1993/Vol. 10, Springer Wien New York.

\section{Faure \& Hartlief 1998}

M.G. Faure, T. Hartlief, 'Een schadefonds als alternatief voor aansprakelijkheid en verzekering?', Rechtsgeleerd Magazine Themis, 1998, p. 211-228.

\section{Faure \& Hartlief 2001}

M.G. Faure, T. Hartlief, Schade door arbeidsongevallen en nieuwe beroepsziekten, Den Haag: Boom Juridische Uitgevers.

\section{Faure 2003}

M.G. Faure, Proportionele aansprakelijkheid, in: A. Hammerstein, A.J. Akkermans, M.G. Faure, W.H. van Boom, Causaliteit, Den Haag: Sdu Uitgevers BV. 
Bibliography

Faure et al. 2006

M. Faure, T. Hartlief, N. Philipsen, Funding of personal injury litigation and claims culture; Evidence from the Netherlands, Utrecht Law Review, 2006/2.

\section{Fleming 1985}

J.G. Fleming, An introduction to the law of torts,

Oxford: Clarendon press.

\section{Fluit 2006}

B. Fluit, Werkgever proportioneel aansprakelijk: HR 31 maart 2006, RvdW 2006, 328, Praktisch procederen, 2006/5, p. 176-180.

\section{Fransen van de Putte 2005}

A.S. Fransen van de Putte, Asbest en de AVB-verzekering, Aansprakelijkheid Verzekering \& Schade, 2005/2, p. 67-72.

\section{Frenk 1995}

N. Frenk, Toerekening naar kansbepaling, Nederlands Juristenblad, 1995/13, p. 482-491.

\section{Frost et al. 2011}

G. Frost, A. Darnton, A.H Harding, The effect of smoking on the risk of lung cancer mortality for asbestos workers in Great Britain (1971-2005), The Annals of Occupational Hygiene, Januuary 2011, p. 1-9.

\section{Garcia Maynez 1949}

E. Garcia Maynes, Justice and Legal Security, Philosophy and Phenomenological Research, Vol. 9/nr. 3, p. 496-503.

International Phenomenological Society

\section{Gatowski et al. 2001}

S.I. Gatowski, S.A. Dobbin, J.T. Richardson, G.P. Ginsburg, M.L. Merlino, V. Dahir, Asking the Gatekeepers: A National Survey of Judges on Judging Expert Evidence in a Post- Daubert World, Law and Human Behavior, 2001/25(5), p. 433-458.

\section{Gezondheidsraad 1990}

Gezondheidsraad, Passief roken, Den Haag: publicatienummer 1990/18.

\section{Gezondheidsraad 1998}

Gezondheidsraad, Protocollen asbestziekten: maligne mesothelioom, Rijswijk: publicatienummer 1998/10.

\section{Gezondheidsraad 1999}

Gezondheidsraad, Protocollen asbestziekten: asbestose. Den Haag: publicatienummer 1999/04. 


\section{Gezondheidsraad 2003}

Gezondheidsraad, Volksgezondheidsschade door passief roken, Den Haag: publicatienummer 2003/21.

\section{Gezondheidsraad 2005}

Gezondheidsraad, Protocollen asbestziekten: longkanker. Den Haag: publicatienummer $2005 / 09$.

\section{Giard 2007}

R.W.M. Giard, Het vaststellen van personenschade: dokteren aan het deskundigenonderzoek, Nederlands Tijdschrift voor Burgerlijk Recht, 2007/10, p. 442-449.

\section{Giard \& Stolker 2003}

R.W.M. Giard, C.J.J.M. Stolker, Medische aansprakelijkheid: de rol van de dokter als deskundige, Nederlands Juristenblad, 2003/12, p. 610-616.

Gibbs et al. 2007

A. Gibbs, R.L. Attanoos, A. Churg, H. Weil, The "Helsinki Criteria" for Attribution of Lung Cancer to Asbestos Exposure: How Robust are the Criteria?, Archives of Pathology \& Laboratory Medicine, 2007, 131/2, p. 181-183.

\section{Giesen 1997}

I. Giesen, 'Res ipsa loquitur, een bijzonder vermoeden in het aansprakelijkheidsrecht', Weekblad voor Privaatrecht, Notariaat en Registratie, 1997, p. 241-246.

\section{Giesen 2001}

I. Giesen, Bewijs en aansprakelijkheid: Een rechtsvergelijkend onderzoek naar de bewijslast, de bewijsvoeringslast, het bewijsrisico en de bewijsrisico-omkering in het aansprakelijkheidsrecht, Den Haag: Schoordijk Instituut, Boom Juridische uitgevers.

\section{Giesen 2006}

I. Giesen, Proportioneel vermogensrecht: deining aan de Haagse kust, Weekblad voor Privaatrecht, Notariaat en Registratie, 2006/6680, p. 645-646.

\section{Giesen \& Tjong Tjin Tai 2008}

I. Giesen, T.F.E. Tjong Tjin Tai, Proportionele tendensen in het verbintenissenrecht, Deventer: Kluwer.

\section{Giesen 2011}

I. Giesen, (Dis)Proportionele duidelijkheid, Nederlands Tijdschrift voor Burgerlijk Recht, $2011 / 4$, p. 149-150. 
Bibliography

\section{Giliker \& Beckwith 2000}

P. Giliker, S. Beckwith, Tort,

London: Sweet \& Maxwell.

\section{Greenland 1999}

S. Greenland, Relation of Probability of Causation to Relative Risk and Doubling Dose: A Methodologic Error That Has Become a Social Problem, American Journal of Public Health, 1999, Vol. 89/8, p. 1166-1169.

\section{Haritz 2010}

M.M. Haritz, An inconvenient deliberation: the precautionary principle's contribution to the uncertainties surrounding climate change liability,

Oisterwijk: Box Press Publishers.

\section{Harpwood 2000}

V. Harpwood, Principles of tort law,

London: Cavendish Publishing Limited, fourth edition.

\section{Hart \& Aberle 1996}

E.M. Hart, D.R. Aberle, Radiologic Methods, in; P. Harber, M.B. Schenker, J.R. Balmes; Occupational and Environmental Respiratory Disease,

Mosby.

\section{Hartkamp 2006}

A.S. Hartkamp, Law of obligations, in: J.M.J. Chorus, P.H.M. Gerver, E.H. Hondius, Introduction to Dutch law,

Kluwer Law International, fourth edition.

\section{Hartlief 1997}

T. Hartlief, Ieder draagt zijn eigen schade, Deventer: Kluwer.

\section{Hartlief 1999}

T. Hartlief, Een tweetal arresten over de werkgeversaansprakelijkheid voor beroepsziekten, Nederlands Tijdschrift voor Sociaal Recht, 1999/6, p. 163-168.

\section{Hartlief 2000}

T. Hartlief, Proportionele aansprakelijkheid: een introductie, in; A.J. Akkermans, M. Faure, T. Hartlief, Proportionele aansprakelijkheid,

Den Haag: Boom Juridische Uitgevers. 


\section{Hartlief 2003a}

T. Hartlief, Schadevergoedingsrecht, in: J. Spier, T. Hartlief, G.E. van Maanen, R.D. Vriesendorp, Verbintenissen uit de wet en schadevergoeding,

Deventer: Kluwer, derde druk.

\section{Hartlief 2003b}

T. Hartlief, Affectieschade: vergoeden of erkennen? De rol van het vermogensrecht bij het verwerken van het leed van naasten, Nederlands Tijdschrift voor Burgerlijk Recht, 2003/2, p. 72-82.

\section{Hartlief 2003c}

T. Hartlief, Vergoeding van arbeidsgerelateerde schade op andere leest geschoeid, Aansprakelijkheid in beroep, bedrijf of ambt, 2003, p. 151-172.

\section{Hartlief 2005}

T. Hartlief, Asbest en aansprakelijkheid: de reikwijdte van de rechtspraak omtrent werkgeversaansprakelijkheid, Aansprakelijkheid Verzekering \& Schade, april 2005, p. 41-48.

\section{Hartlief 2006}

T. Hartlief, Stilstand en vooruitgang in het aansprakelijkheidsrecht, Nederlands Juristenblad, 2006/37, p. 2107.

\section{Hartlief et al. 2009}

T. Hartlief, J. Hijma, H.J. Snijders, Advies over doorbreking van de verjaringstermijn en stelplicht en bewijslast voor aansprakelijkheid voor het Instituut Asbestslachtoffers, Instituut Asbestslachtoffers, 15 juni 2009.

\section{Hartman \& Dekker 2007}

M. Hartman, B.P. Dekker, Help! De dokter verzuipt: Medische aspecten van de vaststelling van letselschade, Nederlands Tijdschrift voor Burgerlijk Recht, 2007/10, p. 450-453.

\section{Hartman \& Dekker 2008}

M. Hartman, B.P. Dekker, De rolverdeling tussen rechter en medische deskundige; Reactie op kroniek medische aansprakelijkheid, Aansprakelijkheid Verzekering \& Schade, april 2008, p. 91-92.

\section{Hayes et al. 1997}

D.H. Hayes, B. Corrin, P.N. Stidolph, K. Browne, Malignant mesothelioma in south east England: clinicopathological experience of 272 cases, Thorax, 1997/52, p. 507-512.

\section{Henderson et al. 2004}

D.W. Henderson, K. Rodelsperger, H.J. Woitowitz, J. Leigh, After Helsinki: a multidisciplinairy review of the relationship between asbestos exposure and lung cancer, with emphasis on studies published during 1997-2004, Pathology, 2004/36(6), p. 517-550. 
Bibliography

\section{Hendrix \& Akkermans 2007}

L.G.J. Hendrix, A.J. Akkermans, Causaliteitsonzekerheid bij informed consent. Beschouwingen naar aanleiding van Chester v. Afshar, Tijdschrift voor Gezondheidsrecht, 2007/07, p. 498515.

\section{Hepple et al. 2000}

B.A. Hepple, D.R. Howarth, M.H. Matthews, Tort; Cases and Materials, Butterworths, fifth edition.

\section{Hessel et al. 2005}

P.A. Hessel, J.F. Gamble, J.C. McDonald, Asbestos, asbestosis, and lung cancer: a critical assessment of the epidemiological evidence, Thorax, 2005/60, p. 433-436.

\section{Heuts 2006}

L. Heuts, 'Lucia de B. is onschuldig', Filosofie Magazine, 2006/1, p. 1-3.

\section{Hill 1965}

A.B. Hill, The Environment and Disease: Association or Causation?, Proceedings of the Royal Society of Medicine, 1965/58, p. 295-300.

\section{Hillerdal \& Henderson 1997}

G. Hillerdal, D.W. Henderson, Asbestos, asbestosis, pleural plaques and lung cancer, Scandinavian Journal Work Environment Health 1997/23, p. 93-103.

\section{Hoogsteden 1997}

H.C. Hoogsteden, Asbestgerelateerde aandoeningen van de long en pleura, in: J. De Ruiter, Asbestslachtoffers, Advies in opdracht van het Ministerie van Sociale Zaken en Werkgelegenheid.

Den Haag.

\section{Hoop 2007}

R.I.R. Hoop, Shifts in Work-Related Injuries: An Explanatory Analysis, in: S. Klosse, T. Hartlief (eds), Shifts in Compensating Work-Related Injuries and Diseases, Springer Wien New York.

\section{Hughes \& Arber 2008}

N. Hughes, A. Arber, The lived experience of patients with pleural mesothelioma, International Journal of Palliative Nursing, 2008/2, p. 66-71.

\section{Hyslop 2008}

E. Hyslop, Causal Theories in Chester v. Afshar (2004) UKHL 41, European Review of Private Law, 2008/4, p. 629-644. 


\section{Jansen 1999}

N. Jansen, The idea of a lost chance, Oxford Journal of Legal Studies, 19(2), p. 271-296.

\section{Jones 2006}

M.A. Jones, Proving causation- beyond the "but for" test, Professional Negligence, 2006/4, p. 251-269.

\section{Jongbloed 1995}

A.W. Jongbloed, M.L. Simons, Waarheden, halve waarheden en onwaarheden: statistiek en bewijsrecht, Nederlands Juristenblad, 1995/24, p. 891-897.

\section{Kadner Graziano 2008}

T. Kadner Graziano, Loss of a Chance in European Private Law; 'All or nothing' or Partial Liability in cases of Uncertain Causation, European Review of Private Law, 2008/6, p. 1009. 1042 .

\section{Keirse 2006}

A.L.M. Keirse, Proportionele aansprakelijkheid bij blootstelling aan asbestvezels en tabaksrook, Tijdschrift voor Vergoeding Personenschade, 2006/3, p. 66-75.

\section{Keirse 2010}

A.L.M. Keirse, De meerokende of uitgerookte werknemer en zijn kansen in het aansprakelijkheidsrecht, Nederlands Tijdschrift voor Burgerlijk Recht, 2010/9, p. 352-360.

\section{Kerkmeester 1994}

H.O. Kerkmeester, Boekbespreking: Geen (Een) schijn van kans: beschouwingen over het statistisch causaliteitsbewijs bij milieugezondheidsschade van Faure, Tijdschrift voor Milieuschade en Aansprakelijkheid, 1994, p. 48-48.

\section{Kermeester 1998}

H.O. Kerkmeester, De terugkeer van het bemiddelend vonnis: de doctrine van het kansverlies bij medische aansprakelijkheid, Nederlands Juristenblad, 1998/10, p. 435-441.

\section{Khoury 2006}

L. Khoury, Uncertain causation in medical liability, Oxford and Portland Oregon.

\section{Klaassen 2007}

C.J.M. Klaassen, Proportionele aansprakelijkheid: een goede of kwade kans?, Nederlands Juristenblad, 2007/22, p. 1346-1362.

\section{Klaassen \& Kortmann 2012}

C.J.M. Klaassen, J.S. Kortmann, Causaliteitsperikelen, Deventer: Kluwer. 
Bibliography

\section{Kooten 2002}

H.J. van Kooten, Alternatieve causaliteit, werkgeversaansprakelijkheid en Europees privaatrecht in het House of Lords: Fairchild v. Glenhaven Funeral Services Ltd, Weekblad voor Privaatrecht, Notariaat en Registratie, december 2002/6513, p. 823-824.

\section{Kortmann 2006}

J.S. Kortmann, Karamus/Nefalit: Proportionele aansprakelijkheid?, Nederlands Juristenblad, 2006/26, p. 1404-1412.

\section{Kramer 2006}

A. Kramer, Case Comment; Smoothing the rough justice of the Fairchild principle, Law Quarterly Review, 2006/122, p. 547-553.

\section{Kroes 1993}

B.W. Kroes, Criteria voor causaliteit, Versus Tijdschrift voor Fysiotherapie, 1993, 11/6, p. 345-351.

\section{Kroes 2007}

L.M. Kroes, Bewijslastverdeling en informed consent, Praktisch Procederen, 2007/6, p. $160-167$.

\section{Kruse \& Geiger 2008}

C. Kruse, S. Geiger, House of Lords 3 May 2006, Barker v. Corus Neue Impulse für das Europäische Deliktsrecht vom House of Lords, European Review of Private Law, 2008/2, p. 339-351.

\section{Lee 2001}

P.N. Lee, Relation between exposure to asbestos and smoking jointly and the risk of lung cancer, Journal of Occupational and Environmental Medicine, 2001/58, p. 145-153.

\section{Lemen et al. 1980}

R.A. Lemen, J. M. Dement, J.K. Wagoner, Epidemiology of Asbestos-Related Diseases, Environmental Health Perspectives, 1980/34, p. 1-11.

\section{Liddell 2001}

F.D.K. Liddell, The interaction of asbestos and smoking in lung cancer, The Annals of Occupational Hygiene, 2001/45, p. 341-356.

\section{Liddell \& Armstrong 2002}

F.D.K. Liddell, B.G. Armstrong, The Combination of Effects on Lung Cancer of Cigarette Smoking and Exposure in Guebec Chrysotile Miners and Millers, The Annals of Occupational Hygiene, 2002, Vol. 46/1, p. 5-13. 


\section{Light \& Gary Lee 2003}

R.W. Light, Y.C. Gary Lee, Textbook of Pleural Diseases, Arnold.

\section{Lilienfield \& Stolley 1994}

D.E. Lilienfield, P.D. Stolley, Foundations of Epidemiology,

New York.

\section{Lindenbergh 2000}

S.D. Lindenbergh, Arbeidsongevallen en beroepsziekten,

Deventer: W.E.J. Tjeenk Willink.

\section{Lindenbergh 2005}

S.D. Lindenbergh, Asbest, Aansprakelijkheid en Verzekering, Aansprakelijkheid Verzekering \& Schade, april 2005, p. 39.

\section{Lindenbergh 2006}

S.D. Lindenbergh, Longkanker door asbest en/of roken: proportionele aansprakelijkheid bij onzeker causaal verband, Ars Aequi, 55, 2006/10, p. 736-741.

\section{Lindenbergh 2007}

S.D. Lindenbergh, Inleiding: Vaststelling van schade en de rol van de deskundige daarbij, Nederlands Tijdschrift voor Burgerlijk Recht, 2007/10, p. 428-434.

\section{Maclntyre 2008}

E. Maclntyre, Business Law,

Pearson Education Limited, fourth edition.

\section{Martín-Casals 2008}

M. Martín-Casals, Some Introductory and Comparative Remarks to the Decision of the Swiss Federal Court BGE/ATF 133 III 462 and to the 'Loss of Chance' Doctrine, European Review of Private Law, 2008/6, p. 1043-1050.

\section{Martin-Casals 2009}

M. Martín-Casals, Introduction to the Annotations to Johnston v. NEI International Cumbustion Ltd, European Review of Private Law, 2009/2, p. 177-187.

\section{McGregor 2008}

H. McGregor, Loss of chance: where has it come from and where is it going?, Professional negligence, $2008 / 1$ (24), p. 2-12.

\section{McBride \& Bagshaw 2008}

N.J. McBride, R. Bagshaw, Tort law,

Pearson Education Limited, third edition. 
Bibliography

\section{Meijer \& Lindenbergh 2008}

J.W.M.K. Meijer, S.D. Lindenbergh, Asbestschade buiten de werkomgeving, Nederlands Juristenblad, 2008/8, p. 436-443.

\section{Merrill 2010}

R.M. Merrill, Introduction to Epidemiology, Jones and Bartlett Publishers.

\section{Miller 2002}

C. Miller, Judicial approaches to contested causation: Fairchild v. Glenhaven Funeral Services in context, Law, Probability \& Risk, 2002/1 (2), p. 119-139.

\section{Mohren et al. 2007}

D. Mohren, N. Jansen, L. van Amersfoort, I. Kant, An Epidemiological Approach of Fatigue and Work,

Amersfoort: Wilco.

\section{Montanaro et al. 2003}

F. Montanaro, F. Bray, V. Gennaro, E. Merler, J.E. Tyczynski, D.M. Parkin, Pleural mesothelioma incidence in Europe: evidence of some deceleration in the increasing trends, Cancer Causes Control, 2003/14 (8), p. 791-803.

\section{Mossman \& Gee 1989}

B.T. Mossman, J.B.L. Gee, Asbestos-related diseases, New England Journal of Medicine 1989/320, p. 1721-1730.

\section{Mullis \& Nolan 2003}

A. Mullis, D. Nolan, Tort, in; The all England law reports annual review 2002,

Reed Elsevier (UK).

\section{Mullis \& Nolan 2007}

A. Mullis, D. Nolan, Tort, in; The all England law reports annual review 2006, Reed Elsevier (UK).

\section{Muscat \& Wynder 1991}

J.E. Muscat, E.L. Wynder, Cigarette smoking, asbestos exposure and malignant mesothelioma, Cancer Research, 1991/51, p. 2263-2267.

\section{Nelson \& Kelsey 2002}

H.H. Nelson, K.T. Kelsey, The molecular epidemiology of asbestos and tobacco in lung cancer, Oncogene, 2002/21, p. 7284-7288. 


\section{Nieuwenhuis 2006}

J.H. Nieuwenhuis, Disproportionele aansprakelijkheid, Rechtsgeleerd Magazijn Themis, 2006/5, p. 177-178.

\section{Oliphant 2008}

K. Oliphant, English case note; Loss of chance in English law, European Review of Private Law, 2008/6, p. 1061-1071.

\section{Padmos 2000}

J.H. Padmos, De Regeling tegemoetkoming asbestslachtoffers, Documenta, 2000/3, p. 376-379.

\section{Paz Garcia Rubio 2004}

Maria Paz Garcia Rubio, Informed Consent and the requirement of causation, Chester v. Afshar, 14 October 2004 (Spanish case note), European Review of Private Law, 2007/3 (15), p. 443-449.

\section{Peeperkorn 2000}

D. Peeperkorn, Het feest van de gedaagden, kritiek op de proportionele leer, in; A.J. Akkermans, M. Faure, T. Hartlief, Proportionele aansprakelijkheid,

Den Haag: Boom Juridische Uitgevers.

\section{Peeters 2007}

M.G.P. Peeters, Compensatie en erkenning voor werken met asbestziekten, Wolf.

\section{Philipsen 2007}

N.J. Philipsen, Industrial Accidents and Occupational Diseases: Some Empirical Findings for The Netherlands, Belgium, Germany, and Great-Britain, in: S. Klosse, T. Hartlief (eds), Shifts in Compensating Work-Related Injuries and Diseases, Springer Wien New York.

\section{Planteydt 1991}

H.T. Planteydt, Asbestos Exposure and Health, Tijdschrift voor Milieuschade en Aansprakelijkheid, 1991, p. 56-59.

\section{Porta 2008}

M. Porta, A dictionary of epidemiology,

Oxford University Press, fifth edition.

\section{Prosser 1950}

W.L. Prosser, Proximate cause in California, California Law Review, August 1950, p. 369-425. 
Bibliography

\section{Reid et al. 2006}

A. Reid, N.H. de Klerk, G.L. Ambrosini, The risk of lung cancer with increasing time since ceasing exposure to asbestos and quitting smoking, Journal of Occupational and Environmental Medicine, 2006/63, p. 509-512.

\section{Roest 2008}

C.J. Roest, De bewijslastverdeling in RSI-zaken,

Tilburg: Celsus Juridische Uitgeverij.

\section{Rogers 2000}

H. Rogers, Causal uncertainty in English law, in: A.J. Akkermans, M. Faure, T. Hartlief, Proportionele aansprakelijkheid,

Den Haag: Boom Juridische Uitgevers.

\section{Roijackers 2009}

C.A.M. Roijackers, De verleiding van de metafoor; een beschouwing over causaliteit en proportionaliteit, Letsel \& Schade 2009/3, p. 6-28.

\section{Roijckers 2011}

C.A.M. Roijackers, Redactioneel: Twee arresten over causaliteitsonzekerheid, Letsel \& Schade $2011 / 2$, p. 3-4.

\section{Rothman 2002}

K.J. Rothman, Epidemiology: An Introduction, Oxford University Press

\section{Rothman \& Greenland 2005}

K.J. Rothman, S. Greenland, Basic Concepts, in; W. Ahrens, I. Pigeot, Handbook of Epidemiology,

Berlin: Springer.

Rothman et al. 2008

K.J. Rothman, S. Greenland, T.L. Lash, Modern Epidemiology,

Wolters Kluwer, third edition.

\section{Ruers 1997}

R.F. Ruers, Asbest en deregulering, Nederlands Juristenblad, 1997/26, p. 1174.

\section{Ruers 2012}

R.F. Ruers, Macht en tegenmacht in de Nederlandse asbestregulering, Den Haag: Boom Juridische Uitgevers. 


\section{Schothorst-Gransier 2006}

E.J.P. Schothorst-Gransier, Proportionele aansprakelijkheid bij asbestgerelateerde longkanker, Bedrijfsjuridische Berichten, 2006/27, p. 97-98.

\section{Schuurman 2010}

A.H. Schuurman, Medische Expertise, Ars Aequi, juli/augustus 2010, p. 518-521.

\section{Selikoff et al. 1968}

I.J. Selikoff, E. Cuyler Hammond, J. Churg, Asbestos Exposure, Smoking, and Neoplasia, Journal of the American Medical Association, 1986, 204/2, p. 106-112.

\section{SER 2005}

Advisory Report: Evaluation of the Working Conditions Act 1998, The Hague, 17 June 2005.

\section{Sinninge Damsté et al. 2007}

H.E.J. Sinninghe Damsté, S. Siesling, A. Burdorf, Milieublootstelling aan asbest in de regio Goor vastgesteld als oorzaak van maligne pleuramesothelioom bij vrouwen, Nederlands Tijdschrift Geneeskunde, 2007/151 (44), p. 2453-2459.

\section{Slot 2005}

P. Slot, Risk calculation recommended for compensation in case of lung cancer after working with asbestos, Network \# 3 (Health in the workplace), 2005/20, p. 39.

\section{Smeehuijzen 2003}

J.L. Smeehuijzen, Wie is de deskundige eigenlijk? Pleidooi voor een 'disclosure statement', Tijdschrift voor Vergoeding Personenschade, 2003/4, p. 126-129.

\section{Smulders et al. 2010}

Y.M. Smulders, C.D.A. Stehouwer, M.H.H. Kramer, A. Thijs, De rol van epidemiologisch bewijs in de zorg voor individuele patiënten, Nederlands Tijdschrift voor Geneeskunde, 2010/154: A1910, p. 1-5.

\section{Sobczak et al. 2009}

F. Sobczak, D.M.R. Townend, G.E. van Maanen, Dutch case note: Liability for pleural plaques in the Netherlands, European Review of Private Law, 2009/2, p. 207-217.

\section{Sobczak 2010a}

F. Sobczak, Proportionele aansprakelijkheid; de $C R_{v} B$ laat zich leiden door de Hoge Raad en vice versa?, Nederlands Tijdschrift voor Burgerlijk Recht, 2010/10, p. 407-412.

\section{Sobczak 2010b}

F. Sobczak, Proportionality in Tort Law; A Comparison between Dutch and English Laws with Regard to the Problem of Multiple Causation in Asbestos-Related Cases, European Review of Private Law, 2010/6, p. 1155-1179. 
Bibliography

\section{Sobczak 2011}

F. Sobczak, Proportionele aansprakelijkheid voor mesothelioom? Een beschouwing aan de hand van het Engelse recht, Letsel \& Schade, 2011/2, p. 32-41.

\section{Souhami \& Moxham 2002}

R.L. Souhami, J. Moxham, Textbook of Medicine, Churchill Livingstone.

\section{Spier 1990}

J. Spier, Sluipende schade,

Deventer: Kluwer.

\section{Spier 1997}

J. Spier, Asbestslachtoffers, Aansprakelijkheid \& Verzekering, 1997/3, p. 60-62.

\section{Spier 1998a}

J. Spier, 'De Des-dochters, noot bij HR 9 oktober 1992, RvdW 1992, 219', Nederlands Tijdschrift voor Burgerlijk Recht, 1992, p. 193-198.

\section{Spier $1998 b$}

J. Spier, Schade en loss occurrence-verzekeringen,

Deventer: Kluwer.

\section{Spier \& Haazen 2000}

J. Spier, O. Haazen, Comparative Conclusions on Causation, in: J. Spier (ed.), Unification of Tort Law: Causation, Principles of European Tort Law,

Kluwer Law International.

\section{Spier et al. 2003}

J. Spier, T. Hartlief, G.E. van Maanen, R.D. Vriesendorp, Verbintenissen uit de wet en schadevergoeding,

Deventer: Kluwer, derde druk.

\section{Stauch 1997}

M. Stauch, Causation, Risk and Loss of Chance in Medical Negligence, Oxford Journal of Legal Studies, 1997, 17/2, p. 205-225.

\section{Steele \& Wikeley 1997}

J.Steele, N. Wikeley, Dust on the Streets and Liability for Environmental Cancers, The Modern Law Review 1997, 60/2, p. 265-276. 


\section{Stolker \& Levine 1999}

C.J.J.M. Stolker, S. Levine, Compensation for the Fear of Contracting Asbestos-related Diseases - Critical Reflections on an Important Supreme Court Decision and its relevance for Europe, European Journal of Private Law, 1999/1, p.1-19.

\section{Swagemakers \& Taminau 2007}

C.A.M. Swagemakers, H.W.P.B. Taminau, Themanummer: De zieke werknemer; procedurele obstakels voor de zieke werknemer, Arbeid Integraal, 2007, p. 1-18.

\section{Tamasauskas et al. 2004}

Tamasauskas (Danish), C. Hattenhauer (German), K.N. Christodoulou (Greek), A. Ruda (Spanish), Fairchild v. Glenhaven Funeral Services Ltd and others, Fox v. Spousal (Midlands) Ltd, Matthews v. Associated Portland Cement Manufacturers (1978) Ltd and others [2002] UKHL 22, European Review of Private Law, 2004/2 (12), p. 215-258.

\section{Tan 2007a}

R.L.M.M. Tan, Alternatieve causaliteit, een Engels perspectief, Ars Aequi, 56, 2007/12, p. 933-940.

\section{Tan 2007b}

R.L.M.M. Tan, Nul plus nul plus nul is nul? Grieves v Everard, De grenzen van aansprakelijkheid voor het House of Lords, Weekblad voor Privaatrecht, Notariaat en Registratie, december 2007/6733, p. 1003-1004.

\section{Tan 2008}

R.L.M.M. Tan, Over het mogelijke en het waarschijnlijke, salomonsoordelen in het aansprakelijkheidsrecht, Aansprakelijkheid Verzekering \& Schade, februari 2008, p. 23-27.

\section{Timmreck 1994}

T.C. Timmreck, An introduction to epidemiology,

London: Jones and Barlett Publishers.

\section{Tolman 2008}

M.J. Tolman, De uitleg van de dekking onder de polis, Aansprakelijkheid Verzekering \& Schade, april 2008, p. 64-72.

\section{Tossavainen 1997}

A. Tossavainen, Asbestos, abestosis, and cancer: the Helsinki criteria for diagnosis and attribiution, Scandanavian Journal of Work, Environment \& Health, 1997, 23(4), p. 311 316. 
Bibliography

\section{Townend 2006}

D.M.R. Townend, Handling the Instruments that Regulate Biotechnology, in: L. Landeweerd, L.M. Houdebine, R.H.J. ter Meulen, Bio Technology-Ethics; An introduction, Florence: Pontecorboli.

\section{Tzankova 2003}

I.N. Tzankova, Een 'academy of experts': nodig of overbodig?, Tijdschrift voor Vergoeding Personenschade, 2003/4, p. 122-125.

\section{Van \& Nijs 1996}

A.J. Van, H.G.T. Nijs, Asbest, tabaksrook en longkanker: Aansprakelijkheidsverdeling bij verschillende samenwerkende causale factoren, Tijdschrift voor Milieuschade en Aansprakelijkheidsrecht 1996/3, p. 45-48.

\section{Van 1995}

A.J. Van, Onzekerheid over daderschap en causaliteit. Drie visies op civielrechtelijke aansprakelijkheid, meerdaderschap en Multi-causaliteit, Arnhem: Gouda Quint.

\section{Van 2000}

A.J. Van, Bewijs van causaal verband met behulp van epidemiologische gegevens, in;

A.J. Akkermans, M. Faure, T. Hartlief, Proportionele aansprakelijkheid, Den Haag: Boom Juridische Uitgevers.

\section{Van 2003}

A.J. Van, Vraag het aan de deskundige! Maar hoe?, Tijdschrift voor Vergoeding Personenschade, 2003/4, p. 105-110.

\section{Van \& Wijne 2012}

A.J. Van, R.P. Wijne, 'Lies, damned lies, and statistics' De berekening van het verlies van een kans bij medische aansprakelijkheid, Tijdschrift voor Vergoeding Personenschade, 2012/1, p. 16-24.

\section{Vandenbroucke \& Hofman 1999}

J.P. Vandenbroucke, A. Hofman, Grondslagen der epidemiologie, Maarssen: Elsevier/Bunge.

\section{Van Boom 2000}

W.H. van Boom, Verjaring mesothelioomclaims doorbroken, Aansprakelijkheid \& Verzekering, 2000/3-4, p. 55-69.

\section{Van Boom 2005a}

W.H. van Boom, 'Een uiting van maatschappelijke betrokkenheid', Aansprakelijkheid Verzekering \& Schade, april 2005, p. 60-67. 


\section{Van Boom 2005b}

W.H. van Boom, (Onder)aannemer uit onrechtmatige daad aansprakelijk voor mesothelioom van werknemer opdrachtgever (hoofdaannemer), Jurisprudentie Aansprakelijkheidsrecht, 2005/2, p. $139-141$.

\section{Van Boom \& Borgers 2004}

W.H. van Boom, M.J. Borgers, G. van der Laan, De rekenende rechter,

Den Haag: Boom Juridische Uitgevers.

\section{Van Dam 2006}

C.C van Dam, European Tort Law,

Oxford: University Press, first edition.

\section{Van Dijk 1999}

Chr.H van Dijk, Proportionele aansprakelijkheid bij medische fouten vindt navolging, Aansprakelijkheid \& Verzekering, 1999/2, p. 37-41.

\section{Van Dijk 2000}

Chr.H van Dijk; Onzeker causaal verband in de rechtspraak, in; A.J. Akkermans, M. Faure, T. Hartlief, Proportionele aansprakelijkheid,

Den Haag: Boom Juridische Uitgevers.

\section{Van Dijk \& Maclean 2002}

Chr. H. van Dijk, M.M. MacLean, Het ontstaan van schade in de loss-occurance-verzekering; een kwestie van uitleg (deel 2), Aansprakelijkheid Verzekering \& Schade, 2002/2, p. 33-40.

\section{Van Dijk 2006}

Chr.H van Dijk, De Hoge Raad stemt in met het leerstuk van proportionele aansprakelijkheid, Nederlands Tijdschrift voor Burgerlijk Recht, 2006/7, p. 294-306.

\section{Van Dijk 2007}

Chr.H van Dijk, Hoe te beoordelen of de deskundige deskundig is?, Nederlands Tijdschrift voor Burgerlijk Recht, 2007/10, p. 434-441.

\section{Van Dijk \& Osch 2008}

T.J.J. van Dijk, N.J. Osch, Convenant Instituut Asbestslachtoffers: tien jaar later, Verkeersrecht, 2008/12, p. 378-380.

\section{Van Dijk 2010}

Chr.H van Dijk, De proportionele benadering bij medische aansprakelijkheid, in; T. Hartlief, W.R. kastelein, E.N.F.M. de Kezel, R.J.P. Kottenhagen, M.J.J. de Ridder, J.L. Smeehuijzen, Medische aansprakelijkheid, Den Haag: Sdu Uitgevers bv. 
Bibliography

\section{Van Dunné 1994}

J.M. van Dunné, Asbest en aansprakelijkheid,

Arnhem: Gouda Quint BV.

\section{Van Gerven et al. 2000}

W. van Gerven, P. Larouche, J. Lever, Cases, Materials and Text on National, Supranational, and International tort law,

Oxford: Hart Publishing.

\section{Van Kampen \& MacLean 2006}

T. A. van Kampen, M.M. MacLean, Proportionaliteit: verdeling van aansprakelijkheid of van schade?, PIV Bulletin, 2006/4, p. 1-5.

\section{Van Maanen 1993}

G.E. van Maanen, 'De civielrechterlijke aansprakelijkheid voor kernongevallen naar Nederlands recht', in: Aansprakelijkheid voor nucleaire risico's,

Antwerpen: Maklu.

\section{Van Maanen 2000}

G.E. van Maanen, Proportionele schadevergoeding bij asbestclaims. De zaak Schaier/De Schelde, in: A.J. Akkermans, M. Faure, T. Hartlief, Proportionele aansprakelijkheid, Den Haag: Boom Juridische Uitgevers.

\section{Van Maanen 2006}

G.E. van Maanen, Civiele letselschadeclaims bij de Centrale Raad van Beroep. Beter af bij de Hoge Raad?, Tijdschrift voor Vergoeding Personenschade, 2006/3, p. 57-65.

\section{Van Maanen \& Valk 2008}

G.E. van Maanen, W.L. Valk, Proportionele tendensen in het verbintenissenrecht? Een rechtsgeleerde dialoog over het preadvies van Giesen en Tjong Tjin Tai voor de Vereniging van Burgerlijk Recht, Nederlands Tijdschrift voor Burgerlijk Recht, oktober 2008, p. 316-327.

\section{Van Tricht 2011}

O.P van Tricht, Wederom proportionele aansprakelijkheid en causaal verband, PIV bulletin, 2011/2, p. 6-9.

\section{Van Velthoven \& Van Wijck 2008}

B.C.J. van Velthoven, P.W. van Wijck, Proportionele aansprakelijkheid vanuit ex ante perspectief, Aansprakelijkheid Verzekering \& Schade, 2008/3, p. 130-140. 


\section{Van der Laan 2004}

G. van der Laan, Het vaststellen van beroepsziekten: Gebruik van epidemiologische gegevens voor de individuele gevalsbeoordeling, in: W.H. van Boom, M.J. Borgers, G. van der Laan, De rekenende rechter,

Den Haag: Boom Juridische Uitgevers.

\section{Van der Laan 2005}

G. van der Laan, Mesothelioom rond Goor en ver daarbuiten: het asbestdrama ontvouwt zich verder, Nederlands Tijdschrift voor Geneeskunde, 2005/151, p. 2422-2425.

\section{Van den Akker \& Hengeveld 1997}

E.J.A.M. van den Akker, W.J. Hengeveld, Werkgeversaansprakelijkheid voor blootstelling aan asbest, Aansprakelijkheid \& Verzekering, juni 1997/3, p. 55-59.

\section{Van der Meer 2007}

K. van der Meer, Een beroepsrisicoverzekering ter vervanging van werkgeversaansprakelijkheid opnieuw bekeken, Aansprakelijkheid Verzekering \& Schade, 2007/2, p. 63-67.

\section{Van Dort 2007}

R.M.J.T. van Dort, De rol van de deskundige bij het berekenen of begroten van letselschades!, Nederlands Tijdschrift voor Burgerlijk Recht, 2007/10, p. 453-456.

\section{Van Velthoven 2011}

B.C.J. van Velthoven, Schadekansen bij medische fouten: Proportionele aansprakelijkheid in de praktijk, Tijdschrift voor Gezondheidsrecht, 2011/35 (1), p. 18-37.

\section{Vegter 2004}

M.S.A. Vegter, Predispositie en eigen schuld bij RSI en andere multicausale ziekten, Tijdschrift voor Vergoeding Personenschade, 2004/3, p. 73-79.

\section{Vegter 2005}

M.S.A. Vegter, Vergoeding van psychisch letsel door de werkgever, Den Haag: SDU

\section{Verheij et al. 1999}

B. Verheij, J. Hage, G. van Maanen, De logica van de onrechtmatige daad, Nederlands Tijdschrift voor Burgerlijk Recht, 1999/4 (16), p. 95-102.

\section{Verheij 2007}

A.J. Verheij, Kroniek werkgeversaansprakelijkheid, Aansprakelijkheid Verzekering \& Schade, 2007/11, p. 68-74. 


\section{Verheij 2008}

A.J. Verheij, Kroniek van werkgeversaansprakelijkheid, Aansprakelijkheid Verzekering \& Schade, 2008/3, p. 153-162.

\section{Verheugt 2009}

J.W.P. Verheugt, Inleiding in het Nederlandse recht, Boom Juridische Uitgevers: $15^{\text {de }}$ druk.

\section{Verkerk 2007}

R.R. Verkerk, Procesrechtelijke waarborgen voor een betrouwbaar deskundigenonderzoek, Nederlands Tijdschrift voor Burgerlijk Recht, 2007/10, p. 491-500.

\section{Verkerk 2009}

R.R. Verkerk, Comparative aspects of expert evidence in civil litigation, The International Journal of Evidence \& Proof, 2009/13, p. 167-197.

\section{Verkerk 2010}

R.R. Verkerk, Fact-Finding in Civil Litigation. A Comparative Perspective, Intersentia.

\section{Visscher 2007}

L.T. Visscher, Schadevergoedingsrecht, in; W.C.T. Weterings (red.), De economische analyse van het recht,

Den Haag: Boom Juridische Uitgevers.

\section{Vloemans 2008}

N. Vloemans, Kroniek aansprakelijkheid voor niet- loondienstgerelateerde asbestschade, Aansprakelijkheid Verzekering \& Schade, februari 2008, p. 35-47.

\section{Wagner et al. 1960}

J.C. Wagner, C.A. Sleggs \& P. Marchand, Diffuse pleural mesothelioma and asbestos exposure in the North-Western Cape Province, British Journal of Industrial Medicine 1960/17, p. 260271.

\section{Wansink 1987}

J. H. Wansink, De algemene aansprakelijkheidsverzekering. Een hernieuwde verzekeringstechnische en verzekeringsrechtelijke beschouwing,

Zwolle: W.E.J. Tjeenk Willink.

\section{Waterman 2005}

Y.R.K. Waterman, Smoking and the workplace in the Netherlands. Rights and obligations of employers and employees, in: R. Blanpain (red.), Smoking and the Workplace, A Comparative review of Smoking in the Workplace, Bulletin of Comparative Labour Regulations, 2005/54, p. $141-168$. 


\section{Waterman 2006}

Y.R.K. Waterman, Asbestos and Smoking: Proportional liability of the Employer in the Netherlands. Turning a Blind Eye to Synergistic Causation, Pan- European Organisation of Personal Injury Lawyers (PEOPIL), Newsbulletin 20 November 2006, p. 9-15.

\section{Waterman 2009}

Y.R.K. Waterman, De aansprakelijkheid van de werkgever voor arbeidsongevallen en beroepsziekten,

Boom Juridische Uitgevers.

\section{Weir 2002}

T. Weir, Tort law,

Oxford: University press.

\section{Wiegersma 1998}

S. Wiegersma, Asbest, Nederlands Juristenblad, 28 augustus 1998/30.

\section{Witjens 2011}

E.M. Witjens, Strafrechtelijke causaliteit: de redelijke toerekening vergeleken met het privaatrecht,

Kluwer BV.

\section{Wraith \& Mengersen 2008}

D. Wraith, K. Mengersen, A Bayesian approach to assess interaction between known risk factors: the risk of lung cancer from exposure to asbestos and smoking, Statistical Methods in Medical Research, 2008/17, p. 171-189.

\section{Young et al. 2004}

R. Young, M. Faure, P. Fenn, Causality and causation in tort law, International Review of Law and Economics, 2004/24, p. 507-523.

\section{Zivkovic 2007}

D. Zivkovic, Proportionele aansprakelijkheid voor de blootstelling aan sigarettenrook op de werkplek, Tijdschrift voor Vergoeding Personenschade, 2007/2, p. 38-45. 



\section{Cases}

\section{The Netherlands}

- Rechtbank's-Gravenhage 4 april 2012, LJN: BW1118.

- Gerechtshof 's-Gravenhage 3 april 2012, LJN: BW0093.

- Gerechtshof Arnhem 20 december 2011, JA 2012, 100.

- Hoge Raad 9 december 2011, NJ 2011, 599.

- Hoge Raad 8 juli 2011, NJ 2011, 311.

- Gerechtshof 's-Hertogenbosch 22 maart 2011, LJN: BP8866.

- Gerechtshof Amsterdam 22 maart 2011, LJN: BP8854.

- Rechtbank Almelo 27 april 2011, LJN: BQ4019.

- Gerechtshof Leeuwarden 8 februari 2011, LJN: BQ0520.

- Hoge Raad 24 december 2010, NJ 2011, 251 (Fortis/Bourgonje).

- Rechtbank Utrecht 8 december 2010, LJN: BO6888.

- Rechtbank Amsterdam 14 juli 2010, LJN: BO3288.

- Rechtbank Amsterdam 4 juli 2010, JA 2011, 4.

- Rechtbank Almelo 13 oktober 2009, LJN: BK0098.

- Gerechtshof 's-Gravenhage 18 augustus 2009, LJN: BJ5651.

- Gerechtshof 's-Gravenhage 7 juli 2009, LJN: BJ3803 (X/Da Vinci College).

- Gerechtshof 's-Gravenhage 28 april 2009, LJN: BI4768.

- Rechtbank Rotterdam 24 april 2009, LJN: BI8604.

- Centrale Raad van Beroep 9 april 2009, LJN: BI2805.

- Rechtbank Haarlem 1 april 2009, LJN: BI1010.

- Gerechtshof Amsterdam 24 maart 2009 (rolnr. C07/01414).

- Gerechtshof Leeuwarden 13 januari 2009, LJN: BH2762.

- Hoge Raad 9 januari 2009, LJN: BG4014 (Riphagen/Isala).

- Hoge Raad 12 december 2008, NJ 2009, 332 (Maatzorg/Van der Graaf).

- Gerechtshof Amsterdam (nevenzittingsplaats Arnhem) 26 augustus 2008, nr. 104.003.877 (unpublished).

- Rechtbank Almelo 9 juli 2008, LJN: BF1904.

- Rechtbank Almelo 4 juni 2008, LJN: BD3218.

- Hoge Raad 16 mei 2008, LJN: BC7683.

- Gerechtshof 's-Hertogenbosch 6 mei 2008, LJN: BD5666.

- Gerechtshof 's-Hertogenbosch 25 maart 2008, JA 2008, 96.

- Rechtbank Utrecht 20 februari 2008, JA 2008, 61.

- Hoge Raad 7 december 2007, NJ 2007, 644.

- Hoge Raad 19 oktober 2007, LJN: BB5172.

- Rechtbank Almelo 2 oktober 2007, LJN: BB4632 (Freriksen-Klokman/Eternit).

- Gerechtshof 's-Gravenhage 7 september 2007, LJN: BB5063.

- Centrale Raad van Beroep 21 juni 2007, LJN: BA8436. 
- Gerechtshof Arnhem 5 juni 2007, LJN: BA6364.

- Rechtbank Zwolle-Lelystad 30 mei 2007, zaaknr. 249185.

- Rechtbank Groningen 15 mei 2007, LJN: BA5126.

- Hoge Raad 27 april 2007, NJ 2008, 462 (Kalai/Petit).

- Rechtbank Maastricht 16 april 2007, LJN: BA3241.

- Gerechtshof Arnhem 27 februari 2007, LJN: AZ9763 (Jansman/Eternit).

- Hoge Raad 16 februari 2007, RvdW 2007, 203 (Gebroeders Tuin Beheer/ mr. X).

- Hoge Raad 19 januari 2007, NJ 2007, 63 (Kranendonk Holding/A. Advocaten).

- Gerechtshof Arnhem 26 september 2006, JAR 2006/30, LJN: AZ0584.

- Rechtbank Maastricht 23 augustus 2006, NJ 2007, 225.

- Rechtbank Rotterdam 1 augustus 2006, LJN: AY5429 (Okker/Eternit).

- Hoge Raad 23 juni 2006, NJ 2006, 354 (Havermans/Luyckx).

- Rechtbank Almelo 28 april 2006, nr. 77519/ KG ZA 06-76 (unpublished).

- Rechtbank Almelo 19 april 2006, JA 2006, 91.

- Hoge Raad 31 maart 2006, NJ 2011, 250 (Nefalit/Karamus).

- Hoge Raad 31 maart 2006, LJN: AU6093 (Hollink/Eternit).

- Hoge Raad 17 februari 2006, NJ 2007, 285 (Van Buuren/Heesbeen).

- Gerechtshof Arnhem 17 januari 2006, JA 2006, 37.

- Hoge Raad 25 november 2005, LJN: AT8782 (Nieborg-Horsting/Eternit).

- Rechtbank Maastricht 13 juli 2005, JA 2006, 44.

- Centrale Raad van Beroep 12 mei 2005, JB 2005/200 (Scheepmaker/Den Helder).

- Hoge Raad 18 maart 2005, NJ 2006, 606 (Baby Kelly).

- Hoge Raad 11 maart 2005, NJ 2010, 309 (ABN AMRO/Nieuwenhuys).

- Rechtbank Amsterdam 22 december 2004, VR 2005, 104.

- Hoge Raad 17 december 2004, NJ 2006, 147 (Hertel/Van der Lugt).

- Centrale Raad van Beroep 4 november 2004, LJN: AR5654.

- Gerechtshof 's-Gravenhage 1 oktober 2004, VR 2005, 109 (Rietveld/Wilton

Fijenoord)

- Gerechtshof Arnhem 6 juli 2004, JAR 2004/186.

- Hoge Raad 4 juni 2004, JAR 2004, 287 (Broug/Gemex).

- Gerechtshof Arnhem 13 april 2004, LJN: AO8064.

- Hoge Raad 9 april 2004, NJ 2004, 308 (D./Achmea).

- Gerechtshof Amsterdam 18 maart 2004, JAR 2004/96 (Winkelaar/Hertel).

- Hoge Raad 5 december 2003, NJ 2004, 74.

- Rechtbank Almelo 29 oktober 2003, NJ 2004, 32.

- Kantongerecht Middelburg 1 september 2003, NJ 2003, 736 (Thier/Groeneveld).

- Rechtbank Amsterdam 28 mei 2003, NJ 2004, 45.

- Rechtbank Almelo 22 mei 2003, LJN: AF 9060.

- Hoge Raad 18 april 2003, RvdW 2003, 81 (Verzekeraars/Fino).

- Hoge Raad 29 november 2002, NJ 2004, 304/305.

- Gerechtshof 's-Gravenhage 10 oktober 2002, NJ 2003, 99.

- Kantongerecht Amsterdam 20 juni 2002, JAR 2004/18 (Ten Pierik/Hertel).

- Hoge Raad 23 november 2001, NJ 2002, 386 (Ingenhut/Stichting Gezondheidszorg Oostelijk Zuid- Limburg). 
- Hoge Raad 23 november 2001, NJ 2002, 387 (Niazmandian/Plasmans).

- Rechtbank Middelburg 30 mei 2001, JAR 2001/232.

- Hoge Raad 26 januari 2001, NJ 2001, 597 (Weststrate/De Schelde).

- Hoge Raad 17 november 2000, NJ 2001, 596 (Unilever/Dikmans).

- Rechtbank Zwolle 31 mei 2000, NJkort: 2000, 89.

- Rechtbank Breda, 25 april 2000, KG 2000, 119.

- Kantongerecht Eindhoven 13 april 2000, JAR 2003/286.

- Gerechtshof Arnhem 24 juni 1997 en 14 december 1999, NJ 2000, 742.

- Hoge Raad 10 december 1999, RvdW 1999, 199 (Fransen/Stichting

Pasteurziekenhuizen).

- Kantongerecht Middelburg 1 december 1999, VR 1999, 117.

- Rechtbank Amsterdam 24 maart 1999, VR 2000, 25.

- Kantongerecht Middelburg 1 februari 1999, TMA 1996/6 (Schaier/De Schelde).

- Rechtbank Almelo 27 januari 1999, VR 2000, 24.

- Rechtbank Amsterdam 28 oktober 1998, NJ 1999, 406.

- Hoge Raad 2 oktober 1998, NJ 1999, 683 (Cijsouw/De Schelde 1).

- Rechtbank Middelburg 11 maart 1998, NJ 1999, 41.

- Hoge Raad 24 oktober 1997, NJ 1998, 257 (Baijings/mr. H).

- Hoge Raad 17 juni 1997, NJ 1997, 736.

- Gerechtshof Amsterdam 4 januari 1996, NJ 1997, 213 (Baby Ruth).

- Hoge Raad 13 Januari 1995, NJ 1997, 175 (De Heel/Korver).

- Rechtbank Amsterdam 9 november 1994, H91.1540.

- Hoge Raad 18 februari 1994, NJ 1994, 368 (Schepers/De Bruijn).

- Hoge Raad 25 juni 1993, NJ 1993, 686 (Cijsouw/De Schelde 1).

- Hoge Raad 9 oktober 1992, NJ 1994, 535 (DES-dochters).

- Hoge Raad 6 april 1990, NJ 1990, 573 (Janssen/Nefabas).

- Hoge Raad 4 november 1988, NJ 1989, 751.

- Hoge Raad 20 november 1987, NJ 1988, 500 (Timmer/Deutman).

- Hoge Raad 4 november 1988, NJ 1989, 751 (ABP/van Stuyvenberg).

- Hoge Raad 8 februari 1985, NJ 1986, 136 (Joe/Chicago Bridge).

- Hoge Raad 8 februari 1985, NJ 1986, 137 (Renteneurose).

- Hoge Raad 10 september 1982, NJ 1983, 687 (Binderen/Kaya).

- Hoge Raad 13 juni 1980, NJ 1980, 185.

- Hoge Raad 2 november 1979, NJ 1980, 77.

- Hoge Raad 21 maart 1975, NJ 1975, 372.

- Hoge Raad 9 juni 1972, NJ 1972, 360.

- Hoge Raad 20 maart 1970, NJ 1970, 251 (Waterwingebied-arrest).

- Hoge Raad 24 januari 1950, NJ 1950, 293.

- Rechtbank Utrecht 28 oktober 1942, NJ 1943, 231. 


\section{England}

- Knowsley Metropolitan Borough Council v Willmore, [2011] UKSC 10.

- Sienciewicz v Greif(UK) Limited, [2011] UKSC 10.

- Willmore v Knowsley MBC, [2009] EWCA Civ. 1211.

- Shortell v Bical Construction Ltd., [2008] QBD Liverpool (16-05-2008).

- Treble v Rio Tinto and Imperial Chemical Industries, [2008] Bristol Country Court.

- Richardson v Russel, [2008] EWHC 1708 (QB).

- Cox v Rolls Royce Industrial Power (India) Ltd, [2007] EWCA Civ 1198.

- Shanks v Swan Hunter Group Plc, [2007] EWHC 1807 (QB).

- Maggs v Anstey, [2007] EWHC 515 (QB).

- Johnston v NEI International Combustion Limited, [2007] UKHL 39.

- Barker v Corus, [2006], UKHL 20.

- Rothwell v Chemical \&Insulating Co Ltd, [2006], 4 ALL ER 1161 [2006].

- Bolton Metropolitan Borough Council v Commercial Uniun and Municipal Mutual Insurance, [2006] EWCH Civ 50.

- Badger v Ministry of Defence, [2005] EWHC 2941 (QB), [2006] 3 ALL ER 173.

- Maquire v Harland \& Woolf, [2005] EWCA Civ 1.

- Gregg v Scott, [2005] UKHL 2.

- Chester v Afshar, [2004] UKHL 41, 4 ALL ER 587.

- Fairchild v Glenhaven Funeral Services Ltd, [2002] UKHL 22.

- John D. Wood \& Co Ltd v Knatchbull, [2002] EWHC 2822 QB.

- Sharif $v$ Garrett \& Co, [2001] EWCA Civ 1269.

- Holtby v Brigham \& Cowan (Hull) Ltd, [2000] 3 ALL ER 421.

- Margereson \& Hancock v J.W. Roberts Ltd, [1996] PIQR 154.

- Caparo Industries plc v Dickman, [1990] 2 AC 605.

- Hotson v East Berkshire Health Authority, [1987] AC 750.

- Wilsher v Essex AHA, [1986] 3 ALL ER 416.

- Anns v Merton London Borough Council, [1978] AC 728.

- McGhee v National Coal Board, [1973] 1 WLR 1.

- Barnett ${ }_{v}$ Chelsea and Kensington Hospital, [1969] QB 428.

- Overseas tankship Ltd v Morts and Doch Engineering Co Ltd, [1961] 1 ALL ER 404.

- Kitchen v Royal Air Forces Association, [1958] 1 W.L.R. 377.

- Bonnington Castings Ltd v Wardlaw, [1956] AC 613.

- Donoghue v Stevenson, [1932] AC 562.

- Chaplin v Hicks, [1911] 2 KB 786, CA.

- Hutchinson v York, Newcastle and Berwick Railway Company, [1850] 5 Exch. 343.

- Priestley v Fowler, [1837] 3 Mees \& Wels 1. 


\section{$\underline{\text { Australia }}$}

- Amaca Pty v Ellis, [2010] HCA 5 (3 March 2010).

\section{United States of America}

- Daubert v Merrell Dow Pharmaceuticals, 509, U.S. 579 (1993).

- Landrigan v Celotex Corp., 177 N.J. 404, 605 A.2d 1079 (Supreme Court New Jersy, 1992).

- Sindell v Abbott Laboratories, 607 P 2d 924, 1980 (Supreme Court of California). 



\section{Samenvatting}

Asbest werd door zijn karakteristieke kenmerken lange tijd beschouwd als een magisch materiaal, met als gevolg dat asbest in meer dan 3000 producten verwerkt werd. Het verleden is echter onomkeerbaar: we zullen de consequenties van ons handelen en nalaten moeten dragen. Ondanks het feit dat de opslag en het verwerken van asbest tegenwoordig is verboden, zal het aantal asbestslachtoffers - vanwege de lange incubatietijd in de nabije toekomst drastisch stijgen. Het groeiende aantal asbestslachtoffers heeft niet alleen veel aandacht gekregen als maatschappelijk vraagstuk, maar heeft ook geleid tot gecompliceerde aansprakelijkheidsrechtelijke vraagstukken en juridisch dispuut. Het overgrote deel van asbestgerelateerde ziekten is een gevolg van beroepsmatige blootstelling aan asbest. Dit neemt echter niet weg dat er nog steeds een kleine kans bestaat dat personen die asbestvezels hebben ingeademd middels thuisblootstelling, paraberoepsmatige blootstelling of milieublootstelling met de 'lange staart' risico's van asbest kunnen worden geconfronteerd. Dit maakt het probleem complexer: asbestgerelateerde ziekten zijn niet enkel werkgerelateerd. Asbestslachtoffers zullen, afhankelijk van de blootstellingsbron, hun (voormalige) werkgever(s), asbestfabrieken en de regering aanspreken op hun nalatigheid in het treffen van efficiënte voorzorgsmaatregelen. Dergelijke claims vallen in de meeste jurisdicties onder het aansprakelijkheidsrecht en zijn te beschouwen als kostbare claims in termen van geld, tijd en emotie. Dit proefschrift handelt over ingewikkelde kwesties in het civiele aansprakelijkheidsrecht, waarbij de nadruk ligt op de technisch juridische problemen die veroorzaakt worden door de medische aard van asbestgerelateerde ziekten.

De problemen, die gepaard gaan met het compenseren van het groeiende aantal asbestslachtoffers, tarten vele rechtssystemen, die zich op hun beurt moeten buigen over exact dezelfde kwesties. Ondanks het feit dat binnen de asbestaansprakelijkheid veel juridische vraagstukken aan de orde komen, ligt de nadruk in dit proefschrift op het causale verband tussen het handelen van de gedaagde en de schade van de eiser. Dit onderzoek is rechtsvergelijkend van aard en heeft de juridische positie van asbestslachtoffers in een civil law jurisdictie (Nederland) en een common law jurisdictie (Engeland) onderzocht. Onzeker causaal verband komt veelvuldig voor in asbestclaims en kan in twee hoofdcategorieën onderverdeeld worden, onzekerheid ten aanzien van de gedaagde (wie heeft de schade veroorzaakt?) en onzekerheid ten aanzien van de oorzaak van de schade (wat heeft de schade veroorzaakt?). Complexe juridische en wetenschappelijke problemen voortkomend uit claims voor mesothelioom en longkanker die mogelijk asbestgerelateerd kan zijn, werden geanalyseerd om een oplossing te vinden voor het probleem van causale onzekerheid. Hierbij werd gestreefd naar het vinden van een eerlijke balans tussen de belangen van de eiser en de belangen van de gedaagde. De medische wetenschap is niet in staat om de oorzaak van de ziekte vast te stellen in zaken waarin de blootstelling aan asbest mogelijk de longkanker van de eiser heeft veroorzaakt, omdat meerdere facto- 


\section{Samenvatting}

ren de longkanker kunnen hebben veroorzaakt of aan de ontwikkeling ervan kunnen hebben bijgedragen. In claims voor mesothelioom daarentegen is de medische wetenschap in staat gebleken om de oorzaak vast te stellen, maar blijkt deze niet in staat om de specifieke schadeveroorzaker aan te wijzen in gevallen waarin twee of meer werkgevers gedurende verschillende dienstverbanden het mesothelioomslachtoffer hebben blootgesteld aan asbest.

In de loop der tijd heeft de traditionele condicio sine qua non (but-for) test, en het daaruit voortvloeiende alles-of-niets resultaat, behoorlijk veel kritiek gekregen in juridische geschriften, met name in gevallen waarin de causale onzekerheid veroorzaakt werd door het feit dat meerdere factoren aanwezig waren die allen de schade zelfstandig veroorzaakt zouden kunnen hebben. Nederlandse rechtbanken en juristen onderkennen de nadelen die samenhangen met het toepassen van de alles-of-niets benadering in claims voor longkanker als een mogelijk gevolg van asbestblootstelling en hebben getracht deze nadelen te ondervangen door het juridische instrument van proportionele aansprakelijkheid te adopteren: de rechter kent niet de volledige vordering toe of wijst aansprakelijkheid in het geheel af, maar kent schade toe naar rato van de veroorzakingswaarschijnlijkheid. De praktische en theoretische gevolgen van de theorie van proportionele aansprakelijkheid, voor het eerst toegepast door de Hoge Raad in 2006, zijn onderzocht om vast te stellen of het wenselijk zou zijn om haar toepassingsbereik uit te breiden. In de zoektocht naar de meest redelijke manier om met het probleem van causale onzekerheid in asbestclaims om te gaan, heeft dit onderzoek, naast de proportionele benaderingen in het aansprakelijkheidsrecht, ook alternatieve oplossingen onderzocht in materieel en procedureel recht, welke kunnen worden gebruikt naast of in plaats van proportionele aansprakelijkheid. De resultaten waren teleurstellend. Ofschoon alle voorgestelde alternatieve oplossingen in het aansprakelijkheidsrecht de problematische positie van de eiser weliswaar verbeteren, resulteren allen toch in een niet te rechtvaardigen alles-of-niets uitkomst. Vervolgens werden alternatieven voor het aansprakelijkheidsrecht onderzocht om te bepalen of instrumenten buiten het aansprakelijkheidsrecht om geschikter zijn om specifieke asbestgerelateerde claims te behandelen. De categorisatie van de causale onzekerheid blijkt van doorslaggevende betekenis voor het al dan niet opzetten van een alternatief vergoedingsstelsel. Het oprichten van een alternatief vergoedingsstelsel dat personen compenseert die lijden aan longkanker als een mogelijk gevolg van asbestblootstelling is, in tegenstelling tot het oprichten van een dergelijk vergoedingsstelsel voor mesothelioomslachtoffers, te complex en daardoor niet wenselijk.

Het vaststellen van causaal verband in asbestclaims vraagt om een multidisciplinaire interactie tussen rechters en deskundigen. De discussie tussen deze verschillende disciplines kan leiden (en heeft reeds geleid) tot miscommunicatie, hetgeen beschouwd wordt als een wereldwijd probleem. De rol van deskundigen in civiele procedures en het gebruik van epidemiologische gegevens om de 'veroorzakingswaarschijnlijkheid' te berekenen in claims inzake longkanker, zijn onderwerp geweest van een kritische beschouwing in het gehele proefschrift, te meer omdat proportionele aansprakelijk (bijna) volledig afhankelijk is van de bevindingen van de aangewezen deskundige(n). Een aantal ideeën is geopperd dat kan bijdragen tot een betere afhandeling van asbestgerelateerde claims en andere claims waarin dezelfde problemen zich manifesteren. Om zo nauwkeurig moge- 
lijk de waarschijnlijkheid vast te stellen dat asbestblootstelling de veroorzaker is van de longkanker van de eiser, is meer informatie vereist over de rookgeschiedenis van de eiser, de chemische aard van de ingeademde asbestvezels, en het (sub)multiplicatieve verband tussen roken en blootstelling aan asbest. Echter, het is van belang te erkennen dat deze informatie niet altijd voorhanden is en dat de epidemiologie - in een individueel geval - niet exact (met 100\% zekerheid) kan vaststellen hoe waarschijnlijk het is dat asbestblootstelling de longkanker heeft veroorzaakt. Het erkennen van deze feiten moet echter niet leiden tot het ongewenste gevolg dat rechtbanken weigeren om epidemiologisch bewijsmateriaal in overweging te nemen: het niet gebruiken van dergelijke gegevens is zelfs meer arbitrair. Rechtbanken dienen zich bewust(er) te worden van de verschillen tussen epidemiologisch causaal verband en juridisch causaal verband en moeten meer gebruik maken van hun discretionaire bevoegdheid om de bevindingen van de deskundigen naar eigen juridisch inzicht te interpreteren.

Alle voorgestelde interne (binnen het aansprakelijkheidsrecht) en externe (buiten het aansprakelijkheidsrecht) oplossingen voor het probleem van causale onzekerheid hebben nadelen. Het is van belang om ons te realiseren dat er eenvoudigweg geen perfecte oplossing voorhanden is in asbestclaims. Het feit dat het probleem van meervoudige juridische causale onzekerheid niet enkel beperkt blijft tot claims voor longkanker, maar zich ook manifesteert in andere letselschadeclaims, is verontrustend. Het is niet redelijk om aansprakelijkheid in zijn geheel af te wijzen in zaken waarin de causale onzekerheid voortkomt uit het feit dat twee of meer juridisch relevante factoren de schade kunnen hebben veroorzaakt. Het toepassingsbereik van proportionele aansprakelijkheid is niet uitsluitend beperkt tot claims voor longkanker als mogelijk gevolg van asbestblootstelling. Proportionele aansprakelijkheid lijkt ook tot de meest redelijke resultaten te leiden in andere letselschadezaken, waarin het probleem van meervoudige juridische causale onzekerheid zich ook voordoet, mits de veroorzakingswaarschijnlijkheid nauwkeurig kan worden vastgesteld en deze de minimumdrempel overschrijdt. 



\section{Summary}

Due to its remarkable properties, asbestos was once considered as a magical material, which has led to its use in more than 3000 products. The past, however, is irreversible: we have to deal with the consequences of our acts and omissions. Although the storage and processing of asbestos is now forbidden, because of its long incubation period, the number of victims diagnosed with asbestos-related injuries will increase drastically in the near future. The rising number of asbestos victims has not only received much attendance within our society but also posed difficult questions for Tort law, which has been subject to much discussion in legal writings. Most asbestos-related injuries are exclusively traceable to occupational exposure to asbestos, but there is a slight possibility that persons who have experienced a household, para-occupational, or environmental exposure to asbestos will also be faced with the long-tail risks connected to asbestos exposure. This emphasizes the problem even more: asbestos-related injuries are not only workrelated. Depending on the source of the exposure to asbestos, asbestos victims blame their (former) employer(s), asbestos factories, and the government for not taking sufficient precautionary measures to prevent them from suffering health damage. Because these claims are managed, in many jurisdictions, through the tort system, they can become costly disputes in terms of money, time, and emotion. Problematic issues within tort regimes have been addressed in this thesis, with a central focus on the technical legal difficulties posed by the medical nature of asbestos-related diseases.

The problem of compensating a growing number of people who have contracted an asbestos-related injury is taxing many legal systems, all facing the exact same problems. Although a variety of problematic legal and scientific issues are captured in claims for asbestos-related injuries, the emphasize in this thesis was put on the proof of causation between the defendant's intervention and the claimant's damage. The research was set in a comparative perspective and addressed the legal position of asbestos victims in a civil law jurisdiction (The Netherlands) and a common law jurisdiction (England). Uncertain causality arises frequently in claims for asbestos-related diseases and can be classified in two main types, uncertainty about the tortfeasor (who caused the damage?) and uncertainty as to the cause of the damage (what caused the damage?). Complex legal and scientific problems that arise in claims for mesothelioma and lung cancer that could have been asbestos-related, have been mapped out in order to find a solution to the problem of uncertain causation, seeking a fair balance between the interests of the claimant and the interests of the defendant. Medical science is unable to determine the cause of the injury in cases where the exposure to asbestos could have caused the claimant's lung cancer as multiple factors could have caused or contributed to the development of lung cancer, and cannot identify the specific tortfeasor who has caused the claimant's mesothelioma in cases where two or more employers have exposed the claimant to asbestos in the course of several different employments. 
Over the years, the traditional condicio sine qua non (but-for) test, and the all-ornothing result that this test produces, has received a considerable amount of criticism in legal writings, particularly in cases where the causal uncertainty is caused by the fact that multiple factors are present which all could have caused the claimant's damage separately. Dutch courts and legal scholars have recognized the drawbacks connected to the allor-nothing result in claims for lung cancer that could have been asbestos-related and have tried to remove these drawbacks by adopting the legal instrument of 'proportional liability': the judge does not simply award or reject the total amount of damages, rather he or she awards damages in proportion to the probability of causation. The practical and theoretical consequences of the proportional liability theory, which was applied for the first time by the Dutch Supreme Court in 2006, have been examined in order to determine whether it would be desirable to extend its range of applications. In search of the most justified way to deal with the problem of uncertain causation in claims for asbestosrelated diseases, this research, apart from the proportional approaches in Tort law, also examined alternative solutions to the problem of uncertain causation in substantive and/or procedural law that can be used alongside or instead of proportional liabity. The results were rather disappointing. Although all proposed alternative solutions in Tort law do improve the problematic position of the claimant, they all result in an all-or-nothing outcome, which does not do justice to the complex situation of causal uncertainty. Subsequently, alternatives to Tort liability have also been examined in order to explore whether instruments outside the area of Tort law are more sufficient to deal with specific claims for asbestos-related cases. The type of causal uncertainty has proved to be a decisive factor to the enactment of an alternative scheme. The foundation of an alternative scheme that awards payments to persons who suffer from lung cancer as a potential consequence of asbestos exposure is, contrary to the foundation of such a scheme in claims for mesothelioma, too complex and therefore not advisable.

The establishment of causation in claims for asbestos-related injuries involves a multidisciplinary interaction between judges and experts and, as a consequence, this crossdisciplinary discussion can lead (and has already led) to miscommunication, which is considered a worldwide problem. The role of experts in civil litigation and the use of epidemiological data to assess the 'Probability of Causation' in claims for lung cancer have been subject to a critical review throughout this thesis, because the proportional liability theory depends almost completely on the findings of the appointed expert(s). A number of ideas have been proposed that could contribute to a better settlement of claims for asbestos-related diseases and other cases in which similar problems arise. In order to adequately assess the probability that asbestos exposure has caused the claimant's lung cancer, more information is required on the claimant's smoking history, the chemical nature of the inhaled asbestos fibres, and the (sub)multiplicative relation between smoking and exposure to asbestos. It must, however, be acknowledged that this information is not always available and that epidemiology cannot precisely (with 100\% certainty) determine the probability that asbestos has caused lung cancer in an individual case. This should not lead to the undesirable consequence that courts will refuse to take epidemiological findings into consideration: not using such findings is even more arbitrary. Courts should, however, be (more) aware of the distinctions between epidemio- 
logical causation and judicial causation and must make use of their discretionary power to interpret the expert's findings in their own judicial way.

All proposed internal (within Tort law) and external (outside Tort law) solutions to the problem of uncertain causation have drawbacks. We have to recognize and realize that there is simply no perfect solution available in such complex cases. Even more striking is the fact that the issue of multiple legal causal uncertainty is not only confined to claims for lung cancer, but also presents itself in other personal injury claims. It is not fair to deny all compensation in cases where the causal uncertainty is caused by the fact that multiple legally relevant factors are present which all could have caused the claimant's damage (multiple legal causal uncertainty). Proportional liability is not exclusively geared for claims for lung cancer that could have been asbestos-related and also seems to produce the most reasonable results in other personal injury cases that are also characterized by the problem of multiple legal causal uncertainty, provided that the Probability of Causation can be assessed accurately and does exceed the minimum threshold that justifies its application. 



\section{Curriculum Vitae}

Faro Sobczak was born on July 9, 1985 in Geleen, the Netherlands. He started to study Dutch law at Maastricht University in 2003 and obtained a bachelor's degree in Dutch law (2006) and a master's degree in Private law (2007). His master thesis, which he wrote under the supervision of prof. mr. G.E. van Maanen, was titled: 'General Terms and Conditions in Contract Law'. During his study he taught first year law students the basics of law, was chairman of several committees at the Law Students' Association JFV Ouranos, and did an internship at a local law firm.

In September 2007, Faro was appointed as Ph.D-candidate and teacher at Maastricht University, Department of Health, Ethics and Society: the home base of Health Law. The research presented in this thesis was conducted under the supervision of prof. mr. G.E. van Maanen and dr. D.M.R. Townend. In 2008, Faro moved to Sheffiled (UK) for two months to work on his thesis at Sheffield University, Faculty of Law. In this period, he also joined Irwin Mitchell's asbestos claims team in order to understand the practical sight of his work. During his work at Maastricht University Faro obtained a Certificate Advanced Academic Writing for Law (2009) and published several articles in the area of Tort law in national and international legal journals. Faro (re)developed and taught courses on 'medical liability', 'patients' rights', 'decision-making in health care', 'right to health care', and 'health law and health ethics' at both the Faculty of Law and the Faculty of Health, Medicine and Life sciences. He was a member of the Ius Commune Research School (Programme: Liability and Insurance) and the research institute CAPHRI and he is a member of several associations in the field of liability law.

As of January 2013, Faro will join Beer advocaten in Amsterdam. 



\section{List of Publications}

\section{Sobczak 2011}

F. Sobczak, Proportionele aansprakelijkheid voor mesothelioom? Een beschouwing aan de hand van het Engelse recht, Letsel \& Schade, 2011/2, p. 32-41.

\section{Sobczak 2010}

F. Sobczak, Proportionality in Tort Law; A Comparison between Dutch and English Laws with Regard to the Problem of Multiple Causation in Asbestos-Related Cases, European Review of Private Law, 2010/6, p. 1155-1179.

\section{Sobczak 2010}

F. Sobczak, Proportionele aansprakelijkheid; de CRvB laat zich leiden door de Hoge Raad en vice versa?, Nederlands Tijdschrift voor Burgerlijk Recht, 2010/10, p. 407-412.

\section{Sobczak et al. 2009}

F. Sobczak, D.M.R. Townend, G.E. van Maanen, Dutch case note: Liability for pleural plaques in the Netherlands, European Review of Private Law, 2009/2, p. 207-217. 